\title{
Status and Trends of Land Change in the Eastern United States-1973 to 2000
}

Professional Paper 1794-D

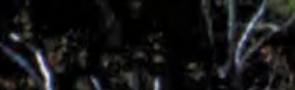

U.S. Department of the Interior U.S. Geological Survey 


\section{Status and Trends of Land Change in the Eastern United States- 1973 to 2000}

Edited by Kristi L. Sayler, William Acevedo, and Janis L. Taylor

Professional Paper 1794-D 


\section{U.S. Department of the Interior \\ SALLY JEWELL, Secretary}

\section{U.S. Geological Survey \\ Suzette M. Kimball, Director}

\section{U.S. Geological Survey, Reston, Virginia: 2016}

For more information on the USGS - the Federal source for science about the Earth, its natural and living resources, natural hazards, and the environment-visit http://www.usgs.gov/ or call 1-888-ASK-USGS (1-888-275-8747).

For an overview of USGS information products, including maps, imagery, and publications, visit http://www.usgs.gov/pubprod/.

To order this and other USGS information products, visit http://store.usgs.gov/.

Any use of trade, product, or firm names is for descriptive purposes only and does not imply endorsement by the U.S. Government.

Although this information product, for the most part, is in the public domain, it also may contain copyrighted materials as noted in the text. Permission to reproduce copyrighted items must be secured from the copyright owner.

Suggested citation:

Sayler, K.L., Acevedo, W., and Taylor, J.L., eds., 2016, Status and trends of land change in the Eastern United States-1973 to 2000: U.S. Geological Survey Professional Paper 1794-D, 195 p., http://dx.doi.org/10.3133/pp1794D.

Cover:

Forest landscape along Blue Ridge Parkway south of Blowing Rock, North Carolina. Photograph by Thomas R. Loveland, 2006.

Inside cover:

Agriculture and forest landscape southeast of Frenchville, Maine. Photograph by Thomas R. Loveland, 2002. 


\section{Foreword}

This Professional Paper is the first multitemporal assessment of late-20th-century land change in the conterminous United States across all regions and all land-use and land-cover sectors. The work is the culmination of nearly 10 years of research and development by the U.S. Geological Survey, with support from the U.S. Environmental Protection Agency and the National Aeronautics and Space Administration, as well as university collaborators. It represents the most complete and comprehensive analysis of the rates, types, distribution, and drivers of recent changes in land use and land cover. The study bridges the gap between coarse-scale continental and global assessments and fine-scale local and regional case studies.

Land-change studies attempt to explain the "what, where, when, how, and why" of changes to the vegetation and to the use of the land. Land-change research is aimed specifically at measuring where change is occurring (and where it is not occurring); which land-use and land-cover classes are changing (and what they are changing to); how much land is changing (and how fast); and what drivers are responsible for the measured changes. The goal is not only to understand the scope of change but also to provide the information base necessary to evaluate, predict, and manage the consequences of change.

Like many key issues in climate change and ecosystem functioning, land use and land cover are both drivers and indicators of environmental quality. The National Research Council has identified the understanding of land-use dynamics as one of the grand challenges for environmental research - no other global-change parameter is so tightly intertwined with issues of past, present, and future land-use practices, weather patterns, soil and carbon dynamics, ecosystem health and diversity, economic development and policy, technology issues, human population size and distribution, and overall human health. People and their use of the land are interrelated in complex ways, and the effects of land-use and land-cover change can have a huge impact on their quality of life, on the goods and services that they can expect from the land, and on the hazards that they may face. Despite these profound consequences, the Intergovernmental Panel on Climate Change's Third Assessment Report has cited the lack of scientific understanding about the timing, magnitude, and direction of response of ecological, social, and economic systems to the combined effects of climate change and land-use and land-cover change as a key uncertainty in determining societal vulnerabilities and predicting both regional and global impacts of climate change.

Prior to this study, only sectorally specific or spatially limited assessments and inventories had been conducted to categorize land change in the United States. These efforts often included only certain land-use and land-cover classes or ownership categories, or they were conducted over short time intervals only, and integrating these various assessments into a comprehensive and consistent national synthesis of land change was not possible. The research presented in this Professional Paper has been specifically designed to provide the first comprehensive measurement of land-cover change in the conterminous United States.

Relying on Landsat satellite imagery — the longest continuous and consistent dataset of synoptic Earth observations - the authors characterize changes across 11 primary land-use and land-cover classes spanning four time periods between 1973 and 2000. For each of these time periods and classes, estimates of change are developed for each of 84 distinct ecological regions — or ecoregions - across the conterminous United States.

The results provide useful, if not essential, information for understanding climate change, biodiversity, resource management and planning, resource security, and disaster planning. A significant conclusion is that no single profile of land-use and land-cover change exists. Numerous different, and often complex, interactions between an ecoregion's socioeconomic drivers and its biological and physical characteristics have produced widespread regional and temporal variability in the rates, types, and total extent of land change. Among the scientific findings presented are estimates of overall forest decline in response to increased rates of disturbance, urbanization, and agricultural intensification.

This research provides a critical ecoregional to national perspective of U.S. land change in the conterminous United States. With the completion of the 1973-2000 assessment, this study lays a foundation for understanding the Nation's land-change dynamics and makes possible a new era for analyzing the consequences of land change, as well as for modeling future land changes.

$$
\begin{gathered}
\text { Suzettr R Kumbale } \\
\text { Director, USGS }
\end{gathered}
$$




\section{Preface}

U.S. Geological Survey (USGS) Professional Paper 1794-D is the fourth in a four-volume series on the status and trends of the Nation's land use and land cover, providing an assessment of the rates and causes of land-use and land-cover change in the Eastern United States between 1973 and 2000. Volumes A, B, and C provide similar analyses for the Western United States, the Great Plains of the United States, and the Midwest-South Central United States, respectively. The assessments of land-use and land-cover trends are conducted on an ecoregion-by-ecoregion basis, and each ecoregion assessment is guided by a nationally consistent study design that includes mapping, statistical methods, field studies, and analysis. Individual assessments provide a picture of the characteristics of land change occurring in a given ecoregion; in combination, they provide a framework for understanding the complex national mosaic of change and also the causes and consequences of change. Thus, each volume in this series provides a regional assessment of how (and how fast) land use and land cover are changing, and why. The four volumes together form the first comprehensive picture of land change across the Nation.

Geographic understanding of land-use and land-cover change is directly relevant to a wide variety of stakeholders, including land and resource managers, policymakers, and scientists. The chapters that follow present brief summaries of the patterns and rates of land change observed in each ecoregion in the Eastern United States, together with field photographs, statistics, and comparisons with other assessments. In addition, a synthesis chapter summarizes the scope of land change observed across the entire Eastern United States. The studies provide a way of integrating information across the landscape, and they form a critical component in the efforts to understand how land use and land cover affect important issues such as the provision of ecological goods and services and also the determination of risks to, and vulnerabilities of, human communities. Results from this project also are published in peer-reviewed journals, and they are further used to produce maps of change and other tools for land management, as well as to provide inputs for carbon-cycle modeling and other climate change research.

This report is only one of the products produced by USGS on land-use and land-cover change in the United States. Other reports and land-cover statistics are available online at http://landcovertrends. usgs.gov.

\section{Acknowledgments}

The U.S. Environmental Protection Agency's Office of Research and Development and the National Aeronautics and Space Administration provided initial funding to support this project.

The U.S. Geological Survey's (USGS) Geographic Analysis and Monitoring Program and Climate and Land Use Change Research and Development Program provided long-term support for this research.

Adam Davis (USGS) provided extensive support in the production of figures and tables.

All photographs contained within this Professional Paper were taken by various members of the Land Cover Trends research project while conducting field investigations between 1999 and 2010.

\section{Author Affiliations}

$\begin{array}{ll}\text { William Acevedo } & \text { U.S. Geological Survey } \\ \text { Roger F. Auch } & \text { U.S. Geological Survey } \\ \text { Mark S. Brooks } & \text { U.S. Geological Survey } \\ \text { Mark A. Drummond } & \text { U.S. Geological Survey } \\ \text { Beverly A. Friesen } & \text { U.S. Geological Survey } \\ \text { Rachel M.K. Headley } & \text { U.S. Geological Survey } \\ \text { Steven Kambly } & \text { U.S. Geological Survey }\end{array}$

Thomas R. Loveland
Thomas R. Moreland, Jr.
Darrell E. Napton
Kristi L. Sayler
Terry L. Sohl
Michael P. Stier
Janis L. Taylor

U.S. Geological Survey U.S. Geological Survey South Dakota State University U.S. Geological Survey U.S. Geological Survey U.S. Geological Survey Stinger Ghaffarian Technologies 


\section{Contents}

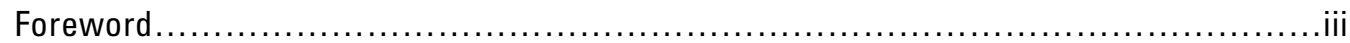

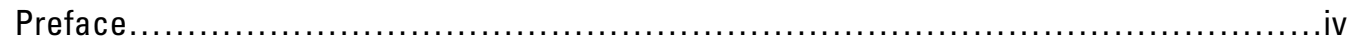

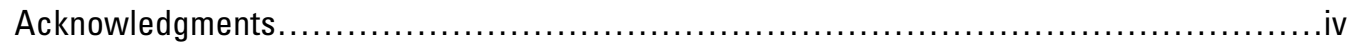

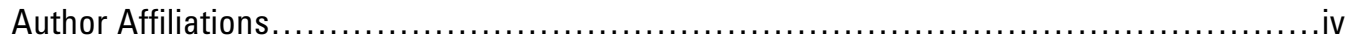

\section{Regional Synthesis}

Land-Cover Trends in the Eastern United States-1973 to $2000 \ldots \ldots \ldots \ldots \ldots \ldots \ldots \ldots \ldots \ldots . \ldots \ldots$

By Thomas R. Loveland, William Acevedo, and Kristi L. Sayler

\section{Northeastern United States Ecoregions}

1. Laurentian Plains and Hills Ecoregion.................................... 19

By Thomas R. Moreland, Jr.

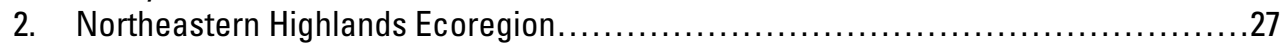

By Steven Kambly

3. Eastern Great Lakes and Hudson Lowlands Ecoregion....................... 35

By Janis L. Taylor

Mid-Atlantic Coast Ecoregions

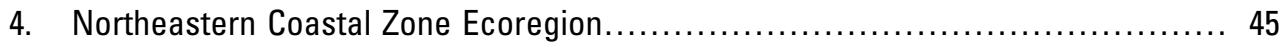

By Roger F. Auch

5. Atlantic Coastal Pine Barrens Ecoregion.................................53

By Terry L. Sohl

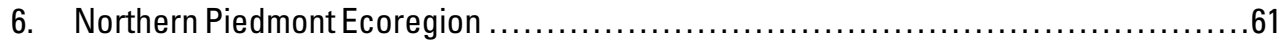

By Roger F. Auch

\section{Appalachian Mountains Ecoregions}

7. Northern Appalachian Plateau and Uplands Ecoregion.......................71

By Mark S. Brooks

8. North Central Appalachians Ecoregion...................................79

By Kristi L. Sayler

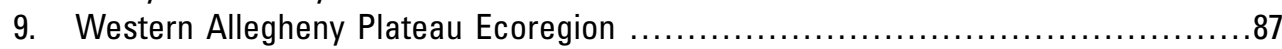

By Kristi L. Sayler

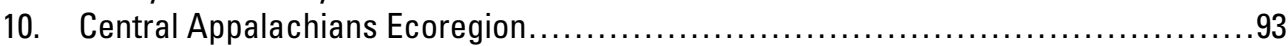

By Kristi L. Sayler

11. Ridge and Valley Ecoregion.............................................. 101

By Beverly A. Friesen and Michael P. Stier

12. Interior Plateau Ecoregion............................................ 109

By Mark A. Drummond

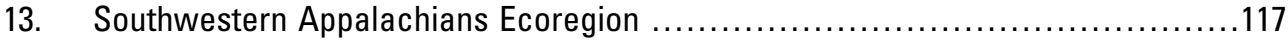

By Terry L. Sohl

14. Blue Ridge Mountains Ecoregion..................................... 125

By Janis L. Taylor, Rachel M.K. Headley, and Darrell E. Napton 


\section{Southeastern United States Ecoregions}

15. Piedmont Ecoregion

By Darrell E. Napton

16. Mississippi Valley Loess Plains Ecoregion

By Janis L. Taylor

17. Southeastern Plains Ecoregion

By Terry L. Sohl

18. Middle Atlantic Coastal Plain Ecoregion

By Roger F. Auch

19. Southern Coastal Plain Ecoregion............................................167

By Mark A. Drummond

20. Southern Florida Coastal Plain Ecoregion

By Steven Kambly

Appendix 1. Map of Ecoregions in Conterminous United States ............................185

Appendix 2. Abbreviations for Ecoregions in the Eastern United States .....................188

Appendix 3. Land-Cover Classification System Used in "Status and Trends

of Land Change" Study .............................................................

Appendix 4. Methodology Used in "Status and Trends of Land Change" Study ................190

\section{Conversion Factors}

\begin{tabular}{lcl}
\hline Inch/Pound to SI & Multiply by & To obtain \\
\hline inch (in.) & Length & \\
inch (in.) & 2.54 & centimeter $(\mathrm{cm})$ \\
foot (ft) & 25.4 & millimeter $(\mathrm{mm})$ \\
mile (mi) & 0.3048 & meter $(\mathrm{m})$ \\
& 1.609 & kilometer $(\mathrm{km})$ \\
\hline acre & Area & \\
acre & 4,047 & square meter $\left(\mathrm{m}^{2}\right)$ \\
square mile (mi $\left.{ }^{2}\right)$ & 0.004047 & square kilometer $\left(\mathrm{km}^{2}\right)$ \\
\hline
\end{tabular}

Temperature in degrees Celsius $\left({ }^{\circ} \mathrm{C}\right)$ may be converted to degrees Fahrenheit $\left({ }^{\circ} \mathrm{F}\right)$ as follows: ${ }^{\circ} \mathrm{F}=\left(1.8 \times{ }^{\circ} \mathrm{C}\right)+32$

Temperature in degrees Fahrenheit $\left({ }^{\circ} \mathrm{F}\right)$ may be converted to degrees Celsius $\left({ }^{\circ} \mathrm{C}\right)$ as follows: ${ }^{\circ} \mathrm{C}=\left({ }^{\circ} \mathrm{F}-32\right) / 1.8$ 


\section{Regional Synthesis}

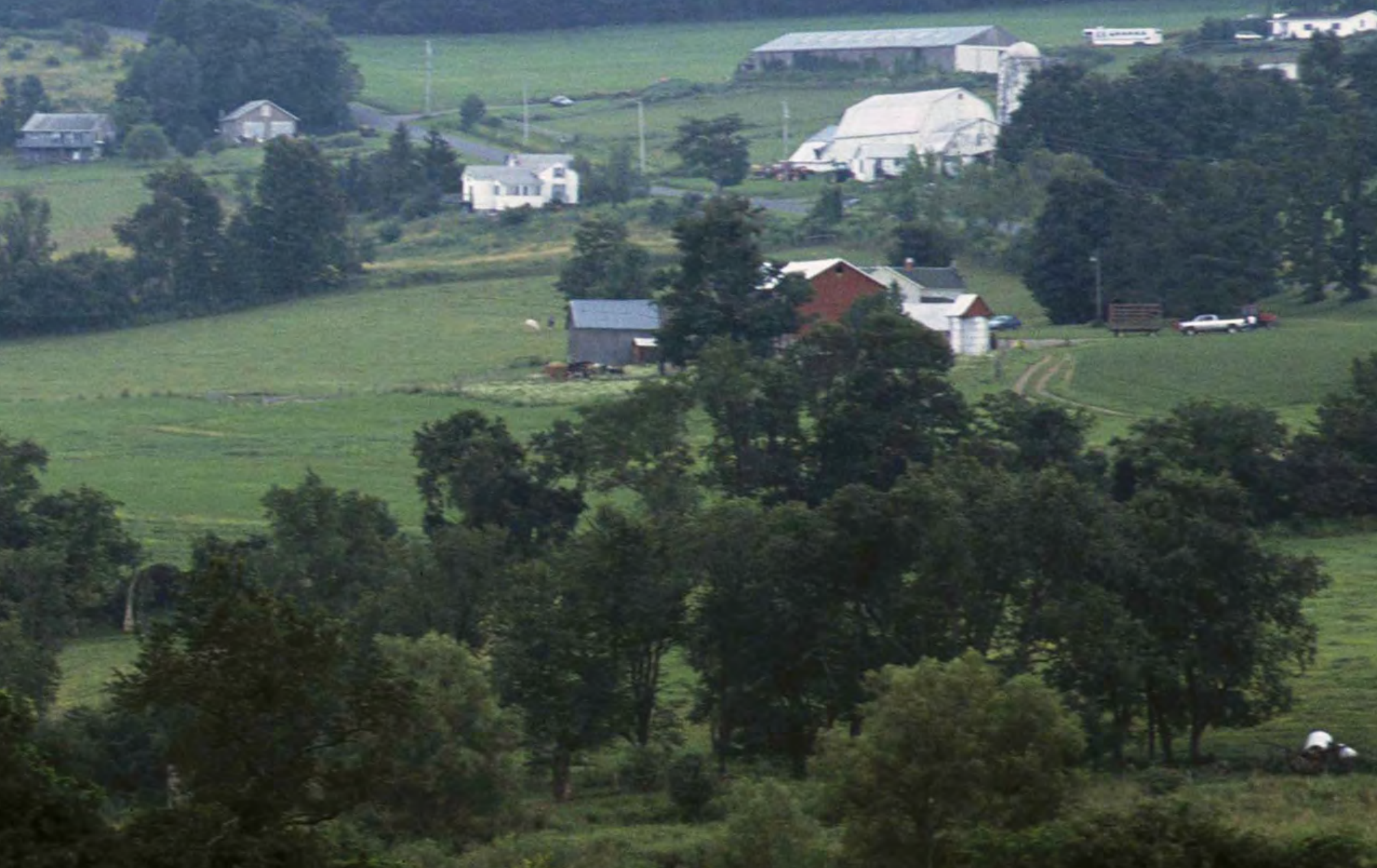

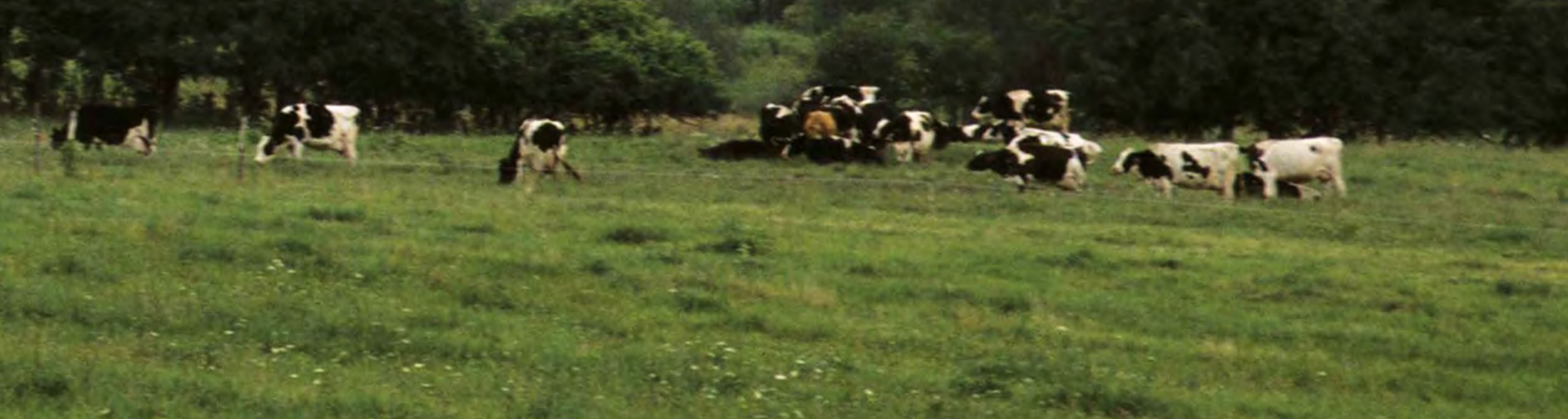




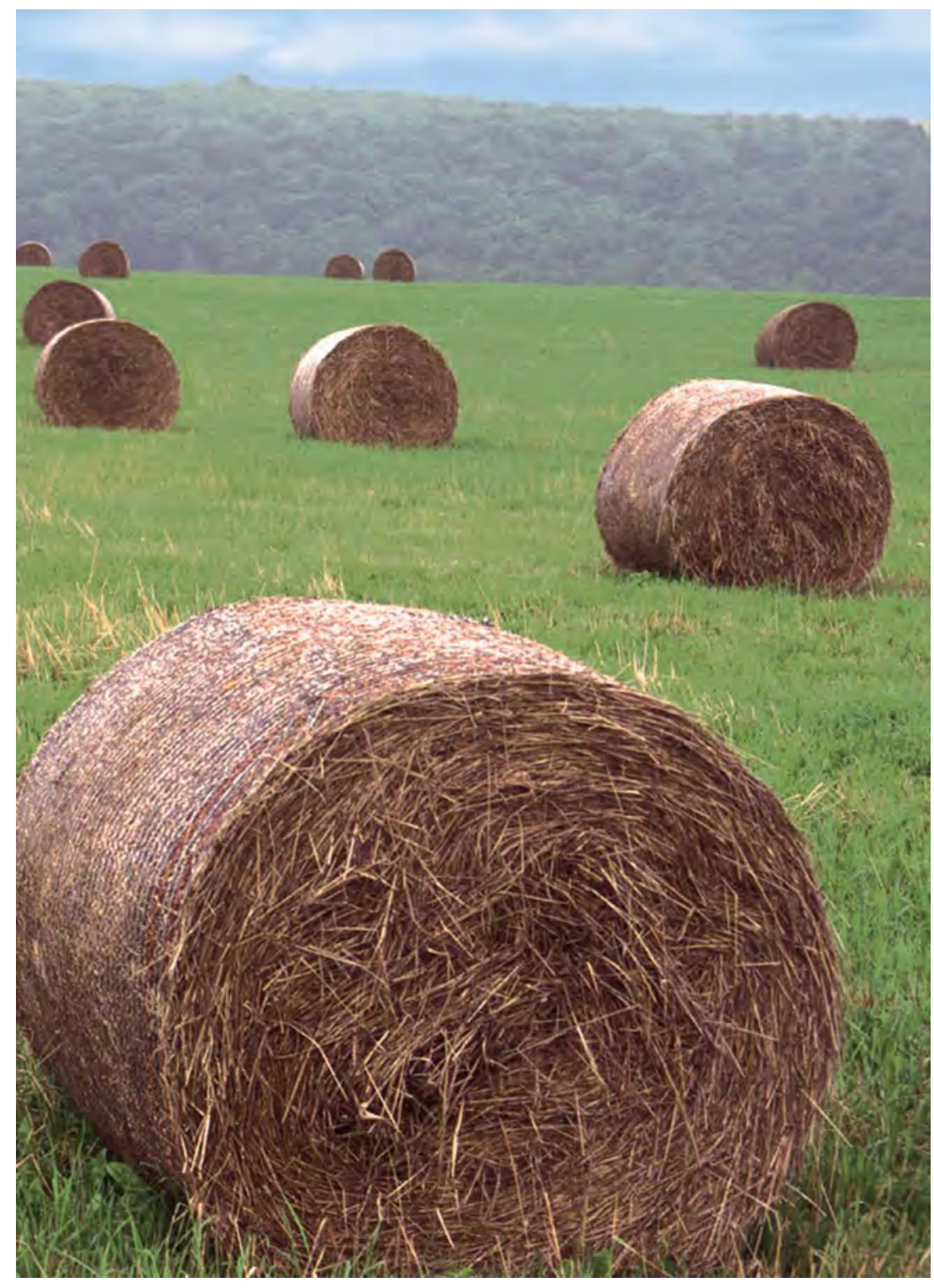




\title{
Land-Cover Trends in the Eastern United States-1973 to 2000
}

\author{
By Thomas R. Loveland, William Acevedo, and Kristi L. Sayler
}

\section{Introduction}

Studies of land-use and land-cover change attempt to explain (1) where such change is occurring, (2) what land-use/ land-cover classes are changing, (3) what types of transformations are occurring, (4) what the rates and (or) amounts of change are, and (5) what the driving forces and proximate causes of land-use/land-cover change are. The reasons for studying land-use/land-cover change include the following: to understand trends in land change, to evaluate and manage the consequences of land change, and to define future scenarios of land change. Challenging issues associated with studying land-use/land-cover change include the measuring, gathering, and documenting of the characteristics of such change.

The Federal Government has many programs that address land-use/land-cover change. Although excellent programs exist for inventorying forest (Gillespie, 1999) and agriculture land uses (Nusser and Goebel, 1997), the sum of these programs cannot be combined to provide a comprehensive picture of land change across the Nation because of the differences in design, definitions, and geographic coverage of each inventory program. Thus, it has been very difficult to draw conclusions or assess the consequences of contemporary land change in the United States.

To provide estimates of the rates of land-cover and land-use change for the United States, without regard to land ownership or land-use/land-cover class, the U.S. Geological Survey, with support from the U.S. Environmental Protection Agency, initiated a study of the rates, causes, and consequences of contemporary land-use and land-cover change. The "Status and Trends of Land Change" study used land-use/land-cover mapping derived from Landsat satellite imagery (and supported by higher resolution aerial photography), a statistical sampling strategy (Stehman and others, 2003), and geographic regionalization to provide information on the types, amounts, and rates of land change in the United States (Loveland and others, 2002). Level III ecoregions (U.S. Environmental Protection Agency, 1999) were selected as the geographic framework for the study because they have homogenous conditions and similar biotic and abiotic characteristics. The ecoregions collectively represent both the resource potential and probable responses to natural and anthropogenic disturbances.
The defining ecoregion characteristics (for example, climate, topography, geology, soils, natural vegetation) will determine the types of land cover that can exist within an area and also will influence the range of land-use practices that are possible. Estimates of land change are based on the interpretation of five study dates (1973, 1980, 1986, 1992, and 2000) of Landsat Multispectral Scanner, Thematic Mapper, and Enhanced Thematic Mapper Plus data for a set of $10 \times 10 \mathrm{~km}$ (or, in some cases, $20 \times 20 \mathrm{~km}$ ) sample blocks randomly selected for each ecoregion. The goal was to provide estimates that are within one percent of the actual land change at an 85-percent confidence level. This approach - explained in detail in Loveland and others (2002), Sohl and others (2004), and Gallant and others (2004) provides clear evidence of the geographic variability in the rates, types, and causes of land change across ecoregions.

\section{Regional Synthesis}

As part of a national assessment of land change, the U.S. Geological Survey completed an analysis of 20 ecoregions in the Eastern United States (fig. 1A). The 20 Eastern United States ecoregions, as defined by the U.S. Environmental Protection Agency (Omernik, 1987; U.S. Environmental Protection Agency, 1999), span about 1,653,852 km² (638,555 $\mathrm{mi}^{2}$ ). For purposes of discussion, the 20 Eastern United States ecoregions have been divided into four main groups, within which the ecoregions share many similar physical, biological, and land-use characteristics: the Northeastern United States Ecoregions, the Mid-Atlantic Coast Ecoregions, the Appalachian Mountains Ecoregions, and the Southeastern United States Ecoregions (fig. 1B).

Areal percentages for all land-use/land-cover classes for all five study dates (1973, 1980, 1986, 1992, and 2000) are presented in table 1. The predominant land-cover class in the Eastern United States in 2000 was forest (52.3 percent); however, the amount of forest land cover declined between 1973 and 2000. Agriculture (21.6 percent) also declined between 1973 and 2000, whereas developed (10.6 percent) increased during that time. Wetland ( 7.5 percent) and water (4.1 percent) stayed relatively consistent in area between 1973 and 2000 . 


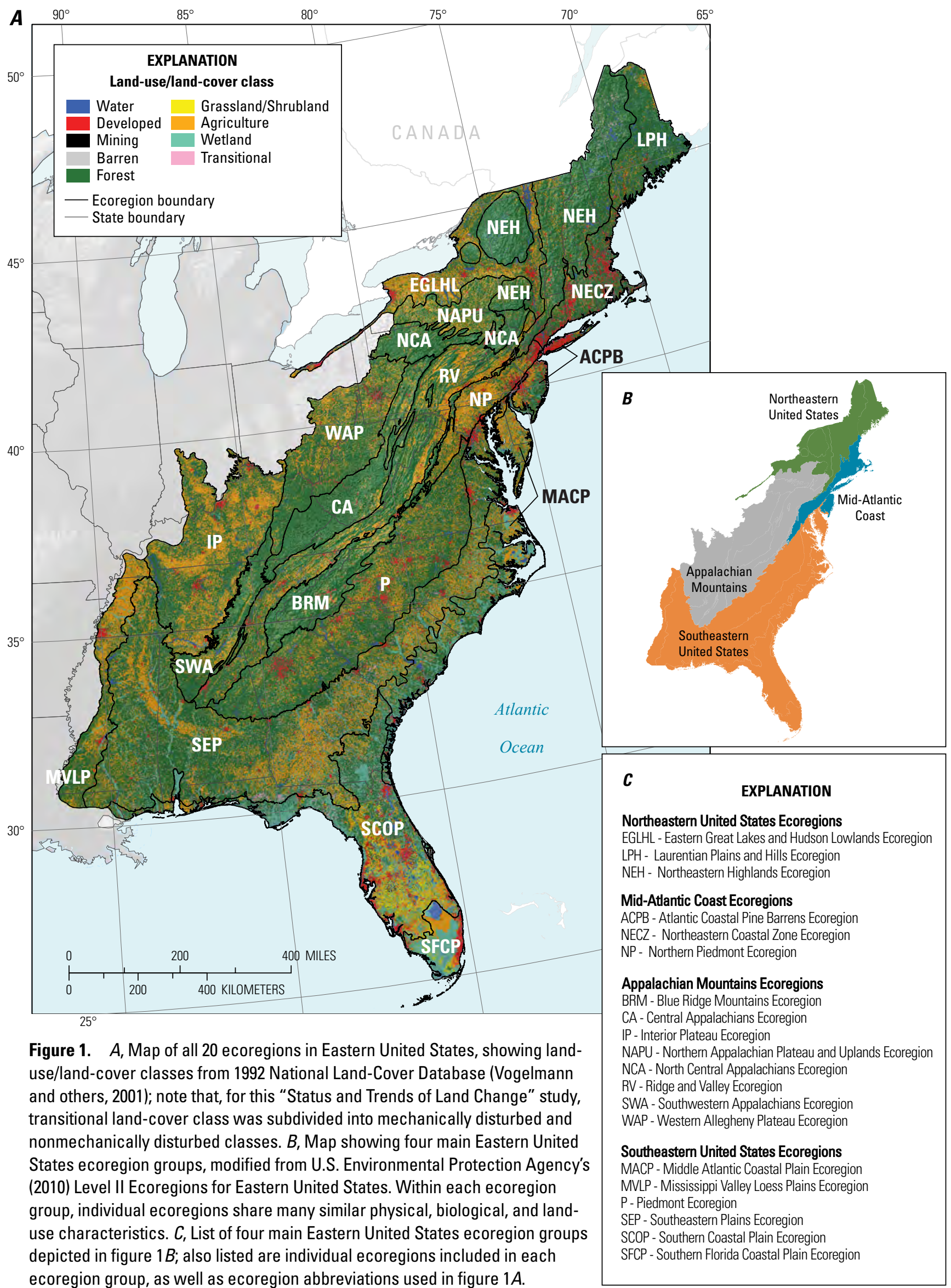


Table 1. Areal percentages of land-use/land-cover classes in all 20 Eastern United States ecoregions for each of five study years $(1973,1980,1986,1992,2000)$ and corresponding margin-of-error values for 85-percent confidence interval (in brackets).

[Percentages are of total area in all Eastern United States ecoregions. See appendix 3 for definitions of land-use/land-cover classifications]

\begin{tabular}{lccccc}
\hline Land-use/land-cover class & $\begin{array}{c}\mathbf{1 9 7 3} \\
\text { [margin of error] } \\
\text { (\% of area) }\end{array}$ & $\begin{array}{c}\mathbf{1 9 8 0} \\
\text { [margin of error] } \\
\text { (\% of area) }\end{array}$ & $\begin{array}{c}\mathbf{1 9 8 6} \\
\text { [margin of error] } \\
\text { (\% of area) }\end{array}$ & $\begin{array}{c}\mathbf{1 9 9 2} \\
\text { [margin of error] } \\
\text { (\% of area) }\end{array}$ & $\begin{array}{c}\mathbf{2 0 0 0} \\
\text { [margin of error] } \\
\text { (\% of area) }\end{array}$ \\
\hline Water & $4.0[0.7]$ & $4.0[0.7]$ & $4.0[0.7]$ & $4.0[0.7]$ & $4.1[0.7]$ \\
Developed & $8.4[2.0]$ & $8.8[2.0]$ & $9.2[2.1]$ & $9.8[2.1]$ & $10.6[2.1]$ \\
Mechanically disturbed & $1.0[0.2]$ & $1.2[0.2]$ & $1.5[0.3]$ & $2.0[0.3]$ & $2.3[0.3]$ \\
Mining & $0.4[0.1]$ & $0.5[0.2]$ & $0.5[0.2]$ & $0.4[0.1]$ & $0.4[0.1]$ \\
Barren & $0.1[<0.1]$ & $0.1[<0.1]$ & $0.1[<0.1]$ & $0.1[<0.1]$ & $0.1[<0.1]$ \\
Forest & $54.6[1.9]$ & $53.8[1.9]$ & $53.2[1.9]$ & $52.8[1.9]$ & $52.3[1.8]$ \\
Grassland/Shrubland & $0.7[0.2]$ & $0.8[0.2]$ & $1.0[0.2]$ & $1.2[0.3]$ & $1.2[0.3]$ \\
Agriculture & $23.1[1.7]$ & $23.0[1.8]$ & $22.7[1.8]$ & $22.0[1.7]$ & $21.6[1.6]$ \\
Wetland & $7.8[0.8]$ & $7.7[0.8]$ & $7.6[0.8]$ & $7.7[0.8]$ & $7.5[0.8]$ \\
Nonmechanically disturbed & $<0.1[<0.1]$ & $<0.1[<0.1]$ & $<0.1[<0.1]$ & $<0.1[<0.1]$ & $0.1[0.1]$ \\
\hline
\end{tabular}

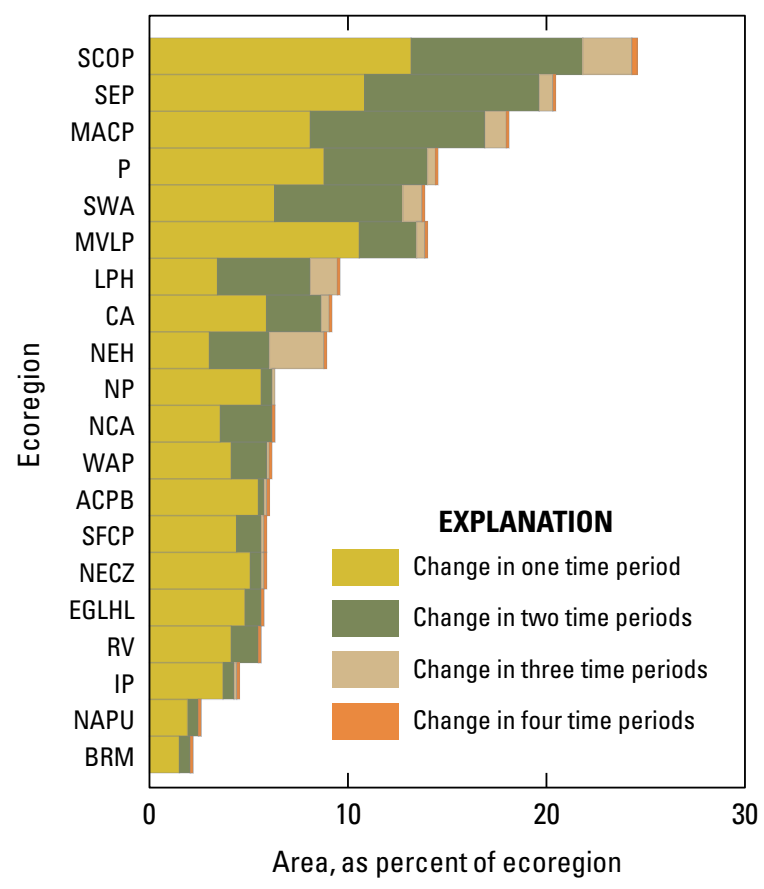

Figure 2. Overall spatial change from 1973 to 2000 for all 20 Eastern United States ecoregions. Each horizontal set of bars shows proportions of ecoregion that changed during one, two, three, or four time periods (1973-1980, 1980-1986, 1986-1992, 1992-2000). Ecoregions that have larger numbers of changes typically have active forest-harvesting cycles, whereas ecoregions that have low numbers of changes usually are characterized by increased urban development. See appendix 2 for key to ecoregion abbreviations.
The overall spatial change (the percentage of land area that changed at least one time) in the Eastern United States ecoregions between 1973 and 2000 was 12.5 percent (table 2), meaning that $207,177 \mathrm{~km}^{2}$ of $1,653,852 \mathrm{~km}^{2}$ changed one or more times. However, the overall amount of change masks the geographic variability of change, which ranged from a low of 2.0 percent in the Blue Ridge Mountains Ecoregion to a high of 24.6 percent in the Southern Coastal Plain Ecoregion (fig. 2). The highest amounts of change generally were in ecoregions that have active timber harvesting, whereas the lowest amounts of change were in ecoregions in which urbanization was the leading driver of land change (table 2). In the Southeastern United States Ecoregions, where change in forest land-cover class was dominant, the overall amount of change was 18.9 percent. In the Appalachian Mountains Ecoregions, where change was far more heterogeneous, the amount of change was 5.8 percent. In the Mid-Atlantic Coast Ecoregions, where urban development dominated land change, the overall amount of change was 5.9 percent. The overall amount of change in the Northeastern United States Ecoregions (8.2 percent) was associated with forest land use.

No single story of land-use/land-cover change in the Eastern United States during the 27-year study period (1973-2000) has emerged. Instead, 20 distinct stories in the 20 ecoregions can be told. Generally speaking, most change was associated with forest harvesting and regrowth, agricultural abandonment, and development. However, in certain ecoregions that have unique natural resources, other conversion mechanisms that correspond to those unique resources were in play. For example, coal mining was an important contributor to land change in the Central Appalachians, Southwestern 
Table 2. Overall spatial change in each Eastern United States ecoregion (in square kilometers and as percent of ecoregion) for entire study period (1973 to 2000) and corresponding margin-of-error values for 85-percent confidence interval (in brackets).

\begin{tabular}{|c|c|c|c|}
\hline \multirow{2}{*}{ Ecoregion } & \multirow{2}{*}{$\begin{array}{l}\text { Ecoregion } \\
\text { area }\left(\mathbf{k m}^{2}\right)\end{array}$} & \multicolumn{2}{|c|}{ Overall spatial change [margin of error] } \\
\hline & & $\left(\mathrm{km}^{2}\right)$ & (\% of ecoregion) \\
\hline \multicolumn{4}{|c|}{ Northeastern United States Ecoregions } \\
\hline Laurentian Plains and Hills Ecoregion & 50,153 & $4,714[802]$ & $9.4[1.6]$ \\
\hline Northeastern Highlands Ecoregion & 127,107 & $11,313[4,195]$ & 8.9 [3.3] \\
\hline Eastern Great Lakes and Hudson Lowlands Ecoregion & 60,591 & $3,393[788]$ & $5.6[1.3]$ \\
\hline Totals & 237,851 & $19,420[4,281]$ & $8.2[1.8]$ \\
\hline \multicolumn{4}{|c|}{ Mid-Atlantic Coast Ecoregions } \\
\hline Northeastern Coastal Zone Ecoregion & 37,158 & $2,118[334]$ & $5.7[0.9]$ \\
\hline Atlantic Coastal Pine Barrens Ecoregion & 19,230 & $1,115[404]$ & $5.8[2.1]$ \\
\hline Northern Piedmont Ecoregion & 30,120 & $1,867[331]$ & $6.2[1.1]$ \\
\hline Totals & 86,508 & $5,101[606]$ & $5.9[0.7]$ \\
\hline \multicolumn{4}{|c|}{ Appalachian Mountains Ecoregions } \\
\hline Northern Appalachian Plateau and Uplands Ecoregion & 29,919 & 718 [209] & $2.4[0.7]$ \\
\hline North Central Appalachians Ecoregion & 30,522 & $1,892[610]$ & $6.2[2.0]$ \\
\hline Western Allegheny Plateau Ecoregion & 84,738 & $5,169[1,102]$ & $6.1[1.3]$ \\
\hline Central Appalachians Ecoregion & 59,738 & $5,436[896]$ & $9.1[1.5]$ \\
\hline Ridge and Valley Ecoregion & 111,043 & $6,107[1,221]$ & $5.5[1.1]$ \\
\hline Interior Plateau Ecoregion & 127,810 & $5,751[1,406]$ & $4.5[1.1]$ \\
\hline Southwestern Appalachians Ecoregion & 35,341 & $4,877[1,308]$ & $13.8[3.7]$ \\
\hline Blue Ridge Mountains Ecoregion & 47,791 & 956 [239] & $2.0[0.5]$ \\
\hline Totals & 526,901 & $30,907[2,634]$ & $5.8[0.5]$ \\
\hline \multicolumn{4}{|c|}{ Southeastern United States Ecoregions } \\
\hline Piedmont Ecoregion & 165,460 & $23,992[7,611]$ & $14.5[4.6]$ \\
\hline Mississippi Valley Loess Plains Ecoregion & 43,775 & $6,041[1,488]$ & $13.8[3.4]$ \\
\hline Southeastern Plains Ecoregion & 336,141 & $68,573[13,109]$ & $20.4[3.9]$ \\
\hline Middle Atlantic Coastal Plain Ecoregion & 89,686 & $16,143[4,036]$ & $18.0 \quad[4.5]$ \\
\hline Southern Coastal Plain Ecoregion & 145,123 & $35,700[5,370]$ & $24.6[3.7]$ \\
\hline Southern Florida Coastal Plain Ecoregion & 22,407 & $1,300[515]$ & $5.8[2.3]$ \\
\hline Totals & 802,591 & $151,749[15,249]$ & $18.9[1.9]$ \\
\hline All Eastern United States ecoregions & $1,653,852$ & $207,177[1,654]$ & $12.5[1.0]$ \\
\hline
\end{tabular}

Appalachians, and Western Allegheny Plateau Ecoregions, as was phosphate mining in the Southern Coastal Plain Ecoregion.

Estimates of gross spatial change and net areal change for each land-cover class in the 20 Eastern United States ecoregions are found in table 3 . Both net- and gross-change statistics must be taken into account when considering land change. The net change in a given land-cover class is the result of the losses in that land-cover class subtracted from the gains, thus, representing the difference in land-cover area between two study dates. On the other hand, gross change is the total area gained and lost in a particular land-cover class (for example, the sum of increases and decreases in forest land-cover class), representing the total area modified between study dates. Gross change is important because it provides a clear indication of the overall amount of change that affected specific land-cover classes, rather than at just two points in time of a specific land-cover class.

The five land-cover classes that had the largest net areal change (either gains or losses) over the entire study period (1973-2000) are as follows (table 3):

- Forest, $-37,271 \mathrm{~km}^{2}$ (margin of error, 7,003 km²)

- Developed, $36,807 \mathrm{~km}^{2}$ (margin of error, $5,156 \mathrm{~km}^{2}$ )

- Agriculture, $-24,947 \mathrm{~km}^{2}$ (margin of error, $5,009 \mathrm{~km}^{2}$ )

- Mechanically disturbed, $20,369 \mathrm{~km}^{2}$ (margin of error, $4,055 \mathrm{~km}^{2}$ )

- Grassland/Shrubland, $8,215 \mathrm{~km}^{2}$ (margin of error, 2,412 $\mathrm{km}^{2}$ ) 
Table 3. Gross spatial changes and net areal changes in land-use/land-cover classes in all 20 Eastern United States ecoregions during entire study period (1973 to 2000) and corresponding margin-of-error values for 85-percent confidence interval (in brackets).

\begin{tabular}{lcccc}
\hline \multirow{2}{*}{\begin{tabular}{l} 
Land-use/land-cover class \\
\cline { 2 - 5 }
\end{tabular}} & \multicolumn{2}{c}{$\begin{array}{c}\text { Gross spatial change (1973-2000) } \\
\text { [margin of error] }\end{array}$} & \multicolumn{2}{c}{$\begin{array}{c}\text { Net areal change (1973-2000) } \\
\text { [margin of error] }\end{array}$} \\
\cline { 2 - 5 } & $\mathbf{( \mathbf { k m } ^ { 2 } )}$ & $\mathbf{( \% \text { of area) }}$ & $\mathbf{( k m}$ ) & (\% change) \\
\hline Water & $3,965[1,111]$ & $0.2[0.1]$ & $2,340[770]$ & 3.6 \\
Developed & $37,282[6,049]$ & $2.3[0.4]$ & $36,807[5,156]$ & 26.6 \\
Mechanically disturbed & $116,623[24,564]$ & $7.1[1.5]$ & $20,369[4,055]$ & 119.9 \\
Mining & $14,241[4,030]$ & $0.9[0.2]$ & $-467[1,876]$ & -6.8 \\
Barren & $154[86]$ & $<0.1[<0.1]$ & $4[24]$ & 0.4 \\
Forest & $172,872[30,572]$ & $10.5[1.8]$ & $-37,271[7,003]$ & -4.1 \\
Grassland/Shrubland & $30,531[5,220]$ & $1.8[0.3]$ & $8,215[2,412]$ & 71.2 \\
Agriculture & $51,429[10,068]$ & $3.1[0.6]$ & $-24,947[5,009]$ & -6.5 \\
Wetland & $13,000[3,092]$ & $0.8[0.2]$ & $-6,053[2,208]$ & -4.7 \\
Nonmechanically disturbed & $1,971[1,200]$ & $0.1[0.1]$ & $1,002[1,124]$ & 620.1 \\
\hline
\end{tabular}

Table 4. Net areal changes in land-use/land-cover classes in all 20 Eastern United States ecoregions during each of four time periods and corresponding margin-of-error values for 85-percent confidence interval (in brackets).

[See appendix 3 for definitions of land-use/land-cover classifications]

\begin{tabular}{lcccc}
\hline \multirow{2}{*}{ Land-use/land-cover class } & \multicolumn{4}{c}{ Net change [margin of error] (km²) } \\
\cline { 2 - 5 } & $\mathbf{1 9 7 3 - 1 9 8 0}$ & $\mathbf{1 9 8 0 - 1 9 8 6}$ & $\mathbf{1 9 8 6 - 1 9 9 2}$ & $\mathbf{1 9 9 2 - 2 0 0 0}$ \\
\hline Water & $465[255]$ & $758[469]$ & $-7[384]$ & $1,119[473]$ \\
Developed & $7,275[1,615]$ & $6,826[1,098]$ & $9,289[1,487]$ & $13,353[2,180]$ \\
Mechanically disturbed & $2,733[3,242]$ & $5,761[3,060]$ & $7,991[4,040]$ & $3,848[4,325]$ \\
Mining & $1,114[781]$ & $-37[520]$ & $-738[828]$ & $-8051,461]$ \\
Barren & $-10[24]$ & $-13[14]$ & $6[9]$ & $20[27]$ \\
Forest & $-12,113[4,462]$ & $-10,109[3,097]$ & $-7,125[6,050]$ & $-7,858[5,597]$ \\
Grassland/Shrubland & $2,246[787]$ & $2,924[1,353]$ & $2,803[1,504]$ & $228[1,881]$ \\
Agriculture & $-447[1,656]$ & $-4,822[1,950]$ & $-12,005[3,297]$ & $-7,629[2,299]$ \\
Wetland & $-1,246[1,084]$ & $-1,609[638]$ & $82[683]$ & $-3,270[1,169]$ \\
Nonmechanically disturbed & $-18[215]$ & $321[350]$ & $-297[242]$ & $993[1,133]$ \\
\hline
\end{tabular}

The five land-cover classes that had the highest gross spatial change over the entire study period (1973-2000) are as follows (table 3):

- Forest, $172,872 \mathrm{~km}^{2}$ (margin of error, $30,572 \mathrm{~km}^{2}$ )

- Mechanically disturbed, $116,623 \mathrm{~km}^{2}$ (margin of error, 24,564 $\mathrm{km}^{2}$ )

- Agriculture, $51,429 \mathrm{~km}^{2}$ (margin of error, $10,068 \mathrm{~km}^{2}$ )

- Developed, 37,282 $\mathrm{km}^{2}$ (margin of error, $6,049 \mathrm{~km}^{2}$ )

- Grassland/Shrubland, $30,531 \mathrm{~km}^{2}$ (margin of error, $5,220 \mathrm{~km}^{2}$ )

A summary of net areal change in each land-cover class for each time period can be found in table 4. Discussions of individual land-cover classes follow.

\section{Forest Land-Cover Class}

Forest experienced the largest amount of change of any land-cover class in the 20 Eastern United States ecoregions during the 27-year study period. Between 1973 and 2000, $105,562 \mathrm{~km}^{2}$ converted to forest land cover, whereas 142,833 $\mathrm{km}^{2}$ of forested land converted to other land-cover classes, resulting in a net loss of $37,271 \mathrm{~km}^{2}$ (table 3 ), a 4.1 percent decrease. This amount of net change, however, masks the true amount of change (that is, turnover) in forested land. The gross change in forest in the Eastern United States was $172,872 \mathrm{~km}^{2}$ (table 3), meaning that 10.5 percent experienced a conversion either to or from the forest land-cover class. 

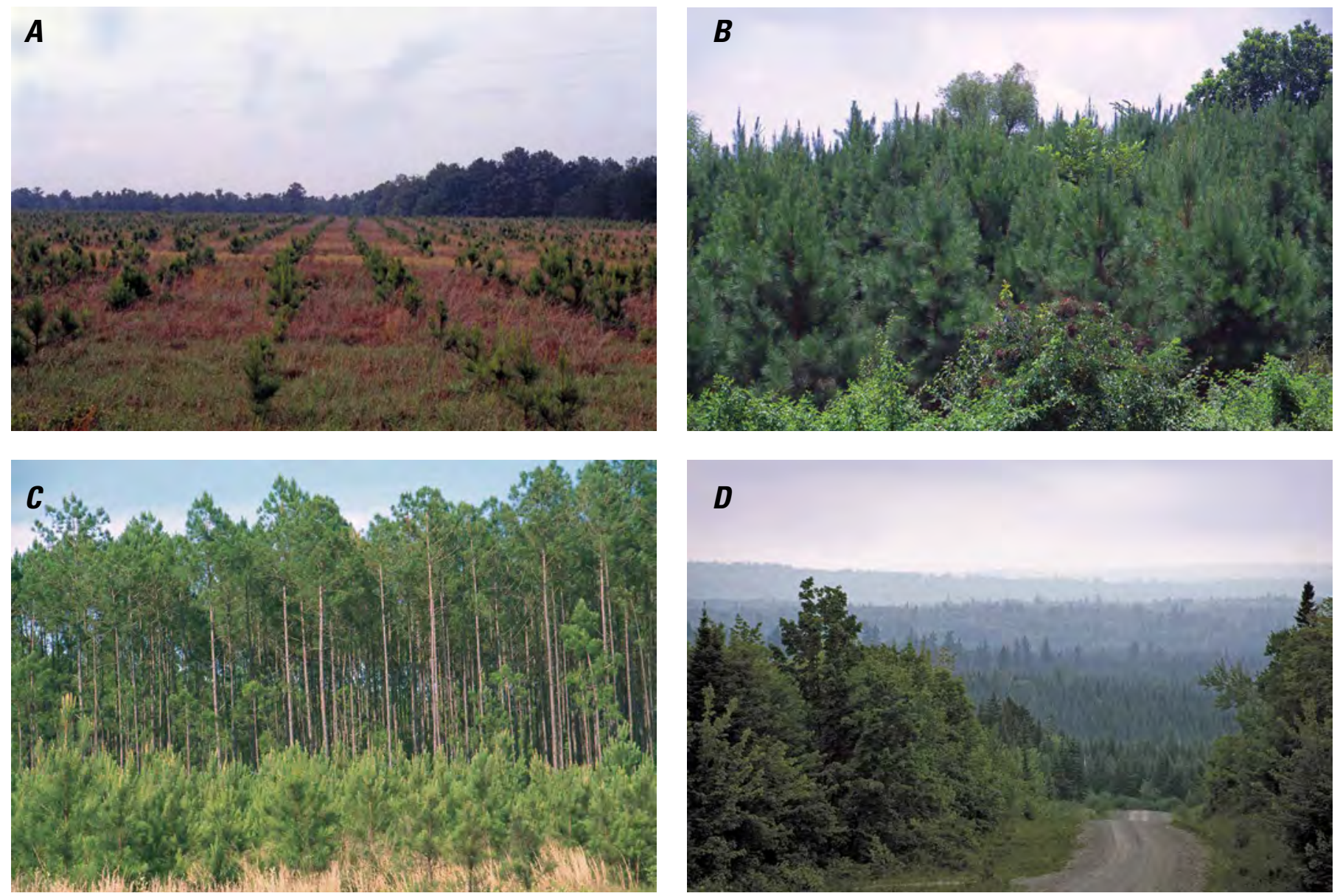

Figure 3. Forested areas in Eastern United States. A, Young pine plantation southwest of Augusta, Georgia, in Southeastern Plains Ecoregion. $B$, Pine plantation north of Jackson, Mississippi, in Mississippi Valley Loess Plains Ecoregion. $C$, Pine plantation that has both young and old trees northeast of Panama City, Florida, in Southern Coastal Plain Ecoregion. $D$, Forest landscape in west-central Maine, in Northeastern Highlands Ecoregion.

Timber production is very important throughout the 20 Eastern United States ecoregions. The Southeastern United States Ecoregions, especially the Southeastern Plains, Southern Coastal Plain, Middle Atlantic Coastal Plain, and Mississippi Valley Loess Plains Ecoregions, contain vast expanses of industrial-scale pine plantations (fig. 3). These ecoregions have a climate advantage that permits harvest cycles of 20 to 25 years for loblolly pine (Pinus taeda) and other southern pine species (Gresham, 2002). Large-scale timber production also is important in the Northeastern United States Ecoregions, especially in the Northeastern Highlands Ecoregion and, to a lesser extent, the Laurentian Plains and Hills Ecoregion.

Only the Mississippi Valley Loess Plains Ecoregion experienced an increase in forest ( 0.6 percent increase); all other Eastern United States ecoregions experienced a decrease. The Piedmont and Southern Coastal Plain Ecoregions experienced the greatest loss of forest $(-4.8$ and -4.2 percent, respectively). Other ecoregions that experienced significant losses in forest were the Northeastern Highlands ( -3.9 percent), Northeastern Coastal Zone ( -3.7 percent),
Middle Atlantic Coastal Plain ( -3.4 percent), and Central Appalachians ( -3.3 percent) Ecoregions (fig. 4C).

The principal conversion from forest was to mechanically disturbed, which consists of clearcut and recently harvested forest. More than $31,000 \mathrm{~km}^{2}$ of forest changed to this transitional land-cover class (fig. 5), suggesting that forest change is very dynamic and cyclic in nature. Southern pine-forest land when harvested or clearcut is classified as mechanically disturbed. The cleared land typically remains in a mechanically disturbed state for a brief period and then is replanted with trees; in some cases, however, the land is left alone for natural regeneration. In much of the South, planted pine trees can reach heights of $2 \mathrm{~m}$ within two years. Thus, the conversion from forest to mechanically disturbed is indicative of extensive timber production in the South. In the northern ecoregions and in certain marginal areas in other ecoregions, slower growth rates can result in a longer forest-cutting-and-regrowth cycle; in such areas, the typical conversion cycle is from forest to mechanically disturbed, then to grassland/shrubland and back to forest. 

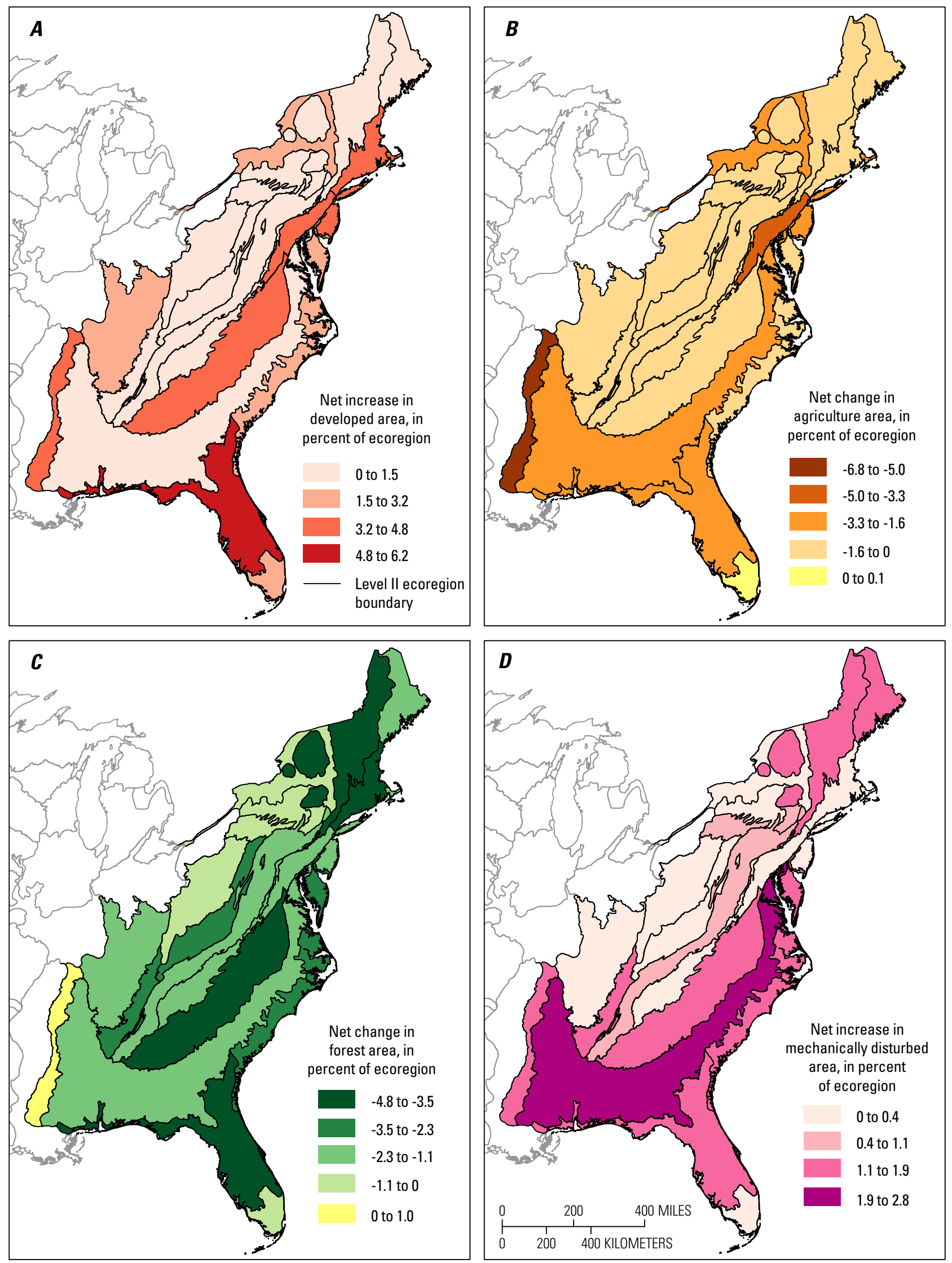

Figure 4. Maps showing net change for $(A)$ developed, $(B)$ agriculture, $(C)$, forest, and $(D)$ mechanically disturbed land-cover classes, for all 20 Eastern United States ecoregions. 
Approximately $19,000 \mathrm{~km}^{2}$ of forest converted to developed (fig. 5); in addition, 7,900 $\mathrm{km}^{2}$ of agricultural land either converted to forest (for example, in Southeastern Plains Ecoregion and in Mississippi Valley Loess Plains Ecoregion) or were abandoned, resulting in afforestation (for example, in Northern Appalachian Plateau and Uplands Ecoregion and in Eastern Great Lakes and Hudson Lowlands Ecoregion). Most conversions from agriculture to forest were motivated by the relative difference in profitability between timber and agricultural uses. After 1986, however, conversion from agriculture to forest and subsequent gains in forest area were often caused by the Conservation Reserve Program, which removed sensitive areas of farmland from production to reduce soil loss.

Forest land use (that is, land managed for the production of forest products or maintained as woody vegetation for indirect benefits such as protection of watersheds or for recreational purposes) declined less rapidly than forest land cover (that is, land covered with trees). Note that harvested forest, where trees may be replanted or regenerated, can be classified as forest land use, even though no trees are present. Although harvested areas generally are replanted with timber, the cycles of forest land use have caused a net decline in the total area of forest land cover. Consider that, in the Eastern United States ecoregions, 78 percent of mechanically disturbed and 73 percent of grassland/shrubland converted back to forest during the study period, implying that the land is continuing to be used for forest production. If those proportions of mechanically disturbed land and grassland/ shrubland revert to forest, then the net loss of forest land use in the Eastern United States ecoregions is $15,387 \mathrm{~km}^{2}$.

\section{Developed Land-Cover Class}

Developed land-cover class includes all the built-up surfaces in the 20 Eastern United States Ecoregions. Most are associated with urban and exurban growth, but this land-cover class also includes transportation systems and many other lowdensity built-up lands (fig. 6). The net increase in the developed land-cover class $\left(36,807 \mathrm{~km}^{2}\right.$; table 3$)$, a 26.6 percent net increase, was almost equal to the loss in the forest land-cover class $\left(-37,271 \mathrm{~km}^{2}\right.$; table 3$)$. The gross change in the developed land-cover class was fairly similar $\left(37,282 \mathrm{~km}^{2}\right.$; table 3$)$ owing to the unidirectional nature of urban growth. Between 1970 and 2000, population in counties within the 20 Eastern United States ecoregions increased by 32.6 percent, from 93.3 million to 123.8 million people (U.S. Census Bureau, 1970-2000 [various years]). The Eastern United States ecoregions that experienced the largest increase in the developed land-cover class during the study period were the Southern Coastal Plain (6.2 percent), Atlantic Coastal Pine Barrens (4.7 percent), Northern Piedmont (4.6 percent), Piedmont (4.5 percent), Mississippi Valley

Loess Plains (4.3 percent), and Northeastern Coastal Zone (4.0 percent) Ecoregions (fig. 4A).

Most newly developed land converted from forest $(19,145$

$\mathrm{km}^{2}$ ) or agriculture $\left(11,879 \mathrm{~km}^{2}\right)$ during the study period (fig. 7). In the Northeastern United States Ecoregions, where agricultural land preservation is important, conversions to developed from forest were more common than those from agriculture. For example, in the Northeastern Coastal Zone Ecoregion, more forest converted to developed than did agriculture, by a 4-to-1 margin, and, in the Northeastern Highlands Ecoregion, the ratio was 10 to 1. However, in the Mississippi Valley Loess Plains Ecoregion, more development occurred on agricultural land than forested land, by a nearly 3-to-1 margin, and in the Atlantic Coastal Pine Barrens and Northern Piedmont Ecoregions, the ratio was 2 to 1 . It is important, however, to recognize that changes over the entire 27-year study period often mask the variability and specific margins of conversion that occurred during each of the four time periods.

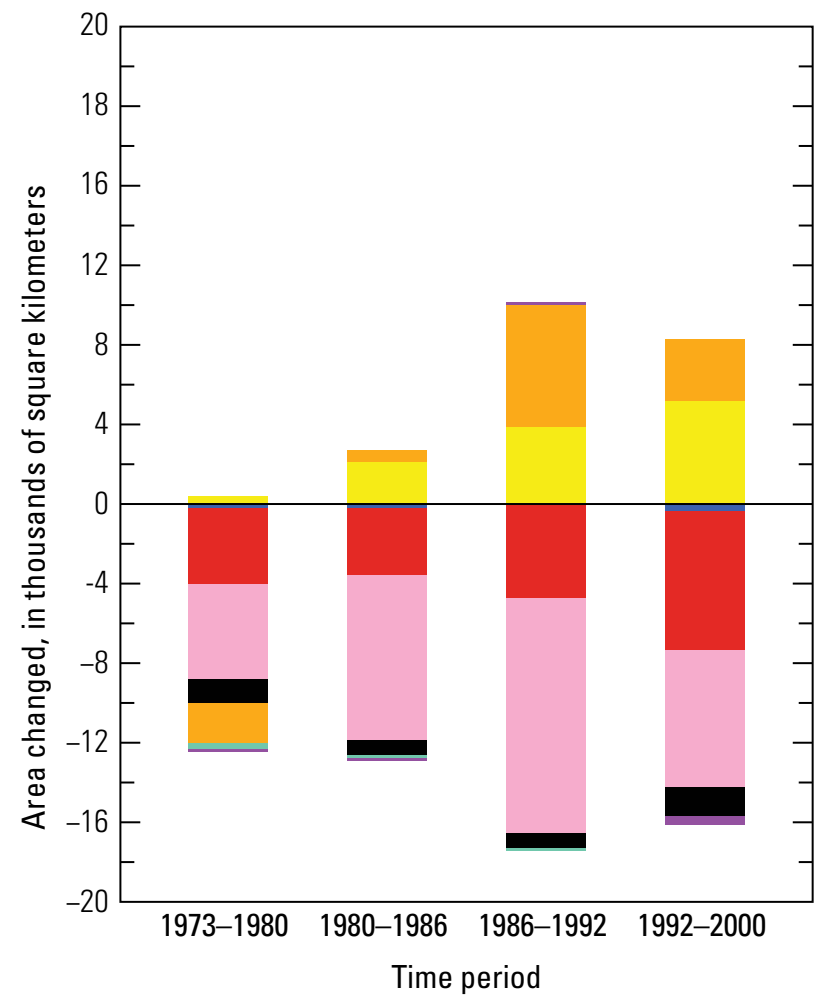

EXPLANATION

Land-use/land-cover class

$\begin{array}{ll}\square \text { Water } & \text { Forest } \\ \text { Developed } & \text { Grassland/Shrubland } \\ \square \text { Transitional } & \square \text { Agriculture } \\ \text { Mining } & \text { Wetland } \\ \square \text { Barren } & \text { Ice/Snow }\end{array}$

Figure 5. Gross change (area gained from, and lost to, other land-cover classes) in forest land-cover class in all 20 Eastern United States ecoregions during entire study period (1973-2000). Colored bars above zero axis indicate land-cover classes that lost area to forest and amounts of area lost, whereas colored bars below zero axis indicate land-cover classes that gained area from forest and amounts of area gained. 

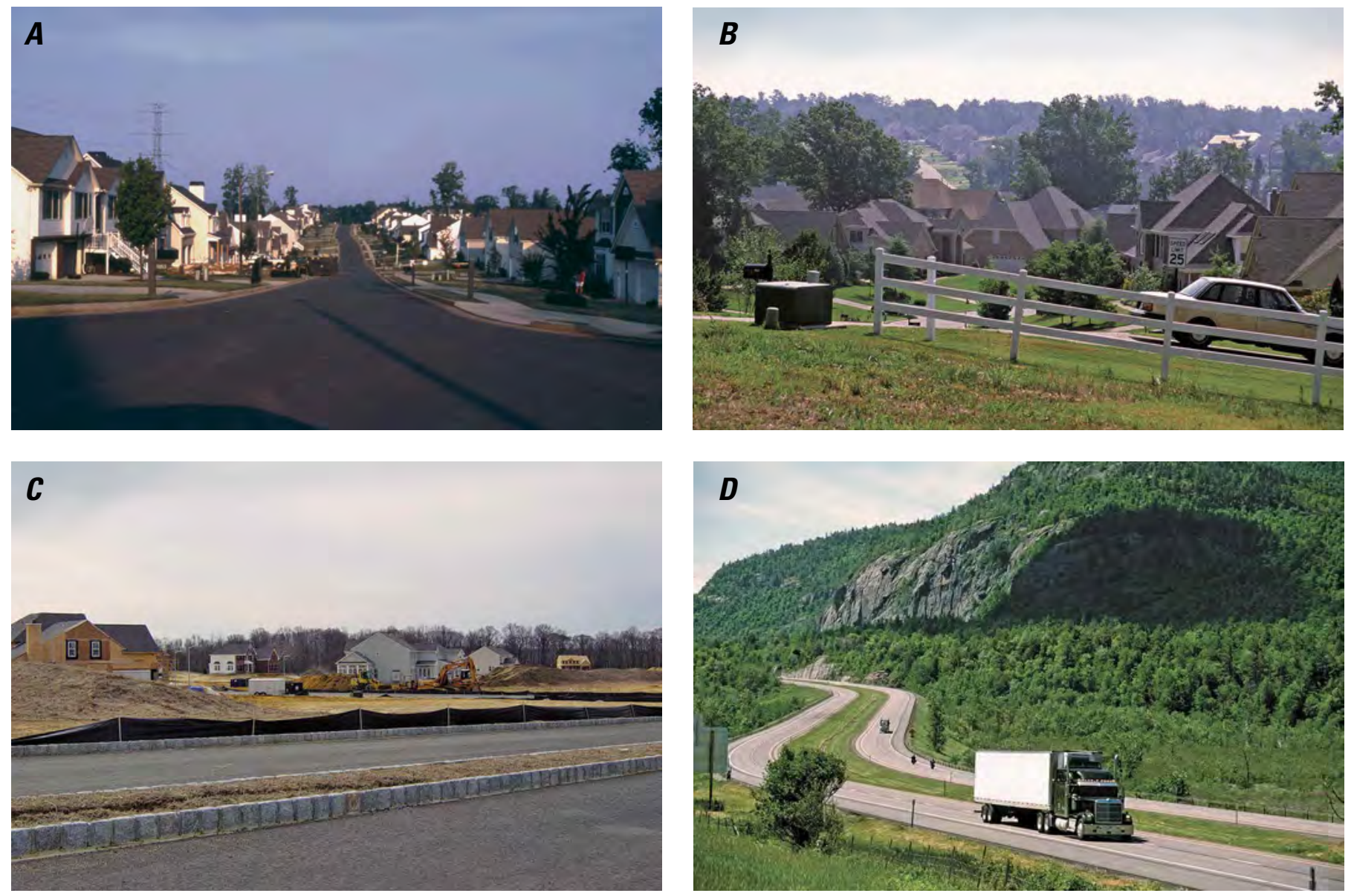

Figure 6. Developed areas in Eastern United States. A, Parkwood Estates housing development northwest of Atlanta, Georgia, in Piedmont Ecoregion. B, Subdivision northeast of Memphis, Tennessee, in Mississippi Valley Loess Plains Ecoregion. C, New subdivision in New Jersey, south of Philadelphia, Pennsylvania, in Atlantic Coastal Pine Barrens Ecoregion. D, Interstate 87, just south of Keeseville, New York, in Northeastern Highlands Ecoregion.

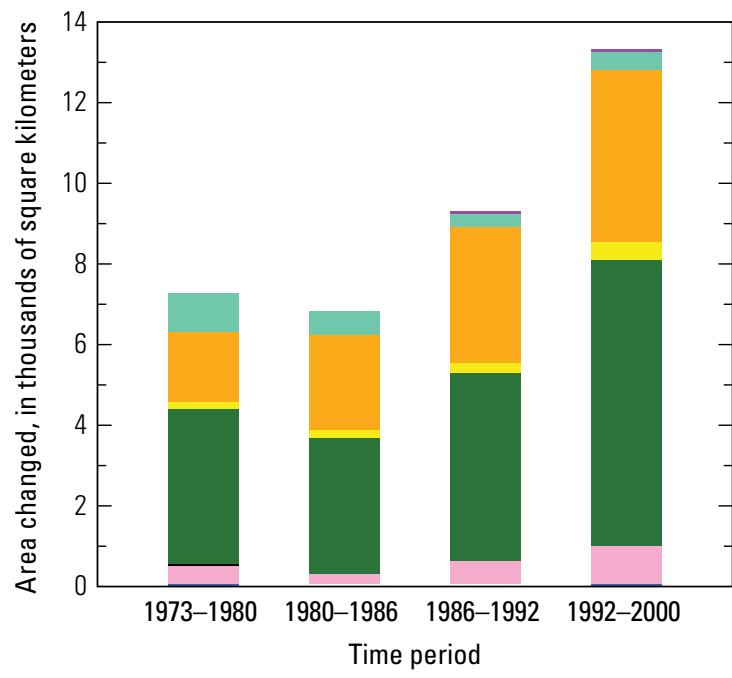

\section{EXPLANATION}

Land-use/land-cover class

Water

$\square$ Developed

$\square$ Transitional

Mining

$\square$ Barren

Forest

Grassland/Shrubland Agriculture

Wetland

Ice/Snow

Figure 7. Estimated area gained in developed land-cover class from other landcover classes in all 20 Eastern United States ecoregions during entire study period (1973-2000). Colored bars indicate land-cover classes that lost area to developed and amounts of area lost. 
The amount of developed land increased at an accelerating rate over the 27-year study period (fig. 7). In each of the four time periods between 1973 and 2000, the percentage of developed land increased, having average annual increases of 0.06 percent (1973-1980), 0.07 percent (1980-1986), 0.09 percent (1986-1992), and 0.10 percent (1992-2000). Although the percentage gains in developed land are relatively small in relation to the overall area, the increasing rate of development may have large effects, such as altering hydrological processes, contributing to urban heat-island effects, threatening biodiversity, and resulting in many other environmental consequences.

\section{Agriculture Land-Cover Class}

Agriculture was the second most common land-cover class in the 20 Eastern United States ecoregions (fig. 8), with an estimated 21.6 percent of the total area in 2000 (table 1). Agriculture declined almost everywhere, experiencing a 6.5 percent net loss $\left(-24,947 \mathrm{~km}^{2}\right)$ between 1973 and 2000. Gross change in agriculture was $51,429 \mathrm{~km}^{2}$ (table 3 ). The only
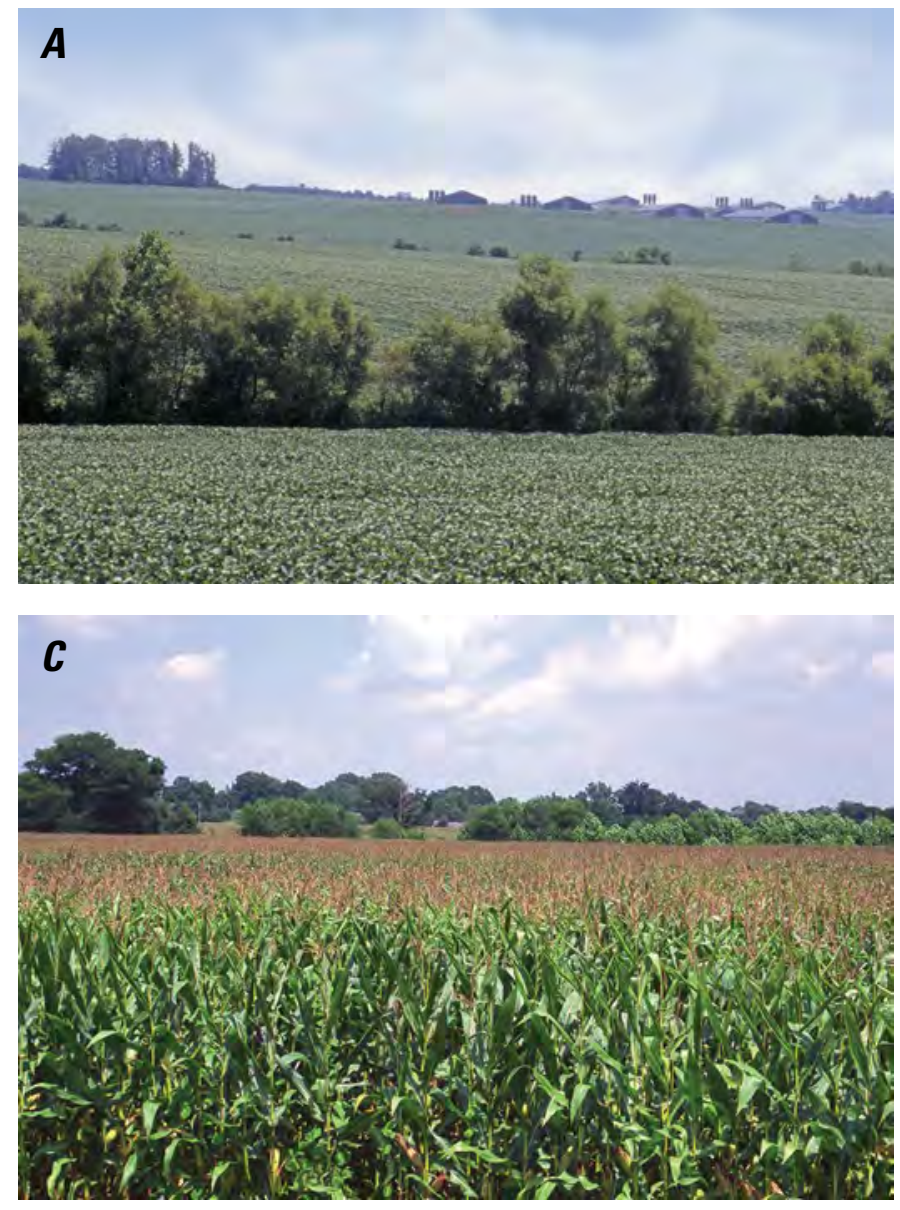

ecoregion that did not experience a loss of agricultural land was the Southern Florida Coastal Plain Ecoregion (fig. 4B). Note that this ecoregion experienced a significant increase in agricultural land between 1973 and 1980 because of the need to replace the sugar cane whose import from Cuba had been banned (Walker and Solecki, 2004). Even in this ecoregion, however, agricultural land declined after 1980, and the net gain over the entire 27-year study period was less than 0.1 percent.

Conversions from agriculture to developed were some of the most common conversions in the Eastern United States ecoregions (11,878 $\mathrm{km}^{2}$ ) (fig. 9), although conversions to forest were more common in the Southeastern United States Ecoregions, where timber production is high. Two ecoregions that experienced substantial conversions from agriculture to developed were the Northern Piedmont and Atlantic Coastal Pine Barrens Ecoregions (3.4 and 3.0 percent, respectively; fig. $4 B$ ). Although the drivers behind the higher rates of conversions from agriculture to developed must still be determined for each individual ecoregion, they likely include lower costs to develop relatively level sites that have better soil-engineering properties.
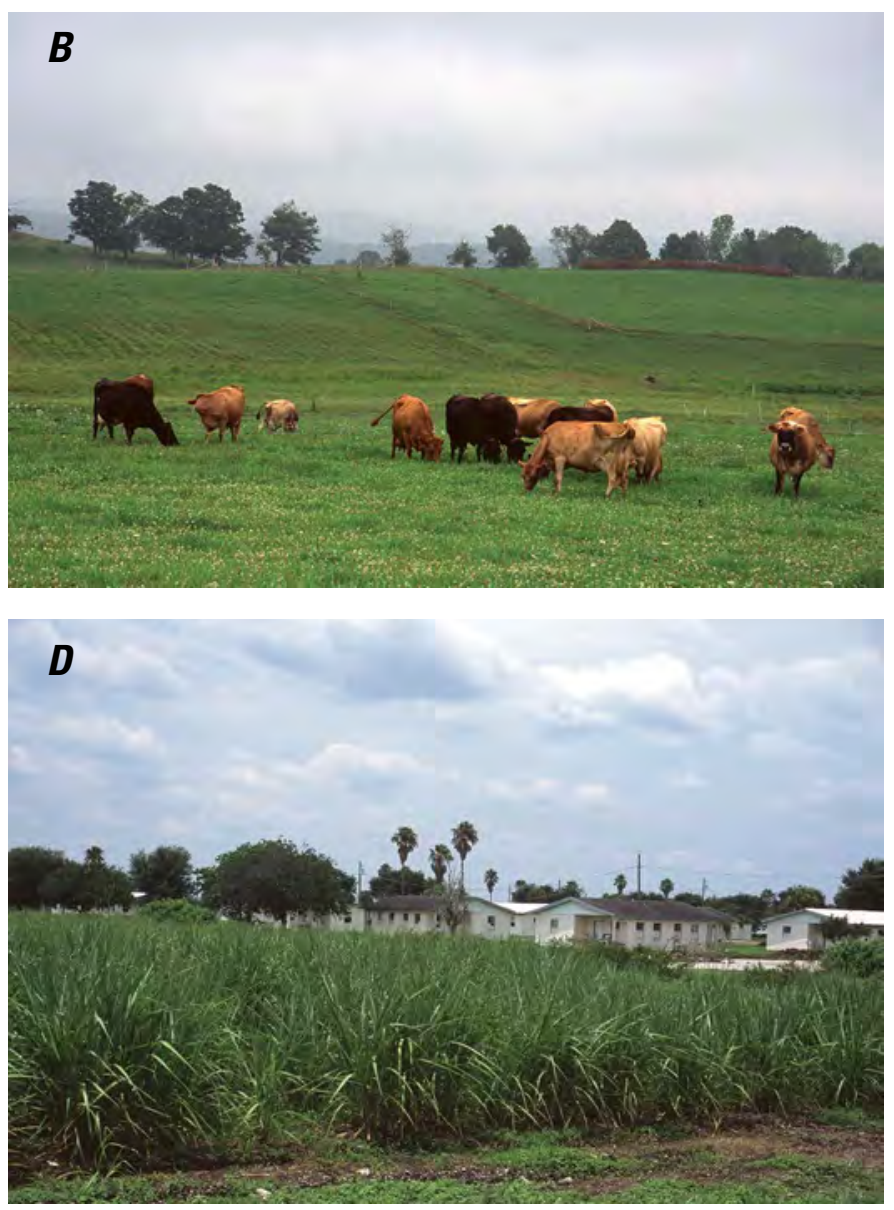

Figure 8. Agricultural areas in Eastern United States. A, Soybean fields with poultry barns in background west of Pageland, South Carolina, in Piedmont Ecoregion. B, Cattle in clover pasture southeast of Sayre, Pennsylvania, in Northern Appalachian Plateau and Uplands Ecoregion. C, Cornfield northeast of Dyersburg, Tennessee, in Mississippi Valley Loess Plains Ecoregion. D, Sugar cane field near housing development west of Pahokee, Florida, in Southern Florida Coastal Plain Ecoregion. 
Substantial conversions from agriculture to forest (more than $12,000 \mathrm{~km}^{2}$ ) occurred in the Mississippi Valley Loess Plains and Southeastern Plains Ecoregions. Note that the rate of agriculture loss accelerated between 1986 and 1992 (fig. 9), indicating that an important driver of change was the enrollment of marginal croplands in the Conservation Reserve Program during that time period. An additional factor that was important in the Northeastern and Southeastern United States Ecoregions (for example, in the Eastern Great Lakes and Hudson Lowlands Ecoregion and in the Southern Coastal Plain Ecoregion) is the abandonment of agricultural land. Nearly $4,500 \mathrm{~km}^{2}$ of agricultural land reverted to grassland/shrubland following cropland abandonment; these lands likely will revert to forest.

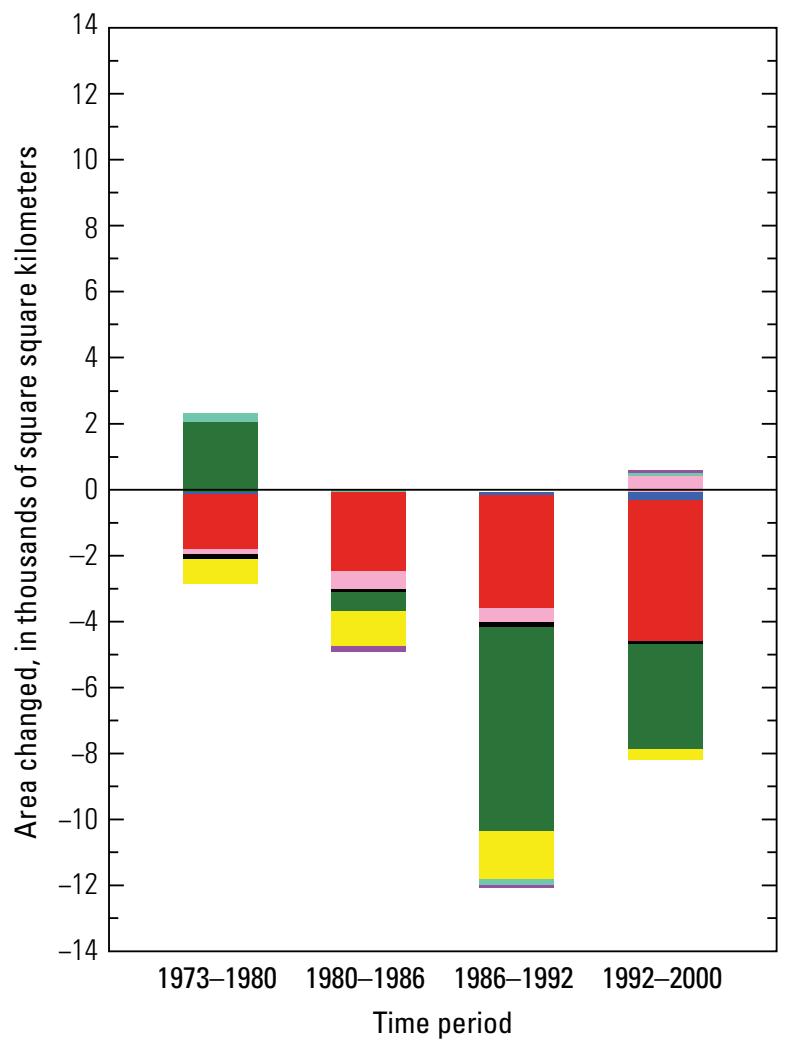

EXPLANATION

Land-use/land-cover class

$\square$ Water
$\square$ Developed
$\square$ Transitional
$\square$ Mining
$\square$ Barren

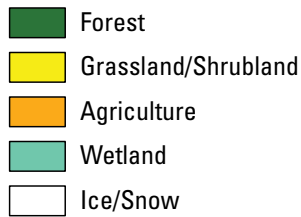

Figure 9. Gross change (area gained from, and lost to, other land-cover classes) in agriculture land-cover class in all 20 Eastern United States ecoregions during entire study period (1973-2000). Colored bars above zero axis indicate land-cover classes that lost area to agriculture and amounts of area lost, whereas colored bars below zero axis indicate land-cover classes that gained area from agriculture and amounts of area gained.

\section{Transitional Land-Cover Classes}

A less obvious dimension of change in the 20 Eastern United States ecoregions involves the transitional landcover classes - mechanically disturbed, nonmechanically disturbed, and grassland/shrubland - that represent transitional stages of land-use/land-cover change (fig. 10). For example, forest that is harvested, whether planned for replanting or regeneration, goes through a transitional stage: in the Southeastern United States Ecoregions, this stage typically is mechanically disturbed; in the Northeastern United States Ecoregions, the typical conversion is from mechanically disturbed to grassland/shrubland. In addition, afforestation associated with abandoned agricultural land typically experiences a grassland/shrubland stage.

At any one time during the 27-year study period, the amount of grassland/shrubland or mechanically disturbed was relatively small. For example, the amount of grassland/ shrubland in 1980 was $13,792 \mathrm{~km}^{2}$, whereas the amount of mechanically disturbed was $19,724 \mathrm{~km}^{2}$. Between 1973 and 2000, the net change in grassland/shrubland and mechanically disturbed was 8,215 and $20,369 \mathrm{~km}^{2}$, respectively (table 3 ); together, the net gain in these two transitional land-cover classes was $28,584 \mathrm{~km}^{2}$, the third largest net land-cover change. The gross amount of transitional land during the 27-year study period was $147,154 \mathrm{~km}^{2}$ (table 3 ), the second largest gross change in the 20 Eastern United States ecoregions.

All mechanically disturbed lands are transitional, with 78 percent destined for forest land cover. Most of the remaining mechanically disturbed lands reverted to wetlands, primarily owing to timber harvesting of wooded wetlands in the Southeastern United States Ecoregions, although a smaller percentage converted to developed. Approximately 73 percent of grassland/shrubland reverted to forest, and most of the remaining grassland/shrubland converted to agriculture.

The nonmechanically disturbed land-cover class reflects changes associated with wildfires, insect infestations, storms, and other similar naturally occurring events. Overall, very few instances of nonmechanical disturbance occurred in the 20 Eastern United States ecoregions. The major examples of nonmechanical disturbance were fires in the Southern Coastal Plain and Southern Florida Coastal Plain Ecoregions, as well as tornado damage in the North Central Appalachians Ecoregion.

Transitional land-cover classes represent short- to medium-term land disturbances. Mechanically disturbed land is particularly prone to erosion, causing the sedimentation of nearby streams. Mechanical disturbances also affect weather and climate variability by increasing surface albedo (Barnes, 2008). They also can alter regional carbon balances, owing to the removal of significant carbon stocks, and they can adversely affect habitat conditions and, ultimately, biodiversity. 

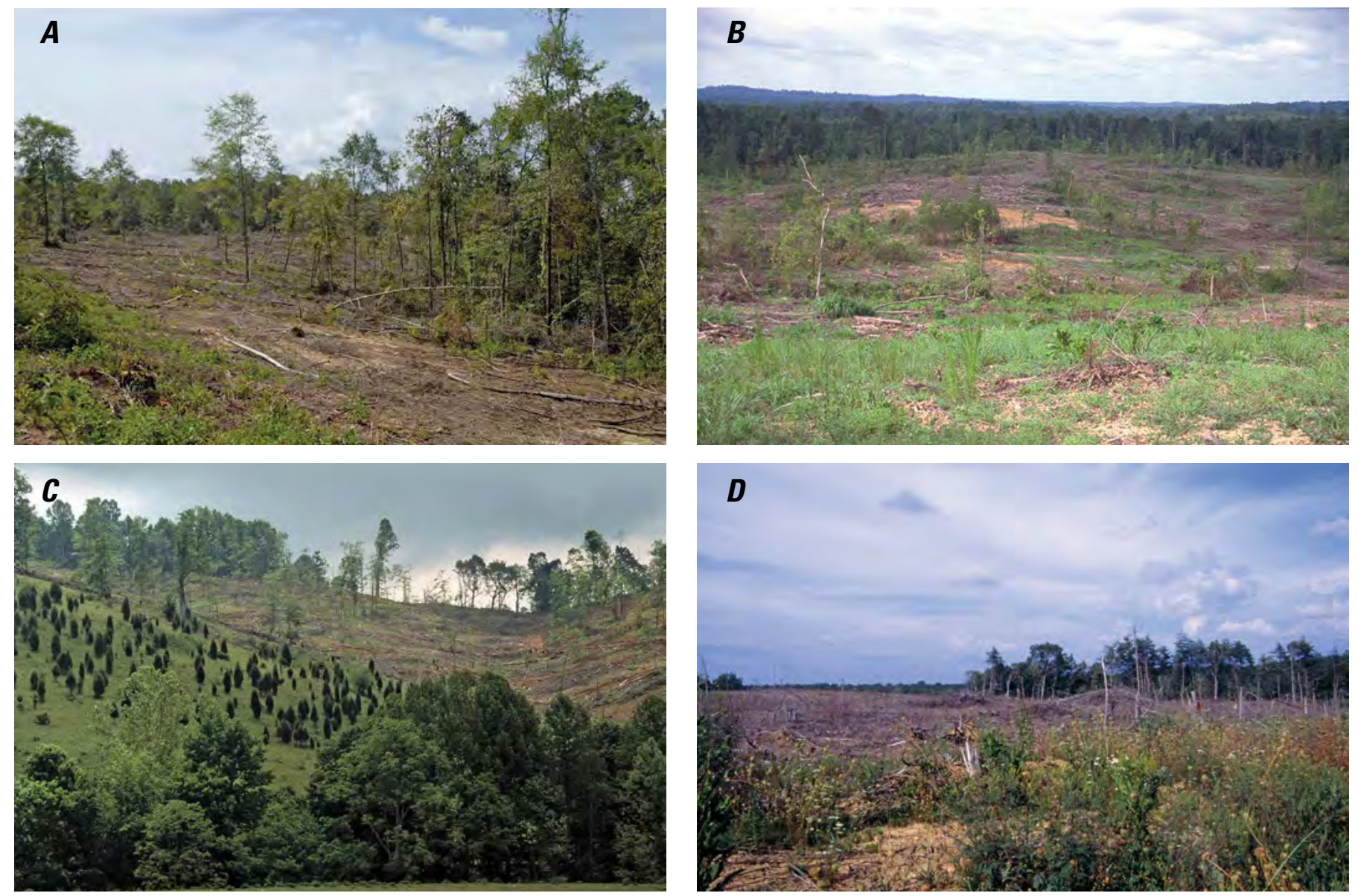

Figure 10. Mechanically disturbed areas in Eastern United States. A, Newly clearcut area in southeastern Mississippi, in Southeastern Plains Ecoregion. $B$, Large clearcut area southwest of Jackson, Mississippi, in Mississippi Valley Loess Plains Ecoregion. $C$, Clearcut hillside east of Lebanon, Virginia, in Ridge and Valley Ecoregion. D, Cleared land west of Crossville, Tennessee, in Southwestern Appalachians Ecoregion.

\section{Water and Wetland Land-Cover Classes}

The water and wetland land-cover classes (fig. 11) covered 4.1 and 7.5 percent, respectively, of the 20 Eastern United States ecoregions in 2000. During the 27-year study period, water increased by 0.1 percent, whereas wetland declined by 0.3 percent (table 1). The largest increases in surface water occurred in the Southern Coastal Plain Ecoregion (0.6 percent) and in the Southern Florida Coastal Plain Ecoregion ( 0.4 percent). In both ecoregions, dredging or other forms of excavation of wetlands for waterfront residential developments were significant reasons for the increase. In the Piedmont Ecoregion ( 0.2 percent), the increase was associated with the development of reservoirs to meet the needs of the expanding population base; the Piedmont Ecoregion has limited groundwater resources, thus, the municipal- and industrial-water supply relies on surface-water impoundments (Daniel and Dahlen, 2002).

About one-third of the 20 Eastern United States ecoregions experienced essentially no change in area of wetlands. The ecoregions that experienced a significant loss of wetlands were the Southern Coastal Plain Ecoregion
(-2.4 percent), the Southern Florida Coastal Plain Ecoregion ( -1.6 percent), and the Middle Atlantic Coastal Plain Ecoregion ( -1.3 percent). All three ecoregions have extensive wetland areas. Agricultural development and urbanization contributed to wetland loss in the Middle Atlantic Coastal Plain and Southern Florida Coastal Plain Ecoregions, whereas urban growth was the primary factor in the Southern Coastal Plain Ecoregion.

\section{Mining Land-Cover Class}

Although the area of the mining land-cover class (fig. 12) remained essentially unchanged across the 20 Eastern United States ecoregions between 1973 and 2000 (table 1), it actually represents the balance between ecoregions that experienced expanded mining operations and several ecoregions that had mining losses. For example, the mining land-cover class increased by 1.5 percent in the Central Appalachians Ecoregion because of expanding coal-mining operations, but it shrunk by 1.2 percent in the Southern Coastal Plain Ecoregion owing 

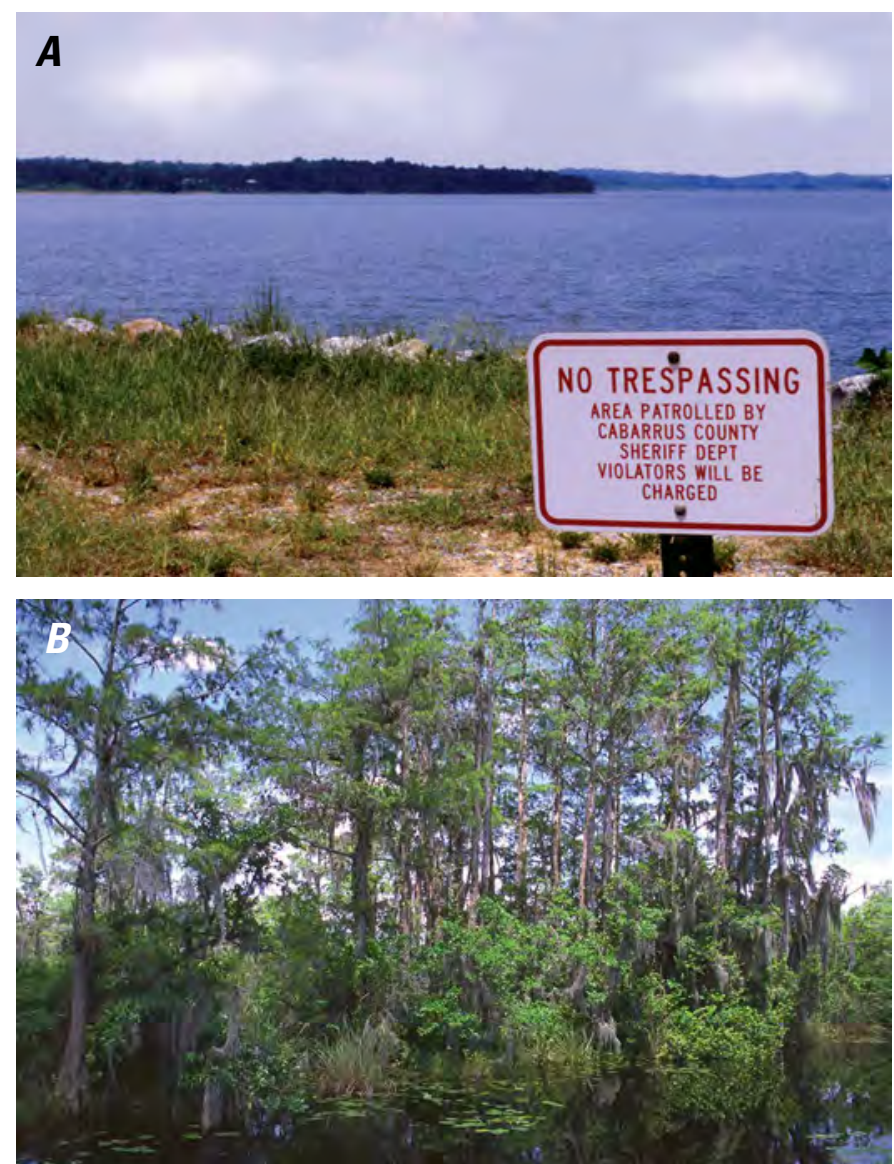

Figure 11. Water and wetland areas in Eastern United States. $A$, Lake Howell (formerly called "Coddle Creek Reservoir"), constructed in 1992-93 west of Kannapolis, North Carolina, in Piedmont Ecoregion. $B$, Wooded wetland in The Everglades, in Southern Florida Coastal Plain Ecoregion.

to a reduction in phosphate mining. Declines in coal mining in the Southwestern Appalachians and Western Allegheny Plateau Ecoregions resulted in a loss of 0.9 and 0.4 percent, respectively, in the mining land-cover class. It is also notable, although to a lesser degree, that rapidly urbanizing ecoregions such as the Northeastern Coastal Zone Ecoregion usually had an increase in aggregate (sand and gravel) mining during the study period. Mined lands in which resources have been exhausted typically were restored to grassland/shrubland or forest.

\section{Barren Land-Cover Class}

No significant changes in the barren land-cover class were found in the 20 Eastern United States ecoregions.

\section{Summary}

Land change in the Eastern United States during the study period was connected primarily to timber harvesting and urban growth. The climate in the Southeastern United States provides the foundation for forest activity: short harvest cycles mean that a substantial amount of land is cycling from forest to cleared conditions (mechanically disturbed) and back to forest. Across the East, agricultural land either is being converted to forest (for example, in the Southeastern United States Ecoregions) or is reverting to forest (for example, in the Northeastern United States Ecoregions) owing to agricultural abandonment. Urban growth, as measured by the increase in the developed landcover class, is expanding and accelerating across the East. All ecoregions are experiencing substantial increases in developed land. Agricultural lands are being lost to urban growth and to forestry practices. Also associated with timber harvesting and expanded urban development is the large amount of transitional, disturbed lands. Timber harvesting and replanting has resulted in conversions from forest to mechanically disturbed to forest in the Southeastern United States Ecoregions and from forest to mechanically disturbed to grassland/shrubland in the Northeastern United States Ecoregions. Transitional land-cover classes represent significant amounts of disturbance that may have adverse consequences for environmental and ecological systems.
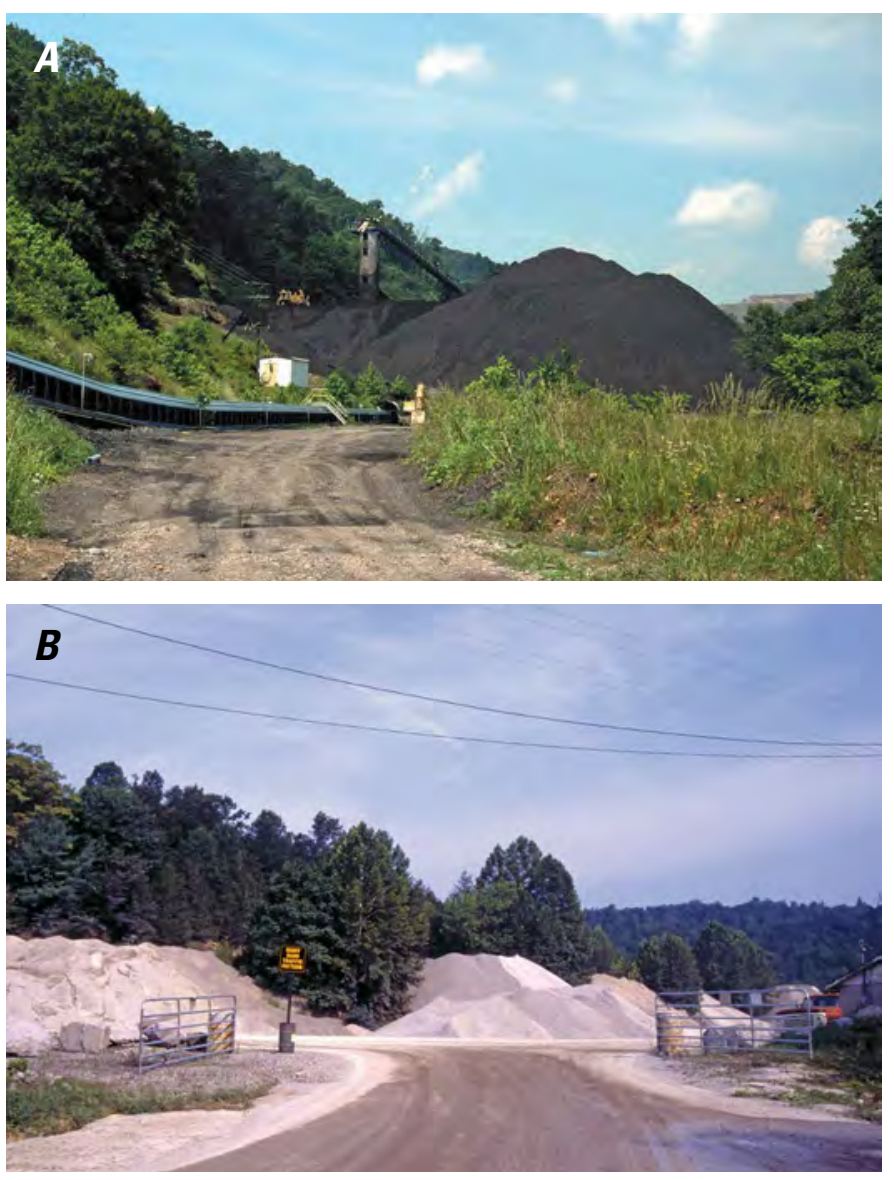

Figure 12. Mining activities in Eastern United States. $A$, Coal mine in Kentucky, in Central Appalachians Ecoregion. B, Quarry in northcentral Tennessee, in Southwestern Appalachians Ecoregion. 
Other land-cover classes such as mining, water, and wetland are changing, but the rates of change are modest. The local importance of such changes may be significant, and they are best understood at the ecoregion level. The diversity in the mosaic of change in the Eastern United States is lost when viewed as a composite. The remaining chapters in this report, which contain summaries of change for each of the 20 Eastern United States ecoregions, document the rates, types, and drivers of late-20th century land-use/land-cover change in the Eastern United States.

\section{References Cited}

Barnes, C.A., and Roy, D.P., 2008, Radiative forcing over the conterminous United States due to contemporary land cover land use albedo change: Geophysical Research Letters, v. 35, no. 9, L09706, doi:10.1029/2008GL033567.

Daniel, C.C., III, and Dahlen, P.R., 2002, Preliminary hydrogeologic assessment and study plan for a regional ground-water resource investigation of the Blue Ridge and Piedmont Provinces of North Carolina: U.S. Geological Survey Water-Resources Investigations Report 02-4105, 60 p., available at http://nc.water.usgs.gov/reports/abstracts/ wri024105.html.

Gallant, A.L., Loveland, T.R., Sohl, T.L., and Napton, D.E., 2004, Using a geographic framework for analyzing land cover issues: Environmental Management, v. 34, no. S1, p. 89-110.

Gillespie, A.J.R., 1999, Rationale for a national annual forest inventory program: Journal of Forestry, v. 97, no. 12, p. 16-20.

Gresham, C.A., 2002, Sustainability of intensive loblolly pine plantation management in the South Carolina Coastal Plain, USA: Forest Ecology and Management, v. 155, p. 69-80.

Loveland, T.R., Sohl, T.L., Stehman, S.V., Gallant, A.L., Sayler, K.L., and Napton, D.E., 2002, A strategy for estimating the rates of recent United States land cover changes: Photogrammetric Engineering \& Remote Sensing, v. 68 , no. 10 , p. $1,091-1,099$.
Nusser, S.M., and Goebel, J.J., 1997, The national resources inventory-A long-term multi-resource monitoring programme: Environmental and Ecological Statistics, v. 4, no. 3, p. 181-204.

Omernik, J.M., 1987, Ecoregions of the conterminous United States: Annals of the Association of American Geographers, v. 77 , no. 1, p. 118-125.

Sohl, T.L., Gallant, A.L., and Loveland, T.R., 2004, The characteristics and interpretability of land surface change and implications for project design: Photogrammetric Engineering \& Remote Sensing, v. 70, no. 4, p. 439-448.

Stehman, S.V., Sohl, T.L., and Loveland, T.R., 2003, Statistical sampling to characterize recent United States land-cover change: Remote Sensing of Environment, v. 86, no. 4, p. 517-529.

U.S. Census Bureau, 1970-2000 [various years], Census of population and housing: U.S. Census Bureau database, accessed April 29, 2015, at http://www.census.gov/prod/ www/decennial.html.

U.S. Environmental Protection Agency, 1999, Level III ecoregions of the continental United States: U.S. Environmental Protection Agency National Health and Environmental Effects Research Laboratory, scale 1:7,500,000, available at ftp://ftp.epa.gov/wed/ecoregions/ usgs/useco_March 1999 _v5.pdf.

U.S. Environmental Protection Agency, 2010, North American terrestrial ecoregions-Level III: U.S. Environmental Protection Agency database, accessed April 29, 2015, at http://www.epa.gov/wed/pages/ecoregions/na_eco. htm\#Downloads.

Vogelmann, J.E., Howard, S.M., Yang, L., Larson, C.R., Wylie, B.K., and van Driel, N., 2001, Completion of the 1990s National Land Cover Data Set for the conterminous United States from Landsat Thematic Mapper data and ancillary data sources: Photogrammetric Engineering \& Remote Sensing, v. 67, p. 650-662.

Walker, R.T., and Solecki, B., 2004, Theorizing land cover and land use change - The case of the Florida Everglades and its degradation: Annals of the Association of American Geographers, v. 94, no. 2, p. 311-328. 


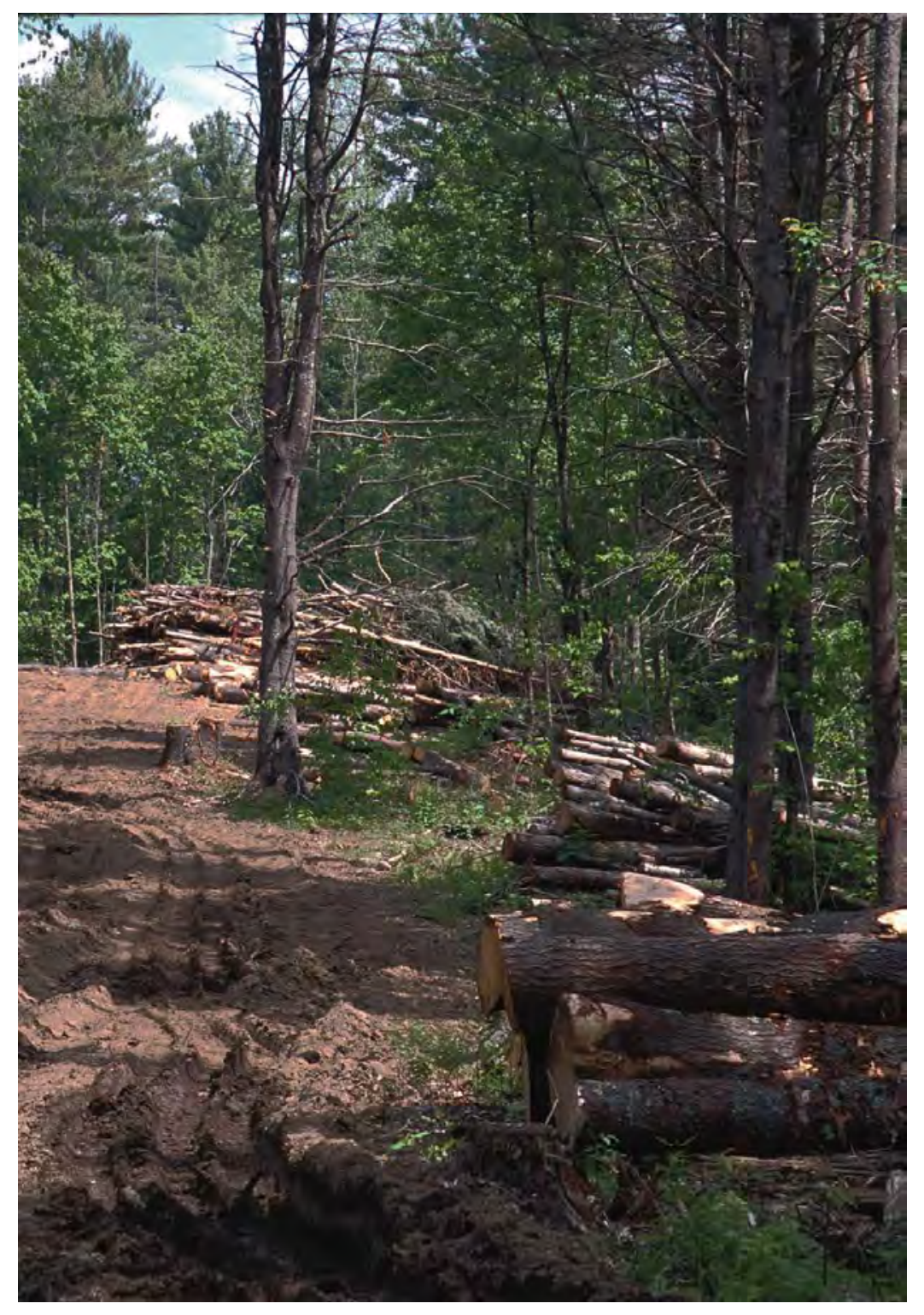




\title{
Laurentian Plains and Hills Ecoregion
}

\author{
By Thomas R. Moreland, Jr.
}

\section{Ecoregion Description}

The Laurentian Plains and Hills Ecoregion, which is located in the northeastern corner of the conterminous United States, lies entirely within the state of Maine, covering roughly about $50,153 \mathrm{~km}^{2}\left(19,364 \mathrm{mi}^{2}\right)$ in its east half (fig. 1). It is bounded to the north and east by Canada, to the west by the more rugged Northeastern Highlands Ecoregion, and to the south and southeast by the Northeastern Coastal Zone Ecoregion and the Atlantic Ocean. Glacial processes have shaped the entire Laurentian Plains and Hills Ecoregion, creating many lakes and wetland areas, and forests cover nearly three-quarters of the ecoregion (fig. 2). The trees mostly are spruce (Picea spp.) and fir (Abies spp.), with some maple (Acer spp.), beech (Fagus spp.), and birch (Betula spp.) trees (Wiken and others, 2011). Timber harvesting is one of the most significant activities in the ecoregion; other human-induced alterations to the landscape include agriculture (fig. 3), which is concentrated on the plains in the northern part of the ecoregion, and development. The average annual precipitation in the ecoregion ranges from $1,041 \mathrm{~mm}$ (41 in.) in the north to about $1,168 \mathrm{~mm}$ (46 in.) in the south. July temperatures average about $15^{\circ}$ to $21^{\circ} \mathrm{C}$; temperatures are usually warmer along the coast than in inland areas, and they are progressively cooler to the north. Average January temperatures vary from about $-8^{\circ}$ to $-5^{\circ} \mathrm{C}$ along the coast, becoming increasingly cooler to the north. In the northernmost part of the ecoregion, the average January temperature is below $-23^{\circ} \mathrm{C}$.

Figure 1. Map of Laurentian Plains and Hills Ecoregion and surrounding ecoregions, showing land-use/land-cover classes from 1992 National Land Cover Dataset (Vogelmann and others, 2001); note that not all land-use/land-cover classes shown in explanation may be depicted on map; note also that, for this "Status and Trends of Land Change" study, transitional land-cover class was subdivided into mechanically disturbed and nonmechanically disturbed classes. Squares indicate locations of $10 \times 10 \mathrm{~km}$ sample blocks analyzed in study. Index map shows locations of geographic features mentioned in text. Abbreviations for Eastern United States ecoregions are listed in appendix 2. See appendix 3 for definitions of land-use/landcover classifications.

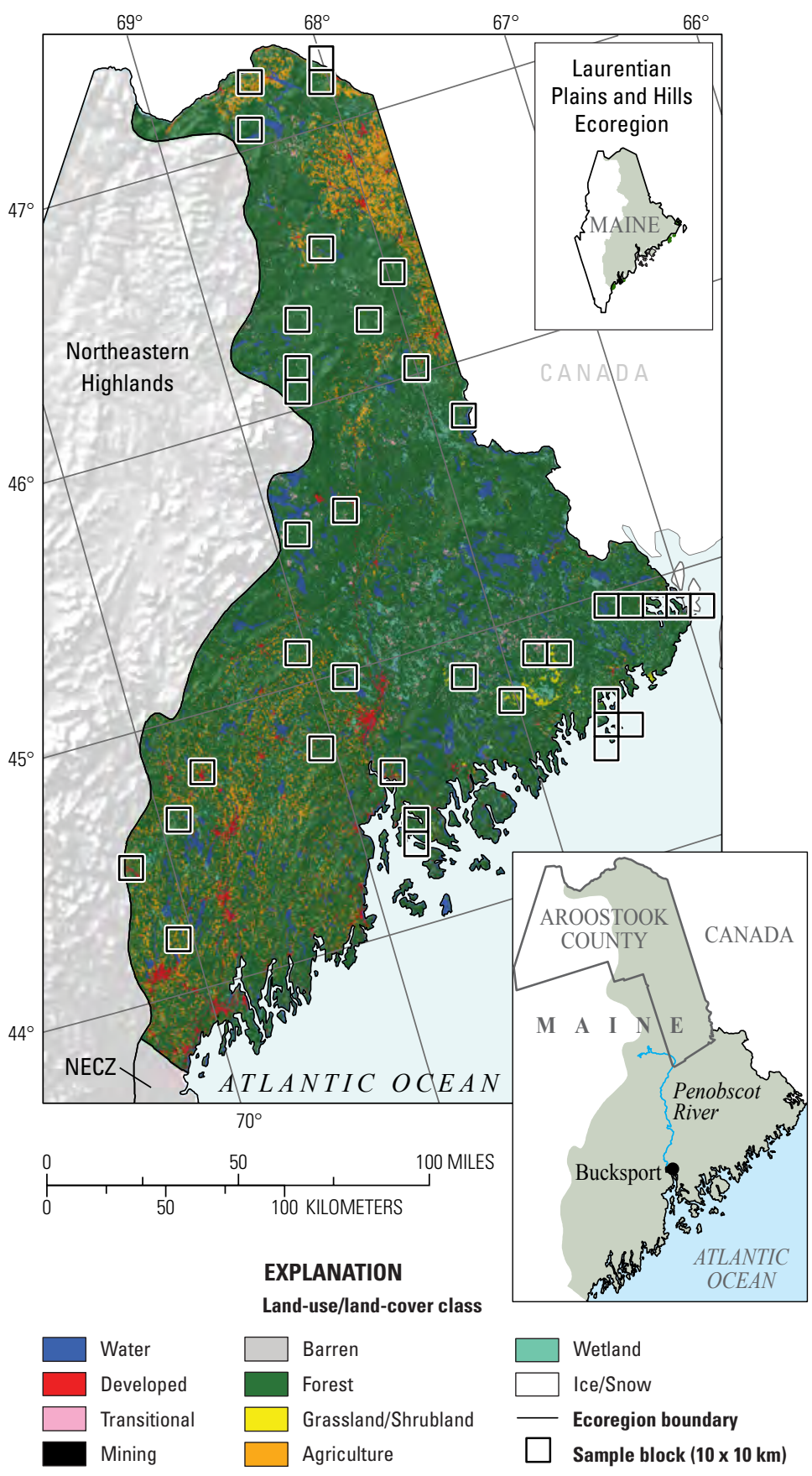




\section{Contemporary Land-Cover Change (1973 to 2000)}

The overall spatial change (the percentage of land area that changed at least one time) in the Laurentian Plains and Hills Ecoregion between 1973 and 2000 is estimated at 9.4 percent (table 1). Compared to other Eastern United States ecoregions, change in the Laurentian Plains and Hills Ecoregion was moderate (fig. 4): about 3.3 percent of the total land area changed only one time, 4.8 percent changed two times, and 1.3 percent changed three times. Most of the change is cyclic in nature, resulting from the harvesting of timber (fig. 5) and subsequent forest regrowth.

Change per time period increased throughout the entire study period. Total change increased over the study period from 2.2 percent between 1973 and 1980 to 5.8 percent between 1992 and 2000 (table 2). When normalized to an average annual rate to account for unequal time periods, the average annual change increased from 0.3 percent between 1973 and 1980 to 0.6 percent between 1980 and 1986, peaking at 0.9 percent between 1986 and 1992 and then decreasing slightly to 0.7 percent between 1992 and 2000 (table 2; fig. 6).

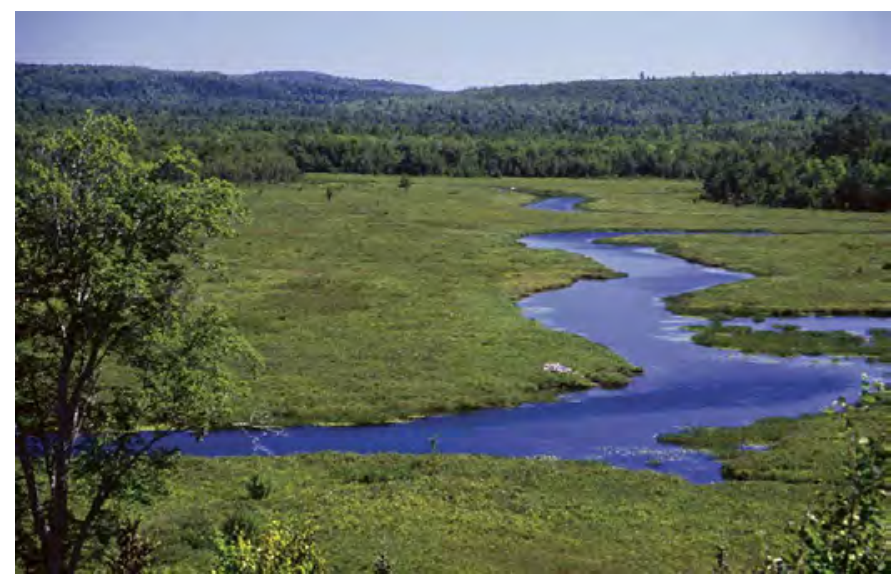

Figure 2. Vista of wetlands in foreground and forested hills in distance, in Laurentian Plains and Hills Ecoregion.

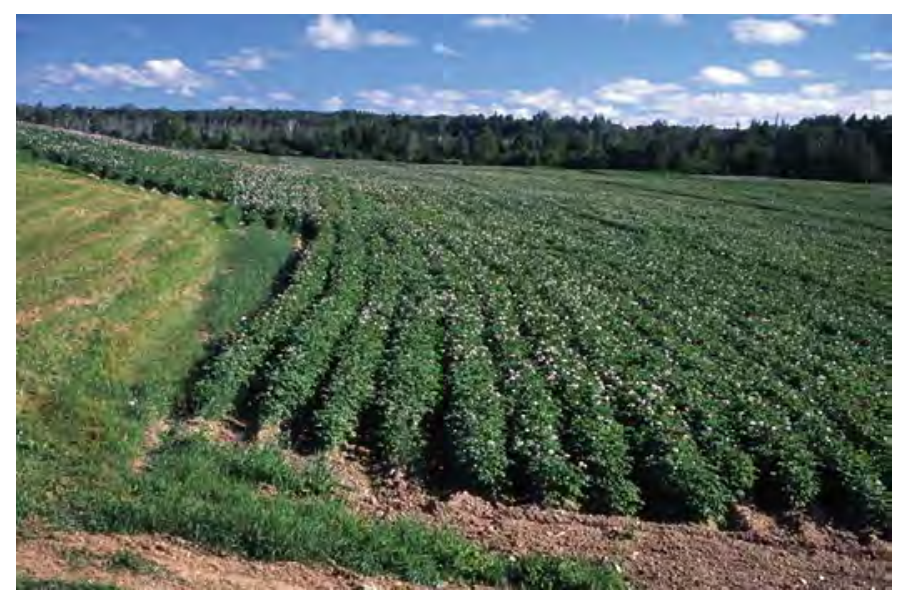

Figure 3. Potato field in Aroostook County, Maine.
Forest was the predominant land-cover class, covering an estimated 72.2 percent of the ecoregion in 1973 and decreasing slightly to 70.1 percent by 2000 (table 3 ). The area covered by water was very stable, remaining at about 12.0 percent throughout the study period. Agriculture decreased very slightly between 1973 and 2000, from 7.8

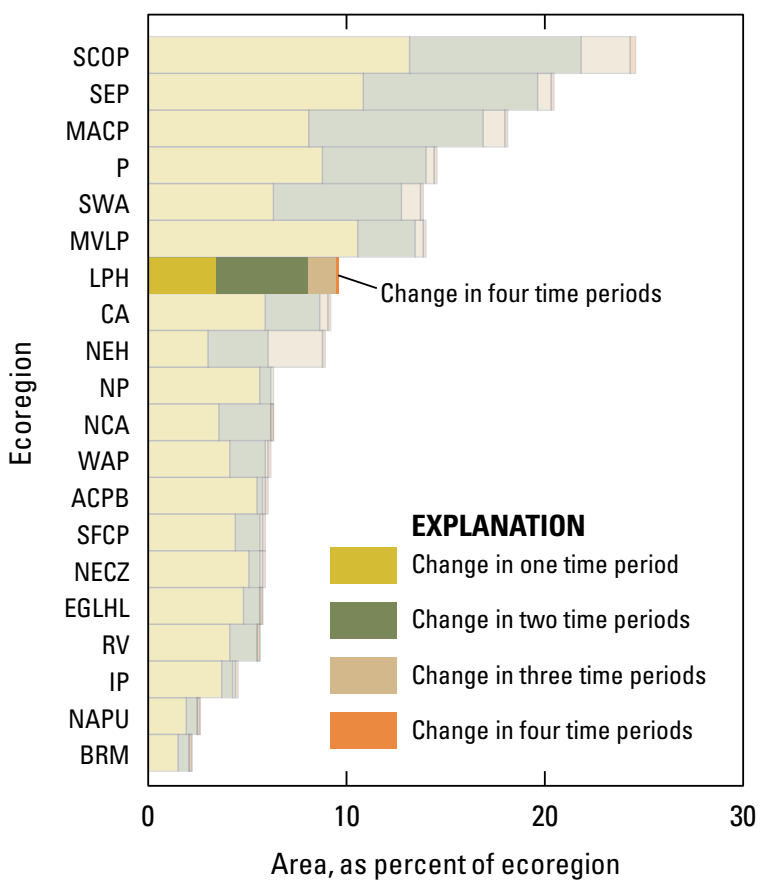

Figure 4. Overall spatial change in Laurentian Plains and Hills Ecoregion (LPH; darker bars) compared with that of all 20 Eastern United States ecoregions (lighter bars). Each horizontal set of bars shows proportions of ecoregion that changed during one, two, three, or four time periods; highest level of spatial change in Laurentian Plains and Hills Ecoregion (four time periods) labeled for clarity. See table 2 for years covered by each time period. See appendix 2 for key to ecoregion abbreviations.

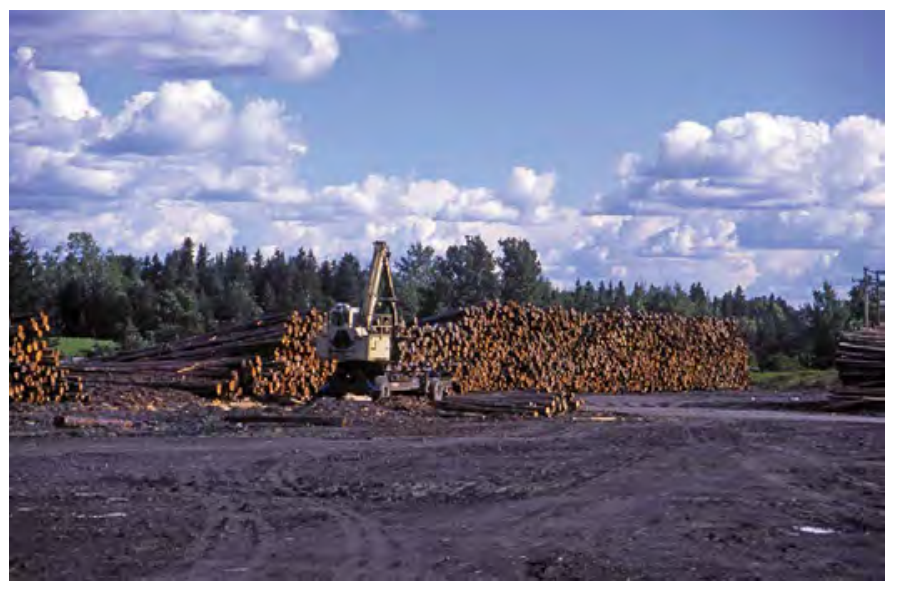

Figure 5. Logs being stacked at edge of forest, in Laurentian Plains and Hills Ecoregion. 
to 7.5 percent of the ecoregion. The amount of developed land increased slightly, from 1.8 percent of the ecoregion in 1973 to 2.1 percent in 2000 . The estimated percentage of the ecoregion covered by mechanically disturbed land increased steadily, from 0.9 percent in 1973 to a high of 2.4 percent in 1992, then decreasing slightly to 2.2 percent in 2000. During the study period, mechanically disturbed land cover almost always was linked to timber harvesting rather than clearing for developed or agriculture.

Net land-cover change in each time period is shown in figure 7. Water, wetland, mining, and barren land-cover classes changed very little in any particular time period, as well as throughout the 27-year study period. Developed increased slightly in each time period, and agriculture decreased gradually in each time period. The amount of forest decreased in each time period except the last, when a slight increase occurred. This change in forested land was mirrored by the increase in the amount of mechanically disturbed land and grassland/shrubland in each time period except the last, when a slight decrease also occurred.

Forest harvesting and regeneration was responsible for most of the change in the ecoregion (table 4). The conversion of forest to mechanically disturbed, an estimated $3,709 \mathrm{~km}^{2}$ between 1973 and 2000, was the leading change throughout the study period. Much of the timber was harvested to provide pulpwood for the paper industry (Colgan and others, 1986; Irland, 2004) (fig. 8). The conversion of mechanically disturbed to forest, an estimated $1,811 \mathrm{~km}^{2}$ between 1973 and 2000, was the second leading change overall, and the second leading change in the last two time periods. The third leading change overall, as well as the second leading

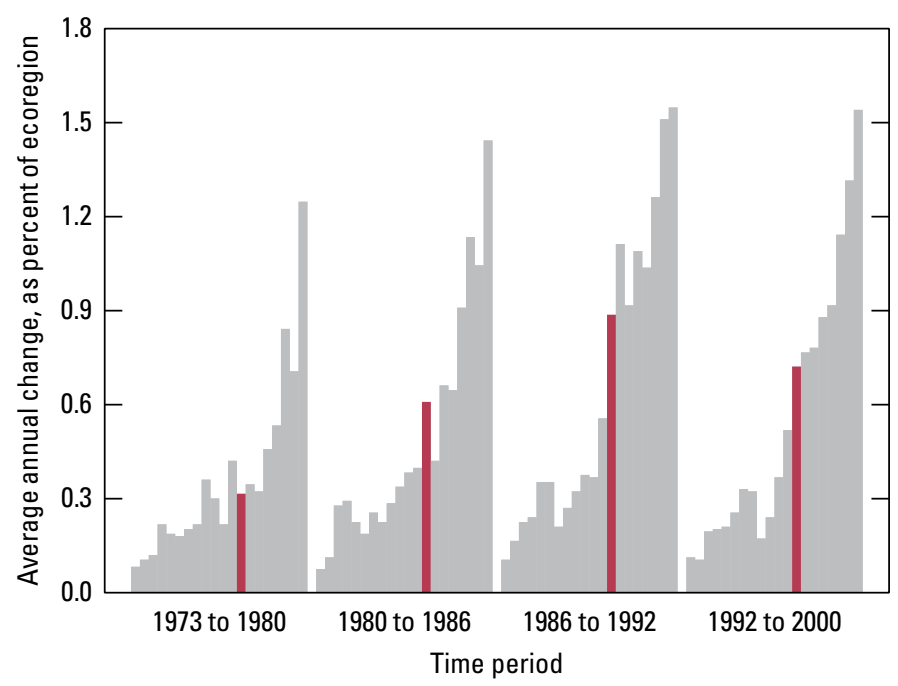

Figure 6. Estimates of land-cover change per time period, normalized to annual rates of change for all 20 Eastern United States ecoregions (gray bars). Estimates of change for Laurentian Plains and Hills Ecoregion are represented by red bars in each time period. change in the first two time periods, was the conversion of mechanically disturbed to grassland/shrubland, an estimated $1,258 \mathrm{~km}^{2}$ between 1973 and 2000 . The conversion of grassland/shrubland to forest, an estimated $1,015 \mathrm{~km}^{2}$ between 1973 and 2000, was the fourth leading change over the entire study period. A minor change in comparison to the other changes was the conversion of an estimated $109 \mathrm{~km}^{2}$ of forest to developed between 1973 and 2000. The conversion of forest to developed increased in each time period.

Between 1973 and 2000, the predominately wooded landscape of the Laurentian Plains and Hills Ecoregion experienced a moderate amount of land-cover change. Average annual change increased from the first time period through the third time period, and then it decreased slightly. Although very little of this change resulted in an increase in developed land, about 90 percent of the change can be attributed to the cyclic harvesting of woodlands and their eventual regrowth.

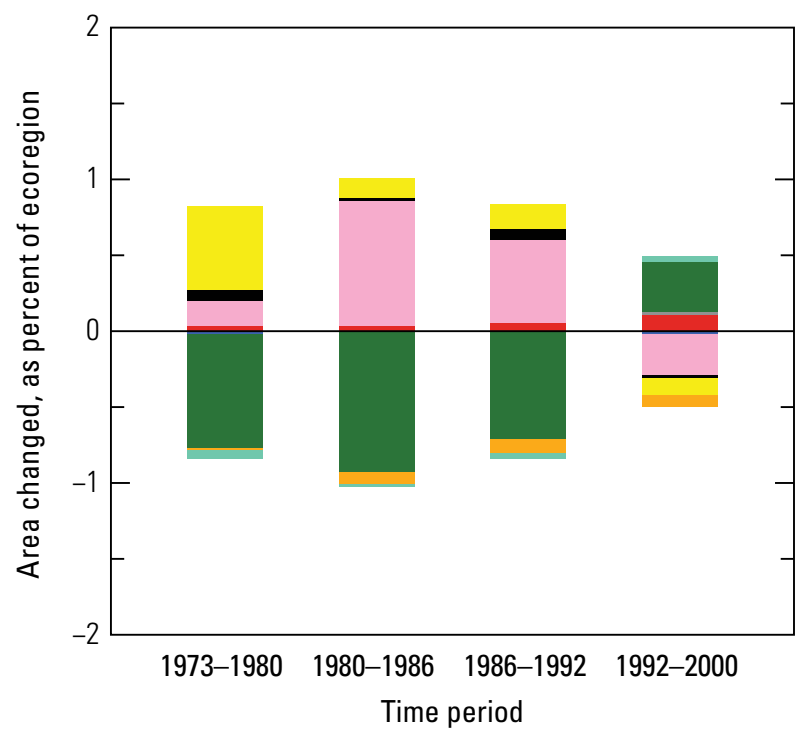

EXPLANATION

Land-use/land-cover class
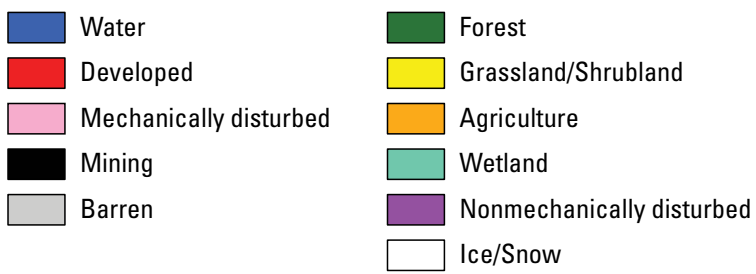

Figure 7. Normalized average net change in Laurentian Plains and Hills Ecoregion by time period for each land-cover class. Bars above zero axis represent net gain, whereas bars below zero represent net loss. Note that not all land-cover classes shown in explanation may be represented in figure. See appendix 3 for definitions of land-use and land-cover classifications. 


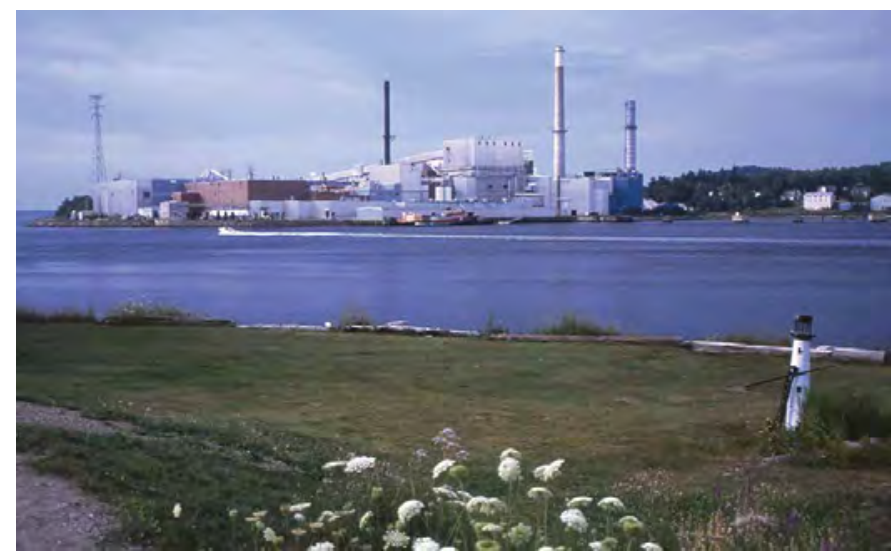

Figure 8. Paper mill along Penobscot River, in Bucksport, Maine.
Table 1. Percentage of Laurentian Plains and Hills Ecoregion land cover that changed at least one time during study period (1973-2000) and associated statistical error.

[Most sample pixels remained unchanged ( 90.6 percent), whereas 9.4 percent changed at least once throughout study period]

\begin{tabular}{ccccccc}
\hline $\begin{array}{c}\text { Number } \\
\text { of } \\
\text { changes }\end{array}$ & $\begin{array}{c}\text { Percent } \\
\text { of } \\
\text { ecoregion }\end{array}$ & $\begin{array}{c}\text { Margin } \\
\text { of error } \\
(+/-\%)\end{array}$ & $\begin{array}{c}\text { Lower } \\
\text { bound } \\
(\%)\end{array}$ & $\begin{array}{c}\text { Upper } \\
\text { bound } \\
(\%)\end{array}$ & $\begin{array}{c}\text { Standard } \\
\text { error } \\
(\%)\end{array}$ & $\begin{array}{c}\text { Relative } \\
\text { error } \\
(\%)\end{array}$ \\
\hline 1 & 3.3 & 0.5 & 2.8 & 3.8 & 0.4 & 11.0 \\
2 & 4.8 & 1.0 & 3.8 & 5.8 & 0.7 & 14.3 \\
3 & 1.3 & 0.5 & 0.9 & 1.8 & 0.3 & 22.9 \\
4 & 0.0 & 0.0 & 0.0 & 0.0 & 0.0 & 40.0 \\
\hline Overall & & & & & & \\
spatial & 9.4 & 1.6 & 7.8 & 11.0 & 1.1 & 11.7 \\
change & & & & & & \\
\hline
\end{tabular}

Table 2. Raw estimates of change in Laurentian Plains and Hills Ecoregion land cover, computed for each of four time periods between 1973 and 2000, and associated error at 85-percent confidence level.

[Estimates of change per period normalized to annual rate of change for each period]

\begin{tabular}{rccccccc}
\hline Period & $\begin{array}{c}\text { Total change } \\
(\% \text { of ecoregion) }\end{array}$ & $\begin{array}{c}\text { Margin of } \\
\text { error } \\
(+/-\%)\end{array}$ & $\begin{array}{c}\text { Lower } \\
\text { bound } \\
(\%)\end{array}$ & $\begin{array}{c}\text { Upper bound } \\
(\%)\end{array}$ & $\begin{array}{c}\text { Standard } \\
\text { error } \\
(\%)\end{array}$ & $\begin{array}{c}\text { Relative } \\
\text { error } \\
(\%)\end{array}$ & $\begin{array}{c}\text { Average rate } \\
(\% \text { per year) }\end{array}$ \\
\hline \multicolumn{7}{c}{ Estimate of change, in percent stratum } \\
\hline $1973-1980$ & 2.2 & 0.6 & 1.6 & 2.8 & 0.4 & 19.0 & 0.3 \\
$1980-1986$ & 3.6 & 0.9 & 2.7 & 4.6 & 0.6 & 16.9 & 0.6 \\
$1986-1992$ & 5.3 & 1.3 & 4.0 & 6.6 & 0.9 & 16.2 & 0.9 \\
$1992-2000$ & 5.8 & 1.2 & 4.6 & 7.0 & 0.8 & 14.1 & 0.7 \\
\hline & & Estimate of change, in square kilometers & & \\
\hline $1973-1980$ & 1,086 & 305 & 781 & 1,391 & 206 & 19 & 155 \\
$1980-1986$ & 1,827 & 458 & 1,369 & 2,285 & 310 & 17 & 305 \\
$1986-1992$ & 2,664 & 638 & 2,026 & 3,302 & 431 & 16 & 444 \\
$1992-2000$ & 2,896 & 602 & 2,294 & 3,498 & 407 & 14 & 362 \\
\hline
\end{tabular}


Table 3. Estimated area (and margin of error) of each land-cover class in Laurentian Plains and Hills Ecoregion, calculated five times between 1973 and 2000. See appendix 3 for definitions of land-cover classifications.

\begin{tabular}{|c|c|c|c|c|c|c|c|c|c|c|c|c|c|c|c|c|c|c|c|c|}
\hline & \multicolumn{2}{|c|}{ Water } & \multicolumn{2}{|c|}{ Developed } & \multicolumn{2}{|c|}{$\begin{array}{l}\text { Mecha- } \\
\text { nically } \\
\text { disturbed }\end{array}$} & \multicolumn{2}{|c|}{ Mining } & \multicolumn{2}{|c|}{ Barren } & \multicolumn{2}{|c|}{ Forest } & \multicolumn{2}{|c|}{$\begin{array}{l}\text { Grassland/ } \\
\text { Shrubland }\end{array}$} & \multicolumn{2}{|c|}{ Agriculture } & \multicolumn{2}{|c|}{ Wetland } & \multicolumn{2}{|c|}{$\begin{array}{c}\text { Non- } \\
\text { mechanically } \\
\text { disturbed }\end{array}$} \\
\hline & $\%$ & $+/-$ & $\%$ & $+/-$ & $\%$ & $+/-$ & $\%$ & $+/-$ & $\%$ & $+/-$ & $\%$ & $+/-$ & $\%$ & $+1-$ & $\%$ & $+/-$ & $\%$ & $+1-$ & $\%$ & $+/-$ \\
\hline \multicolumn{21}{|c|}{ Area, in percent stratum } \\
\hline 1973 & 12.0 & 7.0 & 1.8 & 0.6 & 0.9 & 0.4 & 0.1 & 0.1 & 0.1 & 0.1 & 72.2 & 2.9 & 0.2 & 0.1 & 7.8 & 2.3 & 5.0 & 1.0 & 0.0 & 0.0 \\
\hline 1980 & 12.0 & 7.0 & 1.8 & 0.6 & 1.0 & 0.3 & 0.2 & 0.1 & 0.1 & 0.1 & 71.4 & 2.9 & 0.8 & 0.3 & 7.8 & 2.3 & 4.9 & 1.0 & 0.0 & 0.0 \\
\hline 1992 & 12.0 & 7.0 & 1.9 & 0.7 & 2.4 & 0.7 & 0.2 & 0.2 & 0.1 & 0.1 & 69.8 & 2.7 & 1.1 & 0.3 & 7.6 & 2.3 & 4.8 & 1.0 & 0.0 & 0.0 \\
\hline 2000 & 12.0 & 7.0 & 2.1 & 0.7 & 2.2 & 0.6 & 0.2 & 0.1 & 0.1 & 0.1 & 70.1 & 2.6 & 0.9 & 0.5 & 7.5 & 2.3 & 4.9 & 1.0 & 0.0 & 0.0 \\
\hline $\begin{array}{l}\text { Net } \\
\text { change }\end{array}$ & 0.0 & 0.0 & 0.3 & 0.1 & 1.3 & 0.7 & 0.1 & 0.1 & 0.0 & 0.0 & -2.1 & 0.8 & 0.7 & 0.5 & -0.2 & 0.1 & -0.1 & 0.1 & 0.0 & 0.0 \\
\hline 1980 & 6,003 & 3,499 & 922 & 314 & 525 & 160 & 81 & 50 & 48 & 65 & 35,834 & 1,479 & 387 & 135 & 3,892 & 1,166 & 2,460 & 509 & 0 & 0 \\
\hline 1986 & 6,005 & 3,500 & 945 & 324 & 938 & 297 & 91 & 55 & 48 & 65 & 35,366 & 1,426 & 448 & 151 & 3,858 & 1,144 & 2,455 & 507 & 0 & 0 \\
\hline 1992 & 6,006 & 3,500 & 974 & 332 & 1,215 & 341 & 122 & 87 & 48 & 65 & 35,008 & 1,377 & 532 & 152 & 3,819 & 1,144 & 2,430 & 498 & 0 & 0 \\
\hline 2000 & 5,996 & 3,500 & 1,034 & 347 & 1,083 & 286 & 112 & 69 & 50 & 65 & 35,175 & 1,298 & 476 & 244 & 3,782 & 1,134 & 2,446 & 503 & 0 & 0 \\
\hline $\begin{array}{l}\text { Net } \\
\text { change }\end{array}$ & -11 & 9 & 131 & 43 & 643 & 353 & 65 & 60 & 2 & 2 & $-1,040$ & 398 & 368 & 245 & -115 & 70 & -42 & 62 & 0 & 0 \\
\hline $\begin{array}{l}\text { Gross } \\
\text { change }\end{array}$ & 21 & 10 & 131 & 43 & 2,637 & 647 & 103 & 102 & 2 & 2 & 2,965 & 715 & 1,381 & 467 & 255 & 79 & 125 & 98 & 0 & 0 \\
\hline
\end{tabular}


Table 4. Principal land-cover conversions in Laurentian Plains and Hills Ecoregion, showing amount of area changed (and margin of error, calculated at 85-percent confidence level) for each conversion during each of four time periods and also during overall study period. See appendix 3 for definitions of land-cover classifications.

[Values given for "other" classes are combined totals of values for other land-cover classes not listed in that time period. Abbreviations: n/a, not applicable]

\begin{tabular}{|c|c|c|c|c|c|c|c|}
\hline Period & From class & To class & $\begin{array}{c}\text { Area } \\
\text { changed } \\
\left(\mathbf{k m}^{2}\right)\end{array}$ & $\begin{array}{c}\text { Margin of } \\
\text { error } \\
\left(+/-\mathrm{km}^{2}\right)\end{array}$ & $\begin{array}{c}\text { Standard } \\
\text { error } \\
\left(\mathrm{km}^{2}\right)\end{array}$ & $\begin{array}{l}\text { Percent of } \\
\text { ecoregion }\end{array}$ & $\begin{array}{l}\text { Percent of } \\
\text { all changes }\end{array}$ \\
\hline \multirow[t]{7}{*}{ 1973-1980 } & Forest & Mechanically disturbed & 521 & 158 & 107 & 1.0 & 47.9 \\
\hline & Mechanically disturbed & Grassland/Shrubland & 276 & 133 & 90 & 0.5 & 25.4 \\
\hline & Mechanically disturbed & Forest & 160 & 111 & 75 & 0.3 & 14.8 \\
\hline & Wetland & Mining & 28 & 40 & 27 & 0.1 & 2.6 \\
\hline & Forest & Developed & 17 & 9 & 6 & 0.0 & 1.6 \\
\hline & Other & Other & 84 & $\mathrm{n} / \mathrm{a}$ & $\mathrm{n} / \mathrm{a}$ & 0.2 & 7.7 \\
\hline & & Totals & 1,086 & & & 2.2 & 100.0 \\
\hline \multirow[t]{7}{*}{$1980-1986$} & Forest & Mechanically disturbed & 927 & 293 & 198 & 1.8 & 50.8 \\
\hline & Mechanically disturbed & Grassland/Shrubland & 278 & 133 & 90 & 0.6 & 15.2 \\
\hline & Grassland/Shrubland & Forest & 252 & 117 & 79 & 0.5 & 13.8 \\
\hline & Mechanically disturbed & Forest & 234 & 94 & 64 & 0.5 & 12.8 \\
\hline & Agriculture & Grassland/Shrubland & 30 & 24 & 16 & 0.1 & 1.7 \\
\hline & Other & Other & 106 & $\mathrm{n} / \mathrm{a}$ & $\mathrm{n} / \mathrm{a}$ & 0.2 & 5.8 \\
\hline & & Totals & 1,827 & & & 3.6 & 100.0 \\
\hline \multirow[t]{7}{*}{ 1986-1992 } & Forest & Mechanically disturbed & 1,202 & 334 & 226 & 2.4 & 45.1 \\
\hline & Mechanically disturbed & Forest & 557 & 229 & 155 & 1.1 & 20.9 \\
\hline & Mechanically disturbed & Grassland/Shrubland & 366 & 146 & 99 & 0.7 & 13.7 \\
\hline & Grassland/Shrubland & Forest & 335 & 145 & 98 & 0.7 & 12.6 \\
\hline & Agriculture & Grassland/Shrubland & 56 & 33 & 22 & 0.1 & 2.1 \\
\hline & Other & Other & 149 & $\mathrm{n} / \mathrm{a}$ & $\mathrm{n} / \mathrm{a}$ & 0.3 & 5.6 \\
\hline & & Totals & 2,664 & & & 5.3 & 100.0 \\
\hline \multirow[t]{7}{*}{$1992-2000$} & Forest & Mechanically disturbed & 1,059 & 282 & 191 & 2.1 & 36.6 \\
\hline & Mechanically disturbed & Forest & 861 & 250 & 169 & 1.7 & 29.7 \\
\hline & Grassland/Shrubland & Forest & 414 & 143 & 97 & 0.8 & 14.3 \\
\hline & Mechanically disturbed & Grassland/Shrubland & 339 & 241 & 163 & 0.7 & 11.7 \\
\hline & Agriculture & Forest & 50 & 33 & 22 & 0.1 & 1.7 \\
\hline & Other & Other & 174 & $\mathrm{n} / \mathrm{a}$ & $\mathrm{n} / \mathrm{a}$ & 0.3 & 6.0 \\
\hline & & Totals & 2,896 & & & 5.8 & 100.0 \\
\hline \multirow{7}{*}{$\begin{array}{c}1973-2000 \\
\text { (overall) }\end{array}$} & Forest & Mechanically disturbed & 3,709 & 777 & 526 & 7.4 & 43.8 \\
\hline & Mechanically disturbed & Forest & 1,811 & 497 & 336 & 3.6 & 21.4 \\
\hline & Mechanically disturbed & Grassland/Shrubland & 1,258 & 490 & 331 & 2.5 & 14.9 \\
\hline & Grassland/Shrubland & Forest & 1,015 & 318 & 215 & 2.0 & 12.0 \\
\hline & Forest & Developed & 109 & 38 & 26 & 0.2 & 1.3 \\
\hline & Other & Other & 570 & $\mathrm{n} / \mathrm{a}$ & $\mathrm{n} / \mathrm{a}$ & 1.1 & 6.7 \\
\hline & & Totals & 8,473 & & & 16.9 & 100.0 \\
\hline
\end{tabular}




\section{References Cited}

Colgan, C.S., Irland, L.C., and Benson, J., 1986, The natural resource industries of Maine-An assessment and statistical portrait: Augusta, Financial Authority of Maine and Maine State Planning Office, $135 \mathrm{p}$.

Irland, L.C., 2004, Maine's forest industry-From one era to another, in Barringer, R.E., ed., Changing Maine, 19602010: Gardiner, Maine, Tilbury House, p. 362-387.

Vogelmann, J.E., Howard, S.M., Yang, L., Larson, C.R., Wylie, B.K., and van Driel, N., 2001, Completion of the 1990s National Land Cover Data Set for the conterminous United States from Landsat Thematic Mapper data and ancillary data sources: Photogrammetric Engineering \& Remote Sensing, v. 67, p. 650-662.

Wiken, E., Jiménez Nava, F., and Griffith, G., 2011, North American terrestrial ecoregions-Level III: Montreal, Canada, Commission for Environmental Cooperation, 149 p., accessed May 1, 2013, at http://www.cec.org/ Storage/133/15860_QA07.30-32_NP_NA_Terrestrial_ Ecoregions_Level_3_Final-2june-11.pdf. 



\title{
Chapter 2
}

\section{Northeastern Highlands Ecoregion}

\author{
By Steven Kambly
}

\section{Ecoregion Description}

The Northeastern Highlands Ecoregion is composed of four physically separate areas that cover $127,107 \mathrm{~km}^{2}\left(49,076 \mathrm{mi}^{2}\right)$ in Maine, New Hampshire, Vermont, New York, Massachusetts, Connecticut, New Jersey, and Pennsylvania (fig. 1). The easternmost part of the ecoregion, the largest, is bounded on the east-southeast by the Laurentian Plains and Hills, Northeastern Coastal Zone, and Northern Piedmont Ecoregions, and, on the west-northwest, by the Ridge and Valley and the Eastern Great Lakes and Hudson Lowlands Ecoregions. Both the next largest and the smallest parts of the ecoregion are entirely surrounded by the Eastern Great Lakes and Hudson Lowlands Ecoregion; the remaining part of the ecoregion, southwest of Albany, New York (fig. 1), is bounded by the North Central Appalachians, the Northern Appalachian Plateau and Uplands, and the Eastern Great Lakes and Hudson Lowlands Ecoregions.

The Northeastern Highlands Ecoregion is, for the most part, sparsely populated and characterized by nutrient-poor soils covered with northern hardwood forests and spruce-fir (Picea spp. and Abries spp.,
Figure 1. Map of Northeastern Highlands Ecoregion and surrounding ecoregions, showing land-use/land-cover classes from 1992 National Land Cover Dataset (Vogelmann and others, 2001); note that not all land-use/ land-cover classes shown in explanation may be depicted on map; note also that, for this "Status and Trends of Land Change" study, transitional land-cover class was subdivided into mechanically disturbed and nonmechanically disturbed classes. Squares indicate locations of $10 \times 10 \mathrm{~km}$ sample blocks analyzed in study. Index map shows locations of geographic features mentioned in text. Abbreviations for Eastern United States ecoregions are listed in appendix 2 . See appendix 3 for definitions of land-use/landcover classifications.

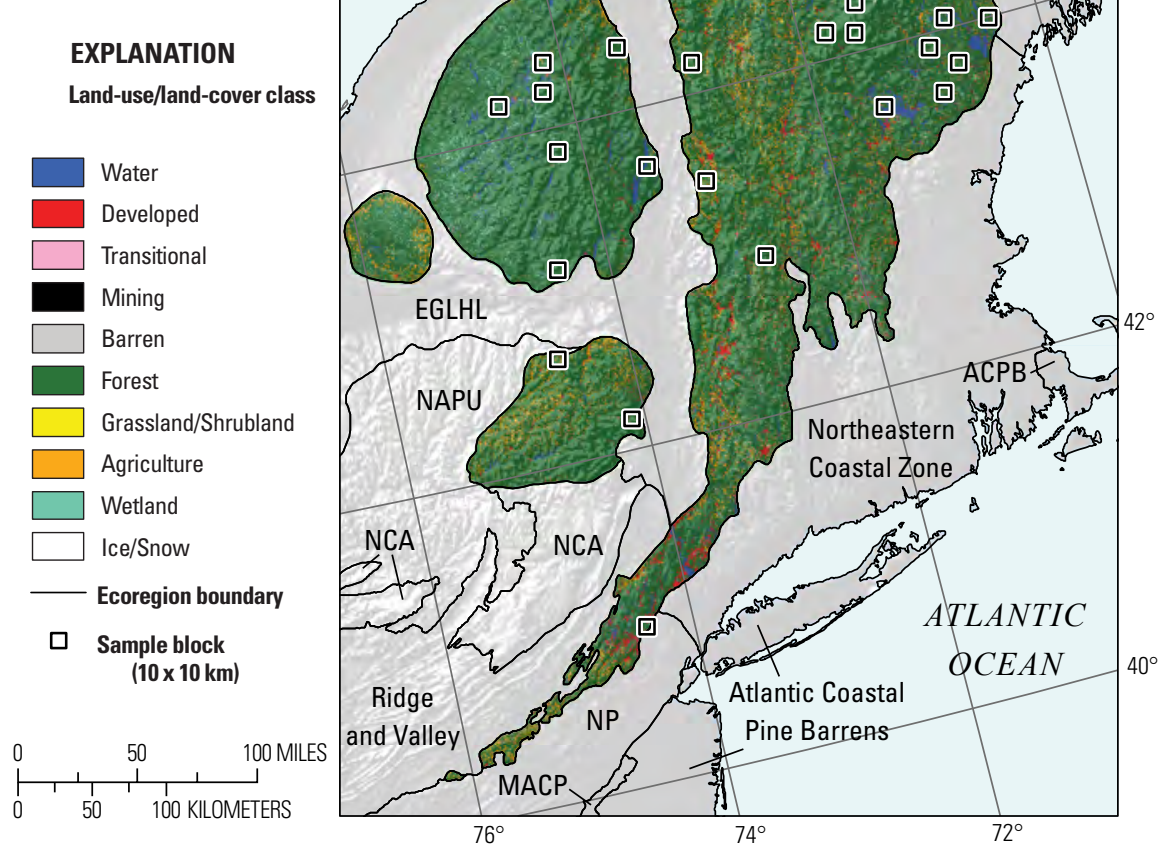


respectively) forests (U.S. Environmental Protection Agency, 2013). Landforms in the ecoregion vary from mountains in the southwestern and central parts to open high hills in the northeastern part. Many mountain ranges - including the White Mountains in New Hampshire, the Green Mountains in Vermont, and the Catskill and Adirondack Mountains in New York-lie within the ecoregion. The ecoregion also shows many remnants of glaciation, including rocky soils, glacial lakes, and wetlands (fig. 2). Annual average rainfall ranges from 940 to $1,397 \mathrm{~mm}(37-55 \mathrm{in}$.), with significantly higher amounts in mountainous areas. Average daily temperatures range from less than $-7^{\circ} \mathrm{C}$ in January to between $16^{\circ}$ and $21^{\circ} \mathrm{C}$ in July.

Although the ecoregion was heavily forested at the beginning of European settlement, much of it was cleared for farmland in the 19th century. Farmland abandonment, beginning in the mid-1800s and continuing through the 20th century, has led to a natural regrowth of forest. Forest harvesting for wood products has been an ongoing activity since the early 1800s, and clearcutting of forests still is evident in western Maine, where timber companies control large tracts of land. Paper and pulp processing is the leading manufacturing activity in Maine. Further south, in New Hampshire, Vermont, and New York, tourism and small-scale farming are more prevalent.

\section{Contemporary Land-Cover Change (1973 to 2000)}

The overall spatial change (the percentage of land area that changed at least one time) in the Northeastern Highlands Ecoregion between 1973 and 2000 is estimated at 8.9 percent (table 1). Compared to other Eastern United States ecoregions, change in the Northeastern Highlands Ecoregion was moderate (fig. 3): about 3.0 percent changed only one time, whereas 3.0 percent and 2.9 percent changed two and three times, respectively. About one-tenth of one percent of the ecoregion's area changed four times (table 1). Total change

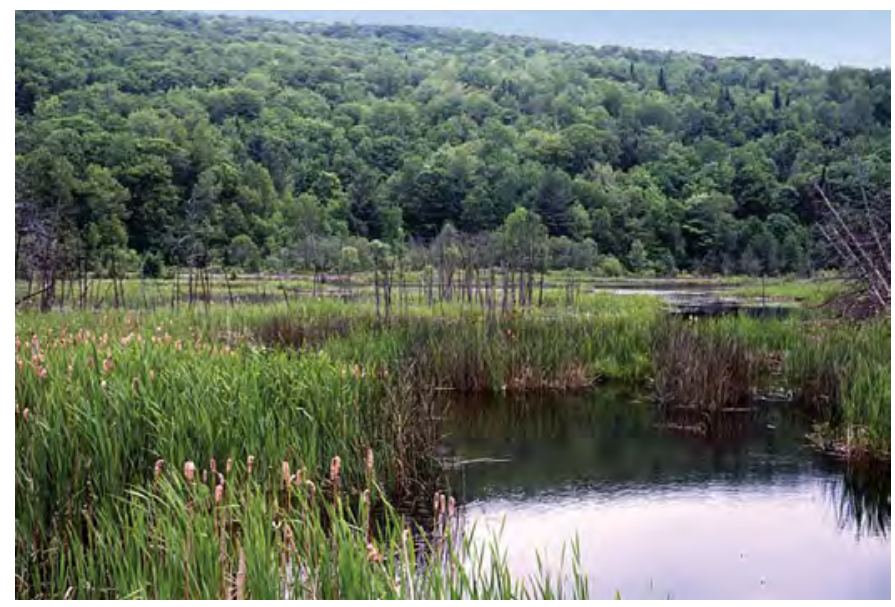

Figure 2. Wetlands area in Northeastern Highlands Ecoregion, many of which are result of glaciation. per time period increased from 2.2 percent between 1973 and 1980 to 6.2 percent between 1992 and 2000 (table 2). When normalized to an average annual rate to account for uneven time periods, land-cover change increased steadily (from 0.3 to 0.9 percent) in the first three time periods (1973-1980, 1980-1986, 1986-1992) and then slowed to 0.8 percent during the last time period (1992-2000) (fig. 4).

Forest harvesting and regrowth was the dominant pattern of change observed (fig. 5). Both selective cutting and clearcutting of forested land created mechanically disturbed land, which, in turn, became grassland/shrubland. Eventually, grassland/shrubland areas tended to revert to forest. This cycle of change involving mechanically disturbed land and grassland/shrubland occurred over an increasing area in the first three time periods (1973-1980, 1980-1986, 1986-1992) but then decreased in area in the last time period (1992-2000).

Primarily as a result of clearcutting and some selective harvesting, forest decreased during the 27-year study period by an estimated 3.9 percent of the ecoregion, or about 4,904 $\mathrm{km}^{2}$ (table 3). However, forest remained the dominant land-cover class, occupying an estimated 81.4 percent of the ecoregion in 2000. As the amount of tree harvesting increased, the percentage of mechanically disturbed land also increased, from 0.6 percent of the ecoregion in 1973 to 2.1 percent in 2000 (table 3). The estimated amount of grassland/

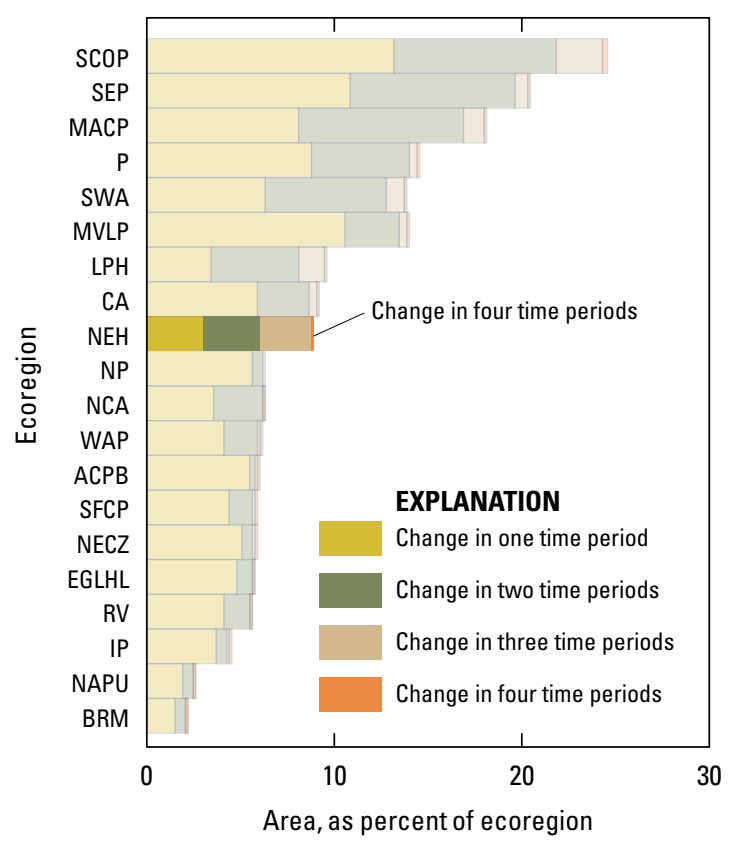

Figure 3. Overall spatial change in Northeastern Highlands Ecoregion (NEH; darker bars) compared with that of all 20 Eastern United States ecoregions (lighter bars). Each horizontal set of bars shows proportions of ecoregion that changed during one, two, three, or four time periods; highest level of spatial change in Northeastern Highlands Ecoregion (four time periods) labeled for clarity. See table 2 for years covered by each time period. See appendix 2 for key to ecoregion abbreviations. 
shrubland increased in the first three time periods (1973-1980, 1980-1986, 1986-1992), from 0.2 to 2.2 percent, and then it decreased slightly to 2.1 percent in the last time period (19922000). Developed land increased from 1.8 to 2.3 percent during the study period (1973-2000), whereas agricultural land remained unchanged during the same period (about 3.3 percent). Forest, mechanically disturbed, and grassland/ shrubland were, by far, the most actively changing land-cover classes, accounting for most of the net change in the ecoregion during the study period (table 4; fig. 6).

In terms of individual conversions, forest to mechanically disturbed was the most common conversion overall in all four time periods (table 4). An estimated $9,322 \mathrm{~km}^{2}$ converted

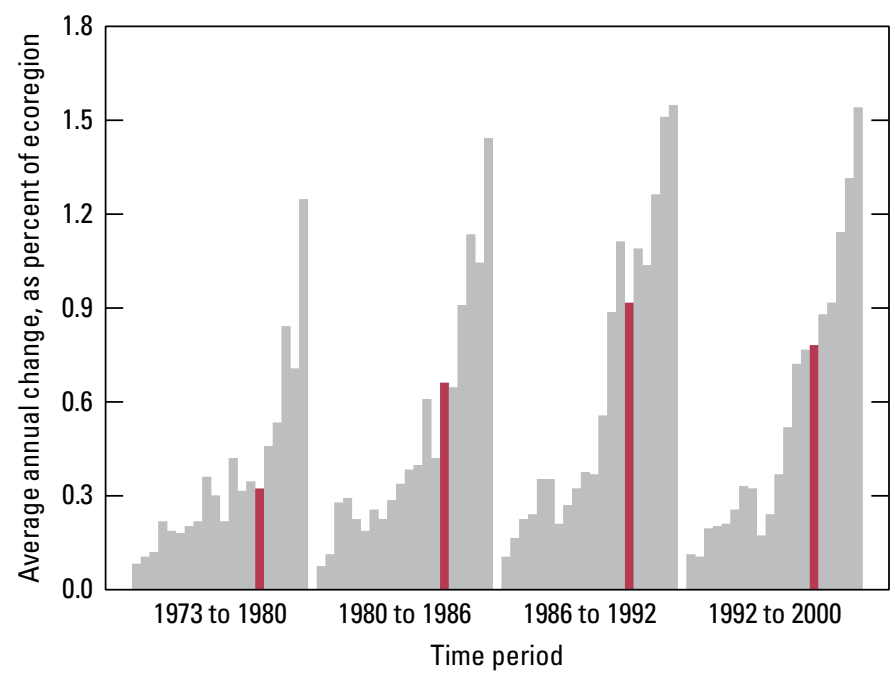

Figure 4. Estimates of land-cover change per time period, normalized to annual rates of change for all 20 Eastern United States ecoregions (gray bars). Estimates of change for Northeastern Highlands Ecoregion are represented by red bars in each time period.

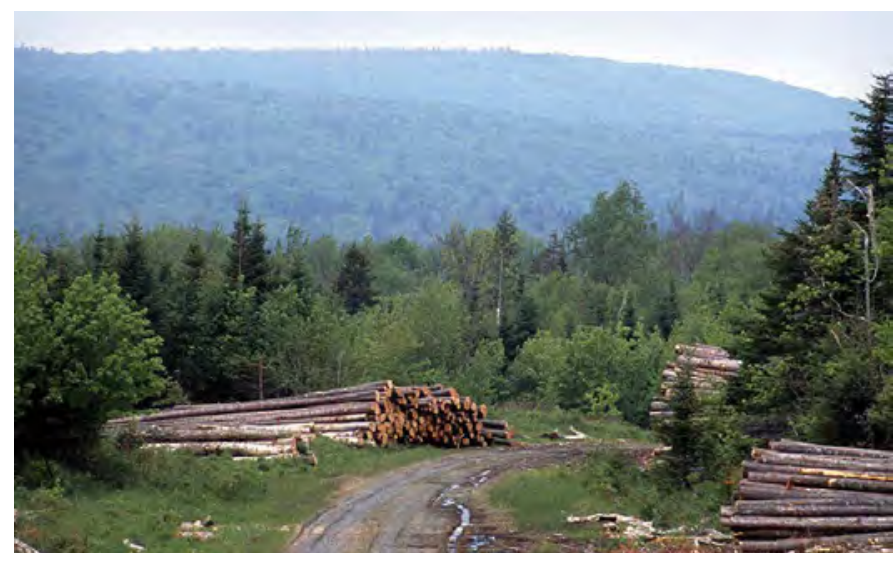

Figure 5. Logging road out of clearcut area in Maine, in Northeastern Highlands Ecoregion. Most land-cover change in ecoregion is due to extensive clearcutting.

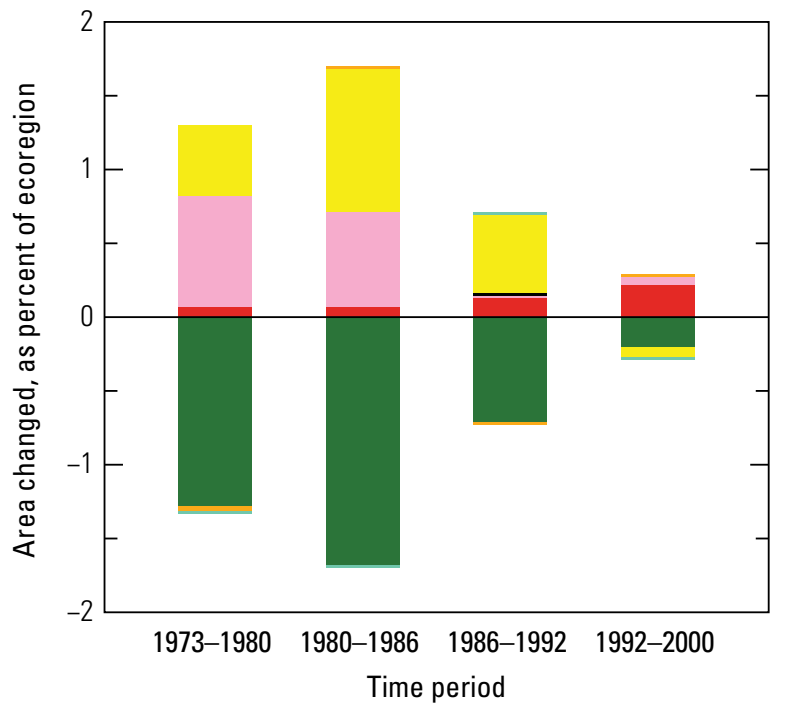

\section{EXPLANATION}

Land-use/land-cover class
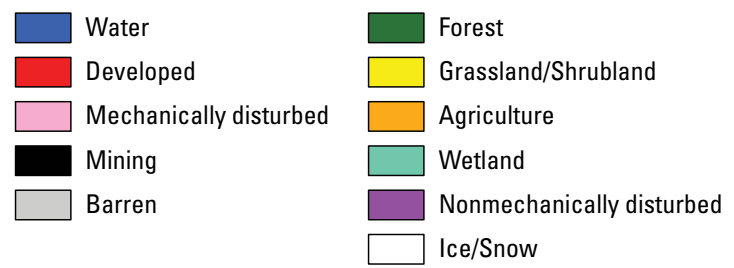

Figure 6. Normalized average net change in Northeastern Highlands Ecoregion by time period for each land-cover class. Bars above zero axis represent net gain, whereas bars below zero represent net loss. Note that not all land-cover classes shown in explanation may be represented in figure. See appendix 3 for definitions of land-use and land-cover classifications.

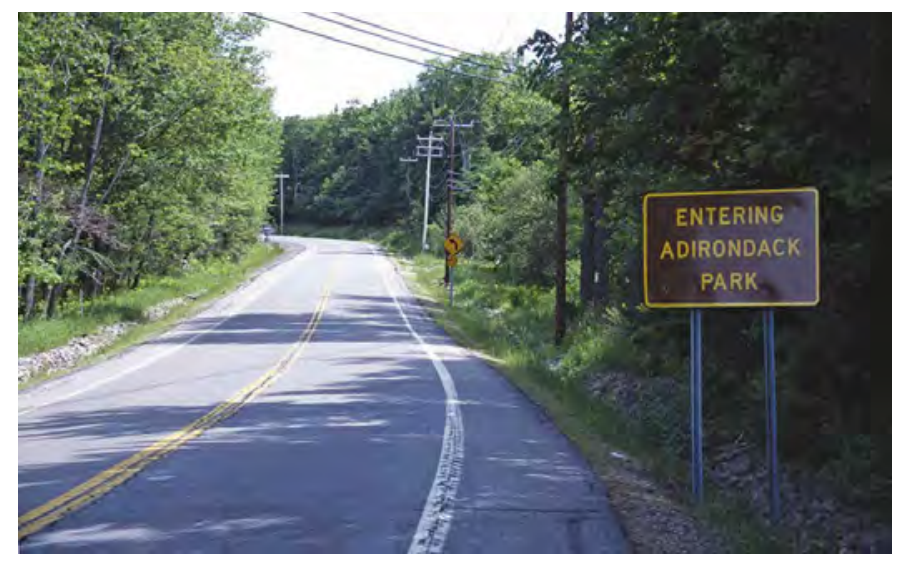

Figure 7. Road into Adirondack State Park, New York, which is example of reserved lands where restrictions are placed on timber harvesting and development. 
from forest to mechanically disturbed between 1973 and 2000 . The second most common conversion both overall and in the first three time periods was from mechanically disturbed to grassland/shrubland, with $6,983 \mathrm{~km}^{2}$ converted. Grassland/ shrubland to forest was the third most common conversion: about $4,641 \mathrm{~km}^{2}$ of grassland/shrubland converted to forest during the study period.

Although 150 years of farmland abandonment has led to regrowth of forests in the Northeastern Highlands Ecoregion, forest harvesting clearly was the dominant type of land-cover change during the 27-year study period. The success of the forest-products industry was affected by regional, national, and global market conditions, in addition to the modernization of production processes, the support from State and Federal programs, and the overall health and quality of forested land (Colgan and others, 1986; Irland, 1999). In State- and Federally owned reserved lands, forestry practices are restricted or disallowed altogether, and this may have played a role in limiting forest harvesting (fig. 7). In general, farming, which was scattered and on a small scale, did not change significantly in the ecoregion during the study period (fig. 8). The slight increase in developed land, in the form of new residential communities and tourist resorts, primarily resulted in the conversion of forest to developed.

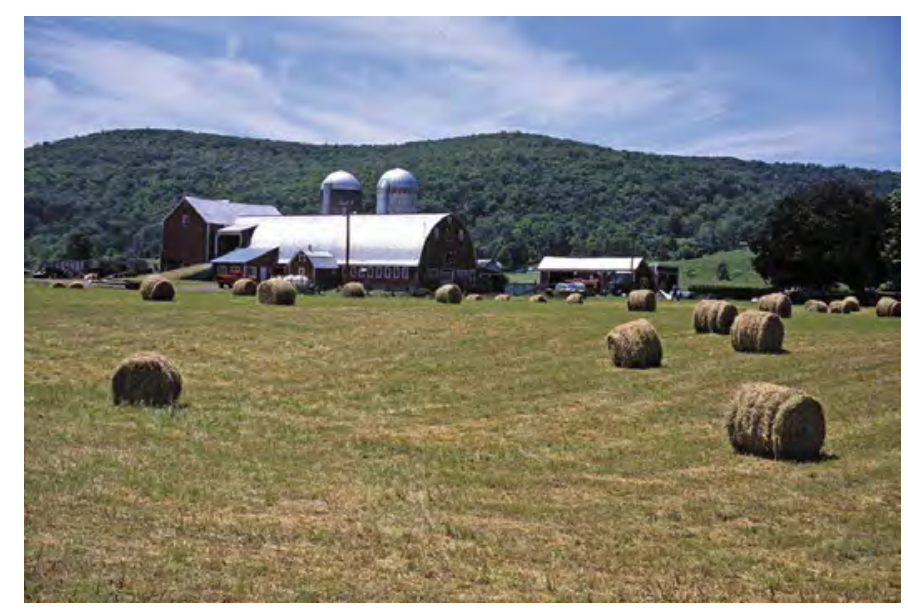

Figure 8. Farm in Northeastern Highlands Ecoregion. Although many farms in ecoregion are prosperous, amount of land in agriculture remained relatively stable during study period (1973-2000). 
Table 1. Percentage of Northeastern Highlands Ecoregion land cover that changed at least one time during study period (1973 to 2000) and associated statistical error.

[Most sample pixels remained unchanged (91.1 percent), whereas 8.9 percent changed at least once throughout study period]

\begin{tabular}{ccccccc}
\hline $\begin{array}{c}\text { Number } \\
\text { of } \\
\text { changes }\end{array}$ & $\begin{array}{c}\text { Percent } \\
\text { of } \\
\text { ecoregion }\end{array}$ & $\begin{array}{c}\text { Margin } \\
\text { of error } \\
(+/-\%)\end{array}$ & $\begin{array}{c}\text { Lower } \\
\text { bound } \\
(\%)\end{array}$ & $\begin{array}{c}\text { Upper } \\
\text { bound } \\
(\%)\end{array}$ & $\begin{array}{c}\text { Standard } \\
\text { error } \\
(\%)\end{array}$ & $\begin{array}{c}\text { Relative } \\
\text { error } \\
(\%)\end{array}$ \\
\hline 1 & 3.0 & 0.9 & 2.1 & 3.9 & 0.6 & 20.6 \\
2 & 3.0 & 1.3 & 1.7 & 4.3 & 0.9 & 29.8 \\
3 & 2.9 & 1.4 & 1.5 & 4.3 & 1.0 & 33.8 \\
4 & 0.1 & 0.1 & 0.0 & 0.2 & 0.1 & 58.9 \\
\hline $\begin{array}{l}\text { Overall } \\
\text { spatial } \\
\text { change }\end{array}$ & 8.9 & 3.3 & 5.6 & 12.2 & 2.2 & 24.8 \\
\hline
\end{tabular}

Table 2. Raw estimates of change in Northeastern Highlands Ecoregion land cover, computed for each of four time periods between 1973 and 2000, and associated error at 85-percent confidence level.

[Estimates of change per period normalized to annual rate of change for each period]

\begin{tabular}{rccccccc}
\hline Period & $\begin{array}{c}\text { Total } \\
\text { change } \\
\text { (\% of } \\
\text { ecoregion) }\end{array}$ & $\begin{array}{c}\text { Margin of } \\
\text { error } \\
(+/-\%)\end{array}$ & $\begin{array}{c}\text { Lower } \\
\text { bound } \\
(\%)\end{array}$ & $\begin{array}{c}\text { Upper } \\
\text { bound } \\
(\%)\end{array}$ & $\begin{array}{c}\text { Standard } \\
\text { error } \\
(\%)\end{array}$ & $\begin{array}{c}\text { Relative } \\
\text { error } \\
(\%)\end{array}$ & $\begin{array}{c}\text { Average } \\
\text { rate } \\
(\% \text { per } \\
\text { year) }\end{array}$ \\
\hline \multicolumn{7}{c}{ Estimate of change, in percent stratum } \\
\hline $1973-1980$ & 2.2 & 1.3 & 1.0 & 3.5 & 0.9 & 38.5 & 0.3 \\
$1980-1986$ & 3.9 & 1.7 & 2.2 & 5.7 & 1.2 & 29.9 & 0.7 \\
$1986-1992$ & 5.5 & 2.1 & 3.4 & 7.7 & 1.5 & 26.5 & 0.9 \\
$1992-2000$ & 6.2 & 2.4 & 3.8 & 8.7 & 1.6 & 26.4 & 0.8 \\
\hline & \multicolumn{7}{c}{ Estimate of change, in square kilometers } \\
\hline $1973-1980$ & 2,855 & 1,617 & 1,239 & 4,472 & 1,098 & 38 & 408 \\
$1980-1986$ & 5,010 & 2,208 & 2,803 & 7,218 & 1,500 & 30 & 835 \\
$1986-1992$ & 7,006 & 2,733 & 4,273 & 9,738 & 1,856 & 26 & 1,168 \\
$1992-2000$ & 7,921 & 3,076 & 4,845 & 10,998 & 2,090 & 26 & 990 \\
\hline
\end{tabular}


Table 3. Estimated area (and margin of error) of each land-cover class in Northeastern Highlands Ecoregion, calculated five times between 1973 and 2000. See appendix 3 for definitions of land-cover classifications.

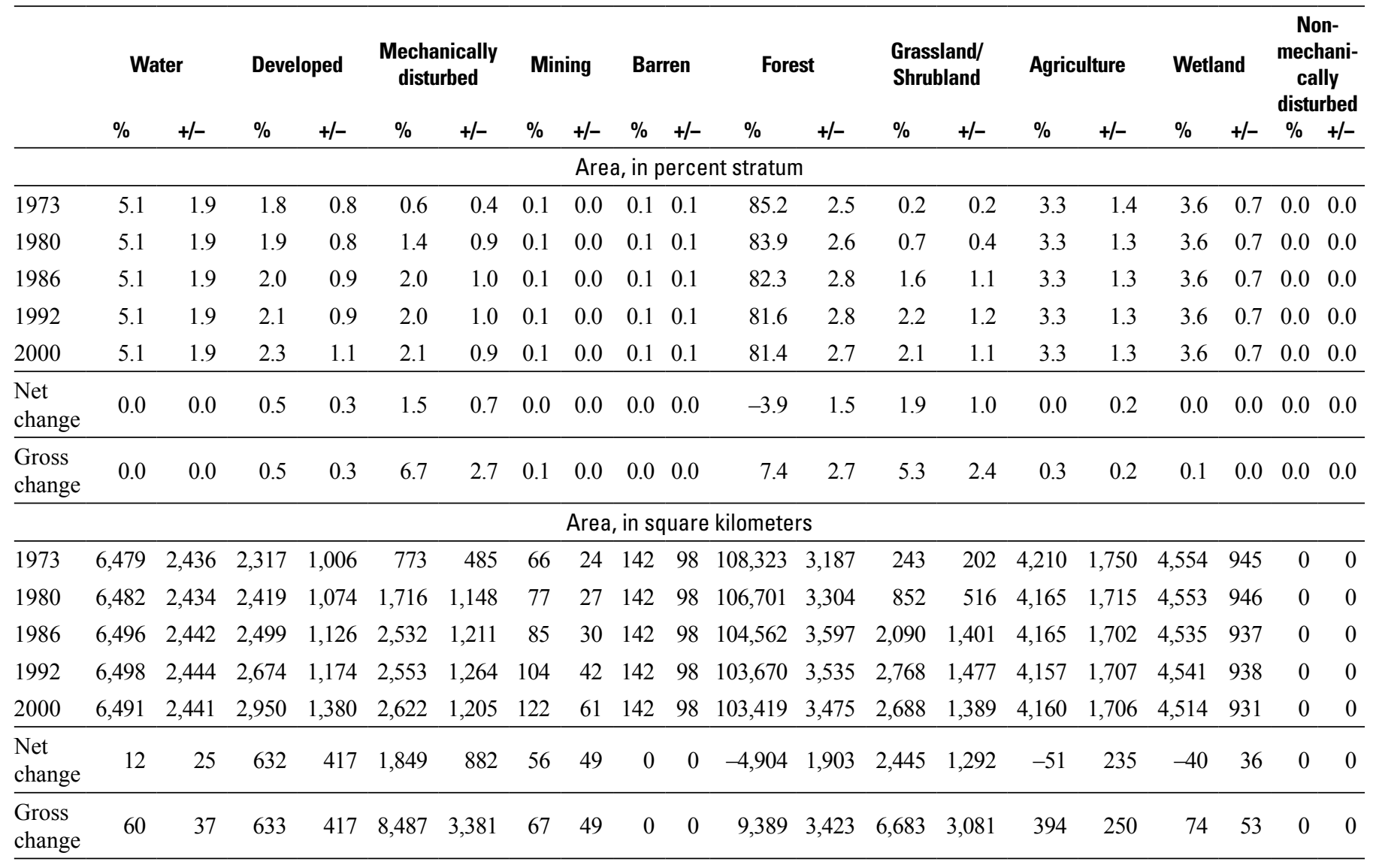


Table 4. Principal land-cover conversions in Northeastern Highlands Ecoregion, showing amount of area changed (and margin of error, calculated at 85-percent confidence level) for each conversion during each of four time periods and also during overall study period. See appendix 3 for definitions of land-cover classifications.

[Values given for "other" classes are combined totals of values for other land-cover classes not listed in that time period. Abbreviations: n/a, not applicable]

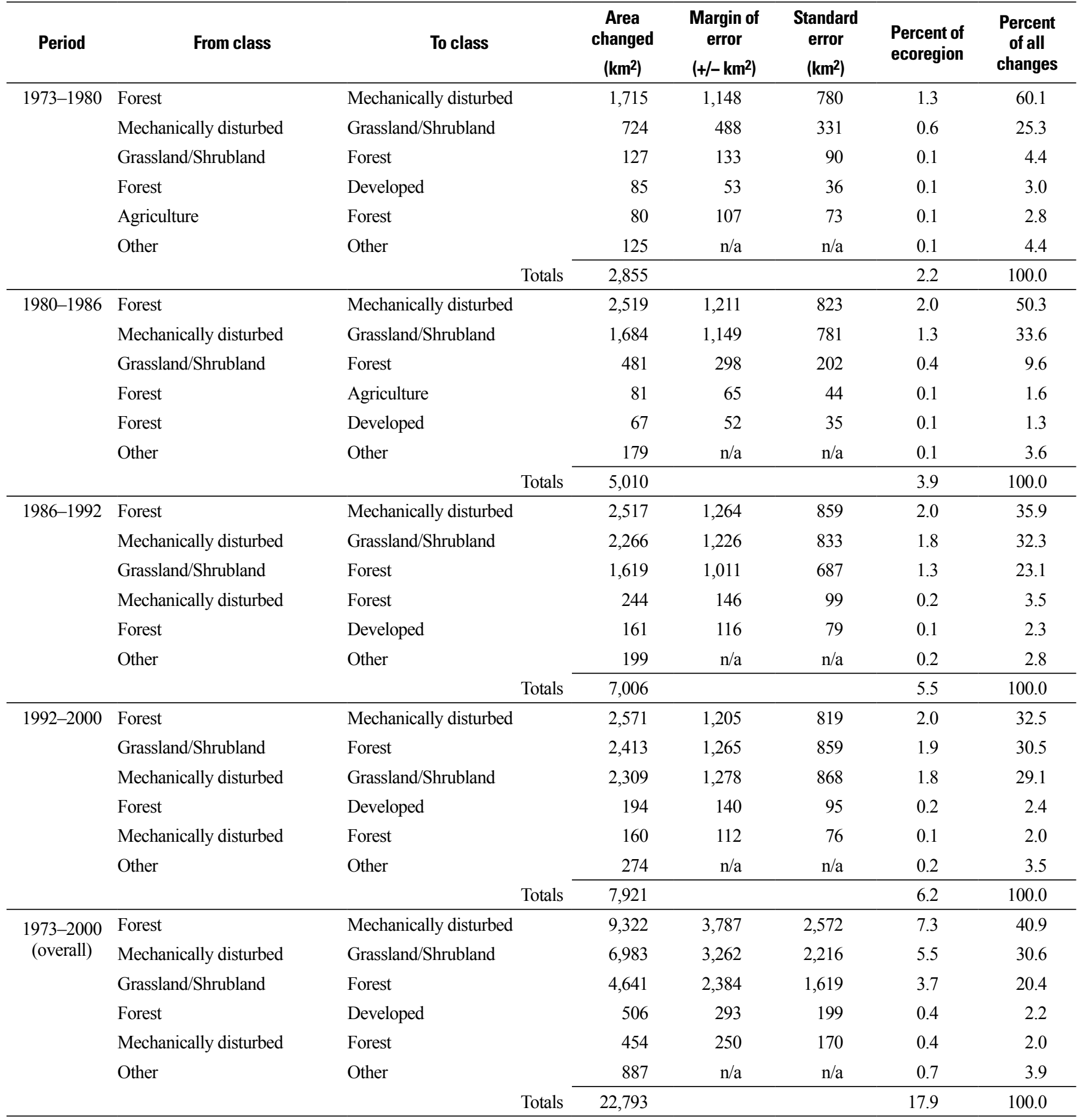




\section{References Cited}

Colgan, C.S., Irland, L.C., and Benson, J., 1986, The natural resource industries of Maine-An assessment and statistical portrait: Augusta, Financial Authority of Maine and Maine State Planning Office, $135 \mathrm{p}$.

Irland, L.C., 1999, The Northeast's changing forest: Petersham, Mass., Harvard Forest [distributed by Harvard University Press], 427 p.

U.S. Environmental Protection Agency, 2013, Primary distinguishing characteristics of Level III Ecoregions of the continental United States: U.S. Environmental Protection Agency, National Health and Environmental Effects Research Laboratory, available at ftp://ftp.epa.gov/wed/ ecoregions/us/Eco_Level_III_descriptions.doc.

Vogelmann, J.E., Howard, S.M., Yang, L., Larson, C.R., Wylie, B.K., and van Driel, N., 2001, Completion of the 1990s National Land Cover Data Set for the conterminous United States from Landsat Thematic Mapper data and ancillary data sources: Photogrammetric Engineering \& Remote Sensing, v. 67, p. 650-662. 


\title{
Chapter 3
}

\section{Eastern Great Lakes and Hudson Lowlands Ecoregion}

\author{
By Janis L. Taylor
}

\section{Ecoregion Description}

The Eastern Great Lakes and Hudson Lowlands Ecoregion, a glaciated region of irregular plains bordered by hills and lakes, is located mostly in New York, but it also extends eastward into western Vermont, including Lake Champlain; in addition, a long, thin finger extends southwestward along Lake Erie into Pennsylvania and Ohio (fig. 1). The ecoregion, which covers about $60,591 \mathrm{~km}^{2}(23,394$ $\mathrm{mi}^{2}$ ), primarily is a mix of forested land, agricultural land, and developed land. Water bodies and rivers are a dominant feature of this forested ecoregion (fig. 2): Lake Champlain makes up much of the far-eastern part of the ecoregion, and Lake Erie and Lake Ontario (along with Canada) form the northern boundary
Figure 1. Map of Eastern Great Lakes and Hudson Lowlands Ecoregion and surrounding ecoregions, showing land-use/ land-cover classes from 1992 National Land Cover Dataset (Vogelmann and others, 2001); note that not all land-use/land-cover classes shown in explanation may be depicted on map; note also that, for this "Status and Trends of Land Change" study, transitional land-cover class was subdivided into mechanically disturbed and nonmechanically disturbed classes. Squares indicate locations of $10 \times 10 \mathrm{~km}$ sample blocks analyzed in study. Index map shows locations of geographic features mentioned in text. Abbreviations for Eastern United States ecoregions are listed in appendix 2. Also shown are parts of four Midwest-South Central United States ecoregions: Erie Drift Plains, Eastern Corn Belt Plains (ECBP), Huron/Erie Lake Plains (HELP), and Southern Michigan/Northern Indiana Drift Plains (SMNIDP). See appendix 3 for definitions of land-use/landcover classifications.

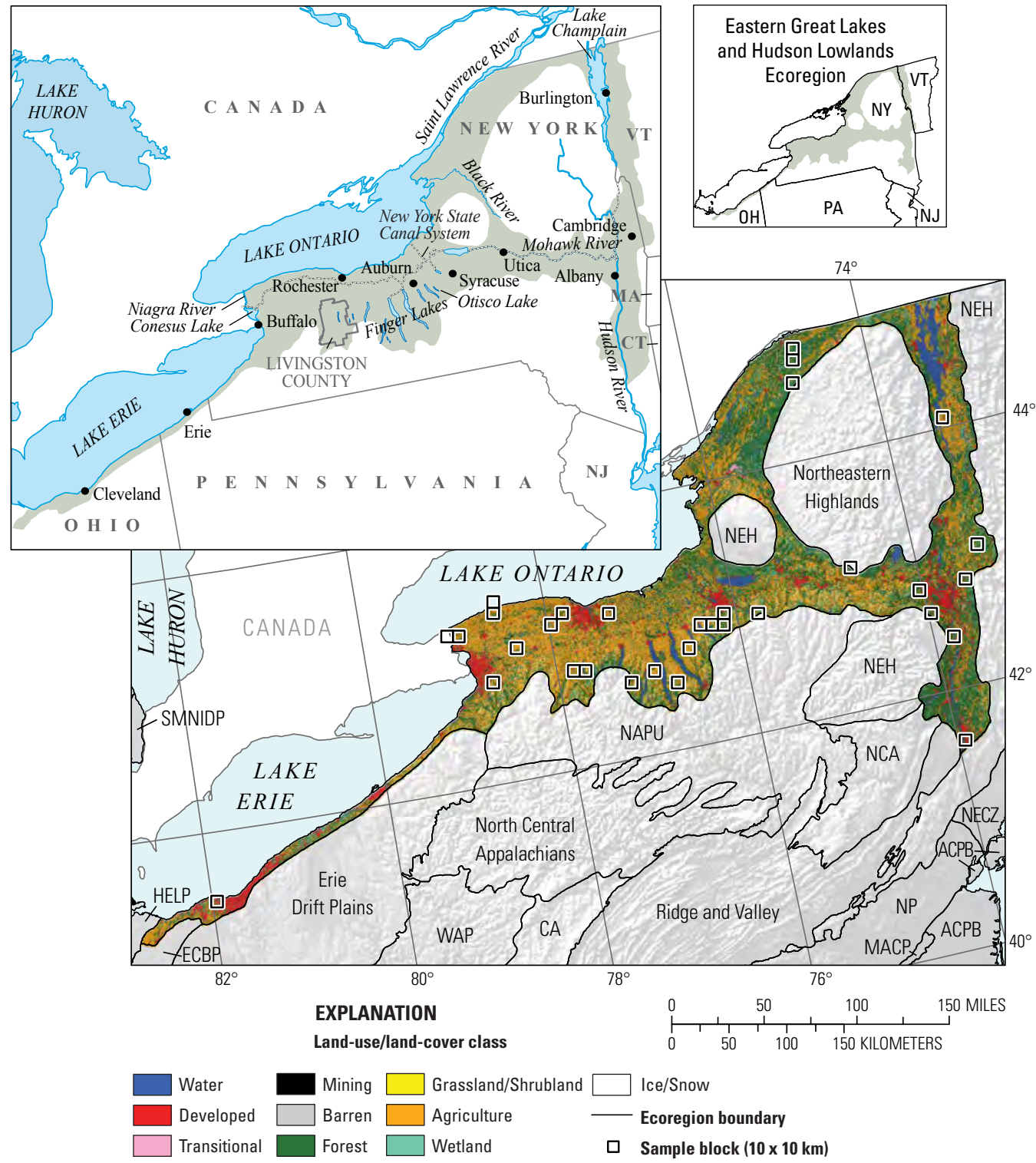


of the ecoregion. The ecoregion is surrounded by, clockwise from east-northeast to west-southwest, the Northeastern Highlands, Ridge and Valley, North Central Appalachians, Northeastern Highlands (again), Northern Appalachian Plateau and Uplands, Erie Drift Plains, Eastern Corn Belt Plains, and Huron/Erie Lake Plains Ecoregions; in addition, it completely surrounds two outliers of the Northeastern Highlands Ecoregion (fig. 1). The Eastern Great Lakes and Hudson Lowlands Ecoregion has less surface irregularity, more agricultural activity, and higher population density than the adjacent Northeastern Highlands and Northern Appalachian Plateau and Uplands Ecoregions (Wiken and others, 2011).

The Eastern Great Lakes and Hudson Lowlands Ecoregion has a severe continental climate that has warm summers, during which temperatures range from $16^{\circ}$ to $19^{\circ} \mathrm{C}$, and cold, snowy winters, during which temperatures range from $-7^{\circ}$ to $-2^{\circ} \mathrm{C}$. Yearly precipitation in the ecoregion ranges from 720 $\mathrm{mm}$ (28 in.) to more than 1,200 $\mathrm{mm}$ (47 in.). The spodosol soils of the river valleys in the ecoregion, which have developed on glacial deposits, are heavier and of better quality than soils in

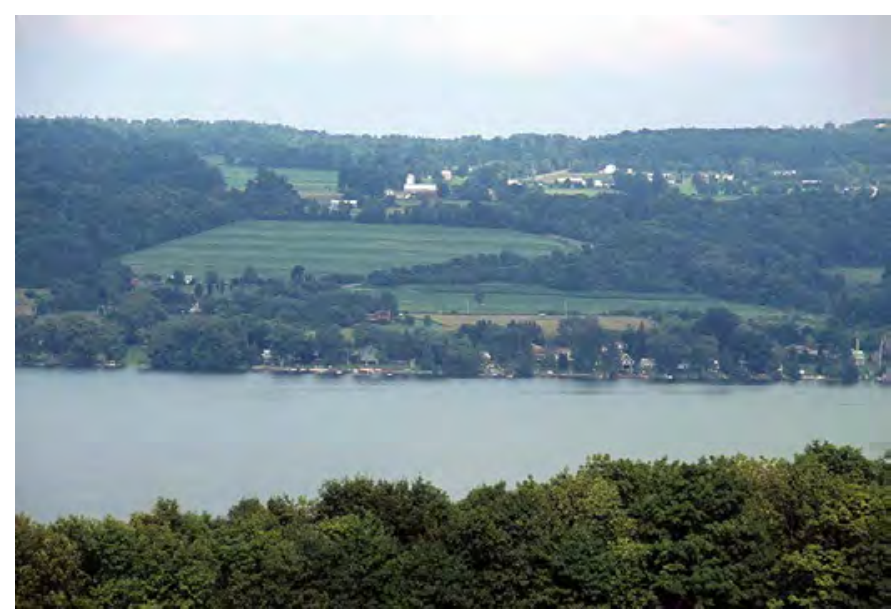

Figure 2. Homes and farm fields on hills surrounding Otisco Lake, east of Auburn, New York.

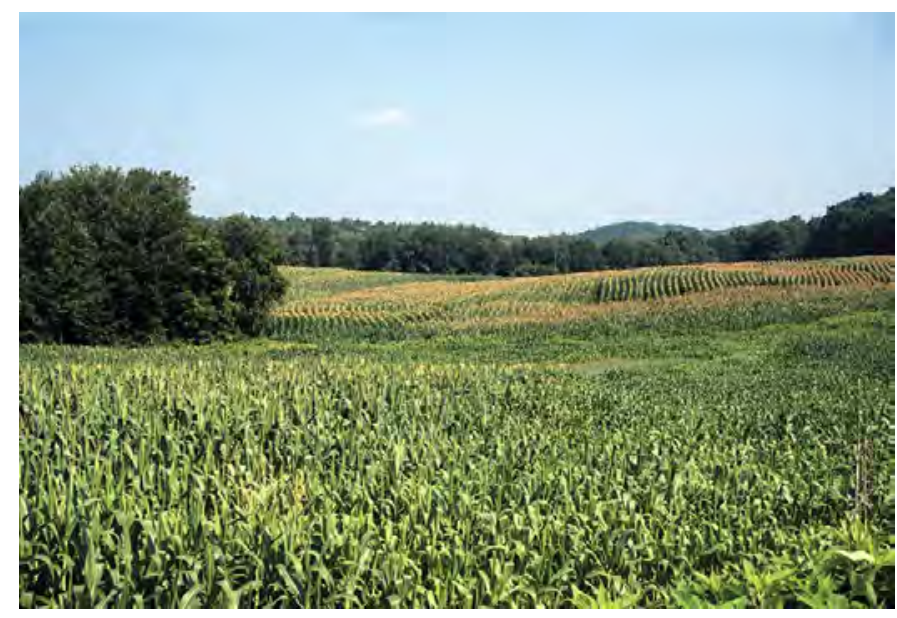

Figure 3. Corn field surrounded by forest, near Cambridge, New York. the higher elevations of adjacent ecoregions, and they provide a strong foundation for agriculture. Major crops grown in the ecoregion include apples, grapes, tart cherries, pears, plums, corn, hay, wheat, oats, barley, soybeans, cabbage, and potatoes (fig. 3). Vineyards and wineries thrive along the shores of Lake Erie and in the Finger Lakes region because these areas have a longer growing season, more winter cloudiness, and greater snowfall amounts than the rest of the ecoregion.

\section{Contemporary Land-Cover Change (1973 to 2000)}

The overall spatial change (the percentage of land that changed at least one time) in the Eastern Great Lakes and Hudson Lowlands Ecoregion between 1973 and 2000 is estimated at 5.6 percent (table 1). Compared to other Eastern United States ecoregions, change in the Eastern Great Lakes and Hudson Lowlands Ecoregion was fairly low (fig. 4): about 4.8 percent changed one time, and 0.7 percent changed two times (table 1). Total change in each of the four time periods was very similar, ranging from 1.3 to 2.1 percent (table 2).

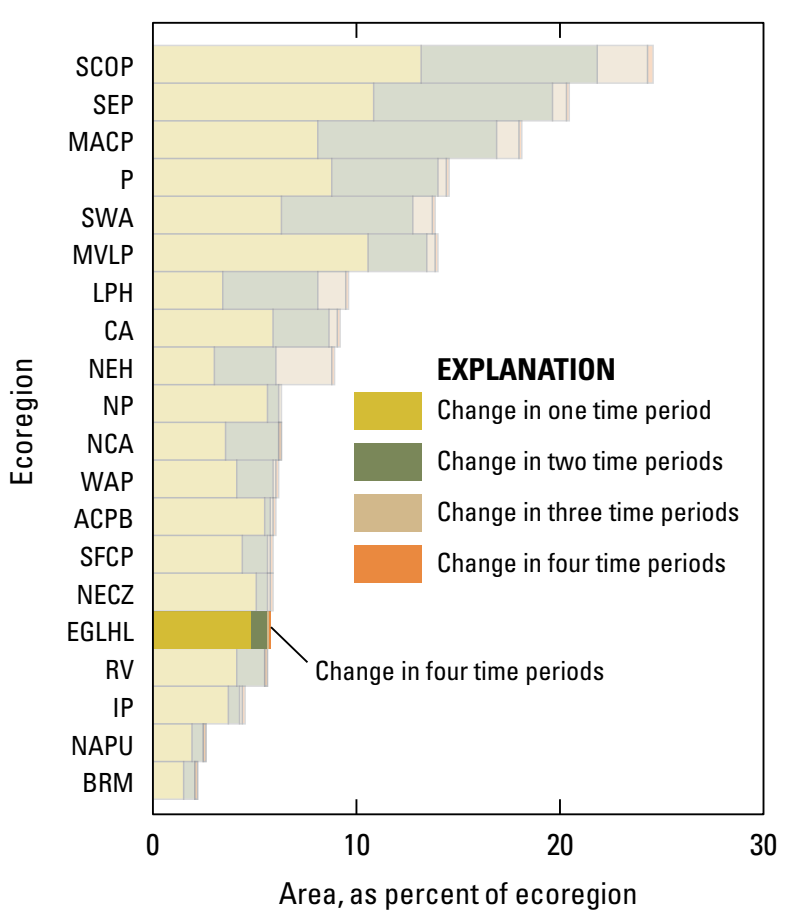

Figure 4. Overall spatial change in Eastern Great Lakes and Hudson Lowlands Ecoregion (EGLHL; darker bars) compared with that of all 20 Eastern United States ecoregions (lighter bars). Each horizontal set of bars shows proportions of ecoregion that changed during one, two, three, or four time periods; highest level of spatial change in Eastern Great Lakes and Hudson Lowlands Ecoregion (four time periods) labeled for clarity. See table 2 for years covered by each time period. See appendix 2 for key to ecoregion abbreviations. 
When normalized to an average annual rate to account for unequal time periods, the rates ranged from a low of 0.2 percent per year in the first two time periods (1973-1980, 1980-1986) to a high of 0.4 percent per year in the third time period (1986-1992) (table 2; fig. 5).

The amount of area occupied by each land-cover class mapped in each of the five study dates is shown in table 3. Forest, agriculture, and developed were the predominant landcover classes, accounting for 88.1 percent of the ecoregion in 2000 (table 3). During the study period, the amount of forested land decreased by 0.5 percent, from 39.4 percent of the ecoregion in 1973 to 38.9 percent in 2000. Agricultural land decreased by 2.1 percent, from 39.7 percent of the ecoregion in 1973 to 37.6 percent in 2000. Developed land changed the most, increasing 2.4 percent, from 9.2 percent of the ecoregion in 1973 to 11.6 percent in 2000.

The conversion of forest to developed was the most common conversion overall during the study period (table 4). The second most common conversion overall was from agriculture to developed. Developed land increased in each of the four time periods (fig. 6): in the first two time periods (1973-1980, 1980-1986), most new developed land was converted from forested land; in the last two time periods (1986-1992, 1992-2000), most came from agricultural land (table 4). The third most common conversion overall was from agriculture to grassland/shrubland. The largest conversion of this type occurred between 1986 and 1992, when $243 \mathrm{~km}^{2}$ of agricultural land was converted to grassland/shrubland (table 4). This type of conversion either was driven by agricultural abandonment or was an intermediate step in the conversion to developed land. Finally, the fourth most common conversion overall was from grassland/shrubland to forest.

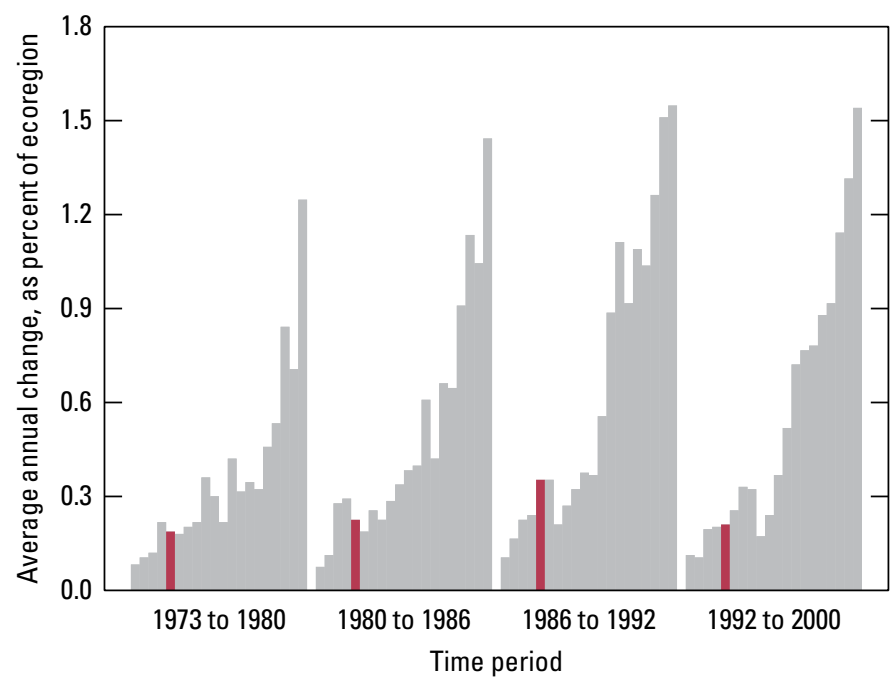

Figure 5. Estimates of land-cover change per time period, normalized to annual rates of change for all 20 Eastern United States ecoregions (gray bars). Estimates of change for Eastern Great Lakes and Hudson Lowlands Ecoregion are represented by red bars in each time period.
The unidirectional land-cover change from agriculture or forest to developed (fig. 7) was driven by an increase in population in and around several large urban centers in the ecoregion, including Albany, Buffalo, Rochester, Syracuse, and Utica, New York; Burlington, Vermont; Erie, Pennsylvania; and Cleveland, Ohio. In addition, tourism and exurban development have increased along rivers and lakes. Populated areas across this ecoregion have long been tied to waterways, which are important traffic arteries that provide easy passage between the Atlantic Ocean and the Great Lakes. For example, the New York State Canal System, which replaced the Erie Canal in the early 1900s, links together many lakes and rivers in the ecoregion. In addition to being transportation routes, the Hudson River, Saint Lawrence River, Mohawk River, Black River, and Niagara River also are scenic and tourist attractions, as well as sources of hydroelectric power. Despite population increases, the Finger Lakes region in upstate New York, as well as the Lake Champlain Basin in northeastern New York and northwestern Vermont, remain important agricultural areas (fig. 8).

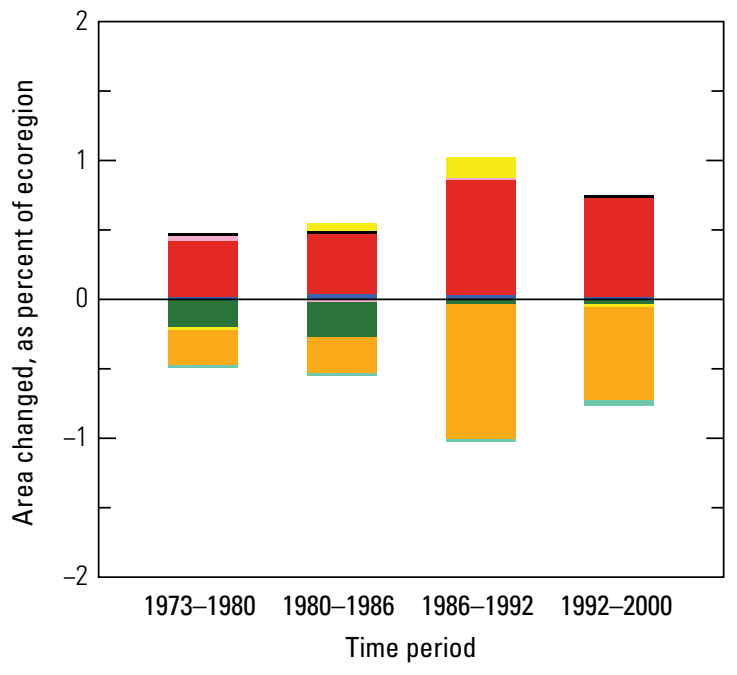

EXPLANATION

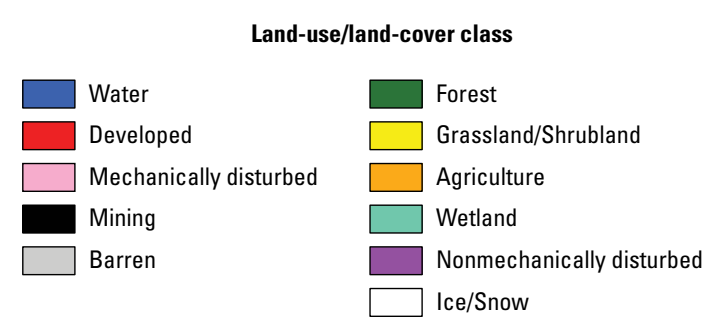

Figure 6. Normalized average net change in Eastern Great Lakes and Hudson Lowlands Ecoregion by time period for each landcover class. Bars above zero axis represent net gain, whereas bars below zero represent net loss. Note that not all land-cover classes shown in explanation may be represented in figure. See appendix 3 for definitions of land-use and land-cover classifications. 


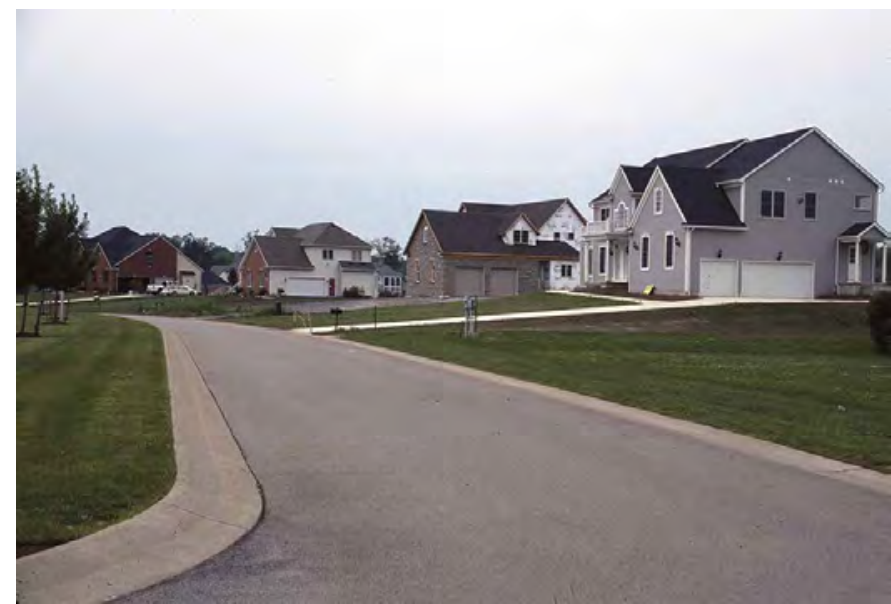

Figure 7. New subdivision southeast of Buffalo, New York.

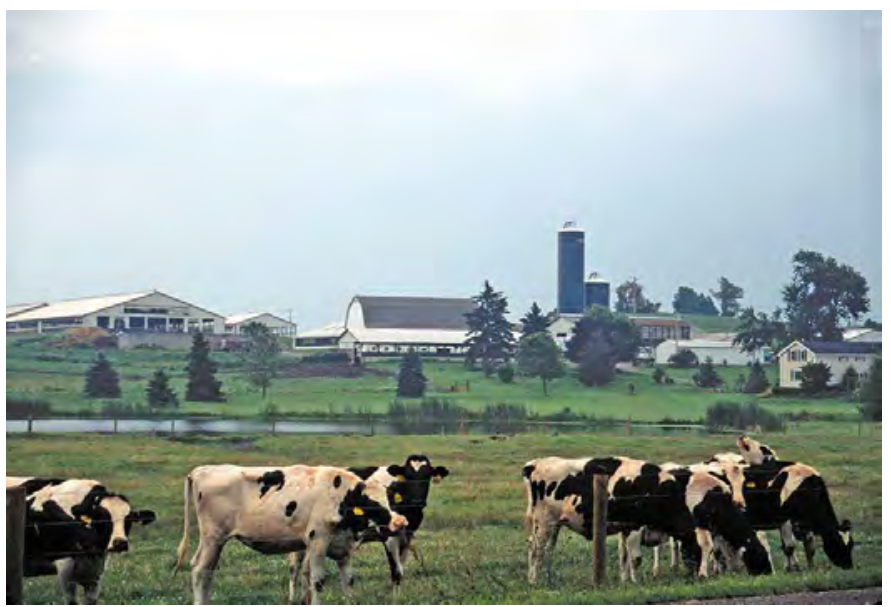

Figure 8. Dairy farm near Conesus Lake, in Livingston County, New York.

Table 1. Percentage of Eastern Great Lakes and Hudson Lowlands Ecoregion land cover that changed at least one time during study period (1973-2000) and associated statistical error.

[Most sample pixels remained unchanged (94.4 percent), whereas 5.6 percent changed at least once throughout study period]

\begin{tabular}{ccccccc}
\hline $\begin{array}{c}\text { Number } \\
\text { of } \\
\text { changes }\end{array}$ & $\begin{array}{c}\text { Percent } \\
\text { of } \\
\text { ecoregion }\end{array}$ & $\begin{array}{c}\text { Margin } \\
\text { of error } \\
(+/-\%)\end{array}$ & $\begin{array}{c}\text { Lower } \\
\text { bound } \\
(\%)\end{array}$ & $\begin{array}{c}\text { Upper } \\
\text { bound } \\
(\%)\end{array}$ & $\begin{array}{c}\text { Standard } \\
\text { error } \\
(\%)\end{array}$ & $\begin{array}{c}\text { Relative } \\
\text { error } \\
(\%)\end{array}$ \\
\hline 1 & 4.8 & 1.2 & 3.6 & 6.1 & 0.8 & 17.2 \\
2 & 0.7 & 0.2 & 0.5 & 0.9 & 0.1 & 17.0 \\
3 & 0.0 & 0.0 & 0.0 & 0.1 & 0.0 & 32.8 \\
4 & 0.0 & 0.0 & 0.0 & 0.0 & 0.0 & 71.6 \\
\hline $\begin{array}{c}\text { Overall } \\
\text { spatial } \\
\text { change }\end{array}$ & 5.6 & 1.3 & 4.3 & 6.9 & 0.9 & 15.4 \\
\hline
\end{tabular}


Table 2. Raw estimates of change in Eastern Great Lakes and Hudson Lowlands Ecoregion land cover, computed for each of four time periods between 1973 and 2000, and associated error at 85-percent confidence level.

[Estimates of change per period normalized to annual rate of change for each time period]

\begin{tabular}{|c|c|c|c|c|c|c|c|}
\hline Period & $\begin{array}{c}\text { Total change } \\
\text { (\% of ecoregion) }\end{array}$ & $\begin{array}{c}\text { Margin of } \\
\text { error } \\
(+/-\%)\end{array}$ & $\begin{array}{c}\text { Lower } \\
\text { bound } \\
(\%)\end{array}$ & $\begin{array}{c}\text { Upper bound } \\
(\%)\end{array}$ & $\begin{array}{c}\text { Standard } \\
\text { error } \\
(\%) \\
\end{array}$ & $\begin{array}{c}\text { Relative } \\
\text { error } \\
(\%)\end{array}$ & $\begin{array}{r}\text { Average rate } \\
\text { (\% per year) }\end{array}$ \\
\hline \multicolumn{8}{|c|}{ Estimate of change, in percent stratum } \\
\hline $1973-1980$ & 1.3 & 0.3 & 1.0 & 1.6 & 0.2 & 16.8 & 0.2 \\
\hline $1980-1986$ & 1.3 & 0.4 & 1.0 & 1.7 & 0.2 & 18.1 & 0.2 \\
\hline $1986-1992$ & 2.1 & 0.6 & 1.5 & 2.7 & 0.4 & 20.1 & 0.4 \\
\hline $1992-2000$ & 1.7 & 0.4 & 1.2 & 2.1 & 0.3 & 17.9 & 0.2 \\
\hline \multicolumn{8}{|c|}{ Estimate of change, in square kilometers } \\
\hline $1973-1980$ & 778 & 193 & 585 & 971 & 130 & 17 & 111 \\
\hline 1980-1986 & 805 & 215 & 590 & 1,021 & 146 & 18 & 134 \\
\hline 1986-1992 & 1,283 & 381 & 902 & 1,665 & 258 & 20 & 214 \\
\hline 1992-2000 & 1,008 & 267 & 741 & 1,276 & 181 & 18 & 126 \\
\hline
\end{tabular}

Table 3. Estimated area (and margin of error) of each land-cover class in Eastern Great Lakes and Hudson Lowlands Ecoregion, calculated five times between 1973 and 2000. See appendix 3 for definitions of land-cover classifications.

\begin{tabular}{|c|c|c|c|c|c|c|c|c|c|c|c|c|c|c|c|c|c|c|c|c|}
\hline & \multicolumn{2}{|c|}{ Water } & \multicolumn{2}{|c|}{ Developed } & \multicolumn{2}{|c|}{$\begin{array}{c}\text { Mechanically } \\
\text { disturbed }\end{array}$} & \multicolumn{2}{|c|}{ Mining } & \multicolumn{2}{|c|}{ Barren } & \multicolumn{2}{|c|}{ Forest } & \multicolumn{2}{|c|}{$\begin{array}{l}\text { Grassland/ } \\
\text { Shrubland }\end{array}$} & \multicolumn{2}{|c|}{ Agriculture } & \multicolumn{2}{|c|}{ Wetland } & \multicolumn{2}{|c|}{$\begin{array}{c}\text { Non- } \\
\text { mechanically } \\
\text { disturbed }\end{array}$} \\
\hline & $\%$ & $+1-$ & $\%$ & $+1-$ & $\%$ & $+/-$ & $\%$ & $+/-$ & $\%$ & $+1-$ & $\%$ & $+/-$ & $\%$ & $+/-$ & $\%$ & $+/-$ & $\%$ & $+1-$ & $\%$ & $+/-$ \\
\hline 1973 & 6.8 & 4.3 & 9.2 & 3.0 & 0.0 & 0.0 & 0.4 & 0.2 & 0.0 & 0.0 & 39.4 & 4.6 & 0.5 & 0.3 & 39.7 & 5.0 & 3.9 & 1.1 & 0.0 & 0.0 \\
\hline 1980 & 6.9 & 4.3 & 9.6 & 3.1 & 0.1 & 0.0 & 0.4 & 0.2 & 0.0 & 0.0 & 39.2 & 4.6 & 0.5 & 0.2 & 39.5 & 5.0 & 3.9 & 1.1 & 0.0 & 0.0 \\
\hline 1992 & 6.9 & 4.3 & 10.9 & 3.4 & 0.1 & 0.0 & 0.4 & 0.2 & 0.0 & 0.0 & 38.9 & 4.6 & 0.7 & 0.3 & 38.3 & 5.0 & 3.9 & 1.1 & 0.0 & 0.0 \\
\hline 2000 & 7.0 & 4.3 & 11.6 & 3.7 & 0.1 & 0.0 & 0.4 & 0.2 & 0.0 & 0.0 & 38.9 & 4.7 & 0.7 & 0.3 & 37.6 & 5.0 & 3.8 & 1.1 & 0.0 & 0.0 \\
\hline $\begin{array}{l}\text { Net } \\
\text { change }\end{array}$ & 0.1 & 0.1 & 2.4 & 1.0 & 0.0 & 0.0 & 0.1 & 0.1 & 0.0 & 0.0 & -0.5 & 0.9 & 0.2 & 0.3 & -2.1 & 0.6 & -0.1 & 0.1 & 0.0 & 0.0 \\
\hline $\begin{array}{l}\text { Gross } \\
\text { change }\end{array}$ & 0.1 & 0.1 & 2.4 & 1.0 & 0.3 & 0.1 & 0.2 & 0.1 & 0.0 & 0.0 & 2.4 & 0.7 & 0.9 & 0.3 & 2.7 & 0.5 & 0.1 & 0.1 & 0.0 & 0.0 \\
\hline 1980 & 4,155 & 2,624 & 5,810 & 1,872 & 35 & 30 & 246 & 129 & 1 & 1 & 23,739 & 2,793 & 299 & 137 & 23,932 & 3,048 & 2,375 & 664 & 0 & 0 \\
\hline 1986 & 4,180 & 2,622 & 6,078 & 1,910 & 28 & 19 & 254 & 130 & 1 & 1 & 23,579 & 2,808 & 334 & 121 & 23,779 & 3,057 & 2,359 & 658 & 0 & 0 \\
\hline 1992 & 4,204 & 2,621 & 6,578 & 2,042 & 35 & 26 & 259 & 130 & 1 & 1 & 23,561 & 2,807 & 421 & 158 & 23,192 & 3,056 & 2,340 & 654 & 0 & 0 \\
\hline 2000 & 4,214 & 2,621 & 7,015 & 2,213 & 37 & 18 & 272 & 130 & 1 & 1 & 23,545 & 2,845 & 404 & 172 & 22,778 & 3,058 & 2,325 & 653 & 0 & 0 \\
\hline $\begin{array}{l}\text { Net } \\
\text { change }\end{array}$ & 67 & 31 & 1,455 & 596 & 22 & 14 & 39 & 32 & 0 & 0 & -318 & 575 & 94 & 161 & $-1,302$ & 340 & -57 & 38 & 0 & 0 \\
\hline $\begin{array}{l}\text { Gross } \\
\text { change }\end{array}$ & 81 & 45 & 1,455 & 596 & 158 & 72 & 102 & 39 & 0 & 0 & 1,443 & 450 & 521 & 179 & 1,627 & 330 & 75 & 49 & 0 & 0 \\
\hline
\end{tabular}


Table 4. Principal land-cover conversions in Eastern Great Lakes and Hudson Lowlands Ecoregion, showing amount of area changed (and margin of error, calculated at 85-percent confidence level) for each conversion during each of four time periods and also during overall study period. See appendix 3 for definitions of land-cover classifications.

[Values given for "other" class are combined totals of values for other land-cover classes not listed in that time period. Abbreviations: n/a, not applicable]

\begin{tabular}{|c|c|c|c|c|c|c|c|c|}
\hline Period & From class & To class & & $\begin{array}{c}\begin{array}{c}\text { Area } \\
\text { changed }\end{array} \\
\left(\mathrm{km}^{2}\right)\end{array}$ & $\begin{array}{c}\text { Margin of } \\
\text { error } \\
\left(+/-\mathrm{km}^{2}\right)\end{array}$ & $\begin{array}{c}\text { Standard } \\
\text { error } \\
\left(\mathbf{k m}^{2}\right)\end{array}$ & $\begin{array}{l}\text { Percent of } \\
\text { ecoregion }\end{array}$ & $\begin{array}{c}\text { Percent of all } \\
\text { changes }\end{array}$ \\
\hline \multirow[t]{7}{*}{ 1973-1980 } & Agriculture & Forest & & 180 & 90 & 61 & 0.3 & 23.1 \\
\hline & Forest & Agriculture & & 174 & 66 & 45 & 0.3 & 22.4 \\
\hline & Forest & Developed & & 160 & 108 & 73 & 0.3 & 20.6 \\
\hline & Agriculture & Developed & & 77 & 47 & 32 & 0.1 & 9.8 \\
\hline & Grassland/Shrubland & Forest & & 57 & 33 & 23 & 0.1 & 7.4 \\
\hline & Other & Other & & 130 & $\mathrm{n} / \mathrm{a}$ & $\mathrm{n} / \mathrm{a}$ & 0.2 & 16.7 \\
\hline & & & Totals & 778 & & & 1.3 & 100.0 \\
\hline \multirow[t]{7}{*}{ 1980-1986 } & Forest & Developed & & 168 & 135 & 92 & 0.3 & 20.9 \\
\hline & Forest & Agriculture & & 147 & 66 & 45 & 0.2 & 18.2 \\
\hline & Agriculture & Grassland/Shrubland & & 122 & 58 & 39 & 0.2 & 15.2 \\
\hline & Grassland/Shrubland & Forest & & 89 & 68 & 46 & 0.1 & 11.1 \\
\hline & Agriculture & Forest & & 85 & 48 & 32 & 0.1 & 10.6 \\
\hline & Other & Other & & 194 & $\mathrm{n} / \mathrm{a}$ & $\mathrm{n} / \mathrm{a}$ & 0.3 & 24.1 \\
\hline & & & Totals & 805 & & & 1.3 & 100.0 \\
\hline \multirow[t]{7}{*}{ 1986-1992 } & Agriculture & Developed & & 304 & 120 & 81 & 0.5 & 23.7 \\
\hline & Agriculture & Grassland/Shrubland & & 243 & 99 & 67 & 0.4 & 18.9 \\
\hline & Grassland/Shrubland & Forest & & 180 & 80 & 54 & 0.3 & 14.0 \\
\hline & Forest & Developed & & 172 & 90 & 61 & 0.3 & 13.4 \\
\hline & Agriculture & Forest & & 124 & 56 & 38 & 0.2 & 9.6 \\
\hline & Other & Other & & 260 & $\mathrm{n} / \mathrm{a}$ & $\mathrm{n} / \mathrm{a}$ & 0.4 & 20.3 \\
\hline & & & Totals & 1,283 & & & 2.1 & 100.0 \\
\hline \multirow[t]{7}{*}{$1992-2000$} & Agriculture & Developed & & 213 & 87 & 59 & 0.4 & 21.1 \\
\hline & Forest & Developed & & 185 & 130 & 88 & 0.3 & 18.3 \\
\hline & Grassland/Shrubland & Forest & & 164 & 58 & 39 & 0.3 & 16.3 \\
\hline & Agriculture & Grassland/Shrubland & & 149 & 75 & 50 & 0.2 & 14.7 \\
\hline & Agriculture & Forest & & 76 & 40 & 27 & 0.1 & 7.6 \\
\hline & Other & Other & & 221 & $\mathrm{n} / \mathrm{a}$ & $\mathrm{n} / \mathrm{a}$ & 0.4 & 21.9 \\
\hline & & & Totals & 1,008 & & & 1.7 & 100.0 \\
\hline \multirow{7}{*}{$\begin{array}{l}\text { 1973-2000 } \\
\text { (overall) }\end{array}$} & Forest & Developed & & 685 & 391 & 265 & 1.1 & 17.7 \\
\hline & Agriculture & Developed & & 664 & 225 & 152 & 1.1 & 17.1 \\
\hline & Agriculture & Grassland/Shrubland & & 554 & 184 & 125 & 0.9 & 14.3 \\
\hline & Grassland/Shrubland & Forest & & 491 & 190 & 128 & 0.8 & 12.7 \\
\hline & Forest & Agriculture & & 478 & 176 & 119 & 0.8 & 12.3 \\
\hline & Other & Other & & 1,004 & $\mathrm{n} / \mathrm{a}$ & $\mathrm{n} / \mathrm{a}$ & 1.7 & 25.9 \\
\hline & & & Totals & 3,875 & & & 6.4 & 100.0 \\
\hline
\end{tabular}




\section{References Cited}

Vogelmann, J.E., Howard, S.M., Yang, L., Larson, C.R., Wylie, B.K., and van Driel, N., 2001, Completion of the 1990s National Land Cover Data set for the conterminous United States from Landsat Thematic Mapper data and ancillary data sources: Photogrammetric Engineering \& Remote Sensing, v. 67, p. 650-662.
Wiken, E., Jiménez Nava, F., and Griffith, G., 2011, North American terrestrial ecoregions-Level III: Montreal, Canada, Commission for Environmental Cooperation, 149 p., accessed May 1, 2013, at http://www.cec.org/ Storage/133/15860_QA07.30-32_NP_NA_Terrestrial_ Ecoregions_Level_3_Final-2june11.pdf. 



\section{Mid-Atlantic Coast Ecoregions}
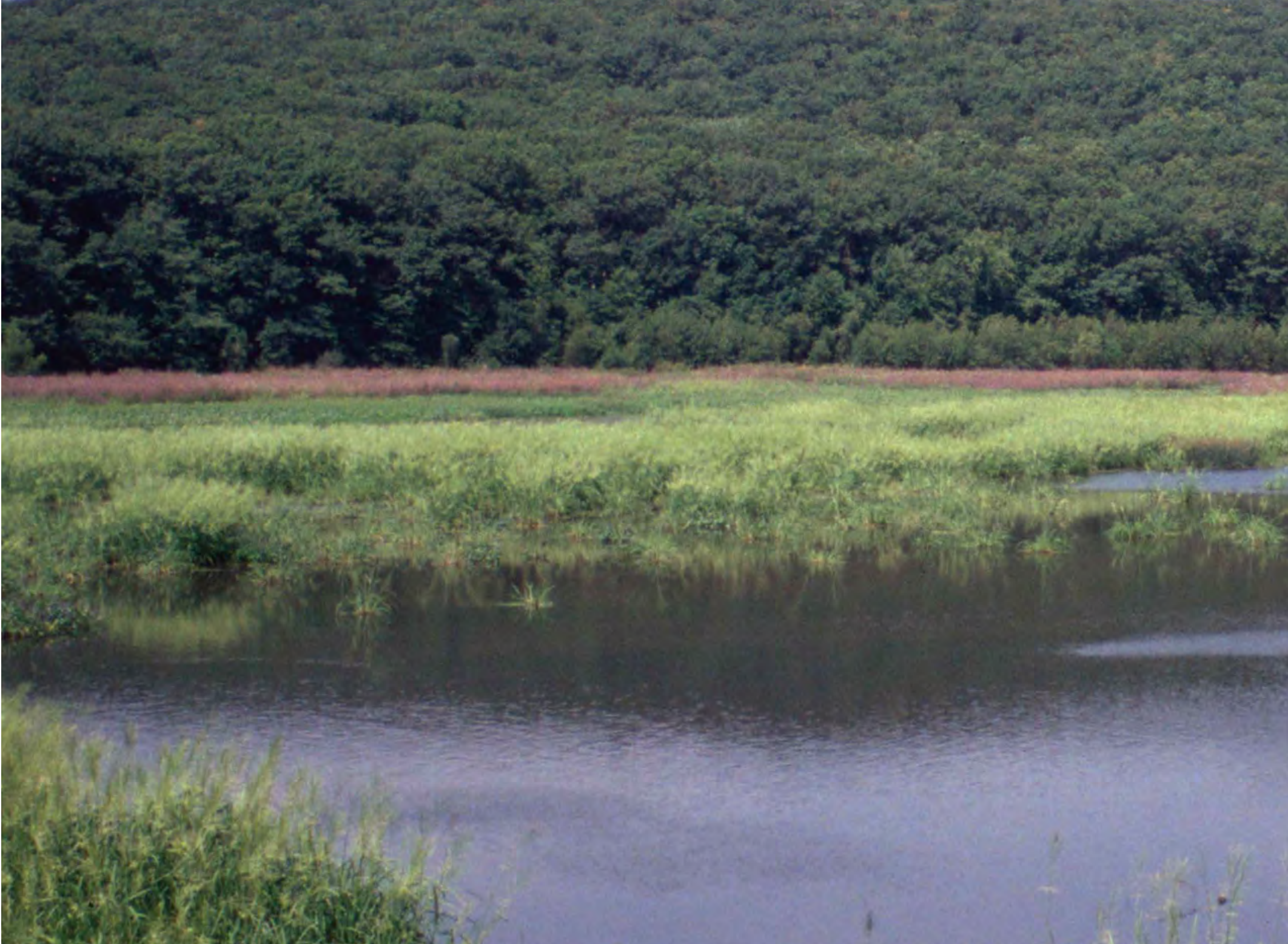

indes

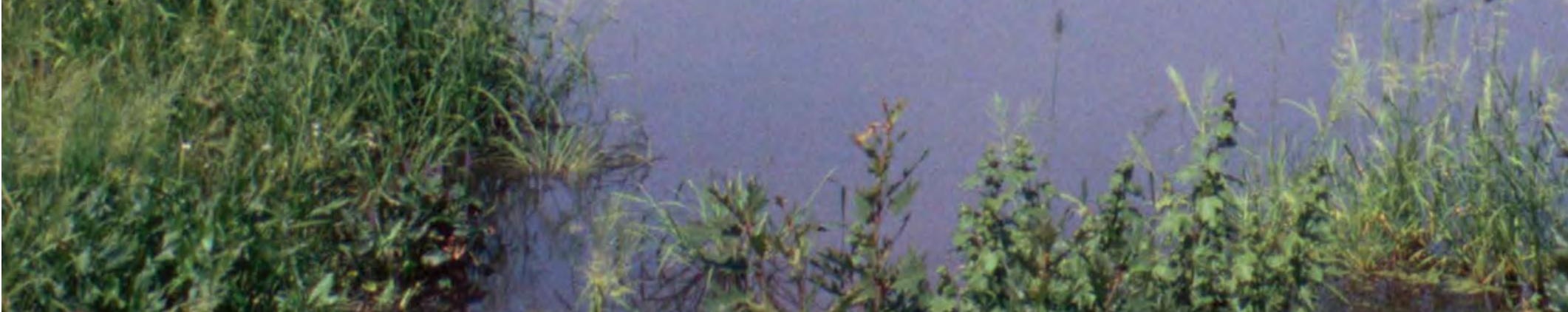




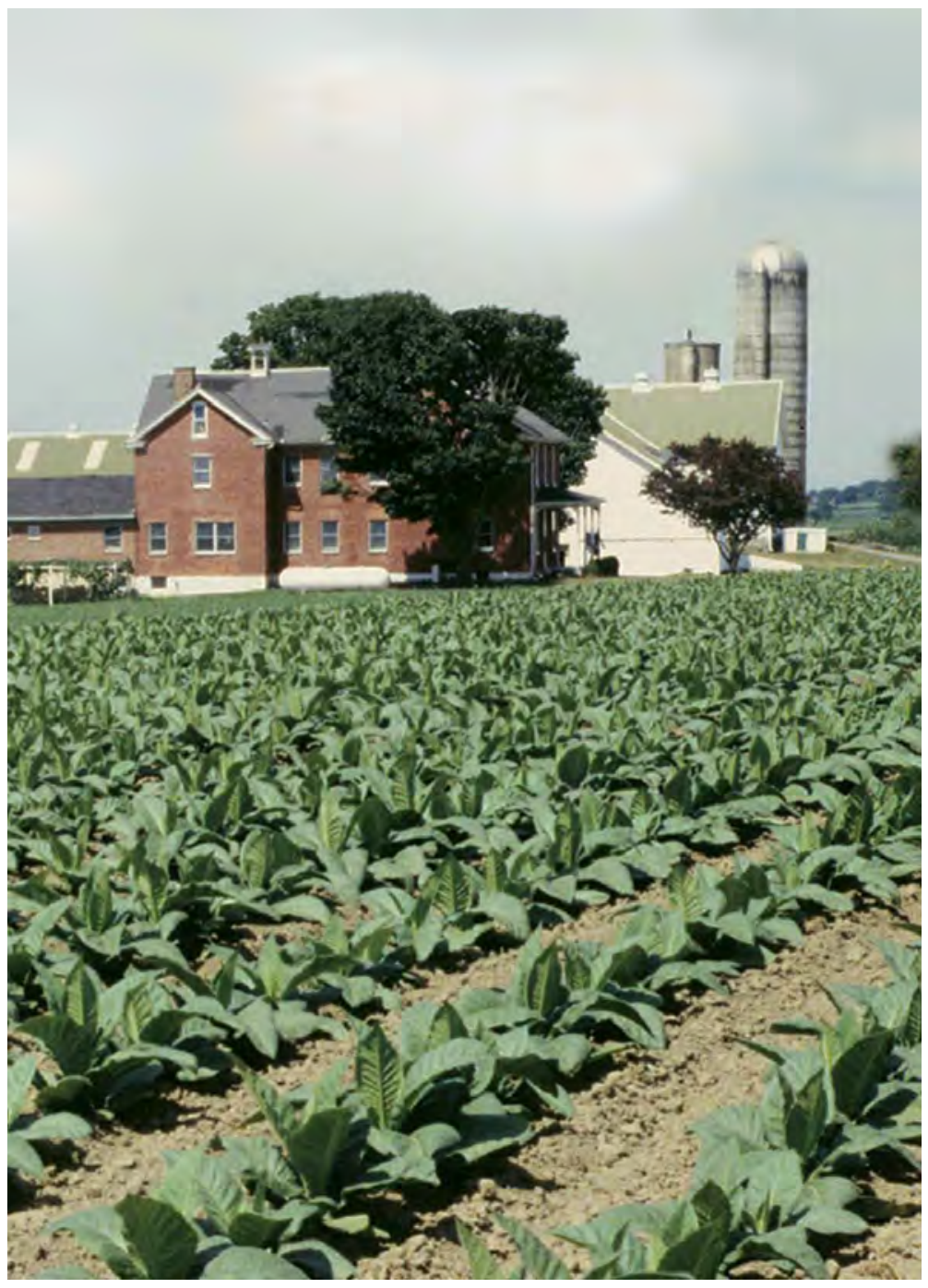




\title{
Chapter 4
}

\section{Northeastern Coastal Zone Ecoregion}

\author{
By Roger F. Auch
}

\section{Ecoregion Description}

The Northeastern Coastal Zone Ecoregion is a northeast-to-southwest-trending ecoregion that covers about $37,158 \mathrm{~km}^{2}\left(14,347 \mathrm{mi}^{2}\right)$ in eight states (Maine, New Hampshire, Vermont, Massachusetts, Rhode Island, Connecticut, New York, and New Jersey) (fig. 1). The ecoregion is bounded on the far northeast by the Laurentian Plains and Hills Ecoregion; on the north-northwest, by the Northeastern Highlands Ecoregion; on the far southwest, by the Northern Piedmont Ecoregion; and on the south and east, by two parts of the Atlantic Coastal Pine Barrens Ecoregion, as well as by the Atlantic Ocean.

The Northeastern Coastal Zone Ecoregion's glaciated past is the reason for its irregular topographic relief, which is more irregular than the neighboring Atlantic Coastal Pine Barrens Ecoregion to the south and east but not as hilly and mountainous as the Northeastern Highlands Ecoregion to the north-northwest. The soils in the Northeastern Coastal Zone Ecoregion tend to be rocky and poor in nutrients (Wiken and others, 2011). Natural vegetation is dominated by hardwood and mixed forests, but it also includes more limited coastal and inland wetlands. The Northeastern Coastal Zone Ecoregion has cold winters and warm summers, with 1,000 to $1,500 \mathrm{~mm}$ (40-60 in.) of precipitation occurring in an average year.

Together, forested land and developed land accounted for more than 70 percent of the ecoregion during the 27 -year study period (table 1 ; figs. $2 A, B$ ). Large areas of developed land are found in the northern part of the

Figure 1. Map of Northeastern Coastal Zone Ecoregion and surrounding ecoregions, showing land-use/land-cover classes from 1992 National Land Cover Dataset (Vogelmann and others, 2001); note that not all land-use/land-cover classes shown in explanation may be depicted on map; note also that, for this "Status and Trends of Land Change" study, transitional landcover class was subdivided into mechanically disturbed and nonmechanically disturbed classes. Squares indicate locations of $10 \times 10 \mathrm{~km}$ sample blocks analyzed in study. Index map shows locations of geographic features mentioned in text. Abbreviations for Eastern United States ecoregions are listed in appendix 2. See appendix 3 for definitions of land-use/land-cover classifications.

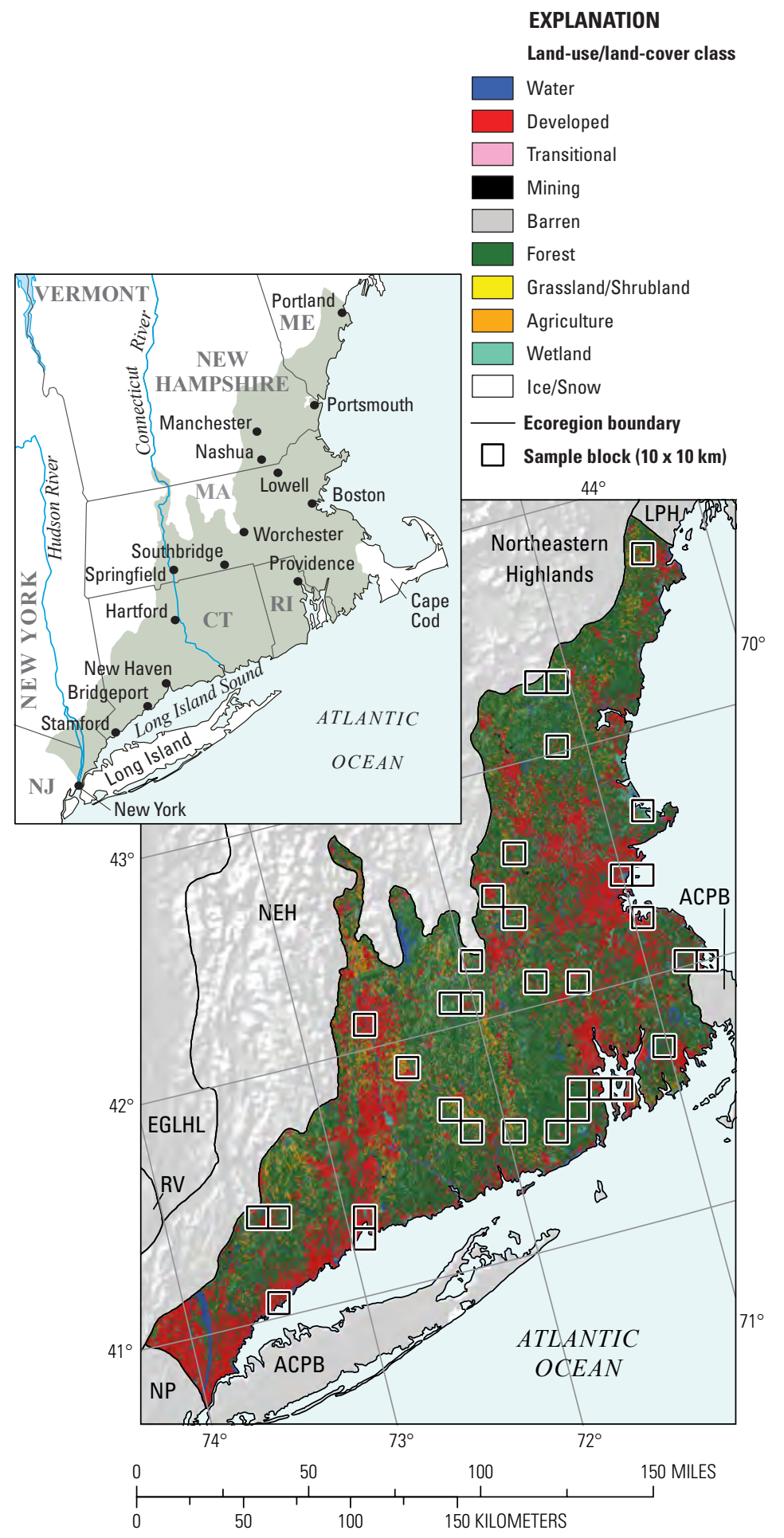

EXPLANATION

Water

Developed

Transitiona

Mining

Barre

Grassland/Shrubland

Agriculture

Wetland $44^{\circ}$

ortheaste highands

] 
New York metropolitan area, as well as eastward along Long Island Sound to New Haven, Connecticut, northward to Hartford, Connecticut, and then along the Connecticut River to Springfield, Massachusetts (fig. 1) (Vogelmann and others, 2001). Other areas of developed land in the ecoregion include metropolitan Providence, Rhode Island, which lies in a ring encircling the upper reaches of Narragansett Bay, and also the radial lines of urbanization that extend from greater Boston, Massachusetts, west to Worchester, Massachusetts, northwest to Nashua, New Hampshire, and south-southeast toward Cape Cod, Massachusetts. Portland, Maine, forms the last urban node in the extreme northeastern part of the ecoregion. According to aggregated county-level data, the ecoregion's population increased by more than 1 million people between 1970 and 2000, reaching 15,269,068 by 2000 (U.S. Census Bureau, 1970-2000 [various years]). Water, wetland, and agriculture are the other common land-cover classes in the ecoregion, but they are smaller and less concentrated than the forest and developed land-cover classes (table 1; figs. $3 A, B$ ). The only notable concentration of agricultural land is found in the Connecticut River valley, north of Hartford, Connecticut.
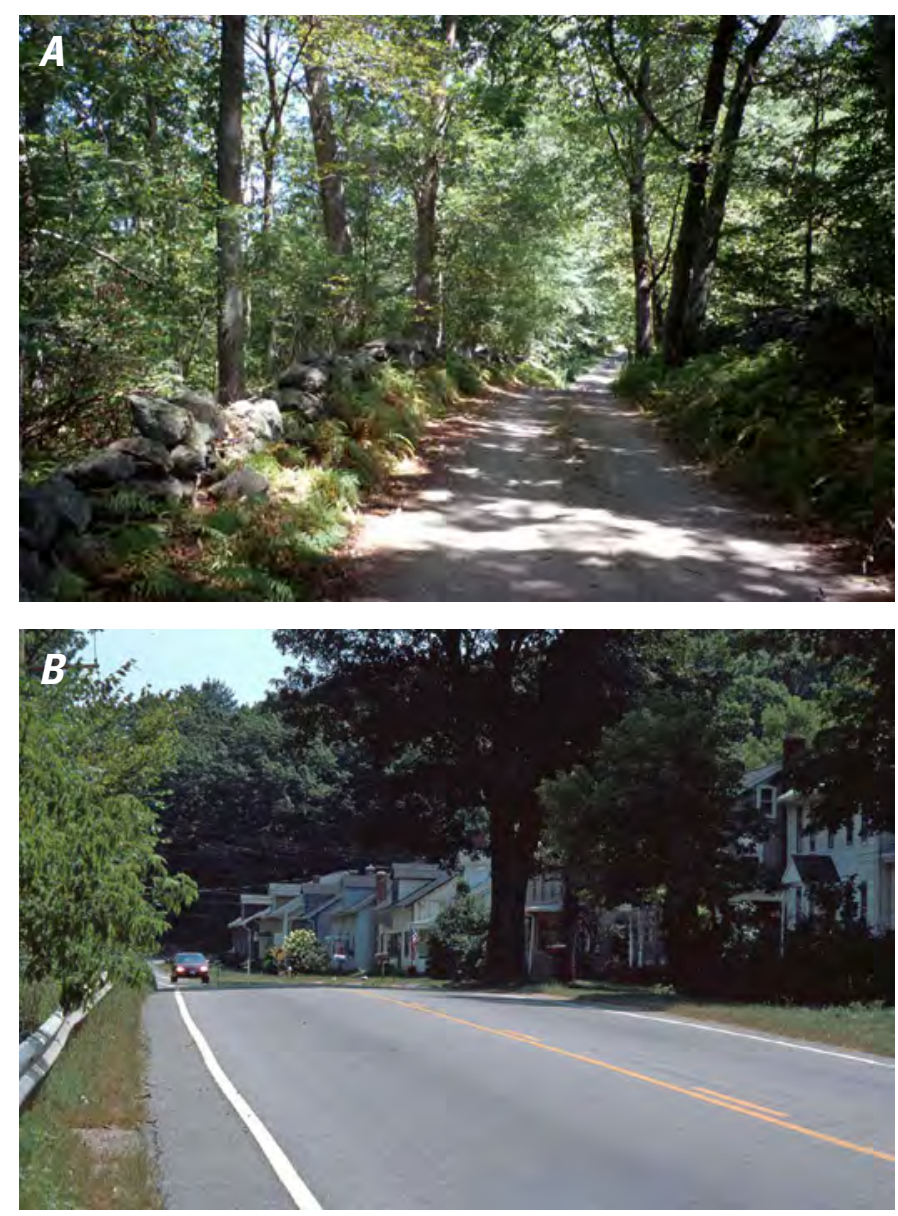

Figure 2. Forest and developed land in Northeastern Coastal Zone Ecoregion. $A$, Forest along old stone fence in eastern Connecticut. $B$, Typical scene in ecoregion of older housing with forest beyond, on outskirts of Southbridge, Massachusetts.

\section{Contemporary Land-Cover Change (1973 to 2000)}

The overall spatial change (the percentage of land area that changed at least one time) in the Northeastern Coastal Zone Ecoregion between 1973 and 2000 is estimated at 5.7 percent (table 2). Compared to other Eastern United States ecoregions, change in the Northeastern Coastal Zone Ecoregion was moderately low (fig. 4). The estimated amount of change in the first two time periods (1973-1980, 19801986) was considerably lower than that of the last two time periods (1986-1992, 1992-2000) (table 3). When normalized to an annual rate to account for unequal time periods, landcover change was highest between 1986 and 1992, at 0.3 percent (table 3; fig. 5). The variability in land-cover change across the ecoregion was low and relatively steady during the study period, as indicated by the low margin of error in the statistical estimates, which range from about 0.2 to about 0.4 percent at an 85-percent confidence level (table 3).
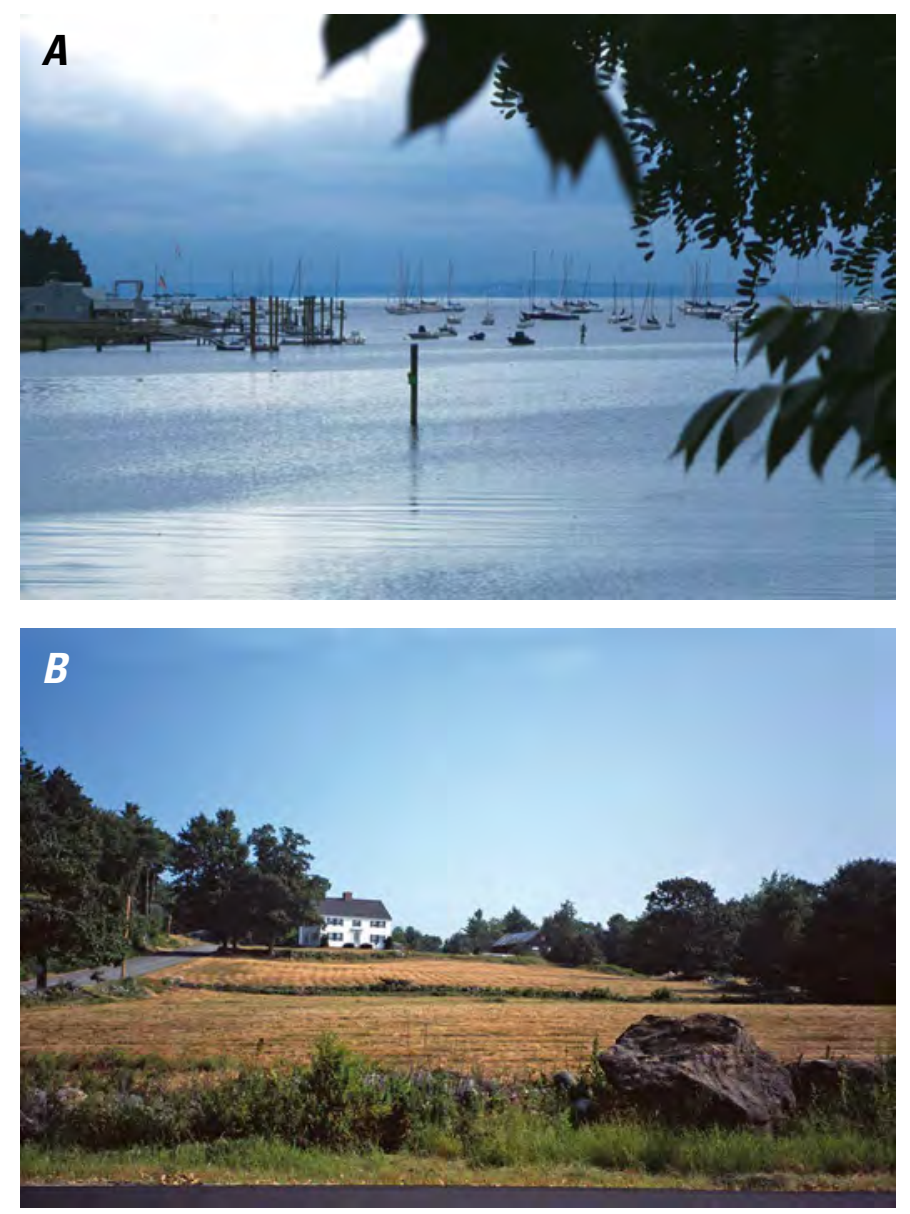

Figure 3. Water and agricultural land in Northeastern Coastal Zone Ecoregion. A, Marina on Long Island Sound, near Stamford, Connecticut. $B$, Farmhouse and fields, in southeastern New Hampshire. 
The dominant land-cover classes, forest and developed, experienced the most net change during the study period (table 1; fig. 6). Developed land increased by an estimated 4.0 percent $\left(1,502 \mathrm{~km}^{2}\right)$ to about 27.2 percent of the ecoregion, one of the highest percentages of developed land of any Eastern United States ecoregion. Much of the new development came from forest land, which decreased by about 3.7 percent $\left(1,361 \mathrm{~km}^{2}\right)$ during the study period (table 1 ; fig. 7). Agricultural land decreased by about 0.8 percent, and, although this may appear to be a small amount of farmland loss, it represents a loss of about 10.1 percent of the estimated agricultural land present in the ecoregion in 1973 (fig. 8). Other, more minor land-cover changes include slight decreases in wetland and slight increases in mechanically disturbed and mining (fig. 9). Increase in developed was the primary reason for these changes, as wetlands and forested lands were developed and demand for construction aggregates increased mining operations.

The ecoregion gained an estimated $1,502 \mathrm{~km}^{2}$ of developed land between 1973 and 2000. Most (about 87 percent) of the net decrease in forest, agriculture, and wetland land-cover classes was due to losses to developed land (table 1; fig. 10). An additional $115 \mathrm{~km}^{2}$ of forests were converted to mining land uses between 1973 and 2000, mostly for

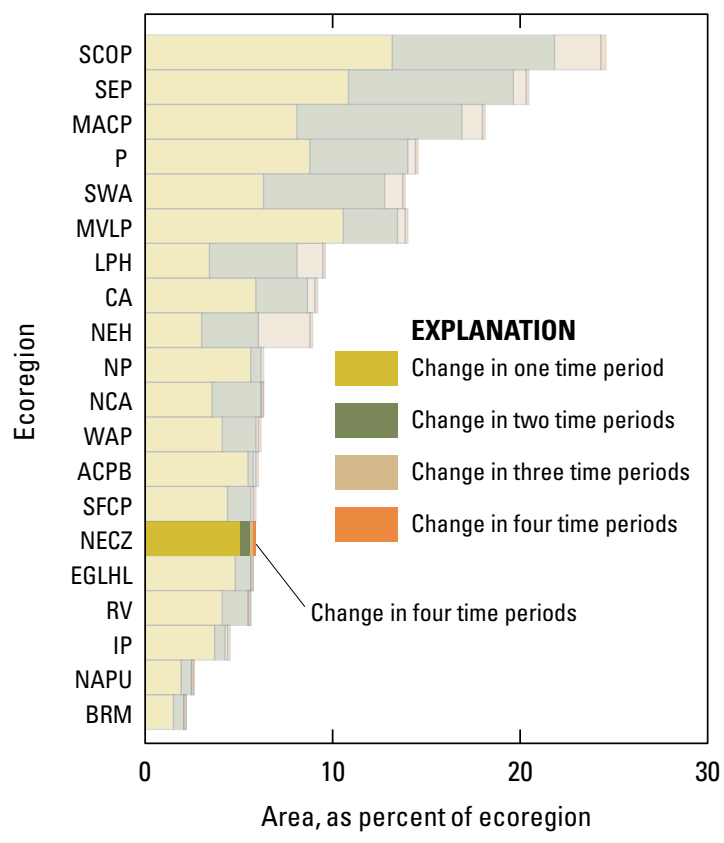

Figure 4. Overall spatial change in Northeastern Coastal Zone Ecoregion (NECZ; darker bars) compared with that of all 20 Eastern United States ecoregions (lighter bars). Each horizontal set of bars shows proportions of ecoregion that changed during one, two, three, or four time periods; highest level of spatial change in Northeastern Coastal Zone Ecoregion (four time periods) labeled for clarity. See table 3 for years covered by each time period. See appendix 2 for key to ecoregion abbreviations.

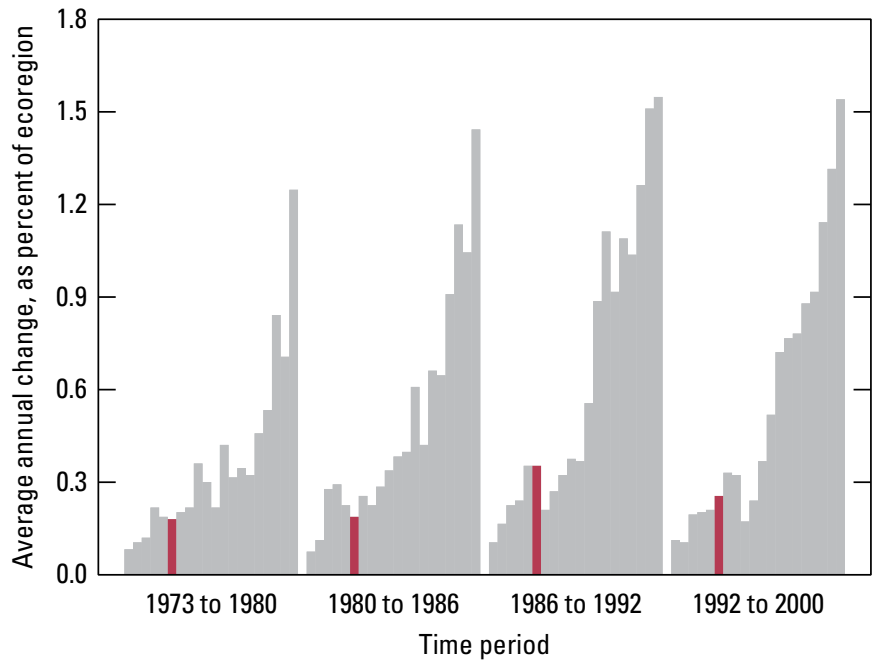

Figure 5. Estimates of land-cover change per time period, normalized to annual rates of change for all 20 Eastern United States ecoregions (gray bars). Estimates of change for Northeastern Coastal Zone Ecoregion are represented by red bars in each time period.

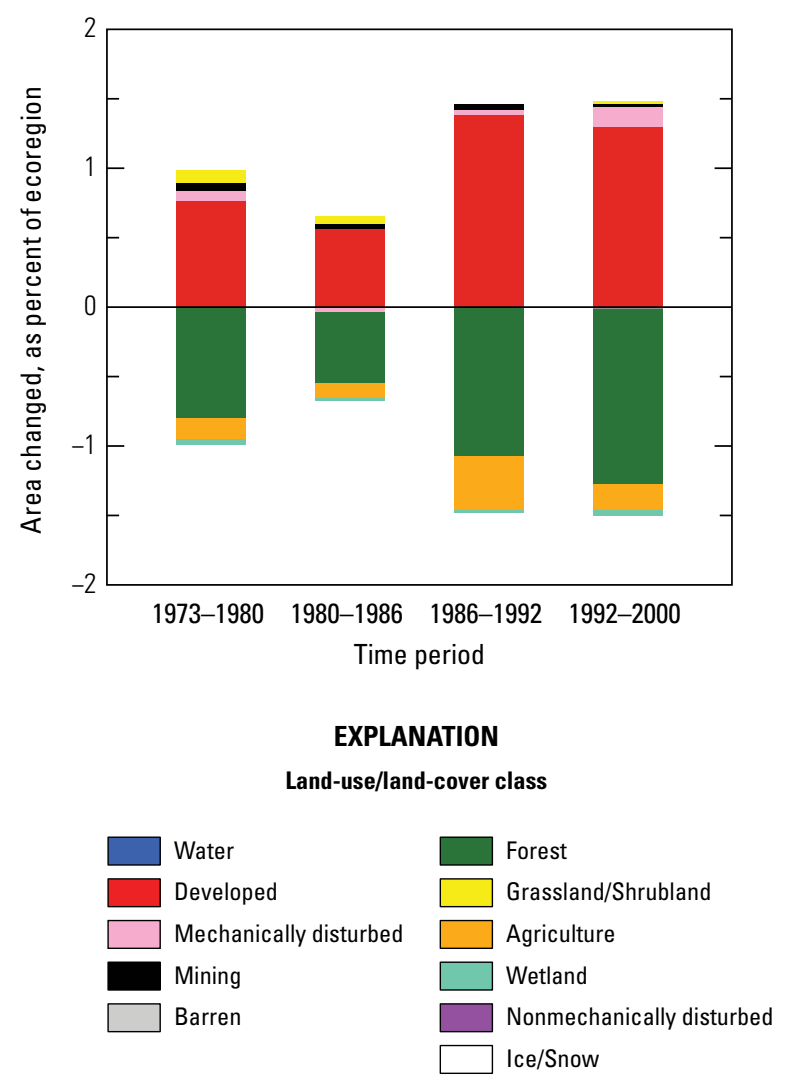

Figure 6. Normalized average net change in Northeastern Coastal Zone Ecoregion by time period for each land-cover class. Bars above zero axis represent net gain, whereas bars below zero represent net loss. Note that not all land-cover classes shown in explanation may be represented in figure. See appendix 3 for definitions of land-use and land-cover classifications. 


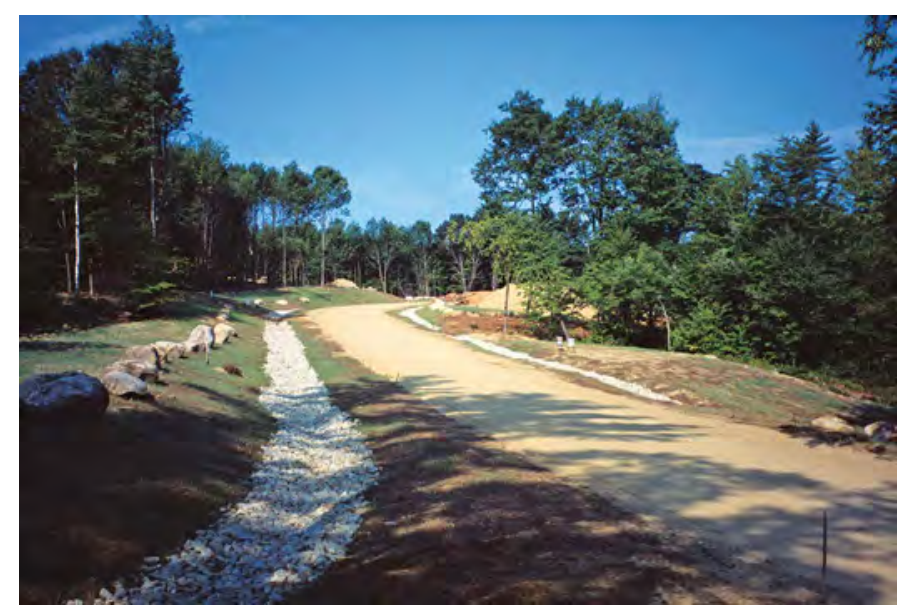

Figure 7. Home site being cleared from forest, in rural southeastern New Hampshire.

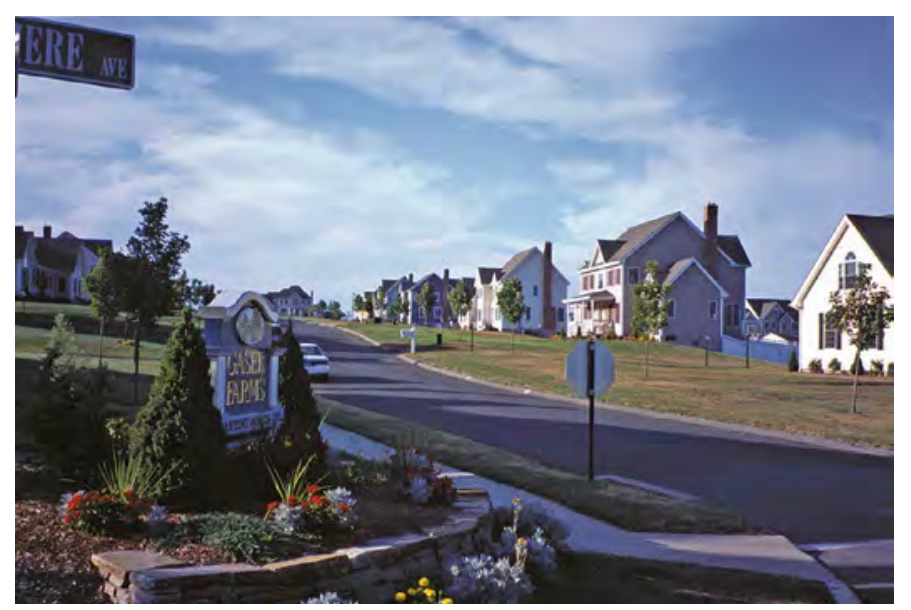

Figure 8. New housing subdivision built on former farmland, about $16 \mathrm{~km}$ northeast of Hartford, Connecticut.

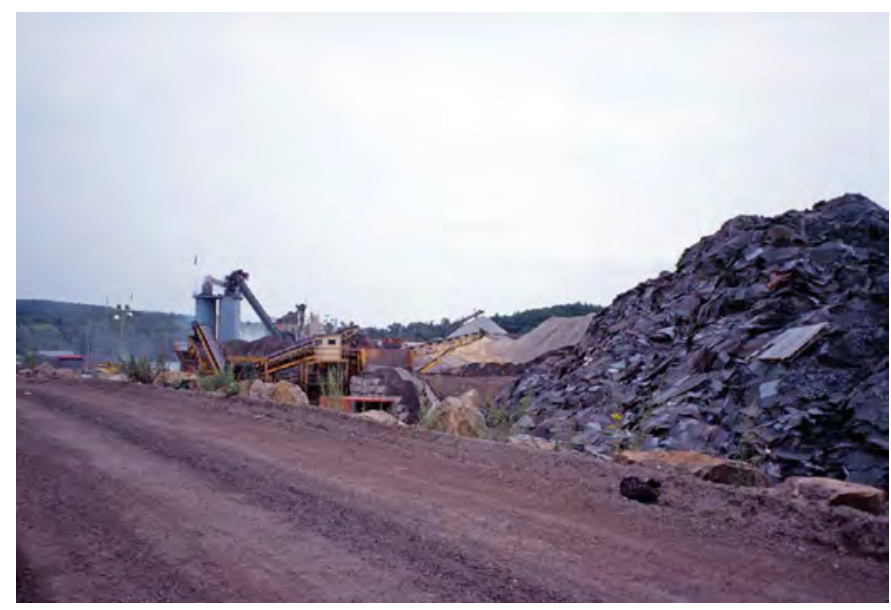

Figure 9. Aggregate mining operation, in south-central Massachusetts. construction aggregates to help maintain or increase the builtland infrastructure, although this change did not rank in the top five conversions for every time period (table 4). Conversions from forest to mining are not always a permanent loss because some of these areas revert back to grassland/shrubland or even forest once mining operations cease. The changes from forest to mechanically disturbed mapped in the Northeastern Coastal Zone Ecoregion primarily were driven by the clearing of land for new development, although, in a few locations, some forest harvesting for wood products occurred.

Other changes in the ecoregion include conversion of grassland/shrubland to forest in the middle two time periods (1980-1986, 1986-1992), which may have been related to vegetation succession either on abandoned farmland or on land that had been logged in the past (fig. 11). Minor changes from forest to agriculture and agriculture to forest also occurred, but they were among the top five changes during only two of the four time periods (1973-1980, 1986-1992) (table 4). In both cases, the conversion was from forest to agriculture, as conversions from agriculture to forest did not place among the top five changes during any time period (table 4).

The main story of land-cover change in the Northeastern Coastal Zone Ecoregion during the 27-year study period was increased urbanization, primarily through unidirectional conversion to developed land uses. The amount of change was relatively low, but it was steady across time. Most of this new developed land came from forested land and, to a lesser extent, from farmland.

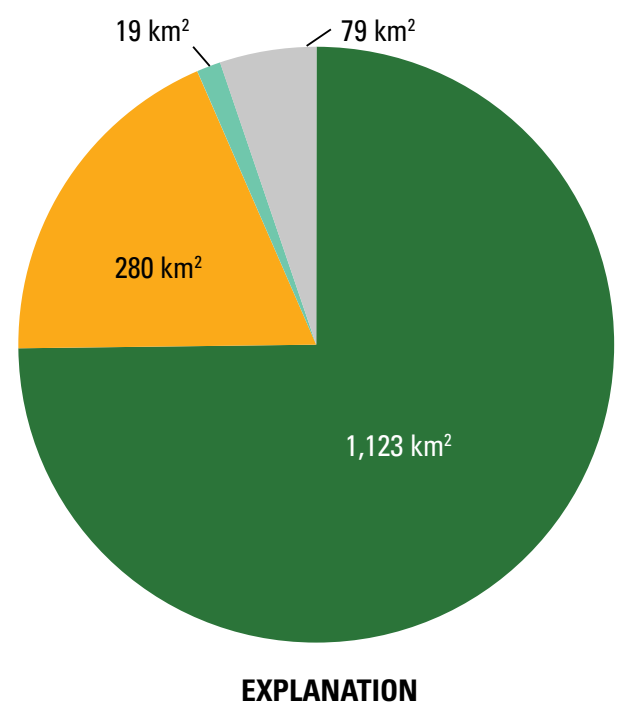

Source Land-use/land-cover class

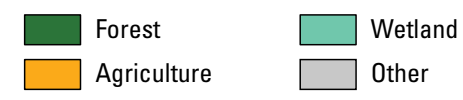

Figure 10. Net areal losses, in square kilometers, of forest, agriculture, wetland, and other land-cover classes to developed land cover in Northeastern Coastal Zone Ecoregion during study period (1973-2000). 


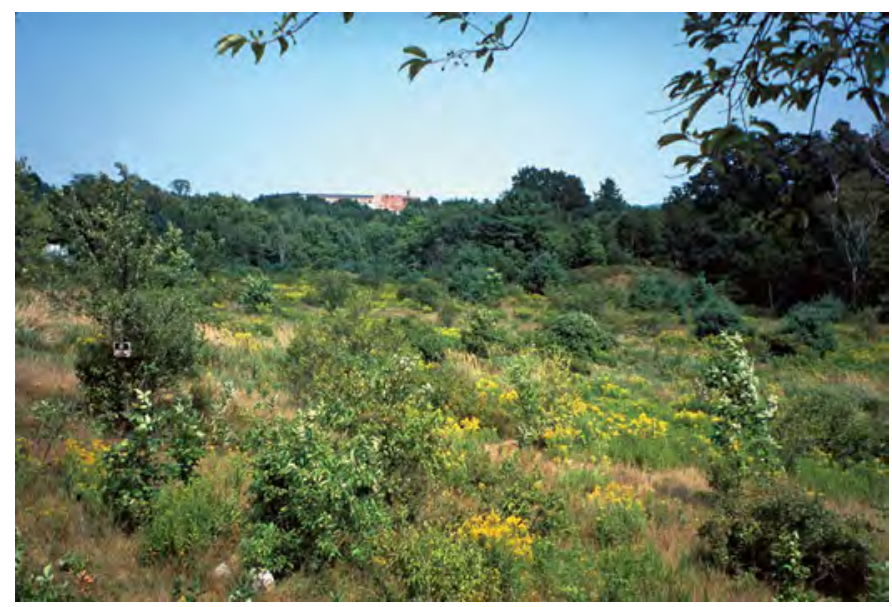

Figure 11. Old farm field undergoing succession to grassland/ shrubland, about $16 \mathrm{~km}$ west of Portland, Maine. Left undisturbed, this field eventually will revert to forest.

Table 1. Estimated area (and margin of error) of each land-cover class in Northeastern Coastal Zone Ecoregion, calculated five times between 1973 and 2000. See appendix 3 for definitions of land-cover classifications.

\begin{tabular}{|c|c|c|c|c|c|c|c|c|c|c|c|c|c|c|c|c|c|c|c|c|}
\hline & \multicolumn{2}{|c|}{ Water } & \multicolumn{2}{|c|}{ Developed } & \multicolumn{2}{|c|}{$\begin{array}{l}\text { Mechanically } \\
\text { disturbed }\end{array}$} & \multicolumn{2}{|c|}{ Mining } & \multicolumn{2}{|c|}{ Barren } & \multicolumn{2}{|c|}{ Forest } & \multicolumn{2}{|c|}{$\begin{array}{l}\text { Grassland/ } \\
\text { Shrubland }\end{array}$} & \multicolumn{2}{|c|}{ Agriculture } & \multicolumn{2}{|c|}{ Wetland } & \multicolumn{2}{|c|}{$\begin{array}{c}\text { Non- } \\
\text { mechanically } \\
\text { disturbed }\end{array}$} \\
\hline & $\%$ & $+/-$ & $\%$ & $+/-$ & $\%$ & $+/-$ & $\%$ & $+/-$ & $\%$ & $+/-$ & $\%$ & $+/-$ & $\%$ & $+/-$ & $\%$ & $+/-$ & $\%$ & $+/-$ & $\%$ & $+/-$ \\
\hline \multicolumn{21}{|c|}{ Area, in percent stratum } \\
\hline 1973 & 10.6 & 4.8 & 23.2 & 5.6 & 0.1 & 0.0 & 0.4 & 0.1 & 0.2 & 0.2 & 50.6 & 5.6 & 0.3 & 0.1 & 8.2 & 1.5 & 6.5 & 1.3 & 0.0 & 0.0 \\
\hline 1980 & 10.7 & 4.7 & 23.9 & 5.6 & 0.1 & 0.0 & 0.5 & 0.1 & 0.2 & 0.2 & 49.8 & 5.5 & 0.4 & 0.1 & 8.0 & 1.5 & 6.4 & 1.3 & 0.0 & 0.0 \\
\hline 1986 & 10.7 & 4.7 & 24.5 & 5.5 & 0.1 & 0.0 & 0.5 & 0.1 & 0.2 & 0.2 & 49.2 & 5.4 & 0.4 & 0.1 & 7.9 & 1.5 & 6.4 & 1.3 & 0.0 & 0.0 \\
\hline 1992 & 10.7 & 4.7 & 25.9 & 5.5 & 0.1 & 0.0 & 0.5 & 0.1 & 0.2 & 0.2 & 48.2 & 5.3 & 0.4 & 0.1 & 7.5 & 1.5 & 6.4 & 1.3 & 0.0 & 0.0 \\
\hline 2000 & 10.7 & 4.7 & 27.2 & 5.4 & 0.3 & 0.1 & 0.6 & 0.1 & 0.2 & 0.2 & 46.9 & 5.2 & 0.4 & 0.1 & 7.3 & 1.4 & 6.4 & 1.3 & 0.0 & 0.0 \\
\hline $\begin{array}{l}\text { Net } \\
\text { change }\end{array}$ & 0.0 & 0.0 & 4.0 & 0.8 & 0.2 & 0.1 & 0.2 & 0.1 & 0.0 & 0.0 & -3.7 & 0.6 & 0.1 & 0.1 & -0.8 & 0.3 & -0.1 & 0.0 & 0.0 & 0.0 \\
\hline $\begin{array}{l}\text { Gross } \\
\text { change }\end{array}$ & 0.1 & 0.0 & 4.0 & 0.8 & 0.5 & 0.1 & 0.3 & 0.1 & 0.0 & 0.0 & 3.7 & 0.6 & 0.4 & 0.1 & 1.0 & 0.3 & 0.1 & 0.0 & 0.0 & 0.0 \\
\hline \multicolumn{21}{|c|}{ Area, in square kilometers } \\
\hline 1973 & 3,956 & 1,765 & 8,607 & 2,078 & 27 & 10 & 147 & 38 & 88 & 64 & 18,791 & 2,068 & 107 & 55 & 3,037 & 572 & 2,399 & 472 & 0 & 0 \\
\hline 1980 & 3,961 & 1,765 & 8,893 & 2,064 & 49 & 16 & 172 & 46 & 87 & 63 & 18,492 & 2,039 & 135 & 55 & 2,981 & 561 & 2,388 & 473 & 0 & 0 \\
\hline 1986 & 3,960 & 1,764 & 9,106 & 2,052 & 41 & 15 & 183 & 47 & 90 & 66 & 18,299 & 2,014 & 154 & 55 & 2,940 & 558 & 2,386 & 472 & 0 & 0 \\
\hline 1992 & 3,962 & 1,764 & 9,622 & 2,040 & 55 & 18 & 197 & 47 & 89 & 66 & 17,902 & 1,987 & 149 & 51 & 2,802 & 542 & 2,380 & 472 & 6 & 9 \\
\hline 2000 & 3,962 & 1,764 & 10,108 & 2,025 & 104 & 30 & 205 & 53 & 87 & 63 & 17,430 & 1,948 & 159 & 53 & 2,731 & 527 & 2,372 & 469 & 0 & 0 \\
\hline $\begin{array}{l}\text { Net } \\
\text { change }\end{array}$ & 6 & 7 & 1,502 & 282 & 77 & 28 & 58 & 34 & -1 & 1 & $-1,361$ & 234 & 52 & 32 & -307 & 129 & -27 & 12 & 0 & 0 \\
\hline $\begin{array}{l}\text { Gross } \\
\text { change }\end{array}$ & 21 & 10 & 1,502 & 282 & 183 & 41 & 109 & 30 & 6 & 8 & 1,369 & 234 & 149 & 37 & 383 & 117 & 37 & 14 & 0 & 0 \\
\hline
\end{tabular}


Table 2. Percentage of Northeastern Coastal Zone Ecoregion land cover that changed at least one time during study period (1973-2000) and associated statistical error.

[Most sample pixels remained unchanged (94.3 percent), whereas 5.7 percent changed at least once throughout study period]

\begin{tabular}{ccccccc}
\hline $\begin{array}{c}\text { Number } \\
\text { of } \\
\text { changes }\end{array}$ & $\begin{array}{c}\text { Percent } \\
\text { of } \\
\text { ecoregion }\end{array}$ & $\begin{array}{c}\text { Margin } \\
\text { of error } \\
(+/-\%)\end{array}$ & $\begin{array}{c}\text { Lower } \\
\text { bound } \\
(\%)\end{array}$ & $\begin{array}{c}\text { Upper } \\
\text { bound } \\
(\%)\end{array}$ & $\begin{array}{c}\text { Standard } \\
\text { error } \\
(\%)\end{array}$ & $\begin{array}{c}\text { Relative } \\
\text { error } \\
(\%)\end{array}$ \\
\hline 1 & 5.1 & 0.8 & 4.2 & 5.9 & 0.6 & 11.2 \\
2 & 0.6 & 0.2 & 0.4 & 0.7 & 0.1 & 18.7 \\
3 & 0.1 & 0.0 & 0.0 & 0.1 & 0.0 & 27.5 \\
4 & 0.0 & 0.0 & 0.0 & 0.0 & 0.0 & 74.4 \\
\hline $\begin{array}{c}\text { Overall } \\
\text { spatial } \\
\text { change }\end{array}$ & 5.7 & 0.9 & 4.8 & 6.6 & 0.6 & 11.0 \\
\hline
\end{tabular}

Table 3. Raw estimates of change in Northeastern Coastal Zone Ecoregion land cover, computed for each of four time periods between 1973 and 2000, and associated error at 85 -percent confidence level

[Estimates of change per period normalized to annual rate of change for each period]

\begin{tabular}{cccccccc}
\hline Period & $\begin{array}{c}\text { Total change } \\
\text { (\% of } \\
\text { ecoregion) }\end{array}$ & $\begin{array}{c}\text { Margin } \\
\text { of error } \\
(+/-\%)\end{array}$ & $\begin{array}{c}\text { Lower } \\
\text { bound } \\
(\%)\end{array}$ & $\begin{array}{c}\text { Upper bound } \\
(\%)\end{array}$ & $\begin{array}{c}\text { Standard } \\
\text { error } \\
(\%)\end{array}$ & $\begin{array}{c}\text { Relative } \\
\text { error } \\
(\%)\end{array}$ & $\begin{array}{c}\text { Average } \\
\text { rate } \\
(\% \text { per } \\
\text { year) }\end{array}$ \\
\hline \multicolumn{7}{c}{ Estimate of change, in percent stratum } \\
\hline $1973-1980$ & 1.3 & 0.3 & 0.9 & 1.6 & 0.2 & 16.9 & 0.2 \\
$1980-1986$ & 1.1 & 0.2 & 0.9 & 1.3 & 0.1 & 12.6 & 0.2 \\
$1986-1992$ & 2.1 & 0.4 & 1.7 & 2.4 & 0.2 & 11.8 & 0.3 \\
$1992-2000$ & 2.0 & 0.4 & 1.6 & 2.4 & 0.3 & 13.0 & 0.2 \\
\hline & & Estimate of change, in square kilometers & & \\
\hline $1973-1980$ & 470 & 118 & 353 & 588 & 79 & 16.9 & 67 \\
$1980-1986$ & 405 & 76 & 329 & 481 & 51 & 12.6 & 67 \\
$1986-1992$ & 774 & 135 & 639 & 909 & 91 & 11.8 & 129 \\
$1992-2000$ & 743 & 143 & 600 & 886 & 97 & 13.0 & 93 \\
\hline
\end{tabular}


Table 4. Principal land-cover conversions in Northeastern Coastal Zone Ecoregion, showing amount of area changed (and margin of error, calculated at 85-percent confidence level) for each conversion during each of four time periods and also during overall study period. See appendix 3 for definitions of land-cover classifications.

[Values given for "other" classes are combined totals of values for other land-cover classes not listed in that time period. Abbreviations: $\mathrm{n} / \mathrm{a}$, not applicable]

\begin{tabular}{|c|c|c|c|c|c|c|c|c|}
\hline Period & From class & To class & & $\begin{array}{c}\text { Area } \\
\text { changed } \\
\left(\mathbf{k m}^{2}\right)\end{array}$ & $\begin{array}{c}\text { Margin } \\
\text { of error } \\
(+/- \\
\text { km²) }^{2}\end{array}$ & $\begin{array}{l}\text { Stan- } \\
\text { dard } \\
\text { error } \\
\left(\mathbf{k m}^{2}\right)\end{array}$ & $\begin{array}{c}\text { Percent } \\
\text { of } \\
\text { ecoregion }\end{array}$ & $\begin{array}{c}\text { Percent } \\
\text { of all } \\
\text { changes }\end{array}$ \\
\hline \multirow[t]{7}{*}{ 1973-1980 } & Forest & Developed & & 223 & 73 & 50 & 0.6 & 47.5 \\
\hline & Agriculture & Developed & & 52 & 22 & 15 & 0.1 & 11.0 \\
\hline & Forest & Mechanically disturbed & & 40 & 14 & 10 & 0.1 & 8.5 \\
\hline & Forest & Mining & & 31 & 15 & 10 & 0.1 & 6.7 \\
\hline & Forest & Agriculture & & 26 & 13 & 9 & 0.1 & 5.6 \\
\hline & Other & Other & & 98 & $\mathrm{n} / \mathrm{a}$ & $\mathrm{n} / \mathrm{a}$ & 0.3 & 20.8 \\
\hline & & & Totals & 470 & & & 1.3 & 100.0 \\
\hline \multirow[t]{7}{*}{ 1980-1986 } & Forest & Developed & & 162 & 44 & 30 & 0.4 & 40.1 \\
\hline & Agriculture & Developed & & 38 & 19 & 13 & 0.1 & 9.4 \\
\hline & Forest & Mechanically disturbed & & 36 & 15 & 10 & 0.1 & 8.9 \\
\hline & Forest & Mining & & 23 & 12 & 8 & 0.1 & 5.7 \\
\hline & Grassland/Shrubland & Forest & & 22 & 8 & 6 & 0.1 & 5.5 \\
\hline & Other & Other & & 123 & $\mathrm{n} / \mathrm{a}$ & $\mathrm{n} / \mathrm{a}$ & 0.3 & 30.5 \\
\hline & & & Totals & 405 & & & 1.1 & 100.0 \\
\hline \multirow[t]{7}{*}{ 1986-1992 } & Forest & Developed & & 368 & 85 & 58 & 1.0 & 47.5 \\
\hline & Agriculture & Developed & & 119 & 36 & 24 & 0.3 & 15.4 \\
\hline & Forest & Mechanically disturbed & & 45 & 17 & 12 & 0.1 & 5.8 \\
\hline & Grassland/Shrubland & Forest & & 38 & 15 & 10 & 0.1 & 4.9 \\
\hline & Forest & Agriculture & & 31 & 18 & 12 & 0.1 & 4.0 \\
\hline & Other & Other & & 173 & $\mathrm{n} / \mathrm{a}$ & $\mathrm{n} / \mathrm{a}$ & 0.5 & 22.3 \\
\hline & & & Totals & 774 & & & 2.1 & 100.0 \\
\hline \multirow[t]{7}{*}{ 1992-2000 } & Forest & Developed & & 369 & 83 & 56 & 1.0 & 49.7 \\
\hline & Forest & Mechanically disturbed & & 95 & 29 & 20 & 0.3 & 12.7 \\
\hline & Agriculture & Developed & & 71 & 29 & 20 & 0.2 & 9.6 \\
\hline & Forest & Mining & & 32 & 12 & 8 & 0.1 & 4.3 \\
\hline & Mechanically disturbed & Developed & & 22 & 8 & 6 & 0.1 & 2.9 \\
\hline & Other & Other & & 154 & $\mathrm{n} / \mathrm{a}$ & $\mathrm{n} / \mathrm{a}$ & 0.4 & 20.8 \\
\hline & & & Totals & 743 & & & 2.0 & 100.0 \\
\hline \multirow{7}{*}{$\begin{array}{c}1973-2000 \\
\text { (overall) }\end{array}$} & Forest & Developed & & 1,123 & 227 & 153 & 3.0 & 47.0 \\
\hline & Agriculture & Developed & & 280 & 87 & 59 & 0.8 & 11.7 \\
\hline & Forest & Mechanically disturbed & & 215 & 59 & 40 & 0.6 & 9.0 \\
\hline & Forest & Mining & & 115 & 35 & 23 & 0.3 & 4.8 \\
\hline & Forest & Agriculture & & 96 & 35 & 24 & 0.3 & 4.0 \\
\hline & Other & Other & & 563 & $\mathrm{n} / \mathrm{a}$ & $\mathrm{n} / \mathrm{a}$ & 1.5 & 23.5 \\
\hline & & & Totals & 2,392 & & & 6.4 & 100.0 \\
\hline
\end{tabular}




\section{References Cited}

U.S. Census Bureau, 1970-2000 [various years], Census of population and housing: U.S. Census Bureau database, accessed May 9, 2013, at http://www.census.gov/prod/ www/decennial.html.

Vogelmann, J.M., Howard, S.M., Yang, L., Larson, C.R., Wylie, B.K., and van Driel, N., 2001, Completion of the 1990s National Land Cover Data Set for the conterminous United States from Landsat Thematic Mapper data and ancillary data sources: Photogrammetric Engineering \& Remote Sensing, v. 67, p. 650-662.

Wiken, E., Jiménez Nava, F., and Griffith, G., 2011, North American terrestrial ecoregions-Level III: Montreal, Canada, Commission for Environmental Cooperation, 149 p., accessed May 1, 2013, at http://www.cec.org/ Storage/133/15860_QA07.30-32_NP_NA_Terrestrial_ Ecoregions_Level_3_Final-2june11.pdf. 


\title{
Chapter 5
}

\section{Atlantic Coastal Pine Barrens Ecoregion}

\author{
By Terry L. Sohl
}

\section{Ecoregion Description}

The Atlantic Coastal Pine Barrens Ecoregion is a disjunct ecoregion that covers about $19,230 \mathrm{~km}^{2}\left(7,425 \mathrm{mi}^{2}\right)$ of the coastal plain of New Jersey, as well as Long Island in New York and Cape Cod, Martha's Vineyard, Nantucket, and other nearby islands in Massachusetts (fig. 1). The ecoregion is bounded by, from northeast to southwest, the Northeastern Coastal Zone, Northern Piedmont, and Middle Atlantic Coastal Plain Ecoregions.

The ecoregion has a wide variety of ecological systems, including Atlantic white cedar (Chamaecyparis thyoides) swamps, stunted forests of pitch pine (Pinus rigida) and oak (Quercus spp.), sphagnum (Sphagnum spp.) bogs, coastal salt ponds, dune systems, and the only maritime grasslands in the Nation (Wiken and others, 2011). Because of generally acidic soils, agricultural activity often is limited to acid-loving crops such as blueberries and cranberries, although some areas of the ecoregion support cultivation of fruits, vegetables, and other crops (fig. 2). Although parts of the ecoregion represent some of the bestpreserved natural habitat in the Eastern United States, other parts are among the most highly developed in the country. The climate is marked by hot summers and cold winters, with an average annual precipitation of about $1,141 \mathrm{~mm}(45$ in.), which is fairly evenly distributed throughout the year.

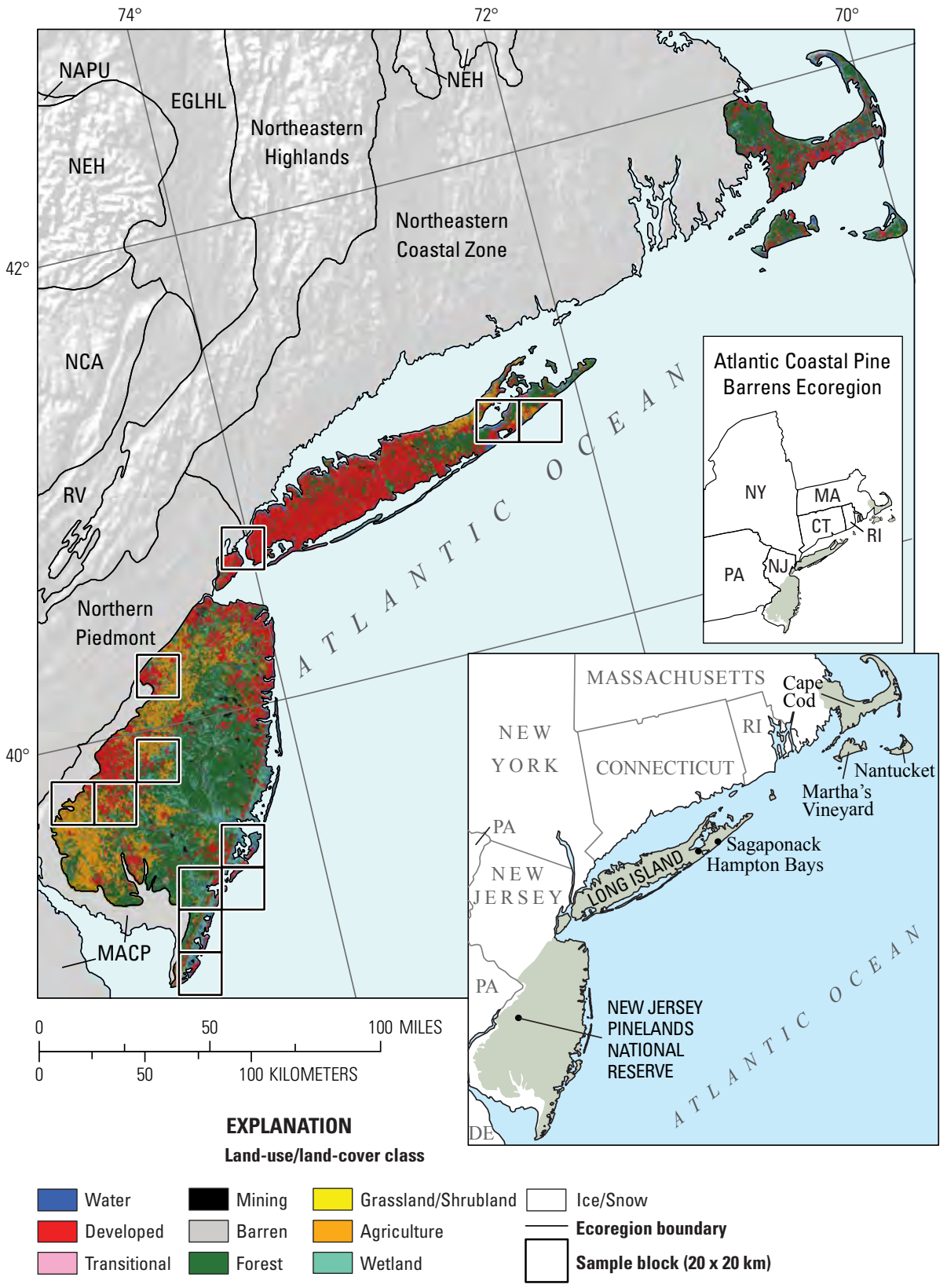

Figure 1. Map of Atlantic Coastal Pine Barrens Ecoregion and surrounding ecoregions, showing land-use/land-cover classes from 1992 National Land Cover Dataset (Vogelmann and others, 2001); note that not all land-use/land-cover classes shown in explanation may be depicted on map; note also that, for this "Status and Trends of Land Change" study, transitional land-cover class was subdivided into mechanically disturbed and nonmechanically disturbed classes. Squares indicate locations of $20 \times 20 \mathrm{~km}$ sample blocks analyzed in study. Index map shows locations of geographic features mentioned in text. Abbreviations for Eastern United States ecoregions are listed in appendix 2 . See appendix 3 for definitions of land-use/land-cover classifications. 


\section{Contemporary Land-Cover Change (1973 to 2000)}

The overall spatial change (the percentage of land area that changed at least one time) in the Atlantic Coastal Pine Barrens Ecoregion between 1973 to 2000 is estimated at 5.8 percent (table 1). Compared to other Eastern United States ecoregions, change in the Atlantic Coastal Pine Barrens Ecoregion was fairly low (fig. 3): about 5.5 percent changed one time, and 0.3 percent changed two times (table 1). Total change per time period was relatively constant, hovering at around 1.5 percent (table 2). When normalized to an average annual rate to account for unequal time periods, the rates of change peaked in the second time period (1980-1986) and then decreased in the remaining two time periods (1986-1992, 1992-2000) (fig. 4). Although overall change rates were low, significant trends in land-cover change are apparent.

The Atlantic Coastal Pine Barrens Ecoregion experienced a 14.6 percent increase in population between 1970 and 2000, from 9.6 to 11.0 million people (U.S. Census Bureau, 19702000 [various years]). Locally, population increases have been more dramatic; for example, Cape Cod doubled in population over the same time period. Accommodation of this growth was the primary driver of land change, as developed land increased steadily from 25.5 to 30.3 percent of the ecoregion between 1973 and 2000 (table 3; fig. 5). Most newly developed land occurred at the expense of agricultural and forested lands, both of which decreased significantly in all four time periods (fig. 6). More than $900 \mathrm{~km}^{2}$ of land was developed between 1973 and 2000, resulting in the loss of $315 \mathrm{~km}^{2}$ of forest land and $529 \mathrm{~km}^{2}$ of agricultural land (tables 3,4). The proportion of all change caused by development steadily increased throughout the study period (table 5).

Agriculture dropped from the third most common land cover in the ecoregion in 1973 to the fifth most common land cover by 2000 (table 3). The decrease in the relative abundance

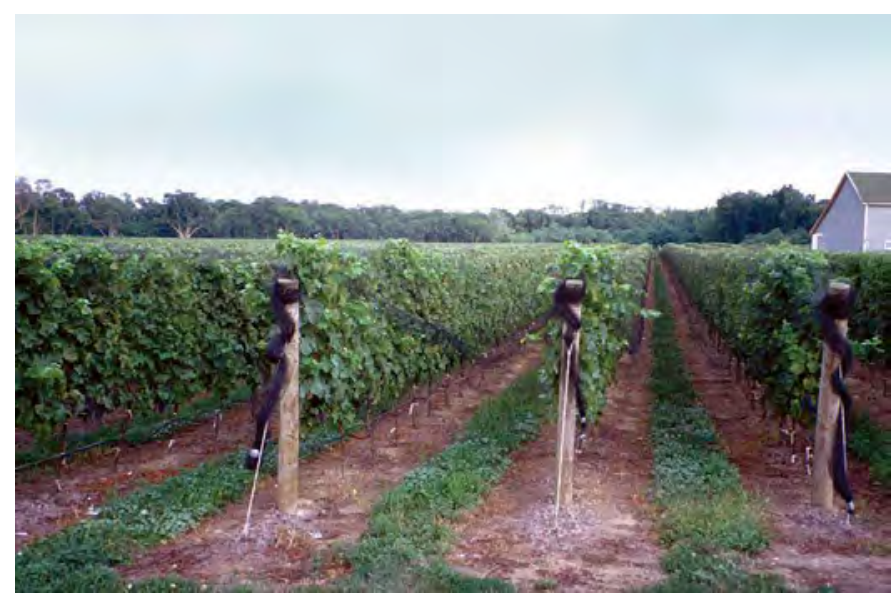

Figure 2. Vineyards in Atlantic Coastal Pine Barrens Ecoregion, a common sight in parts of ecoregion where variety of fruit and vegetable crops are grown.

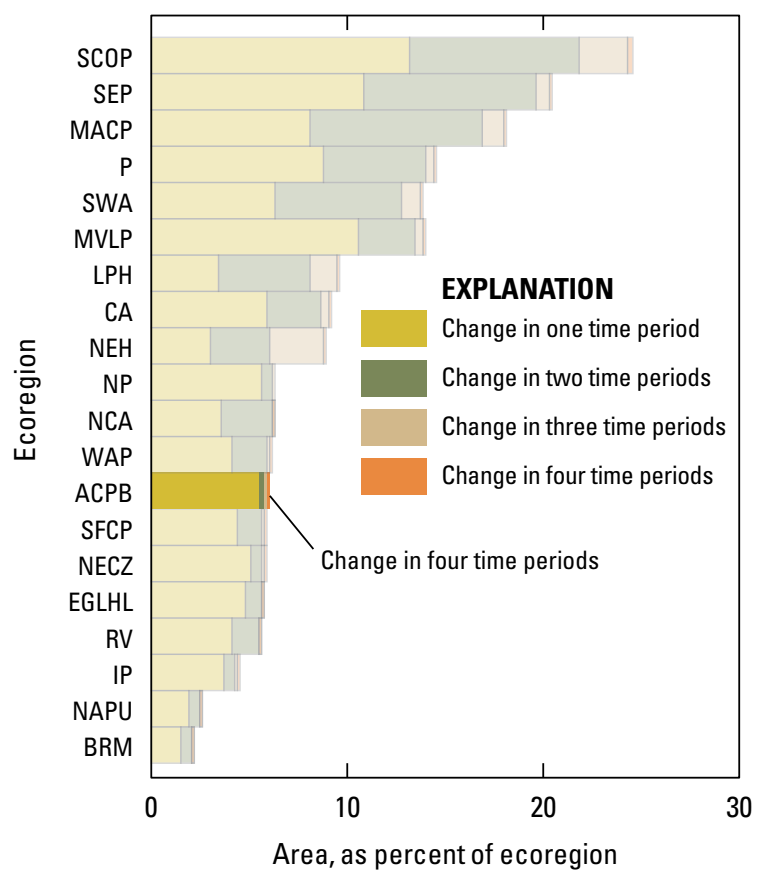

Figure 3. Overall spatial change in Atlantic Coastal Pine Barrens Ecoregion (ACPB; darker bars) compared with that of all 20 Eastern United States ecoregions (lighter bars). Each horizontal set of bars shows proportions of ecoregion that changed during one, two, three, or four time periods; highest level of spatial change in Atlantic Coastal Pine Barrens Ecoregion (four time periods) labeled for clarity. See table 2 for years covered by each time period. See appendix 2 for key to ecoregion abbreviations.

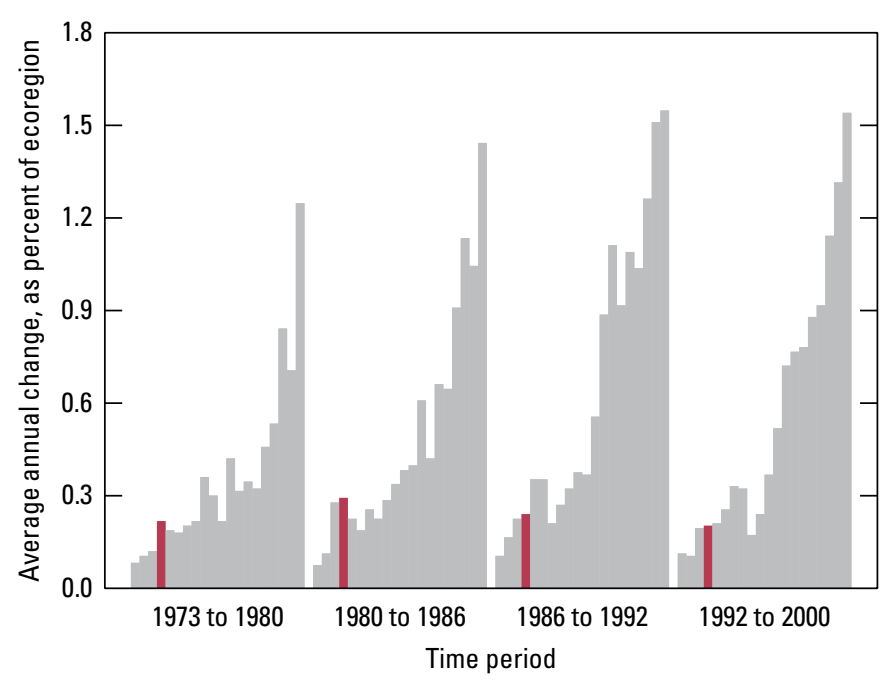

Figure 4. Estimates of land-cover change per time period, normalized to annual rates of change for all 20 Eastern United States ecoregions (gray bars). Estimates of change for Atlantic Coastal Pine Barrens Ecoregion are represented by red bars in each time period. 
of agricultural land is related to a strong effort to protect native ecosystems within the region, especially the unique pine barren forest. As less forested land was available for development, the proportion of developed land originating from agricultural land increased steadily and significantly (table 5).

In addition to development pressures, high tax rates have driven many farmers to switch from vegetable and fruit crops to higher valued products such as nursery stock, flowers, and sod (Hart, 1991). These factors prompted the American Farmland Trust organization to name parts of the ecoregion on Long Island and Cape Cod as one of the 20 most threatened agricultural areas in the United States (Sorensen and others, 1997).

Forested land also decreased steadily between 1973 and 2000. However, efforts to conserve these unique habitats slowed the rate of decrease in the latter half of the 27-year study period. For example, parts of the New Jersey Pine Barrens were designated as the Nation's first National Reserve (the New Jersey Pinelands National Reserve) in 1978 and later (1983) as a U.S. Biosphere Reserve (Mason, 1992; Walker and Solecki, 1999).

Forms of land-cover change other than conversion to developed were relatively minor (tables 3,4 ). Furthermore, changes in the next two most affected land-cover classes (mechanically disturbed and mining) often were driven by the demands of development. The mapping of mechanically disturbed land indicates a temporary, transitory state for a given area, which often leads to permanent development in the ecoregion.

The mining land-cover class showed a small increase during the study period, but most of that increase likely was related to the increased demand for sand and stone aggregates used in construction. Although urban development has occurred throughout the Atlantic Coastal Pine Barrens Ecoregion, recreational opportunities and desire for other coastal amenities also has resulted in concentrations of development along most coastlines in the ecoregion (fig. 7). These and other development pressures likely will continue to drive land-use conversions in the Atlantic Coastal Pine Barrens Ecoregion for the foreseeable future.

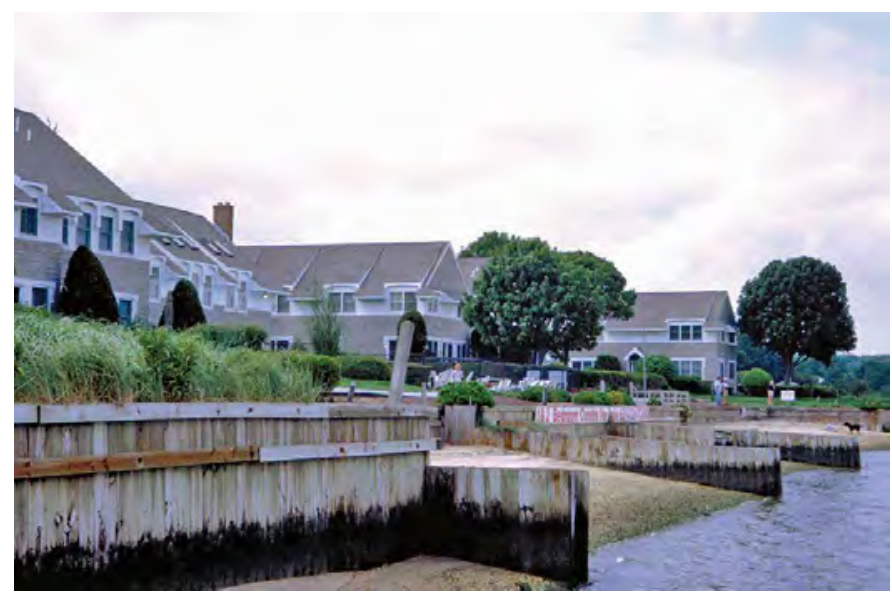

Figure 5. Coastal development on Long Island (Hampton Bays, New York), in Atlantic Coastal Plain Pine Barrens Ecoregion.

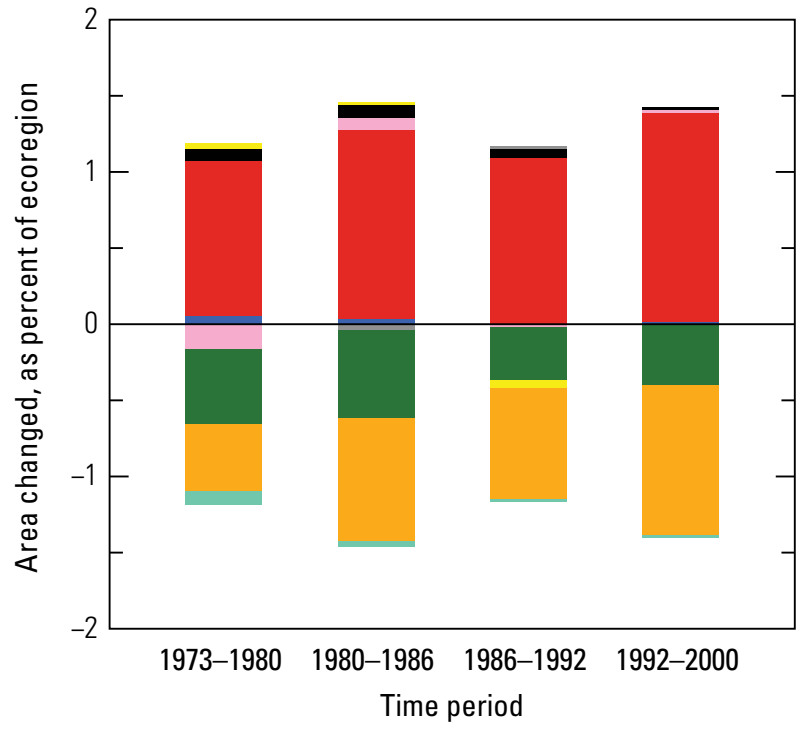

\section{EXPLANATION}

Land-use/land-cover class
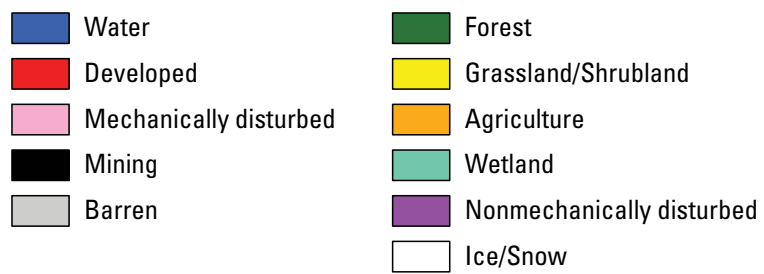

Figure 6. Normalized average net change in Atlantic Coastal Pine Barrens Ecoregion by time period for each land-cover class. Bars above zero axis represent net gain, whereas bars below zero represent net loss. Note that not all land-cover classes shown in explanation may be represented in figure. See appendix 3 for definitions of land-use and land-cover classifications.

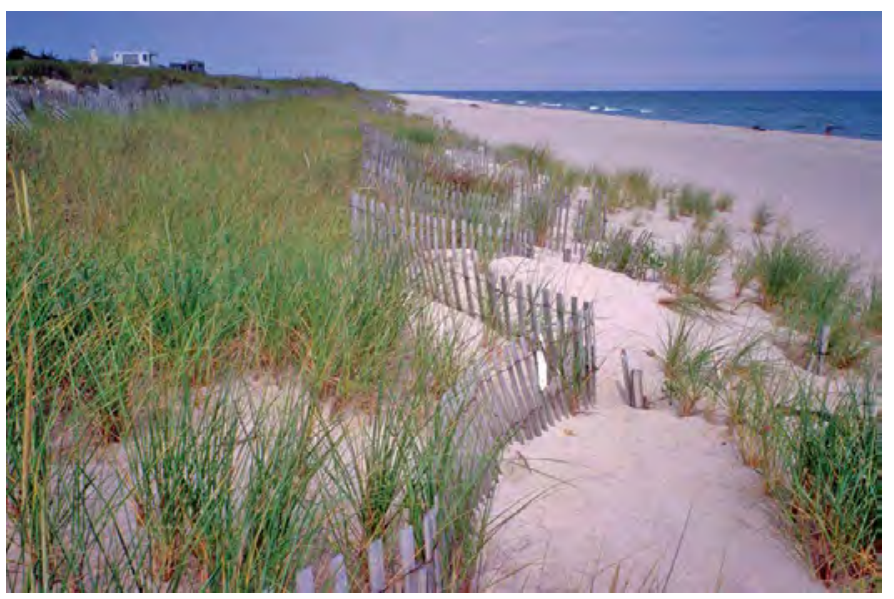

Figure 7. Coastal housing and sand-dune-stabilization fences on Long Island (Sagaponack, New York), in Atlantic Coastal Pine Barrens Ecoregion. 
Table 1. Percentage of Atlantic Coastal Pine Barrens Ecoregion land cover that changed at least one time during study period (1973-2000) and associated statistical error.

[Most sample pixels remained unchanged ( 94.2 percent), whereas 5.8 percent changed at least once throughout study period]

\begin{tabular}{ccccccc}
\hline $\begin{array}{c}\text { Number } \\
\text { of } \\
\text { changes }\end{array}$ & $\begin{array}{c}\text { Percent } \\
\text { of } \\
\text { ecoregion }\end{array}$ & $\begin{array}{c}\text { Margin } \\
\text { of error } \\
(+/-\%)\end{array}$ & $\begin{array}{c}\text { Lower } \\
\text { bound } \\
(\%)\end{array}$ & $\begin{array}{c}\text { Upper } \\
\text { bound } \\
(\%)\end{array}$ & $\begin{array}{c}\text { Standard } \\
\text { error } \\
(\%)\end{array}$ & $\begin{array}{c}\text { Relative } \\
\text { error } \\
(\%)\end{array}$ \\
\hline 1 & 5.5 & 2.0 & 3.5 & 7.5 & 1.2 & 22.6 \\
2 & 0.3 & 0.2 & 0.2 & 0.5 & 0.1 & 29.5 \\
3 & 0.0 & 0.0 & 0.0 & 0.0 & 0.0 & 42.1 \\
4 & 0.0 & 0.0 & 0.0 & 0.0 & 0.0 & 57.6 \\
\hline $\begin{array}{c}\text { Overall } \\
\text { spatial } \\
\text { change }\end{array}$ & 5.8 & 2.1 & 3.8 & 7.9 & 1.3 & 22.5 \\
\hline
\end{tabular}

Table 2. Raw estimates of change in Atlantic Coastal Pine Barrens Ecoregion land cover, computed for each of four time periods between 1973 and 2000, and associated error at 85-percent confidence level.

[Estimates of change per period normalized to annual rate of change for each period]

\begin{tabular}{cccccccc}
\hline Period & $\begin{array}{c}\text { Total change } \\
(\% \text { of ecoregion) }\end{array}$ & $\begin{array}{c}\text { Margin of } \\
\text { error } \\
(+/-\%)\end{array}$ & $\begin{array}{c}\text { Lower } \\
\text { bound } \\
(\%)\end{array}$ & $\begin{array}{c}\text { Upper bound } \\
(\%)\end{array}$ & $\begin{array}{c}\text { Standard } \\
\text { error } \\
(\%)\end{array}$ & $\begin{array}{c}\text { Relative } \\
\text { error } \\
(\%)\end{array}$ & $\begin{array}{c}\text { Average rate } \\
(\% \text { per year) }\end{array}$ \\
\hline \multicolumn{7}{c}{ Estimate of change, in percent stratum } \\
\hline $1973-1980$ & 1.5 & 0.5 & 0.9 & 2.0 & 0.3 & 23.2 & 0.2 \\
$1980-1986$ & 1.7 & 0.6 & 1.2 & 2.3 & 0.4 & 20.3 & 0.3 \\
$1986-1992$ & 1.4 & 0.5 & 0.9 & 1.9 & 0.3 & 22.2 & 0.2 \\
$1992-2000$ & 1.6 & 0.8 & 0.8 & 2.4 & 0.5 & 31.1 & 0.2 \\
\hline & & Estimate of change, in square kilometers & & \\
\hline $1973-1980$ & 285 & 105 & 180 & 391 & 66 & 23.2 & 41 \\
$1980-1986$ & 333 & 107 & 225 & 440 & 67 & 20.3 & 55 \\
$1986-1992$ & 272 & 96 & 176 & 368 & 60 & 22.2 & 45 \\
$1992-2000$ & 312 & 155 & 157 & 467 & 97 & 31.1 & 39 \\
\hline
\end{tabular}


Table 3. Estimated area (and margin of error) of each land-cover class in Atlantic Coastal Pine Barrens Ecoregion, calculated five times between 1973 and 2000. See appendix 3 for definitions of land-cover classifications.

\begin{tabular}{|c|c|c|c|c|c|c|c|c|c|c|c|c|c|c|c|c|c|c|c|c|}
\hline & \multicolumn{2}{|c|}{ Water } & \multicolumn{2}{|c|}{ Developed } & \multicolumn{2}{|c|}{$\begin{array}{c}\text { Me- } \\
\text { chanically } \\
\text { disturbed }\end{array}$} & \multicolumn{2}{|c|}{ Mining } & \multicolumn{2}{|c|}{ Barren } & \multicolumn{2}{|c|}{ Forest } & \multicolumn{2}{|c|}{$\begin{array}{l}\text { Grass- } \\
\text { land/ } \\
\text { Shru- } \\
\text { bland }\end{array}$} & \multicolumn{2}{|c|}{ Agriculture } & \multicolumn{2}{|c|}{ Wetland } & \multicolumn{2}{|c|}{$\begin{array}{c}\text { Non- } \\
\text { mechanically } \\
\text { disturbed }\end{array}$} \\
\hline \multicolumn{21}{|c|}{ Area, in percent stratum } \\
\hline 1973 & 16.9 & 7.4 & 25.5 & 8.3 & 0.2 & 0.1 & 0.4 & 0.2 & 0.8 & 0.6 & 23.3 & 6.3 & 0.1 & 0.1 & 17.4 & 8.5 & 15.3 & 5.8 & 0.0 & 0.0 \\
\hline 1992 & 17.0 & 7.4 & 28.9 & 8.4 & 0.1 & 0.1 & 0.6 & 0.3 & 0.8 & 0.5 & 21.9 & 6.1 & 0.1 & 0.1 & 15.4 & 7.5 & 15.2 & 5.9 & 0.0 & 0.0 \\
\hline 2000 & 17.1 & 7.4 & 30.3 & 8.4 & 0.1 & 0.1 & 0.6 & 0.3 & 0.8 & 0.5 & 21.5 & 6.0 & 0.1 & 0.1 & 14.5 & 6.9 & 15.1 & 5.9 & 0.0 & 0.0 \\
\hline $\begin{array}{l}\text { Net } \\
\text { change }\end{array}$ & 0.1 & 0.1 & 4.7 & 1.8 & -0.1 & 0.1 & 0.2 & 0.1 & 0.0 & 0.1 & -1.8 & 0.6 & 0.0 & 0.0 & -3.0 & 1.9 & -0.2 & 0.1 & 0.0 & 0.0 \\
\hline 1973 & 3,259 & 1,429 & 4,908 & 1,604 & 38 & 20 & 77 & 32 & 153 & 107 & 4,482 & 1,216 & 19 & 17 & 3,350 & 1,631 & 2,944 & 1,122 & 0 & 0 \\
\hline 1980 & 3,270 & 1,425 & 5,105 & 1,619 & 7 & 4 & 91 & 40 & 152 & 107 & 4,385 & 1,182 & 27 & 29 & 3,266 & 1,589 & 2,926 & 1,127 & 0 & 0 \\
\hline 1986 & 3,278 & 1,425 & 5,344 & 1,619 & 20 & 19 & 110 & 50 & 147 & 105 & 4,270 & 1,169 & 29 & 30 & 3,112 & 1,507 & 2,920 & 1,129 & 0 & 0 \\
\hline 1992 & 3,278 & 1,423 & 5,555 & 1,615 & 17 & 15 & 122 & 51 & 147 & 105 & 4,202 & 1,168 & 21 & 19 & 2,971 & 1,437 & 2,916 & 1,126 & 0 & 0 \\
\hline 2000 & 3,282 & 1,423 & 5,820 & 1,612 & 18 & 13 & 124 & 52 & 146 & 102 & 4,127 & 1,148 & 20 & 18 & 2,782 & 1,320 & 2,911 & 1,126 & 0 & 0 \\
\hline $\begin{array}{l}\text { Net } \\
\text { change }\end{array}$ & 22 & 23 & 913 & 345 & -19 & 22 & 47 & 26 & -7 & 12 & -355 & 111 & 1 & 2 & -568 & 369 & -34 & 21 & 0 & 0 \\
\hline $\begin{array}{l}\text { Gross } \\
\text { change }\end{array}$ & 42 & 19 & 913 & 345 & 75 & 50 & 54 & 27 & 21 & 17 & 371 & 104 & 21 & 26 & 577 & 366 & 47 & 23 & 0 & 0 \\
\hline
\end{tabular}


Table 4. Principal land-cover conversions in Atlantic Coastal Pine Barrens Ecoregion, showing amount of area changed (and margin of error, calculated at 85-percent confidence level) for each conversion during each of four time periods and also during overall study period. See appendix 3 for definitions of land-cover classifications.

[Values given for "other" classes are combined totals of values for other land-cover classes not listed in that time period. Abbreviations: n/a, not applicable]

\begin{tabular}{|c|c|c|c|c|c|c|c|}
\hline Period & From class & To class & $\begin{array}{c}\begin{array}{c}\text { Area } \\
\text { changed }\end{array} \\
\left(\mathbf{k m}^{2}\right)\end{array}$ & $\begin{array}{c}\text { Margin of } \\
\text { error } \\
\left(+/-\mathrm{km}^{2}\right)\end{array}$ & $\begin{array}{c}\text { Standard } \\
\text { error } \\
\left(\mathbf{k m}^{2}\right)\end{array}$ & $\begin{array}{l}\text { Percent of } \\
\text { ecoregion }\end{array}$ & $\begin{array}{c}\text { Percent of all } \\
\text { changes }\end{array}$ \\
\hline \multirow[t]{7}{*}{ 1973-1980 } & Forest & Developed & 88 & 45 & 28 & 0.5 & 30.9 \\
\hline & Agriculture & Developed & 81 & 76 & 47 & 0.4 & 28.5 \\
\hline & Mechanically disturbed & Developed & 22 & 18 & 11 & 0.1 & 7.7 \\
\hline & Forest & Mining & 12 & 7 & 5 & 0.1 & 4.1 \\
\hline & Wetland & Agriculture & 11 & 16 & 10 & 0.1 & 3.8 \\
\hline & Other & Other & 71 & $\mathrm{n} / \mathrm{a}$ & $\mathrm{n} / \mathrm{a}$ & 0.4 & 25.0 \\
\hline & & Totals & 285 & & & 1.5 & 100.0 \\
\hline \multirow[t]{7}{*}{$1980-1986$} & Agriculture & Developed & 138 & 86 & 54 & 0.7 & 41.4 \\
\hline & Forest & Developed & 98 & 32 & 20 & 0.5 & 29.5 \\
\hline & Forest & Mining & 17 & 13 & 8 & 0.1 & 5.0 \\
\hline & Agriculture & Forest & 10 & 6 & 4 & 0.1 & 3.1 \\
\hline & Agriculture & Mechanically disturbed & 10 & 11 & 7 & 0.1 & 3.0 \\
\hline & Other & Other & 60 & $\mathrm{n} / \mathrm{a}$ & $\mathrm{n} / \mathrm{a}$ & 0.3 & 17.9 \\
\hline & & Totals & 333 & & & 1.7 & 100.0 \\
\hline \multirow[t]{7}{*}{ 1986-1992 } & Agriculture & Developed & 130 & 68 & 43 & 0.7 & 47.8 \\
\hline & Forest & Developed & 61 & 25 & 16 & 0.3 & 22.4 \\
\hline & Mechanically disturbed & Developed & 14 & 17 & 11 & 0.1 & 5.2 \\
\hline & Agriculture & Mechanically disturbed & 9 & 11 & 7 & 0.0 & 3.2 \\
\hline & Agriculture & Forest & 8 & 7 & 5 & 0.0 & 2.8 \\
\hline & Other & Other & 50 & $\mathrm{n} / \mathrm{a}$ & $\mathrm{n} / \mathrm{a}$ & 0.3 & 18.6 \\
\hline & & Totals & 272 & & & 1.4 & 100.0 \\
\hline \multirow[t]{7}{*}{$1992-2000$} & Agriculture & Developed & 180 & 132 & 83 & 0.9 & 57.7 \\
\hline & Forest & Developed & 68 & 24 & 15 & 0.4 & 21.9 \\
\hline & Mechanically disturbed & Developed & 12 & 12 & 8 & 0.1 & 3.8 \\
\hline & Agriculture & Mechanically disturbed & 8 & 11 & 7 & 0.0 & 2.6 \\
\hline & Forest & Mechanically disturbed & 6 & 4 & 2 & 0.0 & 1.9 \\
\hline & Other & Other & 38 & $\mathrm{n} / \mathrm{a}$ & $\mathrm{n} / \mathrm{a}$ & 0.2 & 12.2 \\
\hline & & Totals & 312 & & & 1.6 & 100.0 \\
\hline \multirow{7}{*}{$\begin{array}{c}\text { 1973-2000 } \\
\text { (overall) }\end{array}$} & Agriculture & Developed & 529 & 340 & 213 & 2.8 & 44.0 \\
\hline & Forest & Developed & 315 & 89 & 56 & 1.6 & 26.2 \\
\hline & Mechanically disturbed & Developed & 49 & 40 & 25 & 0.3 & 4.0 \\
\hline & Forest & Mining & 36 & 24 & 15 & 0.2 & 3.0 \\
\hline & Agriculture & Forest & 28 & 17 & 11 & 0.1 & 2.3 \\
\hline & Other & Other & 245 & $\mathrm{n} / \mathrm{a}$ & $\mathrm{n} / \mathrm{a}$ & 1.3 & 20.4 \\
\hline & & Totals & 1,202 & & & 6.2 & 100.0 \\
\hline
\end{tabular}


Table 5. Areal percentage of all land-cover classes, and percentage of agriculture land-cover class, that changed to developed land-cover class in Atlantic Coastal Pine Barrens Ecoregion during each of four time periods between 1973 and 2000.

[Percentage of all conversions to developed land-cover class increased between 1973 and 2000, whereas percentage of developed land-cover class that converted from agriculture land-cover class also steadily increased]

\begin{tabular}{ccc}
\hline \multirow{2}{*}{ Period } & \multicolumn{2}{c}{ Developed } \\
\cline { 2 - 3 } & $\begin{array}{c}\text { Total change } \\
\text { (\% of ecoregion) }\end{array}$ & $\begin{array}{c}\text { Change } \\
\text { from agriculture } \\
\text { (\% of ecoregion) }\end{array}$ \\
\hline $1973-1980$ & 68.9 & 41.2 \\
$1980-1986$ & 72.1 & 57.5 \\
$1986-1992$ & 77.9 & 61.5 \\
$1992-2000$ & 84.8 & 69.5 \\
\hline
\end{tabular}

\section{References Cited}

Hart, J.F., 1991, The perimetropolitan bow wave: Geographical Review, v. 81, no. 1, p. 35-51.

Mason, R.J., 1992, Contested lands - Conflict and compromise in New Jersey's Pine Barrens: Philadelphia, Pa., Temple University Press, $257 \mathrm{p}$.

Sorensen, A.A., Greene, R.P., and Russ, K., 1997, Farming on the edge: American Farmland Trust, Center for Agriculture in the Environment, Northern Illinois University.

U.S. Census Bureau, 1970-2000 [various years], Census of population and housing: U.S. Census Bureau database, accessed May 9, 2013, at http://www.census.gov/prod/ www/decennial.html.

Vogelmann, J.E., Howard, S.M., Yang, L., Larson, C.R., Wylie, B.K., and van Driel, N., 2001, Completion of the 1990s National Land Cover Data Set for the conterminous United States from Landsat Thematic Mapper data and ancillary data sources: Photogrammetric Engineering \& Remote Sensing, v. 67, p. 650-662.

Walker, R.T., and Solecki, W.D, 1999, Managing land use and land cover change- - The New Jersey Pinelands Biosphere Reserve: Annals of the Association of American Geographers, v. 89 , no. 2 , p. $220-237$.

Wiken, E., Jiménez Nava, F., and Griffith, G., 2011, North American terrestrial ecoregions-Level III: Montreal, Canada, Commission for Environmental Cooperation, 149 p., accessed May 1, 2013, at http://www.cec.org/ Storage/133/15860_QA07.30-32_NP_NA_Terrestrial_ Ecoregions_Level_3_Final-2june11.pdf. 



\title{
Chapter 6
}

\section{Northern Piedmont Ecoregion}

\author{
By Roger F. Auch
}

\section{Ecoregion Description}

The Northern Piedmont Ecoregion, which trends northeast to southwest, covers about $30,120 \mathrm{~km}^{2}\left(11,629 \mathrm{mi}^{2}\right)$ in New Jersey, Pennsylvania, Delaware, Maryland, the District of Columbia, and Virginia (fig. 1). The Northern Piedmont Ecoregion includes the western parts of metropolitan areas of New York, New York; Philadelphia, Pennsylvania; Baltimore, Maryland; and Washington, D.C. The ecoregion is surrounded by (counterclockwise, from the northeast) the Northeastern Coastal Zone, Northeastern Highlands, Ridge and Valley, Blue Ridge Mountains, Piedmont, Southeastern Plains, Middle Atlantic Coastal Plain, and Atlantic Coastal Pine Barrens Ecoregions.

The Northern Piedmont Ecoregion lies between the topographically flatter coastal areas to the southeast and the more mountainous regions to the west and north. The landforms include low, rounded hills, irregular plains, and open valleys (Wiken and others, 2011). Soils vary across the ecoregion, ranging from thin, stony soils on prominent ridges and low mountains to fertile, limestone-derived soils in some plains and valleys. The climate includes moderate winters and warm, humid summers, with more than $1,000 \mathrm{~mm}$ (40 in.) of precipitation falling in an average year.

Although the population density typically decreases from east to west across the Northern Piedmont Ecoregion, its population grew by nearly 2 million people between 1970 and 2000 , reaching $11,434,000$ in 2000, according to aggregated county-level data (U.S. Census Bureau, 1970-2000 [various years]). Land use varies from busy urban and suburban areas to intensively farmed and densely populated locales to relatively quiet, pastoral places. The predominant land-cover classes form a mosaic of agricultural, forested, and developed lands, but the mixture varies, depending on local conditions (figs. $2 A, B, C$ ). Agricultural lands range from intensively cultivated cornfields and horticultural

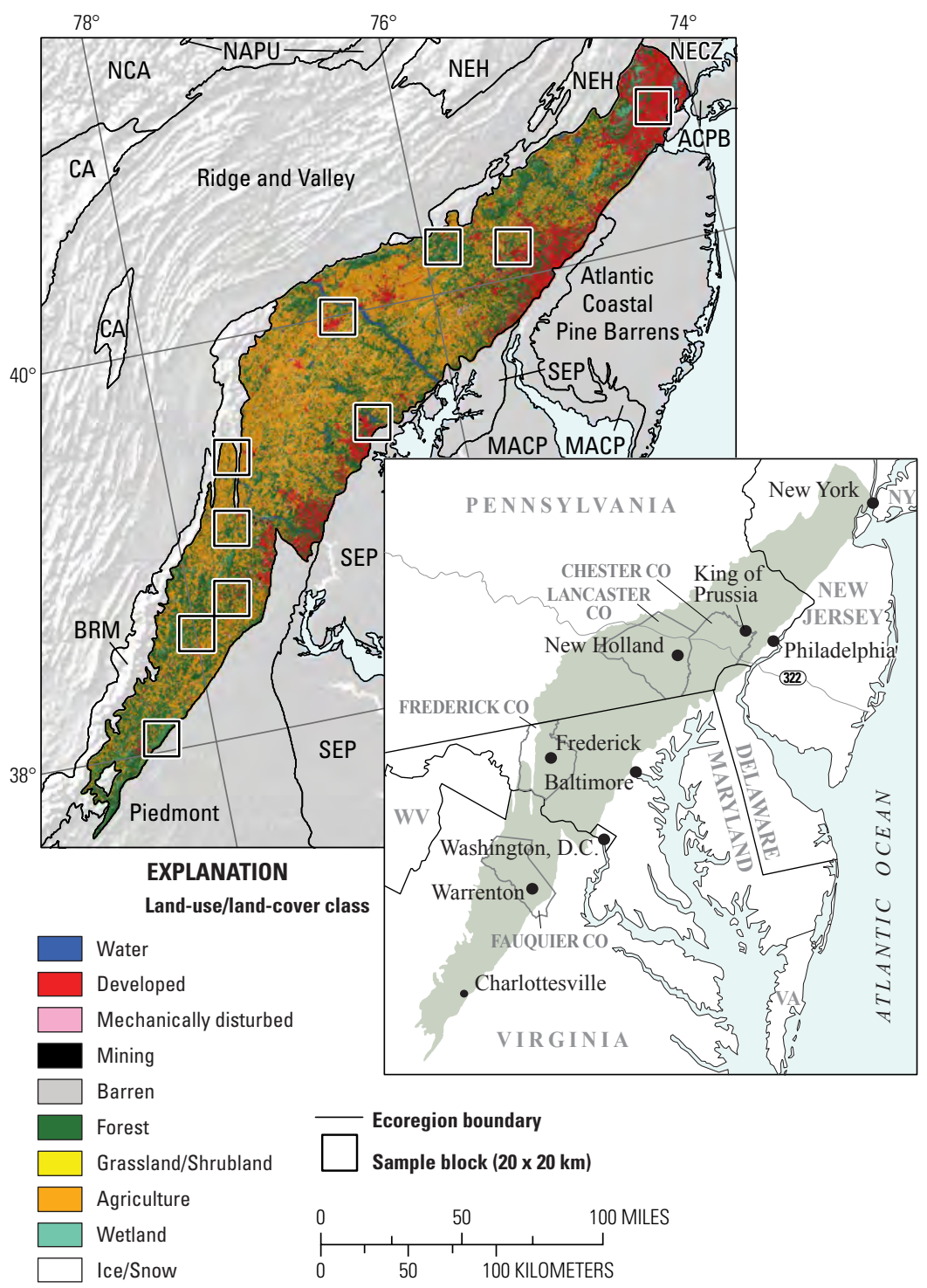

Figure 1. Map of Northern Piedmont Ecoregion and surrounding ecoregions, showing land-use/land-cover classes from 1992 National Land Cover Dataset (Vogelmann and others, 2001); note that not all land-use/land-cover classes shown in explanation may be depicted on map; note also that, for this "Status and Trends of Land Change" study, transitional land-cover class was subdivided into mechanically disturbed and nonmechanically disturbed classes. Squares indicate locations of $20 \times 20 \mathrm{~km}$ sample blocks analyzed in study. Index map shows locations of geographic features mentioned in text. Abbreviations for Eastern United States ecoregions are listed in appendix 2. See appendix 3 for definitions of land-use/land-cover classifications. 

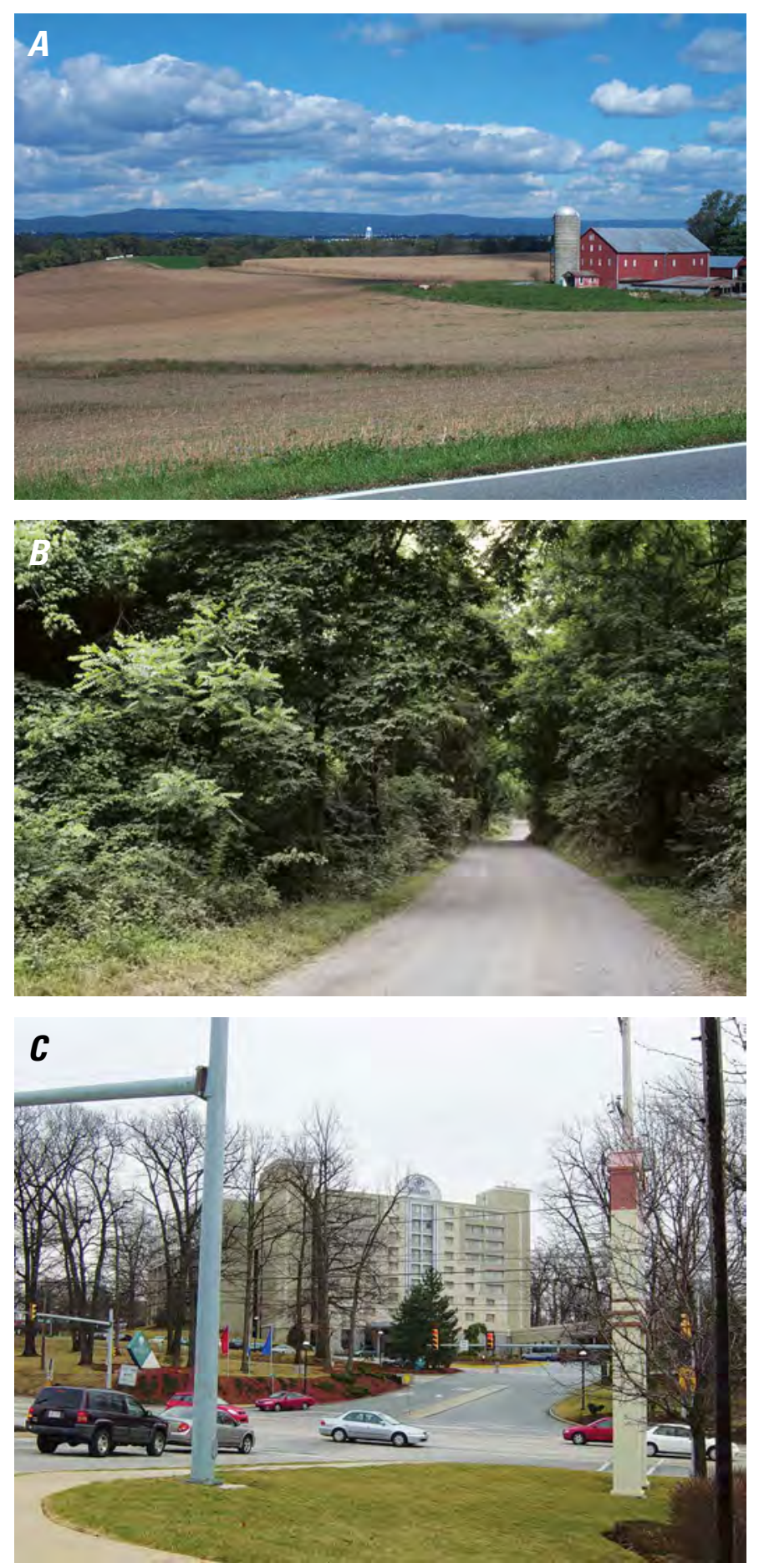

Figure 2. Agricultural, forested, and developed lands in Northern Piedmont Ecoregion. A, Typical farm in Northern Piedmont Ecoregion, near Frederick, Maryland. $B$, Road through forested area in northern Virginia. $C$, Traffic at intersection in commercial area in King of Prussia, Pennsylvania, about 25 km northwest of downtown Philadelphia. nurseries to less intensively used hayfields and pasturelands (figs. $3 A, B$ ). Forest typically is on land that has marginal utility for agricultural use, such as that which has steep slopes and poor-quality soils. Forested areas also are often used as various public resources (Morel and Gottmann, 1961, p. 362, 371-383; Marsh and Lewis, 1995, p. 27; Matlack, 1997).

\section{Contemporary Land-Cover Change (1973 to 2000)}

The overall spatial change (the percentage of land area that changed at least one time) in the Northern Piedmont Ecoregion between 1973 and 2000 is estimated at 6.2 percent (table 1). Compared to other Eastern United States ecoregions, change in the Northern Piedmont Ecoregion was fairly low, but it placed nearly in the median position (fig. 4). Most of the
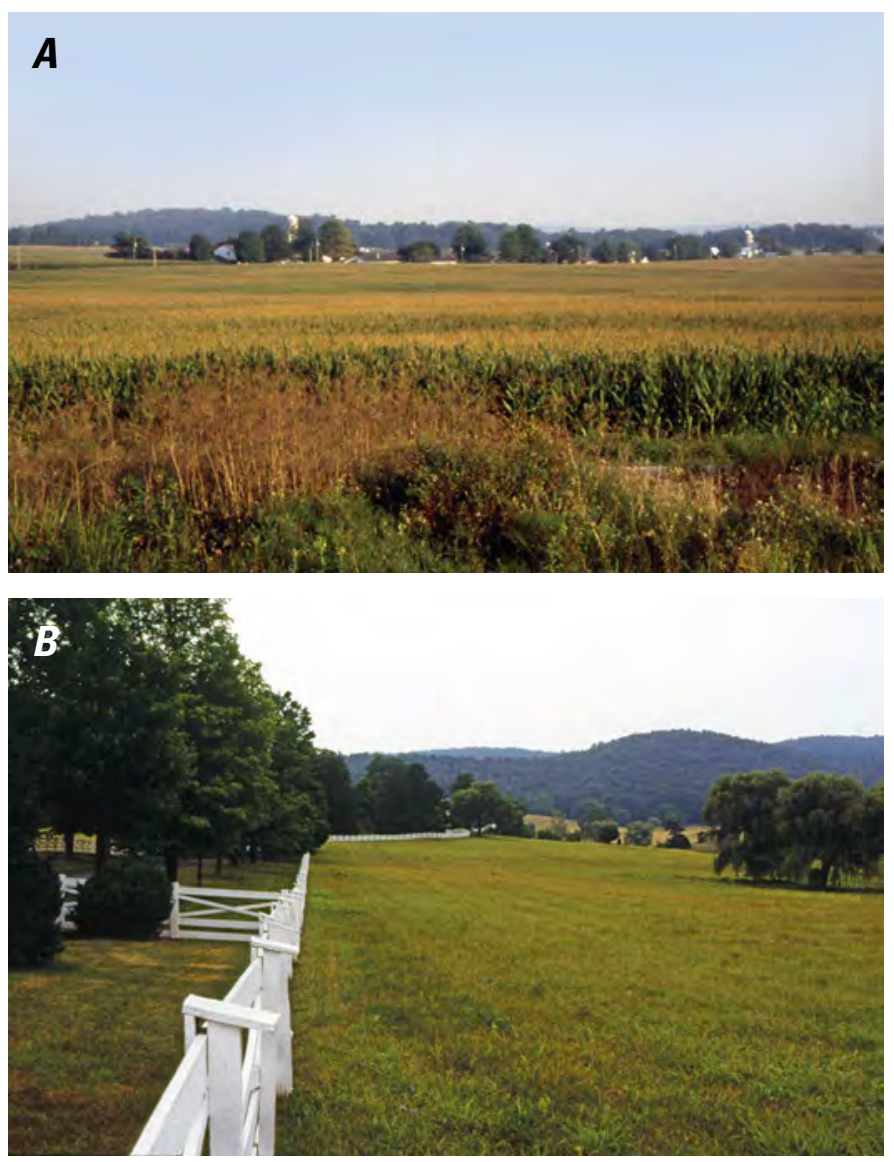

Figure 3. Agricultural lands in Northern Piedmont Ecoregion. $A$, Corn field on outskirts of New Holland, in intensively cultivated Lancaster County, Pennsylvania. $B$, Horse fence in pasture, nestled among forested hills near Charlottesville, Virginia. Thoroughbred horse breeding is long-standing tradition in Northern Piedmont Ecoregion. 


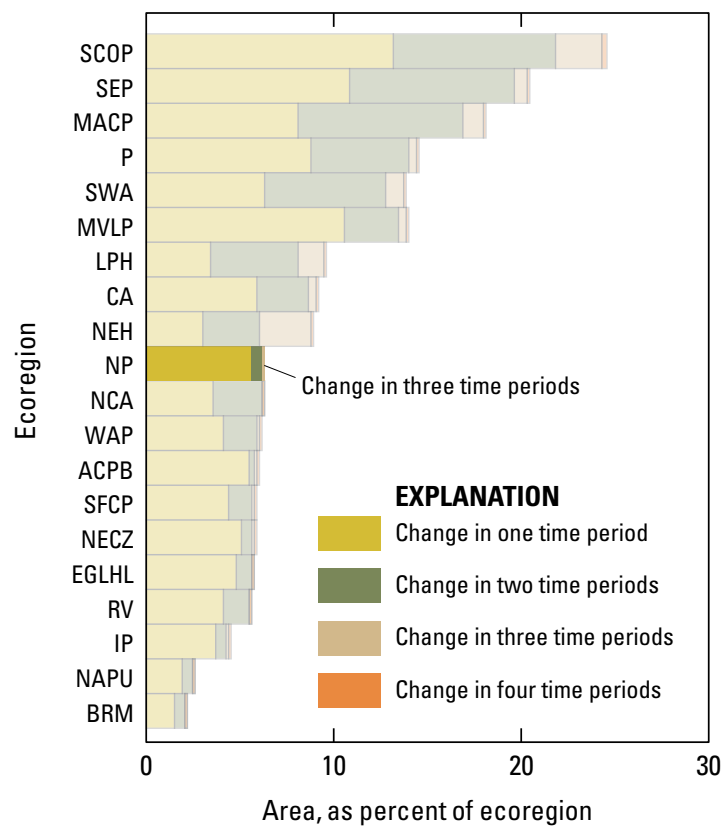

Figure 4. Overall spatial change in Northern Piedmont Ecoregion (NP; darker bars) compared with that of all 20 Eastern United States ecoregions (lighter bars). Each horizontal set of bars shows proportions of ecoregion that changed during one, two, three, or four time periods; highest level of spatial change in Northern Piedmont Ecoregion (three time periods) labeled for clarity. See table 2 for years covered by each time period. See appendix 2 for key to ecoregion abbreviations.

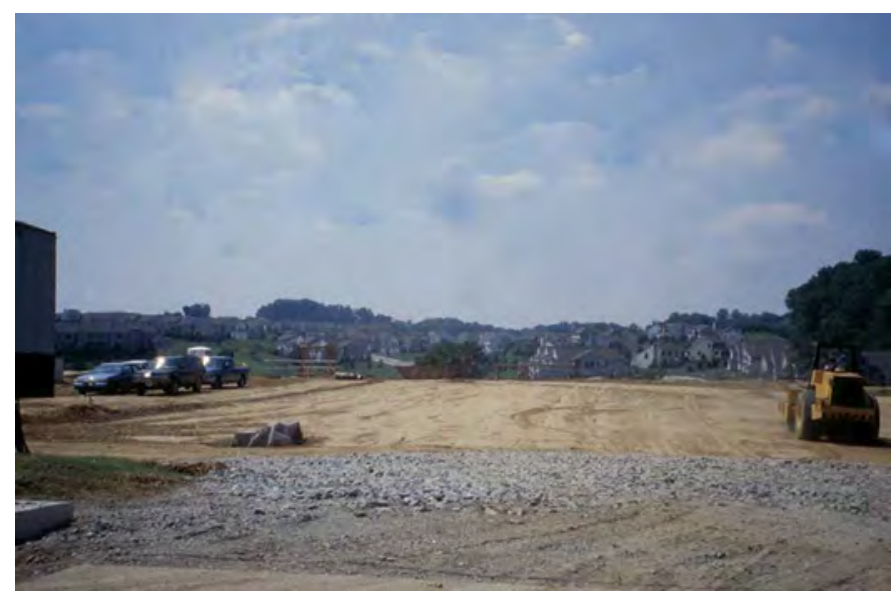

Figure 5. Land being cleared for new development along U.S. Route 322, in southeastern Chester County, Pennsylvania. Houses in background likely were built during study period (1973-2000). land-cover change (about 70 percent) was to newly developed land (fig. 5). The amount of change per time period was relatively low, and it was similar over time until the period between 1992 and 2000, which experienced a noticeable increase (table 2). When normalized to an average annual rate to account for uneven time periods, the period between 1992 and 2000 was still the most dynamically changing period (fig. 6). Although rates of change are not very high, they correspond to a steady increase in developed land, a nearpermanent type of change. The margin of error in the study's statistical estimates was relatively low, ranging from about 0.3 to about 0.6 percent at an 85 -percent confidence interval, indicating that land-cover change was more or less evenly distributed across the ecoregion (table 2).

The Northern Piedmont Ecoregion's predominant land-cover classes - agriculture, forest, and developedexperienced the greatest amounts of net change across the study period (table 3 ). Although change was comparatively low in the ecoregion, most change was to newly developed land, and, by the end of the study period, the developed land-cover class gained 4.6 percent, occupying more than 27 percent of the ecoregion area (table 3; fig. 7). This was one of the highest percentages of increase in the developed landcover class among all 20 Eastern United States ecoregions.

The Northern Piedmont Ecoregion, along with the Atlantic Coastal Pine Barrens Ecoregion to the east and the Northeastern Coastal Zone Ecoregion to the northeast, constitute most of Gottmann's (1961) "Megalopolis" region

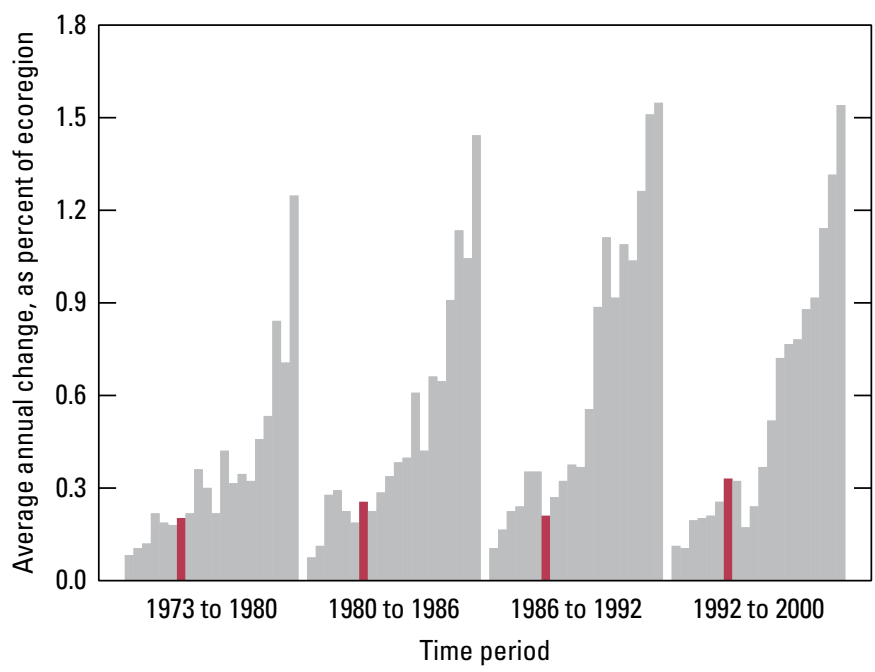

Figure 6. Estimates of land-cover change per time period, normalized to annual rates of change for all 20 Eastern United States ecoregions (gray bars). Estimates of change for Northern Piedmont Ecoregion are represented by red bars in each time period. 


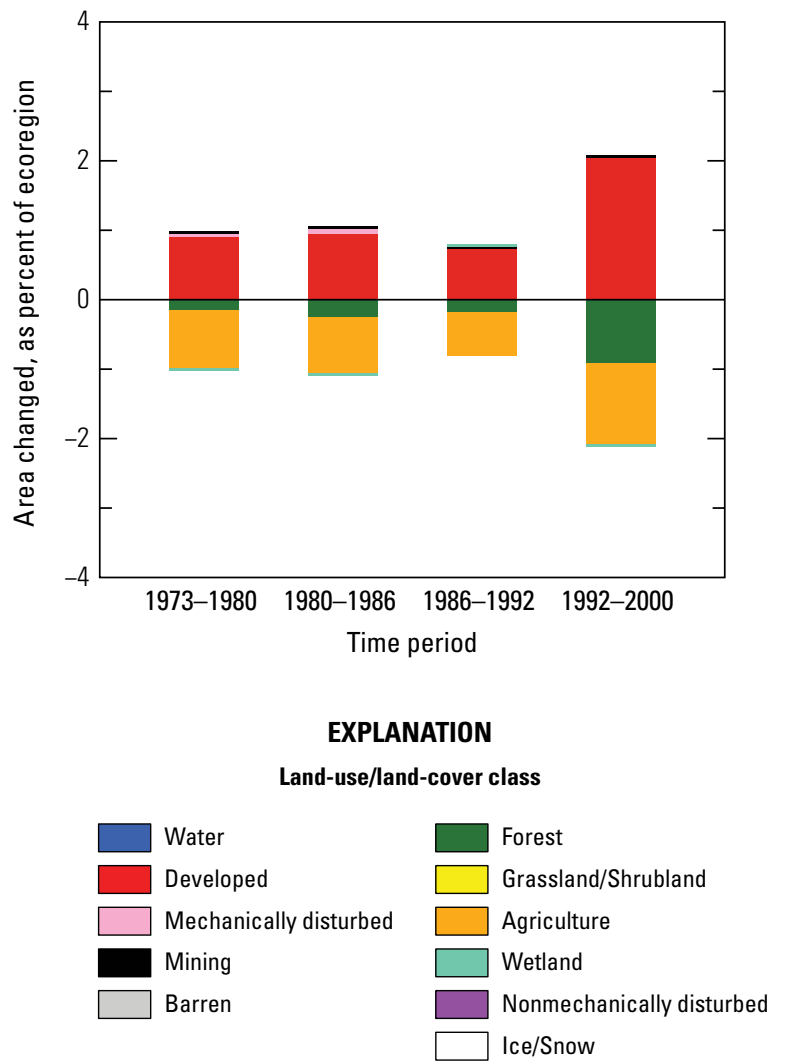

Figure 7. Normalized average net change in Northern Piedmont Ecoregion by time period for each land-cover class. Bars above zero axis represent net gain, whereas bars below zero represent net loss. Note that not all land-cover classes shown in explanation may be represented in figure. See appendix 3 for definitions of land-use and land-cover classifications.

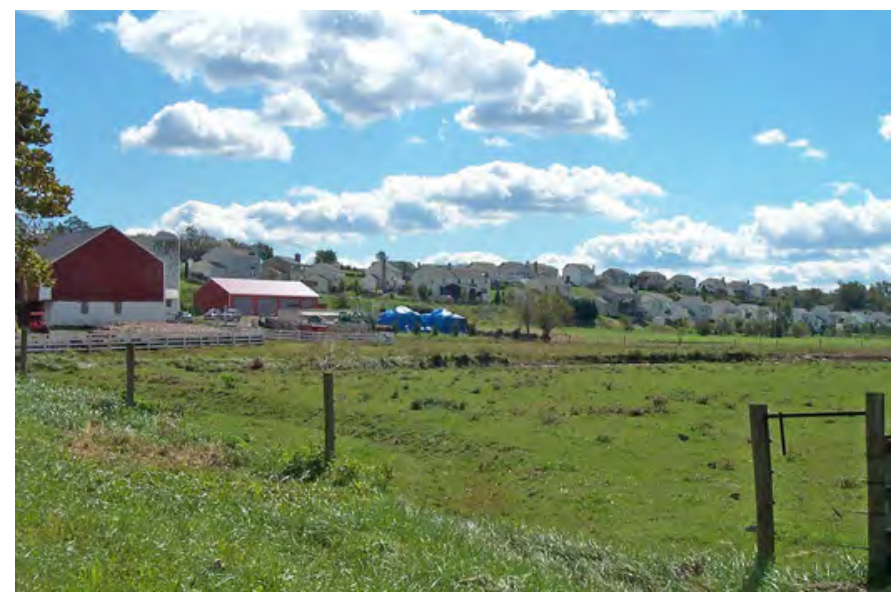

Figure 8. Interface between developed and agricultural land in Frederick County, Maryland, an increasingly common scene in Northern Piedmont Ecoregion. (that is, the northeastern United States urbanizing corridor). The Northern Piedmont Ecoregion's continued urbanization can be seen in the large gains in absolute population (19.9 percent increase), occupied housing units (43.8 percent increase), and employment ( 39.5 percent increase) during the 27-year study period (Auch, 2002). The ecoregion continues its transformation from a once-prominent agricultural area to an urban area. In 1997, the American Farmland Trust declared the Northern Piedmont Ecoregion as the second most "endangered" farming region in the United States (Sorensen and others, 1997) (fig. 8).

The leading land-cover conversions in the Northern Piedmont Ecoregion are shown in table 4. The ecoregion gained an estimated $1,396 \mathrm{~km}^{2}$ of newly developed land between 1973 and 2000 (table 3); most of it came from agriculture $\left(866 \mathrm{~km}^{2}\right)$, but a considerable amount also came from forest $\left(465 \mathrm{~km}^{2}\right)$ (table 4). An additional $59 \mathrm{~km}^{2}$ of developed came from mechanically disturbed, probably the bulldozing or leveling of forested land or farmland for new construction. Less significant changes included conversions back and forth between agriculture and forest (agriculture to forest conversions were more prevalent in earlier time periods) and between forest and mechanically disturbed (likely related to either timber harvesting and regrowth, the clearing of forest for development, or a conversion to agriculture) (fig. 9).

The main story of land-cover change in the Northern Piedmont Ecoregion during the study period was increased urbanization, primarily through the unidirectional land-cover conversion to developed land. The amount of change was comparatively low but steady over time. Most of this newly developed land came at the expense of agricultural land and, to a lesser extent, forested land.

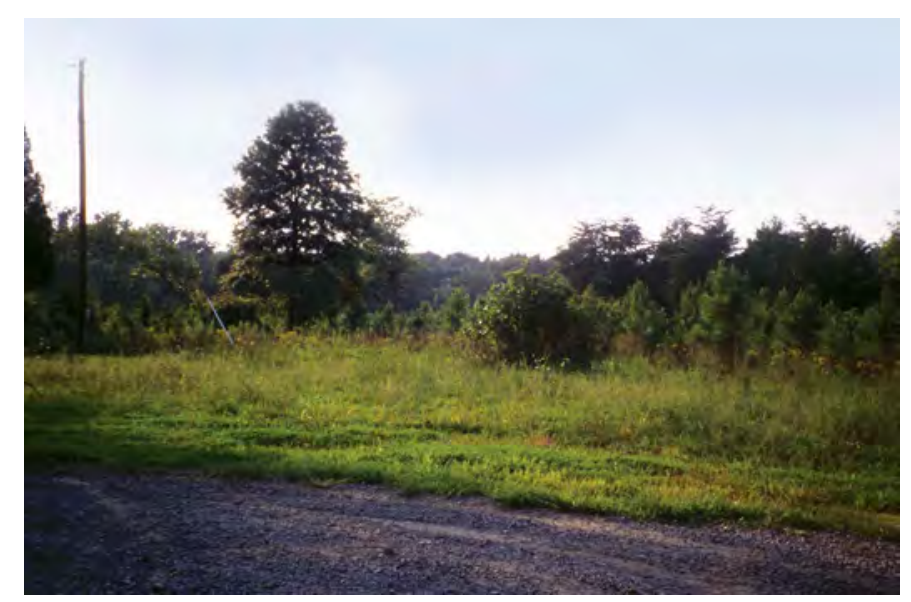

Figure 9. Young stand of planted pines southeast of Warrenton, in Fauquier County, Virginia. 
Table 1. Percentage of Northern Piedmont Ecoregion land cover that changed at least one time during study period (1973-2000), and associated statistical error.

[Most sample pixels remained unchanged ( 93.8 percent), whereas 6.2 percent changed at least once throughout study period. Two dashes (--) indicate that, because zero pixels changed four times during study period, relative error is not calculable

\begin{tabular}{ccccccc}
\hline $\begin{array}{c}\text { Number } \\
\text { of } \\
\text { changes }\end{array}$ & $\begin{array}{c}\text { Percent } \\
\text { of } \\
\text { ecoregion }\end{array}$ & $\begin{array}{c}\text { Margin } \\
\text { of error } \\
(+/-\%)\end{array}$ & $\begin{array}{c}\text { Lower } \\
\text { bound } \\
(\%)\end{array}$ & $\begin{array}{c}\text { Upper } \\
\text { bound } \\
(\%)\end{array}$ & $\begin{array}{c}\text { Standard } \\
\text { error } \\
(\%)\end{array}$ & $\begin{array}{c}\text { Relative } \\
\text { error } \\
(\%)\end{array}$ \\
\hline 1 & 5.6 & 1.0 & 4.6 & 6.7 & 0.7 & 11.8 \\
2 & 0.6 & 0.2 & 0.4 & 0.7 & 0.1 & 22.1 \\
3 & 0.0 & 0.0 & 0.0 & 0.0 & 0.0 & 35.7 \\
4 & 0.0 & 0.0 & 0.0 & 0.0 & 0.0 & -- \\
\hline $\begin{array}{c}\text { Overall } \\
\text { spatial } \\
\text { change }\end{array}$ & 6.2 & 1.1 & 5.1 & 7.3 & 0.7 & 11.0 \\
\hline
\end{tabular}

Table 2. Raw estimates of change in Northern Piedmont Ecoregion land cover, computed for each of four time periods between 1973 and 2000, and associated error at 85-percent confidence level.

[Estimates of change per period normalized to annual rate of change for each period]

\begin{tabular}{cccccccc}
\hline Period & $\begin{array}{c}\text { Total change } \\
(\% \text { of ecoregion) }\end{array}$ & $\begin{array}{c}\text { Margin of } \\
\text { error } \\
(+/-\%)\end{array}$ & $\begin{array}{c}\text { Lower } \\
\text { bound } \\
(\%)\end{array}$ & $\begin{array}{c}\text { Upper bound } \\
(\%)\end{array}$ & $\begin{array}{c}\text { Standard } \\
\text { error } \\
(\%)\end{array}$ & $\begin{array}{c}\text { Relative } \\
\text { error } \\
(\%)\end{array}$ & $\begin{array}{c}\text { Average rate } \\
(\% \text { per year) }\end{array}$ \\
\hline \multicolumn{7}{c}{ (\%stimate of change, in percent stratum } \\
\hline $1973-1980$ & 1.4 & 0.5 & 0.9 & 1.9 & 0.3 & 22.9 & 0.2 \\
$1980-1986$ & 1.5 & 0.3 & 1.2 & 1.9 & 0.2 & 14.2 & 0.3 \\
$1986-1992$ & 1.3 & 0.3 & 1.0 & 1.6 & 0.2 & 15.1 & 0.2 \\
$1992-2000$ & 2.6 & 0.6 & 2.1 & 3.2 & 0.3 & 13.3 & 0.3 \\
\hline $1973-1980$ & 420 & 151 & 268 & 571 & 96 & 22.9 & 60 \\
$1980-1986$ & 460 & 103 & 357 & 563 & 66 & 14.2 & 77 \\
$1986-1992$ & 380 & 91 & 290 & 471 & 58 & 15.1 & 63 \\
$1992-2000$ & 792 & 166 & 626 & 958 & 105 & 13.3 & 99 \\
\hline
\end{tabular}


Table 3. Estimated area (and margin of error) of each land-cover class in Northern Piedmont Ecoregion, calculated five times between 1973 and 2000. See appendix 3 for definitions of land-cover classifications.

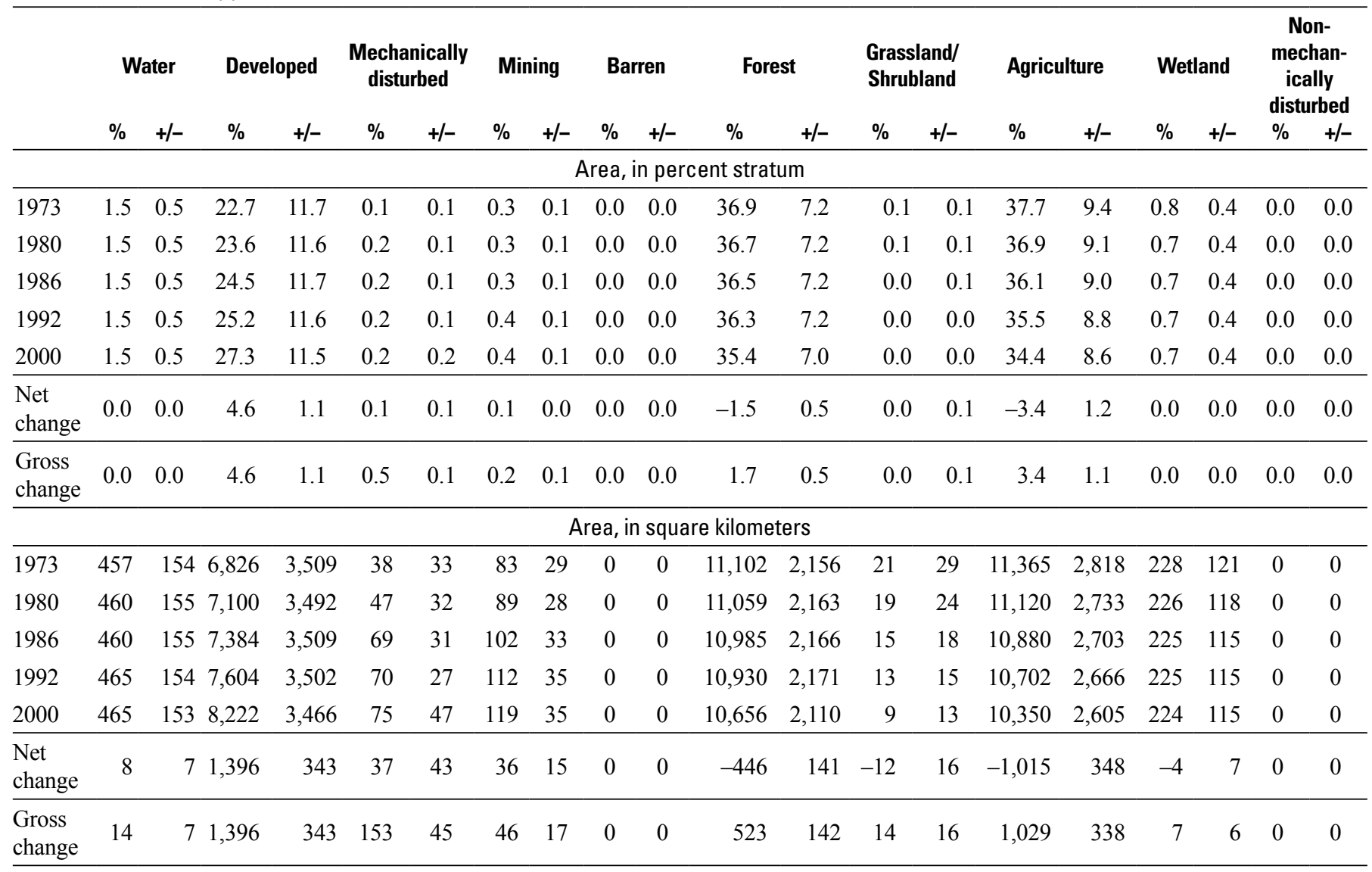


Table 4. Principal land-cover conversions in Northern Piedmont Ecoregion, showing amount of area changed (and margin of error, calculated at 85-percent confidence level) for each conversion during each of four time periods and also during overall study period. See appendix 3 for definitions of land-cover classifications.

[Values given for "other" classes are combined totals of values for other land-cover classes not listed in that time period. Abbreviations: n/a, not applicable]

\begin{tabular}{|c|c|c|c|c|c|c|c|}
\hline Period & From class & To class & $\begin{array}{c}\begin{array}{c}\text { Area } \\
\text { changed }\end{array} \\
\left(\mathrm{km}^{2}\right)\end{array}$ & $\begin{array}{c}\text { Margin of } \\
\text { error } \\
\left(+/-\mathbf{k m}^{2}\right)\end{array}$ & $\begin{array}{c}\text { Standard } \\
\text { error } \\
\left(\mathrm{km}^{2}\right)\end{array}$ & $\begin{array}{l}\text { Percent of } \\
\text { ecoregion }\end{array}$ & $\begin{array}{c}\text { Percent of all } \\
\text { changes }\end{array}$ \\
\hline \multirow[t]{7}{*}{ 1973-1980 } & Agriculture & Developed & 192 & 151 & 96 & 0.6 & 45.7 \\
\hline & Forest & Developed & 79 & 45 & 29 & 0.3 & 18.9 \\
\hline & Agriculture & Forest & 43 & 34 & 22 & 0.1 & 10.3 \\
\hline & Mechanically disturbed & Forest & 27 & 27 & 17 & 0.1 & 6.4 \\
\hline & Forest & Mechanically disturbed & 20 & 13 & 9 & 0.1 & 4.9 \\
\hline & Other & Other & 58 & $\mathrm{n} / \mathrm{a}$ & $\mathrm{n} / \mathrm{a}$ & 0.2 & 13.8 \\
\hline & & Totals & 420 & & & 1.4 & 100.0 \\
\hline \multirow[t]{7}{*}{ 1980-1986 } & Agriculture & Developed & 186 & 77 & 49 & 0.6 & 40.4 \\
\hline & Forest & Developed & 89 & 35 & 22 & 0.3 & 19.3 \\
\hline & Agriculture & Forest & 54 & 26 & 17 & 0.2 & 11.7 \\
\hline & Forest & Mechanically disturbed & 39 & 19 & 12 & 0.1 & 8.5 \\
\hline & Mechanically disturbed & Forest & 22 & 18 & 11 & 0.1 & 4.7 \\
\hline & Other & Other & 71 & $\mathrm{n} / \mathrm{a}$ & $\mathrm{n} / \mathrm{a}$ & 0.2 & 15.4 \\
\hline & & Totals & 460 & & & 1.5 & 100.0 \\
\hline \multirow[t]{7}{*}{ 1986-1992 } & Agriculture & Developed & 129 & 47 & 30 & 0.4 & 33.9 \\
\hline & Forest & Developed & 76 & 36 & 23 & 0.3 & 20.2 \\
\hline & Mechanically disturbed & Forest & 37 & 23 & 15 & 0.1 & 9.8 \\
\hline & Forest & Mechanically disturbed & 35 & 21 & 13 & 0.1 & 9.1 \\
\hline & Agriculture & Forest & 29 & 19 & 12 & 0.1 & 7.6 \\
\hline & Other & Other & 75 & $\mathrm{n} / \mathrm{a}$ & $\mathrm{n} / \mathrm{a}$ & 0.2 & 19.7 \\
\hline & & Totals & 380 & & & 1.3 & 100.0 \\
\hline \multirow[t]{7}{*}{ 1992-2000 } & Agriculture & Developed & 360 & 136 & 87 & 1.2 & 45.5 \\
\hline & Forest & Developed & 221 & 73 & 46 & 0.7 & 27.9 \\
\hline & Forest & Mechanically disturbed & 61 & 42 & 27 & 0.2 & 7.7 \\
\hline & Mechanically disturbed & Developed & 34 & 17 & 11 & 0.1 & 4.3 \\
\hline & Forest & Agriculture & 34 & 19 & 12 & 0.1 & 4.3 \\
\hline & Other & Other & 82 & $\mathrm{n} / \mathrm{a}$ & $\mathrm{n} / \mathrm{a}$ & 0.3 & 10.3 \\
\hline & & Totals & 792 & & & 2.6 & 100.0 \\
\hline \multirow{7}{*}{$\begin{array}{c}1973-2000 \\
\text { (overall) }\end{array}$} & Agriculture & Developed & 866 & 332 & 211 & 2.9 & 42.2 \\
\hline & Forest & Developed & 465 & 135 & 86 & 1.5 & 22.7 \\
\hline & Forest & Mechanically disturbed & 156 & 80 & 51 & 0.5 & 7.6 \\
\hline & Agriculture & Forest & 148 & 74 & 47 & 0.5 & 7.2 \\
\hline & Mechanically disturbed & Forest & 108 & 75 & 48 & 0.4 & 5.3 \\
\hline & Other & Other & 309 & $\mathrm{n} / \mathrm{a}$ & $\mathrm{n} / \mathrm{a}$ & 1.0 & 15.1 \\
\hline & & Totals & 2,052 & & & 6.8 & 100.0 \\
\hline
\end{tabular}




\section{References Cited}

Auch, R.F., 2002, Land use/land cover change in the Northern Piedmont Ecoregion, 1970-2000: Brookings, South Dakota State University, Master's thesis, 211 p.

Gottmann, J., 1961, Megalopolis-The urbanized northeastern seaboard of the United States: New York, The Twentieth Century Fund, 810 p.

Marsh, B., and Lewis, P., 1995, Landforms and human habitat, in Miller, E.W., ed., A geography of Pennsylvania: University Park, Pennsylvania State University Press, p. $17-43$.

Matlack, R.G., 1997, Four centuries of forest clearance and regeneration in the hinterland of a large city: Journal of Biogeography, v. 24, p. 281-295.

Morel, H., and Gottmann, J., 1961, The woodlands-Their uses and wildlife, in Gottmann, J., Megalopolis-The urbanized northeastern seaboard of the United States: New York, The Twentieth Century Fund, p. 341-383.
Sorensen, A.A., Greene, R.B., and Russ, K., 1997, Farming on the edge: DeKalb, Ill., American Farmland Trust, Center for Agriculture in the Environment, 29 p.

U.S. Census Bureau, 1970-2000 [various years], Census of population and housing: U.S. Census Bureau database, accessed May 9, 2013, at http://www.census.gov/prod/ www/decennial.html.

Vogelmann, J.M., Howard, S.M., Yang, L., Larson, C.R., Wylie, B.K., and van Driel, N., 2001, Completion of the 1990s National Land Cover Data Set for the conterminous United States from Landsat Thematic Mapper data and ancillary data sources: Photogrammetric Engineering \& Remote Sensing, v. 67, p. 650-662.

Wiken, E., Jiménez Nava, F., and Griffith, G., 2011, North American terrestrial ecoregions-Level III: Montreal, Canada, Commission for Environmental Cooperation, 149 p., accessed May 1, 2013, at http://www.cec.org/ Storage/133/15860 QA07.30-32 NP NA Terrestrial Ecoregions_Level_3_Final-2june11.pdf. 


\section{Appalachian Mountains Ecoregions}
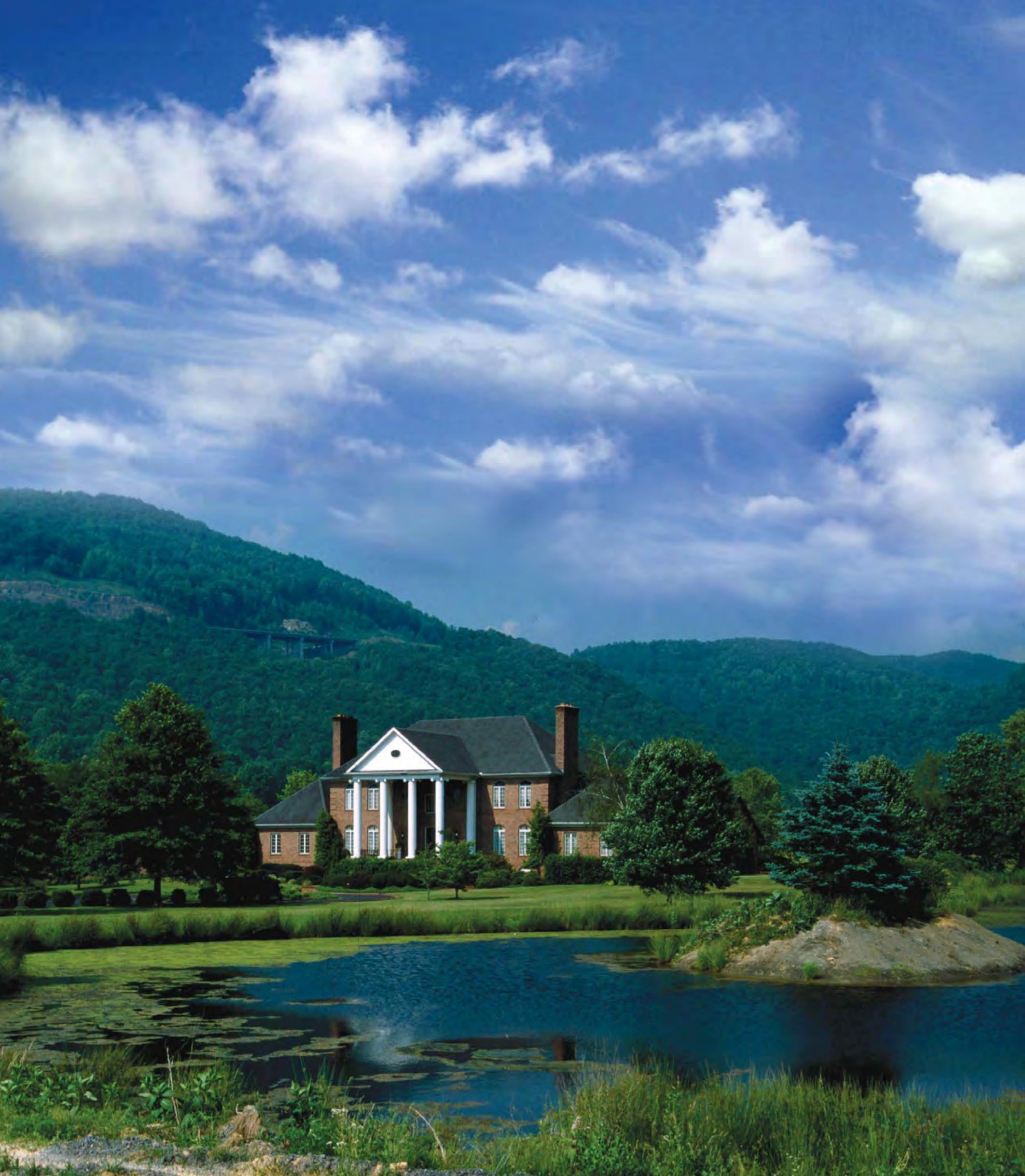


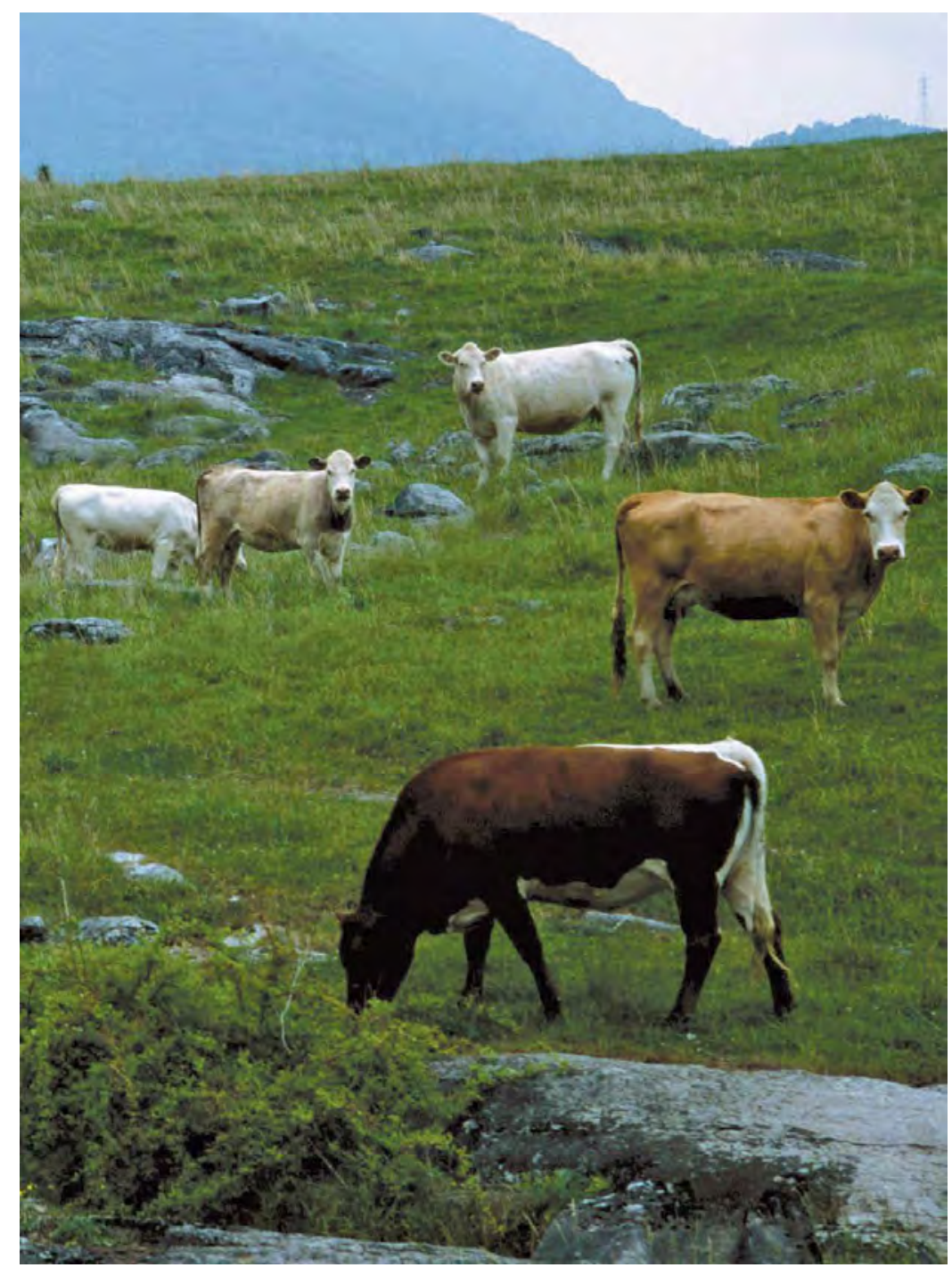




\title{
Chapter 7
}

\section{Northern Appalachian Plateau and Uplands Ecoregion}

\author{
By Mark S. Brooks
}

\section{Ecoregion Description}

The Northern Appalachian Plateau and Uplands Ecoregion, which is located in south-central New York and northeastern Pennsylvania, covers about 29,919 $\mathrm{km}^{2}\left(11,552 \mathrm{mi}^{2}\right)$ (fig. 1). The ecoregion is bounded on the north by the Eastern Great Lakes and Hudson Lowlands Ecoregion; on the east, by the Northeastern Highlands and North Central Appalachians Ecoregions; on the south, by the Ridge and Valley and North Central Appalachians Ecoregions; and on the far west, by the Erie Drift Plains Ecoregion. The ecoregion spans the area between the less irregular, more agricultural and urbanized ecoregions to the north and west and the more mountainous and forested, less populated ecoregions to the south and east (Wiken and others, 2011). The landscape is rural, with rolling hills and fertile stream valleys. The climate in the ecoregion is temperate: average temperature in January is $-6.1^{\circ} \mathrm{C}$ and, in July, is $20.7^{\circ} \mathrm{C}$; average annual precipitation is more than $940 \mathrm{~mm}$ (37 in.) (National Oceanic and Atmospheric Administration, 2002).

Forest and agriculture are the dominant land-cover classes in the Northern Appalachian Plateau and Uplands Ecoregion (fig. 2). The forest is composed of northern hardwoods that include sugar maple (Acer saccharum), red maple (Acer rubrum), white ash (Fraxinus americana), American beech (Fagus grandifolia), northern red oak (Quercus rubra), sweet cherry (Prunus avium), and eastern

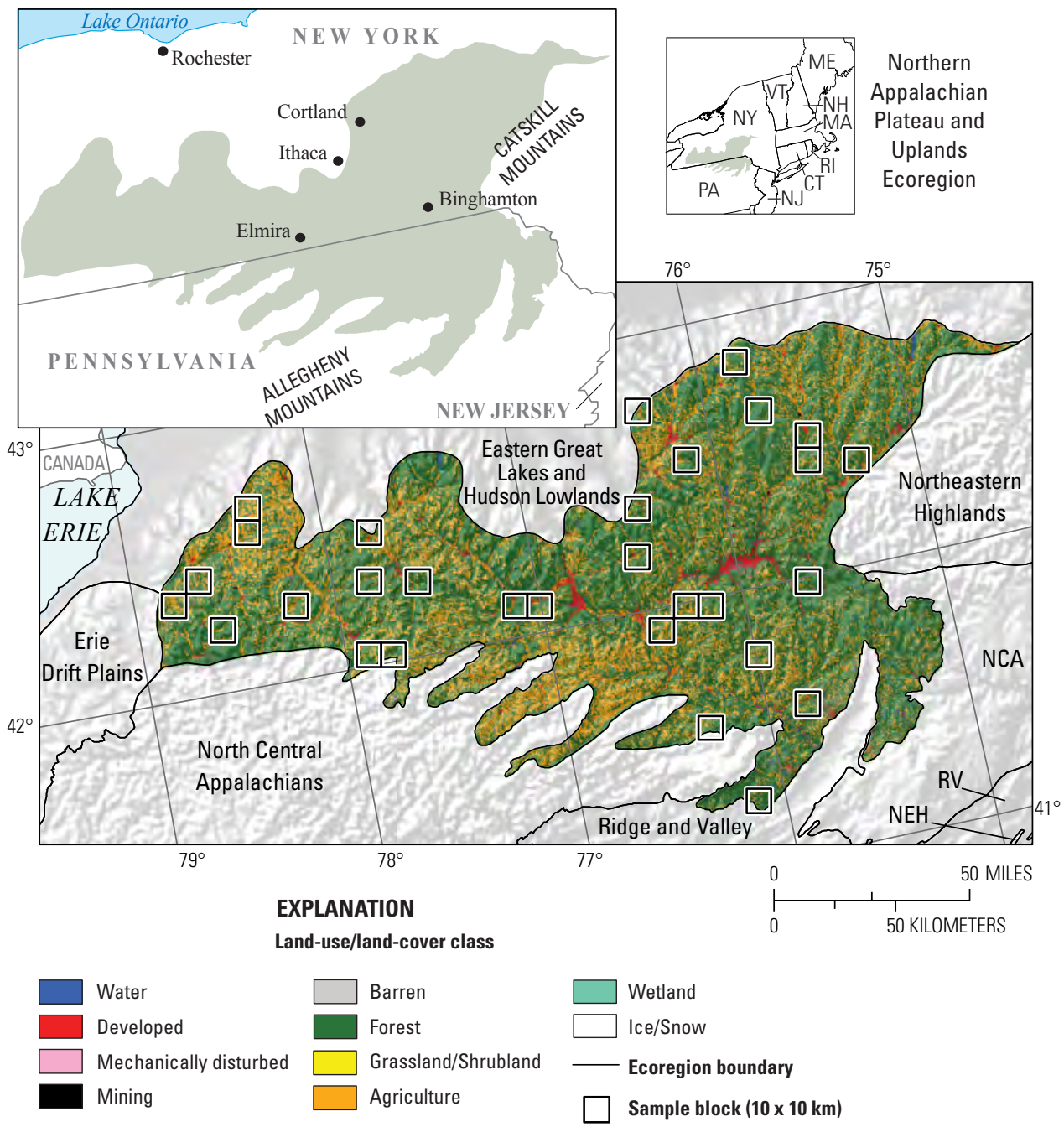

Figure 1. Map of Northern Appalachian Plateau and Uplands Ecoregion and surrounding ecoregions, showing land-use/land-cover classes from 1992 National Land Cover Dataset (Vogelmann and others, 2001); note that not all land-use/land-cover classes shown in explanation may be depicted on map; note also that, for this "Status and Trends of Land Change" study, transitional land-cover class was subdivided into mechanically disturbed and nonmechanically disturbed classes. Squares indicate locations of $10 \times 10 \mathrm{~km}$ sample blocks analyzed in study. Index map shows locations of geographic features mentioned in text. Abbreviations for Eastern United States ecoregions are listed in appendix 2. Also shown is part of one Midwest-South Central United States ecoregion, Erie Drift Plains. See appendix 3 for definitions of land-use/land-cover classifications. 
hemlock (Tsuga canadensis) (Smallidge, 1998). Dairy and cattle farming, along with the production of corn, wheat, and hay, are the major agricultural activities in the ecoregion (Fick and Cox, 1995) (fig. 3).

\section{Contemporary Land-Cover Change (1973 to 2000)}

The overall spatial change (the percentage of land area that changed at least one time) in the Northern Appalachian Plateau and Uplands Ecoregion between 1973 and 2000 is estimated at 2.4 percent (table 1). Compared to other Eastern United States ecoregions, change in the Northern Appalachian Plateau and Uplands Ecoregion was very low (fig. 4): an estimated 1.8 percent changed land cover one time, and only 0.7 percent changed multiple times (table 1 ).

The estimated change per time period varied modestly during the 27-year study period (fig. 5). The first two time

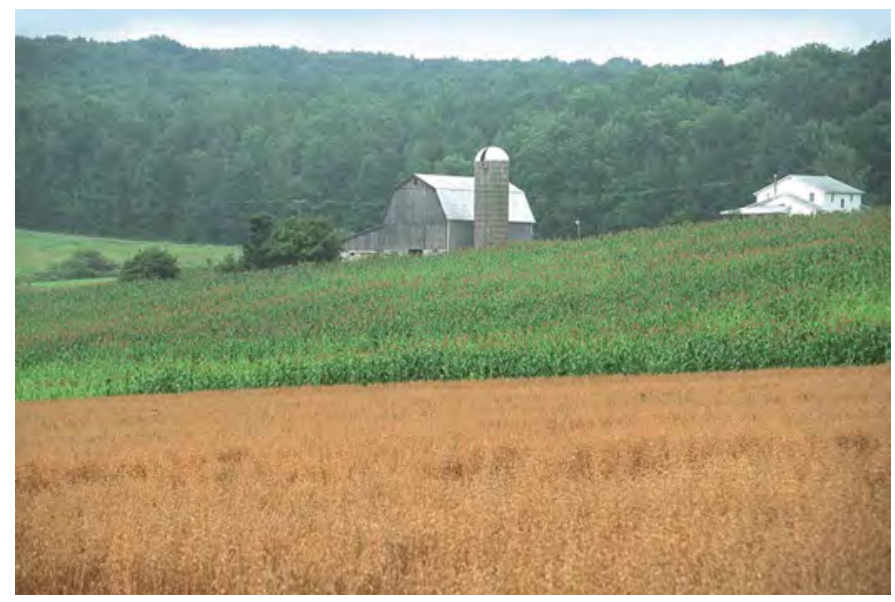

Figure 2. Typical farm in Northern Appalachian Plateau and Uplands Ecoregion.

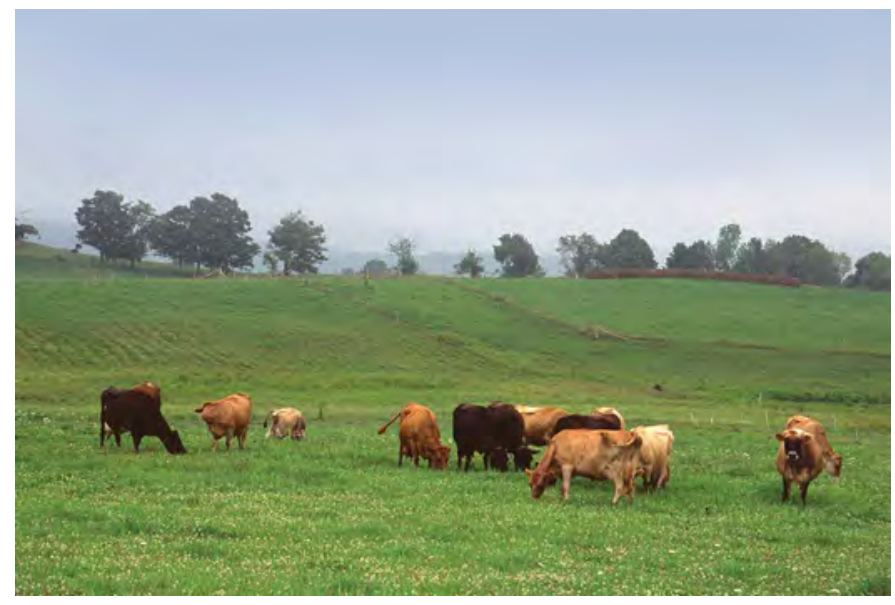

Figure 3. Cattle grazing in open pasture, in Northern Appalachian Plateau and Uplands Ecoregion.

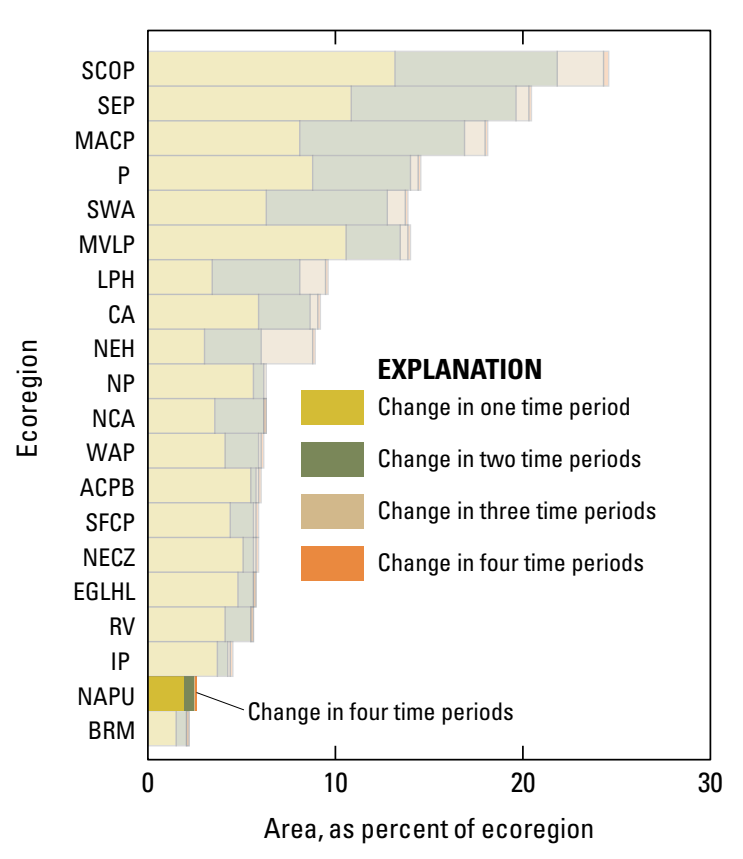

Figure 4. Overall spatial change in Northern Appalachian Plateau and Uplands Ecoregion (NAPU; darker bars) compared with that of all 20 Eastern United States ecoregions (lighter bars). Each horizontal set of bars shows proportions of ecoregion that changed during one, two, three, or four time periods; highest level of spatial change in Northern Appalachian Plateau and Uplands Ecoregion (four time periods) labeled for clarity. See table 2 for years covered by each time period. See appendix 2 for key to ecoregion abbreviations.

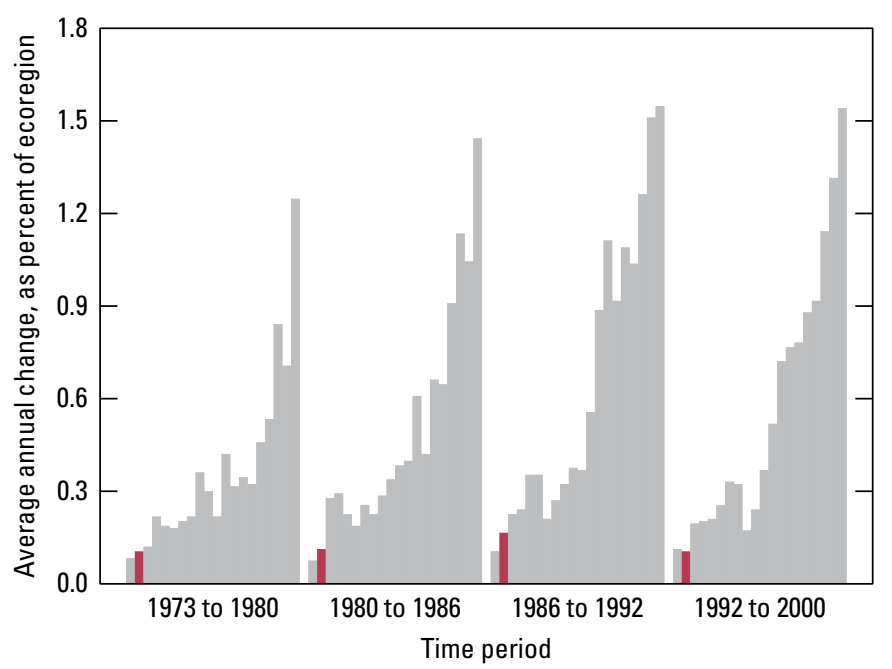

Figure 5. Estimates of land-cover change per time period, normalized to annual rates of change for all 20 Eastern United States ecoregions (gray bars). Estimates of change for Northern Appalachian Plateau and Uplands Ecoregion are represented by red bars in each time period. 
periods (1972-1980, 1980-1986) experienced a change of 0.7 percent. The third time period (1986-1992) had the only increase in change, from 0.7 to 1.0 percent. Finally, in the last time period (1992-2000), the change was 0.8 percent. The margin of error at the 85-percent confidence level was very low during all time periods, ranging from about 0.2 to about 0.3 percent. When normalized to an average annual rate to account for uneven time periods, the average annual rate of change for each time period was 0.1 percent, with the exception of the third time period (1986-1992), which had a rate of change of 0.2 percent (table 2). Overall, the land cover in the Northern Appalachian Plateau and Uplands Ecoregion was extremely stable throughout the study period.

The dominant land-cover classes in the Northern Appalachian Plateau and Uplands Ecoregion in 2000

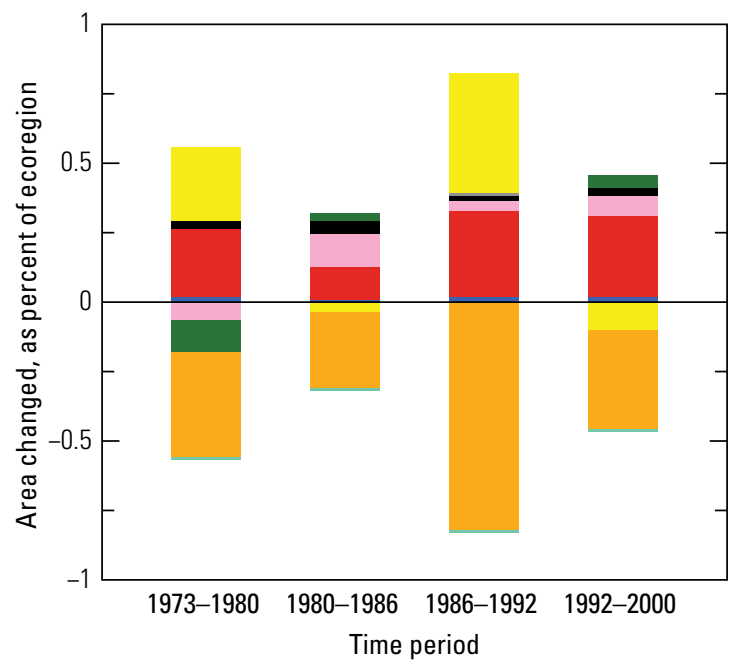

EXPLANATION

Land-use/land-cover class
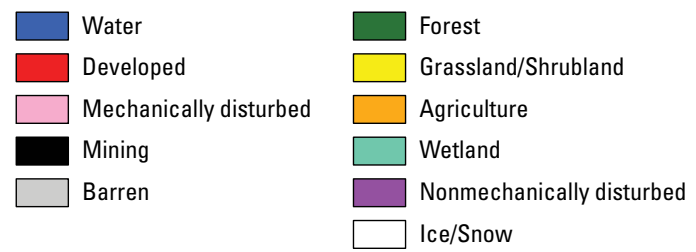

Figure 6. Normalized average net change in Northern Appalachian Plateau and Uplands Ecoregion by time period for each land-cover class. Bars above zero axis represent net gain, whereas bars below zero represent net loss. Note that not all land-cover classes shown in explanation may be represented in figure. See appendix 3 for definitions of land-use and land-cover classifications. were forest (60.0 percent), agriculture (33.9 percent), and developed (3.3 percent) (table 3 ). Net change for all landcover classes, with the exception of agriculture, was modest during the study period (1973-2000). Agriculture had the largest net change, with a 0.9 percent loss of ecoregion area between 1973 and 2000. Land-cover classes that gained ecoregion area at the expense of agriculture included developed ( 0.5 percent increase) and grassland/shrubland (0.3 percent increase) (table 3; fig. 6).

The top two land-cover conversions during the study period pointed to the overall loss of agricultural land in the ecoregion: an estimated $161 \mathrm{~km}^{2}$ of agricultural land converted to grassland/shrubland, and $159 \mathrm{~km}^{2}$ converted to forest (table 4). The third-leading conversion was from grassland/shrubland to forest $\left(136 \mathrm{~km}^{2}\right)$. The secondand third-leading conversions resulted from the natural progression of abandoned agricultural land reverting back to forest. Principal factors that contribute to the abandonment of agricultural lands are hilly topography, poor road access, poor drainage, and poor soil (Flinn and others, 2005). The fourth- and fifth-leading conversions involved the clearing of forest for agricultural land $\left(125 \mathrm{~km}^{2}\right)$ and the mechanical disturbance of forested land because of timber harvesting ( 85 $\mathrm{km}^{2}$ ) (table 4).

Land cover in the Northern Appalachian Plateau and Uplands Ecoregion was stable throughout the study period (1973-2000). The loss of agricultural land was the most significant land-cover change, as farmland decreased in each time period. The greatest amount of agricultural land was abandoned during the period between 1986 and 1992, with an estimated $148 \mathrm{~km}^{2}$ converting to forested land, grassland/ shrubland, or developed land (table 4; fig. 7).

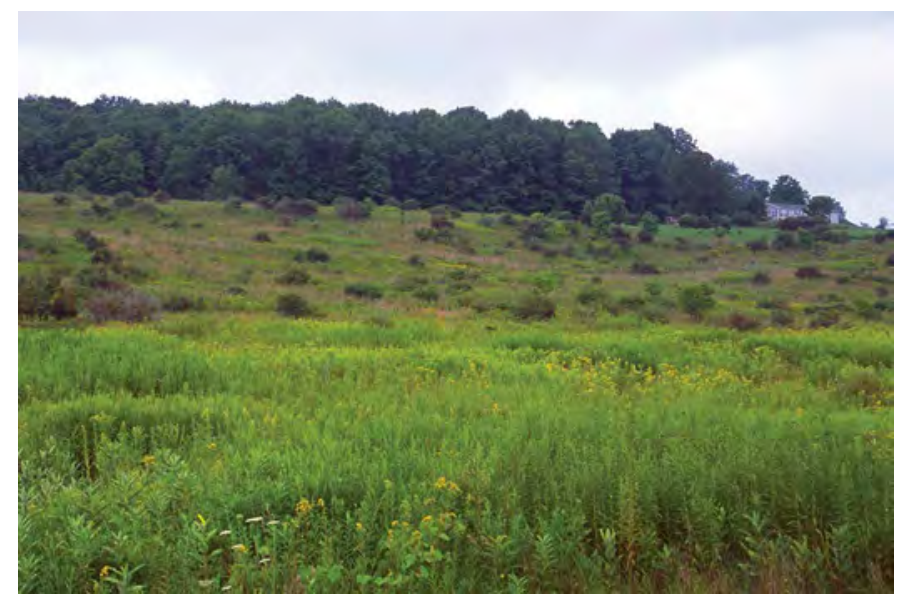

Figure 7. Abandoned agricultural land (pasture) reverting to grassland/shrubland, a common type of land-cover change in Northern Appalachian Plateau and Uplands Ecoregion. 
Table 1. Percentage of Northern Appalachian Plateau and Uplands Ecoregion land cover that changed at least one time during study period (1973-2000) and associated statistical error.

\begin{tabular}{ccccccc}
\multicolumn{6}{c}{$\begin{array}{l}\text { [Most sample pixels remained unchanged (97.6 percent), whereas } 2.4 \text { percent } \\
\text { changed at least once throughout study period] }\end{array}$} \\
\hline $\begin{array}{c}\text { Number } \\
\text { of } \\
\text { changes }\end{array}$ & $\begin{array}{c}\text { Percent } \\
\text { of } \\
\text { ecoregion }\end{array}$ & $\begin{array}{c}\text { Margin } \\
\text { of error } \\
(+/ \mathbf{-} \%)\end{array}$ & $\begin{array}{c}\text { Lower } \\
\text { bound } \\
(\%)\end{array}$ & $\begin{array}{c}\text { Upper } \\
\text { bound } \\
(\%)\end{array}$ & $\begin{array}{c}\text { Standard } \\
\text { error } \\
(\%)\end{array}$ & $\begin{array}{c}\text { Relative } \\
\text { error } \\
(\%)\end{array}$ \\
\hline 1 & 1.8 & 0.5 & 1.3 & 2.4 & 0.4 & 19.6 \\
2 & 0.6 & 0.2 & 0.3 & 0.8 & 0.2 & 30.4 \\
3 & 0.1 & 0.0 & 0.0 & 0.1 & 0.0 & 30.0 \\
4 & 0.0 & 0.0 & 0.0 & 0.0 & 0.0 & 94.8 \\
\hline $\begin{array}{c}\text { Overall } \\
\text { spatial }\end{array}$ & 2.4 & 0.7 & 1.8 & 3.1 & 0.4 & 18.4 \\
change & & & & & & \\
\hline
\end{tabular}

Table 2. Raw estimates of change in Northern Appalachian Plateau and Uplands Ecoregion land cover, computed for each of four time periods between 1973 and 2000, and associated error at 85-percent confidence level

[Estimates of change per period normalized to annual rate of change for each period]

\begin{tabular}{|c|c|c|c|c|c|c|c|}
\hline Period & $\begin{array}{c}\text { Total change } \\
\text { ( } \% \text { of ecoregion) }\end{array}$ & $\begin{array}{c}\text { Margin of } \\
\text { error } \\
(+/-\%) \\
\end{array}$ & $\begin{array}{c}\text { Lower } \\
\text { bound } \\
(\%) \\
\end{array}$ & $\begin{array}{c}\text { Upper } \\
\text { bound } \\
(\%) \\
\end{array}$ & $\begin{array}{c}\text { Standard } \\
\text { error } \\
(\%) \\
\end{array}$ & $\begin{array}{c}\text { Relative } \\
\text { error } \\
(\%) \\
\end{array}$ & $\begin{array}{l}\text { Average rate } \\
\text { (\% per year) }\end{array}$ \\
\hline \multicolumn{8}{|c|}{ Estimate of change, in percent stratum } \\
\hline $1973-1980$ & 0.7 & 0.3 & 0.4 & 1.0 & 0.2 & 29.7 & 0.1 \\
\hline 1980-1986 & 0.7 & 0.2 & 0.5 & 0.8 & 0.1 & 17.4 & 0.1 \\
\hline 1986-1992 & 1.0 & 0.3 & 0.7 & 1.3 & 0.2 & 20.4 & 0.2 \\
\hline 1992-2000 & 0.8 & 0.3 & 0.5 & 1.1 & 0.2 & 24.0 & 0.1 \\
\hline \multicolumn{8}{|c|}{ Estimate of change, in square kilometers } \\
\hline 1973-1980 & 215 & 94 & 121 & 310 & 64 & 29.7 & 31 \\
\hline $1980-1986$ & 196 & 50 & 146 & 246 & 34 & 17.4 & 33 \\
\hline 1986-1992 & 294 & 89 & 206 & 383 & 60 & 20.4 & 49 \\
\hline 1992-2000 & 236 & 84 & 152 & 319 & 57 & 24.0 & 29 \\
\hline
\end{tabular}


Table 3. Estimated area (and margin of error) of each land-cover class in Northern Appalachian Plateau and Uplands Ecoregion, calculated five times between 1973 and 2000. See appendix 3 for definitions of land-cover classifications.

\begin{tabular}{|c|c|c|c|c|c|c|c|c|c|c|c|c|c|c|c|c|c|c|c|c|}
\hline & \multicolumn{2}{|c|}{ Water } & \multicolumn{2}{|c|}{ Developed } & \multicolumn{2}{|c|}{$\begin{array}{l}\text { Mechani- } \\
\text { cally dis- } \\
\text { turbed }\end{array}$} & \multicolumn{2}{|c|}{ Mining } & \multicolumn{2}{|c|}{ Barren } & \multicolumn{2}{|c|}{ Forest } & \multicolumn{2}{|c|}{$\begin{array}{l}\text { Grassland/ } \\
\text { Shrubland }\end{array}$} & \multicolumn{2}{|c|}{ Agriculture } & \multicolumn{2}{|c|}{ Wetland } & \multicolumn{2}{|c|}{$\begin{array}{c}\text { Non- } \\
\text { mecha- } \\
\text { nically } \\
\text { disturbed }\end{array}$} \\
\hline \multicolumn{21}{|c|}{ Area, in percent stratum } \\
\hline 1973 & 0.9 & 0.2 & 2.8 & 0.8 & 0.0 & 0.0 & 0.1 & 0.0 & 0.0 & 0.0 & 60.1 & 2.3 & 0.1 & 0.0 & 34.9 & 2.4 & 1.2 & 0.4 & 0.0 & 0.0 \\
\hline 1992 & 0.9 & 0.2 & 3.1 & 0.9 & 0.1 & 0.0 & 0.1 & 0.1 & 0.0 & 0.0 & 60.0 & 2.2 & 0.4 & 0.2 & 34.1 & 2.5 & 1.2 & 0.4 & 0.0 & 0.0 \\
\hline 2000 & 0.9 & 0.2 & 3.3 & 0.9 & 0.1 & 0.1 & 0.2 & 0.1 & 0.0 & 0.0 & 60.0 & 2.2 & 0.3 & 0.1 & 33.9 & 2.5 & 1.2 & 0.4 & 0.0 & 0.0 \\
\hline $\begin{array}{l}\text { Net } \\
\text { change }\end{array}$ & 0.0 & 0.0 & 0.5 & 0.2 & 0.1 & 0.1 & 0.1 & 0.0 & 0.0 & 0.0 & 0.0 & 0.3 & 0.3 & 0.1 & -0.9 & 0.6 & 0.0 & 0.0 & 0.0 & 0.0 \\
\hline 1973 & 264 & 55 & 829 & 234 & 14 & 12 & 29 & 13 & 0 & 0 & 17,973 & 697 & 17 & 11 & 10,429 & 733 & 365 & 128 & 0 & 0 \\
\hline 1980 & 267 & 55 & 866 & 246 & 6 & 5 & 34 & 15 & 0 & 0 & 17,954 & 693 & 56 & 26 & 10,373 & 747 & 364 & 128 & 0 & 0 \\
\hline 1986 & 269 & 56 & 885 & 245 & 23 & 9 & 40 & 17 & 0 & 0 & 17,958 & 688 & 51 & 22 & 10,331 & 744 & 362 & 128 & 0 & 0 \\
\hline 1992 & 271 & 56 & 932 & 256 & 27 & 13 & 44 & 19 & 1 & 1 & 17,958 & 673 & 116 & 51 & 10,208 & 753 & 362 & 128 & 0 & 0 \\
\hline 2000 & 274 & 56 & 975 & 269 & 39 & 22 & 47 & 20 & 1 & 1 & 17,966 & 662 & 101 & 43 & 10,155 & 755 & 361 & 128 & 0 & 0 \\
\hline $\begin{array}{l}\text { Net } \\
\text { change }\end{array}$ & 10 & 4 & 146 & 74 & 24 & 25 & 18 & 10 & 1 & 1 & -7 & 97 & 84 & 39 & -273 & 177 & -3 & 3 & 0 & 0 \\
\hline $\begin{array}{l}\text { Gross } \\
\text { change }\end{array}$ & 12 & 5 & 146 & 74 & 112 & 30 & 21 & 10 & 1 & 1 & 392 & 90 & 219 & 93 & 466 & 151 & 4 & 3 & 0 & 0 \\
\hline
\end{tabular}


Table 4. Principal land-cover conversions in Northern Appalachian Plateau and Uplands Ecoregion, showing amount of area changed (and margin of error, calculated at 85-percent confidence level) for each conversion during each of four time periods and also during overall study period. See appendix 3 for definitions of land-cover classifications.

[Values given for "other" classes are combined totals of values for other land-cover classes not listed in that time period. Abbreviations: n/a, not applicable]

\begin{tabular}{|c|c|c|c|c|c|c|c|}
\hline Period & From class & To class & $\begin{array}{c}\begin{array}{c}\text { Area } \\
\text { changed }\end{array} \\
\left(\mathrm{km}^{2}\right)\end{array}$ & $\begin{array}{c}\text { Margin of } \\
\text { error } \\
\left(+/-\mathbf{k m}^{2}\right)\end{array}$ & $\begin{array}{c}\text { Standard } \\
\text { error } \\
\left(\mathrm{km}^{2}\right)\end{array}$ & $\begin{array}{l}\text { Percent of } \\
\text { ecoregion }\end{array}$ & $\begin{array}{c}\text { Percent of all } \\
\text { changes }\end{array}$ \\
\hline \multirow[t]{7}{*}{ 1973-1980 } & Agriculture & Forest & 59 & 48 & 32 & 0.2 & 27.4 \\
\hline & Forest & Agriculture & 49 & 39 & 26 & 0.2 & 22.9 \\
\hline & Agriculture & Grassland/Shrubland & 36 & 23 & 16 & 0.1 & 16.7 \\
\hline & Forest & Developed & 24 & 15 & 10 & 0.1 & 11.0 \\
\hline & Agriculture & Developed & 13 & 10 & 7 & 0.0 & 6.1 \\
\hline & Other & Other & 34 & $\mathrm{n} / \mathrm{a}$ & $\mathrm{n} / \mathrm{a}$ & 0.1 & 15.9 \\
\hline & & Totals & 215 & & & 0.7 & 100.0 \\
\hline \multirow[t]{7}{*}{ 1980-1986 } & Grassland/Shrubland & Forest & 41 & 24 & 16 & 0.1 & 20.7 \\
\hline & Agriculture & Grassland/Shrubland & 34 & 17 & 11 & 0.1 & 17.5 \\
\hline & Forest & Agriculture & 33 & 18 & 12 & 0.1 & 16.9 \\
\hline & Agriculture & Forest & 32 & 14 & 10 & 0.1 & 16.1 \\
\hline & Forest & Mechanically disturbed & 20 & 9 & 6 & 0.1 & 10.4 \\
\hline & Other & Other & 36 & $\mathrm{n} / \mathrm{a}$ & $\mathrm{n} / \mathrm{a}$ & 0.1 & 18.4 \\
\hline & & Totals & 196 & & & 0.7 & 100.0 \\
\hline \multirow[t]{7}{*}{ 1986-1992 } & Agriculture & Grassland/Shrubland & 67 & 42 & 29 & 0.2 & 22.8 \\
\hline & Agriculture & Forest & 52 & 24 & 16 & 0.2 & 17.8 \\
\hline & Agriculture & Developed & 29 & 23 & 15 & 0.1 & 9.9 \\
\hline & Grassland/Shrubland & Forest & 29 & 14 & 9 & 0.1 & 9.8 \\
\hline & Forest & Agriculture & 27 & 13 & 9 & 0.1 & 9.2 \\
\hline & Other & Other & 90 & $\mathrm{n} / \mathrm{a}$ & $\mathrm{n} / \mathrm{a}$ & 0.3 & 30.5 \\
\hline & & Totals & 294 & & & 1.0 & 100.0 \\
\hline \multirow[t]{7}{*}{ 1992-2000 } & Grassland/Shrubland & Forest & 62 & 39 & 27 & 0.2 & 26.2 \\
\hline & Forest & Mechanically disturbed & 34 & 19 & 13 & 0.1 & 14.3 \\
\hline & Agriculture & Grassland/Shrubland & 24 & 18 & 12 & 0.1 & 10.3 \\
\hline & Agriculture & Developed & 22 & 13 & 9 & 0.1 & 9.5 \\
\hline & Mechanically disturbed & Grassland/Shrubland & 21 & 12 & 8 & 0.1 & 8.9 \\
\hline & Other & Other & 73 & $\mathrm{n} / \mathrm{a}$ & $\mathrm{n} / \mathrm{a}$ & 0.2 & 30.9 \\
\hline & & Totals & 236 & & & 0.8 & 100.0 \\
\hline \multirow{7}{*}{$\begin{array}{c}1973-2000 \\
\text { (overall) }\end{array}$} & Agriculture & Grassland/Shrubland & 161 & 89 & 60 & 0.5 & 17.2 \\
\hline & Agriculture & Forest & 159 & 60 & 40 & 0.5 & 16.9 \\
\hline & Grassland/Shrubland & Forest & 136 & 69 & 47 & 0.5 & 14.4 \\
\hline & Forest & Agriculture & 124 & 68 & 46 & 0.4 & 13.1 \\
\hline & Forest & Mechanically disturbed & 85 & 25 & 17 & 0.3 & 9.1 \\
\hline & Other & Other & 276 & $\mathrm{n} / \mathrm{a}$ & $\mathrm{n} / \mathrm{a}$ & 0.9 & 29.4 \\
\hline & & Totals & 941 & & & 3.1 & 100.0 \\
\hline
\end{tabular}




\section{References Cited}

Fick, Gary W., and Cox, William J., 1995, The agronomy of dairy farming in New York State: Ithaca, N.Y., Cornell University, Department of Soil, Crop and Atmospheric Sciences, SCAS Teaching Series No. T95-1, 8 p.

Flinn, Kathryn M., Vellend, Mark, and Marks, P.L., 2005, Environmental causes and consequences of forest clearance and agricultural abandonment in central New York, USA: Journal of Biogeography, v. 32, p. 439-452.

National Oceanic and Atmospheric Administration, 2002, Monthly station normals of temperature, precipitation, and heating and cooling degree days, 1971-2000-New York [revised]: National Oceanic and Atmospheric Administration, National Environmental Satellite, Data, and Information Service, Climatography of the United States No. 81, 36 p., accessed November 6, 2013, at http://www. ncdc.noaa.gov/climatenormals/clim81/NYnorm.pdf.
Smallidge, Peter, 1998, New York's forests-Then and now: The New York Forest Owner, v. 36, no. 1, p. 8-9.

Vogelmann, J.E., Howard, S.M., Yang, L., Larson, C.R., Wylie, B.K., and van Driel, N., 2001, Completion of the 1990s National Land Cover Data Set for the conterminous United States from Landsat Thematic Mapper data and ancillary data sources: Photogrammetric Engineering \& Remote Sensing, v. 67, p. 650-662.

Wiken, E., Jiménez Nava, F., and Griffith, G., 2011, North American terrestrial ecoregions-Level III: Montreal, Canada, Commission for Environmental Cooperation, 149 p., accessed May 1, 2013, at http://www.cec.org/ Storage/133/15860_QA07.30-32_NP_NA_Terrestrial_ Ecoregions_Level_3_Final-2june11.pdf. 



\title{
North Central Appalachians Ecoregion
}

\author{
By Kristi L. Sayler
}

\section{Ecoregion Description}

The North Central Appalachians Ecoregion is a forested, sedimentary upland area punctuated by high hills and low mountains (Woods and others, 1996). The ecoregion, which covers about $30,522 \mathrm{~km}^{2}\left(11,784 \mathrm{mi}^{2}\right)$, consists of two parts (fig. 1). The unglaciated western part of the ecoregion is surrounded by (clockwise, from the north) the Northern Appalachian Plateau and Uplands, Ridge and Valley, Central Appalachians, Western Allegheny Plateau, and Erie Drift Plains Ecoregions. This part of the ecoregion, which lies along the headwaters of the Allegheny and Susquehanna Rivers in northern-central Pennsylvania, with a small fraction in southern New York, is at the northern fringe of the Appalachian coal belt and includes substantial parts of Pennsylvania's oil and gas production (Woods and others, 1996). This forested landscape also supports the major economic activities of forestry and recreation (figs. 2,3). The eastern part

Figure 1. Map of North Central Appalachians Ecoregion and surrounding ecoregions, showing land-use/landcover classes from 1992 National Land Cover Dataset (Vogelmann and others, 2001); note that not all land-use/landcover classes shown in explanation may be depicted on map; note also that, for this "Status and Trends of Land Change" study, transitional land-cover class was subdivided into mechanically disturbed and nonmechanically disturbed classes. Squares indicate locations of $20 \times 20 \mathrm{~km}$ sample blocks analyzed in study. Index map shows locations of geographic features mentioned in text. Abbreviations for Eastern United States ecoregions are listed in appendix 2. Also shown is part of one Midwest-South Central United States ecoregion, Erie Drift Plains. See appendix 3 for definitions of land-use/ land-cover classifications. of the ecoregion is surrounded by (clockwise, from the north) the Northeastern Highlands, Eastern Great Lakes and Hudson Lowlands, Ridge and Valley, and Northern Appalachian Plateau and Uplands Ecoregions. This part of the ecoregion includes the Pocono Mountains of Pennsylvania and parts of the Catskill Mountains of New York and New Jersey, which range from low mountains to rolling hills, as well as a dissected plateau at the east edge of the Allegheny Front (Ackroyd-Kelly, 1987). This area historically has provided an accessible, rural recreation oasis for generations of residents of nearby New York and Philadelphia. The climate of the North Central Appalachians Ecoregion is continental, with cool summers and cold winters. The average annual precipitation ranges from 825 to $1,250 \mathrm{~mm}$ ( 33 to $50 \mathrm{in}$.). 


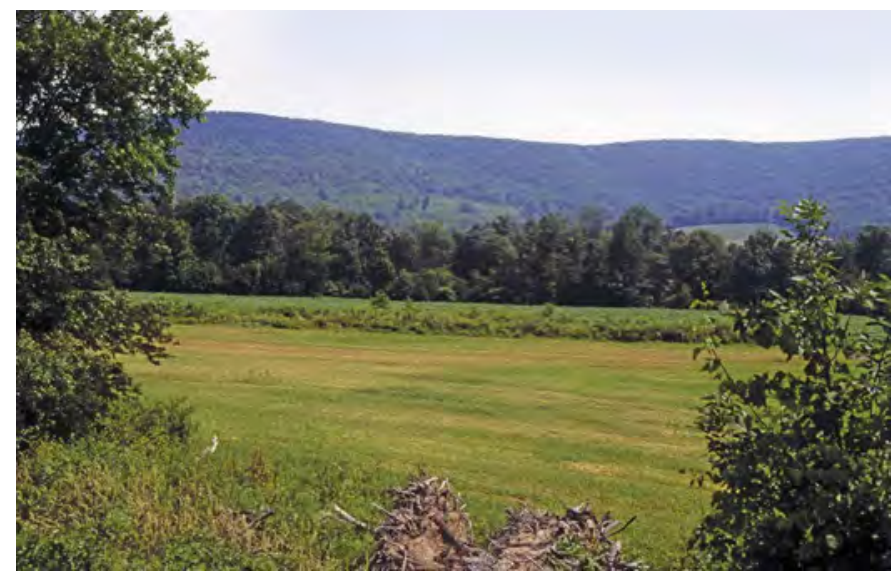

Figure 2. Area of predominately forest and scattered agriculture, in North Central Appalachians Ecoregion.

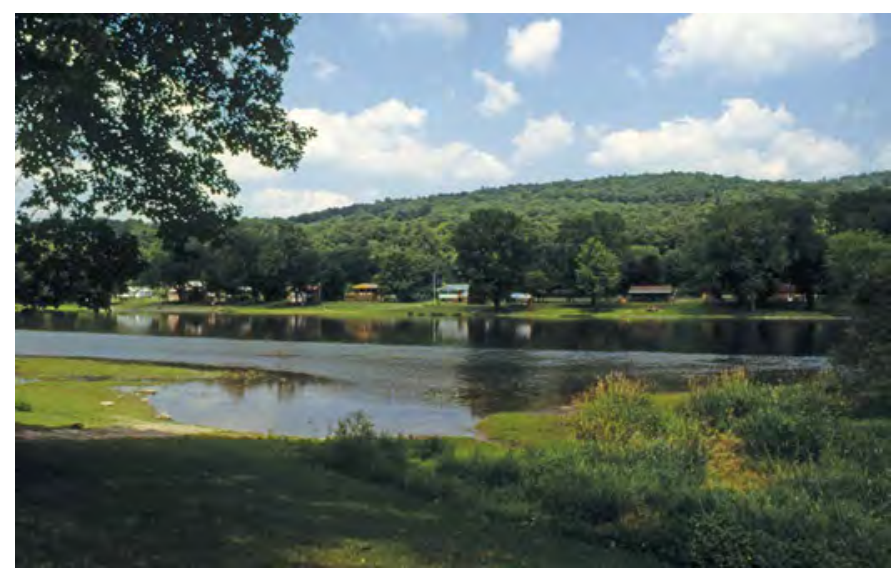

Figure 3. Recreation area along Allegheny River, near Tidioute, Pennsylvania.

\section{Contemporary Land-Cover Change (1973 to 2000)}

The overall spatial change (the percentage of land area that changed at least one time) in the North Central Appalachians Ecoregion between 1973 and 2000 is estimated at 6.2 percent (table 1). Compared to other Eastern United States ecoregions, change in the North Central Appalachians Ecoregion was fairly low (fig. 4): of the 6.2 percent that changed, nearly one-half changed multiple times. When normalized to an average annual rate to account for uneven time periods, the change per time period ranged from 1.5 to 2.9 percent, with margins of error ranging from 0.7 to 1.4 percent at the 85 -percent confidence level (table 2). The average annual rates of change were highest during the period between 1980 and 1986, with an average rate of 0.4 percent per year (fig. 5; table 2); however, this number would have been substantially lower had there not been a cluster of about 42 tornadoes on May 31, 1985 (Monfredo, 1999), which deforested a significant part of the ecoregion. The tornado damage and subsequent return of the affected land

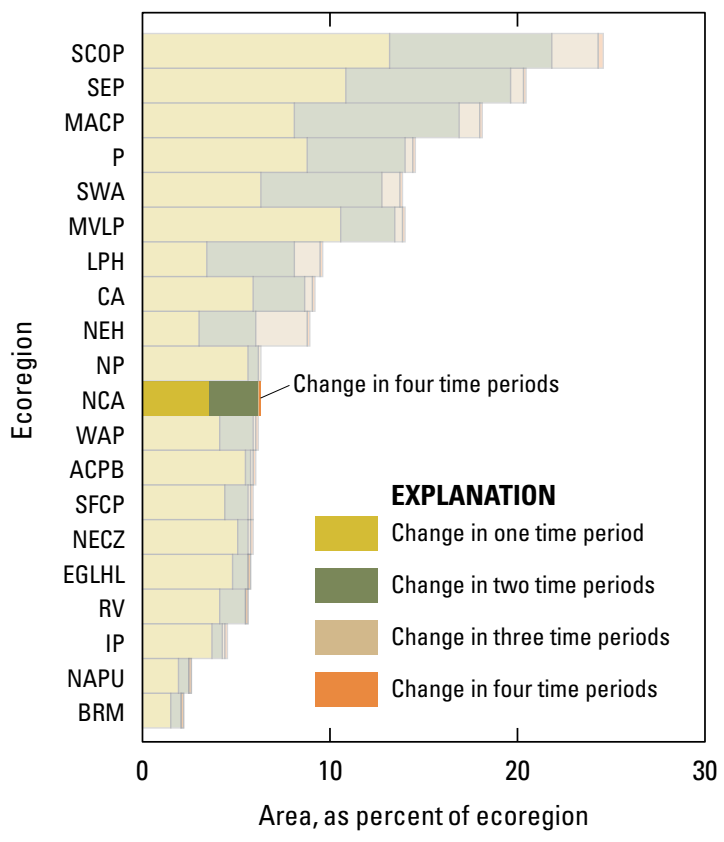

Figure 4. Overall spatial change in North Central Appalachians Ecoregion (NCA; darker bars) compared with that of all 20 Eastern United States ecoregions (lighter bars). Each horizontal set of bars shows proportions of ecoregion that changed during one, two, three, or four time periods; highest level of spatial change in North Central Appalachians Ecoregion (four time periods) labeled for clarity. See table 2 for years covered by each time period. See appendix 2 for key to ecoregion abbreviations.

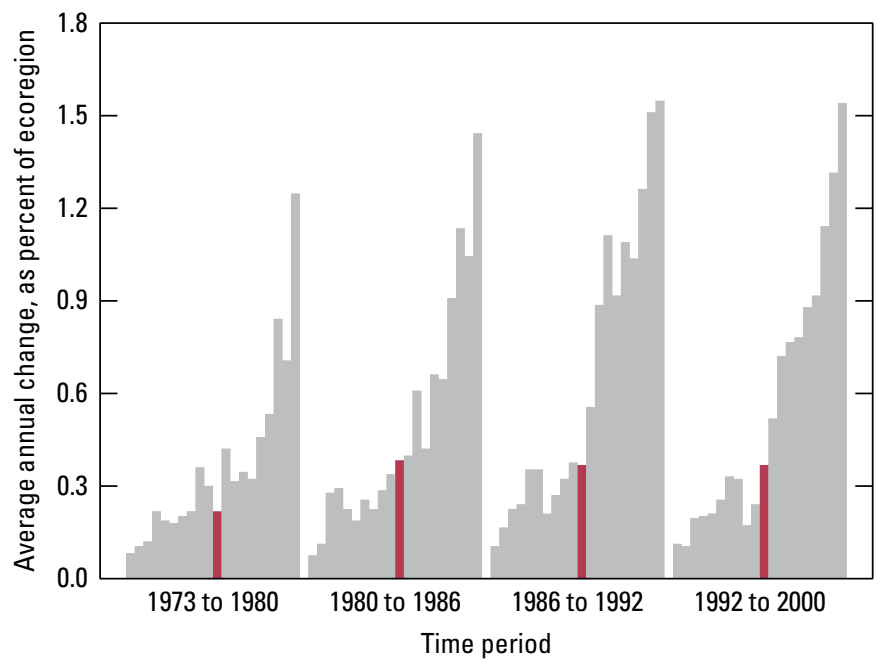

Figure 5. Estimates of land-cover change per time period, normalized to annual rates of change for all 20 Eastern United States ecoregions (gray bars). Estimates of change for North Central Appalachians Ecoregion are represented by red bars in each time period. 
cover to prestorm conditions constituted about 8.1 percent of the total change between 1980 and 2000 in the ecoregion.

Forest constituted 87.4 percent of the ecoregion land cover in 1973, and it decreased by only 0.8 percent during the study period to 86.6 percent in 2000 (table 3 ). This decrease mostly is attributed to forest clearcutting in the ecoregion and also forest loss caused by the tornado activity in 1985 (fig. 6). These clearcuts, which primarily represent the harvesting of hardwood trees for lumber and other wood products, are shown as conversions from forest to mechanically disturbed (fig. 7). The ecoregion is known for its exceptionally high quality of sweet cherry (Prunus avium); other hardwoods commonly harvested include yellow poplar (Liriodendron tulipifera), white ash (Fraxinus americana), red maple (Acer rubrum), and sugar maple (Acer saccharum) (Napton and others, 2003).

Both mining and developed had either very small or zero percent increases in all time periods. Surface coal mining, quarries, gravel pits, and natural-gas-field developments

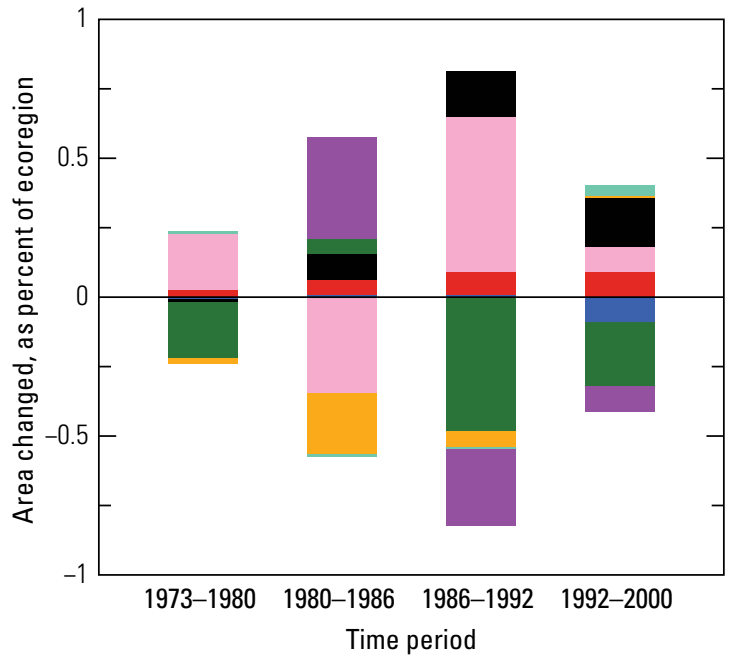

\section{EXPLANATION}

Land-use/land-cover class

$\square$ Water
$\square$ Developed
$\square$ Mechanically disturbed
Mining
$\square$ Barren

$\square$ Forest
$\square$ Grassland/Shrubland
$\square$ Agriculture
$\square$ Wetland
$\square$ Nonmechanically disturbed
$\square$ Ice/Snow

Figure 6. Normalized average net change in North Central Appalachians Ecoregion by time period for each land-cover class. Bars above zero axis represent net gain, whereas bars below zero represent net loss. Note that not all land-cover classes shown in explanation may be represented in figure. See appendix 3 for definitions of land-use and land-cover classifications.

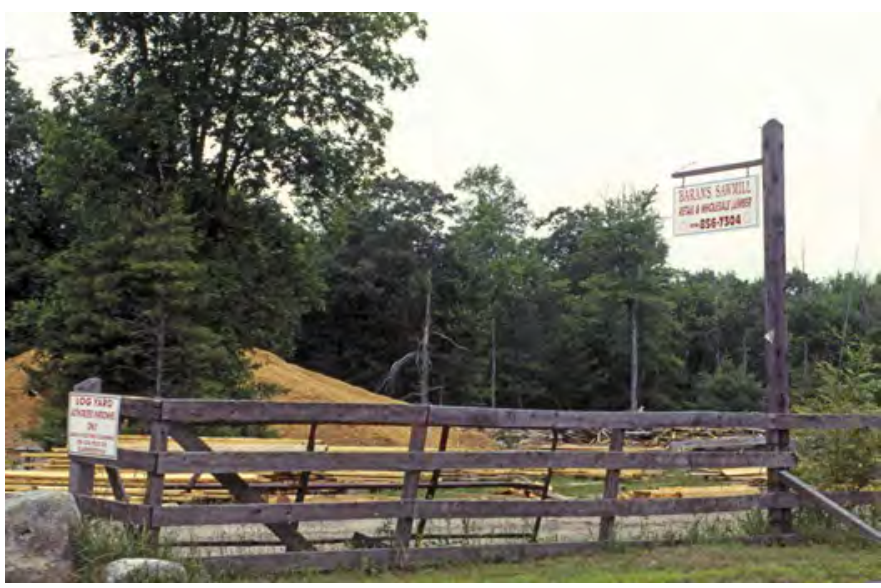

Figure 7. Small sawmill in North Central Appalachians Ecoregion, about $16 \mathrm{~km}$ northwest of Port Jervis, New York.

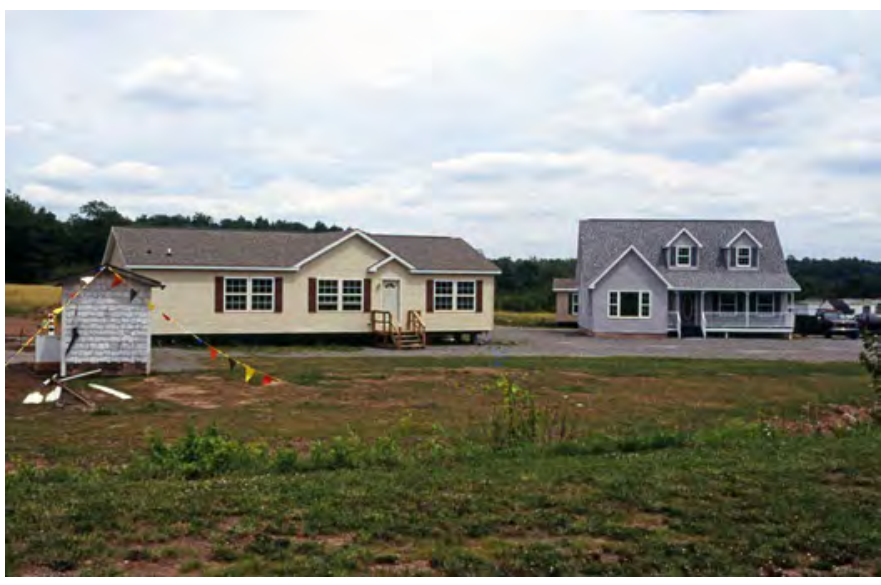

Figure 8. Modular homes waiting to be transferred to housing sites, in North Central Appalachians Ecoregion.

all contributed to the 0.3 percent increase in mining in the ecoregion. Developed increased slightly ( 0.3 percent), primarily in the eastern part of the ecoregion where nearness to the Pocono and Catskill Mountains enables individuals to have second homes and still live and work near New York City (fig. 8).

All the leading land-cover conversions were related to the vast forests of the North Central Appalachians Ecoregion. Forest to mechanically disturbed and also mechanically disturbed to forest were the top two land-cover conversions during all time periods (table 4). These two conversions were related to the forest harvest-and-regrowth cycles of the timber industry. The other main agent of land-cover change was tornado activity, shown as the conversion from forest to nonmechanically disturbed between 1980 and 1986 and then the subsequent conversion of nonmechanically disturbed to forest as the affected forest areas regenerated (table 4). Overall, these conversions accounted for 80.5 percent of the area that changed in the ecoregion during the 27-year study period. 
Table 1. Percentage of North Central Appalachians Ecoregion land cover that changed at least one time during study period (1973-2000) and associated statistical error.

\begin{tabular}{|c|c|c|c|c|c|c|}
\hline $\begin{array}{c}\text { Number } \\
\text { of } \\
\text { changes }\end{array}$ & $\begin{array}{c}\text { Percent } \\
\text { of } \\
\text { ecoregion }\end{array}$ & $\begin{array}{l}\text { Margin } \\
\text { of error } \\
(+/-\%) \\
\end{array}$ & $\begin{array}{c}\text { Lower } \\
\text { bound } \\
(\%) \\
\end{array}$ & $\begin{array}{c}\text { Upper } \\
\text { bound } \\
(\%) \\
\end{array}$ & $\begin{array}{c}\text { Standard } \\
\text { error } \\
(\%) \\
\end{array}$ & $\begin{array}{c}\begin{array}{c}\text { Relative } \\
\text { error } \\
(\%)\end{array} \\
\end{array}$ \\
\hline 1 & 3.5 & 0.9 & 2.5 & 4.4 & 0.6 & 17.2 \\
\hline 2 & 2.6 & 1.1 & 1.5 & 3.7 & 0.7 & 27.4 \\
\hline 3 & 0.1 & 0.0 & 0.0 & 0.1 & 0.0 & 31.8 \\
\hline 4 & 0.0 & 0.0 & 0.0 & 0.0 & 0.0 & 42.3 \\
\hline $\begin{array}{l}\text { Overall } \\
\text { spatial } \\
\text { change }\end{array}$ & 6.2 & 2.0 & 4.2 & 8.1 & 1.3 & 20.3 \\
\hline
\end{tabular}

Table 2. Raw estimates of change in North Central Appalachians Ecoregion land cover, computed for each of four time periods between 1973 and 2000, and associated error at 85-percent confidence level.

[Estimates of change per period normalized to annual rate of change for each period]

\begin{tabular}{cccccccc}
\hline Period & $\begin{array}{c}\text { Total change } \\
(\% \text { of ecoregion) }\end{array}$ & $\begin{array}{c}\text { Margin of } \\
\text { error } \\
(+/-\%)\end{array}$ & $\begin{array}{c}\text { Lower } \\
\text { bound } \\
(\%)\end{array}$ & $\begin{array}{c}\text { Upper bound } \\
(\%)\end{array}$ & $\begin{array}{c}\text { Standard } \\
\text { error } \\
(\%)\end{array}$ & $\begin{array}{c}\text { Relative } \\
\text { error } \\
(\%)\end{array}$ & $\begin{array}{c}\text { Average rate } \\
(\% \text { per year) }\end{array}$ \\
\hline \multicolumn{7}{c}{ Estimate of change, in percent stratum } \\
\hline $1973-1980$ & 1.5 & 0.8 & 0.8 & 2.3 & 0.5 & 31.7 & 0.2 \\
$1980-1986$ & 2.3 & 1.4 & 0.9 & 3.7 & 0.9 & 39.2 & 0.4 \\
$1986-1992$ & 2.2 & 0.7 & 1.5 & 3.0 & 0.5 & 21.2 & 0.4 \\
$1992-2000$ & 2.9 & 0.7 & 2.2 & 3.7 & 0.5 & 16.2 & 0.4 \\
\hline & & Estimate of change, in square kilometers & & \\
\hline $1973-1980$ & 463 & 231 & 232 & 693 & 147 & 31.7 & 66 \\
$1980-1986$ & 694 & 429 & 266 & 1,123 & 272 & 39.2 & 116 \\
$1986-1992$ & 676 & 225 & 451 & 901 & 143 & 21.2 & 113 \\
$1992-2000$ & 898 & 229 & 669 & 1,126 & 145 & 16.2 & 112 \\
\hline
\end{tabular}


Table 3. Estimated area (and margin of error) of each land-cover class in North Central Appalachians Ecoregion, calculated five times between 1973 and 2000. See appendix 3 for definitions of land-cover classifications.

\begin{tabular}{|c|c|c|c|c|c|c|c|c|c|c|c|c|c|c|c|c|c|c|c|c|}
\hline & \multicolumn{2}{|c|}{ Water } & \multicolumn{2}{|c|}{ Developed } & \multicolumn{2}{|c|}{$\begin{array}{c}\text { Me- } \\
\text { chanically } \\
\text { disturbed }\end{array}$} & \multicolumn{2}{|c|}{ Mining } & \multicolumn{2}{|c|}{ Barren } & \multicolumn{2}{|c|}{ Forest } & \multicolumn{2}{|c|}{$\begin{array}{l}\text { Grassland/ } \\
\text { Shrubland }\end{array}$} & \multicolumn{2}{|c|}{ Agriculture } & \multicolumn{2}{|c|}{ Wetland } & \multicolumn{2}{|c|}{$\begin{array}{c}\text { Non- } \\
\text { mechanically } \\
\text { disturbed }\end{array}$} \\
\hline & $\%$ & $+/-$ & $\%$ & $+/-$ & $\%$ & $+/-$ & $\%$ & $+/-$ & $\%$ & $+1-$ & $\%$ & $+/-$ & $\%$ & $+/-$ & $\%$ & $+1-$ & $\%$ & $+/-$ & $\%$ & $+/-$ \\
\hline \multicolumn{21}{|c|}{ Area, in percent stratum } \\
\hline 1973 & 1.5 & 0.9 & 1.3 & 0.9 & 1.0 & 0.5 & 0.4 & 0.3 & 0.0 & 0.0 & 87.4 & 3.9 & 0.0 & 0.0 & 7.4 & 3.8 & 1.0 & 0.7 & 0.0 & 0.0 \\
\hline 1980 & 1.5 & 0.9 & 1.3 & 0.9 & 1.2 & 0.6 & 0.4 & 0.3 & 0.0 & 0.0 & 87.2 & 3.9 & 0.0 & 0.0 & 7.4 & 3.8 & 1.0 & 0.7 & 0.0 & 0.0 \\
\hline 1986 & 1.5 & 0.9 & 1.4 & 1.0 & 0.8 & 0.3 & 0.5 & 0.4 & 0.0 & 0.0 & 87.3 & 3.8 & 0.0 & 0.0 & 7.2 & 3.8 & 1.0 & 0.7 & 0.4 & 0.4 \\
\hline 1992 & 1.5 & 0.9 & 1.5 & 1.1 & 1.4 & 0.5 & 0.6 & 0.6 & 0.0 & 0.0 & 86.8 & 3.8 & 0.0 & 0.0 & 7.1 & 3.8 & 1.0 & 0.7 & 0.1 & 0.1 \\
\hline 2000 & 1.4 & 0.9 & 1.6 & 1.1 & 1.5 & 0.4 & 0.8 & 0.8 & 0.0 & 0.0 & 86.6 & 3.8 & 0.0 & 0.0 & 7.1 & 3.8 & 1.1 & 0.7 & 0.0 & 0.0 \\
\hline $\begin{array}{l}\text { Net } \\
\text { change }\end{array}$ & -0.1 & 0.1 & 0.3 & 0.2 & 0.5 & 0.6 & 0.4 & 0.5 & 0.0 & 0.0 & -0.9 & 1.0 & 0.0 & 0.0 & -0.3 & 0.3 & 0.0 & 0.0 & 0.0 & 0.0 \\
\hline $\begin{array}{l}\text { Gross } \\
\text { change }\end{array}$ & 0.1 & 0.1 & 0.3 & 0.2 & 1.7 & 0.6 & 0.6 & 0.5 & 0.0 & 0.0 & 2.8 & 0.8 & 0.0 & 0.0 & 0.3 & 0.3 & 0.1 & 0.1 & 0.7 & 0.8 \\
\hline \multicolumn{21}{|c|}{ Area, in square kilometers } \\
\hline 1973 & 451 & 284 & 400 & 283 & 297 & 151 & 118 & 93 & 1 & 1 & 26,684 & 1,203 & 1 & 1 & 2,256 & 1,157 & 313 & 204 & 0 & 0 \\
\hline 1980 & 447 & 282 & 409 & 289 & 358 & 186 & 117 & 94 & 1 & 1 & 2,6621 & 1,192 & 1 & 1 & 2,252 & 1,152 & 315 & 206 & 0 & 0 \\
\hline 1986 & 451 & 284 & 426 & 299 & 251 & 102 & 143 & 110 & 1 & 1 & 26,638 & 1,156 & 1 & 1 & 2,186 & 1,149 & 312 & 203 & 112 & 117 \\
\hline 1992 & 455 & 287 & 452 & 321 & 420 & 146 & 195 & 169 & 1 & 1 & 26,490 & 1,173 & 1 & 1 & 2,171 & 1,145 & 309 & 202 & 28 & 28 \\
\hline 2000 & 428 & 261 & 481 & 333 & 448 & 137 & 247 & 233 & 1 & 1 & 26,418 & 1,160 & 1 & 1 & 2,175 & 1,147 & 321 & 208 & 2 & 3 \\
\hline $\begin{array}{l}\text { Net } \\
\text { change }\end{array}$ & -22 & 25 & 81 & 54 & 151 & 186 & 129 & 159 & 0 & 0 & -267 & 297 & 0 & 0 & -82 & 97 & 8 & 9 & 2 & 3 \\
\hline $\begin{array}{l}\text { Gross } \\
\text { change }\end{array}$ & 40 & 38 & 86 & 53 & 522 & 182 & 174 & 150 & 0 & 0 & 845 & 255 & 0 & 0 & 102 & 98 & 27 & 31 & 222 & 232 \\
\hline
\end{tabular}


Table 4. Principal land-cover conversions in North Central Appalachians Ecoregion, showing amount of area changed (and margin of error, calculated at 85-percent confidence level) for each conversion during each of four time periods and also during overall study period. See appendix 3 for definitions of land-cover classifications.

[Values given for "other" classes are combined totals of values for other land-cover classes not listed in that time period. Abbreviations: n/a, not applicable]

\begin{tabular}{|c|c|c|c|c|c|c|c|}
\hline Period & From class & To class & $\begin{array}{c}\begin{array}{c}\text { Area } \\
\text { changed }\end{array} \\
\left(\mathrm{km}^{2}\right)\end{array}$ & $\begin{array}{c}\text { Margin } \\
\text { of error } \\
\left(+/-\mathbf{k m}^{2}\right)\end{array}$ & $\begin{array}{c}\text { Standard } \\
\text { error } \\
\left(\mathrm{km}^{2}\right)\end{array}$ & $\begin{array}{l}\text { Percent of } \\
\text { ecoregion }\end{array}$ & $\begin{array}{c}\text { Percent of all } \\
\text { changes }\end{array}$ \\
\hline \multirow[t]{7}{*}{$1973-1980$} & Forest & Mechanically disturbed & 210 & 115 & 73 & 0.7 & 45.3 \\
\hline & Mechanically disturbed & Forest & 162 & 81 & 51 & 0.5 & 34.9 \\
\hline & Forest & Mining & 22 & 16 & 10 & 0.1 & 4.7 \\
\hline & Agriculture & Forest & 16 & 18 & 12 & 0.1 & 3.4 \\
\hline & Mining & Mechanically disturbed & 14 & 21 & 13 & 0.0 & 3.1 \\
\hline & Other & Other & 40 & $\mathrm{n} / \mathrm{a}$ & $\mathrm{n} / \mathrm{a}$ & 0.1 & 8.6 \\
\hline & & Totals & 463 & & & 1.5 & 100.0 \\
\hline \multirow[t]{7}{*}{ 1980-1986 } & Mechanically disturbed & Forest & 268 & 170 & 108 & 0.9 & 38.6 \\
\hline & Forest & Mechanically disturbed & 162 & 83 & 53 & 0.5 & 23.3 \\
\hline & Forest & Nonmechanically disturbed & 108 & 114 & 73 & 0.4 & 15.5 \\
\hline & Agriculture & Forest & 63 & 92 & 58 & 0.2 & 9.0 \\
\hline & Forest & Mining & 35 & 31 & 20 & 0.1 & 5.0 \\
\hline & Other & Other & 60 & $\mathrm{n} / \mathrm{a}$ & $\mathrm{n} / \mathrm{a}$ & 0.2 & 8.6 \\
\hline & & Totals & 694 & & & 2.3 & 100.0 \\
\hline \multirow[t]{7}{*}{ 1986-1992 } & Forest & Mechanically disturbed & 305 & 118 & 75 & 1.0 & 45.1 \\
\hline & Mechanically disturbed & Forest & 136 & 73 & 46 & 0.4 & 20.2 \\
\hline & Nonmechanically disturbed & Forest & 83 & 89 & 57 & 0.3 & 12.4 \\
\hline & Forest & Mining & 61 & 63 & 40 & 0.2 & 9.1 \\
\hline & Forest & Developed & 27 & 17 & 11 & 0.1 & 3.9 \\
\hline & Other & Other & 63 & $\mathrm{n} / \mathrm{a}$ & $\mathrm{n} / \mathrm{a}$ & 0.2 & 9.4 \\
\hline & & Totals & 676 & & & 2.2 & 100.0 \\
\hline \multirow[t]{7}{*}{ 1992-2000 } & Forest & Mechanically disturbed & 379 & 119 & 75 & 1.2 & 42.2 \\
\hline & Mechanically disturbed & Forest & 362 & 134 & 85 & 1.2 & 40.3 \\
\hline & Forest & Mining & 56 & 69 & 44 & 0.2 & 6.2 \\
\hline & Forest & Developed & 27 & 14 & 9 & 0.1 & 3.0 \\
\hline & Nonmechanically disturbed & Forest & 26 & 26 & 16 & 0.1 & 2.9 \\
\hline & Other & Other & 48 & $\mathrm{n} / \mathrm{a}$ & $\mathrm{n} / \mathrm{a}$ & 0.2 & 5.4 \\
\hline & & Totals & 898 & & & 2.9 & 100.0 \\
\hline \multirow{7}{*}{$\begin{array}{c}\text { 1973-2000 } \\
\text { (overall) }\end{array}$} & Forest & Mechanically disturbed & 1,055 & 348 & 221 & 3.5 & 38.6 \\
\hline & Mechanically disturbed & Forest & 928 & 390 & 248 & 3.0 & 34.0 \\
\hline & Forest & Mining & 174 & 163 & 104 & 0.6 & 6.4 \\
\hline & Nonmechanically disturbed & Forest & 110 & 114 & 72 & 0.4 & 4.0 \\
\hline & Forest & Nonmechanically disturbed & 108 & 114 & 73 & 0.4 & 3.9 \\
\hline & Other & Other & 357 & $\mathrm{n} / \mathrm{a}$ & $\mathrm{n} / \mathrm{a}$ & 1.2 & 13.1 \\
\hline & & Totals & 2,730 & & & 8.9 & 100.0 \\
\hline
\end{tabular}




\section{References Cited}

Ackroyd-Kelly, I.H., 1987, The near country-The historical geography of Pocono resorts: The Pennsylvania Geographer, v. 25 , no. 1, p. $18-23$.

Monfredo, W., 1999, Significant tornado activity in southwestern Pennsylvania: The Pennsylvania Geographer, v. 37 , no. 2 , p. $43-63$.

Napton, D., Sohl, T.L., Auch, R.F., and Loveland, T.R., 2003, Land use and land cover change in the North Central Appalachians ecoregion: The Pennsylvania Geographer, v. 41, no.2, p. 46-66.

Vogelmann, J.E., Howard, S.M., Yang, L., Larson, C.R., Wylie, B.K., and van Driel, N., 2001, Completion of the 1990s National Land Cover Data Set for the conterminous United States from Landsat Thematic Mapper data and ancillary data sources: Photogrammetric Engineering \& Remote Sensing, v. 67, p. 650-662.

Woods, A.J., Omernik, J.M., Brown, D.D., and Kiilsgaard, C.W., 1996, Level III and IV ecoregions of Pennsylvania and the Blue Ridge Mountains, the Ridge and Valley, and Central Appalachians of Virginia, West Virginia, and Maryland: U.S. Environmental Protection Agency, National Health and Environmental Effects Research Laboratory, Corvallis, Oreg., EPA/600/R-96/077, 50 p. 



\title{
Western Allegheny Plateau Ecoregion
}

\author{
By Kristi L. Sayler
}

\section{Ecoregion Description}

The Western Allegheny Plateau Ecoregion covers about $84,738 \mathrm{~km}^{2}\left(32,717 \mathrm{mi}^{2}\right)$ (fig. 1) in parts of southwestern Pennsylvania, southeastern Ohio, northwestern West Virginia, and northeastern Kentucky (Wiken and others, 2011). The ecoregion is surrounded by (clockwise, from the northernmost part) the North Central Appalachians, Central Appalachians, Southwestern Appalachians, Interior Plateau, Eastern Corn Belt Plains, and Erie Drift Plains Ecoregions.

The Western Allegheny Plateau Ecoregion's forest mostly is mixed oak (Quercus spp.), and mixed-temperate forests still exist today (2016) on most of the remaining rounded hills that have not been mined. Dairy, livestock, and general farming, as well as residential developments, are concentrated in the valleys (fig. 2). Pittsburgh, Pennsylvania, which is the largest urban area in the ecoregion, has shown some expansion despite an overall population decrease in the ecoregion. Coal mining is still active in parts of Pennsylvania, West Virginia, Kentucky, and, to a lesser extent, Ohio (figs. 3,4). The Ohio and Allegheny Rivers have been adversely affected in the ecoregion in the past by acid-mine drainage and industrial pollution, which has caused degradation of the stream habitats and loss of fish species (Cooper, 1983); however, water quality has improved somewhat, and a few species have returned to the area.

Figure 1. Map of Western Allegheny Plateau Ecoregion and surrounding ecoregions, showing land-use/land-cover classes from 1992 National Land Cover Dataset (Vogelmann and others, 2001); note that not all land-use/land-cover classes shown in explanation may be depicted on map; note also that, for this "Status and Trends of Land Change" study, transitional land-cover class was subdivided into mechanically disturbed and nonmechanically disturbed classes. Squares indicate locations of $10 \times 10 \mathrm{~km}$ sample blocks analyzed in study. Index map shows locations of geographic features mentioned in text. Abbreviations for Eastern United States ecoregions are listed in appendix 2. Also shown are parts of three Midwest-South Central United States ecoregions: Eastern Corn Belt Plains, Erie Drift Plains, and Huron/Erie Lake Plains (HELP). See appendix 3 for definitions of land-use/land-cover classifications.

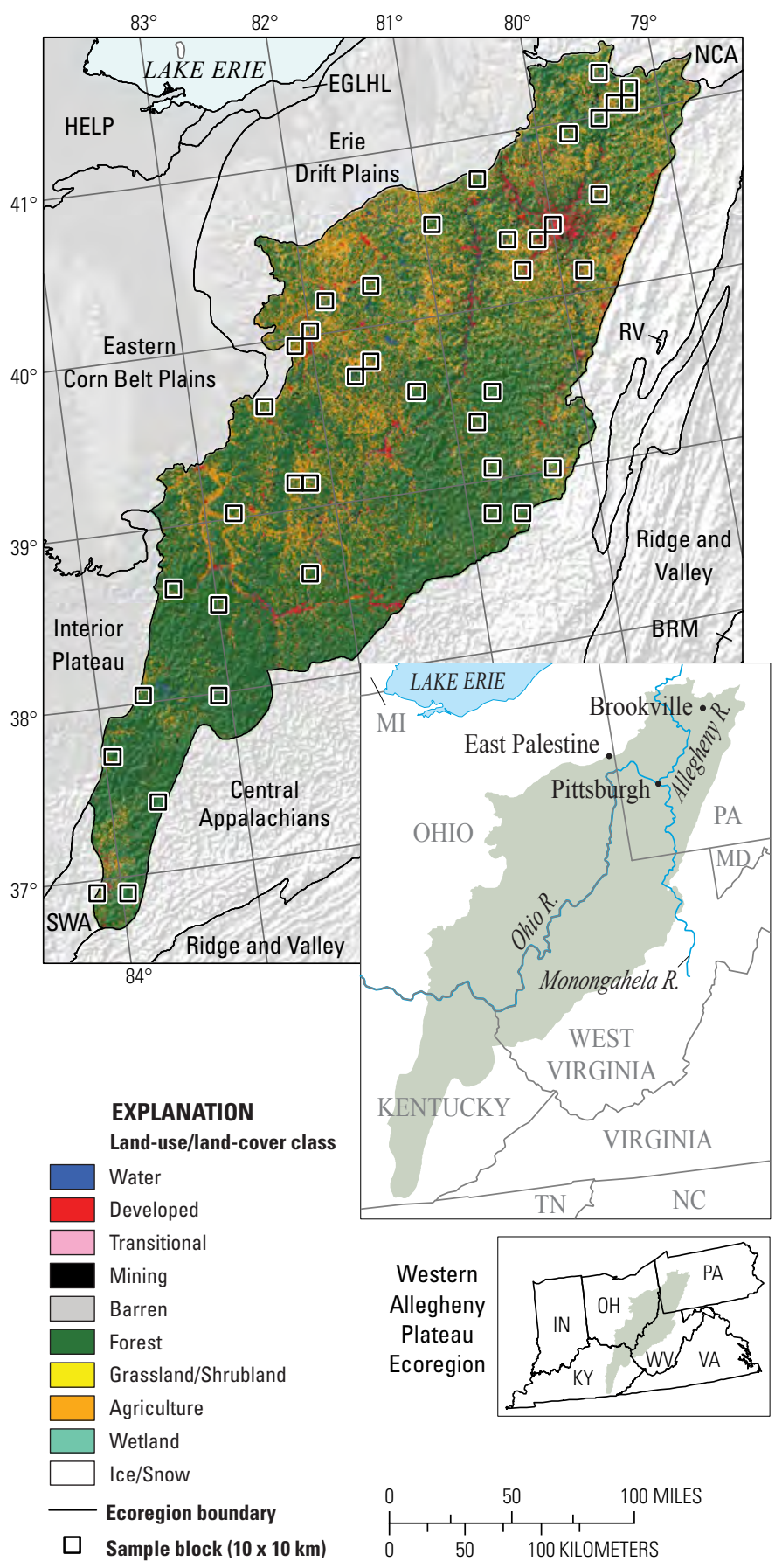




\section{Contemporary Land-Cover Change (1973 to 2000)}

The overall spatial change (the percentage of land area that changed at least one time) in the Western Allegheny Plateau Ecoregion between 1973 and 2000 is estimated at 6.1 percent (table 1). Compared to other Eastern United States ecoregions, change in the Western Allegheny Plateau Ecoregion was low (fig. 5): an estimated 4.0 percent changed only one time. The other 2.1 percent that changed multiple times (table 1) likely was the result of coal-mining and timberharvesting activities, which tend to cycle through multiple land-cover conversions. The change per time period ranged from 1.9 to 2.2 percent, with margins of error ranging from 0.5 to 0.8 percent at the 85 -percent confidence level (table 2). When normalized to an average annual rate to account for unequal time periods, the period between 1986 and 1992 had the greatest rate of change, at 0.4 percent (table 2 ; fig. 6). This was a period of change for the coal-mining regions of Ohio and West Virginia: Ohio coal production was decreasing

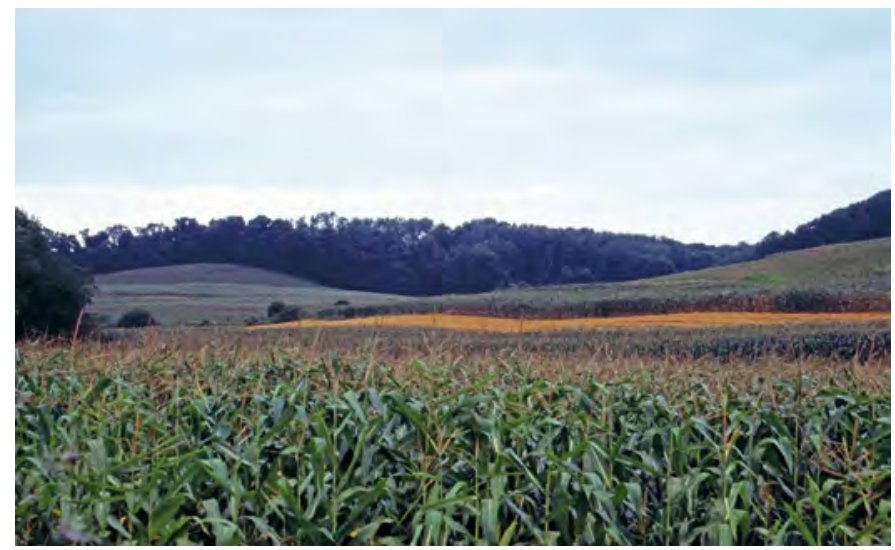

Figure 2. Fields of corn and oats in valley and forested hills in background, in Western Allegheny Plateau Ecoregion.

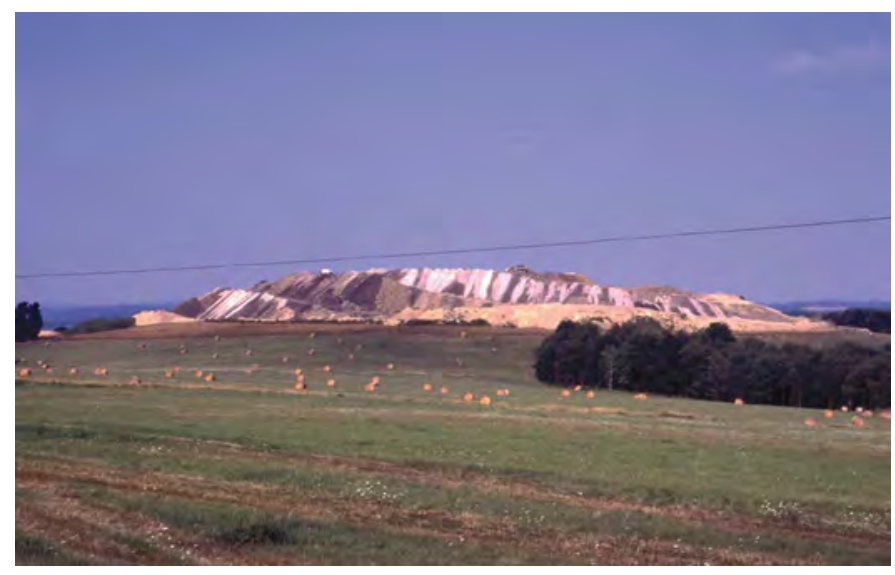

Figure 3. Hayfield in foreground and coal mine on horizon, southwest of Brookville, Pennsylvania. because of stricter regulations on surface mining and higher environmental emission standards than at previous times (Crowell, 1995), whereas West Virginia showed an increase in the extraction of low-sulfur coal (Fox, 1999) in order to meet the Federal standards of the 1990 Clean Air Act.

Most land-cover classes in the Western Allegheny Plateau Ecoregion experienced little change during the 27-year

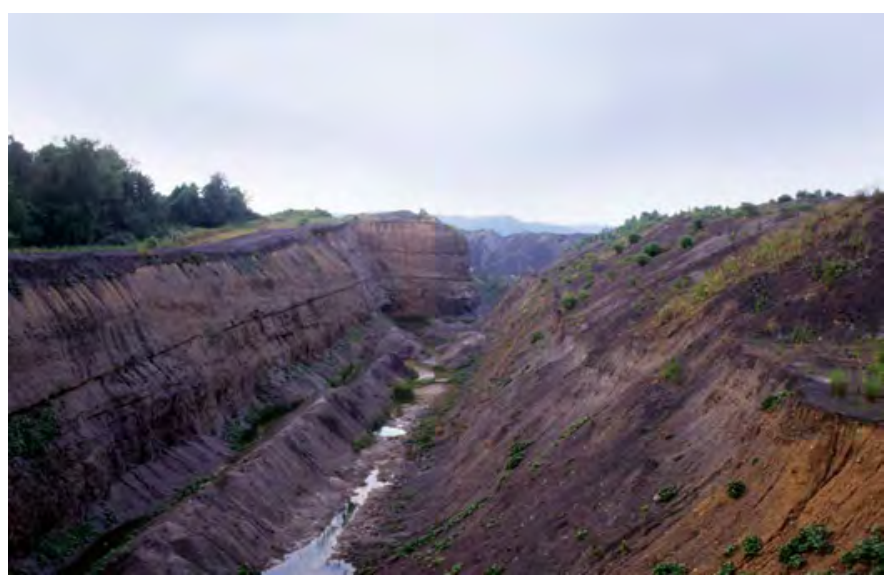

Figure 4. Coal mining south of East Palestine, Ohio.

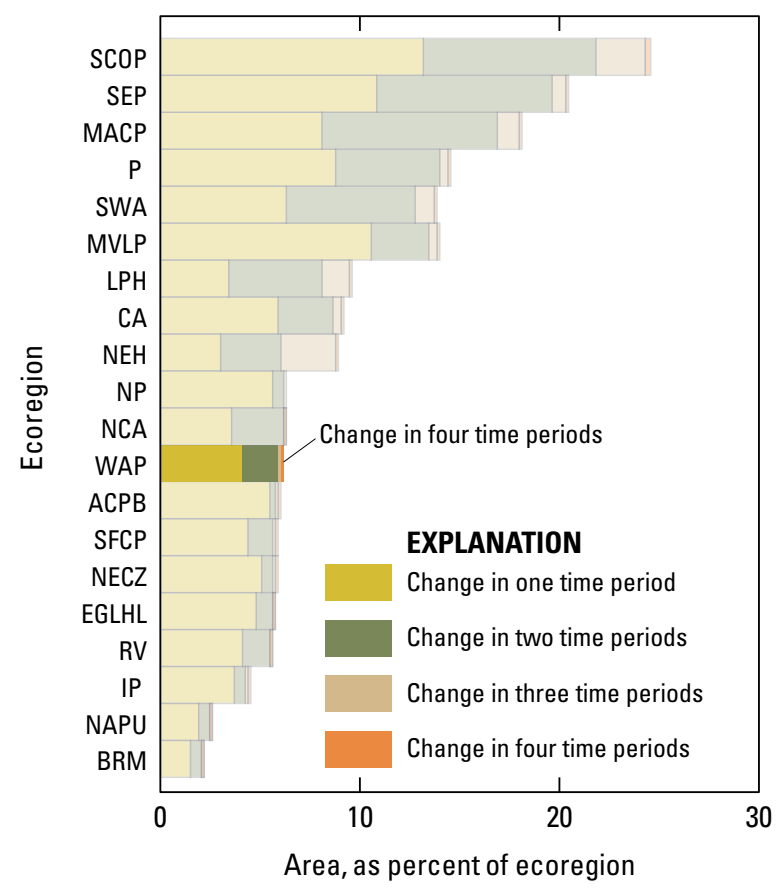

Figure 5. Overall spatial change in Western Allegheny Plateau Ecoregion (WAP; darker bars) compared with that of all 20 Eastern United States ecoregions (lighter bars). Each horizontal set of bars shows proportions of ecoregion that changed during one, two, three, or four time periods; highest level of spatial change in Western Allegheny Plateau Ecoregion (four time periods) labeled for clarity. See table 2 for years covered by each time period. See appendix 2 for key to ecoregion abbreviations. 
study period (table 3 ). Forest and agriculture showed steady decreases, whereas developed increased during each time period, resulting in an increase of $423 \mathrm{~km}^{2}$ between 1973 and 2000 (table 3; fig. 7). Grassland/shrubland increased from 1.5 percent of the ecoregion in 1973 to 2.6 percent in 2000 . Grassland/shrubland had net increases in all four time periods, whereas mining and forest showed decreases in most time periods. Net changes in other land-cover classes fluctuated throughout the study period (1973-2000) (fig. 8).

With a few exceptions for timber cutting, the top three leading land-cover conversions during each time period (that is, mining to grassland/shrubland, grassland/shrubland to forest, and forest to mining) were related to coal-mining activities in the ecoregion (table 4). Mining and forest-clearing activities caused the most common net changes in the Western Allegheny Plateau Ecoregion.

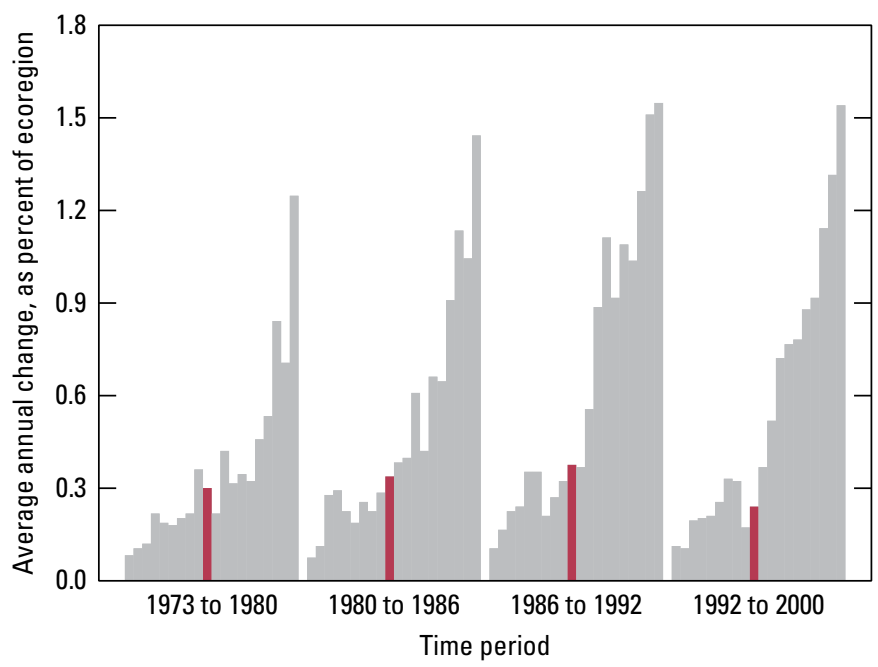

Figure 6. Estimates of land-cover change per time period, normalized to annual rates of change for all 20 Eastern United States ecoregions (gray bars). Estimates of change for Western Allegheny Plateau Ecoregion are represented by red bars in each time period.

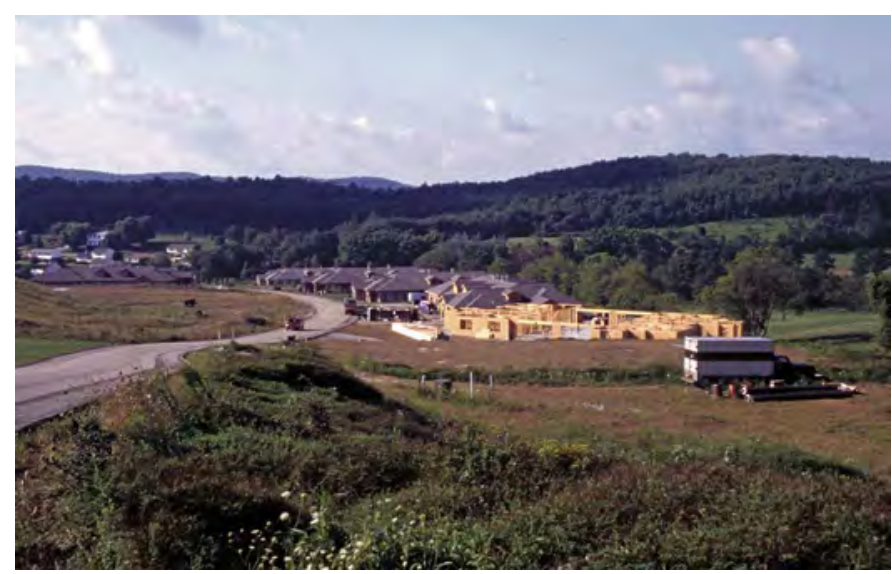

Figure 7. New housing tract in suburb southeast of Pittsburgh, Pennsylvania.

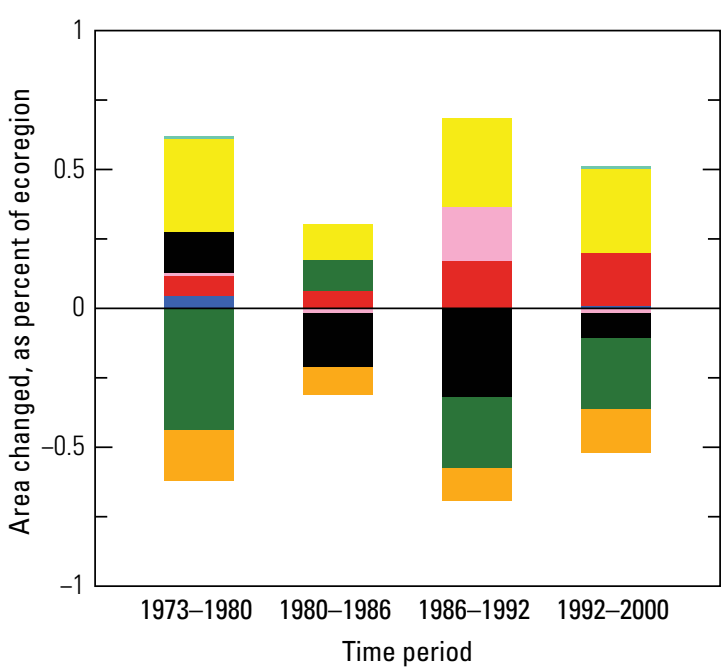

EXPLANATION

Land-use/land-cover class

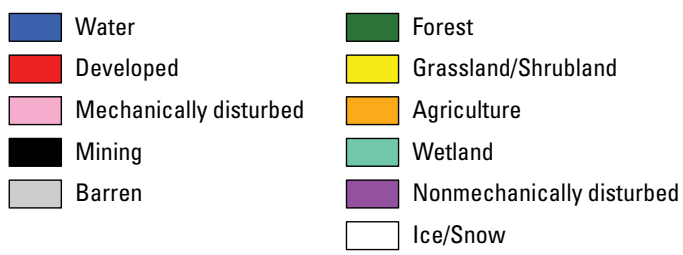

Figure 8. Normalized average net change in Western Allegheny Plateau Ecoregion by time period for each land-cover class. Bars above zero axis represent net gain, whereas bars below zero represent net loss. Note that not all land-cover classes shown in explanation may be represented in figure. See appendix 3 for definitions of land-use and land-cover classifications.

Table 1. Percentage of Western Allegheny Plateau Ecoregion land cover that changed at least one time during study period (1973-2000) and associated statistical error.

[Most sample pixels remained unchanged (93.9 percent), whereas 6.1 percent changed at least once throughout study period]

\begin{tabular}{ccccccc}
\hline $\begin{array}{c}\text { Number } \\
\text { of } \\
\text { changes }\end{array}$ & $\begin{array}{c}\text { Percent } \\
\text { of } \\
\text { ecoregion }\end{array}$ & $\begin{array}{c}\text { Margin } \\
\text { of error } \\
(+/-\%)\end{array}$ & $\begin{array}{c}\text { Lower } \\
\text { bound } \\
(\%)\end{array}$ & $\begin{array}{c}\text { Upper } \\
\text { bound } \\
(\%)\end{array}$ & $\begin{array}{c}\text { Standard } \\
\text { error } \\
(\%)\end{array}$ & $\begin{array}{c}\text { Relative } \\
\text { error } \\
(\%)\end{array}$ \\
\hline 1 & 4.0 & 0.7 & 3.3 & 4.8 & 0.5 & 12.1 \\
2 & 1.9 & 0.6 & 1.3 & 2.5 & 0.4 & 22.3 \\
3 & 0.2 & 0.1 & 0.1 & 0.2 & 0.1 & 32.6 \\
4 & 0.0 & 0.0 & 0.0 & 0.0 & 0.0 & 48.6 \\
\hline $\begin{array}{c}\text { Overall } \\
\text { spatial }\end{array}$ & 6.1 & 1.3 & 4.8 & 7.4 & 0.9 & 14.7 \\
change & & & & & & \\
\hline
\end{tabular}


Table 2. Raw estimates of change in Western Allegheny Plateau Ecoregion land cover, computed for each of four time periods between 1973 and 2000, and associated error at 85-percent confidence level.

[Estimates of change per period normalized to annual rate of change for each period]

\begin{tabular}{cccccccc}
\hline Period & $\begin{array}{c}\text { Total change } \\
(\% \text { of ecoregion) }\end{array}$ & $\begin{array}{c}\text { Margin of } \\
\text { error } \\
(+/-\%)\end{array}$ & $\begin{array}{c}\text { Lower } \\
\text { bound } \\
(\%)\end{array}$ & $\begin{array}{c}\text { Upper bound } \\
(\%)\end{array}$ & $\begin{array}{c}\text { Standard } \\
\text { error } \\
(\%)\end{array}$ & $\begin{array}{c}\text { Relative } \\
\text { error } \\
(\%)\end{array}$ & $\begin{array}{c}\text { Average rate } \\
(\% \text { per year) }\end{array}$ \\
\hline \multicolumn{7}{c}{ Estimate of change, in percent stratum } \\
\hline $1973-1980$ & 2.1 & 0.6 & 1.5 & 2.6 & 0.4 & 18.4 & 0.3 \\
$1980-1986$ & 2.0 & 0.8 & 1.2 & 2.8 & 0.5 & 26.4 & 0.3 \\
$1986-1992$ & 2.2 & 0.6 & 1.7 & 2.8 & 0.4 & 17.9 & 0.4 \\
$1992-2000$ & 1.9 & 0.5 & 1.5 & 2.4 & 0.3 & 16.8 & 0.2 \\
\hline & 1,755 & 474 & 1,281 & 2,230 & 323 & 18.4 & 251 \\
\hline $1973-1980$ & 1,721 & 666 & 1,055 & 2,387 & 454 & 26.4 & 287 \\
$1980-1986$ & 1,898 & 500 & 1,398 & 2,398 & 341 & 17.9 & 316 \\
$1992-2000$ & 1,635 & 403 & 1,233 & 2,038 & 274 & 16.8 & 204 \\
\hline
\end{tabular}

Table 3. Estimated area (and margin of error) of each land-cover class in Western Allegheny Plateau Ecoregion, calculated five times between 1973 and 2000. See appendix 3 for definitions of land-cover classifications.

\begin{tabular}{|c|c|c|c|c|c|c|c|c|c|c|c|c|c|c|c|c|c|c|c|c|}
\hline & \multicolumn{2}{|c|}{ Water } & \multicolumn{2}{|c|}{ Developed } & \multicolumn{2}{|c|}{$\begin{array}{l}\text { Mechanical- } \\
\text { ly disturbed }\end{array}$} & \multicolumn{2}{|c|}{ Mining } & \multicolumn{2}{|c|}{ Barren } & \multicolumn{2}{|c|}{ Forest } & \multicolumn{2}{|c|}{$\begin{array}{l}\text { Grassland/ } \\
\text { Shrubland }\end{array}$} & \multicolumn{2}{|c|}{ Agriculture } & \multicolumn{2}{|c|}{ Wetland } & \multicolumn{2}{|c|}{$\begin{array}{c}\text { Non- } \\
\text { mechanically } \\
\text { disturbed }\end{array}$} \\
\hline & $\%$ & $+/-$ & $\%$ & $+/-$ & $\%$ & $+/-$ & $\%$ & $+/-$ & $\%$ & $+/-$ & $\%$ & $+1-$ & $\%$ & $+/-$ & $\%$ & $+/-$ & $\%$ & $+/-$ & $\%$ & $+/-$ \\
\hline 1973 & 1.3 & 0.4 & 6.9 & 3.1 & 0.1 & 0.0 & 1.1 & 0.4 & 0.0 & 0.0 & 64.6 & 3.7 & 1.5 & 0.8 & 24.4 & 2.7 & 0.1 & 0.1 & 0.0 & 0.0 \\
\hline 1980 & 1.3 & 0.4 & 7.0 & 3.1 & 0.1 & 0.1 & 1.2 & 0.5 & 0.0 & 0.0 & 64.1 & 3.6 & 1.9 & 0.7 & 24.2 & 2.7 & 0.2 & 0.1 & 0.0 & 0.0 \\
\hline 1992 & 1.3 & 0.4 & 7.2 & 3.2 & 0.3 & 0.1 & 0.7 & 0.2 & 0.0 & 0.0 & 64.0 & 3.7 & 2.3 & 0.9 & 24.0 & 2.7 & 0.2 & 0.1 & 0.0 & 0.0 \\
\hline 2000 & 1.3 & 0.4 & 7.4 & 3.2 & 0.3 & 0.1 & 0.6 & 0.2 & 0.0 & 0.0 & 63.7 & 3.7 & 2.6 & 1.0 & 23.9 & 2.7 & 0.2 & 0.1 & 0.0 & 0.0 \\
\hline $\begin{array}{l}\text { Net } \\
\text { change }\end{array}$ & 0.1 & 0.1 & 0.5 & 0.2 & 0.2 & 0.1 & -0.5 & 0.3 & 0.0 & 0.0 & -0.8 & 0.7 & 1.1 & 0.8 & -0.5 & 0.3 & 0.0 & 0.0 & 0.0 & 0.0 \\
\hline $\begin{array}{l}\text { Gross } \\
\text { change }\end{array}$ & 0.1 & 0.1 & 0.5 & 0.2 & 0.8 & 0.2 & 1.6 & 0.6 & 0.0 & 0.0 & 2.7 & 0.6 & 2.2 & 0.8 & 1.3 & 0.3 & 0.0 & 0.0 & 0.0 & 0.0 \\
\hline 1980 & 1,118 & 374 & 5,940 & 2,624 & 84 & 47 & 1,033 & 416 & 0 & 0 & 54,331 & 3,085 & 1,576 & 617 & 20,524 & 2,257 & 130 & 55 & 0 & 0 \\
\hline 1986 & 1,120 & 374 & 5,993 & 2,625 & 74 & 31 & 863 & 332 & 0 & 0 & 54,429 & 3,087 & 1,683 & 621 & 20,445 & 2,256 & 130 & 55 & 0 & 0 \\
\hline 1992 & 1,122 & 372 & 6,136 & 2,670 & 244 & 104 & 593 & 202 & 0 & 0 & 54,214 & 3,153 & 1,954 & 763 & 20,345 & 2,272 & 130 & 55 & 0 & 0 \\
\hline 2000 & 1,128 & 373 & 6,301 & 2,694 & 231 & 67 & 512 & 189 & 0 & 0 & 53,998 & 3,132 & 2,209 & 851 & 20,217 & 2,300 & 141 & 60 & 0 & 0 \\
\hline $\begin{array}{l}\text { Net } \\
\text { change }\end{array}$ & 47 & 49 & 423 & 143 & 156 & 71 & -393 & 271 & 0 & 0 & -705 & 573 & 920 & 706 & -465 & 227 & 17 & 17 & 0 & 0 \\
\hline $\begin{array}{l}\text { Gross } \\
\text { change }\end{array}$ & 57 & 49 & 424 & 143 & 693 & 210 & 1,370 & 502 & 0 & 0 & 2,327 & 484 & 1,829 & 664 & 1,110 & 213 & 17 & 17 & 0 & 0 \\
\hline
\end{tabular}


Table 4. Principal land-cover conversions in Western Allegheny Plateau Ecoregion, showing amount of area changed (and margin of error, calculated at 85-percent confidence level) for each conversion during each of four time periods and also during overall study period. See appendix 3 for definitions of land-cover classifications.

[Values given for "other" classes are combined totals of values for other land-cover classes not listed in that time period. Abbreviations: n/a, not applicable]

\begin{tabular}{|c|c|c|c|c|c|c|c|}
\hline Period & From class & To class & $\begin{array}{c}\begin{array}{c}\text { Area } \\
\text { changed }\end{array} \\
\left(\mathbf{k m}^{2}\right)\end{array}$ & $\begin{array}{c}\text { Margin of } \\
\text { error } \\
\left(+/-\mathbf{k m}^{2}\right)\end{array}$ & $\begin{array}{c}\text { Standard } \\
\text { error } \\
\left(\mathbf{k m}^{2}\right)\end{array}$ & $\begin{array}{l}\text { Percent of } \\
\text { ecoregion }\end{array}$ & $\begin{array}{l}\text { Percent of all } \\
\text { changes }\end{array}$ \\
\hline \multirow[t]{7}{*}{$1973-1980$} & Forest & Mining & 333 & 165 & 112 & 0.4 & 19.0 \\
\hline & Mining & Grassland/Shrubland & 259 & 126 & 86 & 0.3 & 14.7 \\
\hline & Grassland/Shrubland & Forest & 194 & 107 & 73 & 0.2 & 11.1 \\
\hline & Forest & Grassland/Shrubland & 173 & 111 & 76 & 0.2 & 9.8 \\
\hline & Forest & Agriculture & 119 & 52 & 36 & 0.1 & 6.8 \\
\hline & Other & Other & 677 & $\mathrm{n} / \mathrm{a}$ & $\mathrm{n} / \mathrm{a}$ & 0.8 & 38.6 \\
\hline & & Totals & 1,755 & & & 2.1 & 100.0 \\
\hline \multirow[t]{7}{*}{$1980-1986$} & Grassland/Shrubland & Forest & 414 & 249 & 169 & 0.5 & 24.0 \\
\hline & Mining & Grassland/Shrubland & 407 & 271 & 185 & 0.5 & 23.6 \\
\hline & Forest & Mining & 202 & 105 & 71 & 0.2 & 11.7 \\
\hline & Forest & Agriculture & 113 & 53 & 36 & 0.1 & 6.5 \\
\hline & Agriculture & Mining & 82 & 78 & 53 & 0.1 & 4.8 \\
\hline & Other & Other & 504 & $\mathrm{n} / \mathrm{a}$ & $\mathrm{n} / \mathrm{a}$ & 0.6 & 29.3 \\
\hline & & Totals & 1,721 & & & 2.0 & 100.0 \\
\hline \multirow[t]{7}{*}{$1986-1992$} & Mining & Grassland/Shrubland & 372 & 221 & 151 & 0.4 & 19.6 \\
\hline & Grassland/Shrubland & Forest & 238 & 72 & 49 & 0.3 & 12.5 \\
\hline & Forest & Mechanically disturbed & 223 & 102 & 70 & 0.3 & 11.7 \\
\hline & Forest & Mining & 186 & 88 & 60 & 0.2 & 9.8 \\
\hline & Forest & Grassland/Shrubland & 149 & 88 & 60 & 0.2 & 7.8 \\
\hline & Other & Other & 730 & $\mathrm{n} / \mathrm{a}$ & $\mathrm{n} / \mathrm{a}$ & 0.9 & 38.5 \\
\hline & & Totals & 1,898 & & & 2.2 & 100.0 \\
\hline \multirow[t]{7}{*}{$1992-2000$} & Forest & Mechanically disturbed & 215 & 117 & 80 & 0.3 & 13.1 \\
\hline & Mining & Grassland/Shrubland & 214 & 67 & 45 & 0.3 & 13.1 \\
\hline & Grassland/Shrubland & Forest & 142 & 42 & 29 & 0.2 & 8.7 \\
\hline & Forest & Grassland/Shrubland & 138 & 99 & 68 & 0.2 & 8.4 \\
\hline & Mechanically disturbed & Forest & 135 & 72 & 49 & 0.2 & 8.2 \\
\hline & Other & Other & 792 & $\mathrm{n} / \mathrm{a}$ & $\mathrm{n} / \mathrm{a}$ & 0.9 & 48.4 \\
\hline & & Totals & 1,635 & & & 1.9 & 100.0 \\
\hline \multirow{7}{*}{$\begin{array}{l}1973-2000 \\
\text { (overall) }\end{array}$} & Mining & Grassland/Shrubland & 1,253 & 666 & 453 & 1.5 & 17.9 \\
\hline & Grassland/Shrubland & Forest & 987 & 379 & 258 & 1.2 & 14.1 \\
\hline & Forest & Mining & 849 & 333 & 227 & 1.0 & 12.1 \\
\hline & Forest & Mechanically disturbed & 580 & 151 & 103 & 0.7 & 8.3 \\
\hline & Forest & Grassland/Shrubland & 528 & 257 & 175 & 0.6 & 7.5 \\
\hline & Other & Other & 2,813 & $\mathrm{n} / \mathrm{a}$ & $\mathrm{n} / \mathrm{a}$ & 3.3 & 40.1 \\
\hline & & Totals & 7,010 & & & 8.3 & 100.0 \\
\hline
\end{tabular}




\section{References Cited}

Cooper, E.L., 1983, Fishes of Pennsylvania and the northeastern United States: University Park, Pennsylvania State University Press, 183 p.

Crowell, D.L., 1995, History of the coal-mining industry in Ohio: Ohio Division of Geological Survey Bulletin 72, 204 p.

Fox, J., 1999, Mountaintop removal in West Virginia-An environmental sacrifice zone: Organization and Environment, v. 12 , no. 2 , p. 163-183.

Vogelmann, J.E., Howard, S.M., Yang, L., Larson, C.R., Wylie, B.K., and van Driel, N., 2001, Completion of the 1990s National Land Cover Data Set for the conterminous United States from Landsat Thematic Mapper data and ancillary data sources: Photogrammetric Engineering \& Remote Sensing, v. 67, p. 650-662.

Wiken, E., Jiménez Nava, F., and Griffith, G., 2011, North American terrestrial ecoregions-Level III: Montreal, Canada, Commission for Environmental Cooperation, 149 p., accessed May 1, 2013, at http://www.cec.org/ Storage/133/15860_QA07.30-32_NP_NA_Terrestrial_ Ecoregions_Level_3_Final-2june11.pdf. 


\title{
Chapter 10
}

\section{Central Appalachians Ecoregion}

\author{
By Kristi L. Sayler
}

\section{Ecoregion Description}

The Central Appalachians Ecoregion, which covers about $59,738 \mathrm{~km}^{2}\left(23,065 \mathrm{mi}^{2}\right)$ (fig. 1), stretches from central Pennsylvania through Maryland, West Virginia, Virginia, and Kentucky, into northern Tennessee (Wiken and others, 2011). The ecoregion is surrounded by (clockwise, from the northernmost part) the North Central Appalachians, Ridge and Valley, Southwestern Appalachians, and Western Allegheny Plateau Ecoregions.

The Central Appalachians Ecoregion primarily is a dissected and rugged high plateau underlain by sandstone, shale, conglomerate, and coal. Local relief varies from less than 15 to more than $594 \mathrm{~m}$, and the highest mountain elevations range from about 366 to $1,402 \mathrm{~m}$ (Woods and others, 1996). The climate is variable because of topographic influences in the ecoregion. Precipitation is distributed uniformly throughout the year, but the late summer and early fall seasons tend to be drier, with an average annual precipitation of about $1,125 \mathrm{~mm}(45$ in.) (Raitz and Ulack, 1984). The rugged terrain, cool climate, and infertile soils limit agriculture, and the resulting land cover is mostly forest. A mixed mesophytic forest consisting of areas of oak (Quercus spp.) and northern hardwood trees covers the high hills and low mountains (fig. 2). Coal mining is common in the ecoregion and is one of the major drivers of land-cover change (fig. 3). Agricultural land is in the valleys, where the annual growing season can be as long as 165 days (Woods and others, 1996) (fig. 4). The main agricultural activities include livestock and dairy farming, as well as the growing of Christmas trees on plantations.

Figure 1. Map of Central Appalachians Ecoregion and surrounding ecoregions, showing land-use/land-cover classes from 1992 National Land Cover Dataset (Vogelmann and others, 2001); note that not all land-use/land-cover classes shown in explanation may be depicted on map; note also that, for this "Status and Trends of Land Change" study, transitional land-cover class was subdivided into mechanically disturbed and nonmechanically disturbed classes. Squares indicate locations of $10 \times 10 \mathrm{~km}$ sample blocks analyzed in study. Index map shows locations of geographic features mentioned in text. Abbreviations for Eastern United States ecoregions are listed in appendix 2. Also shown are parts of three Midwest-South Central United States ecoregions: Eastern Corn Belt Plains, Erie Drift Plains (EDP), and Huron/Erie Lake Plains (HELP). See appendix 3 for definitions of land-use/land-cover classifications.

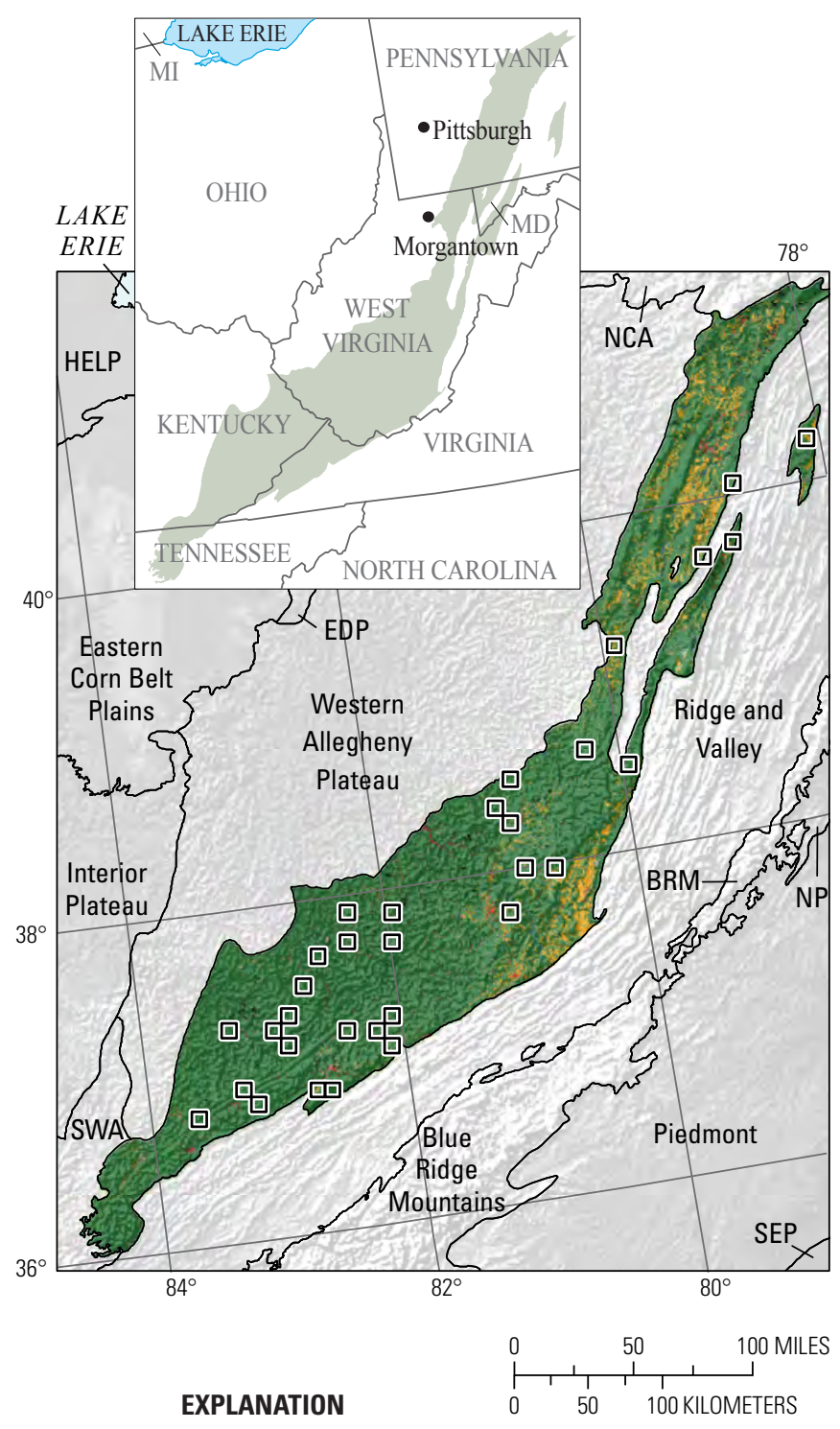

Land-use/land-cover class
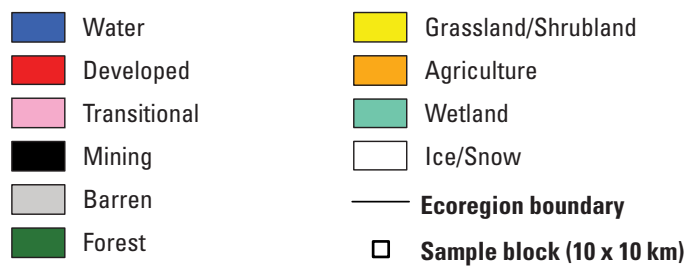


\section{Contemporary Land-Cover Change (1973 to 2000)}

The overall spatial change (the percentage of land area that changed at least one time) in the Central Appalachians Ecoregion between 1973 and 2000 is estimated at 9.1 percent (fig. 5). Compared to other Eastern United States ecoregions, change in the Central Appalachians Ecoregion was moderate (fig. 5). An estimated 5.9 percent of the ecoregion changed only one time, and an estimated 3.2 percent changed multiple times (table 1). Most of the change in the ecoregion was tied closely to coal mining, and the highest amounts of change were concentrated in coal mining areas. Most of the multiplechange areas represent, first, the conversion of forest to mechanically disturbed, mining, and grassland/shrubland, as coal mines become established and expand in forested areas, and, second, the subsequest conversion of mining to grassland/ shrubland and forest, as mines eventually close down and are abandoned or reclaimed. The total change per time period ranged from 2.4 to 4.1 percent (table 2 ). When normalized to an average annual rate to account for unequal time periods, the

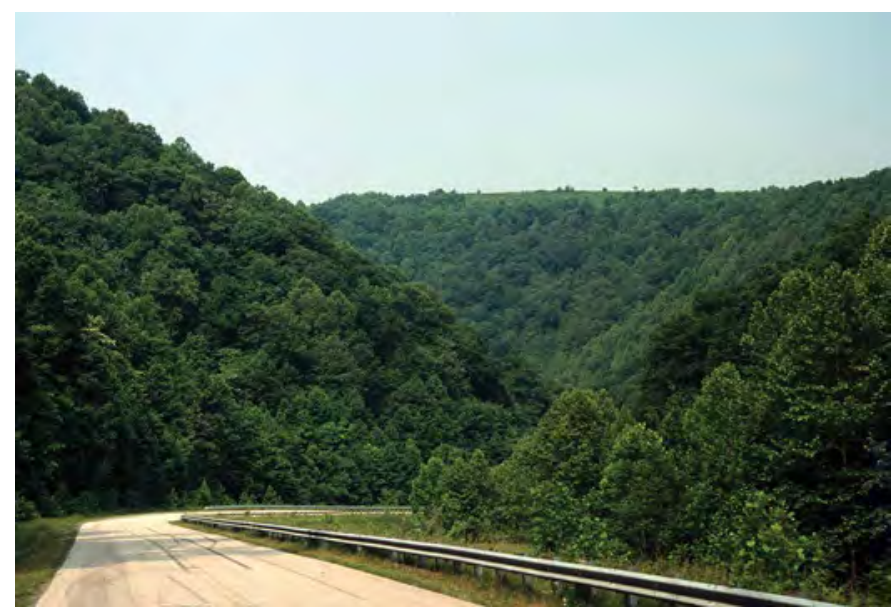

Figure 2. Road through forested hills, in Central Appalachians Ecoregion.

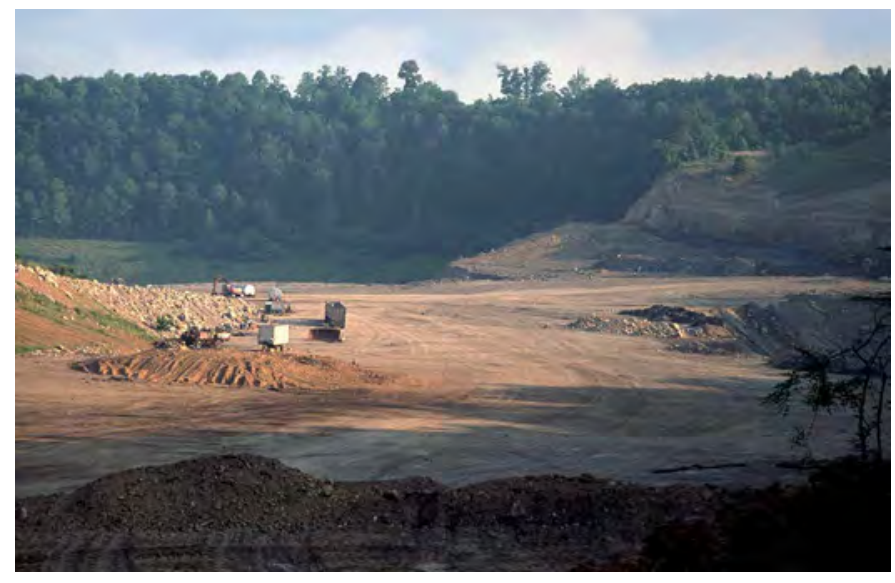

Figure 3. Coal mine in southern West Virginia. period between 1986 and 1992 had the highest rate of change, at 0.6 percent (table 2; fig. 6), likely because of a resurgence of coal mining in West Virginia in the 1990s (Fox, 1999).

The mining, grassland/shrubland, and forest land-cover classes experienced the most change during the 27-year study period (table 3 ). Mining nearly doubled, from 1.7 percent of the ecoregion in 1973 to 3.2 percent in 2000. Conversely,

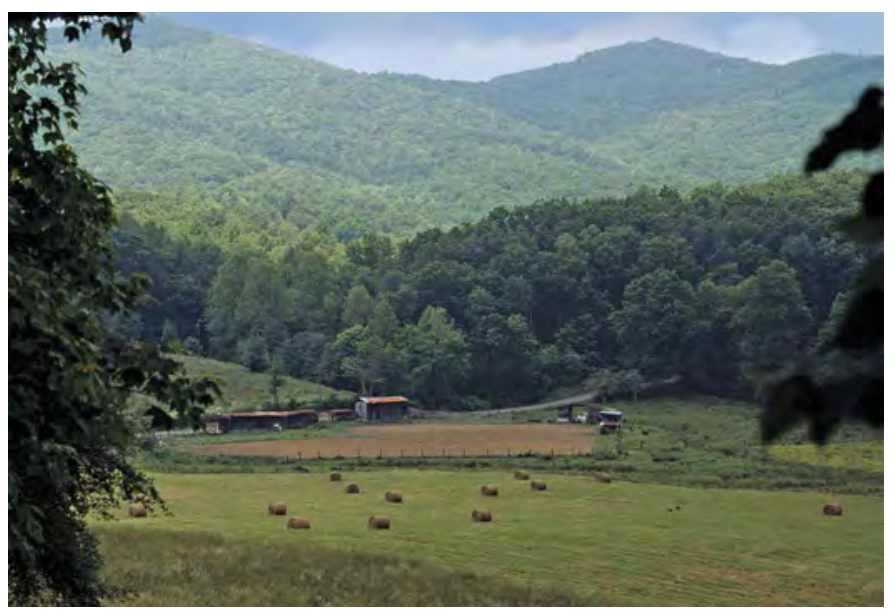

Figure 4. Forested hills and agriculture in valley in Central Appalachians Ecoregion.

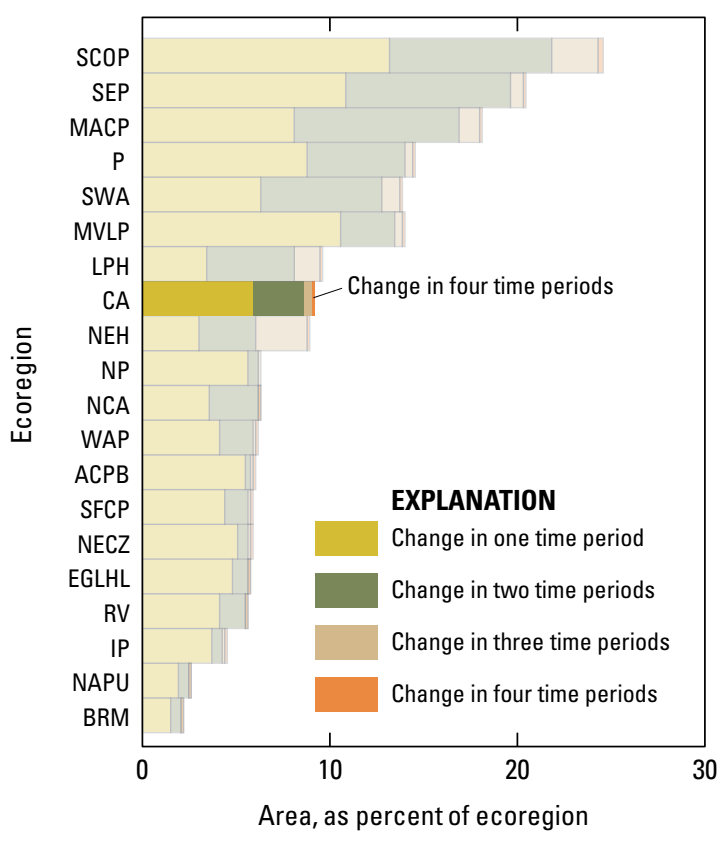

Figure 5. Overall spatial change in Central Appalachians Ecoregion (CA; darker bars) compared with that of all 20 Eastern United States ecoregions (lighter bars). Each horizontal set of bars shows proportions of ecoregion that changed during one, two, three, or four time periods; highest level of spatial change in Central Appalachians Ecoregion (four time periods) labeled for clarity. See table 2 for years covered by each time period. See appendix 2 for key to ecoregion abbreviations. 
forest decreased, from 86.6 percent in 1973 to 83.2 percent in 2000 (fig. 7). Grassland/shrubland increased throughout the study period as old mining areas reverted to forest. Agriculture decreased slightly because of abandonment and subsequent reversion to forest. Developed increased slightly during the four time periods, in contrast to the population of the ecoregion, which has steadily decreased since the 1980s (fig. 8). The net changes in land-cover classes in the ecoregion during the study period are shown in figure 9 . The changes were relatively minor until the period between 1992 and 2000, when a resurgence in forest clearing for mining activities occurred.

The leading land-cover conversions also were all related to coal mining in the ecoregion. Forest to mining was the most common conversion during all time periods, ranging from 458 to $1,099 \mathrm{~km}^{2}$ per time period (table 4). During every time period, at least 65 percent of all changes were connected to mining activities in the ecoregion.

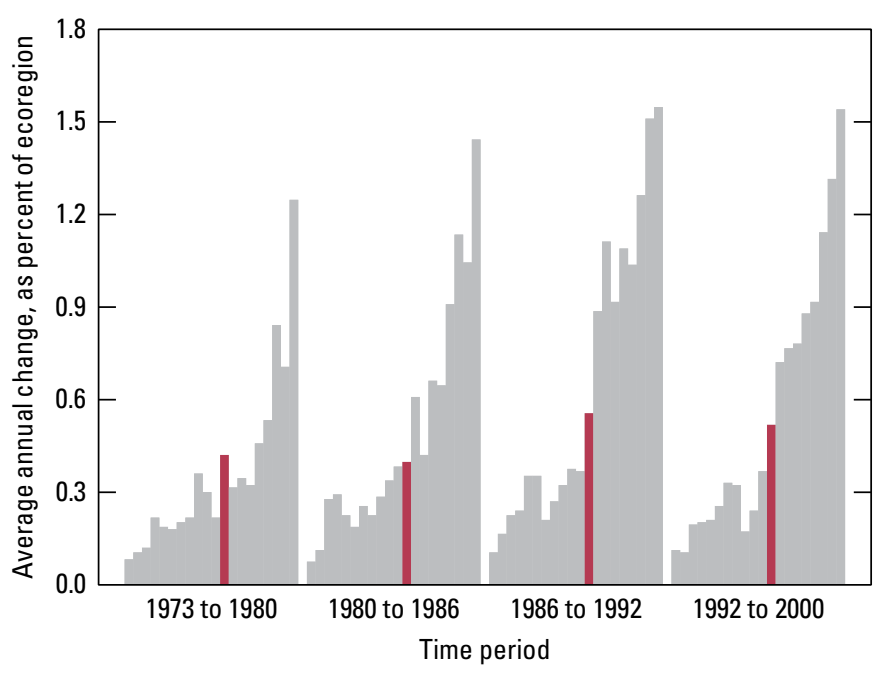

Figure 6. Estimates of land-cover change per time period, normalized to annual rates of change for all 20 Eastern United States ecoregions (gray bars). Estimates of change for Central Appalachians Ecoregion are represented by red bars in each time period.

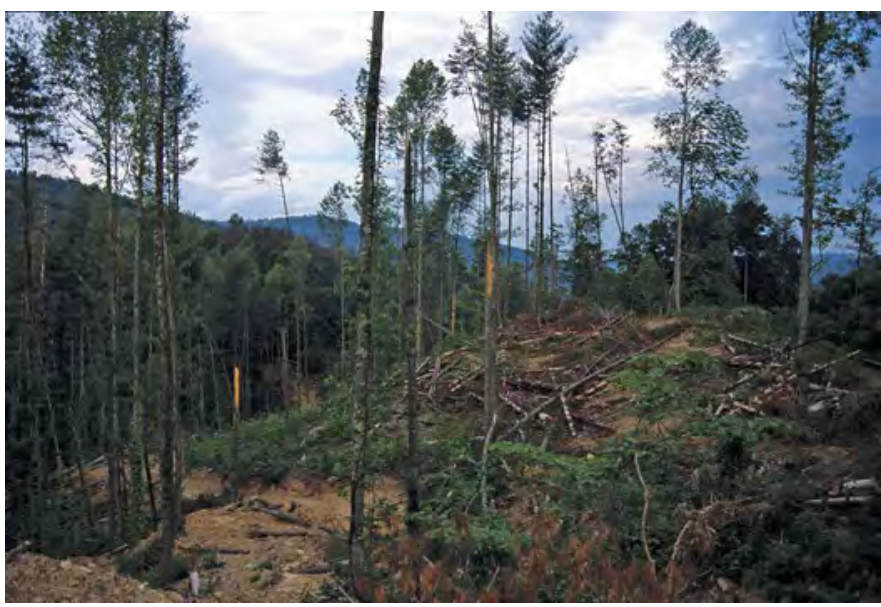

Figure 7. Active logging of hardwood forests in Central Appalachians Ecoregion.

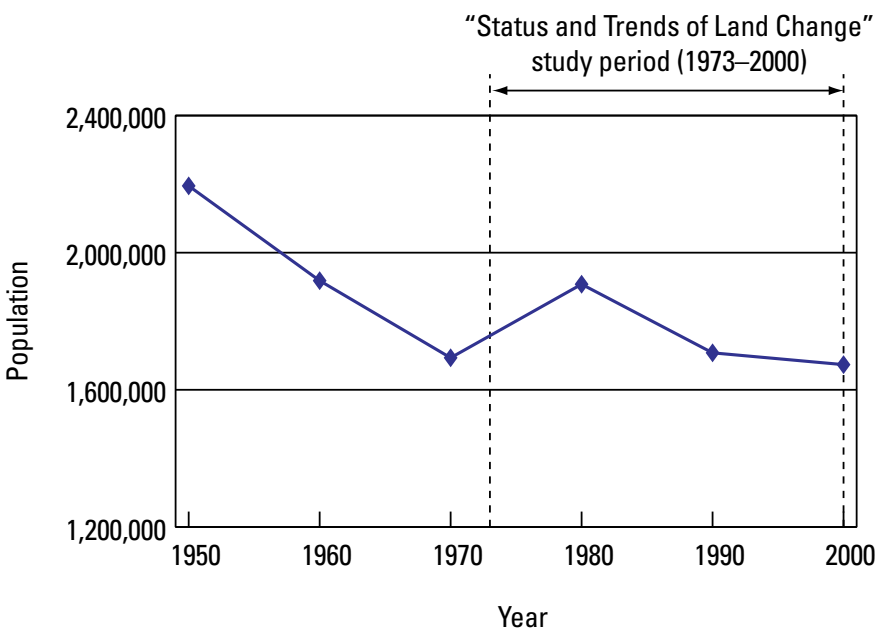

Figure 8. Population levels in Central Appalachians Ecoregion between 1950 and 2000 (U.S. Census Bureau, 1970-2000 [various years]). 


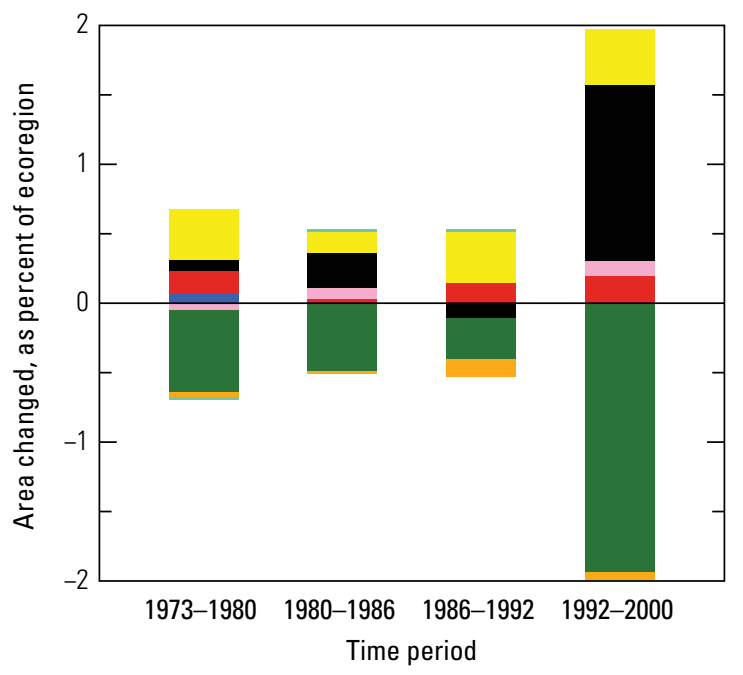

EXPLANATION

Land-use/land-cover class

$\begin{array}{ll}\square \text { Water } & \square \text { Forest } \\ \square \text { Developed } & \square \text { Grassland/Shrubland } \\ \square \text { Mechanically disturbed } & \square \text { Agriculture } \\ \text { Mining } & \text { Wetland } \\ \square \text { Barren } & \text { Nonmechanically disturbed } \\ & \text { Ice/Snow }\end{array}$

Figure 9. Normalized average net change in Central

Appalachians Ecoregion by time period for each land-cover class.

Bars above zero axis represent net gain, whereas bars below zero represent net loss. Note that not all land-cover classes shown in explanation may be represented in figure. See appendix 3 for definitions of land-use and land-cover classifications. 
Table 1. Percentage of Central Appalachians Ecoregion land cover that changed at least one time during study period (1973-2000) and associated statistical error.

[Most sample pixels remained unchanged ( 90.9 percent), whereas 9.1 percent changed at least once throughout study period]

\begin{tabular}{ccccccc}
\hline $\begin{array}{c}\text { Number } \\
\text { of } \\
\text { changes }\end{array}$ & $\begin{array}{c}\text { Percent } \\
\text { of } \\
\text { ecoregion }\end{array}$ & $\begin{array}{c}\text { Margin } \\
\text { of error } \\
(+/-\%)\end{array}$ & $\begin{array}{c}\text { Lower } \\
\text { bound } \\
(\%)\end{array}$ & $\begin{array}{c}\text { Upper } \\
\text { bound } \\
(\%)\end{array}$ & $\begin{array}{c}\text { Standard } \\
\text { error } \\
(\%)\end{array}$ & $\begin{array}{c}\text { Relative } \\
\text { error } \\
(\%)\end{array}$ \\
\hline 1 & 5.9 & 1.1 & 4.8 & 7.0 & 0.7 & 12.6 \\
2 & 2.8 & 0.6 & 2.2 & 3.4 & 0.4 & 14.1 \\
3 & 0.4 & 0.1 & 0.3 & 0.5 & 0.1 & 23.4 \\
4 & 0.0 & 0.0 & 0.0 & 0.0 & 0.0 & 29.6 \\
\hline $\begin{array}{c}\text { Overall } \\
\text { spatial } \\
\text { change }\end{array}$ & 9.1 & 1.5 & 7.6 & 10.6 & 1.0 & 11.0 \\
\hline
\end{tabular}

Table 2. Raw estimates of change in Central Appalachians Ecoregion land cover, computed for each of four time periods between 1973 and 2000, and associated error at 85-percent confidence level.

[Estimates of change per period normalized to annual rate of change for each period]

\begin{tabular}{cccccccc}
\hline Period & $\begin{array}{c}\text { Total change } \\
(\% \text { of ecoregion) }\end{array}$ & $\begin{array}{c}\text { Margin of } \\
\text { error } \\
(+/-\%)\end{array}$ & $\begin{array}{c}\text { Lower } \\
\text { bound } \\
(\%)\end{array}$ & $\begin{array}{c}\text { Upper bound } \\
(\%)\end{array}$ & $\begin{array}{c}\text { Standard } \\
\text { error } \\
(\%)\end{array}$ & $\begin{array}{c}\text { Relative } \\
\text { error } \\
(\%)\end{array}$ & $\begin{array}{c}\text { Average rate } \\
(\% \text { per year) }\end{array}$ \\
\hline \multicolumn{7}{c}{ Estimate of change, in percent stratum } \\
\hline $1973-1980$ & 2.9 & 0.7 & 2.3 & 3.6 & 0.4 & 15.1 & 0.4 \\
$1980-1986$ & 2.4 & 0.5 & 1.9 & 2.9 & 0.4 & 15.0 & 0.4 \\
$1986-1992$ & 3.3 & 0.6 & 2.7 & 3.9 & 0.4 & 12.1 & 0.6 \\
$1992-2000$ & 4.1 & 1.1 & 3.1 & 5.2 & 0.7 & 17.3 & 0.5 \\
\hline & & Estimate of change, in square kilometers & & \\
\hline $1973-1980$ & 1,754 & 390 & 1,364 & 2,145 & 265 & 15.1 & 251 \\
$1980-1986$ & 1,423 & 316 & 1,107 & 1,738 & 214 & 15.0 & 237 \\
$1986-1992$ & 1,981 & 354 & 1,627 & 2,335 & 240 & 12.1 & 330 \\
$1992-2000$ & 2,471 & 632 & 1,839 & 3,103 & 428 & 17.3 & 309 \\
\hline
\end{tabular}


Table 3. Estimated area (and margin of error) of each land-cover class in Central Appalachians Ecoregion, calculated five times between 1973 and 2000. See appendix 3 for definitions of land-cover classifications.

\begin{tabular}{|c|c|c|c|c|c|c|c|c|c|c|c|c|c|c|c|c|c|c|c|c|}
\hline & \multicolumn{2}{|c|}{ Water } & \multicolumn{2}{|c|}{ Developed } & \multicolumn{2}{|c|}{$\begin{array}{c}\text { Me- } \\
\text { chanically } \\
\text { disturbed }\end{array}$} & \multicolumn{2}{|c|}{ Mining } & \multicolumn{2}{|c|}{ Barren } & \multicolumn{2}{|c|}{ Forest } & \multicolumn{2}{|c|}{$\begin{array}{l}\text { Grassland/ } \\
\text { Shrubland }\end{array}$} & \multicolumn{2}{|c|}{ Agriculture } & \multicolumn{2}{|c|}{ Wetland } & \multicolumn{2}{|c|}{$\begin{array}{c}\text { Non- } \\
\text { mechanically } \\
\text { disturbed }\end{array}$} \\
\hline & $\%$ & $+/-$ & $\%$ & $+/-$ & $\%$ & $+/-$ & $\%$ & $+/-$ & $\%$ & $+/-$ & $\%$ & $+1-$ & $\%$ & $+/-$ & $\%$ & $+/-$ & $\%$ & $+/-$ & $\%$ & $+/-$ \\
\hline \multicolumn{21}{|c|}{ Area, in percent stratum } \\
\hline 1973 & 0.5 & 0.3 & 3.1 & 0.6 & 0.3 & 0.2 & 1.7 & 0.5 & 0.0 & 0.0 & 86.6 & 2.0 & 0.5 & 0.2 & 7.0 & 2.0 & 0.3 & 0.2 & 0.0 & 0.0 \\
\hline 1980 & 0.6 & 0.3 & 3.2 & 0.7 & 0.2 & 0.1 & 1.8 & 0.5 & 0.0 & 0.0 & 86.0 & 2.0 & 0.9 & 0.3 & 7.0 & 2.0 & 0.2 & 0.2 & 0.0 & 0.0 \\
\hline 1986 & 0.6 & 0.3 & 3.3 & 0.7 & 0.3 & 0.1 & 2.1 & 0.5 & 0.0 & 0.0 & 85.5 & 2.0 & 1.0 & 0.3 & 7.0 & 2.0 & 0.2 & 0.2 & 0.0 & 0.0 \\
\hline 1992 & 0.6 & 0.3 & 3.4 & 0.7 & 0.3 & 0.1 & 2.0 & 0.5 & 0.0 & 0.0 & 85.2 & 2.0 & 1.4 & 0.4 & 6.9 & 2.0 & 0.3 & 0.2 & 0.0 & 0.0 \\
\hline 2000 & 0.6 & 0.3 & 3.6 & 0.8 & 0.4 & 0.2 & 3.2 & 1.0 & 0.0 & 0.0 & 83.2 & 2.0 & 1.8 & 0.5 & 6.8 & 2.0 & 0.3 & 0.2 & 0.0 & 0.0 \\
\hline $\begin{array}{l}\text { Net } \\
\text { change }\end{array}$ & 0.1 & 0.1 & 0.5 & 0.2 & 0.1 & 0.3 & 1.5 & 0.9 & 0.0 & 0.0 & -3.3 & 1.0 & 1.3 & 0.4 & -0.2 & 0.2 & 0.0 & 0.0 & 0.0 & 0.0 \\
\hline $\begin{array}{l}\text { Gross } \\
\text { change }\end{array}$ & 0.1 & 0.1 & 0.5 & 0.2 & 1.3 & 0.4 & 3.7 & 0.9 & 0.0 & 0.0 & 5.0 & 1.0 & 1.9 & 0.5 & 0.4 & 0.2 & 0.0 & 0.0 & 0.0 & 0.0 \\
\hline \multicolumn{21}{|c|}{ Area, in square kilometers } \\
\hline 1973 & 308 & 159 & 1,834 & 375 & 181 & 128 & 1,041 & 282 & 2 & 2 & 51,718 & 1,222 & 307 & 132 & 4,194 & 1,190 & 151 & 141 & 0 & 0 \\
\hline 1980 & 355 & 165 & 1,932 & 390 & 149 & 73 & 1,081 & 285 & 2 & 2 & 51,368 & 1,206 & 527 & 174 & 4,179 & 1,193 & 145 & 133 & 0 & 0 \\
\hline 1986 & 355 & 165 & 1,957 & 394 & 188 & 86 & 1,236 & 296 & 2 & 2 & 51,072 & 1,205 & 615 & 176 & 4,168 & 1,190 & 146 & 134 & 0 & 0 \\
\hline 1992 & 358 & 165 & 2,038 & 417 & 185 & 81 & 1,178 & 276 & 3 & 2 & 50,889 & 1,223 & 840 & 211 & 4,096 & 1,174 & 151 & 141 & 0 & 0 \\
\hline 2000 & 366 & 165 & 2,156 & 449 & 247 & 132 & 1,938 & 583 & 2 & 2 & 49,731 & 1,171 & 1,073 & 315 & 4,074 & 1,166 & 151 & 141 & 0 & 0 \\
\hline $\begin{array}{l}\text { Net } \\
\text { change }\end{array}$ & 58 & 64 & 322 & 133 & 66 & 177 & 897 & 552 & 0 & 0 & $-1,987$ & 593 & 765 & 250 & -121 & 91 & 0 & 0 & 0 & 0 \\
\hline $\begin{array}{l}\text { Gross } \\
\text { change }\end{array}$ & 58 & 64 & 323 & 133 & 794 & 226 & 2,215 & 566 & 0 & 0 & 2,958 & 571 & 1,135 & 271 & 260 & 90 & 11 & 16 & 0 & 0 \\
\hline
\end{tabular}


Table 4. Principal land-cover conversions in Central Appalachians Ecoregion, showing amount of area changed (and margin of error, calculated at 85-percent confidence level) for each conversion during each of four time periods and also during overall study period. See appendix 3 for definitions of land-cover classifications.

[Values given for "other" classes are combined totals of values for other land-cover classes not listed in that time period. Abbreviations: n/a, not applicable]

\begin{tabular}{|c|c|c|c|c|c|c|c|}
\hline Period & From class & To class & $\begin{array}{c}\begin{array}{c}\text { Area } \\
\text { changed }\end{array} \\
\left(\mathrm{km}^{2}\right)\end{array}$ & $\begin{array}{c}\text { Margin of } \\
\text { error } \\
\left(+/-\mathbf{k m}^{2}\right)\end{array}$ & $\begin{array}{c}\text { Standard } \\
\text { error } \\
\left(\mathrm{km}^{2}\right)\end{array}$ & $\begin{array}{l}\text { Percent of } \\
\text { ecoregion }\end{array}$ & $\begin{array}{c}\text { Percent of all } \\
\text { changes }\end{array}$ \\
\hline \multirow[t]{7}{*}{$1973-1980$} & Forest & Mining & 539 & 186 & 126 & 0.9 & 30.7 \\
\hline & Mining & Forest & 427 & 219 & 149 & 0.7 & 24.3 \\
\hline & Forest & Grassland/Shrubland & 185 & 78 & 53 & 0.3 & 10.6 \\
\hline & Forest & Mechanically disturbed & 121 & 63 & 43 & 0.2 & 6.9 \\
\hline & Mining & Grassland/Shrubland & 80 & 40 & 27 & 0.1 & 4.6 \\
\hline & Other & Other & 402 & $\mathrm{n} / \mathrm{a}$ & $\mathrm{n} / \mathrm{a}$ & 0.7 & 22.9 \\
\hline & & Totals & 1,754 & & & 2.9 & 100.0 \\
\hline \multirow[t]{7}{*}{ 1980-1986 } & Forest & Mining & 458 & 141 & 95 & 0.8 & 32.2 \\
\hline & Mining & Forest & 188 & 120 & 82 & 0.3 & 13.2 \\
\hline & Forest & Mechanically disturbed & 158 & 74 & 50 & 0.3 & 11.1 \\
\hline & Grassland/Shrubland & Forest & 154 & 64 & 44 & 0.3 & 10.8 \\
\hline & Mining & Grassland/Shrubland & 121 & 39 & 27 & 0.2 & 8.5 \\
\hline & Other & Other & 344 & $\mathrm{n} / \mathrm{a}$ & $\mathrm{n} / \mathrm{a}$ & 0.6 & 24.2 \\
\hline & & Totals & 1,423 & & & 2.4 & 100.0 \\
\hline \multirow[t]{7}{*}{ 1986-1992 } & Forest & Mining & 530 & 143 & 97 & 0.9 & 26.7 \\
\hline & Mining & Forest & 365 & 169 & 115 & 0.6 & 18.4 \\
\hline & Mining & Grassland/Shrubland & 240 & 77 & 52 & 0.4 & 12.1 \\
\hline & Grassland/Shrubland & Forest & 169 & 60 & 41 & 0.3 & 8.5 \\
\hline & Forest & Mechanically disturbed & 161 & 75 & 51 & 0.3 & 8.1 \\
\hline & Other & Other & 517 & $\mathrm{n} / \mathrm{a}$ & $\mathrm{n} / \mathrm{a}$ & 0.9 & 26.1 \\
\hline & & Totals & 1,981 & & & 3.3 & 100.0 \\
\hline \multirow[t]{7}{*}{$1992-2000$} & Forest & Mining & 1,099 & 500 & 339 & 1.8 & 44.5 \\
\hline & Mining & Grassland/Shrubland & 263 & 126 & 85 & 0.4 & 10.7 \\
\hline & Forest & Mechanically disturbed & 231 & 130 & 88 & 0.4 & 9.3 \\
\hline & Forest & Grassland/Shrubland & 182 & 88 & 59 & 0.3 & 7.4 \\
\hline & Grassland/Shrubland & Forest & 178 & 86 & 58 & 0.3 & 7.2 \\
\hline & Other & Other & 518 & $\mathrm{n} / \mathrm{a}$ & $\mathrm{n} / \mathrm{a}$ & 0.9 & 21.0 \\
\hline & & Totals & 2,471 & & & 4.1 & 100.0 \\
\hline \multirow{7}{*}{$\begin{array}{c}1973-2000 \\
\text { (overall) }\end{array}$} & Forest & Mining & 2,626 & 714 & 484 & 4.4 & 34.4 \\
\hline & Mining & Forest & 1,094 & 420 & 284 & 1.8 & 14.3 \\
\hline & Mining & Grassland/Shrubland & 705 & 195 & 132 & 1.2 & 9.2 \\
\hline & Forest & Mechanically disturbed & 671 & 248 & 168 & 1.1 & 8.8 \\
\hline & Forest & Grassland/Shrubland & 597 & 184 & 125 & 1.0 & 7.8 \\
\hline & Other & Other & 1,936 & $\mathrm{n} / \mathrm{a}$ & $\mathrm{n} / \mathrm{a}$ & 3.2 & 25.4 \\
\hline & & Totals & 7,629 & & & 12.8 & 100.0 \\
\hline
\end{tabular}




\section{References Cited}

Fox, J., 1999, Mountaintop removal in West Virginia-An environmental sacrifice zone: Organization and Environment, v. 12 , no. 2 , p. $163-183$.

Raitz, K.B., and Ulack, R., 1984, Appalachia, a regional geography_Land, people, and development: Boulder, Colo., Westview Press, 396 p.

U.S. Census Bureau, 1970-2000 [various years], Census of population and housing: U.S. Census Bureau database, accessed May 9, 2013, at http://www.census.gov/prod/www/ decennial.html.

Vogelmann, J.E., Howard, S.M., Yang, L., Larson, C.R., Wylie, B.K., and van Driel, N., 2001, Completion of the 1990s National Land Cover Data Set for the conterminous United States from Landsat Thematic Mapper data and ancillary data sources: Photogrammetric Engineering \& Remote Sensing, v. 67 , p. 650-662.

Wiken, E., Jiménez Nava, F., and Griffith, G., 2011, North American terrestrial ecoregions-Level III: Montreal, Canada, Commission for Environmental Cooperation, 149 p., accessed May 1, 2013, at http://www.cec.org/ Storage/133/15860_QA07.30-32_NP_NA_Terrestrial_ Ecoregions_Level_3_Final-2june11.pdf.

Woods, A.J., Omernik, J.M., Brown, D.D., and Kiilsgaard, C.W., 1996, Level III and IV ecoregions of Pennsylvania and the Blue Ridge Mountains, the Ridge and Valley, and Central Appalachians of Virginia, West Virginia, and Maryland: U.S. Environmental Protection Agency, National Health and Environmental Effects Research Laboratory, Corvallis, Oreg., EPA/600/R-96/077, $50 \mathrm{p}$. 


\title{
Chapter 11
}

\section{Ridge and Valley Ecoregion}

\author{
By Beverly A. Friesen and Michael P. Stier
}

\section{Ecoregion Description}

The Ridge and Valley Ecoregion is a long, narrow ecoregion that covers $111,043 \mathrm{~km}^{2}\left(42,874 \mathrm{mi}^{2}\right)$, stretching about $1,600 \mathrm{~km}$ from the southeastern corner of New York to northeastern Alabama and including parts of seven states in between: New Jersey, Pennsylvania, Maryland, West Virginia, Virginia, Tennessee, and Georgia (fig. 1). Major cities within this ecoregion are Birmingham, Alabama, and Chattanooga and

Figure 1. Map of Ridge and Valley Ecoregion and surrounding ecoregions, showing land-use/land-cover classes from 1992 National Land Cover Dataset (Vogelmann and others, 2001); note that not all land-use/land-cover classes shown in explanation may be depicted on map; note also that, for this "Status and Trends of Land Change" study, transitional land-cover class was subdivided into mechanically disturbed and nonmechanically disturbed classes. Squares indicate locations of $10 \times 10 \mathrm{~km}$ sample blocks analyzed in study. Index map shows locations of geographic features mentioned in text. Abbreviations for Eastern United States ecoregions are listed in appendix 2. Also shown are parts of six Midwest-South Central United States ecoregions: Central Corn Belt Plains (CCBP), Eastern Corn Belt Plains, Erie Drift Plains, Huron/Erie Lake Plains (HELP), Interior River Lowland (IRL), and Southern Michigan/Northern Indiana Drift Plains (SMNIDP). See appendix 3 for definitions of land-use/land-cover classifications.

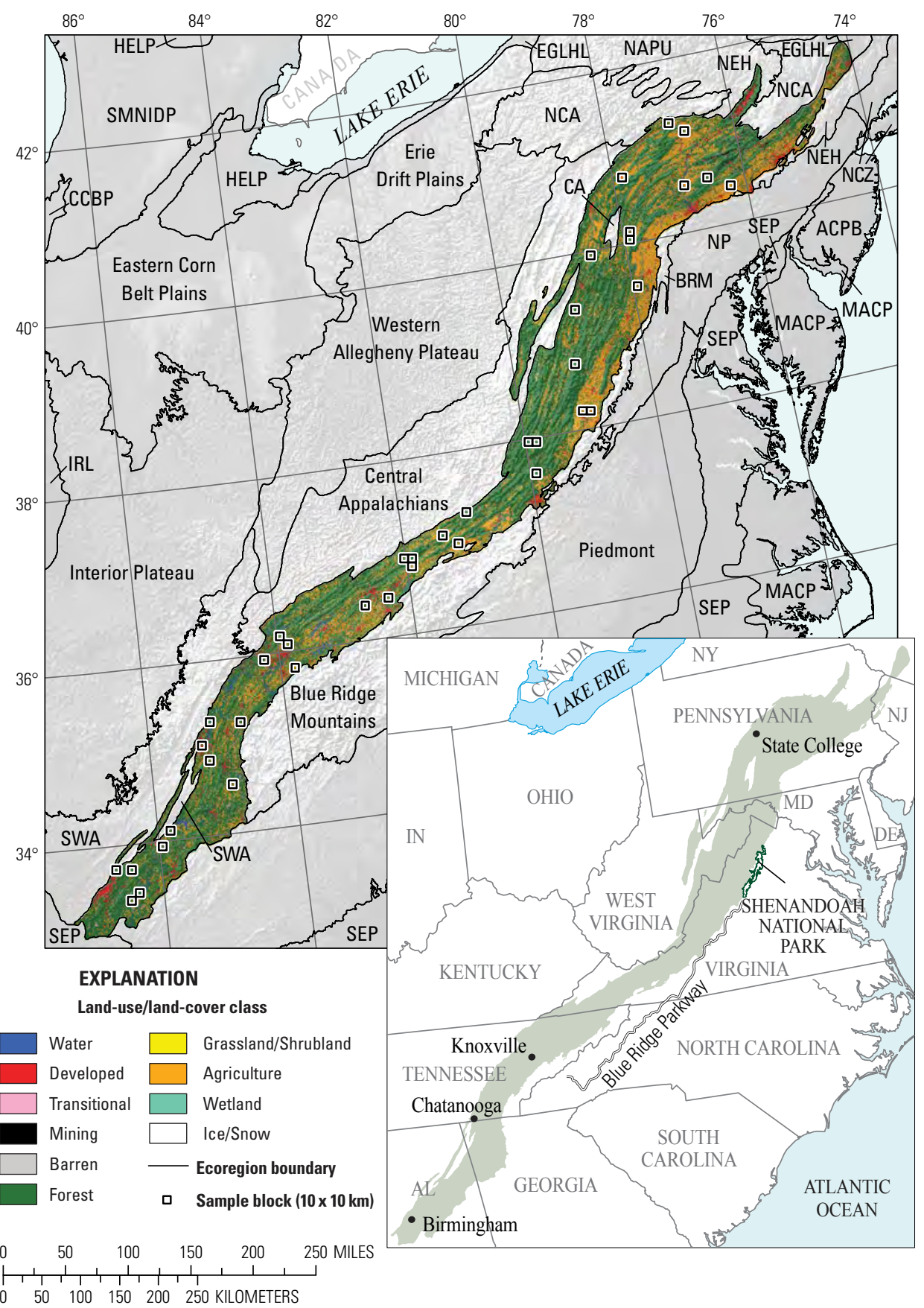


Knoxville, Tennessee. The ecoregion is surrounded by (clockwise, from its northeasternmost tip) the Eastern Great Lakes and Hudson Lowlands, Northeastern Highlands, Northern Piedmont, Blue Ridge Mountains, Piedmont, Southeastern Plains, Southwestern Appalachians, Central Appalachians, North Central Appalachians, and Northern Appalachian Plateau and Uplands Ecoregions.

This northeast-southwest-trending ecoregion is nestled between generally higher areas of more rugged, mountainous terrain that, in general, has more forested land. The roughly parallel ridges and lowland valleys that make up this area are the result of extreme folding and faulting events (Wiken and others, 2011) (fig. 2). Elevations range from 152 to 1,311 $\mathrm{m}$. Managed lands constitute more than 13 percent of the ecoregion area, ranging from State parks to wild and scenic rivers (Conservation Biology Institute, 2001). The Blue Ridge Parkway, a designated parkway administered by the National Park Service, dips into the eastern part of the ecoregion in Virginia, as do small parts of Shenandoah National Park.

\section{Contemporary Land-Cover Change (1973 to 2000)}

The overall spatial change (the percentage of land area that changed at least one time) in the Ridge and Valley Ecoregion between 1973 and 2000 is estimated at 5.5 percent (table 1). Compared to other Eastern United States ecoregions, change in the Ridge and Valley Ecoregion was relatively low (fig. 3): of the land that changed, 4.1 percent changed one time, and 1.5 percent changed two or more times (table 1). In this ecoregion, multiple changes often indicate cyclic disturbances; most of the multiple changes in this ecoregion represent areas of clearcuts and subsequent forest regrowth (fig. 4).

The overall change per time period for the Ridge and Valley Ecoregion ranges from a low of 1.3 percent between 1980 and 1986 to a high of 2.6 percent between 1992 and

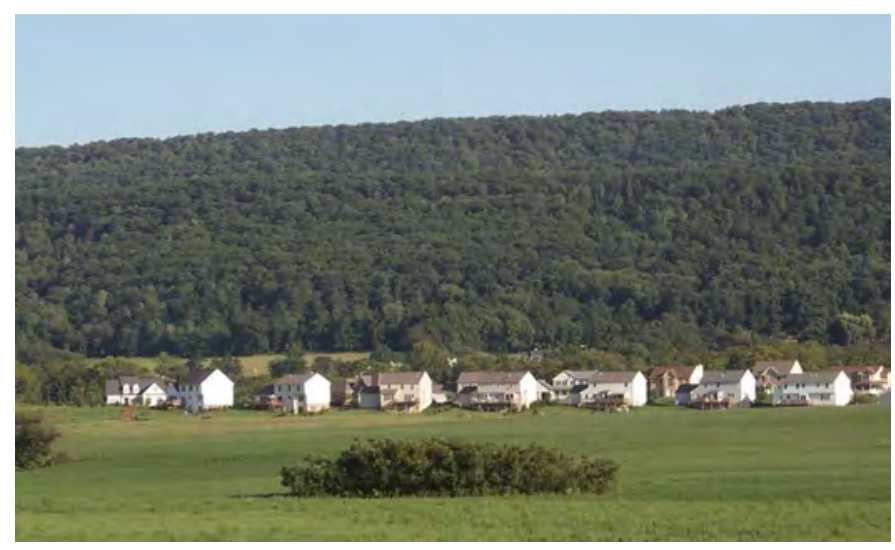

Figure 2. Typical scene in Ridge and Valley Ecoregion of forested areas dominating hilly topography and developed and agricultural lands occupying valleys.
2000 (table 2). All estimates have an associated margin of error of less than about 1.0 percent, although the margin of error increases with the higher amount of change in the period between 1992 and 2000 (table 2). When normalized to an average annual rate to account for uneven time periods, change per time period gradually increased over the study period, from 0.2 to 0.3 percent annual change (table 2; fig. 5). The period between 1992 and 2000 was the most actively changing period.

Forest, agriculture, and developed land-cover classes accounted for almost 96 percent of the ecoregion area during the 27-year study period. The percentages of each land-cover class for the five mapped dates between 1973 and 2000 are shown in table 3: forest decreased from 57.3 percent in 1973 to 55.8 percent in 2000 (table 3), and mechanically disturbed (clearcuts) increased, starting in the period between 1986 and 1992. A small decrease in agriculture, from 31.2 to 30.4 percent, was recorded between 1973 and 2000; this decrease was due to both the abandonment of agricultural fields and the conversion of agricultural land to developed land. Decreases in forest and agriculture were countered by a 1.4 percent net increase in developed, from 7.9 percent of the ecoregion in 1973 to 9.3

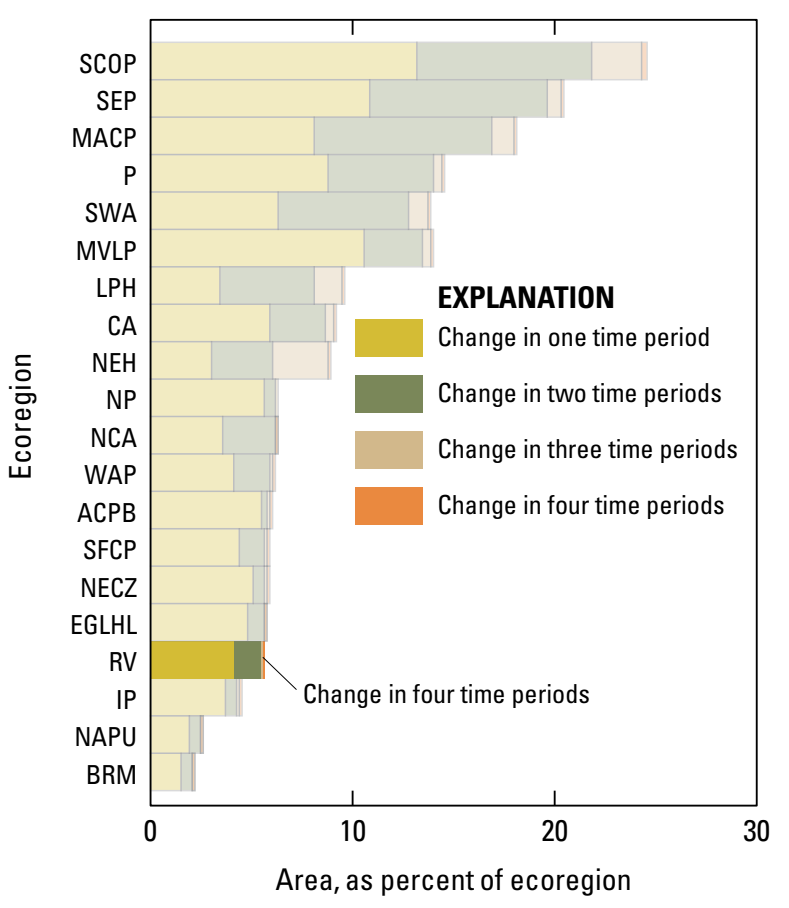

Figure 3. Overall spatial change in Ridge and Valley Ecoregion (RV; darker bars) compared with that of all 20 Eastern United States ecoregions (lighter bars). Each horizontal set of bars shows proportions of ecoregion that changed during one, two, three, or four time periods; highest level of spatial change in Ridge and Valley Ecoregion (four time periods) labeled for clarity. See table 2 for years covered by each time period. See appendix 2 for key to ecoregion abbreviations. 
percent in 2000. These net changes are summarized by landcover class for each time period in figure 6 .

The five most common land-cover conversions by time period are reported in table 4 . The greatest consistent change over the 27-year study period was the conversion of forest to mechanically disturbed, followed by the reversion of mechanically disturbed to forest (forest regrowth). The amount of land that changed from forest to mechanically disturbed more than doubled between the second period (1986-1992; $535 \mathrm{~km}^{2}$ ) and the fourth period (1992-2000; 1,169 $\left.\mathrm{km}^{2}\right)$, owing to the clearing of trees. In contrast, only $482 \mathrm{~km}^{2}$ of mechanically disturbed reverted to forest between 1992 and 2000. Other leading conversions were the cyclic changes from forest to agriculture and from agriculture to forest, as well as the unidirectional changes from agriculture and forest to developed.

The amount of land that converted from both forest and agriculture to developed more than doubled between 1992 and 2000 , when compared to any previous period; this was the same time period in which the amount of clearcutting more than doubled. Although many clearcut areas have reverted to forest, mechanically disturbed represents a temporary state that also can lead to permanent conversion to developed.

The quantity of clearcuts, coupled with the increased amount of forest and agriculture converting to developed, highlights the net loss of forest in this ecoregion during the 27-year study period. These changes also suggest a possible accelerating trend in the clearing of forested and agricultural land for development. Increases in developed and mechanically disturbed lands and decreases in forested and agricultural lands in the Ridge and Valley Ecoregion were corroborated by a Southern Forest Resource Assessment from the National Resource Inventory data of the U.S. Department of Agriculture, Natural Resources Conservation Service (Wear, 2002). This study showed that, for the southern states between 1982 and 1997, strong economic growth led to population growth and increased urbanization at the expense of agricultural and forested lands. This trend was more noticeable in the southern part of the ecoregion than

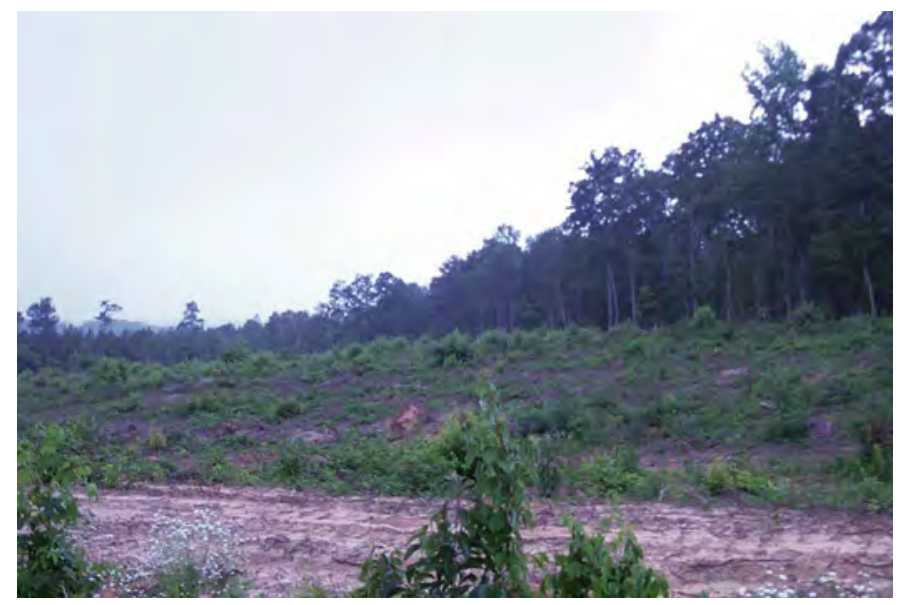

Figure 4. Regrowth in clearcut area, in central Alabama.

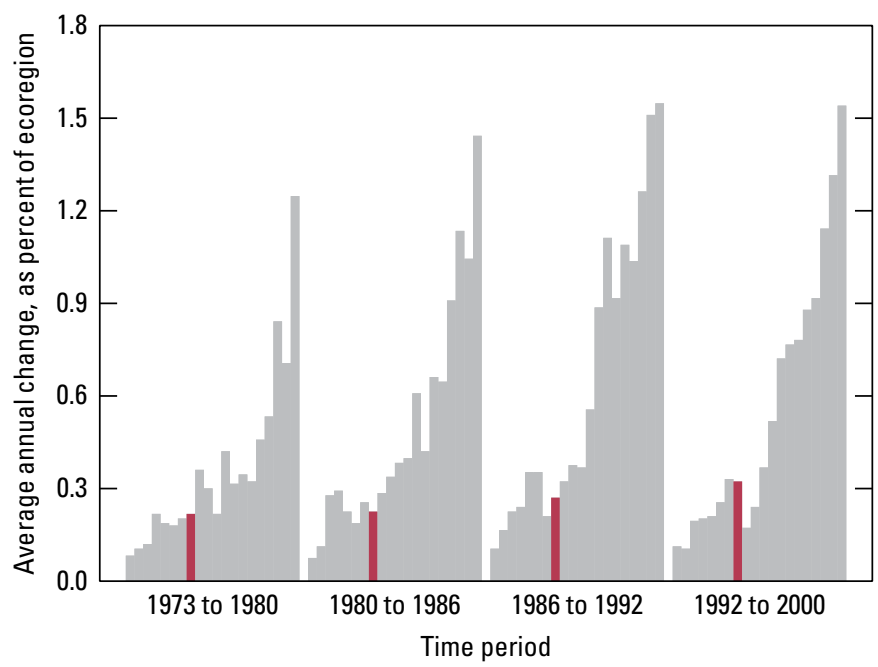

Figure 5. Estimates of land-cover change per time period, normalized to annual rates of change for all 20 Eastern United States ecoregions (gray bars). Estimates of change for Ridge and Valley Ecoregion are represented by red bars in each time period.

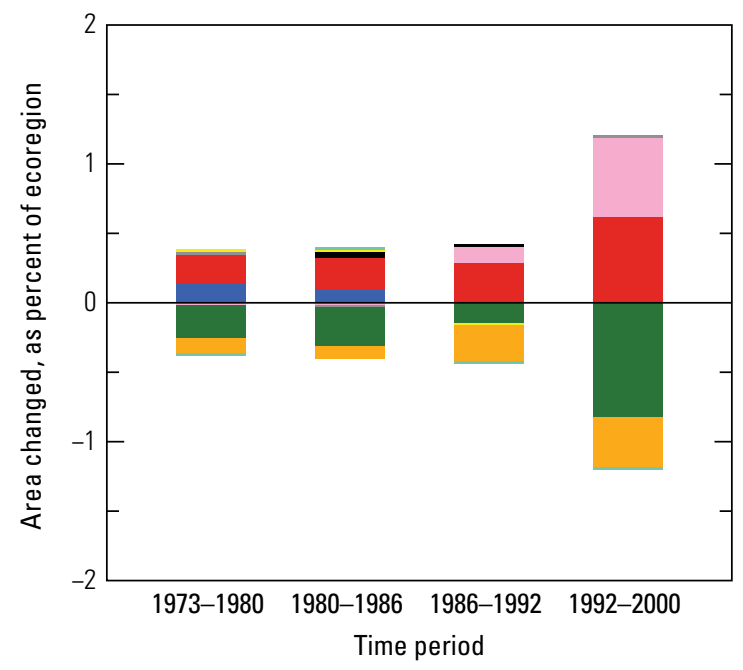

EXPLANATION

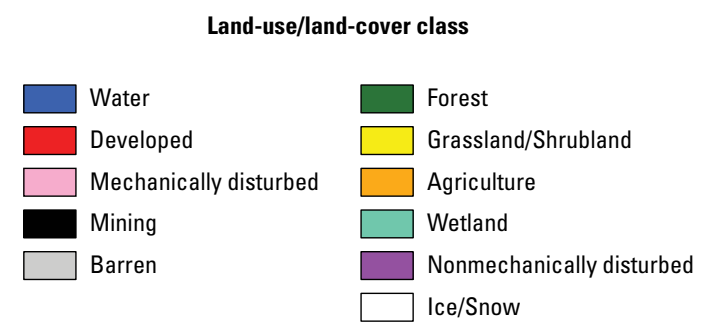

Figure 6. Normalized average net change in Ridge and Valley Ecoregion by time period for each land-cover class. Bars above zero axis represent net gain, whereas bars below zero represent net loss. Note that not all land-cover classes shown in explanation may be represented in figure. See appendix 3 for definitions of landuse and land-cover classifications. 
in the northern part, which also coincides with the largest urban centers in the ecoregion (Birmingham, Alabama, and Chattanooga and Knoxville, Tennessee) (fig. 7). Forecasts for the northern, central, and southern parts of the Ridge and Valley Ecoregion showed continued and increased loss of

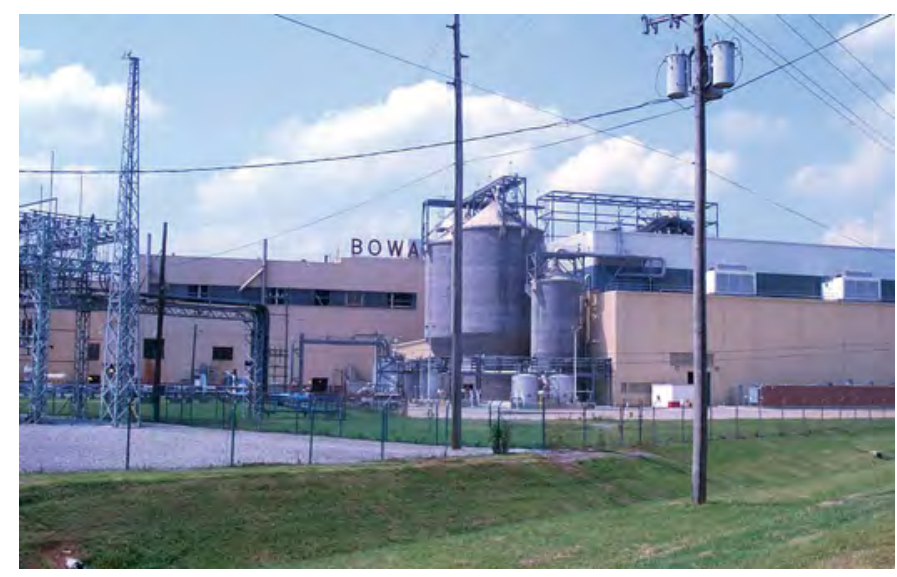

Figure 7. Paper mill in Ridge and Valley Ecoregion. Industry is fairly common in ecoregion, especially along interstate highways and exits in its northern part, in Pennsylvania and Virginia, and in its southern part, around Birmingham, Alabama, and Chattanooga and Knoxville, Tennessee. forest between 1992 and 2020, with higher losses predicted for the southern part of the ecoregion (Wear, 2002). In addition, pressures from development likely will continue to drive land-use conversions in the Ridge and Valley Ecoregion for the foreseeable future (fig. 8).

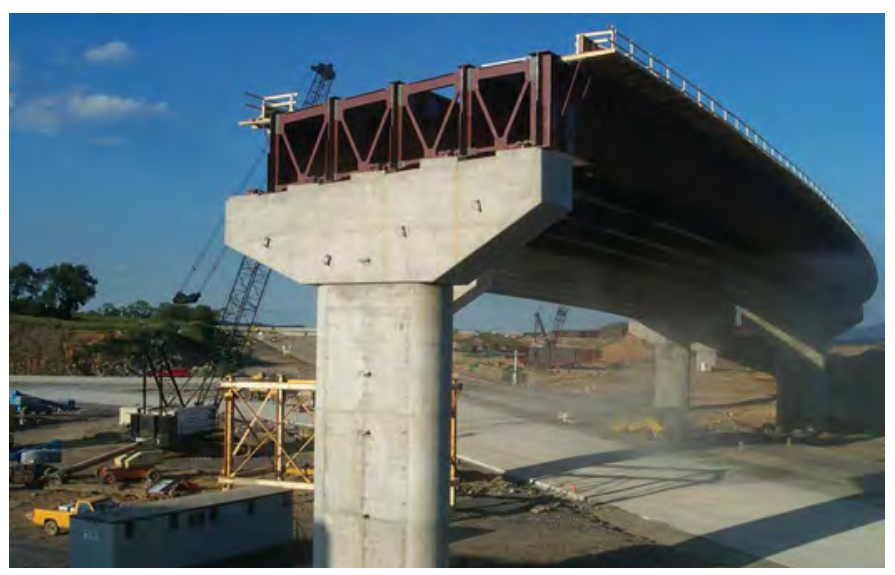

Figure 8. Overpass under construction, near State College, Pennsylvania. 
Table 1. Percentage of Ridge and Valley Ecoregion land cover that changed at least one time during study period (1973-2000) and associated statistical error.

[Most sample pixels remained unchanged (94.5 percent), whereas 5.5 percent changed at least once throughout study period]

\begin{tabular}{ccccccc}
\hline $\begin{array}{c}\text { Number } \\
\text { of } \\
\text { changes }\end{array}$ & $\begin{array}{c}\text { Percent } \\
\text { of } \\
\text { ecoregion }\end{array}$ & $\begin{array}{c}\text { Margin } \\
\text { of error } \\
(+/-\%)\end{array}$ & $\begin{array}{c}\text { Lower } \\
\text { bound } \\
(\%)\end{array}$ & $\begin{array}{c}\text { Upper } \\
\text { bound } \\
(\%)\end{array}$ & $\begin{array}{c}\text { Standard } \\
\text { error } \\
(\%)\end{array}$ & $\begin{array}{c}\text { Relative } \\
\text { error } \\
(\%)\end{array}$ \\
\hline 1 & 4.1 & 0.8 & 3.3 & 4.8 & 0.5 & 12.8 \\
2 & 1.4 & 0.4 & 1.0 & 1.8 & 0.3 & 19.5 \\
3 & 0.1 & 0.0 & 0.0 & 0.1 & 0.0 & 37.4 \\
4 & 0.0 & 0.0 & 0.0 & 0.0 & 0.0 & 57.1 \\
\hline $\begin{array}{l}\text { Overall } \\
\text { spatial } \\
\text { change }\end{array}$ & 5.5 & 1.1 & 4.4 & 6.6 & 0.7 & 13.3 \\
\hline
\end{tabular}

Table 2. Raw estimates of change in Ridge and Valley Ecoregion land cover, computed for each of four time periods between 1973 and 2000, and associated error at 85-percent confidence level.

[Estimates of change per period normalized to annual rate of change for each period]

\begin{tabular}{rccccccc}
\hline Period & $\begin{array}{c}\text { Total change } \\
(\% \text { of ecoregion) }\end{array}$ & $\begin{array}{c}\text { Margin of } \\
\text { error } \\
(+/-\%)\end{array}$ & $\begin{array}{c}\text { Lower } \\
\text { bound } \\
(\%)\end{array}$ & $\begin{array}{c}\text { Upper bound } \\
(\%)\end{array}$ & $\begin{array}{c}\text { Standard } \\
\text { error } \\
(\%)\end{array}$ & $\begin{array}{c}\text { Relative } \\
\text { error } \\
(\%)\end{array}$ & $\begin{array}{c}\text { Average rate } \\
(\% \text { per year) }\end{array}$ \\
\hline \multicolumn{7}{c}{ Estimate of change, in percent stratum } \\
\hline $1973-1980$ & 1.5 & 0.4 & 1.1 & 2.0 & 0.3 & 20.0 & 0.2 \\
$1980-1986$ & 1.3 & 0.4 & 1.0 & 1.7 & 0.3 & 19.0 & 0.2 \\
$1986-1992$ & 1.6 & 0.4 & 1.2 & 2.0 & 0.2 & 15.1 & 0.3 \\
$1992-2000$ & 2.6 & 0.6 & 2.0 & 3.2 & 0.4 & 15.8 & 0.3 \\
\hline & & Estimate of change, in square kilometers & & \\
\hline $1973-1980$ & 1,693 & 497 & 1,196 & 2,190 & 338 & 20.0 & 242 \\
$1980-1986$ & 1,482 & 414 & 1,067 & 1,896 & 282 & 19.0 & 247 \\
$1986-1992$ & 1,778 & 395 & 1,383 & 2,173 & 269 & 15.1 & 296 \\
$1992-2000$ & 2,878 & 668 & 2,210 & 3,545 & 455 & 15.8 & 360 \\
\hline
\end{tabular}


Table 3. Estimated area (and margin of error) of each land-cover class in Ridge and Valley Ecoregion, calculated five times between 1973 and 2000. See appendix 3 for definitions of land-cover classifications.

\begin{tabular}{|c|c|c|c|c|c|c|c|c|c|c|c|c|c|c|c|c|c|c|c|c|}
\hline & \multicolumn{2}{|c|}{ Water } & \multicolumn{2}{|c|}{ Developed } & \multicolumn{2}{|c|}{$\begin{array}{c}\text { Me- } \\
\text { chanically } \\
\text { disturbed }\end{array}$} & \multicolumn{2}{|c|}{ Mining } & \multicolumn{2}{|c|}{ Barren } & \multicolumn{2}{|c|}{ Forest } & \multicolumn{2}{|c|}{$\begin{array}{l}\text { Grassland/ } \\
\text { Shrubland }\end{array}$} & \multicolumn{2}{|c|}{ Agriculture } & \multicolumn{2}{|c|}{ Wetland } & \multicolumn{2}{|c|}{$\begin{array}{c}\text { Non- } \\
\text { mechanically } \\
\text { disturbed }\end{array}$} \\
\hline & $\%$ & $+/-$ & $\%$ & $+/-$ & $\%$ & $+/-$ & $\%$ & $+/-$ & $\%$ & $+/-$ & $\%$ & $+/-$ & $\%$ & $+/-$ & $\%$ & $+/-$ & $\%$ & $+/-$ & $\%$ & $+/-$ \\
\hline \multicolumn{21}{|c|}{ Area, in percent stratum } \\
\hline 1973 & 2.2 & 0.9 & 7.9 & 3.0 & 0.4 & 0.2 & 0.2 & 0.1 & 0.0 & 0.0 & 57.3 & 5.1 & 0.1 & 0.1 & 31.2 & 4.6 & 0.7 & 0.3 & 0.0 & 0.0 \\
\hline 1980 & 2.3 & 0.9 & 8.1 & 3.0 & 0.4 & 0.2 & 0.2 & 0.1 & 0.0 & 0.0 & 57.0 & 5.1 & 0.1 & 0.1 & 31.1 & 4.6 & 0.7 & 0.3 & 0.0 & 0.0 \\
\hline 1986 & 2.4 & 0.9 & 8.4 & 3.0 & 0.4 & 0.2 & 0.2 & 0.1 & 0.0 & 0.0 & 56.7 & 5.0 & 0.1 & 0.1 & 31.0 & 4.5 & 0.7 & 0.3 & 0.0 & 0.0 \\
\hline 1992 & 2.4 & 0.9 & 8.7 & 3.0 & 0.5 & 0.2 & 0.2 & 0.1 & 0.0 & 0.0 & 56.6 & 5.0 & 0.1 & 0.1 & 30.7 & 4.5 & 0.7 & 0.3 & 0.0 & 0.0 \\
\hline 2000 & 2.4 & 0.9 & 9.3 & 3.0 & 1.1 & 0.4 & 0.3 & 0.1 & 0.0 & 0.0 & 55.8 & 4.9 & 0.1 & 0.1 & 30.4 & 4.4 & 0.7 & 0.3 & 0.0 & 0.0 \\
\hline $\begin{array}{l}\text { Net } \\
\text { change }\end{array}$ & 0.3 & 0.3 & 1.4 & 0.4 & 0.6 & 0.3 & 0.1 & 0.0 & 0.0 & 0.0 & -1.5 & 0.6 & 0.0 & 0.0 & -0.8 & 0.4 & 0.0 & 0.0 & 0.0 & 0.0 \\
\hline $\begin{array}{l}\text { Gross } \\
\text { change }\end{array}$ & 0.3 & 0.3 & 1.4 & 0.4 & 1.9 & 0.5 & 0.1 & 0.1 & 0.0 & 0.0 & 2.9 & 0.6 & 0.1 & 0.1 & 1.4 & 0.3 & 0.0 & 0.0 & 0.0 & 0.0 \\
\hline \multicolumn{21}{|c|}{ Area, in square kilometers } \\
\hline 1973 & 2,433 & 1,019 & 8,802 & 3,280 & 487 & 182 & 222 & 144 & 8 & 7 & 63,600 & 5,659 & 88 & 94 & 34,635 & 5,070 & 767 & 369 & 0 & 0 \\
\hline 1980 & 2,594 & 1,023 & 9,039 & 3,280 & 481 & 213 & 223 & 125 & 20 & 18 & 63,321 & 5,609 & 89 & 81 & 34,513 & 5,071 & 763 & 368 & 0 & 0 \\
\hline 1986 & 2,704 & 1,052 & 9,301 & 3,288 & 459 & 195 & 253 & 140 & 11 & 9 & 63,006 & 5,570 & 120 & 89 & 34,425 & 5,049 & 764 & 369 & 0 & 0 \\
\hline 1992 & 2,710 & 1,051 & 9,623 & 3,314 & 577 & 168 & 264 & 136 & 11 & 9 & 62,843 & 5,583 & 111 & 91 & 34,140 & 5,006 & 763 & 369 & 0 & 0 \\
\hline 2000 & 2,717 & 1,050 & 10,305 & 3,386 & 1,207 & 481 & 278 & 139 & 11 & 9 & 61,929 & 5,480 & 111 & 83 & 33,727 & 4,930 & 757 & 364 & 0 & 0 \\
\hline $\begin{array}{l}\text { Net } \\
\text { change }\end{array}$ & 283 & 367 & 1,504 & 430 & 719 & 354 & 56 & 46 & 3 & 7 & $-1,671$ & 638 & 23 & 54 & -908 & 405 & -10 & 12 & 0 & 0 \\
\hline $\begin{array}{l}\text { Gross } \\
\text { change }\end{array}$ & 293 & 366 & 1,514 & 429 & 2,144 & 579 & 125 & 65 & 21 & 27 & 3,211 & 650 & 107 & 61 & 1,581 & 329 & 17 & 13 & 0 & 0 \\
\hline
\end{tabular}


Table 4. Principal land-cover conversions in Ridge and Valley Ecoregion, showing amount of area changed (and margin of error, calculated at 85-percent confidence level) for each conversion during each of four time periods and also during overall study period. See appendix 3 for definitions of land-cover classifications.

[Values given for "other" classes are combined totals of values for other land-cover classes not listed in that time period. Abbreviations: n/a, not applicable]

\begin{tabular}{|c|c|c|c|c|c|c|c|}
\hline Period & From class & To class & $\begin{array}{c}\text { Area } \\
\text { changed } \\
\left(\mathbf{k m}^{2}\right)\end{array}$ & $\begin{array}{l}\text { Margin of } \\
\text { error } \\
\left(+/-\mathbf{k m}^{2}\right)\end{array}$ & $\begin{array}{c}\text { Standard } \\
\text { error } \\
\left(\mathbf{k m}^{2}\right)\end{array}$ & $\begin{array}{l}\text { Percent of } \\
\text { ecoregion }\end{array}$ & $\begin{array}{l}\text { Percent of all } \\
\text { changes }\end{array}$ \\
\hline \multirow[t]{7}{*}{ 1973-1980 } & Forest & Mechanically disturbed & 420 & 189 & 129 & 0.4 & 24.7 \\
\hline & Mechanically disturbed & Forest & 387 & 155 & 106 & 0.3 & 22.8 \\
\hline & Forest & Agriculture & 159 & 67 & 46 & 0.1 & 9.4 \\
\hline & Agriculture & Forest & 159 & 64 & 44 & 0.1 & 9.4 \\
\hline & Forest & Developed & 148 & 70 & 48 & 0.1 & 8.7 \\
\hline & Other & Other & 421 & $\mathrm{n} / \mathrm{a}$ & $\mathrm{n} / \mathrm{a}$ & 0.4 & 24.9 \\
\hline & & Totals & 1,693 & & & 1.5 & 100.0 \\
\hline \multirow[t]{7}{*}{$1980-1986$} & Forest & Mechanically disturbed & 375 & 166 & 113 & 0.3 & 25.3 \\
\hline & Mechanically disturbed & Forest & 339 & 159 & 108 & 0.3 & 22.9 \\
\hline & Forest & Agriculture & 173 & 67 & 46 & 0.2 & 11.7 \\
\hline & Agriculture & Developed & 145 & 68 & 46 & 0.1 & 9.8 \\
\hline & Forest & Developed & 110 & 39 & 26 & 0.1 & 7.5 \\
\hline & Other & Other & 338 & $\mathrm{n} / \mathrm{a}$ & $\mathrm{n} / \mathrm{a}$ & 0.3 & 22.8 \\
\hline & & Totals & 1,482 & & & 1.3 & 100.0 \\
\hline \multirow[t]{7}{*}{ 1986-1992 } & Forest & Mechanically disturbed & 535 & 166 & 113 & 0.5 & 30.1 \\
\hline & Mechanically disturbed & Forest & 419 & 193 & 131 & 0.4 & 23.6 \\
\hline & Agriculture & Forest & 247 & 101 & 69 & 0.2 & 13.9 \\
\hline & Agriculture & Developed & 155 & 60 & 41 & 0.1 & 8.7 \\
\hline & Forest & Developed & 152 & 66 & 45 & 0.1 & 8.6 \\
\hline & Other & Other & 270 & $\mathrm{n} / \mathrm{a}$ & $\mathrm{n} / \mathrm{a}$ & 0.2 & 15.2 \\
\hline & & Totals & 1,778 & & & 1.6 & 100.0 \\
\hline \multirow[t]{7}{*}{$1992-2000$} & Forest & Mechanically disturbed & 1,169 & 471 & 321 & 1.1 & 40.6 \\
\hline & Mechanically disturbed & Forest & 482 & 147 & 100 & 0.4 & 16.8 \\
\hline & Agriculture & Developed & 331 & 154 & 105 & 0.3 & 11.5 \\
\hline & Forest & Developed & 317 & 126 & 86 & 0.3 & 11.0 \\
\hline & Agriculture & Forest & 269 & 167 & 114 & 0.2 & 9.3 \\
\hline & Other & Other & 309 & $\mathrm{n} / \mathrm{a}$ & $\mathrm{n} / \mathrm{a}$ & 0.3 & 10.8 \\
\hline & & Totals & 2,878 & & & 2.6 & 100.0 \\
\hline \multirow{7}{*}{$\begin{array}{c}1973-2000 \\
\text { (overall) }\end{array}$} & Forest & Mechanically disturbed & 2,498 & 826 & 562 & 2.2 & 31.9 \\
\hline & Mechanically disturbed & Forest & 1,627 & 543 & 370 & 1.5 & 20.8 \\
\hline & Agriculture & Forest & 770 & 250 & 170 & 0.7 & 9.8 \\
\hline & Forest & Developed & 727 & 262 & 178 & 0.7 & 9.3 \\
\hline & Agriculture & Developed & 710 & 258 & 176 & 0.6 & 9.1 \\
\hline & Other & Other & 1,498 & $\mathrm{n} / \mathrm{a}$ & $\mathrm{n} / \mathrm{a}$ & 1.3 & 19.1 \\
\hline & & Totals & 7,831 & & & 7.1 & 100.0 \\
\hline
\end{tabular}




\section{References Cited}

Conservation Biology Institute, 2001, Protected areas database PAD-US (CBI edition), version 2: Corvallis, Ore., Conservation Biology Institute database, available at http:// consbio.org/products/projects/pad-us-cbi-edition.

Vogelmann, J.E., Howard, S.M., Yang, L., Larson, C.R., Wylie, B.K., and van Driel, N., 2001, Completion of the 1990s National Land Cover Data Set for the conterminous United States from Landsat Thematic Mapper data and ancillary data sources: Photogrammetric Engineering \& Remote Sensing, v. 67, p. 650-662.

Wear, D.N., 2002, Land use, in Wear, D.N., and Greis, J.G., eds., Southern forest resource assessment: U.S. Forest Service, Southern Research Station, General Technical Report SRS 53, p. 153-173, available at http://www.srs.fs.usda. gov/pubs/4833.

Wiken, E., Jiménez Nava, F., and Griffith, G., 2011, North American terrestrial ecoregions-Level III: Montreal, Canada, Commission for Environmental Cooperation, 149 p., accessed May 1, 2013 at http://www.cec.org/ Storage/133/15860_QA07.30-32_NP_NA_Terrestrial_ Ecoregions_Level_3_Final-2june11.pdf. 


\title{
Chapter 12
}

\section{Interior Plateau Ecoregion}

\author{
By Mark A. Drummond
}

\section{Ecoregion Description}

The Interior Plateau Ecoregion covers large areas (about 127,810 $\mathrm{km}^{2} ; 49,348 \mathrm{mi}^{2}$ ) of Kentucky and central Tennessee, as well as parts of Ohio, Indiana, and Alabama (Wiken and others, 2011; fig. 1). The ecoregion is surrounded by (clockwise, from the north) the Eastern Corn Belt Plains, Western Allegheny Plateau, Southwestern Appalachians, Southeastern Plains, Mississippi Valley Loess Plains, and Interior River Lowland Ecoregions. The Ohio River, which forms the north border of Kentucky, drains most of the northern part of the ecoregion.

The Interior Plateau Ecoregion is a series of grassland plateaus and forested uplands that generally are lower in elevation than the Appalachian Mountains to the east but higher than the plains to the south. The relatively flat and fertile lowlands, which include the "Bluegrass region" (central Kentucky) and the Nashville Basin (mainly in central Tennessee but also in southern Kentucky and northern Alabama), attracted early settlement and farming. Today, these are highly populated areas that include the cities of Louisville, Kentucky, and Nashville, Tennessee. The Pennyroyal Plateau in south-central Kentucky and northern Tennessee is an intensely cultivated agricultural area that also has a distinctive "flatwood" ecosystem, which is characterized by oak (Quercus spp.) forests and wet conditions that are caused by an underlying hard, dense fragipan soil (Chester and others, 1995).

Rapid subsurface drainage occurs in sinkhole areas such as south-central Kentucky, where extensive cave systems

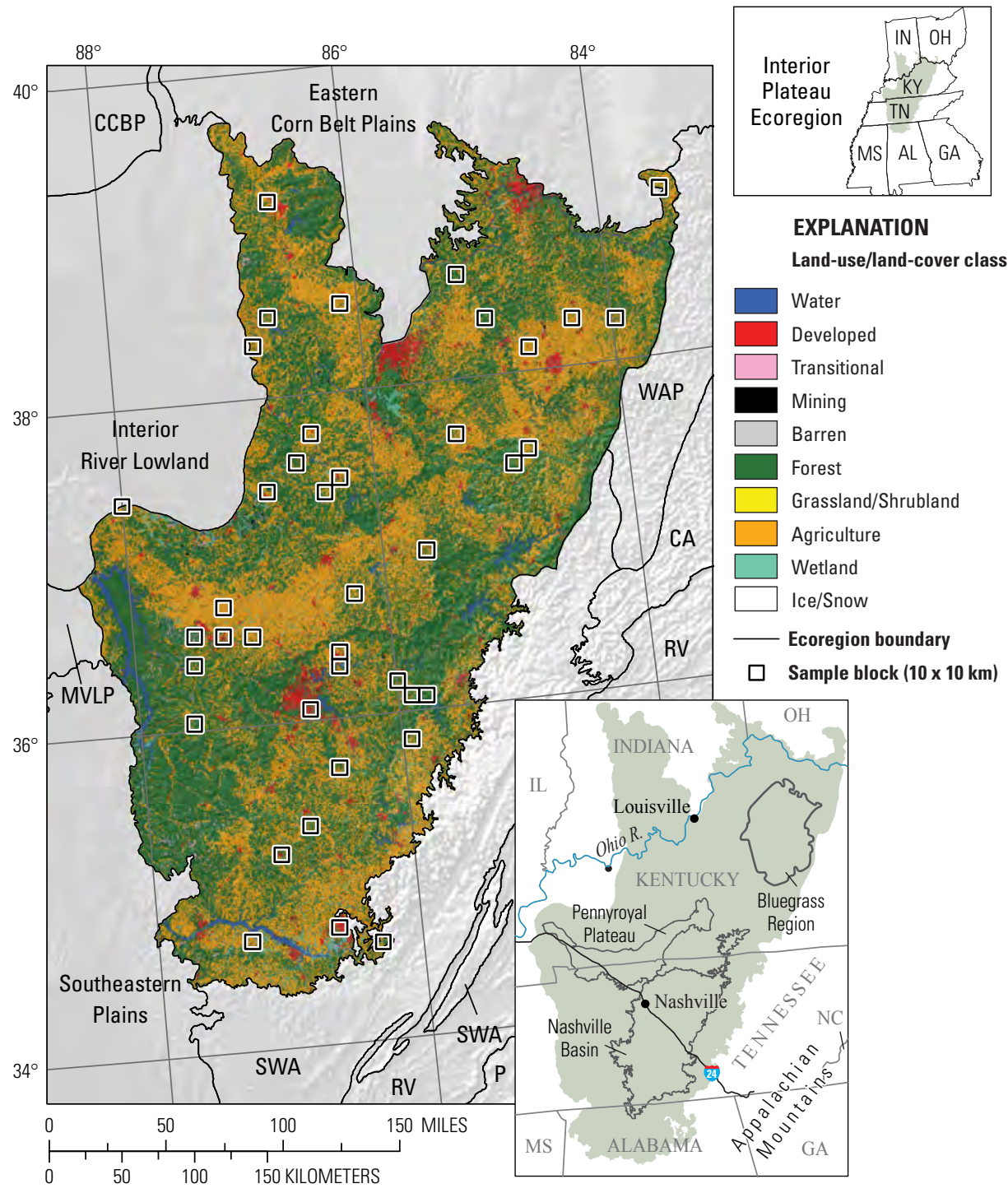

Figure 1. Map of Interior Plateau Ecoregion and surrounding ecoregions, showing land-use/land-cover classes from 1992 National Land Cover Dataset (Vogelmann and others, 2001); note that not all land-use/land-cover classes shown in explanation may be depicted on map; note also that, for this "Status and Trends of Land Change" study, transitional land-cover class was subdivided into mechanically disturbed and nonmechanically disturbed classes. Squares indicate locations of $10 \times 10 \mathrm{~km}$ sample blocks analyzed in study. Index map shows locations of geographic features mentioned in text. Abbreviations for Eastern United States ecoregions are listed in appendix 2. Also shown are parts of three Midwest-South Central United States ecoregions: Central Corn Belt Plains (CCBP), Eastern Corn Belt Plains, and Interior River Lowland. See appendix 3 for definitions of land-use/land-cover classifications. 
wind through the karst limestone landscape. Water quality of the associated aquifers and streams is a special concern in watersheds where agriculture and coal mining are prevalent.

Across the Interior Plateau Ecoregion, climate conditions are humid temperate, with annual precipitation averaging about 1,200 mm (47.2 in.). Oak-hickory (Quercus spp. and Carya spp., respectively) stands are the most common forest type, although mixed stands of eastern red-cedar (Juniperus virginiana) and hardwoods grow in many rocky areas and limestone glades (fig. 2). Bluestem (Andropogon spp.) prairie is the most common type of grassland. Historically, fire was an important natural process for maintaining open-canopied, savannalike conditions on the plateaus (Chester and others, 1995; Hudson, 2002).

Population in the Interior Plateau Ecoregion has increased steadily by about 40 percent between 1970 and 2000, from 4.4 million to 6.2 million people (U.S. Census Bureau, 1970-2000 [various years]). Automobile manufacturing has expanded into the ecoregion from other industrial areas of the United States, and tourism and service industries also are important at several locations. Major agricultural products include soybeans, corn, tobacco, and dairy (fig. 3). The Bluegrass area has unique land uses, including a tradition of racehorse breeding and training farms, as well as the production of high-value burley tobacco.

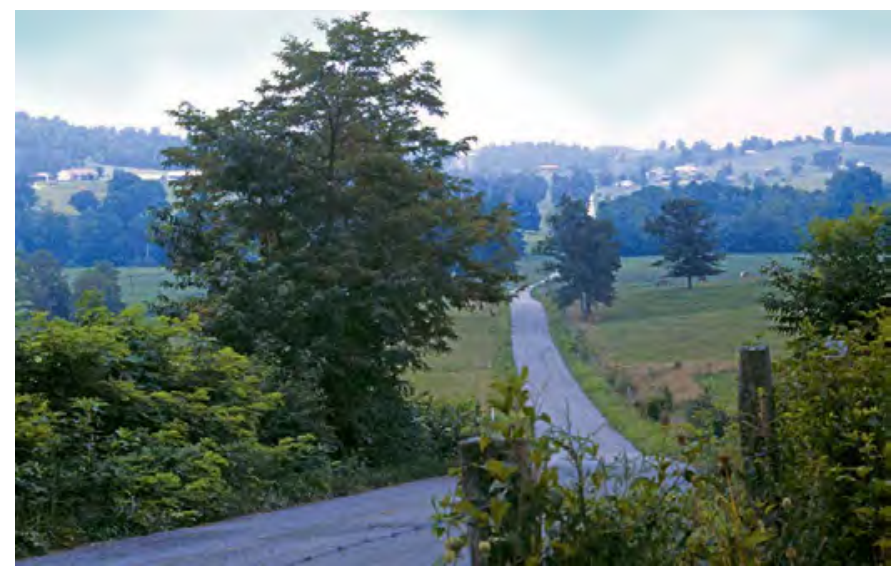

Figure 2. Roadside vista of pastureland, forest, and farms in southcentral Kentucky, in central part of Interior Plateau Ecoregion.

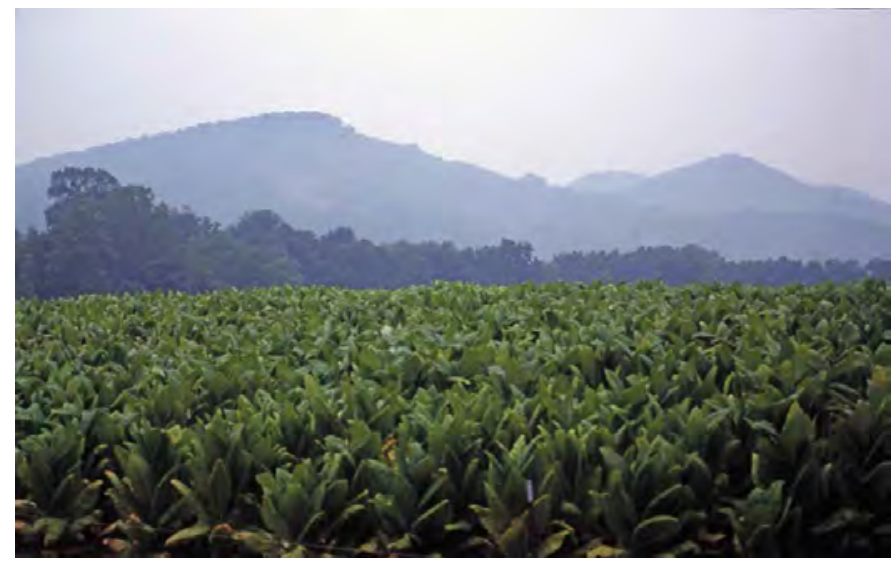

Figure 3. Tobacco field in central Tennessee.

\section{Contemporary Land-Cover Change (1973 to 2000)}

The overall spatial change (the percentage of land area that changed at least one time) in the Interior Plateau Ecoregion between 1973 and 2000 is estimated at 4.5 percent (table 1), meaning that 95.5 percent of the total area was stable. Compared to other Eastern United States ecoregions, change in the Interior Plateau Ecoregion was relatively low (fig. 4): an estimated 3.7 percent of the ecoregion changed only one time. The percentage of ecoregion area that changed multiple times also was relatively low: an estimated 0.8 percent changed twice, and 0.1 percent changed three times (table 1). When normalized to an average annual rate to account for unequal time periods, the highest total change occurred during the period between 1980 and 1986 (1.7 percent), with an annual rate of 0.3 percent (table 2 ; fig. 5 ). The lowest rate of change occurred during the period between 1973 and 1980, when total change was less than 1 percent ( 0.8 percent), and the annual rate was 0.1 percent.

Agricultural land, forested land, and developed land accounted for more than 96 percent of the ecoregion

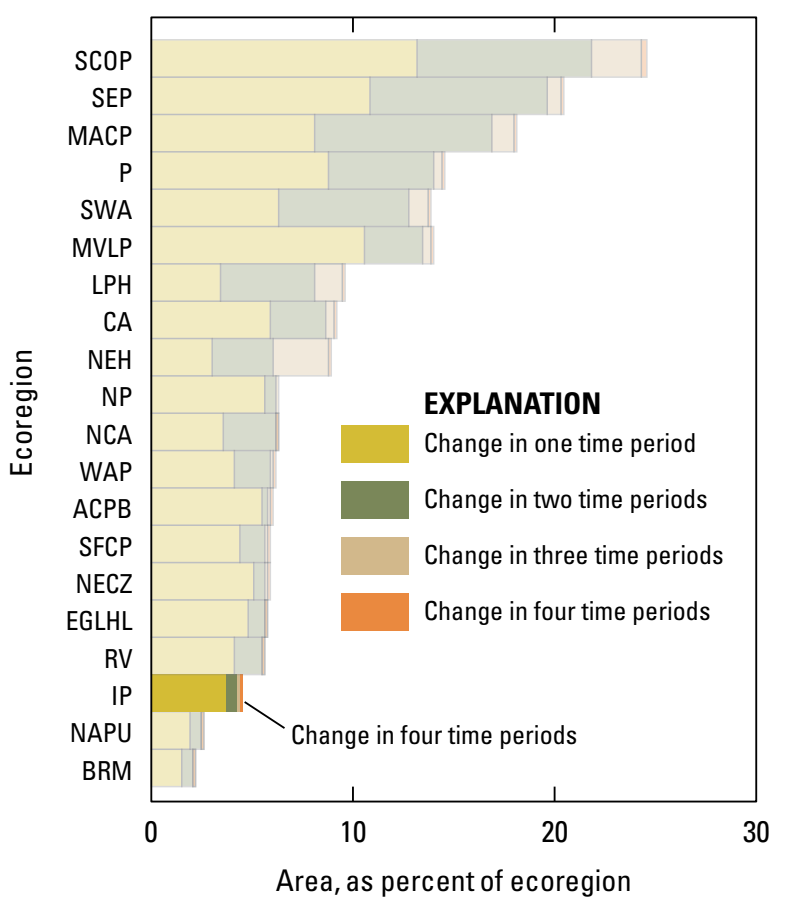

Figure 4. Overall spatial change in Interior Plateau Ecoregion (IP; darker bars) compared with that of all 20 Eastern United States ecoregions (lighter bars). Each horizontal set of bars shows proportions of ecoregion that changed during one, two, three, or four time periods; highest level of spatial change in Interior Plateau Ecoregion (four time periods) labeled for clarity. See table 2 for years covered by each time period. See appendix 2 for key to ecoregion abbreviations. 
area in 2000. Agriculture is the most common land cover, and it constituted 50.9 percent of the ecoregion in 1973, decreasing to 50.0 percent in 2000 (table 3). Forest was the next most common land cover, with a high of 39.0 percent of the ecoregion in 1973 and a low of 37.7 percent in 2000. Developed had a steady gain, from 6.9 percent of the ecoregion in 1973 to 8.6 percent in 2000 (fig. 6). Other small gains of about 0.2 percent each occurred between 1973 and 2000 in mechanically disturbed and grassland/shrubland. Developed experienced the greatest increase (1.7 percent) in ecoregion area between 1973 and 2000 (table 3). Net losses occurred in forest ( 1.3 percent) and agriculture ( 0.8 percent). Although the increase in developed generally accelerated over the 27-year study period (fig. 7), the highest rate of increase was between 1980 and 1986 ( 0.6 percent), which is also the period that has

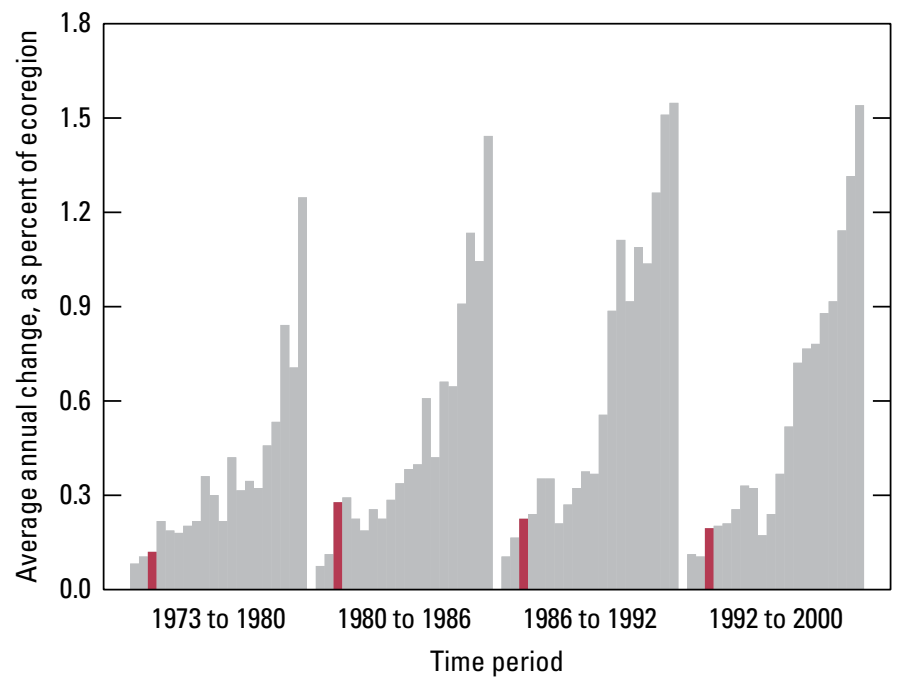

Figure 5. Estimates of land-cover change per time period, normalized to annual rates of change for all 20 Eastern United States ecoregions (gray bars). Estimates of change for Interior Plateau Ecoregion are represented by red bars in each time period.

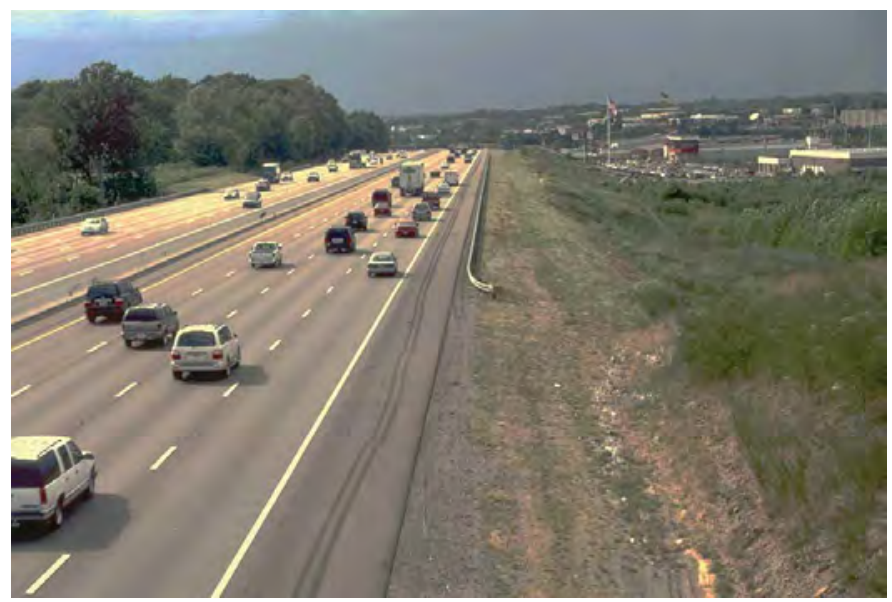

Figure 6. Suburban development next to Interstate 24, outside of Nashville, Tennessee. the highest overall rate of ecoregion change (1.7 percent). Most of the land converting to developed (nearly 60 percent) came from agriculture. Conversely, most of the loss in agriculture was to developed, except in the period between 1973 and 1980, when the conversion of agricultural land to grassland/shrubland was highest.

Between 1973 and 2000, the most common land-cover conversion $\left(1,373 \mathrm{~km}^{2}\right)$ was from forest to agriculture (table 4). However, this conversion did not result in a net increase in agricultural land because, at the same time, agricultural land was being converted to developed land and to grassland/shrubland at an overall higher rate. Conversion from agricultural land to developed land was the second most common change $\left(1,250 \mathrm{~km}^{2}\right)$. The various gains and losses of agricultural land during the study period are masked by a low net rate of change ( -0.8 percent) (table 3 ). Cyclic changes involving mechanical disturbance of forested areas and subsequent reforestation were less common, although they did increase through time (fig. 8).

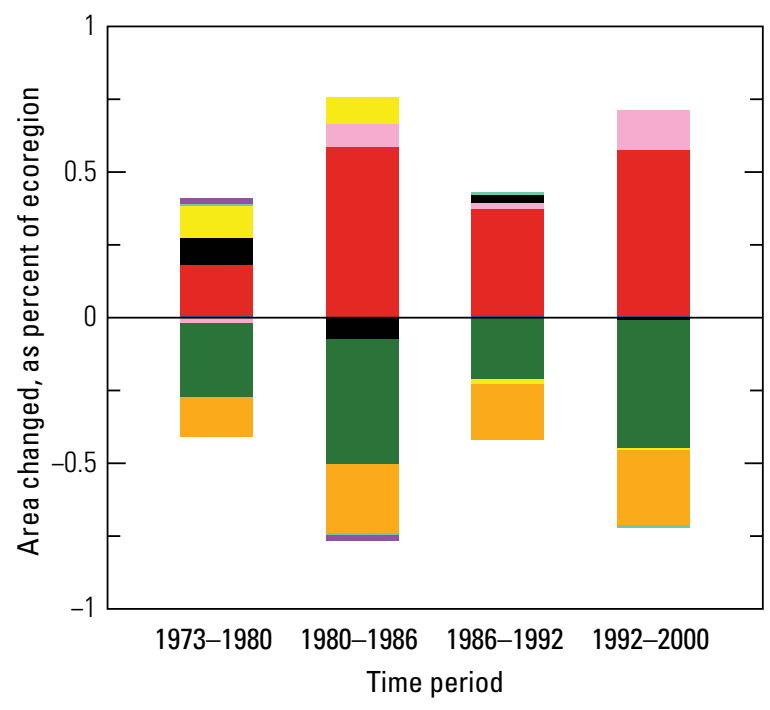

EXPLANATION

Land-use/land-cover class

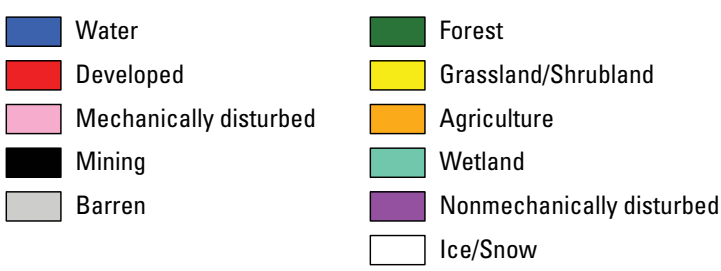

Figure 7. Normalized average net change in Interior Plateau Ecoregion by time period for each land-cover class. Bars above zero axis represent net gain, whereas bars below zero represent net loss. Note that not all land-cover classes shown in explanation may be represented in figure. See appendix 3 for definitions of land-use and land-cover classifications. 


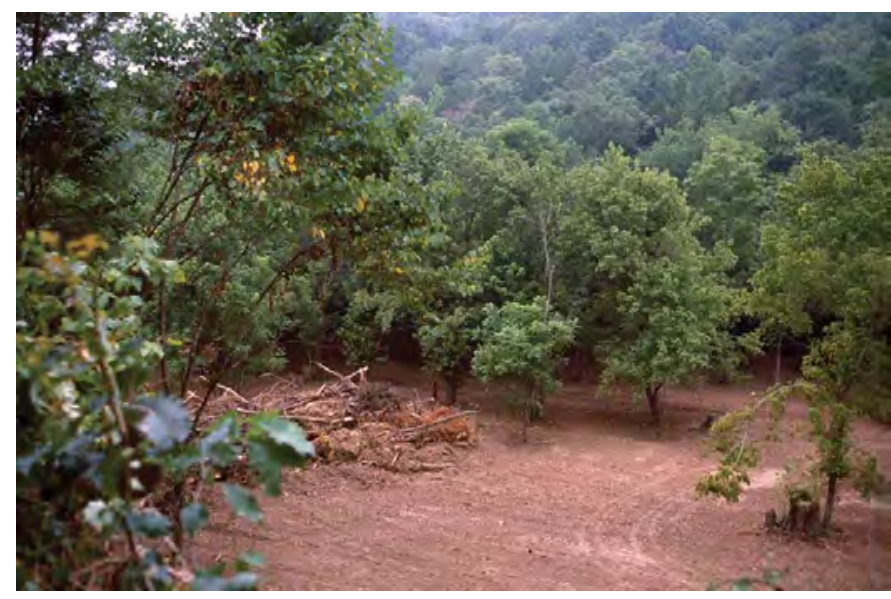

Figure 8. Forest being cleared near east edge of Interior Plateau Ecoregion.
Table 1. Percentage of Interior Plateau Ecoregion land cover that changed at least one time during study period (1973-2000) and associated statistical error.

[Most sample pixels remained unchanged ( 95.5 percent), whereas 4.5 percent changed at least once throughout study period]

\begin{tabular}{ccccccc}
\hline $\begin{array}{c}\text { Number } \\
\text { of } \\
\text { changes }\end{array}$ & $\begin{array}{c}\text { Percent } \\
\text { of } \\
\text { ecoregion }\end{array}$ & $\begin{array}{c}\text { Margin } \\
\text { of error } \\
(+/-\%)\end{array}$ & $\begin{array}{c}\text { Lower } \\
\text { bound } \\
(\%)\end{array}$ & $\begin{array}{c}\text { Upper } \\
\text { bound } \\
(\%)\end{array}$ & $\begin{array}{c}\text { Standard } \\
\text { error } \\
(\%)\end{array}$ & $\begin{array}{c}\text { Relative } \\
\text { error } \\
(\%)\end{array}$ \\
\hline 1 & 3.7 & 0.9 & 2.8 & 4.6 & 0.6 & 16.8 \\
2 & 0.8 & 0.2 & 0.5 & 1.0 & 0.2 & 21.4 \\
3 & 0.1 & 0.0 & 0.0 & 0.1 & 0.0 & 34.3 \\
4 & 0.0 & 0.0 & 0.0 & 0.0 & 0.0 & 67.7 \\
\hline $\begin{array}{c}\text { Overall } \\
\text { spatial } \\
\text { change }\end{array}$ & 4.5 & 1.1 & 3.4 & 5.6 & 0.7 & 16.2 \\
\hline
\end{tabular}

Table 2. Raw estimates of change in Interior Plateau Ecoregion land cover, computed for each of four time periods between 1973 and 2000, and associated error at 85-percent confidence level. [Estimates of change per period normalized to annual rate of change for each time period]

\begin{tabular}{rccccccc}
\hline Period & $\begin{array}{c}\text { Total change } \\
(\% \text { of ecoregion) }\end{array}$ & $\begin{array}{c}\text { Margin of } \\
\text { error } \\
(+/-\%)\end{array}$ & $\begin{array}{c}\text { Lower } \\
\text { bound } \\
(\%)\end{array}$ & $\begin{array}{c}\text { Upper bound } \\
(\%)\end{array}$ & $\begin{array}{c}\text { Standard } \\
\text { error } \\
(\%)\end{array}$ & $\begin{array}{c}\text { Relative } \\
\text { error } \\
(\%)\end{array}$ & $\begin{array}{c}\text { Average rate } \\
(\% \text { per year) }\end{array}$ \\
\hline \multicolumn{7}{c}{ Estimate of change, in percent stratum } \\
\hline $1973-1980$ & 0.8 & 0.2 & 0.6 & 1.1 & 0.2 & 20.0 & 0.1 \\
$1980-1986$ & 1.7 & 0.5 & 1.2 & 2.1 & 0.3 & 19.2 & 0.3 \\
$1986-1992$ & 1.4 & 0.4 & 1.0 & 1.7 & 0.3 & 20.1 & 0.2 \\
$1992-2000$ & 1.6 & 0.4 & 1.2 & 2.0 & 0.3 & 17.6 & 0.2 \\
\hline & 1,6 & Estimate of change, in square kilometers & & \\
\hline $1973-1980$ & 1,080 & 318 & 762 & 1,397 & 216 & 20.0 & 154 \\
$1980-1986$ & 2,135 & 603 & 1,532 & 2,738 & 411 & 19.2 & 356 \\
$1986-1992$ & 1,726 & 508 & 1,218 & 2,235 & 346 & 20.1 & 288 \\
$1992-2000$ & 1,984 & 513 & 1,471 & 2,497 & 349 & 17.6 & 248 \\
\hline
\end{tabular}


Table 3. Estimated area (and margin of error) of each land-cover class in Interior Plateau Ecoregion, calculated five times between 1973 and 2000. See appendix 3 for definitions of land-cover classifications.

\begin{tabular}{|c|c|c|c|c|c|c|c|c|c|c|c|c|c|c|c|c|c|c|c|c|}
\hline & \multicolumn{2}{|c|}{ Water } & \multicolumn{2}{|c|}{ Developed } & \multicolumn{2}{|c|}{$\begin{array}{l}\text { Mecha- } \\
\text { nically } \\
\text { disturbed }\end{array}$} & \multicolumn{2}{|c|}{ Mining } & \multicolumn{2}{|c|}{ Barren } & \multicolumn{2}{|c|}{ Forest } & \multicolumn{2}{|c|}{$\begin{array}{l}\text { Grassland/ } \\
\text { Shrubland }\end{array}$} & \multicolumn{2}{|c|}{ Agriculture } & \multicolumn{2}{|c|}{ Wetland } & \multicolumn{2}{|c|}{$\begin{array}{c}\text { Non- } \\
\text { mechanically } \\
\text { disturbed }\end{array}$} \\
\hline & $\%$ & $+1-$ & $\%$ & $+/-$ & $\%$ & $+/-$ & $\%$ & $+/-$ & $\%$ & $+/-$ & $\%$ & $+1-$ & $\%$ & $+/-$ & $\%$ & $+/-$ & $\%$ & $+1-$ & $\%$ & $+/-$ \\
\hline 1973 & 1.5 & 0.9 & 6.9 & 3.1 & 0.0 & 0.0 & 0.1 & 0.0 & 0.0 & 0.0 & 39.0 & 4.4 & 0.8 & 0.7 & 50.9 & 5.0 & 0.7 & 0.3 & 0.0 & 0.0 \\
\hline 1980 & 1.6 & 0.9 & 7.1 & 3.1 & 0.0 & 0.0 & 0.2 & 0.1 & 0.0 & 0.0 & 38.8 & 4.5 & 0.9 & 0.7 & 50.7 & 5.0 & 0.7 & 0.3 & 0.0 & 0.0 \\
\hline 1992 & 1.6 & 0.9 & 8.1 & 3.5 & 0.1 & 0.1 & 0.1 & 0.1 & 0.0 & 0.0 & 38.1 & 4.5 & 1.0 & 0.7 & 50.3 & 5.1 & 0.7 & 0.3 & 0.0 & 0.0 \\
\hline 2000 & 1.6 & 0.9 & 8.6 & 3.7 & 0.3 & 0.1 & 0.1 & 0.1 & 0.0 & 0.0 & 37.7 & 4.5 & 1.0 & 0.7 & 50.0 & 5.2 & 0.7 & 0.3 & 0.0 & 0.0 \\
\hline $\begin{array}{l}\text { Net } \\
\text { change }\end{array}$ & 0.0 & 0.0 & 1.7 & 0.8 & 0.2 & 0.1 & 0.0 & 0.0 & 0.0 & 0.0 & -1.3 & 0.6 & 0.2 & 0.3 & -0.8 & 0.7 & 0.0 & 0.0 & 0.0 & 0.0 \\
\hline $\begin{array}{l}\text { Gross } \\
\text { change }\end{array}$ & 0.1 & 0.0 & 1.7 & 0.8 & 0.5 & 0.2 & 0.3 & 0.3 & 0.0 & 0.0 & 1.9 & 0.6 & 0.7 & 0.3 & 2.0 & 0.6 & 0.0 & 0.0 & 0.0 & 0.0 \\
\hline 1980 & 1,986 & 1,172 & 9,087 & 3,971 & 18 & 11 & 230 & 162 & 1 & 1 & 49,532 & 5,707 & 1,161 & 926 & 64,830 & 6,390 & 943 & 441 & 21 & 30 \\
\hline 1986 & 1,993 & 1,172 & 9,829 & 4,338 & 127 & 76 & 138 & 54 & 1 & 1 & 48,981 & 5,707 & 1,278 & 931 & 64,524 & 6,502 & 938 & 440 & 0 & 0 \\
\hline 1992 & 2,009 & 1,171 & 10,291 & 4,485 & 150 & 78 & 176 & 75 & 1 & 1 & 48,710 & 5,785 & 1,265 & 910 & 64,269 & 6,574 & 939 & 437 & 0 & 0 \\
\hline 2000 & 2,024 & 1,168 & 11,013 & 4,690 & 322 & 145 & 161 & 88 & 1 & 1 & 48,149 & 5,729 & 1,263 & 915 & 63,938 & 6,597 & 938 & 438 & 0 & 0 \\
\hline $\begin{array}{l}\text { Net } \\
\text { change }\end{array}$ & 48 & 25 & 2,154 & 978 & 285 & 145 & 51 & 56 & 0 & 0 & $-1,715$ & 755 & 243 & 393 & $-1,067$ & 905 & 3 & 11 & 0 & 0 \\
\hline $\begin{array}{l}\text { Gross } \\
\text { change }\end{array}$ & 92 & 24 & 2,160 & 978 & 656 & 274 & 358 & 376 & 0 & 0 & 2,430 & 707 & 916 & 405 & 2,545 & 762 & 34 & 27 & 42 & 61 \\
\hline
\end{tabular}


Table 4. Principal land-cover conversions in Interior Plateau Ecoregion, showing amount of area changed (and margin of error, calculated at 85-percent confidence level) for each conversion during each of four time periods and also during overall study period. See appendix 3 for definitions of land-cover classifications.

[Values given for "other" classes are combined totals of values for other land-cover classes not listed in that time period. Abbreviations: n/a, not applicable]

\begin{tabular}{|c|c|c|c|c|c|c|c|}
\hline Period & From class & To class & $\begin{array}{c}\begin{array}{c}\text { Area } \\
\text { changed }\end{array} \\
\left(\mathrm{km}^{2}\right)\end{array}$ & $\begin{array}{c}\text { Margin of } \\
\text { error } \\
\left(+/-\mathrm{km}^{2}\right)\end{array}$ & $\begin{array}{c}\text { Standard } \\
\text { error } \\
\left(\mathrm{km}^{2}\right)\end{array}$ & $\begin{array}{l}\text { Percent of } \\
\text { ecoregion }\end{array}$ & $\begin{array}{c}\text { Percent of all } \\
\text { changes }\end{array}$ \\
\hline \multirow[t]{7}{*}{ 1973-1980 } & Forest & Agriculture & 218 & 104 & 71 & 0.2 & 20.2 \\
\hline & Agriculture & Grassland/Shrubland & 210 & 75 & 51 & 0.2 & 19.4 \\
\hline & Grassland/Shrubland & Forest & 124 & 52 & 36 & 0.1 & 11.4 \\
\hline & Forest & Developed & 105 & 73 & 49 & 0.1 & 9.7 \\
\hline & Agriculture & Developed & 103 & 61 & 41 & 0.1 & 9.6 \\
\hline & Other & Other & 320 & $\mathrm{n} / \mathrm{a}$ & $\mathrm{n} / \mathrm{a}$ & 0.3 & 29.7 \\
\hline & & Totals & 1,080 & & & 0.8 & 100.0 \\
\hline \multirow[t]{7}{*}{ 1980-1986 } & Agriculture & Developed & 464 & 247 & 168 & 0.4 & 21.7 \\
\hline & Forest & Agriculture & 460 & 168 & 115 & 0.4 & 21.6 \\
\hline & Forest & Developed & 235 & 176 & 120 & 0.2 & 11.0 \\
\hline & Agriculture & Grassland/Shrubland & 207 & 109 & 74 & 0.2 & 9.7 \\
\hline & Grassland/Shrubland & Forest & 195 & 61 & 42 & 0.2 & 9.1 \\
\hline & Other & Other & 575 & $\mathrm{n} / \mathrm{a}$ & $\mathrm{n} / \mathrm{a}$ & 0.4 & 26.9 \\
\hline & & Totals & 2,135 & & & 1.7 & 100.0 \\
\hline \multirow[t]{7}{*}{ 1986-1992 } & Forest & Agriculture & 365 & 252 & 171 & 0.3 & 21.1 \\
\hline & Agriculture & Developed & 281 & 170 & 116 & 0.2 & 16.3 \\
\hline & Grassland/Shrubland & Forest & 218 & 91 & 62 & 0.2 & 12.6 \\
\hline & Agriculture & Grassland/Shrubland & 193 & 76 & 52 & 0.2 & 11.2 \\
\hline & Forest & Developed & 125 & 125 & 85 & 0.1 & 7.2 \\
\hline & Other & Other & 545 & $\mathrm{n} / \mathrm{a}$ & $\mathrm{n} / \mathrm{a}$ & 0.4 & 31.6 \\
\hline & & Totals & 1,726 & & & 1.4 & 100.0 \\
\hline \multirow[t]{7}{*}{ 1992-2000 } & Agriculture & Developed & 403 & 165 & 112 & 0.3 & 20.3 \\
\hline & Forest & Agriculture & 330 & 218 & 149 & 0.3 & 16.6 \\
\hline & Forest & Mechanically disturbed & 288 & 144 & 98 & 0.2 & 14.5 \\
\hline & Forest & Developed & 240 & 137 & 93 & 0.2 & 12.1 \\
\hline & Agriculture & Forest & 165 & 130 & 89 & 0.1 & 8.3 \\
\hline & Other & Other & 559 & $\mathrm{n} / \mathrm{a}$ & $\mathrm{n} / \mathrm{a}$ & 0.4 & 28.2 \\
\hline & & Totals & 1,984 & & & 1.6 & 100.0 \\
\hline \multirow{7}{*}{$\begin{array}{c}1973-2000 \\
\text { (overall) }\end{array}$} & Forest & Agriculture & 1,373 & 597 & 407 & 1.1 & 19.8 \\
\hline & Agriculture & Developed & 1,250 & 566 & 386 & 1.0 & 18.1 \\
\hline & Forest & Developed & 704 & 480 & 327 & 0.6 & 10.2 \\
\hline & Agriculture & Grassland/Shrubland & 694 & 247 & 168 & 0.5 & 10.0 \\
\hline & Grassland/Shrubland & Forest & 663 & 214 & 146 & 0.5 & 9.6 \\
\hline & Other & Other & 2,241 & $\mathrm{n} / \mathrm{a}$ & $\mathrm{n} / \mathrm{a}$ & 1.8 & 32.4 \\
\hline & & Totals & 6,925 & & & 5.4 & 100.0 \\
\hline
\end{tabular}




\section{References Cited}

Chester, E.W., Noel, S.M., Baskin, J.M., Baskin, C.C., and McReynolds, M.L., 1995, A phytosociological analysis of an old-growth upland wet woods on the Pennyroyal Plain, southcentral Kentucky, USA: Natural Areas Journal, v. 15, p. 297-307.

Hudson, J.C., 2002, Across this land-A regional geography of the United States and Canada: Baltimore, The Johns Hopkins University Press, 474 p.

U.S. Census Bureau, 1970-2000 [various years], Census of population and housing: U.S. Census Bureau database, accessed May 9, 2013, at http://www.census.gov/prod/ www/decennial.html.
Vogelmann, J.E., Howard, S.M., Yang, L., Larson, C.R., Wylie, B.K., and van Driel, N., 2001, Completion of the 1990s National Land Cover Data Set for the conterminous United States from Landsat Thematic Mapper data and ancillary data sources: Photogrammetric Engineering \& Remote Sensing, v. 67, p. 650-662.

Wiken, E., Jiménez Nava, F., and Griffith, G., 2011, North American terrestrial ecoregions-Level III: Montreal, Canada, Commission for Environmental Cooperation, 149 p., accessed May 1, 2013, at http://www.cec.org/ Storage/133/15860_QA07.30-32_NP_NA_Terrestrial_ Ecoregions_Level_3_Final-2june11.pdf. 



\section{Southwestern Appalachians Ecoregion}

\author{
By Terry L. Sohl
}

\section{Ecoregion Description}

The Southwestern Appalachians Ecoregion covers about $35,341 \mathrm{~km}^{2}\left(13,645 \mathrm{mi}^{2}\right)$, stretching from north-central Alabama to southeastern Kentucky (fig. 1) and including part of east-central Tennessee and the northwestern tip of Georgia. The ecoregion is bounded on the north-northwest by the Interior Plateau Ecoregion; on the east-northeast, by the Western Allegheny Plateau and Central Appalachians Ecoregions; on the southeast, by the Ridge and Valley Ecoregion; and on the southwest, by the Southeastern Plains Ecoregion.

Much of the Southwestern Appalachians Ecoregion consists of open low mountains, but some parts have steep slopes with local relief of as much as $300 \mathrm{~m}$. About threefourths of the ecoregion is covered by forest, primarily mixed oak (Quercus spp.) communities and shortleaf pines (Pinus echinata) (fig. 2). Agriculture is practiced on lower slopes and valley floors, the greatest concentration of agricultural land being in northeastern Alabama. Mining is a locally significant land-use activity, especially in the southern part of the ecoregion where the local abundance of coal, limestone, and iron deposits led to a booming steel industry in the first half of the 20th century. No large cities (that is, cities that have populations greater than 100,000) are completely within the ecoregion's borders, but the greater metropolitan areas of Birmingham and Huntsville, Alabama, and Chattanooga, Tennessee, are partly within the ecoregion.

Figure 1. Map of Southwestern Appalachians Ecoregion and surrounding ecoregions, showing land-use/land-cover classes from 1992 National Land Cover Dataset (Vogelmann and others, 2001); note that not all land-use/land-cover classes shown in explanation may be depicted on map; note also that, for this "Status and Trends of Land Change" study, transitional landcover class was subdivided into mechanically disturbed and nonmechanically disturbed classes. Squares indicate locations of $10 \times 10 \mathrm{~km}$ sample blocks analyzed in study. Index map shows locations of geographic features mentioned in text. Abbreviations for Eastern United States ecoregions are listed in appendix 2. Also shown is part of one Midwest-South Central United States ecoregion, Interior River Lowland. See appendix 3 for definitions of land-use/land-cover classifications.

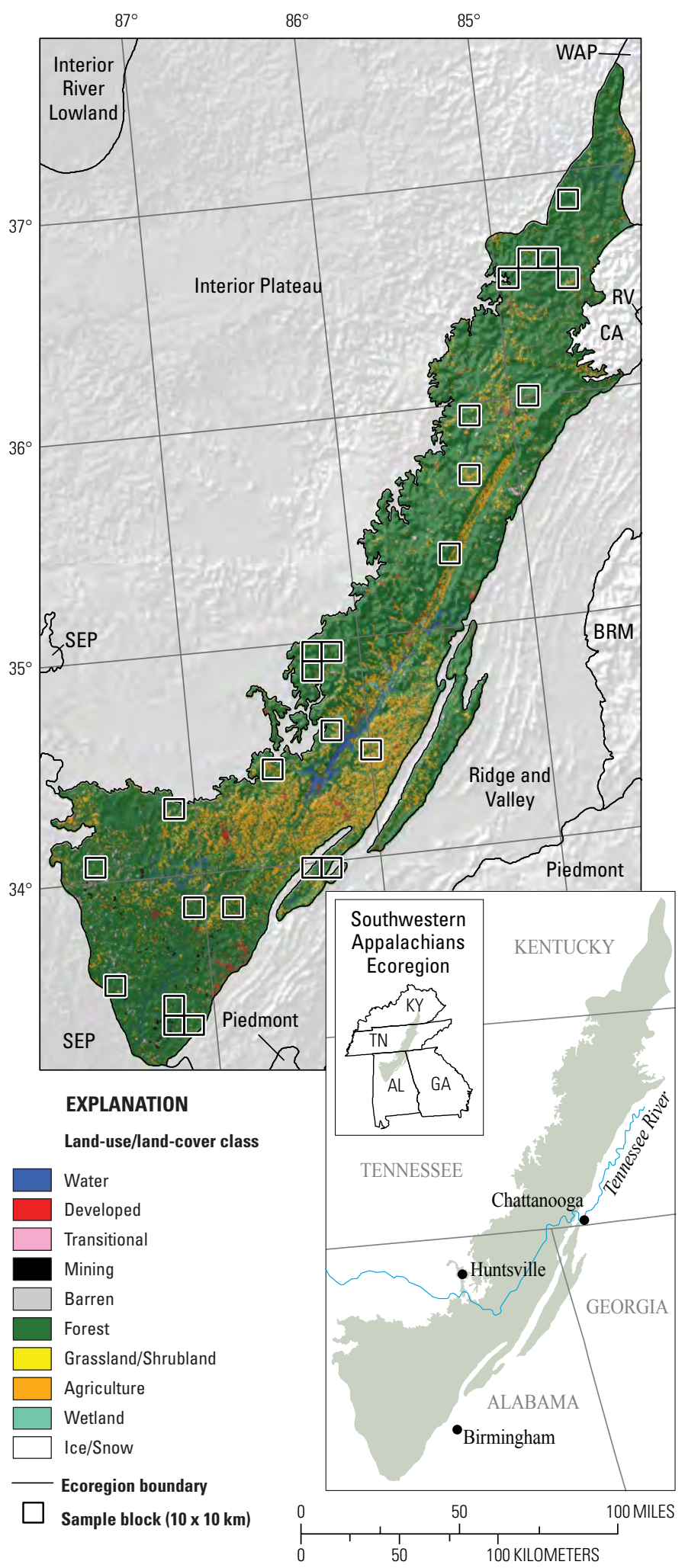




\section{Contemporary Land-Cover Change (1973 to 2000)}

The overall spatial change (the percentage of land area that changed at least one time) in the Southwestern Appalachians Ecoregion between 1973 and 2000 is estimated at 13.8 percent (table 1). Compared to other Eastern United States ecoregions, change in the Southwestern Appalachians Ecoregion is moderately high (fig. 3). The total amount of change increased in each successive time period (table 2). When normalized to an average annual rate to account for unequal time periods, change was lower during the first time period (1973-1980), and it was both higher and relatively steady for the last three time periods (1980-1986, 1986-1992, 1992-2000) (table 2; fig. 4).

No individual land-cover class changed by more than 2.7 percent of the total ecoregion area during the 27 -year study period (table 3 ). However, two factors that notably drove land-cover conversion in the ecoregion were forestry activity and mining activity. Forest consistently showed some of the largest amount of net change, with fairly consistent decreases in all four time periods (fig. 5). The conversion from forest to mechanically disturbed was the most common land-cover conversion in all four time periods, whereas the conversion from mechanically disturbed to forest (representing regeneration of cut forest land) was the second or third most common conversion (table 4). Forestry-related activities (both cutting and regeneration) clearly were one of the most significant factors affecting land-cover change in the ecoregion in all time periods (figs. 6,7).

Mining activity was the second most important factor that drove land-cover change in the ecoregion (fig. 6). Much of the surface mining in the ecoregion, especially in northern Alabama, is for coal, iron, and limestone, all primary materials required for the production of steel. The Birmingham, Alabama,

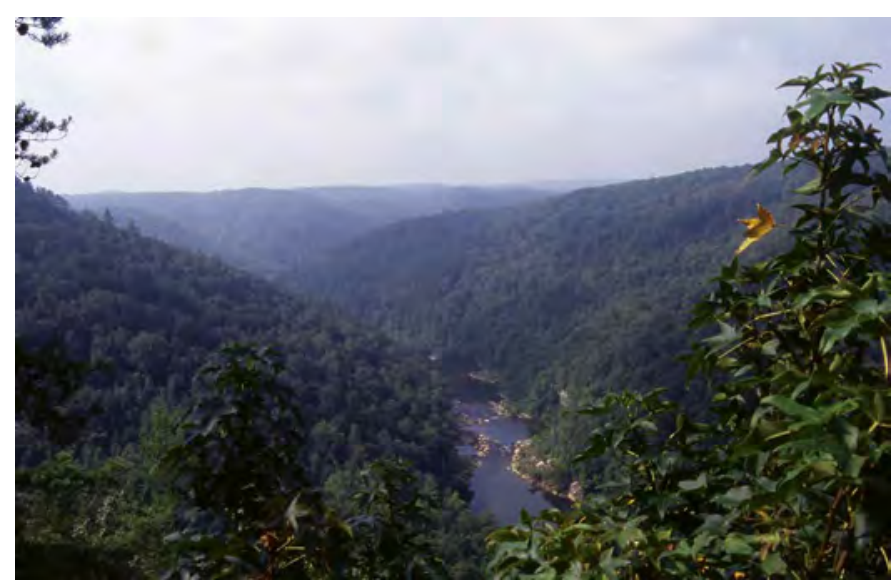

Figure 2. Forested hills in Southwestern Appalachians Ecoregion. Forests, which cover about three-fourths of ecoregion, are prevalent on most hilly and mountainous slopes.

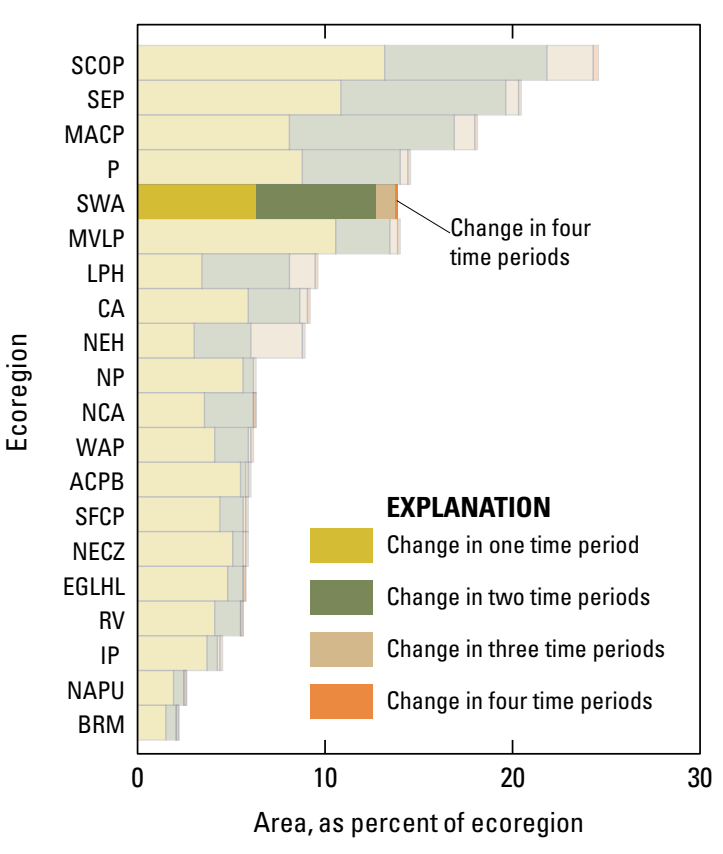

Figure 3. Overall spatial change in Southwestern Appalachians Ecoregion (SWA; darker bars) compared with that of all 20 Eastern United States ecoregions (lighter bars). Each horizontal set of bars shows proportions of ecoregion that changed during one, two, three, or four time periods; highest level of spatial change in Southwestern Appalachians Ecoregion (four time periods) labeled for clarity. See table 2 for years covered by each time period. See appendix 2 for key to ecoregion abbreviations.

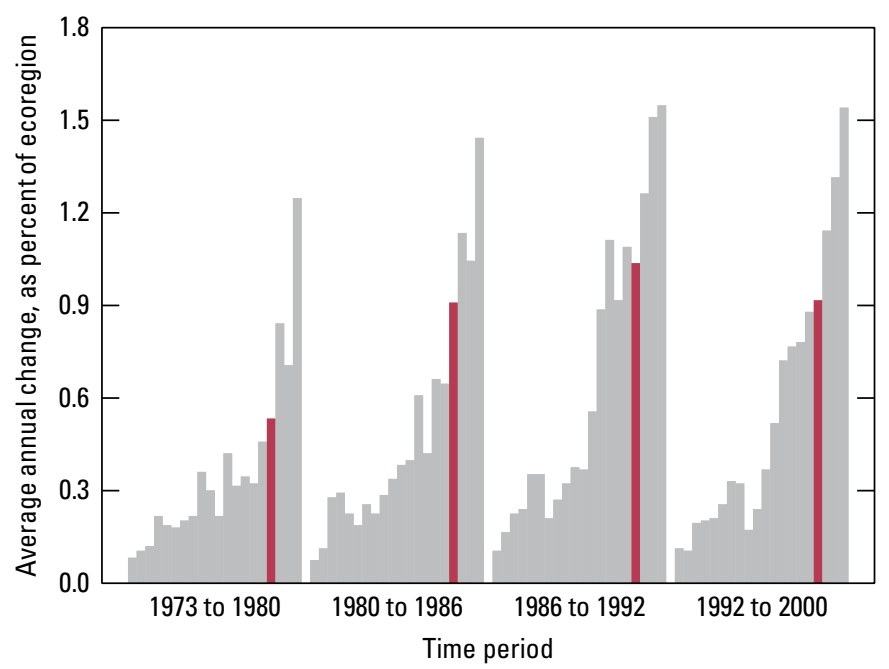

Figure 4. Estimates of land-cover change per time period, normalized to annual rates of change for all 20 Eastern United States ecoregions (gray bars). Estimates of change for Southwestern Appalachians Ecoregion are represented by red bars in each time period. 
metropolitan area, which is partly within the southern part of the ecoregion, was once known as the "Pittsburgh of the South" (Lewis, 2008). The related mining and steel industries were key components of much of the area's economy in much of the 20th century; however, the local steel industry began to decline in the second half of the 20th century. Imports of less expensive foreign steel into the United States increased significantly after 1980 , contributing to additional closures of steel facilities in the ecoregion (L.W. Gerard, 2001, written commun.). With these declines, local demand for the raw materials needed by the industry also declined. As production halted at the surface mines, many were revegetated, thus converting to grassland/ shrubland and eventually reverting to forest. Although 610 $\mathrm{km}^{2}$ of newly mined lands were established between 1973 and 2000 , more than $1,000 \mathrm{~km}^{2}$ of mined lands were reclaimed during the same time period, resulting in a net decline of

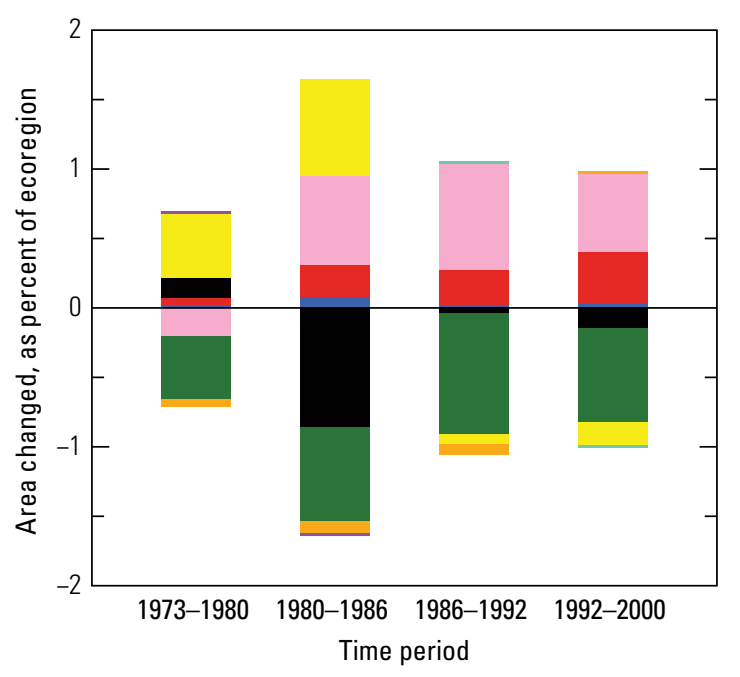

EXPLANATION

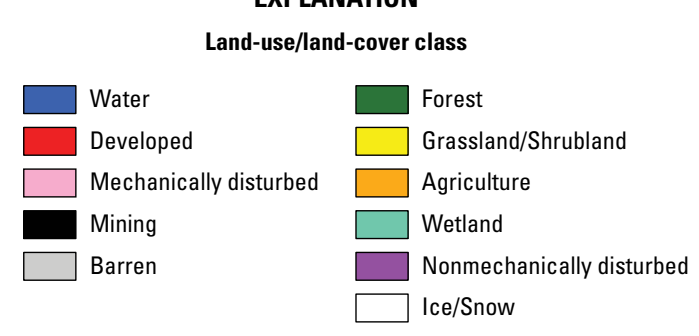

Figure 5. Normalized average net change in Southwestern Appalachians Ecoregion by time period for each land-cover class. Bars above zero axis represent net gain, whereas bars below zero represent net loss. Note that not all land-cover classes shown in explanation may be represented in figure. See appendix 3 for definitions of land-use and land-cover classifications. more than $300 \mathrm{~km}^{2}$ (table 3; fig. 8). The most significant decline was between 1980 and 1986, when mined land area decreased by more than 50 percent within the ecoregion, with very minor decreases in the last two time periods (table 3; fig. 5). Changes related to the reclamation of mined lands (including mining converting to grassland/shrubland and eventually reverting to forest) were significant land-cover conversions during all time periods (table 4).

Other land-cover conversions generally were minor in the ecoregion. Developed steadily increased throughout the study period, resulting in a net gain of more than $300 \mathrm{~km}^{2}$ between 1973 and 2000. Urban centers on the fringes of the ecoregion (for example, Birmingham, Alabama) showed only minor population gains or even decreased in population during the study period, but growth in the surrounding suburbs was the primary driver behind the net gain in developed land.

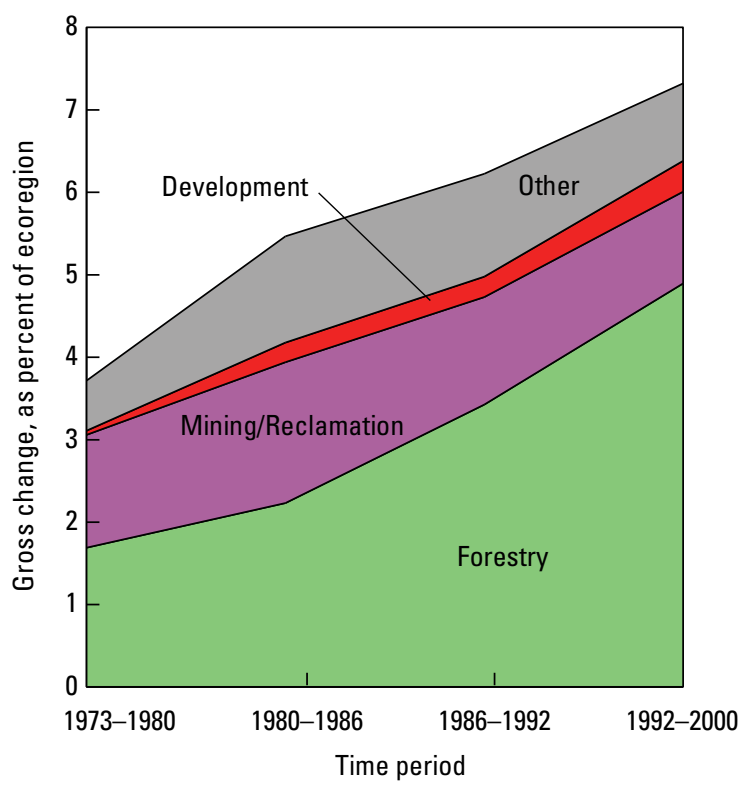

Figure 6. Gross changes in forestry (which includes both forest and mechanically disturbed land-cover classes), mining/ reclamation (which includes both mining and grassland/shrubland land-cover classes), development (developed land-cover class), and other land uses in Southwestern Appalachians Ecoregion during 27-year study period. Forestry activity (forest cutting and regeneration) and mining activity (new mining and mining reclamation) accounted for most change in ecoregion. 


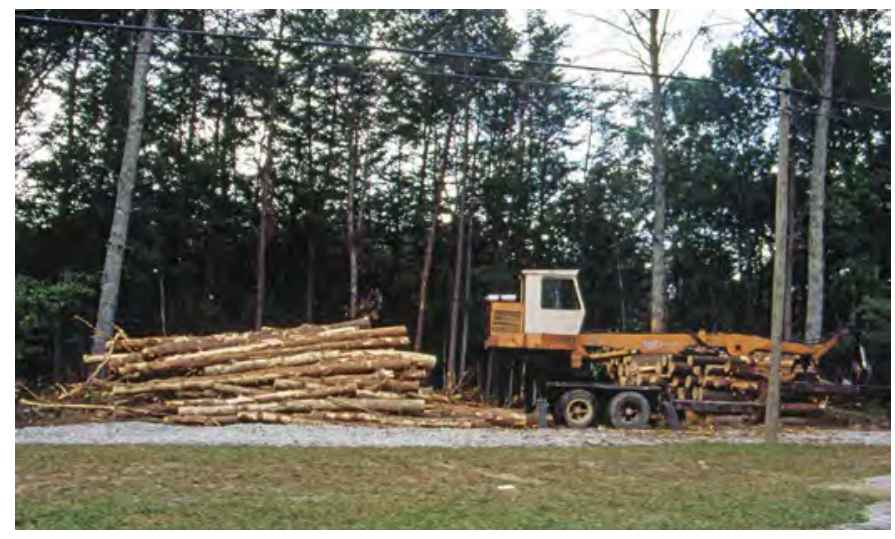

Figure 7. Timber-harvesting operation in Southwestern Appalachians Ecoregion. Most logged lands were either replanted or allowed to regenerate naturally to forest.

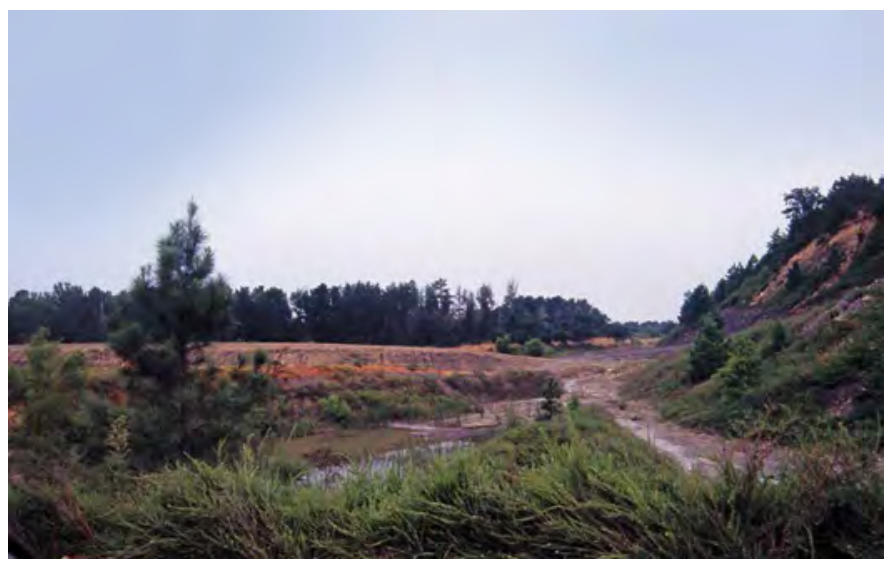

Figure 8. Gravel mine in Southwestern Appalachians Ecoregion. Mining activity historically has been important component of economy in much of ecoregion; however, amount of actively mined lands decreased during 27-year study period, and many older mines were either reclaimed or allowed to revegetate naturally. 
Table 1. Percentage of Southwestern Appalachians Ecoregion land cover that changed at least one time during study period (1973-2000) and associated statistical error.

\begin{tabular}{cccccccc}
\multicolumn{6}{l}{$\begin{array}{l}\text { [Most sample pixels remained unchanged (86.2 percent), whereas } 13.8 \text { percent } \\
\text { changed at least once throughout study period] }\end{array}$} \\
$\begin{array}{c}\text { Number } \\
\text { of } \\
\text { changes }\end{array}$ & $\begin{array}{c}\text { Percent } \\
\text { of } \\
\text { ecoregion }\end{array}$ & $\begin{array}{c}\text { Margin } \\
\text { of error } \\
(+/-\%)\end{array}$ & $\begin{array}{c}\text { Lower } \\
\text { bound } \\
(\%)\end{array}$ & $\begin{array}{c}\text { Upper } \\
\text { bound } \\
(\%)\end{array}$ & $\begin{array}{c}\text { Standard } \\
\text { error } \\
(\%)\end{array}$ & $\begin{array}{c}\text { Relative } \\
\text { error } \\
(\%)\end{array}$ \\
\hline 1 & 6.3 & 1.5 & 4.8 & 7.7 & 1.0 & 15.7 \\
2 & 6.3 & 2.0 & 4.3 & 8.3 & 1.3 & 21.3 \\
3 & 1.1 & 0.4 & 0.7 & 1.5 & 0.3 & 24.2 \\
4 & 0.1 & 0.1 & 0.0 & 0.2 & 0.0 & 37.9 \\
\hline $\begin{array}{l}\text { Overall } \\
\text { spatial } \\
\text { change }\end{array}$ & 13.8 & 3.7 & 10.1 & 17.6 & 2.5 & 18.1 \\
\hline
\end{tabular}

Table 2. Raw estimates of change in Southwestern Appalachians Ecoregion land cover, computed for each of four time periods between 1973 and 2000, and associated error at 85-percent confidence level.

[Estimates of change per period normalized to annual rate of change for each period]

\begin{tabular}{|c|c|c|c|c|c|c|c|}
\hline Period & $\begin{array}{c}\text { Total change } \\
\text { (\% of ecoregion) }\end{array}$ & $\begin{array}{c}\text { Margin of } \\
\text { error } \\
(+/-\%)\end{array}$ & $\begin{array}{l}\text { Lower } \\
\text { bound } \\
(\%)\end{array}$ & $\begin{array}{l}\text { Upper bound } \\
(\%)\end{array}$ & $\begin{array}{c}\text { Standard } \\
\text { error } \\
(\%)\end{array}$ & $\begin{array}{c}\text { Relative } \\
\text { error } \\
(\%)\end{array}$ & $\begin{array}{r}\text { Average rate } \\
\text { (\% per year) }\end{array}$ \\
\hline \multicolumn{8}{|c|}{ Estimate of change, in percent stratum } \\
\hline 1973-1980 & 3.7 & 1.2 & 2.5 & 5.0 & 0.8 & 22.4 & 0.5 \\
\hline 1980-1986 & 5.5 & 1.5 & 3.9 & 7.0 & 1.0 & 19.0 & 0.9 \\
\hline 1986-1992 & 6.2 & 1.8 & 4.4 & 8.0 & 1.2 & 19.7 & 1.0 \\
\hline 1992-2000 & 7.3 & 2.3 & 5.1 & 9.6 & 1.5 & 20.8 & 0.9 \\
\hline \multicolumn{8}{|c|}{ Estimate of change, in square kilometers } \\
\hline 1973-1980 & 1,313 & 438 & 875 & 1,750 & 294 & 22.4 & 188 \\
\hline 1980-1986 & 1,931 & 545 & 1,386 & 2,477 & 367 & 19.0 & 322 \\
\hline 1986-1992 & 2,199 & 646 & 1,553 & 2,845 & 434 & 19.7 & 367 \\
\hline 1992-2000 & 2,587 & 799 & 1,787 & 3,386 & 538 & 20.8 & 323 \\
\hline
\end{tabular}


Table 3. Estimated area (and margin of error) of each land-cover class in Southwestern Appalachians Ecoregion, calculated five times between 1973 and 2000 . See appendix 3 for definitions of land-cover classifications.

\begin{tabular}{|c|c|c|c|c|c|c|c|c|c|c|c|c|c|c|c|c|c|c|c|c|}
\hline & \multicolumn{2}{|c|}{ Water } & \multicolumn{2}{|c|}{ Developed } & \multicolumn{2}{|c|}{$\begin{array}{l}\text { Mechanical- } \\
\text { ly disturbed }\end{array}$} & \multicolumn{2}{|c|}{ Mining } & \multicolumn{2}{|c|}{ Barren } & \multicolumn{2}{|c|}{ Forest } & \multicolumn{2}{|c|}{$\begin{array}{l}\text { Grassland/ } \\
\text { Shrubland }\end{array}$} & \multicolumn{2}{|c|}{ Agriculture } & \multicolumn{2}{|c|}{ Wetland } & \multicolumn{2}{|c|}{$\begin{array}{c}\text { Non- } \\
\text { mechanically } \\
\text { disturbed }\end{array}$} \\
\hline & $\%$ & $+/-$ & $\%$ & $+/-$ & $\%$ & $+/-$ & $\%$ & $+/-$ & $\%$ & $+/-$ & $\%$ & $+/-$ & $\%$ & $+1-$ & $\%$ & $+1-$ & $\%$ & $+/-$ & $\%$ & $+/-$ \\
\hline \multicolumn{21}{|c|}{ Area, in percent stratum } \\
\hline 1973 & 0.5 & 0.2 & 1.8 & 0.6 & 1.1 & 0.6 & 1.6 & 0.8 & 0.0 & 0.0 & 78.0 & 3.9 & 0.4 & 0.2 & 16.5 & 4.1 & 0.2 & 0.1 & 0.0 & 0.0 \\
\hline 1980 & 0.5 & 0.2 & 1.8 & 0.7 & 0.9 & 0.3 & 1.7 & 0.7 & 0.0 & 0.0 & 77.6 & 3.9 & 0.9 & 0.4 & 16.4 & 4.1 & 0.2 & 0.1 & 0.0 & 0.0 \\
\hline 1986 & 0.6 & 0.2 & 2.1 & 0.8 & 1.5 & 0.5 & 0.8 & 0.5 & 0.0 & 0.0 & 76.9 & 3.9 & 1.6 & 0.5 & 16.3 & 4.1 & 0.2 & 0.1 & 0.0 & 0.0 \\
\hline 1992 & 0.6 & 0.2 & 2.3 & 0.9 & 2.3 & 1.0 & 0.8 & 0.6 & 0.0 & 0.0 & 76.0 & 3.8 & 1.5 & 0.6 & 16.3 & 4.1 & 0.2 & 0.1 & 0.0 & 0.0 \\
\hline 2000 & 0.6 & 0.2 & 2.7 & 1.0 & 2.9 & 1.0 & 0.7 & 0.4 & 0.0 & 0.0 & 75.4 & 4.0 & 1.3 & 0.6 & 16.3 & 4.1 & 0.2 & 0.1 & 0.0 & 0.0 \\
\hline $\begin{array}{l}\text { Net } \\
\text { change }\end{array}$ & 0.2 & 0.1 & 0.9 & 0.5 & 1.8 & 0.8 & -0.9 & 0.8 & 0.0 & 0.0 & -2.7 & 1.1 & 0.9 & 0.4 & -0.2 & 0.3 & 0.0 & 0.0 & 0.0 & 0.0 \\
\hline $\begin{array}{l}\text { Gross } \\
\text { change }\end{array}$ & 0.2 & 0.1 & 0.9 & 0.5 & 4.6 & 1.2 & 2.7 & 1.2 & 0.0 & 0.0 & 6.0 & 1.4 & 2.2 & 0.7 & 0.9 & 0.2 & 0.0 & 0.0 & 0.0 & 0.1 \\
\hline \multicolumn{21}{|c|}{ Area, in square kilometers } \\
\hline 1973 & 165 & 59 & 634 & 224 & 384 & 195 & 551 & 295 & 1 & 1 & 27,583 & 1,374 & 139 & 62 & 5,823 & 1,443 & 60 & 32 & 0 & 0 \\
\hline 1980 & 175 & 61 & 652 & 232 & 314 & 119 & 600 & 263 & 1 & 1 & 27,425 & 1,362 & 305 & 135 & 5,803 & 1,441 & 60 & 32 & 7 & 10 \\
\hline 1986 & 201 & 74 & 736 & 277 & 543 & 168 & 295 & 160 & 1 & 1 & 27,186 & 1,372 & 549 & 187 & 5,772 & 1,445 & 60 & 32 & 0 & 0 \\
\hline 1992 & 209 & 74 & 824 & 314 & 819 & 366 & 281 & 204 & 1 & 1 & 26,875 & 1,344 & 528 & 205 & 5,745 & 1,445 & 60 & 32 & 0 & 0 \\
\hline 2000 & 221 & 81 & 955 & 368 & 1,020 & 350 & 233 & 127 & 1 & 1 & 26,635 & 1,409 & 467 & 208 & 5,750 & 1,452 & 59 & 32 & 0 & 0 \\
\hline $\begin{array}{l}\text { Net } \\
\text { change }\end{array}$ & 56 & 40 & 321 & 162 & 636 & 297 & -318 & 270 & 0 & 0 & -948 & 405 & 327 & 159 & -74 & 111 & -1 & 1 & 0 & 0 \\
\hline $\begin{array}{l}\text { Gross } \\
\text { change }\end{array}$ & 56 & 40 & 321 & 162 & 1,642 & 416 & 937 & 412 & 0 & 0 & 2,109 & 494 & 786 & 242 & 332 & 87 & 1 & 1 & 14 & 20 \\
\hline
\end{tabular}


Table 4. Principal land-cover conversions in Southwestern Appalachians Ecoregion, showing amount of area changed (and margin of error, calculated at 85-percent confidence level) for each conversion during each of four time periods and also during overall study period. See appendix 3 for definitions of land-cover classifications.

[Values given for "other" classes are combined totals of values for other land-cover classes not listed in that time period. Abbreviations: n/a, not applicable]

\begin{tabular}{|c|c|c|c|c|c|c|c|}
\hline Period & From class & To class & $\begin{array}{c}\begin{array}{c}\text { Area } \\
\text { changed }\end{array} \\
\left(\mathbf{k m}^{2}\right)\end{array}$ & $\begin{array}{c}\text { Margin of } \\
\text { error } \\
\left(+/-\mathbf{k m}^{2}\right)\end{array}$ & $\begin{array}{c}\text { Standard } \\
\text { error } \\
\left(\mathbf{k m}^{2}\right) \\
\end{array}$ & $\begin{array}{l}\text { Percent of } \\
\text { ecoregion }\end{array}$ & $\begin{array}{l}\text { Percent of all } \\
\text { changes }\end{array}$ \\
\hline \multirow[t]{7}{*}{$1973-1980$} & Forest & Mechanically disturbed & 302 & 115 & 77 & 0.9 & 23.0 \\
\hline & Mechanically disturbed & Forest & 295 & 186 & 125 & 0.8 & 22.4 \\
\hline & Forest & Mining & 239 & 116 & 78 & 0.7 & 18.2 \\
\hline & Mining & Forest & 115 & 101 & 68 & 0.3 & 8.7 \\
\hline & Mining & Grassland/Shrubland & 101 & 94 & 63 & 0.3 & 7.7 \\
\hline & Other & Other & 262 & $\mathrm{n} / \mathrm{a}$ & $\mathrm{n} / \mathrm{a}$ & 0.7 & 20.0 \\
\hline & & Totals & 1,313 & & & 3.7 & 100.0 \\
\hline \multirow[t]{7}{*}{$1980-1986$} & Forest & Mechanically disturbed & 531 & 164 & 110 & 1.5 & 27.5 \\
\hline & Mining & Grassland/Shrubland & 298 & 142 & 95 & 0.8 & 15.4 \\
\hline & Mechanically disturbed & Forest & 256 & 107 & 72 & 0.7 & 13.3 \\
\hline & Grassland/Shrubland & Forest & 187 & 99 & 67 & 0.5 & 9.7 \\
\hline & Mining & Forest & 154 & 84 & 56 & 0.4 & 8.0 \\
\hline & Other & Other & 505 & $\mathrm{n} / \mathrm{a}$ & $\mathrm{n} / \mathrm{a}$ & 1.4 & 26.2 \\
\hline & & Totals & 1,931 & & & 5.5 & 100.0 \\
\hline \multirow[t]{7}{*}{ 1986-1992 } & Forest & Mechanically disturbed & 789 & 351 & 236 & 2.2 & 35.9 \\
\hline & Mechanically disturbed & Forest & 421 & 148 & 100 & 1.2 & 19.1 \\
\hline & Grassland/Shrubland & Forest & 283 & 93 & 62 & 0.8 & 12.9 \\
\hline & Mining & Grassland/Shrubland & 136 & 76 & 51 & 0.4 & 6.2 \\
\hline & Forest & Mining & 134 & 94 & 63 & 0.4 & 6.1 \\
\hline & Other & Other & 435 & $\mathrm{n} / \mathrm{a}$ & $\mathrm{n} / \mathrm{a}$ & 1.2 & 19.8 \\
\hline & & Totals & 2,199 & & & 6.2 & 100.0 \\
\hline \multirow[t]{7}{*}{ 1992-2000 } & Forest & Mechanically disturbed & 1,003 & 346 & 233 & 2.8 & 38.8 \\
\hline & Mechanically disturbed & Forest & 726 & 356 & 239 & 2.1 & 28.1 \\
\hline & Grassland/Shrubland & Forest & 244 & 104 & 70 & 0.7 & 9.4 \\
\hline & Mining & Grassland/Shrubland & 136 & 122 & 82 & 0.4 & 5.3 \\
\hline & Forest & Mining & 94 & 61 & 41 & 0.3 & 3.6 \\
\hline & Other & Other & 384 & $\mathrm{n} / \mathrm{a}$ & $\mathrm{n} / \mathrm{a}$ & 1.1 & 14.9 \\
\hline & & Totals & 2,587 & & & 7.3 & 100.0 \\
\hline \multirow{7}{*}{$\begin{array}{c}1973-2000 \\
\text { (overall) }\end{array}$} & Forest & Mechanically disturbed & 2,626 & 876 & 589 & 7.4 & 32.7 \\
\hline & Mechanically disturbed & Forest & 1,698 & 709 & 477 & 4.8 & 21.1 \\
\hline & Grassland/Shrubland & Forest & 750 & 274 & 184 & 2.1 & 9.3 \\
\hline & Mining & Grassland/Shrubland & 671 & 359 & 241 & 1.9 & 8.4 \\
\hline & Forest & Mining & 610 & 314 & 211 & 1.7 & 7.6 \\
\hline & Other & Other & 1,675 & $\mathrm{n} / \mathrm{a}$ & $\mathrm{n} / \mathrm{a}$ & 4.7 & 20.9 \\
\hline & & Totals & 8,030 & & & 22.7 & 100.0 \\
\hline
\end{tabular}




\section{References Cited}

Lewis, H.J., 2008, Birmingham: Encyclopedia of Alabama, accessed September 4, 2015, at http://www. encyclopediaofalabama.org/article/h-1421.

Vogelmann, J.E., Howard, S.M., Yang, L., Larson, C.R., Wylie, B.K., and van Driel, N., 2001, Completion of the 1990s National Land Cover Data Set for the conterminous United States from Landsat Thematic Mapper data and ancillary data sources: Photogrammetric Engineering \& Remote Sensing, v. 67, p. 650-662. 


\title{
Chapter 14
}

\section{Blue Ridge Mountains Ecoregion}

\author{
By Janis L. Taylor, Rachel M.K. Headley, and Darrell E. Napton
}

\section{Ecoregion Description}

The Blue Ridge Mountains Ecoregion, in the southern Appalachian Mountains, is the easternmost of the Appalachian highland ecoregions (fig. 1). More than $1,100 \mathrm{~km}$ long and ranging between 8 and $80 \mathrm{~km}$ wide, the ecoregion covers about $47,791 \mathrm{~km}^{2}\left(18,452 \mathrm{mi}^{2}\right)$ in eight states: Georgia, South Carolina, North Carolina, Tennessee, Virginia, West Virginia, Maryland, and Pennsylvania. The ecoregion is bounded on the west-northwest by the Ridge and Valley Ecoregion; and on the east-southeast, by the Piedmont and Northern Piedmont Ecoregions.

The Blue Ridge Mountains Ecoregion primarily is forested, with cool summers and cold winters. Almost onethird of the ecoregion is under public ownership, including two national parks (Great Smoky Mountains National Park and Shenandoah National Park), the Blue Ridge Parkway, seven national forests, and 29 wilderness areas (Nash, 1999). Areas within the Great Smoky Mountains National Park have been declared an International Biosphere Reserve because of the large number of endemic species of flora and fauna present there (Bousquet, 2000). The overall landscape is a mosaic of large continuous blocks of forest intermixed with agriculture and dotted with small parcels of developed land.

Figure 1. Map of Blue Ridge Mountains Ecoregion and surrounding ecoregions, showing land-use/land-cover classes from 1992 National Land Cover Dataset (Vogelmann and others, 2001); note that not all land-use/land-cover classes shown in explanation may be depicted on map; note also that, for this "Status and Trends of Land Change" study, transitional land-cover class was subdivided into mechanically disturbed and nonmechanically disturbed classes. Squares indicate locations of $20 \times 20 \mathrm{~km}$ sample blocks analyzed in study. Index map shows locations of geographic features mentioned in text. Abbreviations for Eastern United States ecoregions are listed in appendix 2. Also shown are parts of two Midwest-South Central United States ecoregions: Eastern Corn Belt Plains and Erie Drift Plains. See appendix 3 for definitions of land-use/ land-cover classifications.

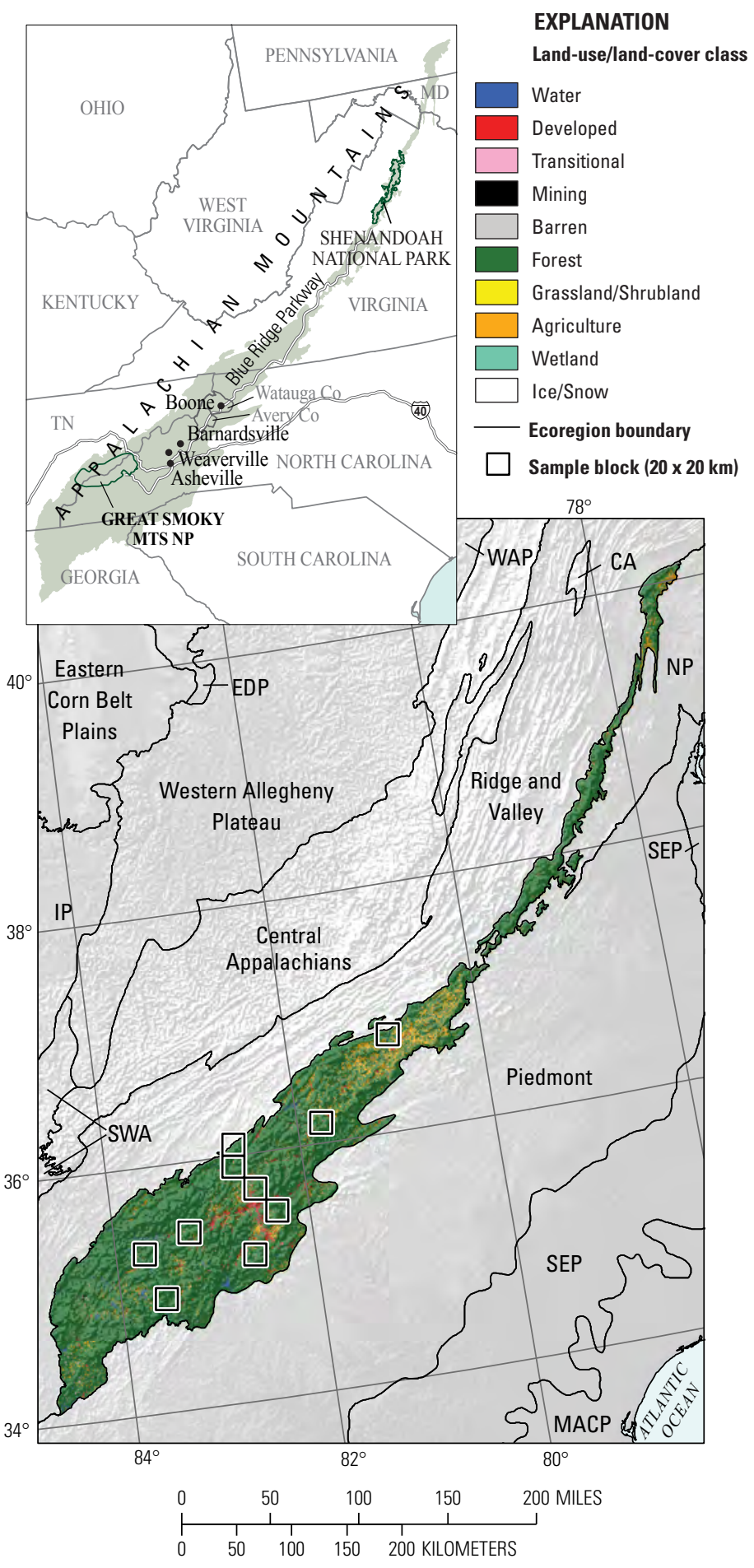




\section{Contemporary Land-Cover Change (1973 to 2000)}

Land cover in the Blue Ridge Mountains Ecoregion is fairly stable. The overall spatial change (the percentage of land area that changed at least one time) in the Blue Ridge Mountains Ecoregion between 1973 and 2000 is estimated at 2.0 percent (table 1). Compared to other Eastern United States ecoregions, change in the Blue Ridge Mountains Ecoregion was the lowest of all (fig. 2): of the land that changed, threefourths changed only one time, whereas one-fourth changed twice (table 1). Estimated changes in each of the four time periods were low, ranging from 0.4 percent between 1980 and 1986 to 0.9 percent between 1992 and 2000 (table 2). When normalized to an average annual rate to account for uneven time periods, change per time period was 0.1 percent per year in all time periods (table 2; fig. 3).

The percentage of each land-cover class on each of five mapped dates between 1973 and 2000 is shown in table 3 . Three land-cover classes (forest, agriculture, and developed) accounted for about 99.2 percent of the ecoregion in 2000.

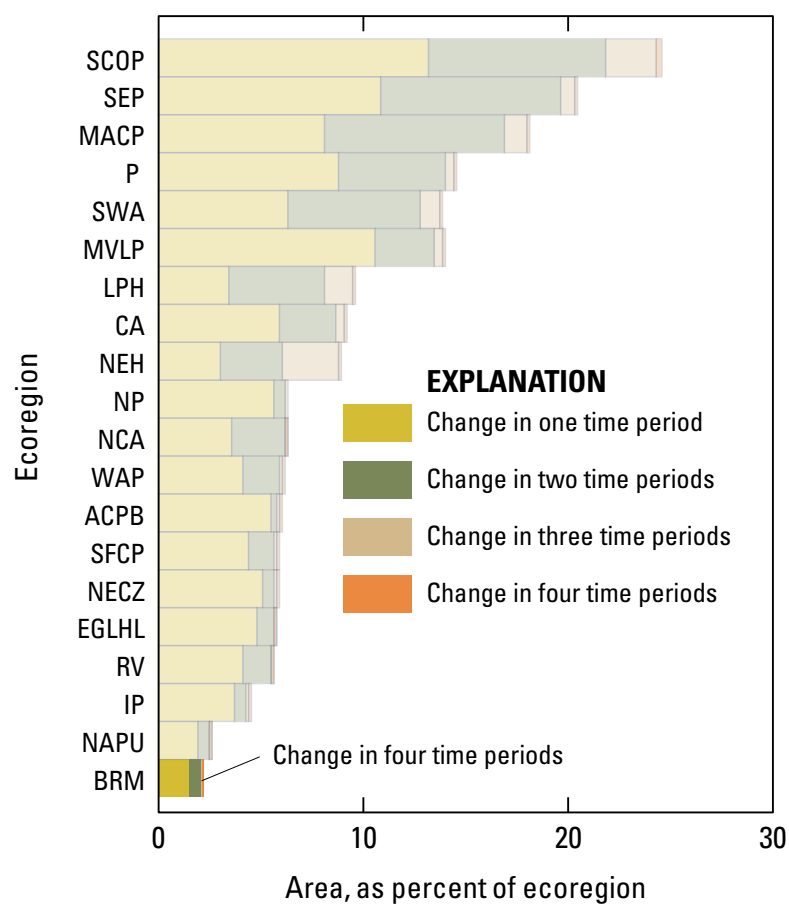

Figure 2. Overall spatial change in Blue Ridge Mountains Ecoregion (BRM; darker bars) compared with that of all 20 Eastern United States ecoregions (lighter bars). Each horizontal set of bars shows proportions of ecoregion that changed during one, two, three, or four time periods; highest level of spatial change in Blue Ridge Mountains Ecoregion (four time periods) labeled for clarity. See table 2 for years covered by each time period. See appendix 2 for key to ecoregion abbreviations.
Forest, the most common land-cover class, makes up nearly 80 percent of the ecoregion. During the entire study period, forest decreased from 79.5 percent of the ecoregion in 1973 to 78.3 percent in 2000 , a 1.2 percent decrease. Changes to forest during the study period included both unidirectional and cyclical conversions. Some forest was converted to developed, whereas some forested land was harvested for timber and then reverted to forest in subsequent years. Agriculture was the second most common land-cover class, occupying about 13.7 percent of the ecoregion in 2000 (table 3; fig. 4). During the entire study period, agriculture remained relatively stable, experiencing minor gains and losses in each time period.

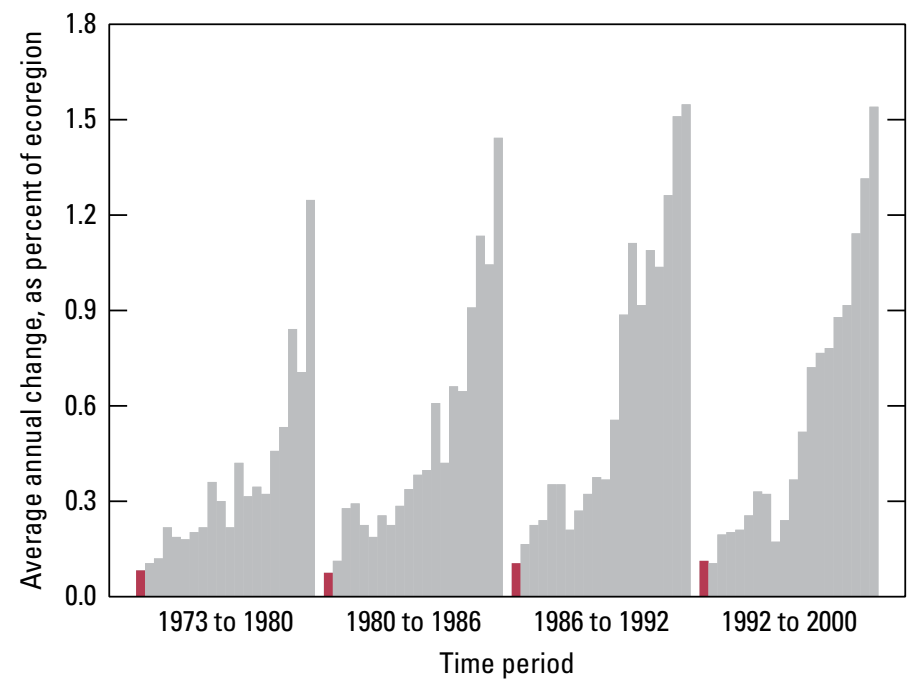

Figure 3. Estimates of land-cover change per time period, normalized to annual rates of change for all 20 Eastern United States ecoregions (gray bars). Estimates of change for Blue Ridge Mountains Ecoregion are represented by red bars in each time period.

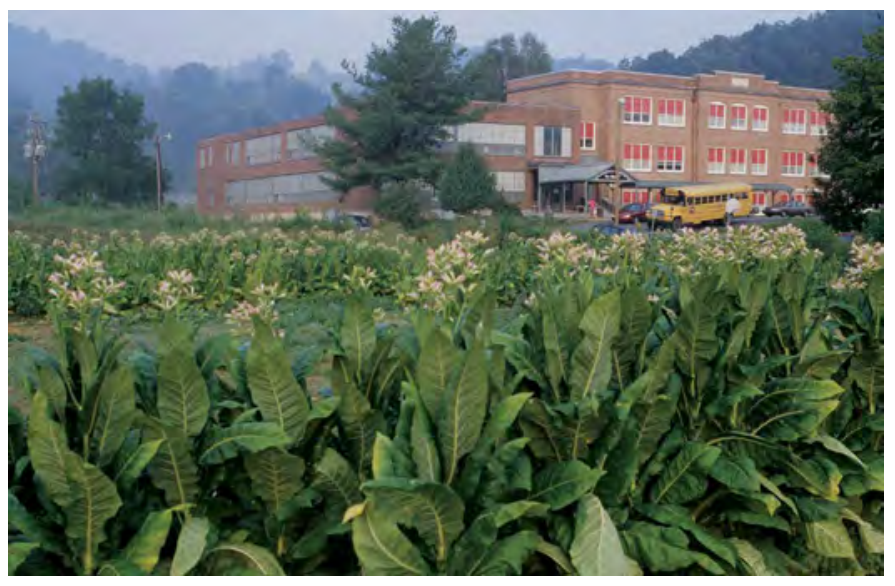

Figure 4. Tobacco field next to school, in Barnardsville, North Carolina. 
Developed, the third most common land-cover class, increased by 1.1 percent of the ecoregion, from 6.1 percent in 1972 to 7.2 percent in 2000 (table 3; figs. 5,6).

The conversion of forest to developed dominated in three of the four study periods (1973-1980, 1980-1986, 1992-2000) (table 4; fig. 7). The most common conversion of this type occurred between 1992 and 2000, when $191 \mathrm{~km}^{2}$ of forest converted to developed (table 4; fig. 8). Between 1986 and 1992, the most common land-cover conversion was from forest to mechanically disturbed: about $87 \mathrm{~km}^{2}$ of forest was cut, likely a result of commercial timber harvesting for pulpwood used to produce paper and packaging materials (Southern Appalachian Man and the Biosphere, 1996).

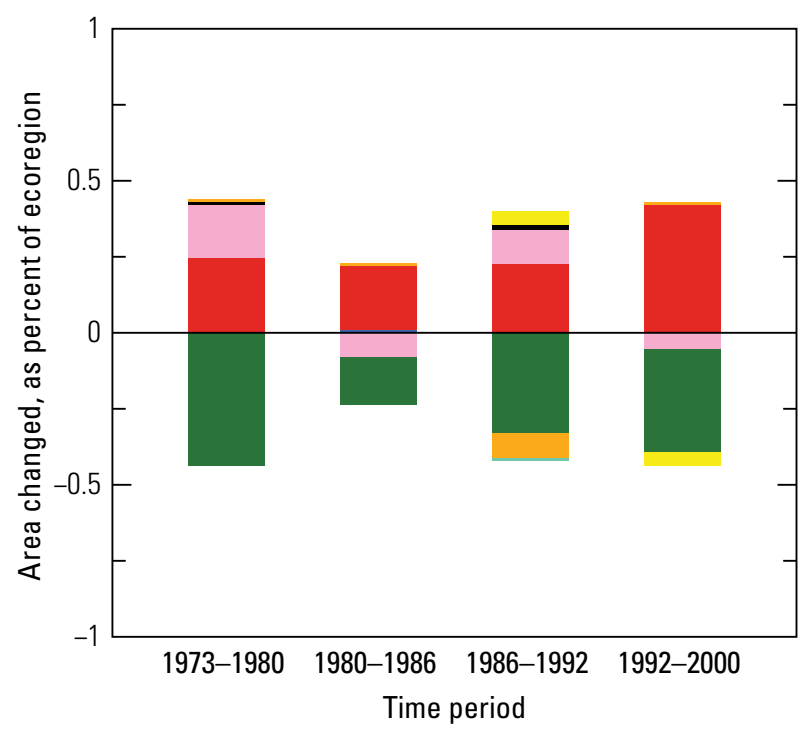

EXPLANATION

Land-use/land-cover class

$\square$ Water
$\square$ Developed
$\square$ Mechanically disturbed
$\square$ Mining
$\square$ Barren

Forest
$\square$ Grassland/Shrubland
$\square$ Agriculture
Wetland
Nonmechanically disturbed
$\square$ Ice/Snow

Figure 5. Normalized average net change in Blue Ridge Mountains Ecoregion by time period for each land-cover class. Bars above zero axis represent net gain, whereas bars below zero represent net loss. Note that not all land-cover classes shown in explanation may be represented in figure. See appendix 3 for definitions of land-use and land-cover classifications.
Overall, little change occurred in this amenity-rich ecoregion between 1973 and 2000. Most of the land-cover change that occurred was to developed, as existing urban areas expanded and exurban development increased. Between 1970 and 2000, population within the ecoregion increased by 63 percent, almost double the national increase of 34 percent (U.S. Census Bureau, 1970-2000 [various years]). Seasonal residents are drawn to the mountains, both in the summer, for a respite from the warmth and humidity of the South, and in the winter, for snow-related recreation such as skiing (Gade and others, 2002); accordingly, an increase in seasonal housing was seen in Avery and Watauga Counties, North Carolina, between 1970 and 2000 (U.S. Census Bureau, 1970-2000 [various years]).

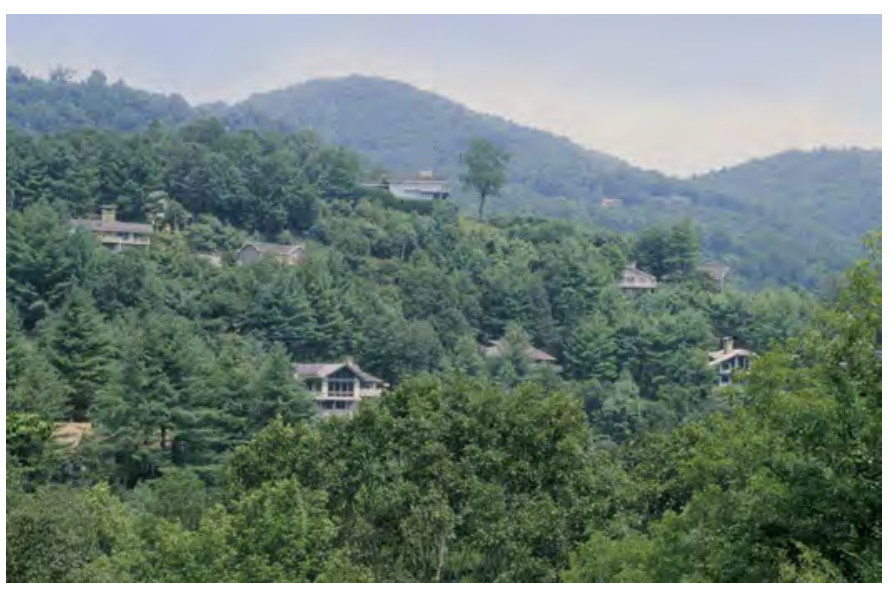

Figure 6. Homes built along ridgeline, near Boone, North Carolina.

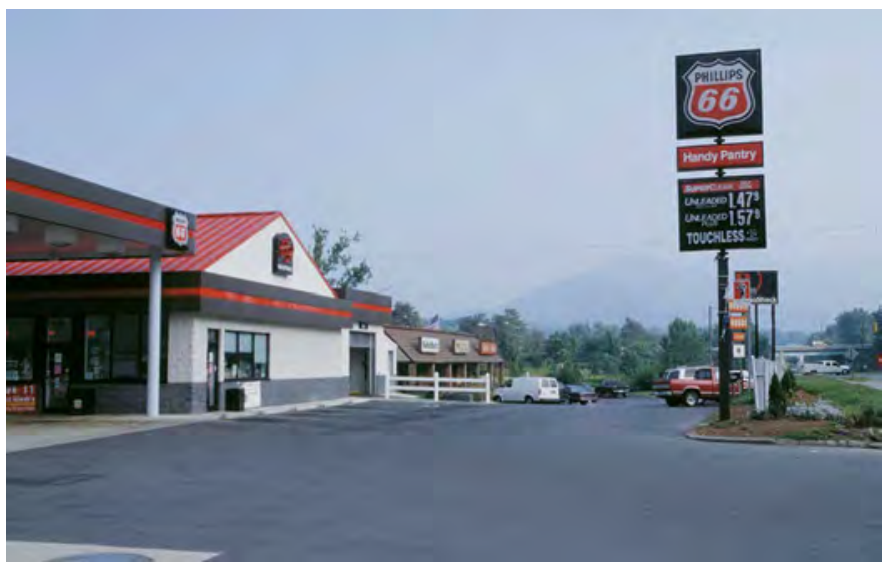

Figure 7. Gas station and strip mall on Interstate 40, near Asheville, North Carolina. 


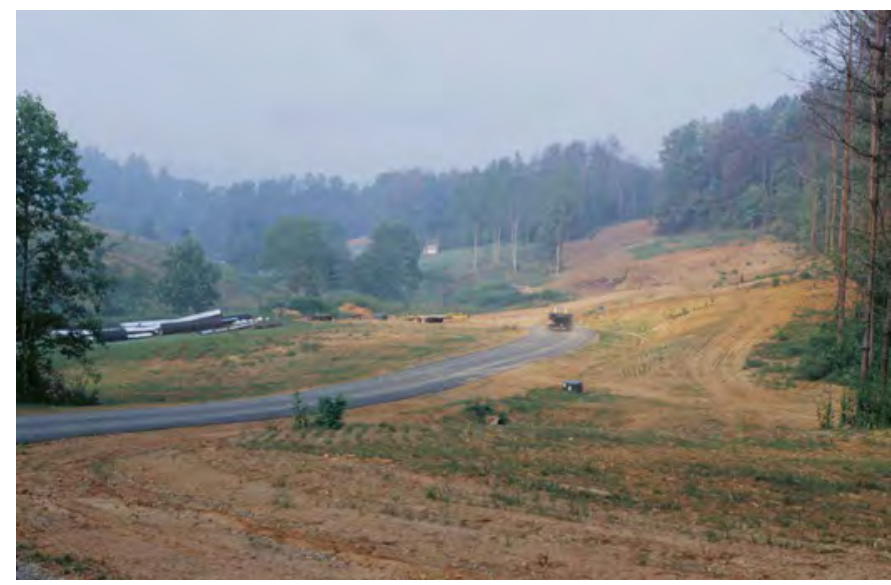

Figure 8. Land being cleared for new development in Twin Brook Hills subdivision, near Weaverville, North Carolina.
Table 1. Percentage of Blue Ridge Mountains Ecoregion land cover that changed at least one time during study period (19732000) and associated statistical error.

[Most sample pixels remained unchanged (98.0 percent), whereas 2.0 percent changed at least once throughout study period]

\begin{tabular}{ccccccc}
\hline $\begin{array}{c}\text { Number } \\
\text { of } \\
\text { changes }\end{array}$ & $\begin{array}{c}\text { Percent } \\
\text { of } \\
\text { ecoregion }\end{array}$ & $\begin{array}{c}\text { Margin } \\
\text { of error } \\
(+/-\%)\end{array}$ & $\begin{array}{c}\text { Lower } \\
\text { bound } \\
(\%)\end{array}$ & $\begin{array}{c}\text { Upper } \\
\text { bound } \\
(\%)\end{array}$ & $\begin{array}{c}\text { Standard } \\
\text { error } \\
(\%)\end{array}$ & $\begin{array}{c}\text { Relative } \\
\text { error } \\
(\%)\end{array}$ \\
\hline 1 & 1.5 & 0.4 & 1.1 & 2.0 & 0.3 & 18.7 \\
2 & 0.5 & 0.2 & 0.3 & 0.6 & 0.1 & 20.1 \\
3 & 0.0 & 0.0 & 0.0 & 0.0 & 0.0 & 91.8 \\
4 & 0.0 & 0.0 & 0.0 & 0.0 & 0.0 & 95.7 \\
\hline $\begin{array}{c}\text { Overall } \\
\text { spatial } \\
\text { change }\end{array}$ & 2.0 & 0.5 & 1.5 & 2.5 & 0.3 & 14.5 \\
\hline
\end{tabular}

Table 2. Raw estimates of change in Blue Ridge Mountains Ecoregion land cover, computed for each of four time periods between 1973 and 2000, and associated error at 85-percent confidence level.

[Estimates of change per period normalized to annual rate of change for each period]

\begin{tabular}{|c|c|c|c|c|c|c|c|}
\hline Period & $\begin{array}{c}\text { Total change } \\
\text { (\% of ecoregion) }\end{array}$ & $\begin{array}{c}\text { Margin of } \\
\text { error } \\
(+/-\%)\end{array}$ & $\begin{array}{c}\text { Lower } \\
\text { bound } \\
(\%)\end{array}$ & $\begin{array}{c}\text { Upper bound } \\
(\%)\end{array}$ & $\begin{array}{c}\text { Standard } \\
\text { error } \\
(\%)\end{array}$ & $\begin{array}{c}\text { Relative } \\
\text { error } \\
(\%)\end{array}$ & $\begin{array}{l}\text { Average rate } \\
\text { (\% per year) }\end{array}$ \\
\hline \multicolumn{8}{|c|}{ Estimate of change, in percent stratum } \\
\hline $1973-1980$ & 0.5 & 0.2 & 0.4 & 0.7 & 0.1 & 19.1 & 0.1 \\
\hline $1980-1986$ & 0.4 & 0.2 & 0.3 & 0.6 & 0.1 & 24.6 & 0.1 \\
\hline 1986-1992 & 0.6 & 0.2 & 0.4 & 0.8 & 0.1 & 23.7 & 0.1 \\
\hline $1992-2000$ & 0.9 & 0.2 & 0.7 & 1.1 & 0.1 & 12.7 & 0.1 \\
\hline \multicolumn{8}{|c|}{ Estimate of change, in square kilometers } \\
\hline $1973-1980$ & 255 & 76 & 178 & 331 & 49 & 19.1 & 36 \\
\hline $1980-1986$ & 209 & 81 & 128 & 289 & 51 & 24.6 & 35 \\
\hline 1986-1992 & 295 & 110 & 185 & 406 & 70 & 23.7 & 49 \\
\hline $1992-2000$ & 430 & 86 & 344 & 515 & 54 & 12.7 & 54 \\
\hline
\end{tabular}


Table 3. Estimated area (and margin of error) of each land-cover class in Blue Ridge Mountains Ecoregion, calculated five times between 1973 and 2000. See appendix 3 for definitions of land-cover classifications.

\begin{tabular}{|c|c|c|c|c|c|c|c|c|c|c|c|c|c|c|c|c|c|c|c|c|}
\hline & \multicolumn{2}{|c|}{ Water } & \multicolumn{2}{|c|}{ Developed } & \multicolumn{2}{|c|}{$\begin{array}{l}\text { Mechanically } \\
\text { disturbed }\end{array}$} & \multicolumn{2}{|c|}{ Mining } & \multicolumn{2}{|c|}{ Barren } & \multicolumn{2}{|c|}{ Forest } & \multicolumn{2}{|c|}{$\begin{array}{l}\text { Grassland/ } \\
\text { Shrubland }\end{array}$} & \multicolumn{2}{|c|}{ Agriculture } & \multicolumn{2}{|c|}{ Wetland } & \multicolumn{2}{|c|}{$\begin{array}{c}\text { Non- } \\
\text { mechanically } \\
\text { disturbed }\end{array}$} \\
\hline & $\%$ & $+/-$ & $\%$ & $+/-$ & $\%$ & $+/-$ & $\%$ & $+/-$ & $\%$ & $+/-$ & $\%$ & $+/-$ & $\%$ & $+/-$ & $\%$ & $+/-$ & $\%$ & $+/-$ & $\%$ & $+/-$ \\
\hline \multicolumn{21}{|c|}{ Area, in percent stratum } \\
\hline 1973 & 0.5 & 0.3 & 6.1 & 2.1 & 0.0 & 0.0 & 0.0 & 0.0 & 0.0 & 0.0 & 79.5 & 5.4 & 0.1 & 0.1 & 13.7 & 4.7 & 0.0 & 0.0 & 0.0 & 0.0 \\
\hline 1980 & 0.5 & 0.3 & 6.3 & 2.1 & 0.2 & 0.1 & 0.1 & 0.0 & 0.0 & 0.0 & 79.1 & 5.3 & 0.1 & 0.1 & 13.7 & 4.7 & 0.0 & 0.0 & 0.0 & 0.0 \\
\hline 1992 & 0.5 & 0.3 & 6.7 & 2.2 & 0.2 & 0.1 & 0.1 & 0.0 & 0.0 & 0.0 & 78.6 & 5.3 & 0.1 & 0.1 & 13.6 & 4.7 & 0.0 & 0.0 & 0.0 & 0.0 \\
\hline 2000 & 0.5 & 0.3 & 7.2 & 2.3 & 0.2 & 0.1 & 0.1 & 0.1 & 0.0 & 0.0 & 78.3 & 5.4 & 0.1 & 0.1 & 13.7 & 4.7 & 0.0 & 0.0 & 0.0 & 0.0 \\
\hline $\begin{array}{l}\text { Net } \\
\text { change }\end{array}$ & 0.0 & 0.0 & 1.1 & 0.4 & 0.2 & 0.1 & 0.0 & 0.0 & 0.0 & 0.0 & -1.3 & 0.4 & 0.0 & 0.0 & -0.1 & 0.1 & 0.0 & 0.0 & 0.0 & 0.0 \\
\hline $\begin{array}{l}\text { Gross } \\
\text { change }\end{array}$ & 0.0 & 0.0 & 1.1 & 0.4 & 0.7 & 0.3 & 0.0 & 0.0 & 0.0 & 0.0 & 1.5 & 0.4 & 0.1 & 0.1 & 0.2 & 0.1 & 0.0 & 0.0 & 0.0 & 0.0 \\
\hline 1980 & 243 & 134 & 3,014 & 1,011 & 98 & 43 & 27 & 21 & 2 & 2 & 37,809 & 2,518 & 28 & 25 & 6,556 & 2,225 & 14 & 10 & 0 & 0 \\
\hline 1986 & 247 & 133 & 3,115 & 1,060 & 60 & 37 & 31 & 22 & 2 & 2 & 37,734 & 2,560 & 28 & 25 & 6,560 & 2,234 & 14 & 10 & 0 & 0 \\
\hline 1992 & 248 & 133 & 3,223 & 1,048 & 116 & 56 & 38 & 23 & 2 & 2 & 37,580 & 2,541 & 50 & 43 & 6,521 & 2,230 & 14 & 10 & 0 & 0 \\
\hline 2000 & 248 & 133 & 3,426 & 1,083 & 91 & 55 & 38 & 24 & 2 & 2 & 37,417 & 2,559 & 31 & 28 & 6,524 & 2,231 & 14 & 10 & 0 & 0 \\
\hline $\begin{array}{l}\text { Net } \\
\text { change }\end{array}$ & 6 & 8 & 529 & 214 & 76 & 50 & 17 & 10 & 0 & 0 & -600 & 190 & 3 & 4 & -31 & 39 & 0 & 0 & 0 & 0 \\
\hline $\begin{array}{l}\text { Gross } \\
\text { change }\end{array}$ & 6 & 8 & 529 & 214 & 342 & 122 & 21 & 13 & 0 & 0 & 715 & 169 & 47 & 67 & 92 & 59 & 0 & 0 & 0 & 0 \\
\hline
\end{tabular}


Table 4. Principal land-cover conversions in Blue Ridge Mountains Ecoregion, showing amount of area changed (and margin of error, calculated at 85-percent confidence level) for each conversion during each of four time periods and also during overall study period. See appendix 3 for definitions of land-cover classifications.

[Values given for "other" classes are combined totals of values for other land-cover classes not listed in that time period. Abbreviations: n/a, not applicable]

\begin{tabular}{|c|c|c|c|c|c|c|c|}
\hline Period & From class & To class & $\begin{array}{c}\begin{array}{c}\text { Area } \\
\text { changed }\end{array} \\
\left(\mathbf{k m}^{2}\right)\end{array}$ & $\begin{array}{c}\text { Margin of } \\
\text { error } \\
\left(+/-\mathrm{km}^{2}\right)\end{array}$ & $\begin{array}{c}\text { Standard } \\
\text { error } \\
\left(\mathbf{k m}^{2}\right)\end{array}$ & $\begin{array}{l}\text { Percent of } \\
\text { ecoregion }\end{array}$ & $\begin{array}{l}\text { Percent of all } \\
\text { changes }\end{array}$ \\
\hline \multirow[t]{7}{*}{ 1973-1980 } & Forest & Developed & 112 & 59 & 37 & 0.2 & 43.9 \\
\hline & Forest & Mechanically disturbed & 83 & 44 & 28 & 0.2 & 32.7 \\
\hline & Forest & Agriculture & 23 & 19 & 12 & 0.0 & 8.9 \\
\hline & Mechanically disturbed & Forest & 8 & 7 & 5 & 0.0 & 3.2 \\
\hline & Agriculture & Forest & 8 & 8 & 5 & 0.0 & 3.1 \\
\hline & Other & Other & 21 & $\mathrm{n} / \mathrm{a}$ & $\mathrm{n} / \mathrm{a}$ & 0.0 & 8.1 \\
\hline & & Totals & 255 & & & 0.5 & 100.0 \\
\hline \multirow[t]{7}{*}{ 1980-1986 } & Forest & Developed & 95 & 68 & 43 & 0.2 & 45.4 \\
\hline & Mechanically disturbed & Forest & 61 & 36 & 23 & 0.1 & 29.1 \\
\hline & Forest & Mechanically disturbed & 28 & 19 & 12 & 0.1 & 13.5 \\
\hline & Forest & Agriculture & 10 & 10 & 6 & 0.0 & 4.8 \\
\hline & Agriculture & Developed & 6 & 8 & 5 & 0.0 & 2.8 \\
\hline & Other & Other & 9 & $\mathrm{n} / \mathrm{a}$ & $\mathrm{n} / \mathrm{a}$ & 0.0 & 4.4 \\
\hline & & Totals & 209 & & & 0.4 & 100.0 \\
\hline \multirow[t]{7}{*}{ 1986-1992 } & Forest & Mechanically disturbed & 87 & 43 & 27 & 0.2 & 29.3 \\
\hline & Forest & Developed & 66 & 53 & 34 & 0.1 & 22.3 \\
\hline & Agriculture & Developed & 42 & 41 & 26 & 0.1 & 14.2 \\
\hline & Mechanically disturbed & Forest & 31 & 19 & 12 & 0.1 & 10.6 \\
\hline & Forest & Grassland/Shrubland & 22 & 33 & 21 & 0.0 & 7.5 \\
\hline & Other & Other & 47 & $\mathrm{n} / \mathrm{a}$ & $\mathrm{n} / \mathrm{a}$ & 0.1 & 16.1 \\
\hline & & Totals & 295 & & & 0.6 & 100.0 \\
\hline \multirow[t]{7}{*}{$1992-2000$} & Forest & Developed & 191 & 71 & 45 & 0.4 & 44.4 \\
\hline & Mechanically disturbed & Forest & 104 & 55 & 35 & 0.2 & 24.2 \\
\hline & Forest & Mechanically disturbed & 85 & 56 & 35 & 0.2 & 19.9 \\
\hline & Grassland/Shrubland & Forest & 15 & 22 & 14 & 0.0 & 3.4 \\
\hline & Grassland/Shrubland & Agriculture & 8 & 11 & 7 & 0.0 & 1.8 \\
\hline & Other & Other & 27 & $\mathrm{n} / \mathrm{a}$ & $\mathrm{n} / \mathrm{a}$ & 0.1 & 6.3 \\
\hline & & Totals & 430 & & & 0.9 & 100.0 \\
\hline \multirow{7}{*}{$\begin{array}{c}1973-2000 \\
\text { (overall) }\end{array}$} & Forest & Developed & 463 & 195 & 124 & 1.0 & 39.0 \\
\hline & Forest & Mechanically disturbed & 284 & 94 & 60 & 0.6 & 23.9 \\
\hline & Mechanically disturbed & Forest & 204 & 77 & 49 & 0.4 & 17.2 \\
\hline & Agriculture & Developed & 61 & 51 & 33 & 0.1 & 5.1 \\
\hline & Forest & Agriculture & 52 & 40 & 25 & 0.1 & 4.4 \\
\hline & Other & Other & 124 & $\mathrm{n} / \mathrm{a}$ & $\mathrm{n} / \mathrm{a}$ & 0.3 & 10.4 \\
\hline & & Totals & 1,188 & & & 2.5 & 100.0 \\
\hline
\end{tabular}




\section{References Cited}

Bousquet, Woodward S., 2000, Outdoor recreation, in Orr, Douglas M., Jr., and Stuart, A.W., The North Carolina atlas-Portrait for a new century: Chapel Hill, The University of North Carolina Press, p. 409-433.

Gade, O., Rex, A.B., Young, J.E., and Perry, L.B., 2002, North Carolina-People and environments (2d ed.): Boone, N.C., Parkway Publishers, Inc., 602 p.

Nash, Steve, 1999, Blue Ridge 2020-An owner's manual: Chapel Hill, The University of North Carolina Press, 211 p.

Southern Appalachian Man and the Biosphere, 1996, The southern Appalachian assessment: Southern Appalachian Man and the Biosphere, v. 1-5, available at http://www. samab.org/site/publications/.

U.S. Census Bureau, 1970-2000 [various years], Census of population and housing: U.S. Census Bureau database, accessed May 9, 2013, at http://www.census.gov/prod/ www/decennial.html.

Vogelmann, J.E., Howard, S.M., Yang, L., Larson, C.R., Wylie, B.K., and van Driel, N., 2001, Completion of the 1990s National Land Cover Data Set for the conterminous United States from Landsat Thematic Mapper data and ancillary data sources: Photogrammetric Engineering \& Remote Sensing, v. 67, p. 650-662. 



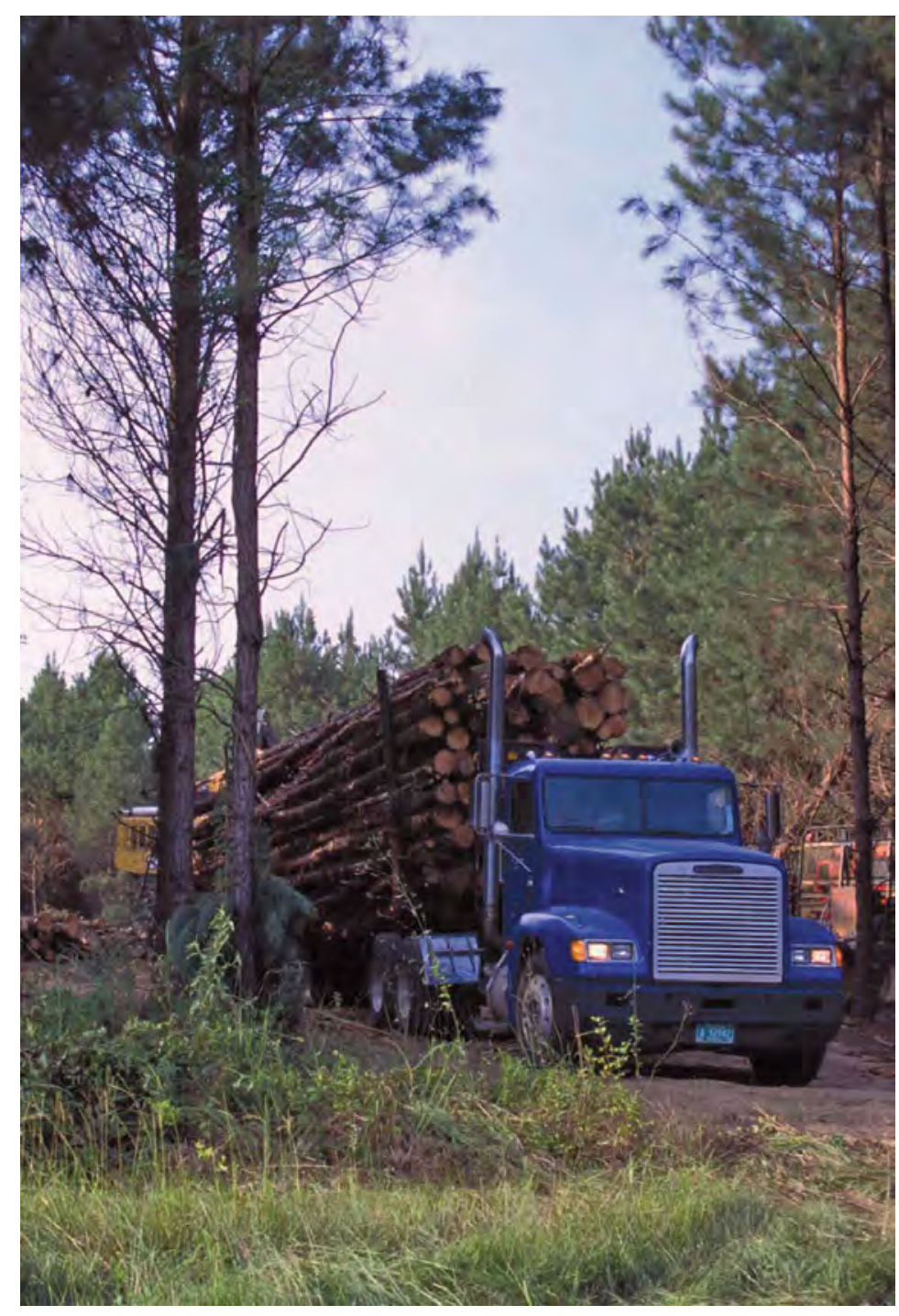




\title{
Chapter 15
}

\section{Piedmont Ecoregion}

\author{
By Darrell E. Napton
}

\section{Ecoregion Description}

The Piedmont Ecoregion, which lies in the area between the flat coastal plains to the southeast and the Appalachian Mountains to the northwest, covers $165,460 \mathrm{~km}^{2}\left(63,884 \mathrm{mi}^{2}\right)$ across parts of five states (Alabama, Georgia, South Carolina, North Carolina, and Virginia) (fig. 1). The ecoregion is bounded on the east and southeast by the Southeastern Plains Ecoregion, and, on the northwest, by the Ridge and Valley, Blue Ridge Mountains, and Northern Piedmont Ecoregions. The Piedmont Ecoregion, the landscape of which is rolling, with steepsided hills and some plains, is underlain by metamorphic and igneous rocks (Wiken and others, 2011). The pre-European vegetation mostly was forests of oak-hickory (Quercus spp.

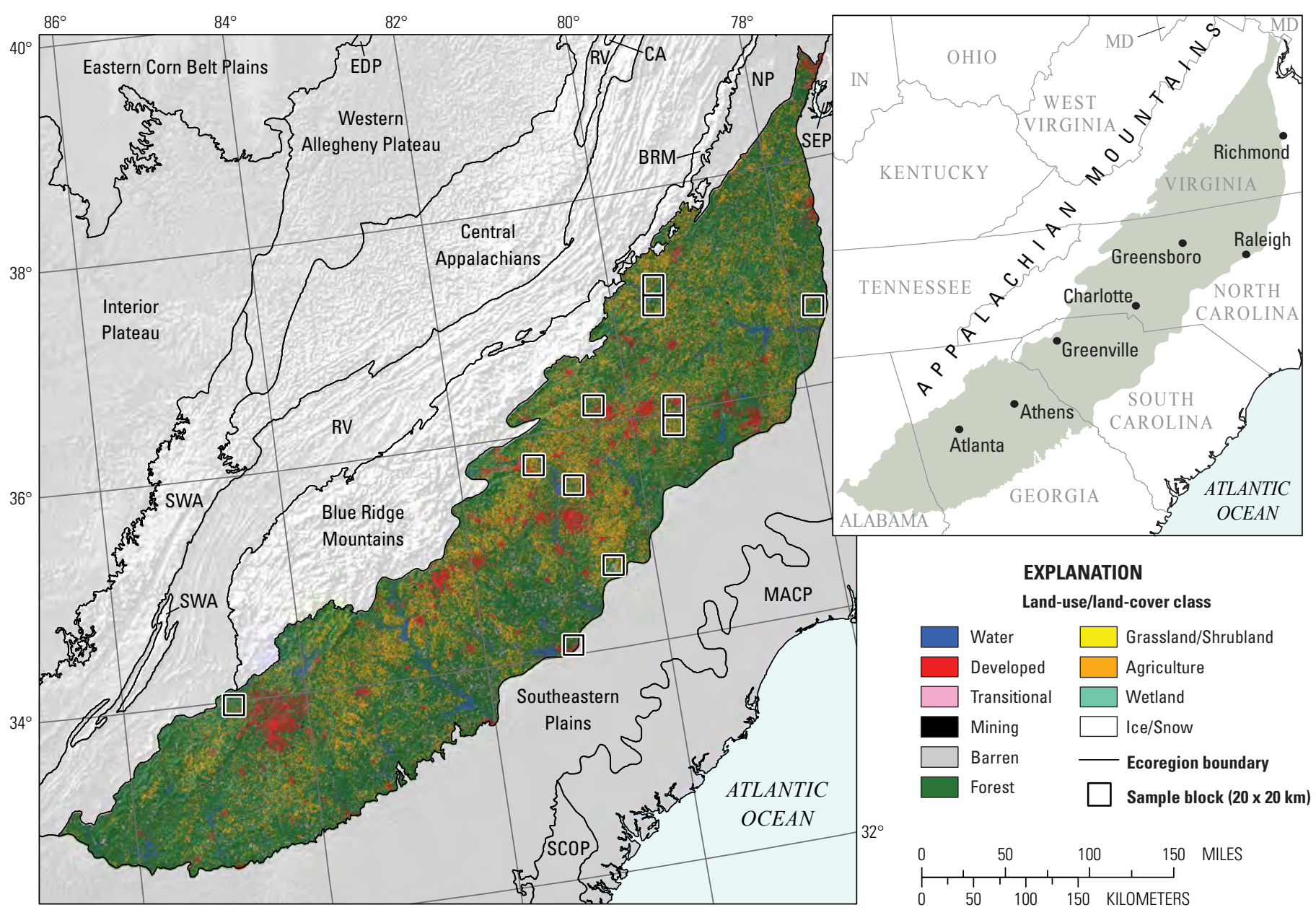

Figure 1. Map of Piedmont Ecoregion and surrounding ecoregions, showing land-use/land-cover classes from 1992 National Land Cover Dataset (Vogelmann and others, 2001); note that not all land-use/land-cover classes shown in explanation may be depicted on map; note also that, for this "Status and Trends of Land Change" study, transitional land-cover class was subdivided into mechanically disturbed and nonmechanically disturbed classes. Squares indicate locations of $20 \times 20 \mathrm{~km}$ sample blocks analyzed in study. Index map shows locations of geographic features mentioned in text. Abbreviations for Eastern United States ecoregions are listed in appendix 2. Also shown are parts of two Midwest-South Central United States ecoregions: Erie Drift Plains (EDP) and Eastern Corn Belt Plains. See appendix 3 for definitions of land-use/land-cover classifications. 
and Carya spp., respectively) and mixed oak-pine (Quercus spp. and Pinus spp., respectively) (Johnson and Sharpe, 1976). The Piedmont Ecoregion became an important farming region during the 19th century; however, beginning with the Civil War, large areas of farmland have reverted to forest during each economic downturn. During this time, Piedmont Ecoregion farmers have faced competition from other ecoregions while coping with soil erosion, declining soil fertility, and increased expenses associated with boll weevil (Anthonomus grandis) management (Manners, 1979; Hart, 1980). Additionally, the small fields and steep slopes of the ecoregion hindered the use of farm machinery (Hart, 1978). As Piedmont Ecoregion farmers lost their competitive advantage, forestry and land development became more competitive uses of land, and the ecoregion gradually reverted to pine and hardwoods intermixed with farms and developed areas (fig. 2) (Brender, 1974).

\section{Contemporary Land-Cover Change (1973 to 2000)}

The overall spatial change (the percentage of land area that changed at least one time) in the Piedmont Ecoregion between 1973 and 2000 is estimated at 14.5 percent (table 1). Compared to other Eastern United States ecoregions, change in the Piedmont Ecoregion was relatively high (fig. 3): about three-fifths of the area changed only one time, whereas twofifths changed two, three, or, in a handful of cases, four times. Most Piedmont Ecoregion land was stable (85.5 percent) and did not convert to a different land-cover class. Land-conversion rates, when normalized to an average annual rate to account for uneven time periods, varied temporally (fig. 4), ranging from a low of 0.5 percent annually between 1973 and 1980 to a high of 1.1 percent annually between 1986 and 1992 (table 2).

An overview of the net land-cover change in the Piedmont Ecoregion by time period is shown in figure

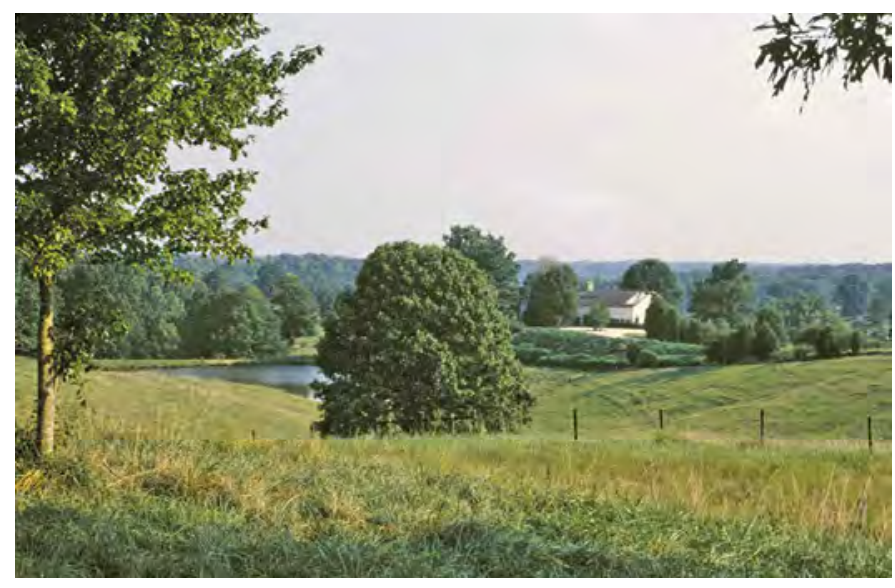

Figure 2. Typical rural landscape in Piedmont Ecoregion, with pasture amidst forest.

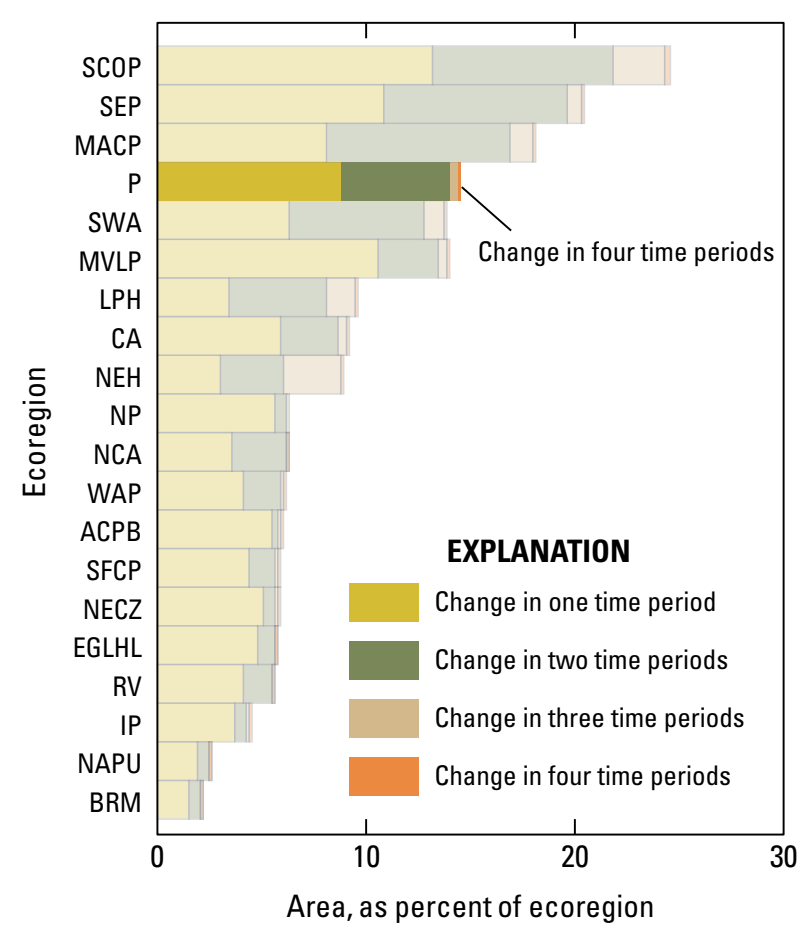

Figure 3. Overall spatial change in Piedmont Ecoregion ( $P$; darker bars) compared with that of all 20 Eastern United States ecoregions (lighter bars). Each horizontal set of bars shows proportions of ecoregion that changed during one, two, three, or four time periods; highest level of spatial change in Piedmont Ecoregion (four time periods) labeled for clarity. See table 2 for years covered by each time period. See appendix 2 for key to ecoregion abbreviations.

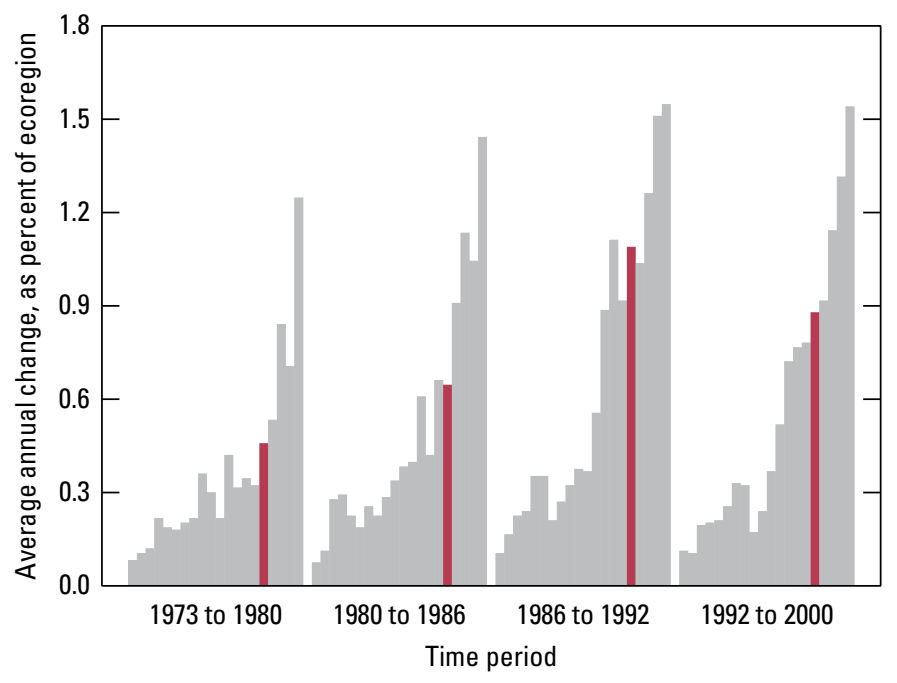

Figure 4. Estimates of land-cover change per time period, normalized to annual rates of change for all 20 Eastern United States ecoregions (gray bars). Estimates of change for Piedmont Ecoregion are represented by red bars in each time period. 
5. Developed land increased steadily and more rapidly throughout the 27-year study period, except between 1980 and 1986. This brief decrease in the rate of land-cover change may have resulted from national efforts to curb inflation, resulting in greatly reduced new housing construction through the early 1980s (National Association of Home Builders, 1973-2000 [various years]). The area of the mechanically disturbed land-cover class increased during the first three time periods (1973-1980, 1980-1986, 1986-1992), and then it decreased during the last time period (1992-2000), possibly because of the decrease in commercial forest harvesting associated with the ecoregion's population growth (van Lear and others, 2004). Forest and agriculture steadily decreased as more land was converted to developed land to accommodate the growing population of the ecoregion.

The top five common land-cover conversions accounted for 89 percent (by area) of the change in the Piedmont Ecoregion (table 3). The top two conversions were from forest to mechanically disturbed and from mechanically disturbed to forest, which represents the cyclical process of forest harvesting and regrowth (fig. 6). Three common conversions

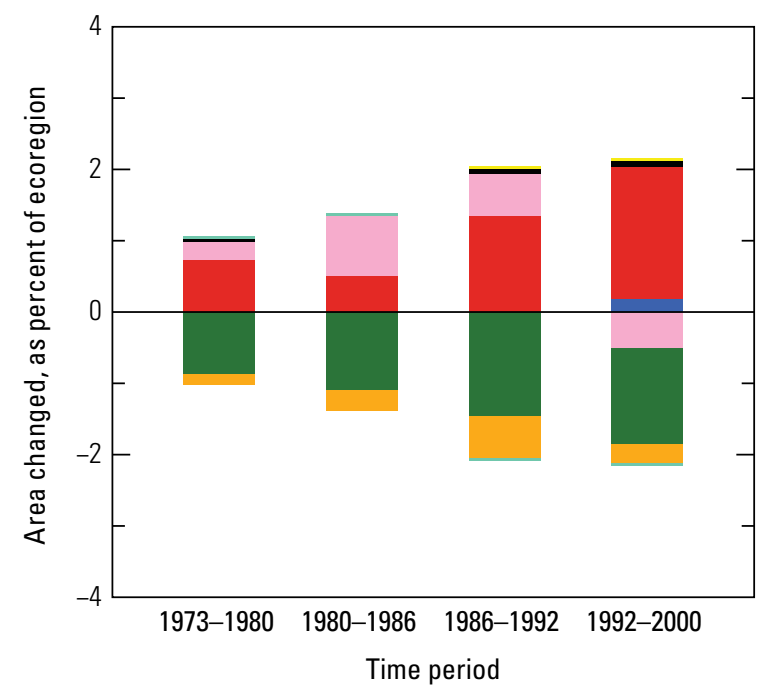

EXPLANATION

Land-use/land-cover class

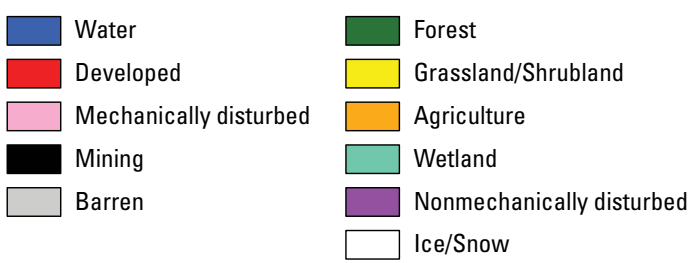

Figure 5. Normalized average net change in Piedmont Ecoregion by time period for each land-cover class. Bars above zero axis represent net gain, whereas bars below zero represent net loss. Note that not all land-cover classes shown in explanation may be represented in figure. See appendix 3 for definitions of land-use and land-cover classifications. resulted in one-way conversions from forest, agriculture, and mechanically disturbed to developed, and the forest-to-water conversion likely was caused by the need to provide potable water for the growing population in the ecoregion.

The major land-cover classes in the Piedmont Ecoregion include forest, agriculture, developed, and water (table 4), which accounted for 97.0 percent or more of the ecoregion in both the beginning (1973) and the end (2000) of the study period, but their relative proportions changed during the study period. For example, developed increased 37.8 percent, from 11.9 to 16.4 percent of the ecoregion. The Piedmont Ecoregion is in the Sun Belt, an area that grew rapidly during the latter part of the 20th century. After 1960, the population of the Piedmont Ecoregion increased faster than that of the rest of the Nation, and it continued through the remainder of the 20th century: the population increased from 7.6 to 13.8 million between 1970 and 2000 (U.S. Census Bureau, 1970-2000 [various years]), an 81.6 percent increase, much higher than the 38.0 percent increase for the conterminous United States. The new residents placed demands on the ecoregion's land, resulting in the development of additional land (fig. 7). Meanwhile, water bodies increased

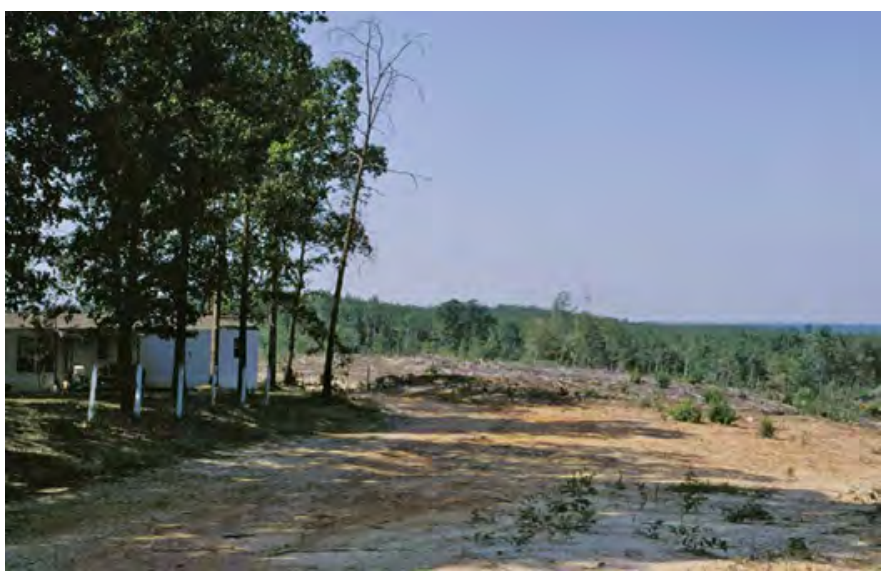

Figure 6. Recently cut forest in Piedmont Ecoregion. Commercial forestry is common in Piedmont Ecoregion.

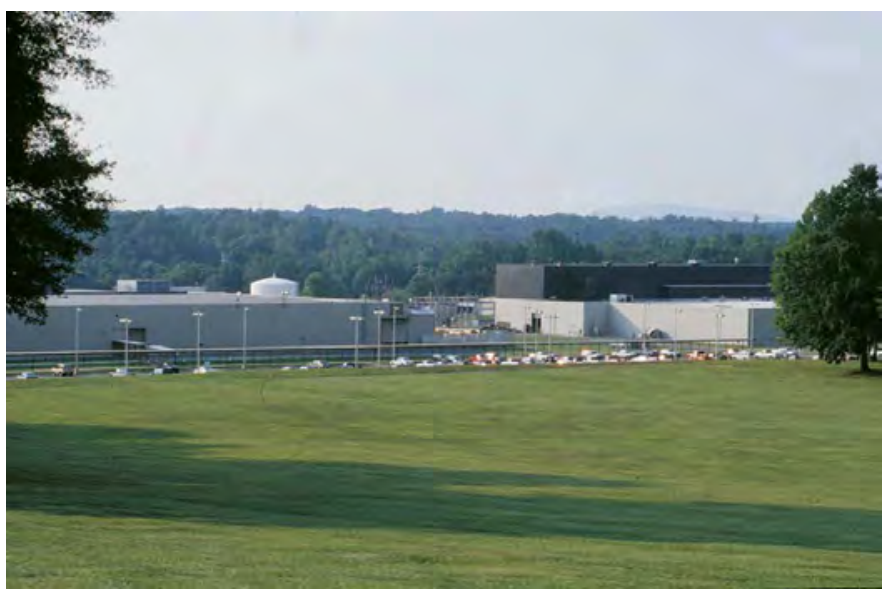

Figure 7. Large industrial plant in rural setting of Piedmont Ecoregion. Such plants provide many new jobs in ecoregion. 
in area by 9.8 percent, most likely to meet the increased need for public drinking water in the Piedmont Ecoregion, an area with scant groundwater resources (Hodler and Schretter, 1986). Forest decreased from 59.8 to 55.1 percent of the ecoregion (a decrease of 7.9 percent from its 1973 level), but forest still accounted for more than one-half of the ecoregion in 2000 (table 4). Forest constituted 71.3 percent of the land that was converted to developed (figs. 8,9). Agricultural land accounted for almost one-quarter (24.3 percent) of the newly developed land, which was about equivalent to its proportion of the ecoregion.

During the past 200 years, most of the original forests in the Piedmont Ecoregion were converted to farmland, but when the farms were unable to remain competitive nationally, much of the ecoregion reverted to forested land. During the last onethird of the 20th century, the Piedmont Ecoregion was one of the fastest developing regions in the Nation.

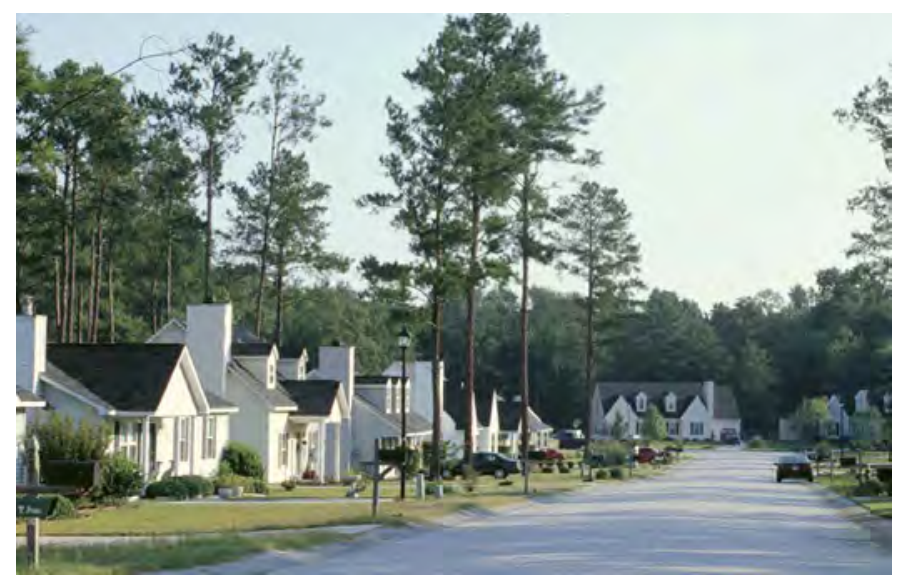

Figure 8. New subdivision built in forested area, in Piedmont Ecoregion.

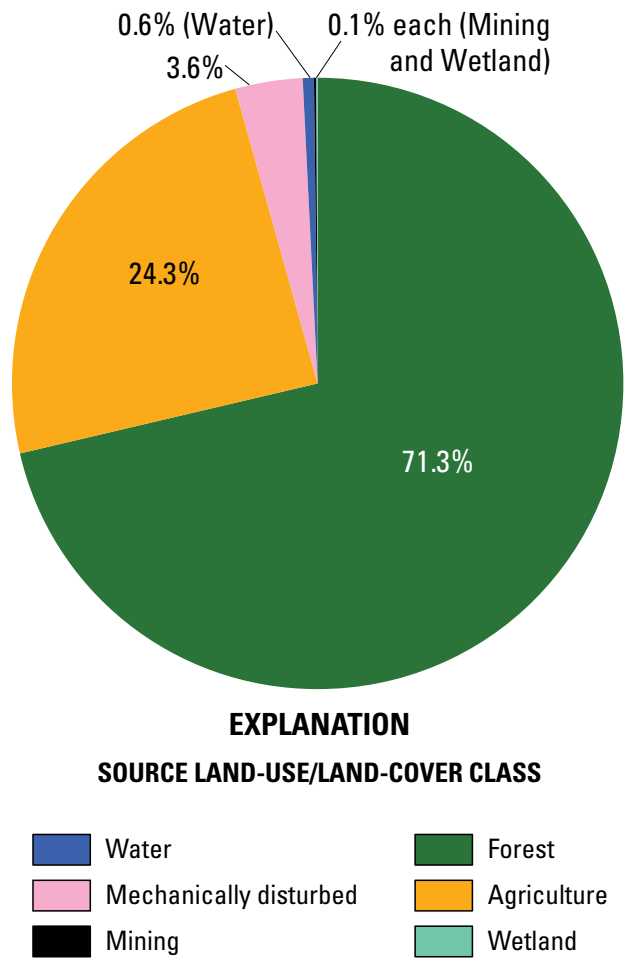

Figure 9. Areal percentages of sources of developed land in Piedmont Ecoregion during study period (1973-2000). 
Table 1. Percentage of Piedmont Ecoregion land cover that changed at least one time during study period (1973-2000) and associated statistical error.

[Most sample pixels remained unchanged ( 85.5 percent), whereas 14.5 percent changed at least once throughout study period]

\begin{tabular}{ccccccc}
\hline $\begin{array}{c}\text { Number } \\
\text { of } \\
\text { changes }\end{array}$ & $\begin{array}{c}\text { Percent } \\
\text { of } \\
\text { ecoregion }\end{array}$ & $\begin{array}{c}\text { Margin } \\
\text { of error } \\
(+/-\%)\end{array}$ & $\begin{array}{c}\text { Lower } \\
\text { bound } \\
(\%)\end{array}$ & $\begin{array}{c}\text { Upper } \\
\text { bound } \\
(\%)\end{array}$ & $\begin{array}{c}\text { Standard } \\
\text { error } \\
(\%)\end{array}$ & $\begin{array}{c}\text { Relative } \\
\text { error } \\
(\%)\end{array}$ \\
\hline 1 & 8.8 & 2.2 & 6.6 & 11.0 & 1.4 & 16.1 \\
2 & 5.2 & 2.6 & 2.7 & 7.8 & 1.7 & 31.7 \\
3 & 0.4 & 0.3 & 0.1 & 0.7 & 0.2 & 49.2 \\
4 & 0.0 & 0.0 & 0.0 & 0.1 & 0.0 & 49.4 \\
\hline $\begin{array}{c}\text { Overall } \\
\text { spatial }\end{array}$ & 14.5 & 4.6 & 9.9 & 19.1 & 3.0 & 20.4 \\
change & & & & & & \\
\hline
\end{tabular}

Table 2. Raw estimates of change in Piedmont Ecoregion land cover, computed for each of four time periods between 1973 and 2000, and associated error at 85-percent confidence level.

[Estimates of change per period normalized to annual rate of change for each period]

\begin{tabular}{rccccccc}
\hline Period & $\begin{array}{c}\text { Total } \\
\text { change } \\
\text { (\% of } \\
\text { ecore- } \\
\text { gion) }\end{array}$ & $\begin{array}{c}\text { Margin of } \\
\text { error } \\
(+/-\%)\end{array}$ & $\begin{array}{c}\text { Lower } \\
\text { bound } \\
(\%)\end{array}$ & $\begin{array}{c}\text { Upper } \\
\text { bound } \\
(\%)\end{array}$ & $\begin{array}{c}\text { Standard } \\
\text { error } \\
(\%)\end{array}$ & $\begin{array}{c}\text { Relative } \\
\text { error } \\
(\%)\end{array}$ & $\begin{array}{c}\text { Average } \\
\text { rate } \\
(\%) \text { per } \\
\text { year) }\end{array}$ \\
\hline \multicolumn{7}{c}{ Estimate of change, in percent stratum } \\
\hline $1973-1980$ & 3.2 & 1.3 & 1.9 & 4.5 & 0.8 & 26.3 & 0.5 \\
$1980-1986$ & 3.9 & 1.9 & 1.9 & 5.8 & 1.2 & 32.0 & 0.6 \\
$1986-1992$ & 6.5 & 2.5 & 4.0 & 9.0 & 1.6 & 24.7 & 1.1 \\
$1992-2000$ & 7.0 & 2.4 & 4.6 & 9.5 & 1.6 & 22.3 & 0.9 \\
\hline $1973-1980$ & 5,276 & 2,164 & 3,112 & 7,441 & 1,388 & 26.3 & 754 \\
$1980-1986$ & 6,419 & 3,207 & 3,213 & 9,626 & 2,057 & 32.0 & 1,070 \\
$1986-1992$ & 10,784 & 4,155 & 6,629 & 14,939 & 2,665 & 24.7 & 1,797 \\
$1992-2000$ & 11,604 & 4,039 & 7,565 & 15,643 & 2,591 & 22.3 & 1,451 \\
\hline
\end{tabular}


Table 3. Principal land-cover conversions in Piedmont Ecoregion, showing amount of area changed (and margin of error, calculated at 85-percent confidence level) for each conversion during each of four time periods and also during overall study period. See appendix 3 for definitions of land-cover classifications.

[Values given for "other" classes are combined totals of values for other land-cover classes not listed in that time period. Abbreviations: n/a, not applicable]

\begin{tabular}{|c|c|c|c|c|c|c|c|}
\hline Period & From class & To class & $\begin{array}{c}\begin{array}{c}\text { Area } \\
\text { changed }\end{array} \\
\left(\mathrm{km}^{2}\right)\end{array}$ & $\begin{array}{c}\text { Margin of } \\
\text { error } \\
\left(+/-\mathrm{km}^{2}\right)\end{array}$ & $\begin{array}{c}\text { Standard } \\
\text { error } \\
\left(\mathbf{k m}^{2}\right)\end{array}$ & $\begin{array}{l}\text { Percent of } \\
\text { ecoregion }\end{array}$ & $\begin{array}{c}\text { Percent } \\
\text { of all } \\
\text { changes }\end{array}$ \\
\hline \multirow[t]{7}{*}{ 1973-1980 } & Forest & Mechanically disturbed & 1,564 & 980 & 628 & 0.9 & 29.6 \\
\hline & Mechanically disturbed & Forest & 1,168 & 794 & 509 & 0.7 & 22.1 \\
\hline & Forest & Developed & 980 & 895 & 574 & 0.6 & 18.6 \\
\hline & Forest & Agriculture & 556 & 261 & 168 & 0.3 & 10.5 \\
\hline & Agriculture & Forest & 537 & 537 & 344 & 0.3 & 10.2 \\
\hline & Other & Other & 472 & $\mathrm{n} / \mathrm{a}$ & $\mathrm{n} / \mathrm{a}$ & 0.3 & 8.9 \\
\hline & & Totals & 5,276 & & & 3.2 & 100.0 \\
\hline \multirow[t]{7}{*}{ 1980-1986 } & Forest & Mechanically disturbed & 2,822 & 2,090 & 1,341 & 1.7 & 44.0 \\
\hline & Mechanically disturbed & Forest & 1,437 & 832 & 533 & 0.9 & 22.4 \\
\hline & Agriculture & Forest & 650 & 734 & 471 & 0.4 & 10.1 \\
\hline & Forest & Agriculture & 533 & 372 & 239 & 0.3 & 8.3 \\
\hline & Forest & Developed & 503 & 201 & 129 & 0.3 & 7.8 \\
\hline & Other & Other & 474 & $\mathrm{n} / \mathrm{a}$ & $\mathrm{n} / \mathrm{a}$ & 0.3 & 7.4 \\
\hline & & Totals & 6,419 & & & 3.9 & 100.0 \\
\hline \multirow[t]{7}{*}{ 1986-1992 } & Forest & Mechanically disturbed & 3,885 & 1,817 & 1,165 & 2.3 & 36.0 \\
\hline & Mechanically disturbed & Forest & 2,914 & 2,222 & 1,425 & 1.8 & 27.0 \\
\hline & Forest & Developed & 1,569 & 859 & 551 & 0.9 & 14.5 \\
\hline & Agriculture & Forest & 791 & 928 & 595 & 0.5 & 7.3 \\
\hline & Agriculture & Developed & 611 & 241 & 155 & 0.4 & 5.7 \\
\hline & Other & Other & 1,014 & $\mathrm{n} / \mathrm{a}$ & $\mathrm{n} / \mathrm{a}$ & 0.6 & 9.4 \\
\hline & & Totals & 10,784 & & & 6.5 & 100.0 \\
\hline \multirow[t]{7}{*}{ 1992-2000 } & Mechanically disturbed & Forest & 3,669 & 1,865 & 1,196 & 2.2 & 31.6 \\
\hline & Forest & Mechanically disturbed & 3,177 & 2,581 & 1,655 & 1.9 & 27.4 \\
\hline & Forest & Developed & 2,263 & 1,374 & 882 & 1.4 & 19.5 \\
\hline & Agriculture & Developed & 653 & 515 & 330 & 0.4 & 5.6 \\
\hline & Forest & Agriculture & 558 & 272 & 174 & 0.3 & 4.8 \\
\hline & Other & Other & 1,285 & $\mathrm{n} / \mathrm{a}$ & $\mathrm{n} / \mathrm{a}$ & 0.8 & 11.1 \\
\hline & & Totals & 11,604 & & & 7.0 & 100.0 \\
\hline \multirow{7}{*}{$\begin{array}{c}1973-2000 \\
\text { (overall) }\end{array}$} & Forest & Mechanically disturbed & 11,447 & 6,997 & 4,488 & 6.9 & 33.6 \\
\hline & Mechanically disturbed & Forest & 9,188 & 5,322 & 3,414 & 5.6 & 27.0 \\
\hline & Forest & Developed & 5,314 & 2,792 & 1,791 & 3.2 & 15.6 \\
\hline & Agriculture & Forest & 2,291 & 2,240 & 1,437 & 1.4 & 6.7 \\
\hline & Forest & Agriculture & 2,208 & 1,035 & 664 & 1.3 & 6.5 \\
\hline & Other & Other & 3,635 & $\mathrm{n} / \mathrm{a}$ & $\mathrm{n} / \mathrm{a}$ & 2.2 & 10.7 \\
\hline & & Totals & 34,084 & & & 20.6 & 100.0 \\
\hline
\end{tabular}


Table 4. Estimated area (and margin of error) of each land-cover class in Piedmont Ecoregion, calculated five times between 1973 and 2000. See appendix 3 for definitions of land-cover classifications.

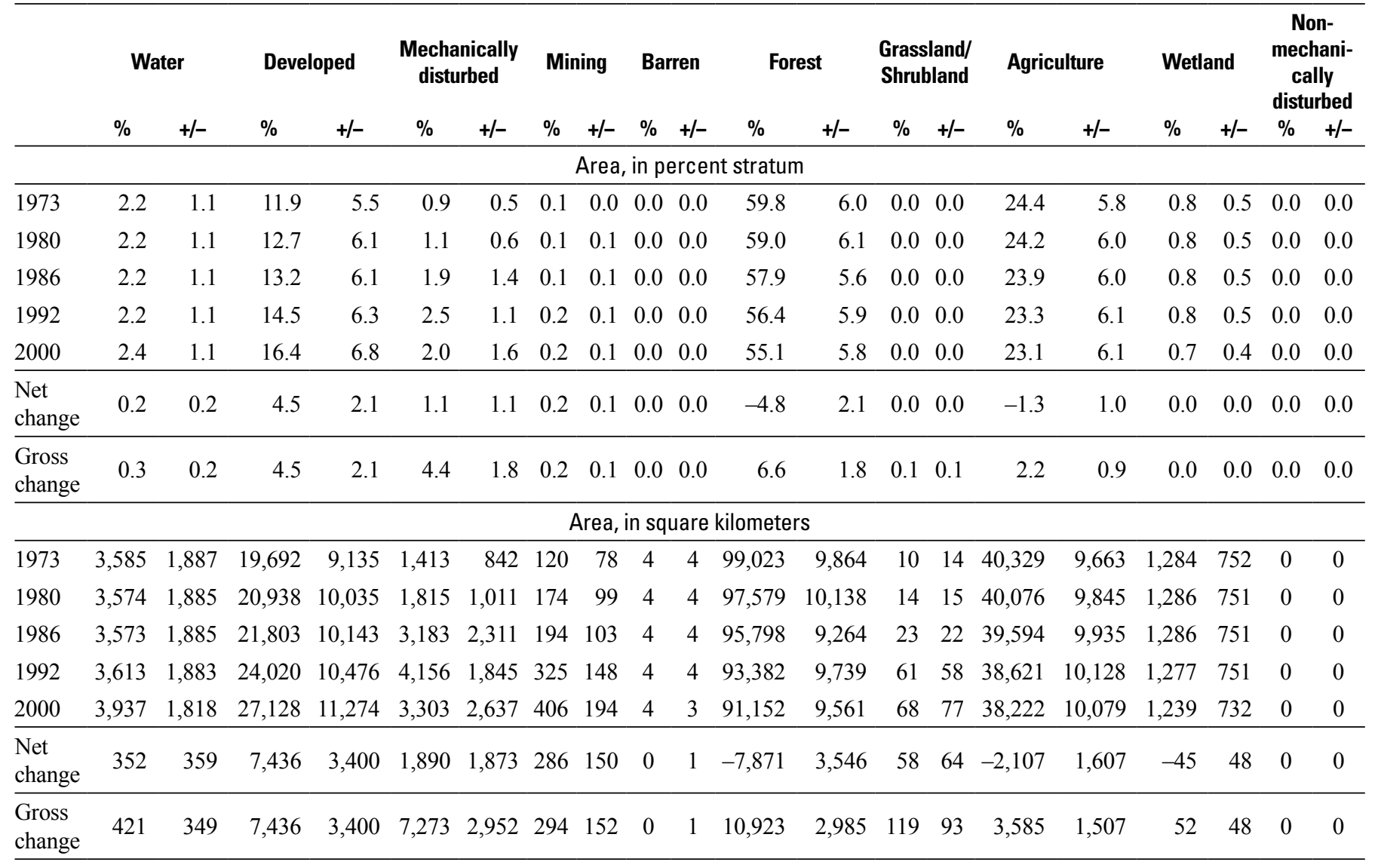




\section{References Cited}

Brender, E.V., 1974, Impact of past land use on the lower Piedmont forest: Journal of Forestry, v. 72, p. 34-36.

Hart, John Fraser, 1978, Cropland concentrations in the South: Annals of the Association of American Geographers, v. 68, no. 4, p. 505-517.

Hart, John Fraser, 1980, Land use change in a Piedmont county: Annals of the Association of American Geographers, v. 70 , no. 4 , p. $492-527$.

Hodler, Thomas W., and Schretter, Howard A., 1986, The atlas of Georgia: Athens, The Institute of Community and Area Development and the University of Georgia, $273 \mathrm{p}$.

Johnson, Carter W., and Sharpe, David M., 1976, An analysis of forest dynamics in the northern Georgia Piedmont: Forest Science, v. 22, no. 3, p. 307-322.

Manners, Ian R., 1979, The persistent problem of the boll weevil-Pest control in principle and practice: Geographical Review, v. 69, no. 1, p. 25-42.

National Association of Home Builders, 1973-2000 [various years], Housing starts: National Association of Home Builders Web site, accessed June 12, 2013, at http://www. nahbclassic.org/generic.aspx?sectionID $=819 \&$ genericConte $\mathrm{ntID}=45409$ \& channelID $=311$.
U.S. Census Bureau, 1970-2000 [various years], Census of population and housing: U.S. Census Bureau database, accessed May 9, 2013, at http://www.census.gov/prod/www/ decennial.html.

van Lear, D.H., Harper, R.A., Kapeluck, P.R., and Carroll, W.D., 2004, History of Piedmont forests-Implications for current pine management: U.S. Forest Service, Southern Research Station, General Technical Report SRS-71, p. 127-131, accessed November 5, 2013, at http://www.srs. fs.usda.gov/pubs/viewpub.php?index $=6620$.

Vogelmann, J.E., Howard, S.M., Yang, L., Larson, C.R., Wylie, B.K., and van Driel, N., 2001, Completion of the 1990s National Land Cover Data Set for the conterminous United States from Landsat Thematic Mapper data and ancillary data sources: Photogrammetric Engineering \& Remote Sensing, v. 67, p. 650-662.

Wiken, E., Jiménez Nava, F., and Griffith, G., 2011, North American terrestrial ecoregions_Level III: Montreal, Canada, Commission for Environmental Cooperation, 149 p., accessed May 1, 2013, at http://www.cec.org/ Storage/133/15860_QA07.30-32_NP_NA_Terrestrial_ Ecoregions_Level_3_Final-2june11.pdf. 


\title{
Mississippi Valley Loess Plains Ecoregion
}

\author{
By Janis L. Taylor
}

\section{Ecoregion Description}

The Mississippi Valley Loess Plains Ecoregion, which extends from western Kentucky south through western Tennessee and Mississippi into Louisiana, is about $750 \mathrm{~km}$ long and as much as $110 \mathrm{~km}$ wide, covering about $43,775 \mathrm{~km}^{2}\left(16,901 \mathrm{mi}^{2}\right)$ (fig. 1). Most of the Mississippi Valley Loess Plains Ecoregion is sandwiched between the Mississippi Alluvial Plain Ecoregion to the west and the Southeastern Plains Ecoregion to the east; in addition, the extreme northern part of the ecoregion is abutted by the Interior River Lowland and Interior Plateau Ecoregions. The topography consists primarily of irregular plains. A thick, highly erodible layer of loess - a unique geologic deposit composed almost entirely of wind-transported, silt-sized grains of quartz and other common

Figure 1. Map of Mississippi Valley Loess Plains Ecoregion and surrounding ecoregions, showing land-use/land-cover classes from 1992 National Land Cover Dataset (Vogelmann and others, 2001); note that not all land-use/ land-cover classes shown in explanation may be depicted on map; note also that, for this "Status and Trends of Land Change" study, transitional land-cover class was subdivided into mechanically disturbed and nonmechanically disturbed classes. Squares indicate locations of $10 \times 10 \mathrm{~km}$ sample blocks analyzed in study. Index map shows locations of geographic features mentioned in text. Abbreviations for Eastern United States ecoregions are listed in appendix 2. Also shown are parts of three Midwest-South Central United States ecoregions: Interior River Lowland (IRL), Mississippi Alluvial Plain, and Ozark Highlands. See appendix 3 for definitions of land-use/land-cover classifications.

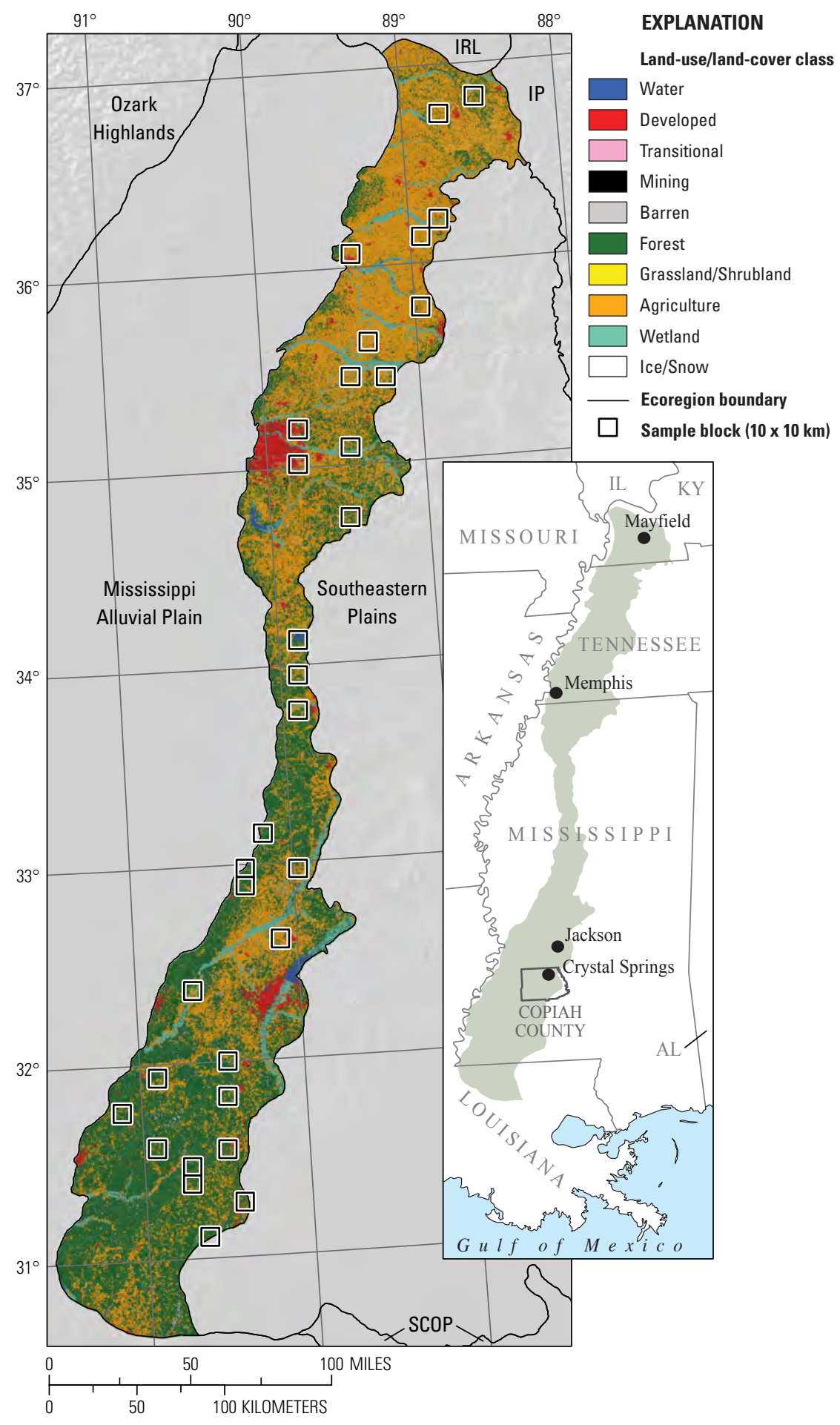


minerals - is the distinguishing characteristic of this ecoregion (Wiken and others, 2011). The principal soils are finely textured, acidic, red and yellow podzols developed from the underlying clays, sands, and loess (Faulkner, 2005). These erodible soils characteristically are poor in organic matter and nutrients but are easily cultivated by using fertilizers.

Average annual temperatures range from $16^{\circ}$ to $20^{\circ} \mathrm{C}$, and annual precipitation ranges from 1,150 to $1,525 \mathrm{~mm}$ (45 to 60 in.), both of which increase from north to south. Most precipitation is in the form of rain, and it occurs mainly during the winter and spring. The annual frost-free period is 200 days or more in most of the ecoregion, but it is as long as 290 days in the southernmost part (U.S. Department of Agriculture, 2006).

\section{Contemporary Land-Cover Change (1973 to 2000)}

The overall spatial change (the percentage of land area that changed at least one time) in the Mississippi Valley Loess Plains Ecoregion between 1973 and 2000 is estimated at 13.8 percent (table 1). Compared to other Eastern United States

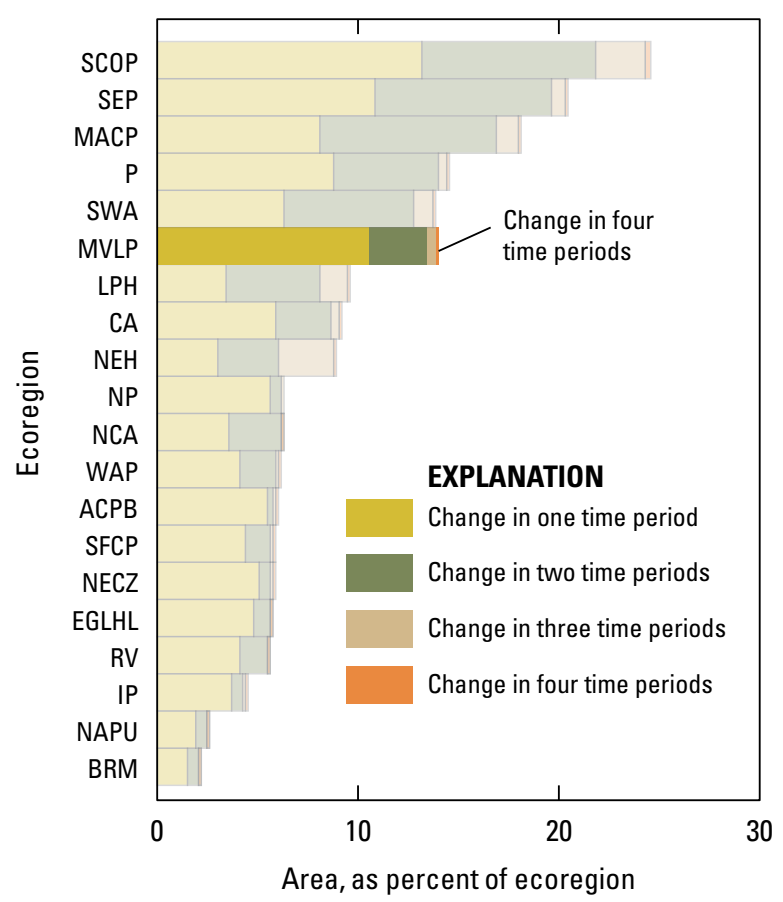

Figure 2. Overall spatial change in Mississippi Valley Loess Plains Ecoregion (MVLP; darker bars) compared with that of all 20 Eastern United States ecoregions (lighter bars). Each horizontal set of bars shows proportions of ecoregion that changed during one, two, three, or four time periods; highest level of spatial change in Mississippi Valley Loess Plains Ecoregion (four time periods) labeled for clarity. See table 2 for years covered by each time period. See appendix 2 for key to ecoregion abbreviations. ecoregions, change in the Mississippi Valley Loess Plains Ecoregion was moderately high (fig. 2): 10.5 percent of the ecoregion changed only one time, 2.9 percent changed two times, and 0.4 percent changed three times (table 1). Estimates of change ranged from a low of 2.4 percent between 1973 and 1980 to a high of 6.6 percent between 1986 and 1992 (table 2). When normalized to an average annual rate to account for unequal time periods, total change ranged from a low of 0.3 percent between 1973 and 1980 to a high of 1.1 percent between 1986 and 1992 (table 2; fig. 3).

The areal percentage of each land-cover class mapped during each of the five study dates between 1973 and 2000 is shown in table 3. Forest, agriculture, and developed land-cover classes accounted for more than 90.0 percent of the ecoregion. During the 27-year study period, agriculture decreased in every time period, from 46.0 percent of the ecoregion in 1973 to 39.3 percent in 2000 (table 3; fig. 4). The most significant decrease in agriculture, which occurred between 1986 and 1992, was accompanied by increases in both forest and developed. Developed increased in each of the four time periods, from 3.6 percent of the ecoregion in 1973 to 7.8 percent in 2000 . The amount of forest changed little between 1973 and 2000, from 43.3 percent in 1973 to 43.9 percent in 2000 .

The most common land-cover conversion during the 27-year study period was from forest to mechanically disturbed (table 4). Agriculture to forest was the second most common conversion during the study period, whereas agriculture to developed was the third most common conversion (table 4). Finally, the fourth most common conversion was from mechanically disturbed to forest.

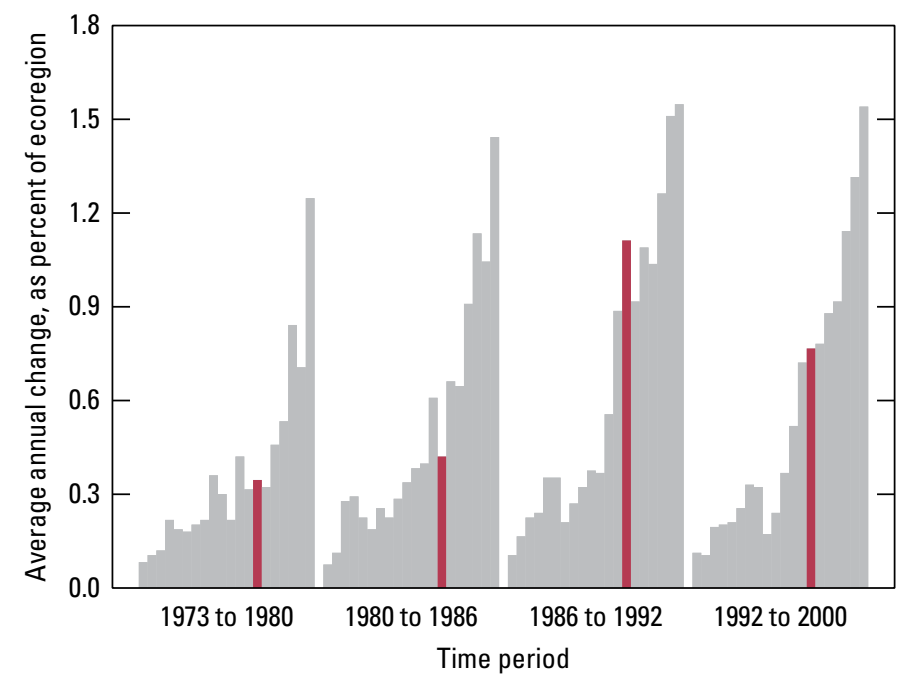

Figure 3. Estimates of land-cover change per time period, normalized to annual rates of change for all 20 Eastern United States ecoregions (gray bars). Estimates of change for Mississippi Valley Loess Plains Ecoregion are represented by $\mathrm{d}$ bars in each time period. 
The southern part of the ecoregion is a mosaic of forested land and cropland, whereas the northern part is dominated by agricultural land. Trees, cotton, corn, soybeans, strawberries, and tobacco are crops commonly grown throughout the ecoregion (fig. 5). In the southern part, longleaf pine (Pinus palustris) is the principal commercially harvested tree in densely forested areas; in the northern part, loblolly pine (Pinus taeda), slash pine (Pinus elliottii), and shortleaf pine (Pinus echinata) are the most common (fig. 6).

The conversion of agriculture to forest is the result of several factors. In 1985, the Food Security Act initiated the Conservation Reserve Program (CRP) (Johnson and Maxwell, 2001), which encouraged the planting of hardwood trees on marginal farmland. In the years 1987, 1992, and 1997, many counties within the ecoregion showed a significant increase in the amount of land enrolled in the CRP (U.S. Department of

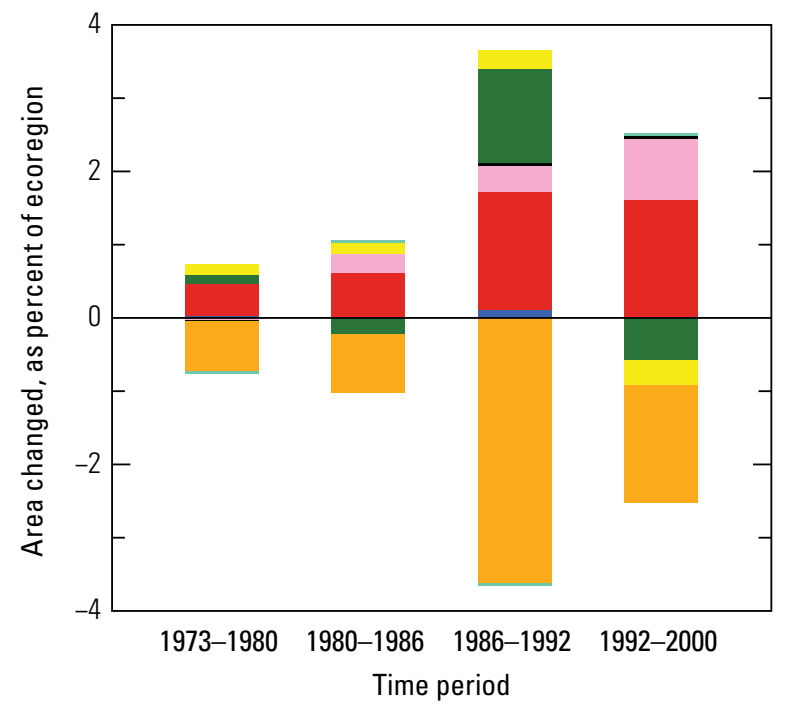

EXPLANATION

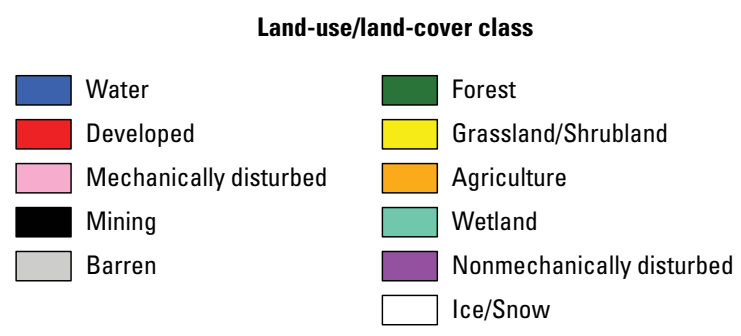

Figure 4. Normalized average net change in Mississippi Valley Loess Plains Ecoregion by time period for each land-cover class. Bars above zero axis represent net gain, whereas bars below zero represent net loss. Note that not all land-cover classes shown in explanation may be represented in figure. See appendix 3 for definitions of land-use and land-cover classifications.
Agriculture, 1970-2000 [various years]). In addition, the U.S. Forest Service during this time promoted afforestation, which is the restoration of forest on abandoned agricultural land (Stanturf and Gardiner, 2000).

During the 27-year study period, many forested areas in the ecoregion were managed as pine plantations. Additionally, the common conversions from forest to mechanically disturbed and from mechanically disturbed to forest represent the short harvest cycles of pine plantations in the ecoregion (fig. 7). Within the ecoregion, the socioeconomic benefits derived from forested land include the sale of hunting leases, carbon credits for sequestration, improvements in water quality, and the production of biofuels and fiber. The unidirectional landcover conversion to developed land was driven by population increases in and around Memphis, Tennessee, and Jackson, Mississippi, the two largest cities in the ecoregion (fig. 8).

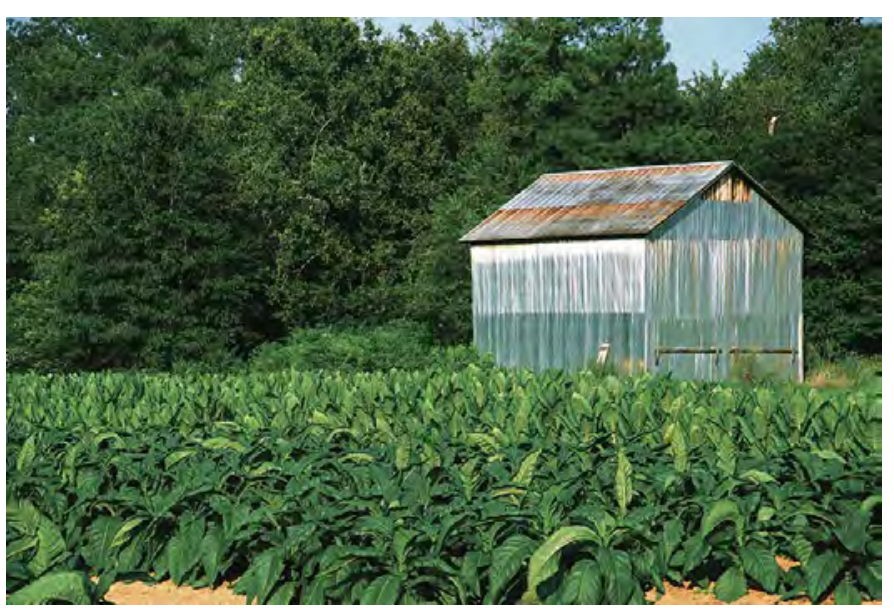

Figure 5. Tobacco field and shed northeast of Mayfield, in western Kentucky.

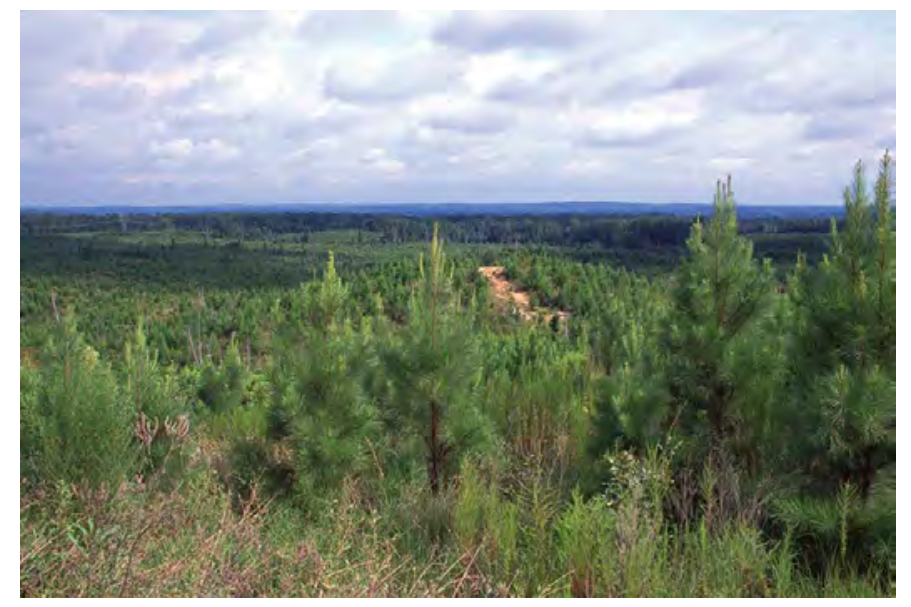

Figure 6. Replanted pine plantation west of Crystal Springs, Mississippi. 


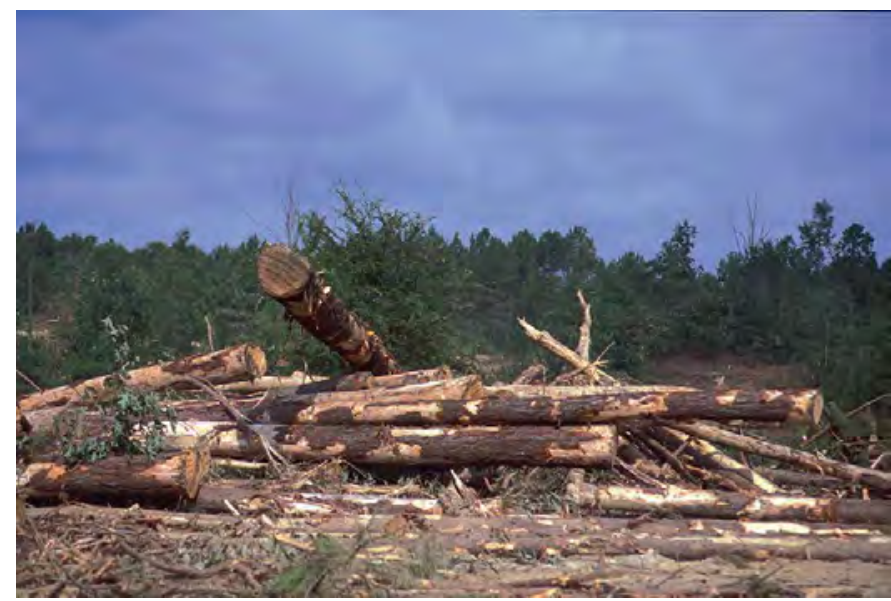

Figure 7. Pile of new logs in huge clearcut just west of Crystal Springs, in Copiah County, Mississippi.

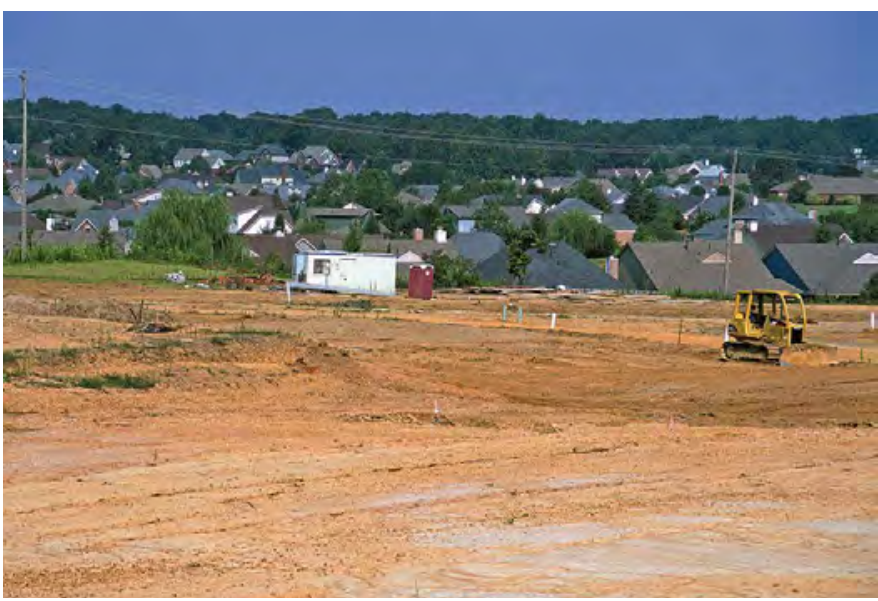

Figure 8. Recently cleared site for new subdivision northeast of Memphis, Tennessee. Existing subdivision is in background.

Table 1. Percentage of Mississippi Valley Loess Plains Ecoregion land cover that changed at least one time during study period (1973-2000) and associated statistical error.

[Most sample pixels remained unchanged ( 86.2 percent), whereas 13.8 percent changed at least once throughout study period]

\begin{tabular}{ccccccc}
\hline $\begin{array}{c}\text { Number } \\
\text { of } \\
\text { changes }\end{array}$ & $\begin{array}{c}\text { Percent } \\
\text { of } \\
\text { ecoregion }\end{array}$ & $\begin{array}{c}\text { Margin } \\
\text { of error } \\
(+/-\%)\end{array}$ & $\begin{array}{c}\text { Lower } \\
\text { bound } \\
(\%)\end{array}$ & $\begin{array}{c}\text { Upper } \\
\text { bound } \\
(\%)\end{array}$ & $\begin{array}{c}\text { Standard } \\
\text { error } \\
(\%)\end{array}$ & $\begin{array}{c}\text { Relative } \\
\text { error } \\
(\%)\end{array}$ \\
\hline 1 & 10.5 & 3.0 & 7.5 & 13.5 & 2.0 & 19.3 \\
2 & 2.9 & 0.8 & 2.1 & 3.7 & 0.5 & 18.7 \\
3 & 0.4 & 0.2 & 0.2 & 0.6 & 0.1 & 33.6 \\
4 & 0.0 & 0.0 & 0.0 & 0.1 & 0.0 & 41.4 \\
\hline $\begin{array}{c}\text { Overall } \\
\text { spatial } \\
\text { change }\end{array}$ & 13.8 & 3.4 & 10.4 & 17.3 & 2.3 & 16.8 \\
\hline
\end{tabular}


Table 2. Raw estimates of change in Mississippi Valley Loess Plains Ecoregion land cover, computed for each of four time periods between 1973 and 2000, and associated error at 85-percent confidence level.

[Estimates of change per period normalized to annual rate of change for each period]

\begin{tabular}{|c|c|c|c|c|c|c|c|}
\hline Period & $\begin{array}{c}\text { Total change } \\
\text { (\% of ecoregion) }\end{array}$ & $\begin{array}{c}\text { Margin of } \\
\text { error } \\
(+/-\%)\end{array}$ & $\begin{array}{c}\text { Lower } \\
\text { bound } \\
(\%)\end{array}$ & $\begin{array}{c}\text { Upper bound } \\
(\%)\end{array}$ & $\begin{array}{c}\text { Standard } \\
\text { error } \\
(\%) \\
\end{array}$ & $\begin{array}{c}\text { Relative } \\
\text { error } \\
(\%)\end{array}$ & $\begin{array}{r}\text { Average rate } \\
\text { (\% per year) }\end{array}$ \\
\hline \multicolumn{8}{|c|}{ Estimate of change, in percent stratum } \\
\hline $1973-1980$ & 2.4 & 0.5 & 1.9 & 2.9 & 0.3 & 13.6 & 0.3 \\
\hline 1980-1986 & 2.5 & 0.8 & 1.7 & 3.3 & 0.5 & 20.8 & 0.4 \\
\hline $1986-1992$ & 6.6 & 1.8 & 4.9 & 8.4 & 1.2 & 18.1 & 1.1 \\
\hline $1992-2000$ & 6.1 & 1.5 & 4.6 & 7.6 & 1.0 & 16.4 & 0.8 \\
\hline \multicolumn{8}{|c|}{ Estimate of change, in square kilometers } \\
\hline $1973-1980$ & 1,050 & 211 & 840 & 1,261 & 143 & 13.6 & 150 \\
\hline $1980-1986$ & 1,099 & 337 & 762 & 1,436 & 228 & 20.8 & 183 \\
\hline 1986-1992 & 2,910 & 777 & 2,133 & 3,688 & 527 & 18.1 & 485 \\
\hline 1992-2000 & 2,675 & 646 & 2,029 & 3,321 & 438 & 16.4 & 334 \\
\hline
\end{tabular}

Table 3. Estimated area (and margin of error) of each land-cover class in the Mississippi Valley Loess Plains Ecoregion, calculated five times between 1973 and 2000. See appendix 3 for definitions of land-cover classifications.

\begin{tabular}{|c|c|c|c|c|c|c|c|c|c|c|c|c|c|c|c|c|c|c|c|c|}
\hline & \multicolumn{2}{|c|}{ Water } & \multicolumn{2}{|c|}{ Developed } & \multicolumn{2}{|c|}{$\begin{array}{l}\text { Mechanical- } \\
\text { ly disturbed }\end{array}$} & \multicolumn{2}{|c|}{ Mining } & \multicolumn{2}{|c|}{ Barren } & \multicolumn{2}{|c|}{ Forest } & \multicolumn{2}{|c|}{$\begin{array}{l}\text { Grassland/ } \\
\text { Shrubland }\end{array}$} & \multicolumn{2}{|c|}{ Agriculture } & \multicolumn{2}{|c|}{ Wetland } & \multicolumn{2}{|c|}{$\begin{array}{c}\text { Non- } \\
\text { mecha- } \\
\text { nically } \\
\text { disturbed }\end{array}$} \\
\hline & $\%$ & $+/-$ & $\%$ & $+/-$ & $\%$ & $+/-$ & $\%$ & $+/-$ & $\%$ & $+/-$ & $\%$ & $+1-$ & $\%$ & $+/-$ & $\%$ & $+1-$ & $\%$ & $+/-$ & $\%$ & $+/-$ \\
\hline \multicolumn{21}{|c|}{ Area, in percent stratum } \\
\hline 1973 & 1.7 & 1.4 & 3.6 & 1.4 & 0.5 & 0.3 & 0.1 & 0.0 & 0.1 & 0.1 & 43.3 & 6.4 & 0.2 & 0.1 & 46.0 & 5.9 & 4.6 & 1.4 & 0.0 & 0.0 \\
\hline 1980 & 1.7 & 1.4 & 4.0 & 1.6 & 0.5 & 0.2 & 0.1 & 0.0 & 0.1 & 0.1 & 43.4 & 6.5 & 0.4 & 0.2 & 45.3 & 5.9 & 4.6 & 1.4 & 0.0 & 0.0 \\
\hline 1986 & 1.7 & 1.3 & 4.6 & 1.9 & 0.8 & 0.4 & 0.1 & 0.0 & 0.1 & 0.1 & 43.2 & 6.5 & 0.5 & 0.2 & 44.5 & 6.0 & 4.6 & 1.4 & 0.0 & 0.0 \\
\hline 1992 & 1.8 & 1.4 & 6.2 & 3.1 & 1.1 & 0.4 & 0.1 & 0.0 & 0.1 & 0.1 & 44.5 & 6.5 & 0.7 & 0.3 & 40.8 & 6.1 & 4.6 & 1.4 & 0.0 & 0.0 \\
\hline 2000 & 1.8 & 1.3 & 7.8 & 4.2 & 1.9 & 0.8 & 0.1 & 0.1 & 0.1 & 0.1 & 43.9 & 6.5 & 0.4 & 0.1 & 39.3 & 6.2 & 4.6 & 1.4 & 0.0 & 0.0 \\
\hline $\begin{array}{l}\text { Net } \\
\text { change }\end{array}$ & 0.2 & 0.1 & 4.3 & 3.2 & 1.4 & 0.7 & 0.1 & 0.1 & 0.0 & 0.0 & 0.6 & 1.4 & 0.2 & 0.1 & -6.7 & 2.7 & 0.0 & 0.1 & 0.0 & 0.0 \\
\hline $\begin{array}{l}\text { Gross } \\
\text { change }\end{array}$ & 0.5 & 0.3 & 4.3 & 3.2 & 3.4 & 1.3 & 0.1 & 0.1 & 0.0 & 0.0 & 5.8 & 1.4 & 1.2 & 0.4 & 7.4 & 2.6 & 0.6 & 0.3 & 0.0 & 0.0 \\
\hline \multicolumn{21}{|c|}{ Area, in square kilometers } \\
\hline 1973 & 734 & 616 & 1,567 & 609 & 226 & 137 & 29 & 18 & 50 & 29 & 18,933 & 2,798 & 89 & 36 & 20,128 & 2,587 & 2,018 & 630 & 0 & 0 \\
\hline 1980 & 752 & 609 & 1,753 & 695 & 210 & 79 & 28 & 19 & 51 & 29 & 18,981 & 2,840 & 156 & 68 & 19,830 & 2,596 & 2,014 & 620 & 0 & 0 \\
\hline 1986 & 757 & 565 & 2,017 & 851 & 329 & 169 & 31 & 18 & 51 & 29 & 18,895 & 2,828 & 212 & 88 & 19,466 & 2,607 & 2,018 & 614 & 0 & 0 \\
\hline 1992 & 807 & 613 & 2,719 & 1,358 & 499 & 195 & 35 & 21 & 51 & 29 & 19,465 & 2,851 & 314 & 114 & 17,881 & 2,660 & 2,003 & 619 & 0 & 0 \\
\hline 2000 & 805 & 578 & 3,435 & 1,838 & 853 & 333 & 59 & 40 & 51 & 29 & 19,216 & 2,841 & 168 & 60 & 17,182 & 2,715 & 2,005 & 615 & 0 & 0 \\
\hline $\begin{array}{l}\text { Net } \\
\text { change }\end{array}$ & 71 & 52 & 1,868 & 1,379 & 627 & 306 & 30 & 29 & 1 & 2 & 283 & 613 & 79 & 44 & $-2,946$ & 1,177 & -13 & 56 & 0 & 0 \\
\hline $\begin{array}{l}\text { Gross } \\
\text { change }\end{array}$ & 216 & 131 & 1,870 & 1,379 & 1,480 & 558 & 47 & 30 & 3 & 2 & 2,541 & 613 & 544 & 191 & 3,229 & 1,150 & 244 & 142 & 0 & 0 \\
\hline
\end{tabular}


Table 4. Principal land-cover conversions in Mississippi Valley Loess Plains Ecoregion, showing amount of area changed (and margin of error, calculated at 85-percent confidence level) for each conversion during each of four time periods and also during overall study period. See appendix 3 for definitions of land-cover classifications.

[Values given for "other" classes are combined totals of values for other land-cover classes not listed in that time period. Abbreviations: n/a, not applicable]

\begin{tabular}{|c|c|c|c|c|c|c|c|}
\hline Period & From class & To class & $\begin{array}{c}\text { Area } \\
\text { changed } \\
\left(\mathrm{km}^{2}\right)\end{array}$ & $\begin{array}{c}\text { Margin of } \\
\text { error } \\
\left(+/-\mathrm{km}^{2}\right)\end{array}$ & $\begin{array}{c}\text { Standard } \\
\text { error } \\
\left(\mathrm{km}^{2}\right)\end{array}$ & $\begin{array}{l}\text { Percent of } \\
\text { ecoregion }\end{array}$ & $\begin{array}{l}\text { Percent of all } \\
\text { changes }\end{array}$ \\
\hline \multirow[t]{7}{*}{$1973-1980$} & Agriculture & Forest & 190 & 69 & 47 & 0.4 & 18.1 \\
\hline & Mechanically disturbed & Forest & 164 & 127 & 86 & 0.4 & 15.6 \\
\hline & Forest & Mechanically disturbed & 148 & 57 & 39 & 0.3 & 14.1 \\
\hline & Agriculture & Developed & 135 & 98 & 67 & 0.3 & 12.8 \\
\hline & Forest & Agriculture & 103 & 34 & 23 & 0.2 & 9.8 \\
\hline & Other & Other & 311 & $\mathrm{n} / \mathrm{a}$ & $\mathrm{n} / \mathrm{a}$ & 0.7 & 29.6 \\
\hline & & Totals & 1,050 & & & 2.4 & 100.0 \\
\hline \multirow[t]{7}{*}{$1980-1986$} & Forest & Mechanically disturbed & 281 & 169 & 114 & 0.6 & 25.5 \\
\hline & Agriculture & Developed & 191 & 154 & 104 & 0.4 & 17.3 \\
\hline & Agriculture & Forest & 158 & 91 & 62 & 0.4 & 14.4 \\
\hline & Mechanically disturbed & Forest & 92 & 45 & 31 & 0.2 & 8.4 \\
\hline & Agriculture & Grassland/Shrubland & 52 & 33 & 23 & 0.1 & 4.7 \\
\hline & Other & Other & 327 & $\mathrm{n} / \mathrm{a}$ & $\mathrm{n} / \mathrm{a}$ & 0.7 & 29.7 \\
\hline & & Totals & 1,099 & & & 2.5 & 100.0 \\
\hline \multirow[t]{7}{*}{ 1986-1992 } & Agriculture & Forest & 908 & 349 & 236 & 2.1 & 31.2 \\
\hline & Agriculture & Developed & 522 & 453 & 307 & 1.2 & 17.9 \\
\hline & Forest & Mechanically disturbed & 410 & 169 & 114 & 0.9 & 14.1 \\
\hline & Mechanically disturbed & Forest & 258 & 155 & 105 & 0.6 & 8.9 \\
\hline & Forest & Developed & 147 & 118 & 80 & 0.3 & 5.0 \\
\hline & Other & Other & 665 & $\mathrm{n} / \mathrm{a}$ & $\mathrm{n} / \mathrm{a}$ & 1.5 & 22.8 \\
\hline & & Totals & 2,910 & & & 6.6 & 100.0 \\
\hline \multirow[t]{7}{*}{ 1992-2000 } & Forest & Mechanically disturbed & 801 & 327 & 222 & 1.8 & 29.9 \\
\hline & Agriculture & Developed & 400 & 285 & 193 & 0.9 & 14.9 \\
\hline & Mechanically disturbed & Forest & 397 & 166 & 112 & 0.9 & 14.8 \\
\hline & Agriculture & Forest & 284 & 99 & 67 & 0.6 & 10.6 \\
\hline & Forest & Developed & 228 & 172 & 117 & 0.5 & 8.5 \\
\hline & Other & Other & 566 & $\mathrm{n} / \mathrm{a}$ & $\mathrm{n} / \mathrm{a}$ & 1.3 & 21.2 \\
\hline & & Totals & 2,675 & & & 6.1 & 100.0 \\
\hline \multirow{7}{*}{$\begin{array}{c}1973-2000 \\
\text { (overall) }\end{array}$} & Forest & Mechanically disturbed & 1,640 & 591 & 400 & 3.7 & 21.2 \\
\hline & Agriculture & Forest & 1,539 & 440 & 298 & 3.5 & 19.9 \\
\hline & Agriculture & Developed & 1,247 & 983 & 666 & 2.8 & 16.1 \\
\hline & Mechanically disturbed & Forest & 910 & 382 & 259 & 2.1 & 11.8 \\
\hline & Forest & Developed & 437 & 316 & 214 & 1.0 & 5.7 \\
\hline & Other & Other & 1,961 & $\mathrm{n} / \mathrm{a}$ & $\mathrm{n} / \mathrm{a}$ & 4.5 & 25.4 \\
\hline & & Totals & 7,735 & & & 17.7 & 100.0 \\
\hline
\end{tabular}




\section{References Cited}

Faulkner, S.P., 2005, Southern Mississippi Valley silty uplands (loess bluffs), in Major land resources of Mississippi: Samuel P. Faulkner, PhD, Web site, accessed June 13, 2013, at http://www.marshdoc1.com/major-land-areas-of-ms.html.

Johnson, J., and Maxwell, B., 2001, The role of the Conservation Reserve Program in controlling rural residential development: Journal of Rural Studies, v. 17, p. 323-332.

Stanturf, John A., and Gardiner, Emile S., 2000, Restoration of bottomland hardwoods in the Lower Mississippi Alluvial Valley, in Sustaining Southern forests-The science of forest assessment: Atlanta, Ga., Southern Forest Resource Assessment, accessed June 13, 2013, at http://www.srs. fs.usda.gov/sustain/conf/fulltext.htm.

U.S. Department of Agriculture, 1970-2000 [various years], Historical census publications: U.S. Census Bureau database, accessed June13, 2013, at http://www.agcensus. usda.gov/Publications/Historical_Publications/index.php.
U.S. Department of Agriculture, 2006, Land resource regions and major land resource areas of the United States, the Caribbean, and the Pacific Basin: U.S. Department of Agriculture, National Resources Conservation Service, U.S. Department of Agriculture Handbook 296, 663 p.

Vogelmann, J.E., Howard, S.M., Yang, L., Larson, C.R., Wylie, B.K., and van Driel, N., 2001, Completion of the 1990s National Land Cover Data set for the conterminous United States from Landsat Thematic Mapper data and ancillary data sources: Photogrammetric Engineering \& Remote Sensing, v. 67, p. 650-662.

Wiken, E., Jiménez Nava, F., and Griffith, G., 2011, North American terrestrial ecoregions - Level III: Montreal, Canada, Commission for Environmental Cooperation, 149 p., accessed May 1, 2013, at http://www.cec.org/ Storage/133/15860_QA07.30-32_NP_NA_Terrestrial_ Ecoregions_Level_3_Final-2june11.pdf. 



\title{
Chapter 17
}

\section{Southeastern Plains Ecoregion}

\author{
By Terry L. Sohl
}

\section{Ecoregion Description}

The Southeastern Plains Ecoregion, which is the largest of the Eastern United States ecoregions, covers about $336,141 \mathrm{~km}^{2}\left(129,785 \mathrm{mi}^{2}\right)$ across 11 states and the District of Columbia, extending from near the Gulf of Mexico in the south to Delaware in the north (Wiken and others, 2011; fig. 1). The ecoregion is bounded on the north and northwest by the Northern Piedmont, Piedmont, Ridge and Valley, Southwestern Appalachians, and Interior Plateau Ecoregions; on the west, by the Mississippi Valley Loess Plains Ecoregion; and on the south and east, by the Mississippi Alluvial Plain, Southern Coastal Plain, and Middle Atlantic Coastal Plain Ecoregions.
Figure 1. Map of Southeastern Plains Ecoregion and surrounding ecoregions, showing land-use/land-cover classes from 1992 National Land Cover Dataset (Vogelmann and others, 2001); note that not all land-use/land-cover classes shown in explanation may be depicted on map; note also that, for this "Status and Trends of Land Change" study, transitional land-cover class was subdivided into mechanically disturbed and nonmechanically disturbed classes. Squares indicate locations of 20 x $20 \mathrm{~km}$ sample blocks analyzed in study. Index map shows locations of geographic features mentioned in text. Abbreviations for Eastern United States ecoregions are listed in appendix 2. Also shown are parts of seven Midwest-South Central United States ecoregions: Central Corn Belt Plains (CCBP), Eastern Corn Belt Plains, Erie Drift Plains (EDP), Huron/ Erie Lake Plains (HELP), Interior River Lowland, Mississippi Alluvial Plain (MAP), and Southern Michigan/Northern Indiana Drift Plains (SMNIDP). See appendix 3 for definitions of land-use/land-cover classifications.

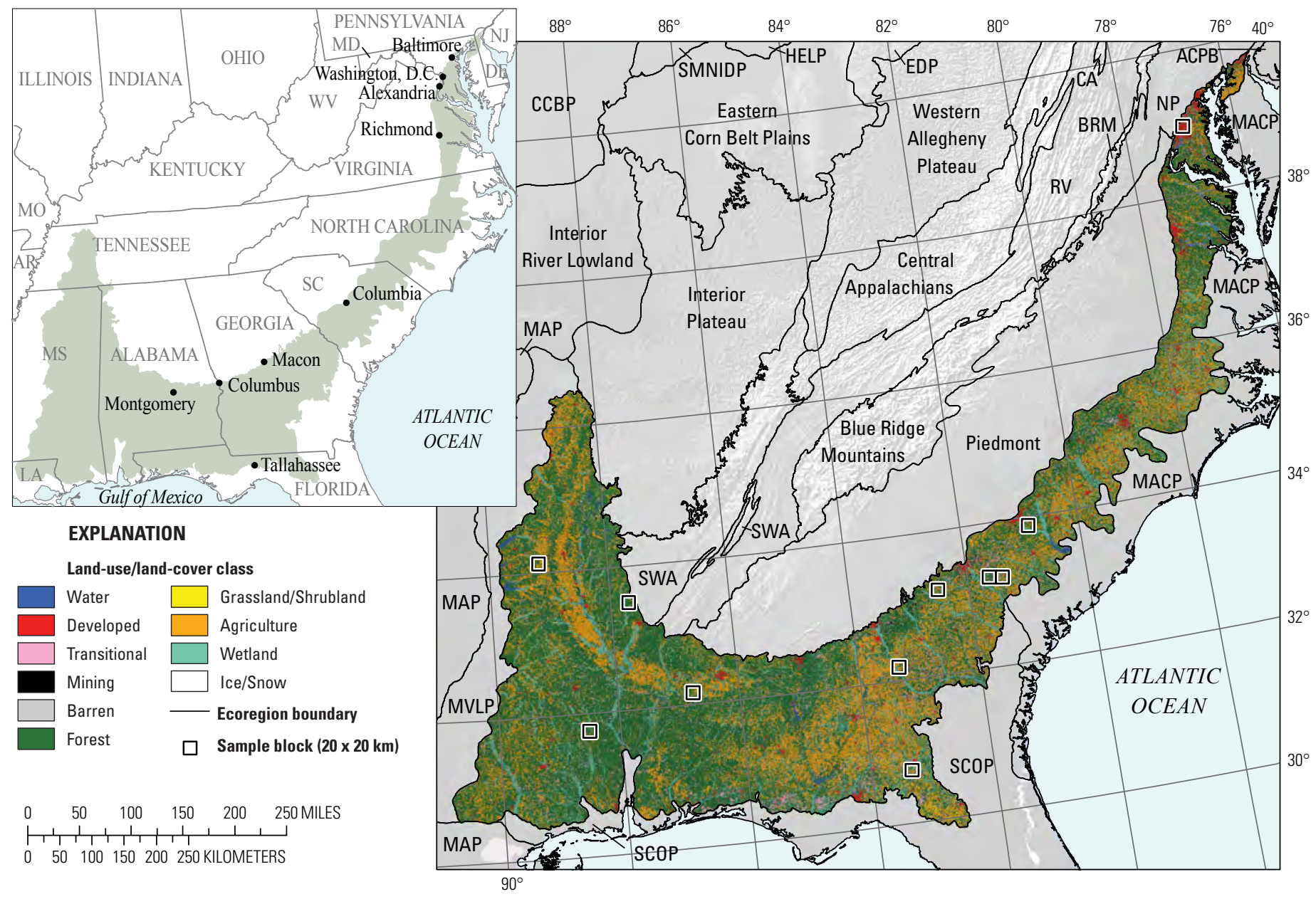


The relatively flat, irregular plains of the Southeastern Plains Ecoregion are covered by a mosaic of cropland, pastureland, forested land, and wetlands. However, although the ecoregion is characterized by a long growing season and abundant rainfall, the relatively poor, sandy soils present in much of the ecoregion limit its agricultural uses, in comparison to other nearby ecoregions. Natural forests of pine (Pinus spp.), hickory (Carya spp.), and oak (Quercus spp.) once covered most of the ecoregion, but much of the natural forest has been replaced by heavily managed timberlands. Montgomery, Alabama, is the only significant urban center (population greater than 100,000) in the interior of the ecoregion, although several urban centers are scattered on or near the edge of the ecoregion (for example, Baltimore, Maryland; Washington, D.C.; Alexandria and Richmond, Virginia; Columbia, South Carolina; Columbus and Macon, Georgia; and Tallahassee, Florida).

\section{Contemporary Land-Cover Change (1973 to 2000)}

The overall spatial change (the percentage of land area that changed at least one time) in the Southeastern Plains Ecoregion between 1973 and 2000 is estimated at 20.4 percent (table 1). Compared to other Eastern United States Ecoregions, change in the Southeastern Plains Ecoregion was very high (fig. 2); in addition, the rates of change per time period increased steadily across the 27 -year study period (table 2). When normalized to an average annual rate to account for uneven time periods, the rates of change increased during the first three time periods (1973-1980, 1980-1986, 1986-1992), peaking between 1986 and 1992, then decreased slightly during the last time period (1992-2000) (table 2; fig. 3).

Despite the high overall rates of change, the net-change statistics for individual land-cover classes during the study period (1973-2000) (table 3) mask the dynamically changing nature of the ecoregion. Forest had a modest net decrease of 1.2 percent $\left(4,119 \mathrm{~km}^{2}\right)$ between 1973 and 2000, even though the Southeastern Plains Ecoregion is home to an extremely dynamic timber industry (fig. 4). Pine plantations were rare in the ecoregion in 1950, but by 2000 they constituted nearly 50 percent of all pine forests in the southeastern United States (Conner and Hartsell, 2002) (fig. 5).

The most common land-cover conversion in every time period was from forest to mechanically disturbed, a conversion that primarily represents clearcutting of forested land (table 4); more than $41,000 \mathrm{~km}^{2}$ of forest experienced this conversion during the study period. The second most common conversion in every time period was from mechanically disturbed to forest, a conversion that represents the regrowth of forest on previously cut lands. Nearly $33,000 \mathrm{~km}^{2}$ of mechanically disturbed land experienced this conversion during the study period, and the mechanically disturbed class showed net increases for all time periods (fig. 6). Newly cut forest patches quickly revegetate to forest, whether through natural regeneration or through direct replanting. Managed pine plantations in the ecoregion have planting-and-cutting cycles as short as 20 years (fig. 7), which leads to a relatively rapid cyclic pattern of forest management, as is shown by the high percentage of areas experiencing two or more conversions during the study period (1973-2000) (table 1). This cyclic nature of forest cutting in the ecoregion results in the low net change in the forest land-cover class but the high overall rates of change for each time period.

Although forest decreased slightly between 1973 and 2000 , forestry, as defined by aggregating both forest and mechanically disturbed land-cover classes, showed a different pattern (table 5). Forestry decreased slightly between 1973 and 1986, but it increased significantly between 1986 and 2000. These figures correspond well with the U.S. Department of Agriculture's Forest Inventory and Analysis data, which identify 1987 as the milestone year when the "South" (that is, States in the southeastern one-quarter of the United States, including most of the Southeastern Plains Ecoregion) started to gain more forested land than it lost, reversing a long-term downward trend in forested land (Conner and Hartsell, 2002). The third most common

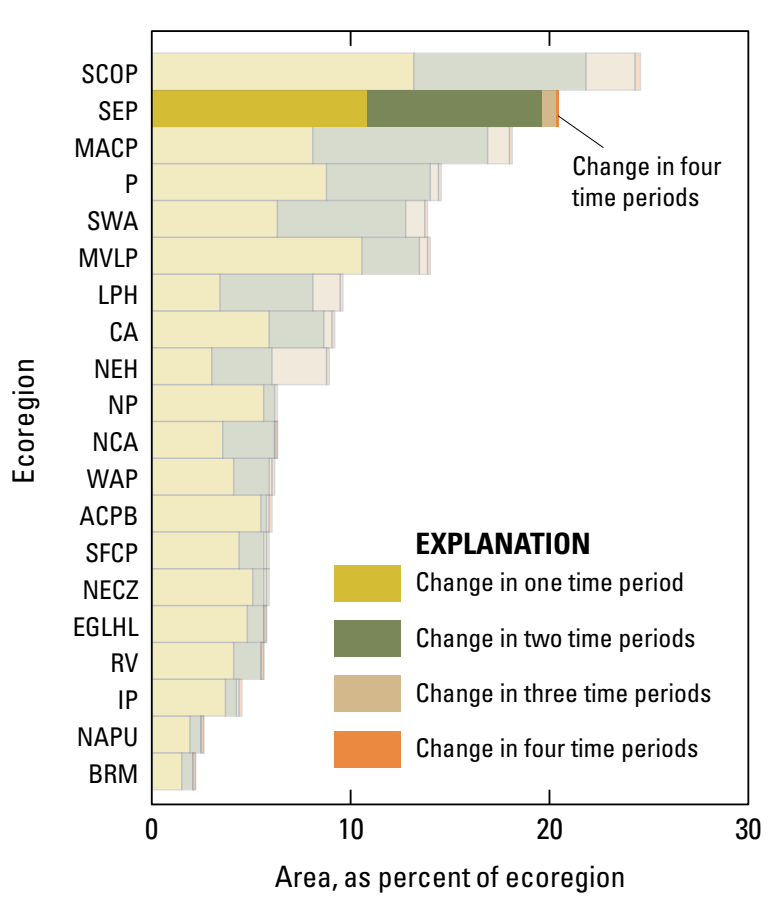

Figure 2. Overall spatial change in Southeastern Plains Ecoregion (SEP; darker bars) compared with that of all 20 Eastern United States ecoregions (lighter bars). Each horizontal set of bars shows proportions of ecoregion that changed during one, two, three, or four time periods; highest level of spatial change in Southeastern Plains Ecoregion (four time periods) labeled for clarity. See table 2 for years covered by each time period. See appendix 2 for key to ecoregion abbreviations. 
land-cover conversion in three of the four time periods, from agriculture to forest, was strongly related to the post1986 increase in forestry. Declining profits from agriculture relative to forestry in the ecoregion led many farmers either to abandon their cropland (which then naturally reverted to forest) or to plant pine as a managed timber crop (Wear, 2002). Programs such as the Conservation Reserve Program (CRP), which was implemented as part of the 1985 Farm Bill legislation, led to widespread conversion of marginal agricultural land to forested land or grassland/shrubland.

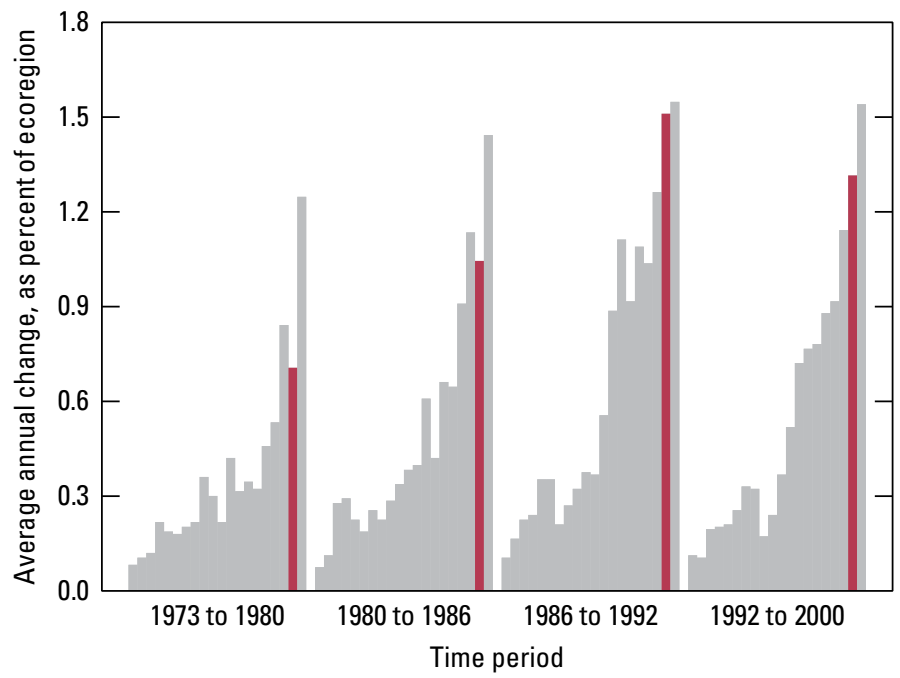

Figure 3. Estimates of land-cover change per time period, normalized to annual rates of change for all 20 Eastern United States ecoregions (gray bars). Estimates of change for Southeastern Plains Ecoregion are represented by red bars in each time period.
More than $4,400 \mathrm{~km}^{2}$ of forest converted to agriculture between 1973 and 2000, most of the change occurring in the earliest time periods (table 4; fig. 8); however, almost 12,000 $\mathrm{km}^{2}$ of agriculture converted to forest (table 4), with additional amounts of agriculture converting to developed. The net result of all the change in agriculture was a decrease of nearly 9,500 $\mathrm{km}^{2}$ of agriculture during the study period (table 3 ).

The other primary driver of land-cover change in the ecoregion was the conversion of forest and agriculture to developed. Between 1970 and 2000, human population

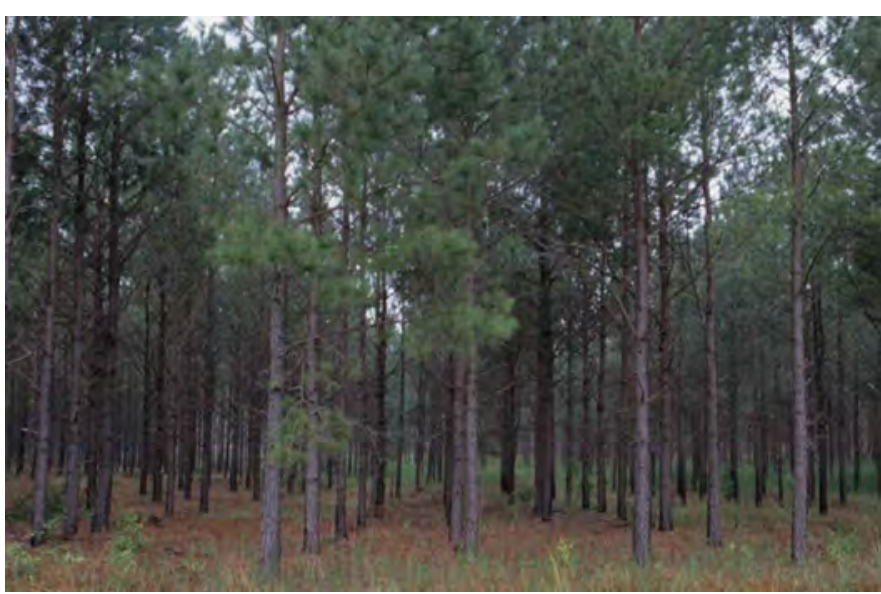

Figure 4. Pine plantation, which is large tract of land planted with regularly spaced pine trees, an increasingly common sight in Southeastern Plains Ecoregion.

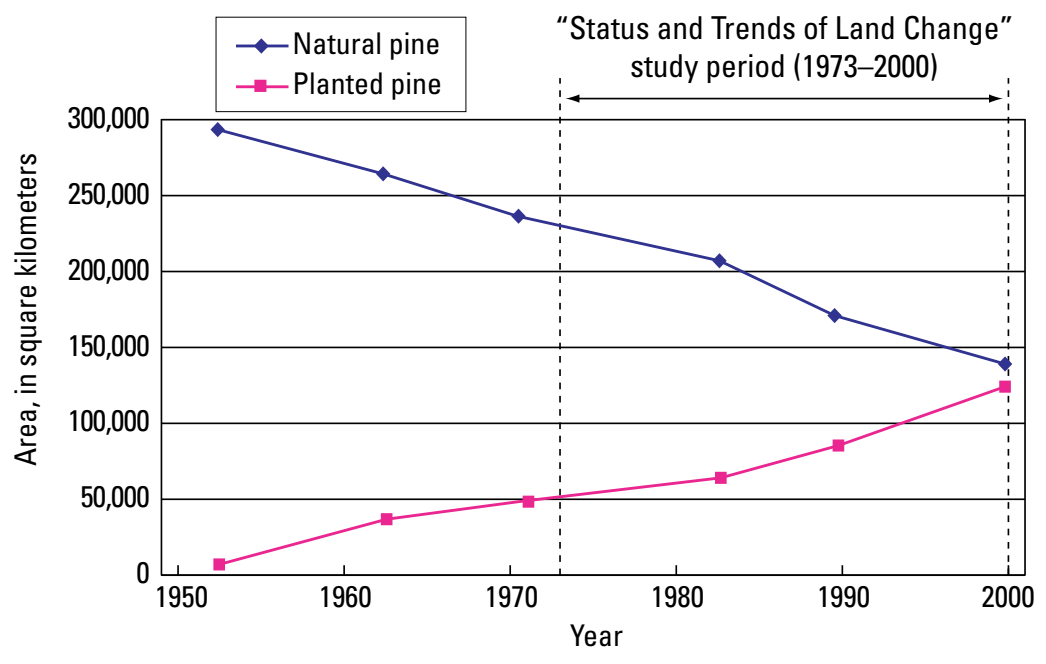

Figure 5. Areal changes in natural pine (in forests) and in planted pine (in commercial pine plantations) in the South between early 1950s and 2000, showing increase in planted pine and decrease in natural pine. Planted pine was nearly absent in early 1950s, but, by 2000 , it covered area nearly as large as that of natural pine in forests (Conner and Hartsell, 2002). 
within the ecoregion increased from 11.2 million to 14.4 million (U.S. Census Bureau, 1970-2000 [various years]). Nearly $4,400 \mathrm{~km}^{2}$ of land were developed between 1973 and 2000 (table 3), most of which came from forest. Forest was consistently developed at two to three times the rate of agriculture in all four time periods.

In terms of net change, the Southeastern Plains Ecoregion experienced only moderate rates of change between 1973 and 2000 , with a 2.8 percent decrease in agriculture, a 2.8 percent increase in mechanically disturbed, a 1.3 percent increase in developed, and only a 1.2 percent decrease in forest (table 3 ). However, in terms of gross change, the Southeastern Plains Ecoregion is one of the most actively changing ecoregions among the Eastern United States ecoregions, with the cyclical cutting and replanting of pine being the most common landcover conversion in the ecoregion. Mechanically disturbed to

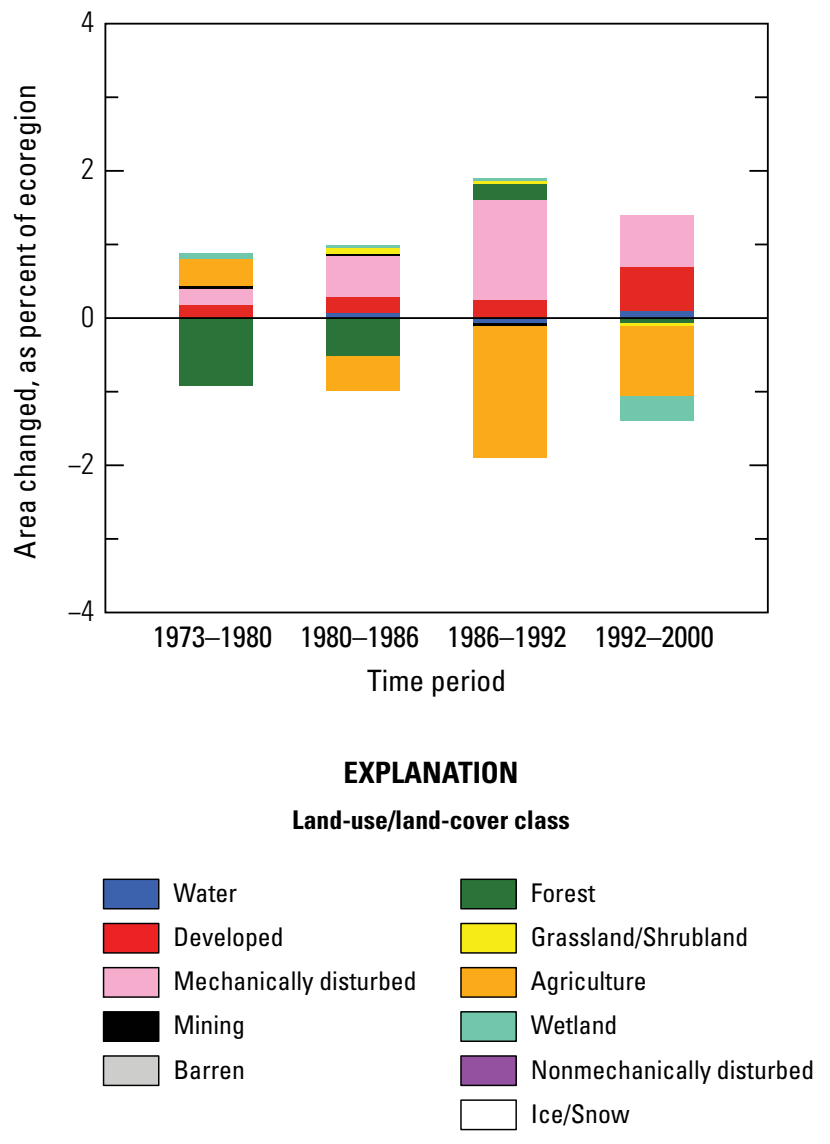

Figure 6. Normalized average net change in Southeastern Plains Ecoregion by time period for each land-cover class. Bars above zero axis represent net gain, whereas bars below zero represent net loss. Note that not all land-cover classes shown in explanation may be represented in figure. See appendix 3 for definitions of land-use and land-cover classifications. forest was the second most common land-cover conversion for all time periods. Despite the 1.2 percent loss of forest in terms of total ecoregion area, forestry actually increased because most mechanically disturbed land in the ecoregion is associated with timber harvest. Significant losses of agriculture also occurred, most losses coming from changes to forest. Agriculture changes likely were associated with farmers converting agricultural fields to higher profit pine plantations, and they also happened in concurrence with implementation of the CRP, with the highest rate of conversion occurring between 1986 and 1992.

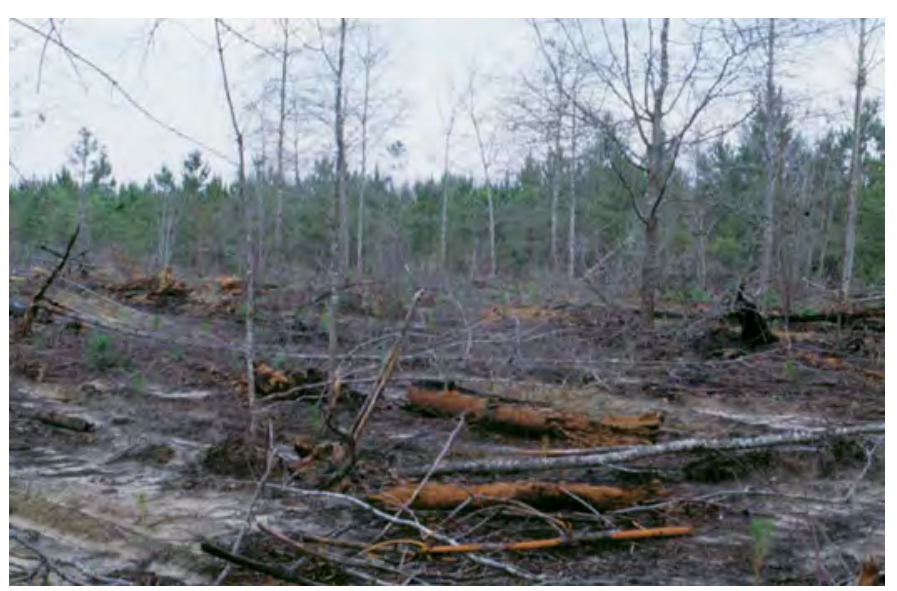

Figure 7. Newly cut forest in Southeastern Plains Ecoregion. Although forest cutting dramatically alters local ecosystem, favorable climate of Southeastern Plains Ecoregion results in rapid vegetation regrowth, whether land is replanted or allowed to regenerate naturally.

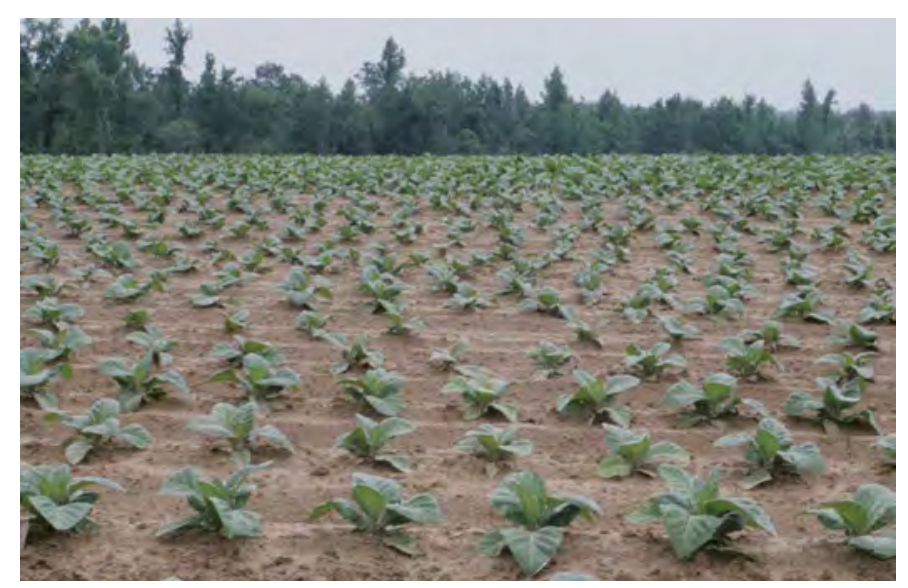

Figure 8. Newly planted tobacco field in Southeastern Plains Ecoregion. Although agricultural land declined by nearly 9,500 $\mathrm{km}^{2}$ between 1973 and 2000 in Southeastern Plains Ecoregion, high-value crops such as tobacco are still economically important in some areas. 
Table 1. Percentage of Southeastern Plains Ecoregion land cover that changed at least one time during study period (1973-2000) and associated statistical error.

[Most sample pixels remained unchanged (79.6 percent), whereas 20.4 percent changed at least once throughout study period]

\begin{tabular}{ccccccc}
\hline $\begin{array}{c}\text { Number } \\
\text { of } \\
\text { changes }\end{array}$ & $\begin{array}{c}\text { Percent } \\
\text { of } \\
\text { ecoregion }\end{array}$ & $\begin{array}{c}\text { Margin } \\
\text { of error } \\
(+/-\%)\end{array}$ & $\begin{array}{c}\text { Lower } \\
\text { bound } \\
(\%)\end{array}$ & $\begin{array}{c}\text { Upper } \\
\text { bound } \\
(\%)\end{array}$ & $\begin{array}{c}\text { Standard } \\
\text { error } \\
(\%)\end{array}$ & $\begin{array}{c}\text { Relative } \\
\text { error } \\
(\%)\end{array}$ \\
\hline 1 & 10.8 & 1.6 & 9.2 & 12.4 & 1.0 & 9.5 \\
2 & 8.8 & 2.3 & 6.5 & 11.1 & 1.5 & 16.9 \\
3 & 0.7 & 0.3 & 0.4 & 1.0 & 0.2 & 24.0 \\
4 & 0.1 & 0.0 & 0.0 & 0.1 & 0.0 & 27.3 \\
\hline $\begin{array}{l}\text { Overall } \\
\text { spatial } \\
\text { change }\end{array}$ & 20.4 & 3.9 & 16.5 & 24.3 & 2.5 & 12.3 \\
\hline
\end{tabular}

Table 2. Raw estimates of change in Southeastern Plains Ecoregion land cover, computed for each of four time periods between 1973 and 2000, and associated error at 85-percent confidence level.

[Estimates of change per period normalized to annual rate of change for each time period]

\begin{tabular}{|c|c|c|c|c|c|c|c|}
\hline Period & $\begin{array}{c}\text { Total change } \\
\text { (\% of ecoregion) }\end{array}$ & $\begin{array}{c}\text { Margin of } \\
\text { error } \\
(+/-\%) \\
\end{array}$ & $\begin{array}{c}\text { Lower } \\
\text { bound } \\
(\%)\end{array}$ & $\begin{array}{l}\text { Upper bound } \\
(\%)\end{array}$ & $\begin{array}{c}\text { Standard } \\
\text { error } \\
(\%) \\
\end{array}$ & $\begin{array}{c}\text { Relative } \\
\text { error } \\
(\%) \\
\end{array}$ & $\begin{array}{l}\text { Average rate } \\
\text { (\% per year) }\end{array}$ \\
\hline \multicolumn{8}{|c|}{ Estimate of change, in percent stratum } \\
\hline 1973-1980 & 4.9 & 1.2 & 3.8 & 6.1 & 0.7 & 15.0 & 0.7 \\
\hline 1980-1986 & 6.2 & 1.6 & 4.6 & 7.9 & 1.1 & 16.9 & 1.0 \\
\hline 1986-1992 & 9.1 & 2.3 & 6.8 & 11.4 & 1.5 & 16.2 & 1.5 \\
\hline $1992-2000$ & 10.5 & 2.3 & 8.2 & 12.8 & 1.5 & 13.9 & 1.3 \\
\hline \multicolumn{8}{|c|}{ Estimate of change, in square kilometers } \\
\hline 1973-1980 & 16,630 & 3,899 & 12,731 & 20,530 & 2,501 & 15.0 & 2,376 \\
\hline $1980-1986$ & 21,004 & 5,545 & 15,459 & 26,549 & 3,557 & 16.9 & 3,501 \\
\hline 1986-1992 & 30,513 & 7,727 & 22,786 & 38,240 & 4,956 & 16.2 & 5,086 \\
\hline 1992-2000 & 35,334 & 7,644 & 27,690 & 42,978 & 4,903 & 13.9 & 4,417 \\
\hline
\end{tabular}


Table 3. Estimated area (and margin of error) of each land-cover class in Southeastern Plains Ecoregion, calculated five times between 1973 and 2000. See appendix 3 for definitions of land-cover classifications.

\begin{tabular}{|c|c|c|c|c|c|c|c|c|c|c|c|c|c|c|c|c|c|c|c|c|}
\hline & \multicolumn{2}{|c|}{ Water } & \multicolumn{2}{|c|}{ Developed } & \multicolumn{2}{|c|}{$\begin{array}{c}\text { Mechanically } \\
\text { disturbed }\end{array}$} & \multicolumn{2}{|c|}{ Mining } & \multicolumn{2}{|c|}{ Barren } & \multicolumn{2}{|c|}{ Forest } & \multicolumn{2}{|c|}{$\begin{array}{l}\text { Grassland/ } \\
\text { Shrubland }\end{array}$} & \multicolumn{2}{|c|}{ Agriculture } & \multicolumn{2}{|c|}{ Wetland } & \multicolumn{2}{|c|}{$\begin{array}{c}\text { Non- } \\
\text { mecha- } \\
\text { nically } \\
\text { disturbed }\end{array}$} \\
\hline \multicolumn{21}{|c|}{ Area, in percent stratum } \\
\hline 1973 & 1.0 & 0.3 & 9.0 & 9.6 & 2.1 & 0.9 & 0.0 & 0.0 & 0.0 & 0.0 & 53.1 & 8.4 & 0.0 & 0.0 & 24.3 & 7.5 & 10.5 & 3.9 & 0.0 & 0.0 \\
\hline 1992 & 1.0 & 0.3 & 9.7 & 9.9 & 4.2 & 1.3 & 0.1 & 0.1 & 0.0 & 0.0 & 51.9 & 8.3 & 0.1 & 0.1 & 22.4 & 7.4 & 10.6 & 4.0 & 0.0 & 0.0 \\
\hline 2000 & 1.1 & 0.4 & 10.3 & 10.0 & 4.9 & 1.3 & 0.1 & 0.0 & 0.0 & 0.0 & 51.8 & 7.9 & 0.1 & 0.1 & 21.5 & 6.8 & 10.3 & 3.8 & 0.0 & 0.0 \\
\hline $\begin{array}{l}\text { Net } \\
\text { change }\end{array}$ & 0.1 & 0.1 & 1.3 & 0.5 & 2.8 & 1.0 & 0.0 & 0.0 & 0.0 & 0.0 & -1.2 & 1.6 & 0.1 & 0.1 & -2.8 & 1.3 & -0.2 & 0.3 & 0.0 & 0.0 \\
\hline 1973 & 3,279 & 1,031 & 30,196 & 32,321 & 7,093 & 2,951 & 151 & 120 & 3 & 4 & 178,350 & 28,226 & 11 & 11 & 81,677 & 25,367 & 35,383 & 13,189 & 0 & 0 \\
\hline 1980 & 3,295 & 1,037 & 30,850 & 32,595 & 7,807 & 2,433 & 223 & 160 & 3 & 4 & 175,341 & 29,156 & 13 & 14 & 82,961 & 26,292 & 35,648 & 13,282 & 0 & 0 \\
\hline 1986 & 3,598 & 1,280 & 31,615 & 32,932 & 9,598 & 3,168 & 296 & 187 & 3 & 4 & 173,634 & 28,853 & 343 & 492 & 81,404 & 26,147 & 35,651 & 13,254 & 0 & 0 \\
\hline 1992 & 3,321 & 1,081 & 32,538 & 33,297 & 14,074 & 4,214 & 271 & 169 & 3 & 4 & 174,407 & 27,977 & 420 & 425 & 75,332 & 24,880 & 35,775 & 13,289 & 0 & 0 \\
\hline 2000 & 3,693 & 1,177 & 34,574 & 33,685 & 16,370 & 4,445 & 266 & 159 & 3 & 4 & 174,231 & 26,617 & 206 & 227 & 72,201 & 23,010 & 34,598 & 12,740 & 0 & 0 \\
\hline $\begin{array}{l}\text { Net } \\
\text { change }\end{array}$ & 414 & 357 & 4,378 & 1,833 & 9,278 & 3,485 & 115 & 156 & 0 & 0 & $-4,119$ & 5,506 & 195 & 223 & $-9,476$ & 4,485 & -785 & 976 & 0 & 0 \\
\hline $\begin{array}{l}\text { Gross } \\
\text { change }\end{array}$ & 1,090 & 1,001 & 4,383 & 1,831 & 21,541 & 4,795 & 379 & 240 & 0 & 0 & 26,423 & 7,277 & 788 & 822 & 14,553 & 6,278 & 2,614 & 1,569 & 0 & 0 \\
\hline
\end{tabular}


Table 4. Principal land-cover conversions in Southeastern Plains Ecoregion, showing amount of area changed (and margin of error, calculated at 85-percent confidence level) for each conversion during each of four time periods and also during overall study period. See appendix 3 for definitions of land-cover classifications.

[Values given for "other" classes are combined totals of values for other land-cover classes not listed in that time period. Abbreviations: n/a, not applicable]

\begin{tabular}{|c|c|c|c|c|c|c|c|}
\hline Period & From class & To class & $\begin{array}{c}\begin{array}{c}\text { Area } \\
\text { changed }\end{array} \\
\left(\mathrm{km}^{2}\right)\end{array}$ & $\begin{array}{c}\text { Margin of } \\
\text { error } \\
\left(+/-\mathbf{k m}^{2}\right)\end{array}$ & $\begin{array}{c}\text { Standard } \\
\text { error } \\
\left(\mathbf{k m}^{2}\right)\end{array}$ & $\begin{array}{l}\text { Percent of } \\
\text { ecoregion }\end{array}$ & $\begin{array}{c}\text { Percent of all } \\
\text { changes }\end{array}$ \\
\hline \multirow[t]{7}{*}{$1973-1980$} & Forest & Mechanically disturbed & 6,602 & 2,112 & 1,354 & 2.0 & 39.7 \\
\hline & Mechanically disturbed & Forest & 5,864 & 2,903 & 1,862 & 1.7 & 35.3 \\
\hline & Forest & Agriculture & 2,125 & 1,332 & 855 & 0.6 & 12.8 \\
\hline & Agriculture & Forest & 625 & 478 & 307 & 0.2 & 3.8 \\
\hline & Forest & Developed & 483 & 325 & 208 & 0.1 & 2.9 \\
\hline & Other & Other & 931 & $\mathrm{n} / \mathrm{a}$ & $\mathrm{n} / \mathrm{a}$ & 0.3 & 5.6 \\
\hline & & Totals & 16,630 & & & 4.9 & 100.0 \\
\hline \multirow[t]{7}{*}{ 1980-1986 } & Forest & Mechanically disturbed & 8,230 & 2,834 & 1,818 & 2.4 & 39.2 \\
\hline & Mechanically disturbed & Forest & 6,540 & 2,255 & 1,446 & 1.9 & 31.1 \\
\hline & Agriculture & Forest & 2,249 & 1,343 & 861 & 0.7 & 10.7 \\
\hline & Forest & Agriculture & 1,347 & 953 & 611 & 0.4 & 6.4 \\
\hline & Forest & Developed & 578 & 367 & 235 & 0.2 & 2.8 \\
\hline & Other & Other & 2,061 & $\mathrm{n} / \mathrm{a}$ & $\mathrm{n} / \mathrm{a}$ & 0.6 & 9.8 \\
\hline & & Totals & 21,004 & & & 6.2 & 100.0 \\
\hline \multirow[t]{7}{*}{ 1986-1992 } & Forest & Mechanically disturbed & 12,649 & 3,884 & 2,491 & 3.8 & 41.5 \\
\hline & Mechanically disturbed & Forest & 8,659 & 2,927 & 1,878 & 2.6 & 28.4 \\
\hline & Agriculture & Forest & 5,510 & 3,351 & 2,149 & 1.6 & 18.1 \\
\hline & Forest & Developed & 578 & 330 & 212 & 0.2 & 1.9 \\
\hline & Forest & Agriculture & 393 & 293 & 188 & 0.1 & 1.3 \\
\hline & Other & Other & 2,724 & $\mathrm{n} / \mathrm{a}$ & $\mathrm{n} / \mathrm{a}$ & 0.8 & 8.9 \\
\hline & & Totals & 30,513 & & & 9.1 & 100.0 \\
\hline \multirow[t]{7}{*}{$1992-2000$} & Forest & Mechanically disturbed & 14,026 & 4,091 & 2,624 & 4.2 & 39.7 \\
\hline & Mechanically disturbed & Forest & 11,936 & 3,839 & 2,462 & 3.6 & 33.8 \\
\hline & Agriculture & Forest & 3,604 & 2,270 & 1,456 & 1.1 & 10.2 \\
\hline & Forest & Developed & 1,415 & 713 & 457 & 0.4 & 4.0 \\
\hline & Wetland & Mechanically disturbed & 1,340 & 794 & 509 & 0.4 & 3.8 \\
\hline & Other & Other & 3,014 & $\mathrm{n} / \mathrm{a}$ & $\mathrm{n} / \mathrm{a}$ & 0.9 & 8.5 \\
\hline & & Totals & 35,334 & & & 10.5 & 100.0 \\
\hline \multirow{7}{*}{$\begin{array}{c}\text { 1973-2000 } \\
\text { (overall) }\end{array}$} & Forest & Mechanically disturbed & 41,506 & 11,143 & 7,148 & 12.3 & 40.1 \\
\hline & Mechanically disturbed & Forest & 32,999 & 9,426 & 6,046 & 9.8 & 31.9 \\
\hline & Agriculture & Forest & 11,988 & 5,442 & 3,491 & 3.6 & 11.6 \\
\hline & Forest & Agriculture & 4,463 & 2,305 & 1,478 & 1.3 & 4.3 \\
\hline & Forest & Developed & 3,055 & 1,365 & 875 & 0.9 & 3.0 \\
\hline & Other & Other & 9,472 & $\mathrm{n} / \mathrm{a}$ & $\mathrm{n} / \mathrm{a}$ & 2.8 & 9.2 \\
\hline & & Totals & 103,482 & & & 30.8 & 100.0 \\
\hline
\end{tabular}


Table 5. Amount of forestry, as defined by both forest and mechanically disturbed land-cover classes, as percentage of ecoregion in Southeastern Plains Ecoregion, calculated five times between 1973 and 2000.

\begin{tabular}{cc}
\hline & $\begin{array}{c}\text { Amount of forestry } \\
\text { (\% of ecoregion) }\end{array}$ \\
\hline 1973 & 55.2 \\
1980 & 54.5 \\
1986 & 54.6 \\
1992 & 56.1 \\
2000 & 56.7 \\
\hline
\end{tabular}

\section{References Cited}

Conner, R.C., and Hartsell, A.J., 2002, Forest area and conditions, in Wear, D.N., and Greis, J.G., eds., Southern forest resource assessment: U.S. Forest Service, Southern Research Station, General Technical Report SRS 53, p. 357-402, available at http://www.srs.fs.usda.gov/pubs/4833.

U.S. Census Bureau, 1970-2000 [various years], Census of population and housing: U.S. Census Bureau database,

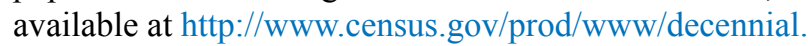
html.

Vogelmann, J.E., Howard, S.M., Yang, L., Larson, C.R., Wylie, B.K., and van Driel, N., 2001, Completion of the 1990s National Land Cover Data Set for the conterminous United States from Landsat Thematic Mapper data and ancillary data sources: Photogrammetric Engineering \& Remote Sensing, v. 67, p. 650-662.

Wear, D.N., 2002, Land use, in Wear, D.N., and Greis, J.G., eds., Southern forest resource assessment: U.S. Forest Service, Southern Research Station, General Technical Report SRS 53, p. 153-173, available at http://www.srs. fs.usda.gov/pubs/4833.

Wiken, E., Jiménez Nava, F., and Griffith, G., 2011, North American terrestrial ecoregions-Level III: Montreal, Canada, Commission for Environmental Cooperation, 149 p., accessed May 1, 2013, at http://www.cec.org/ Storage/133/15860_QA07.30-32_NP_NA_Terrestrial_ Ecoregions_Level_3_Final-2june11.pdf. 


\section{Chapter 18}

\section{Middle Atlantic Coastal Plain Ecoregion}

By Roger F. Auch

\section{Ecoregion Description}

The Middle Atlantic Coastal Plain Ecoregion is a linear ecoregion that covers about $89,686 \mathrm{~km}^{2}\left(34,628 \mathrm{mi}^{2}\right)$, stretching from Delaware Bay and the Delmarva Peninsula in the north nearly to Jacksonville, Florida, in the south. The ecoregion, which includes parts of nine states (New Jersey, Pennsylvania, Delaware, Maryland, Virginia, North Carolina, South Carolina, Georgia, and Florida) (fig. 1), ranges in width from only a few miles, in areas inland of Delaware Bay and in extreme northeastern Florida, to about 70 miles, in parts of North Carolina and South Carolina. The ecoregion is surrounded by (counterclockwise, from the northeast) the Atlantic Coastal Pine Barrens, Northern Piedmont, Southeastern Plains, and Southern Coastal Plain Ecoregions. The topography primarily is flat, and many soil types are poorly drained (Wiken and others, 2011). The ecoregion has moderate to mild winters and hot, humid summers, with an average annual precipitation of 1,000 to $1,500 \mathrm{~mm}$ (40-60 in.).

The predominant land uses in the Middle Atlantic Coastal Plain Ecoregion are farming and forestry, but urban development also is significant locally. Land cover primarily is a mosaic of forest, wetland, and agriculture. Agricultural land is composed mainly of cropland: soybeans, cotton, and some tobacco in the south, and soybeans and corn farther north (fig. 2). Livestock production most

Figure 1. Map of Middle Atlantic Coastal Plain Ecoregion and surrounding ecoregions, showing land-use/land-cover classes from 1992 National Land Cover Dataset (Vogelmann and others, 2001); note that not all land-use/land-cover classes shown in explanation may be depicted on map; note also that, for this "Status and Trends of Land Change" study, transitional land-cover class was subdivided into mechanically disturbed and nonmechanically disturbed classes. Squares indicate locations of $20 \times 20 \mathrm{~km}$ sample blocks analyzed in study. Index map shows locations of geographic features mentioned in text. Abbreviations for Eastern United States ecoregions are listed in appendix 2. Also shown is part of one Midwest-South Central United States ecoregion, Erie Drift Plains (EDP). See appendix 3 for definitions of land-use/land-cover classifications.

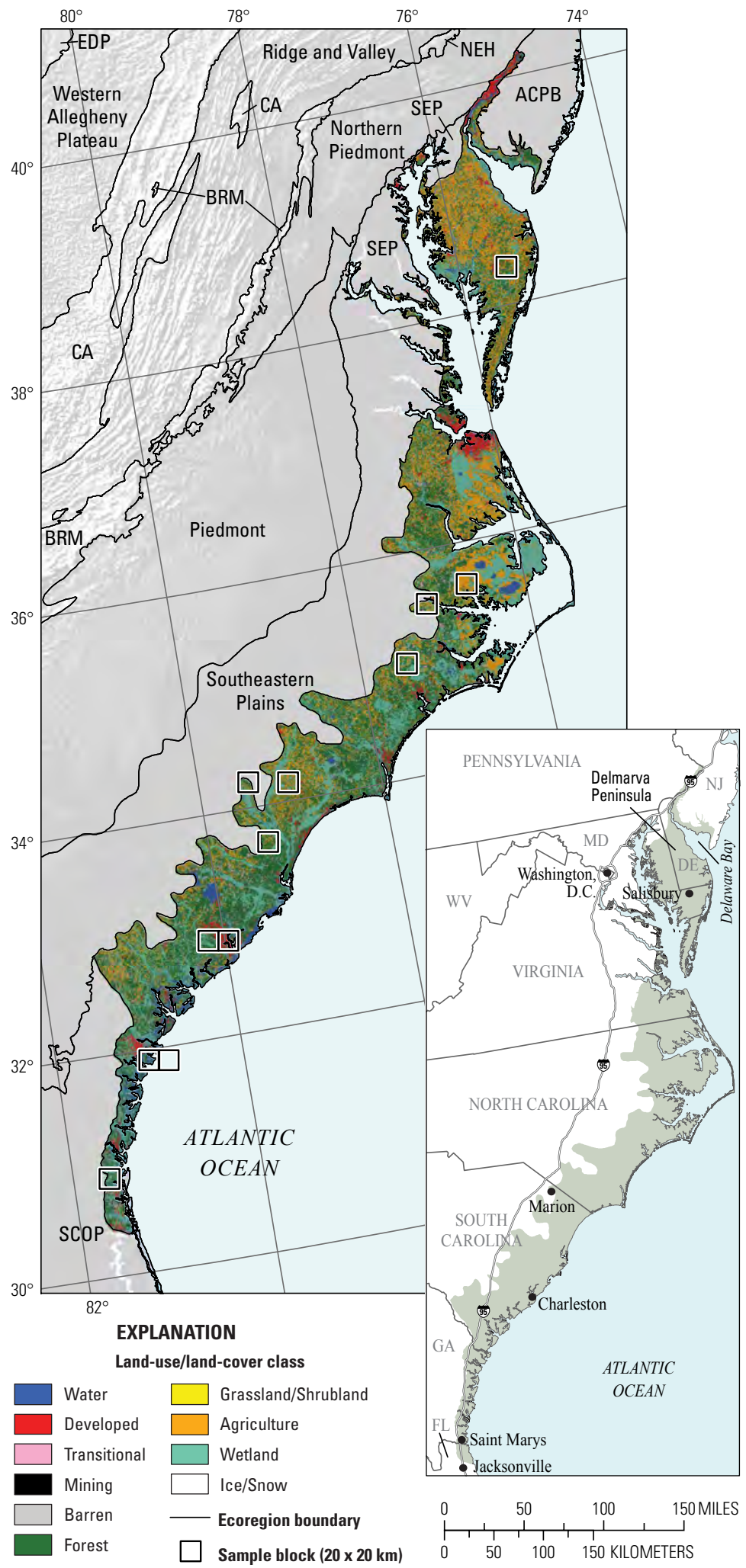


commonly is confined animal-feeding operations, for hogs in North Carolina and poultry on the Delmarva Peninsula (fig. 3) (U.S. Department of Agriculture, 1999). Upland forested areas are composed predominantly of pine (Pinus spp.) or mixed pine and hardwood communities (fig. 4). Wetlands, which are common across the ecoregion, include coastal marshes, bottomland hardwood forests, and shrub bogs (pocosins) (figs. $5 A, B)$. Other land-cover classes that have less extensive areas include water and mechanically disturbed.

\section{Contemporary Land-Cover Change (1973 to 2000)}

The overall spatial change (the percentage of land area that changed at least one time) in the Middle Atlantic Coastal Plain Ecoregion between 1973 and 2000 is estimated at 18.0 percent (table 1). Compared to other Eastern United

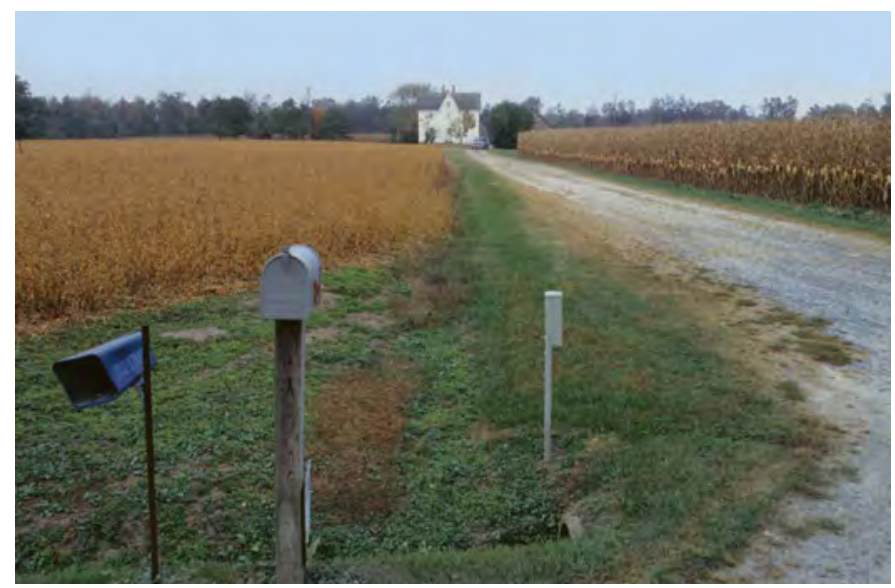

Figure 2. Farm growing corn and soybeans near Salisbury, Maryland.

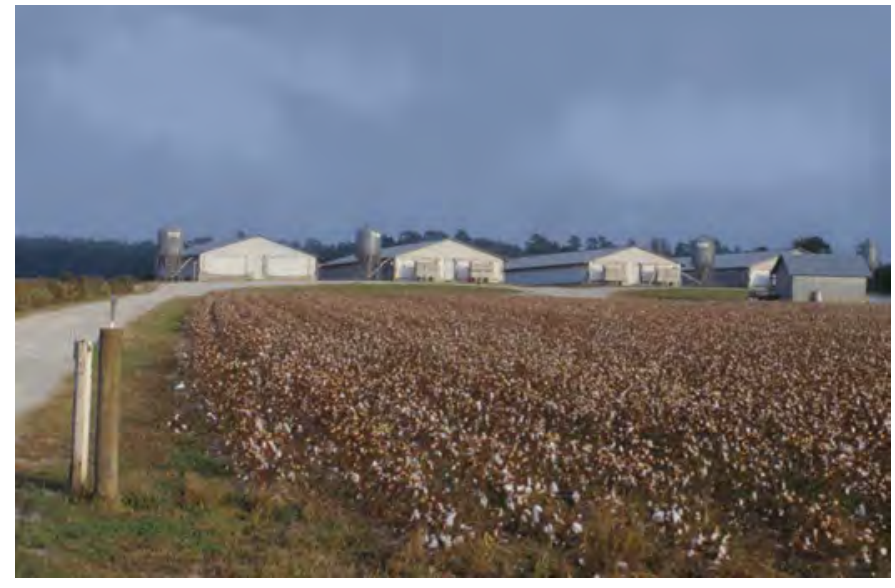

Figure 3. Cotton field and confined animal-feeding units, raising either hogs or poultry, on farm in North Carolina, in Middle Atlantic Coastal Plain Ecoregion.

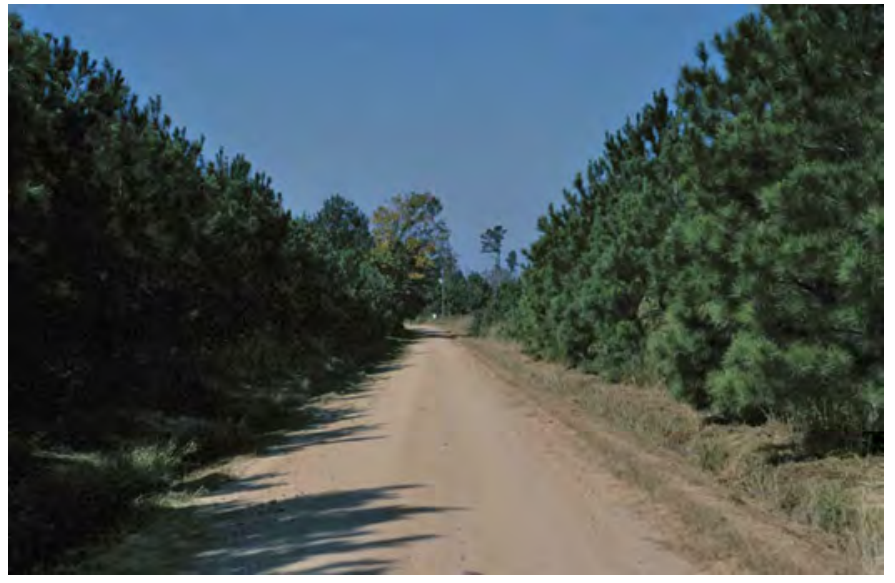

Figure 4. Plantation of even-aged loblolly pine (Pinus taeda), near Marion, South Carolina.
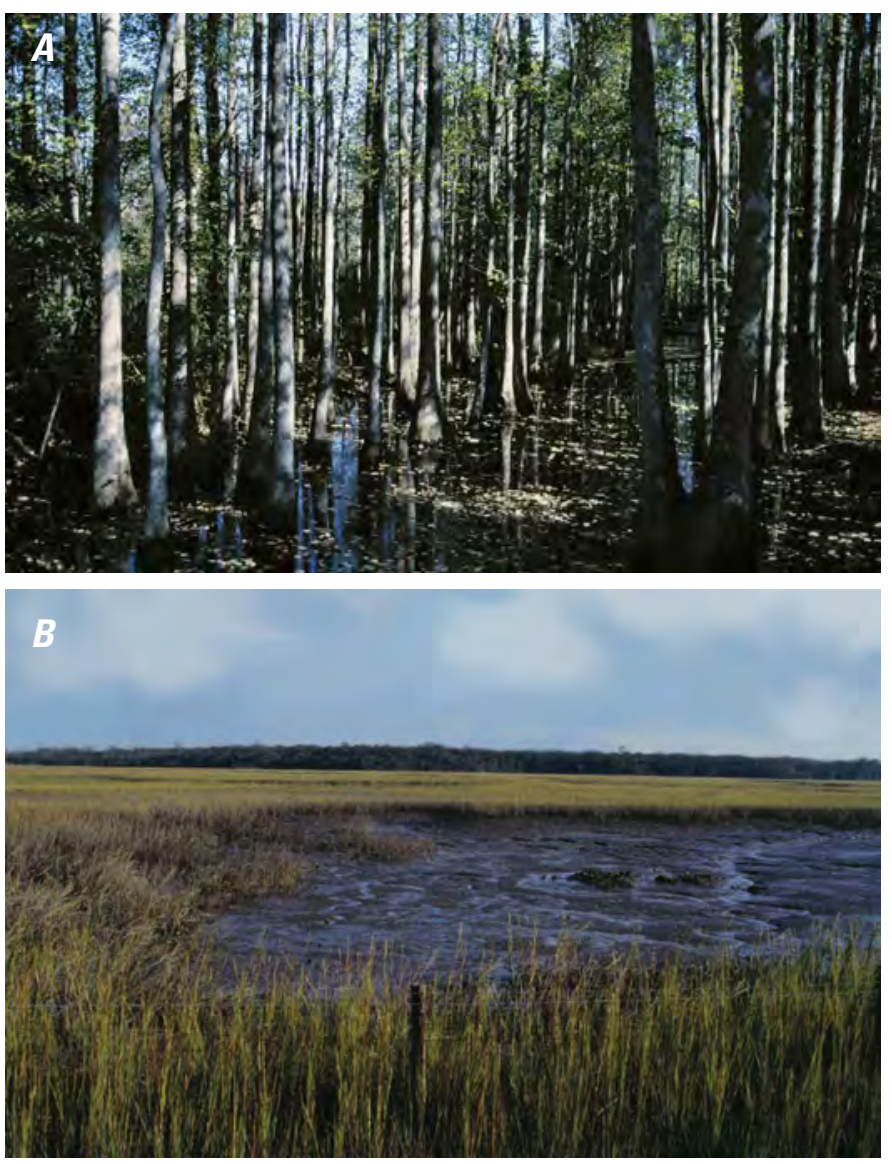

Figure 5. Wetland areas in Middle Atlantic Coastal Plain Ecoregion. A, Forested wetland (bottomland hardwoods) in South Carolina. $B$, Coastal wetland in extreme southeastern Georgia. 


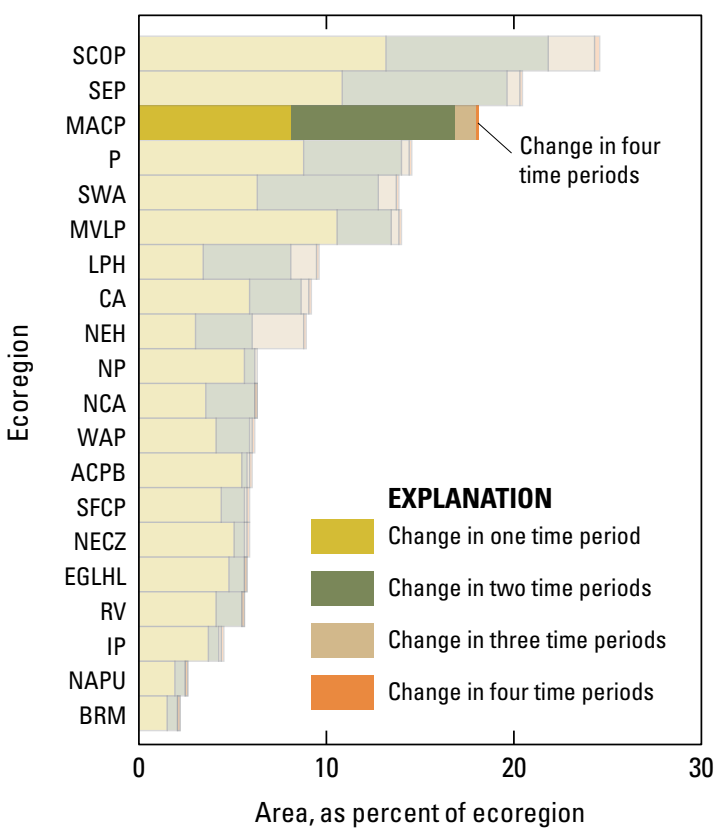

Figure 6. Overall spatial change in Middle Atlantic Coastal Plain Ecoregion (MACP; darker bars) compared with that of all 20 Eastern United States ecoregions (lighter bars). Each horizontal set of bars shows proportions of ecoregion that changed during one, two, three, or four time periods; highest level of spatial change in Middle Atlantic Coastal Plain Ecoregion (four time periods) labeled for clarity. See table 2 for years covered by each time period. See appendix 2 for key to ecoregion abbreviations.

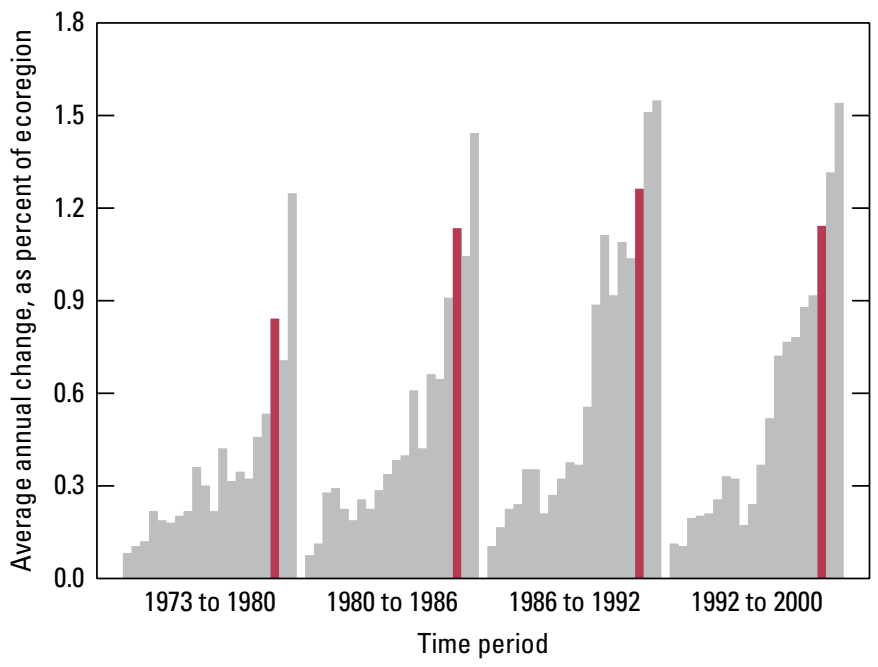

Figure 7. Estimates of land-cover change per time period, normalized to annual rates of change for all 20 Eastern United States ecoregions (gray bars). Estimates of change for Middle Atlantic Coastal Plain Ecoregion are represented by red bars in each time period.
States ecoregions, change in the Middle Atlantic Coastal Plain Ecoregion was high, ranking third overall (fig. 6). The amount of area that changed per time period was relatively high, and it increased during the 27-year study period: the period between 1973 and 1980 experienced the least change, and the period between 1992 and 2000 experienced the most change (table 2). When normalized to an average annual rate to account for uneven time periods, the period between 1973 and 1980 still had the lowest rate of change (at 0.8 percent per year), and the period between 1986 and 1992 still had the highest rate of change (1.3 percent per year). Although the period between 1986 and 1992 was the most dynamic, two other periods (1980-1986, 1992-2000) also had normalized rates that exceeded 1.0 percent per year, a high rate of change among those estimated for all Eastern United States ecoregions (fig. 7).

Two of the Middle Atlantic Coastal Plain Ecoregion's dominant land-cover classes, forest and wetland, experienced considerable net change, although this change was uneven for these classes across time periods (table 3 ). Forest decreased in the first three time periods, ranging from 35.5 to 31.9 percent of the ecoregion, but it increased to 32.1 percent in the last time period, for a net loss in area of 3.4 percent between 1973 and 2000 (table 3; fig. 8). Some of this net loss is due to the conversion of forest to mechanically disturbed, the result of timber harvesting; however, this land is expected to return to forest at a later date. Wetland decreased noticeably in two time periods (1980-1986, 1992-2000), with losses of 0.6 and 0.8 percent, respectively, but it had almost no change during the other two time periods (1973-1980, 1986-1992). Overall, wetland had a net decrease of 1.3 percent during the study period, but some of the wetland that converted to mechanically disturbed in the last time period likely will return to wetland at a later date. The third most common land-cover class, agriculture, did not have a noticeable net change between 1973 and 2000, although it gained a small amount of area between 1973 and 1980 that was offset by losses during two subsequent time periods. The less prevalent land-cover classes of developed and mechanically disturbed had substantial net gains in area, but they experienced somewhat different patterns of change. The total amount of developed had a nearly consistent increase across each time period, ranging from 6.5 percent in 1973 to 9.0 percent in 2000, whereas mechanically disturbed showed more fluctuations in the rate of change, ranging from 2.3 percent in 1973 to 4.2 percent in 2000 (table 3). The developed land-cover class in urban areas almost always has a net increase, as it tends to be a permanent change, whereas other land-cover classes, such as forest, agriculture, wetland, and mechanically disturbed, may experience fluctuating net changes as part of cyclic land uses.

The high rates of land-cover change in the Middle Atlantic Coastal Plain Ecoregion were driven by forest harvesting and regeneration (together representing 72.0 percent of the total change), indicative of cyclic wood production (table 4). Conversions from forest to mechanically disturbed and from mechanically disturbed to forest were the leading land-cover 
conversions for each time period (table 4; figs. $9 A, B$ ). Overall, $19,001 \mathrm{~km}^{2}$ of land fluctuated between these two land-cover classes. Forest may be clearcut for wood harvesting but, subsequently, may return to forest. In addition, land used for farming or forestry may be converted to another use to take advantage of changing economic markets. Another way to consider forest land cover in this ecoregion is to compare the percentage of land that was consistently forest between 1973 and 2000 ("stable" forest, unaltered forest that is at least 30 years of age) with the percentage of land that was forest only part of the time ("dynamic" forest). More than one-half (59.5 percent) of the forested areas remained as forest throughout the study period, whereas 40.5 percent was converted to (or from) forest (table 5). The percentage of stable forest in the Middle Atlantic Coastal Plain Ecoregion was one of the lowest percentages of all Eastern United States ecoregions.

Other leading land-cover changes included disturbances in wetlands and increases in developed land (fig. 10). An estimated $1,963 \mathrm{~km}^{2}$ of wetlands underwent some sort of change (table 3); most of this change was to mechanically disturbed land, but

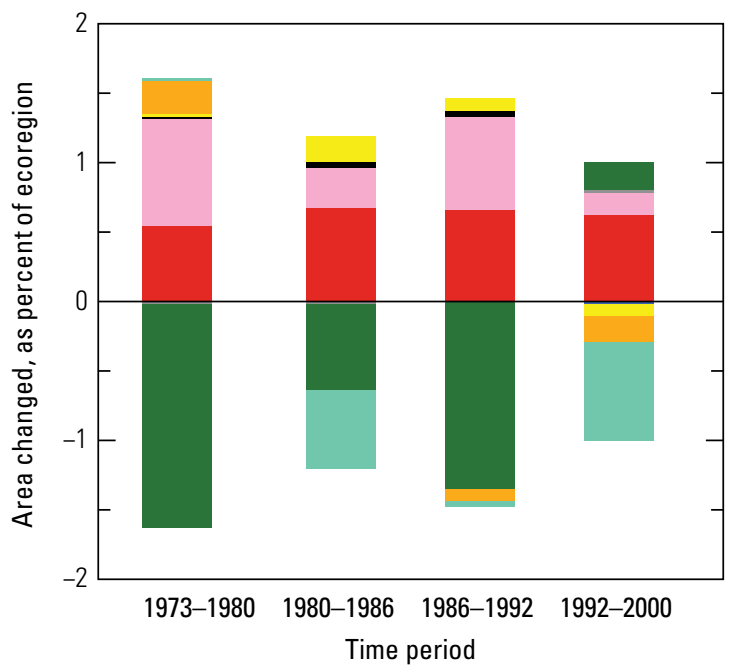

\section{EXPLANATION}

Land-use/land-cover class

$\square$ Water
$\square$ Developed
$\square$ Mechanically disturbed
Mining
$\square$ Barren

$\square$ Forest
$\square$ Grassland/Shrubland
$\square$ Agriculture
$\square$ Wetland
$\square$ Nonmechanically disturbed
$\square$ Ice/Snow

Figure 8. Normalized average net change in Middle Atlantic Coastal Plain Ecoregion by time period for each land-cover class. Bars above zero axis represent net gain, whereas bars below zero represent net loss. Note that not all land-cover classes shown in explanation may be represented in figure. See appendix 3 for definitions of land-use and land-cover classifications.
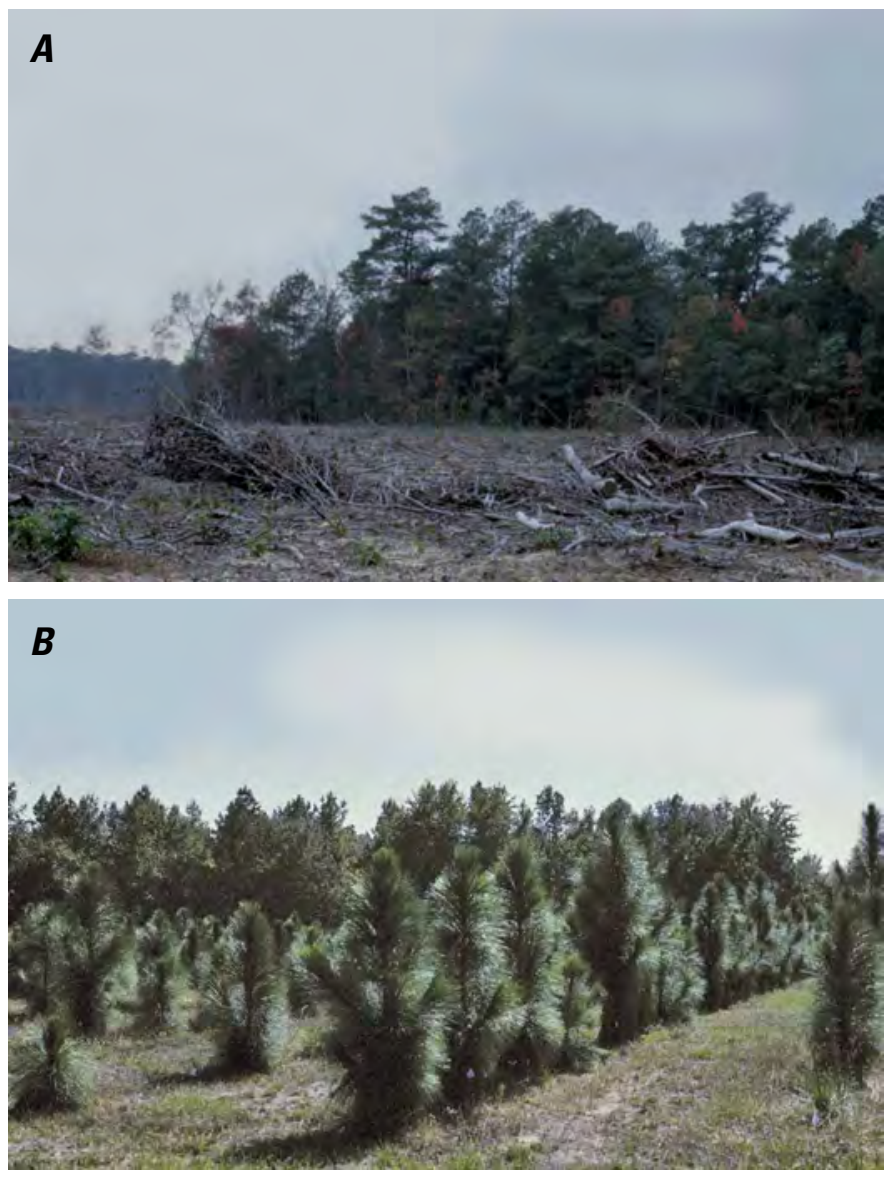

Figure 9. Conversions between forested land and mechanically disturbed land in Middle Atlantic Coastal Plain Ecoregion. A, Tree debris, or slash, remaining after forest clearcut (classified as mechanically disturbed), on eastern shore of Maryland. $B$, Planted field of young pine trees west of Charleston, South Carolina.

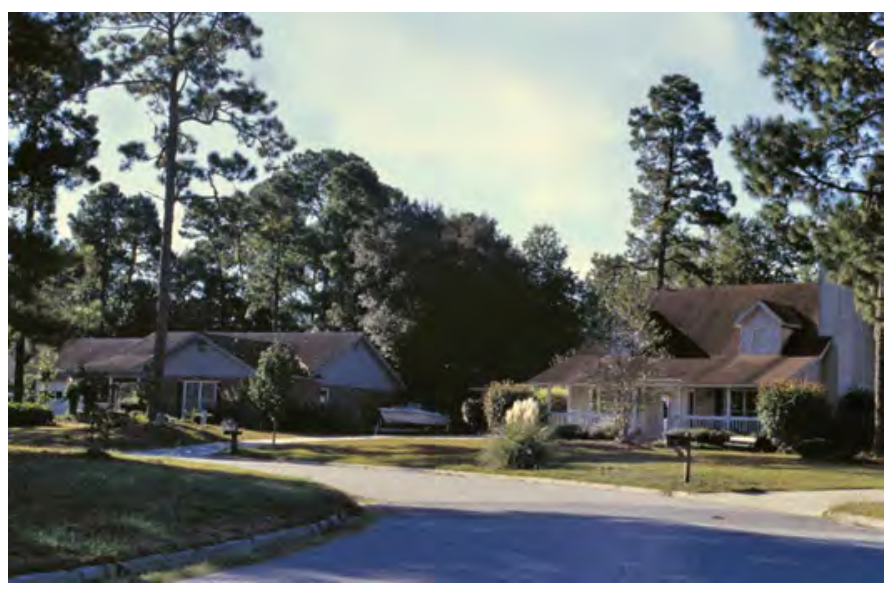

Figure 10. Subdivision near Interstate 95, west of Saint Marys, Georgia. 
about one-half of the wetlands that converted to mechanically disturbed land subsequently reverted to wetland conditions. The conversions back and forth between wetland and mechanically disturbed were the third-leading (wetland to mechanically disturbed) and fifth-leading (mechanically disturbed to wetland) changes overall (table 4); harvesting of timber in forested wetlands, such as bottomland hardwoods, appeared to account for most of these conversions. An estimated $134 \mathrm{~km}^{2}$ of wetland change, however, was an outright conversion to developed land or forested land. In addition, the conversion of forest to developed was either the third or fourth most common landcover change in area by time period: the ecoregion gained an estimated $2,247 \mathrm{~km}^{2}$ of new developed land during the study period (table 3$)$, most of it from forested land $\left(1,741 \mathrm{~km}^{2}\right)$ (table 4), and most of the rest came from either agricultural land $\left(253 \mathrm{~km}^{2}\right)$ or wetlands $\left(134 \mathrm{~km}^{2}\right)$.
Table 1. Percentage of Middle Atlantic Coastal Plain Ecoregion land-cover that changed at least one time during study period (1973-2000) and associated statistical error.

[Most sample pixels remained unchanged ( 82.0 percent), whereas 18.0 percent changed at least once throughout study period]

\begin{tabular}{ccccccc}
\hline $\begin{array}{c}\text { Number } \\
\text { of } \\
\text { changes }\end{array}$ & $\begin{array}{c}\text { Percent } \\
\text { of } \\
\text { ecoregion }\end{array}$ & $\begin{array}{c}\text { Margin } \\
\text { of error } \\
(+/-\%)\end{array}$ & $\begin{array}{c}\text { Lower } \\
\text { bound } \\
(\%)\end{array}$ & $\begin{array}{c}\text { Upper } \\
\text { bound } \\
(\%)\end{array}$ & $\begin{array}{c}\text { Standard } \\
\text { error } \\
(\%)\end{array}$ & $\begin{array}{c}\text { Relative } \\
\text { error } \\
(\%)\end{array}$ \\
\hline 1 & 8.0 & 1.3 & 6.7 & 9.3 & 0.8 & 10.3 \\
2 & 8.7 & 3.0 & 5.7 & 11.6 & 1.9 & 22.0 \\
3 & 1.2 & 0.7 & 0.5 & 1.9 & 0.5 & 39.5 \\
4 & 0.1 & 0.1 & 0.0 & 0.2 & 0.1 & 43.5 \\
\hline $\begin{array}{l}\text { Overall } \\
\text { spatial } \\
\text { change }\end{array}$ & 18.0 & 4.5 & 13.5 & 22.5 & 2.9 & 15.9 \\
\hline
\end{tabular}

Table 2. Raw estimates of change in Middle Atlantic Coastal Plain Ecoregion land cover, computed for each of four time periods between 1973 and 2000, and associated error at 85-percent confidence level.

[Estimates of change per period normalized to annual rate of change for each period]

\begin{tabular}{|c|c|c|c|c|c|c|c|}
\hline Period & $\begin{array}{c}\text { Total change } \\
\text { ( } \% \text { of ecoregion) }\end{array}$ & $\begin{array}{c}\text { Margin of } \\
\text { error } \\
(+/-\%) \\
\end{array}$ & $\begin{array}{c}\text { Lower } \\
\text { bound } \\
(\%) \\
\end{array}$ & $\begin{array}{l}\text { Upper bound } \\
(\%)\end{array}$ & $\begin{array}{c}\text { Standard } \\
\text { error } \\
(\%) \\
\end{array}$ & $\begin{array}{c}\text { Relative } \\
\text { error } \\
(\%) \\
\end{array}$ & $\begin{array}{l}\text { Average rate } \\
\text { ( } \% \text { per year) }\end{array}$ \\
\hline \multicolumn{8}{|c|}{ Estimate of change, in percent stratum } \\
\hline 1973-1980 & 5.9 & 1.6 & 4.2 & 7.5 & 1.0 & 17.7 & 0.8 \\
\hline 1980-1986 & 6.8 & 2.3 & 4.5 & 9.1 & 1.5 & 22.0 & 1.1 \\
\hline 1986-1992 & 7.6 & 2.5 & 5.1 & 10.1 & 1.6 & 21.1 & 1.3 \\
\hline 1992-2000 & 9.2 & 2.6 & 6.5 & 11.8 & 1.7 & 18.5 & 1.1 \\
\hline \multicolumn{8}{|c|}{ Estimate of change, in square kilometers } \\
\hline $1973-1980$ & 5,262 & 1,454 & 3,808 & 6,715 & 932 & 17.7 & 752 \\
\hline 1980-1986 & 6,108 & 2,091 & 4,017 & 8,199 & 1,341 & 22.0 & 1,018 \\
\hline 1986-1992 & 6,805 & 2,235 & 4,571 & 9,040 & 1,433 & 21.1 & 1,134 \\
\hline 1992-2000 & 8,215 & 2,373 & 5,842 & 10,588 & 1,522 & 18.5 & 1,027 \\
\hline
\end{tabular}


Table 3. Estimated area (and margin of error) of each land-cover class in Middle Atlantic Coastal Plain Ecoregion, calculated five times between 1973 and 2000. See appendix 3 for definitions of land-cover classifications.

\begin{tabular}{|c|c|c|c|c|c|c|c|c|c|c|c|c|c|c|c|c|c|c|c|c|}
\hline & \multicolumn{2}{|c|}{ Water } & \multicolumn{2}{|c|}{ Developed } & \multicolumn{2}{|c|}{$\begin{array}{l}\text { Mechanical- } \\
\text { ly disturbed }\end{array}$} & \multicolumn{2}{|c|}{ Mining } & \multicolumn{2}{|c|}{ Barren } & \multicolumn{2}{|c|}{ Forest } & \multicolumn{2}{|c|}{$\begin{array}{l}\text { Grass- } \\
\text { land/ } \\
\text { Shrubland }\end{array}$} & \multicolumn{2}{|c|}{ Agriculture } & \multicolumn{2}{|c|}{ Wetland } & \multicolumn{2}{|c|}{$\begin{array}{c}\text { Non- } \\
\text { mecha- } \\
\text { nically } \\
\text { disturbed }\end{array}$} \\
\hline & $\%$ & $+/-$ & $\%$ & $+1-$ & $\%$ & $+/-$ & $\%$ & $+/-$ & $\%$ & $+/-$ & $\%$ & $+/-$ & $\%$ & $+/-$ & $\%$ & $+/-$ & $\%$ & $+/-$ & $\%$ & $+/-$ \\
\hline \multicolumn{21}{|c|}{ Area, in percent stratum } \\
\hline 1973 & 6.7 & 5.1 & 6.5 & 4.5 & 2.3 & 0.7 & 0.0 & 0.0 & 0.1 & 0.2 & 35.5 & 7.3 & 0.3 & 0.4 & 22.7 & 9.1 & 26.0 & 3.6 & 0.0 & 0.0 \\
\hline 1980 & 6.7 & 5.1 & 7.0 & 4.7 & 3.1 & 1.3 & 0.1 & 0.1 & 0.1 & 0.2 & 33.9 & 6.8 & 0.3 & 0.4 & 22.9 & 9.2 & 26.0 & 3.7 & 0.0 & 0.0 \\
\hline 1986 & 6.7 & 5.1 & 7.7 & 4.9 & 3.4 & 1.4 & 0.1 & 0.1 & 0.1 & 0.2 & 33.2 & 6.8 & 0.5 & 0.5 & 22.9 & 9.2 & 25.4 & 3.5 & 0.0 & 0.0 \\
\hline 1992 & 6.7 & 5.1 & 8.3 & 5.1 & 4.0 & 1.5 & 0.1 & 0.2 & 0.1 & 0.2 & 31.9 & 6.5 & 0.6 & 0.5 & 22.8 & 9.2 & 25.4 & 3.7 & 0.0 & 0.0 \\
\hline 2000 & 6.7 & 5.1 & 9.0 & 5.3 & 4.2 & 1.2 & 0.1 & 0.2 & 0.2 & 0.2 & 32.1 & 7.0 & 0.5 & 0.5 & 22.7 & 9.3 & 24.6 & 3.5 & 0.0 & 0.0 \\
\hline $\begin{array}{l}\text { Net } \\
\text { change }\end{array}$ & 0.0 & 0.0 & 2.5 & 1.2 & 1.9 & 0.9 & 0.1 & 0.1 & 0.0 & 0.0 & -3.4 & 1.8 & 0.2 & 0.3 & 0.0 & 0.6 & -1.3 & 0.7 & 0.0 & 0.0 \\
\hline $\begin{array}{l}\text { ross } \\
\text { lange }\end{array}$ & 0.0 & 0.0 & 2.5 & 1.2 & 6.1 & 1.9 & 0.1 & 0.1 & 0.0 & 0.1 & 7.1 & 2.0 & 0.4 & 0.6 & 1.1 & 0.5 & 2.2 & 0.8 & 0.0 & 0.0 \\
\hline \multicolumn{21}{|c|}{ Area, in square kilometers } \\
\hline 1973 & 5,978 & 4,568 & 5,800 & 4,019 & 2,061 & 646 & 37 & 40 & 132 & 199 & 31,814 & 6,529 & 243 & 346 & 20,343 & 8,121 & 23,278 & 3,252 & 0 & 0 \\
\hline 1980 & 5,986 & 4,576 & 6,299 & 4,197 & 2,757 & 1,185 & 49 & 50 & 125 & 189 & 30,365 & 6,064 & 252 & 345 & 20,556 & 8,276 & 23,298 & 3,294 & 0 & 0 \\
\hline 1986 & 5,994 & 4,585 & 6,900 & 4,434 & 3,022 & 1,244 & 75 & 87 & 120 & 181 & 29,807 & 6,089 & 426 & 408 & 20,549 & 8,290 & 22,793 & 3,176 & 0 & 0 \\
\hline 1992 & 6,002 & 4,585 & 7,485 & 4,607 & 3,625 & 1,311 & 109 & 138 & 124 & 184 & 28,598 & 5,830 & 516 & 483 & 20,471 & 8,273 & 22,755 & 3,284 & 0 & 0 \\
\hline 2000 & 5,994 & 4,574 & 8,047 & 4,797 & 3,768 & 1,076 & 114 & 141 & 143 & 212 & 28,773 & 6,266 & 424 & 407 & 20,319 & 8,350 & 22,104 & 3,157 & 0 & 0 \\
\hline $\begin{array}{l}\text { Net } \\
\text { change }\end{array}$ & 16 & 18 & 2,247 & 1,103 & 1,707 & 797 & 77 & 102 & 10 & 13 & $-3,041$ & 1,606 & 180 & 260 & -24 & 499 & $-1,173$ & 671 & 0 & 0 \\
\hline $\begin{array}{l}\text { Gross } \\
\text { change }\end{array}$ & 41 & 34 & 2,247 & 1,103 & 5,468 & 1,699 & 77 & 102 & 35 & 50 & 6,407 & 1,801 & 400 & 495 & 983 & 481 & 1,963 & 683 & 0 & 0 \\
\hline
\end{tabular}


Table 4. Principal land-cover conversions in Middle Atlantic Coastal Plain Ecoregion, showing amount of area changed (and margin of error, calculated at 85-percent confidence level) for each conversion during each of four time periods and also during overall study period. See appendix 3 for definitions of land-cover classifications.

[Values given for "other" classes are combined totals of values for other land-cover classes not listed in that time period. Abbreviations: n/a, not applicable]

\begin{tabular}{|c|c|c|c|c|c|c|c|}
\hline Period & From class & To class & $\begin{array}{c}\begin{array}{c}\text { Area } \\
\text { changed }\end{array} \\
\left(\mathbf{k m}^{2}\right)\end{array}$ & $\begin{array}{c}\text { Margin of } \\
\text { error } \\
\left(+/-\mathrm{km}^{2}\right)\end{array}$ & $\begin{array}{c}\text { Standard } \\
\text { error } \\
\left(\mathbf{k m}^{2}\right)\end{array}$ & $\begin{array}{l}\text { Percent of } \\
\text { ecoregion }\end{array}$ & $\begin{array}{c}\text { Percent of all } \\
\text { changes }\end{array}$ \\
\hline \multirow[t]{7}{*}{ 1973-1980 } & Forest & Mechanically disturbed & 2,408 & 1,135 & 728 & 2.7 & 45.8 \\
\hline & Mechanically disturbed & Forest & 1,646 & 538 & 345 & 1.8 & 31.3 \\
\hline & Forest & Developed & 444 & 270 & 173 & 0.5 & 8.4 \\
\hline & Forest & Agriculture & 277 & 233 & 149 & 0.3 & 5.3 \\
\hline & Mechanically disturbed & Wetland & 191 & 98 & 63 & 0.2 & 3.6 \\
\hline & Other & Other & 295 & $\mathrm{n} / \mathrm{a}$ & $\mathrm{n} / \mathrm{a}$ & 0.3 & 5.6 \\
\hline & & Totals & 5,262 & & & 5.9 & 100.0 \\
\hline \multirow[t]{7}{*}{ 1980-1986 } & Forest & Mechanically disturbed & 2,128 & 968 & 621 & 2.4 & 34.8 \\
\hline & Mechanically disturbed & Forest & 2,116 & 895 & 574 & 2.4 & 34.6 \\
\hline & Wetland & Mechanically disturbed & 592 & 295 & 189 & 0.7 & 9.7 \\
\hline & Forest & Developed & 498 & 336 & 215 & 0.6 & 8.1 \\
\hline & Mechanically disturbed & Grassland/Shrubland & 179 & 260 & 167 & 0.2 & 2.9 \\
\hline & Other & Other & 596 & $\mathrm{n} / \mathrm{a}$ & $\mathrm{n} / \mathrm{a}$ & 0.7 & 9.8 \\
\hline & & Totals & 6,108 & & & 6.8 & 100.0 \\
\hline \multirow[t]{7}{*}{ 1986-1992 } & Forest & Mechanically disturbed & 2,811 & 1,339 & 859 & 3.1 & 41.3 \\
\hline & Mechanically disturbed & Forest & 1,928 & 919 & 590 & 2.2 & 28.3 \\
\hline & Forest & Developed & 493 & 305 & 196 & 0.5 & 7.2 \\
\hline & Mechanically disturbed & Wetland & 426 & 199 & 127 & 0.5 & 6.3 \\
\hline & Wetland & Mechanically disturbed & 392 & 217 & 139 & 0.4 & 5.8 \\
\hline & Other & Other & 755 & $\mathrm{n} / \mathrm{a}$ & $\mathrm{n} / \mathrm{a}$ & 0.8 & 11.1 \\
\hline & & Totals & 6,805 & & & 7.6 & 100.0 \\
\hline \multirow[t]{7}{*}{$1992-2000$} & Mechanically disturbed & Forest & 3,098 & 1,226 & 787 & 3.5 & 37.7 \\
\hline & Forest & Mechanically disturbed & 2,866 & 923 & 592 & 3.2 & 34.9 \\
\hline & Wetland & Mechanically disturbed & 791 & 281 & 180 & 0.9 & 9.6 \\
\hline & Forest & Developed & 306 & 178 & 114 & 0.3 & 3.7 \\
\hline & Mechanically disturbed & Wetland & 191 & 109 & 70 & 0.2 & 2.3 \\
\hline & Other & Other & 964 & $\mathrm{n} / \mathrm{a}$ & $\mathrm{n} / \mathrm{a}$ & 1.1 & 11.7 \\
\hline & & Totals & 8,215 & & & 9.2 & 100.0 \\
\hline \multirow{7}{*}{$\begin{array}{c}1973-2000 \\
\text { (overall) }\end{array}$} & Forest & Mechanically disturbed & 10,213 & 3,975 & 2,550 & 11.4 & 38.7 \\
\hline & Mechanically disturbed & Forest & 8,788 & 3,196 & 2,050 & 9.8 & 33.3 \\
\hline & Wetland & Mechanically disturbed & 1,903 & 730 & 468 & 2.1 & 7.2 \\
\hline & Forest & Developed & 1,741 & 1,006 & 646 & 1.9 & 6.6 \\
\hline & Mechanically disturbed & Wetland & 942 & 304 & 195 & 1.1 & 3.6 \\
\hline & Other & Other & 2,803 & $\mathrm{n} / \mathrm{a}$ & $\mathrm{n} / \mathrm{a}$ & 3.1 & 10.6 \\
\hline & & Totals & 26,390 & & & 29.4 & 100.0 \\
\hline
\end{tabular}


Table 5. Amounts of "stable" versus "dynamic" forest land cover (as number and percentage of pixels) in sample blocks in Middle Atlantic Coastal Plain Ecoregion throughout study period (1973-2000).

["Stable" forest, forested land that has remained unaltered for at least 30 years; "dynamic" forest, land that was forested only part of that time]

\begin{tabular}{lcc}
\hline \multicolumn{1}{c}{$\begin{array}{c}\text { Amount of forest land cover, } \\
\text { between 1973 and 2000 }\end{array}$} & $\begin{array}{c}\text { Number of } \\
\text { forest pixels }\end{array}$ & $\begin{array}{c}\text { Percentage of } \\
\text { forest pixels }\end{array}$ \\
\hline $\begin{array}{l}\text { Total amount of forest land cover } \\
\text { during study period }\end{array}$ & 464,020 & 100.0 \\
$\begin{array}{l}\text { Amount of stable forest land cover } \\
\text { (that is, amount unchanged) }\end{array}$ & 276,005 & 59.5 \\
$\begin{array}{l}\text { Amount of dynamic forest land } \\
\text { cover (that is, amount affected by, } \\
\text { or resulting from, change) }\end{array}$ & 188,015 & \\
\hline
\end{tabular}

\section{References Cited}

U.S. Department of Agriculture, 1999, 1997 Census of agriculture-Agricultural atlas of the United States, v. 2, subject series, part 1: Washington, D.C., U.S. Government Printing Office, U.S. Department of Agriculture, 163 p.

Vogelmann, J.M., Howard, S.M., Yang, L., Larson, C.R., Wylie, B.K., and van Driel, N., 2001, Completion of the 1990s National Land Cover Data Set for the conterminous United States from Landsat Thematic Mapper data and ancillary data sources: Photogrammetric Engineering \& Remote Sensing, v. 67, p. 650-662.

Wiken, E., Jiménez Nava, F., and Griffith, G., 2011, North American terrestrial ecoregions-Level III: Montreal, Canada, Commission for Environmental Cooperation, 149 p., accessed May 1, 2013, at http://www.cec.org/ Storage/133/15860_QA07.30-32_NP_NA_Terrestrial_ Ecoregions_Level_3_Final-2june-11.pdf. 


\title{
Chapter 19
}

\section{Southern Coastal Plain Ecoregion}

\author{
By Mark A. Drummond
}

\section{Ecoregion Description}

The Southern Coastal Plain

Ecoregion is a subtropical, low-elevation ecoregion situated between the Gulf of Mexico and the Atlantic Ocean (Wiken and others, 2011) (fig. 1). The ecoregion, which covers about $145,123 \mathrm{~km}^{2}\left(56,032 \mathrm{mi}^{2}\right)$, includes parts of central and northern Florida and southeastern Georgia; a very small part of South Carolina; and the Gulf Coasts of Mississippi, Alabama, and a small part of southeastern Louisiana. The ecoregion is bounded on the far west by the Mississippi Alluvial Plain Ecoregion, on the north by the Southeastern Plains Ecoregion, on the northeast by the Middle Atlantic Coastal Plain Ecoregion, and on the far south by the Southern Florida Coastal Plain Ecoregion.

A discontinuous series of barrier islands, beaches, and sand dunes line the coast of the Southern Coastal Plain Ecoregion. The interior of the ecoregion has many large lakes, karst springs, and sandy hills. Swamps and marshlands are present across the ecoregion, from the large Okefenokee Swamp in the north to the northern part of The Everglades tropical wetlands system, most of which lies in the adjacent Southern Florida Coastal Plain Ecoregion to the south. Large natural disturbances that affect the area relatively frequently include hurricanes and tropical storms, as well as wildland fires.

The climate of the ecoregion is warm and humid, and the ecoregion receives abundant precipitation of between 1,000 and $1,500 \mathrm{~mm}$ (40 and 60 in.) annually. The combination of long, frost-free periods of more than 240 days and plentiful water historically has enabled the production

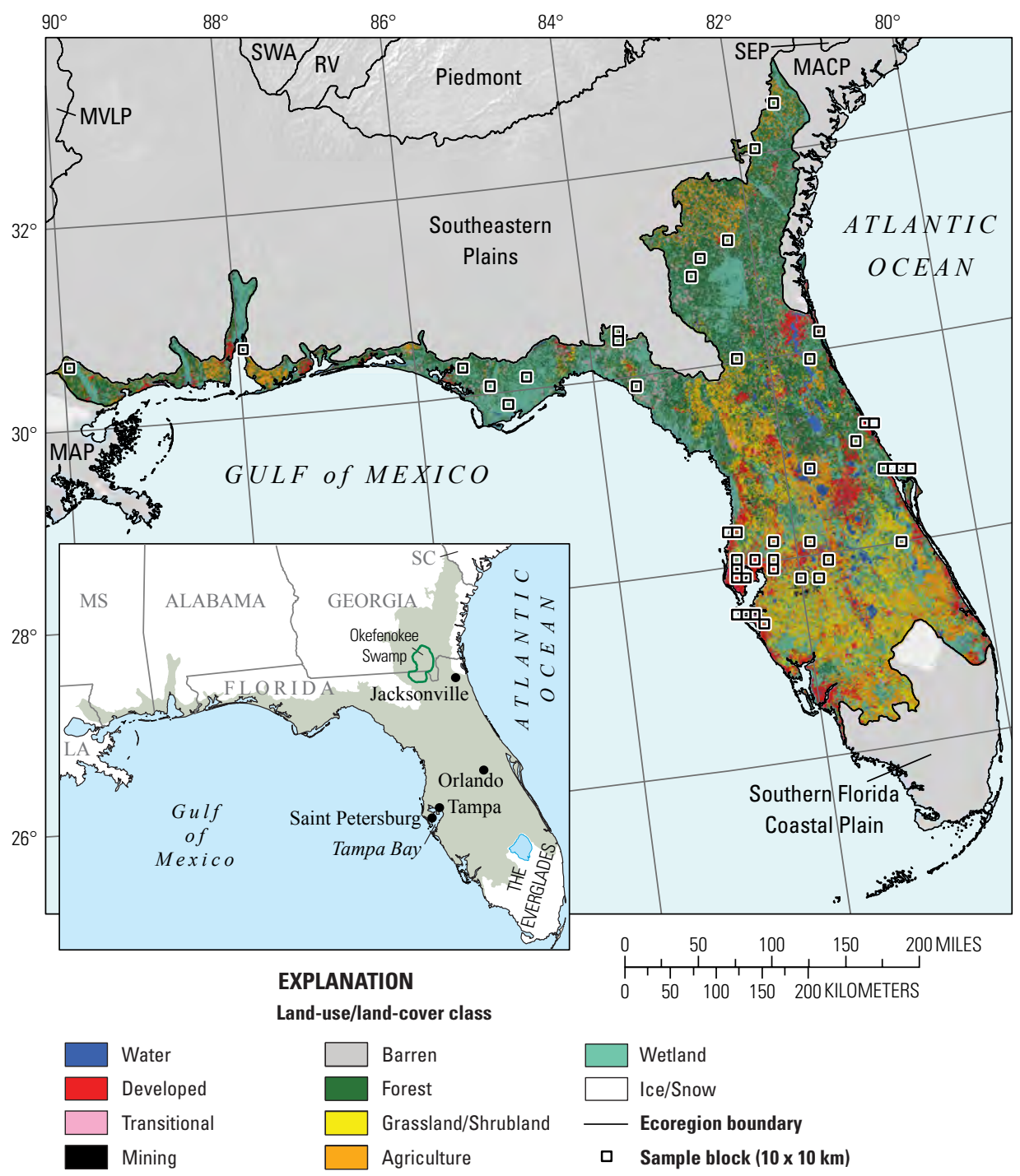

Figure 1. Map of Southern Coastal Plain Ecoregion and surrounding ecoregions, showing land-use/land-cover classes from 1992 National Land Cover Dataset (Vogelmann and others, 2001); note that not all land-use/land-cover classes shown in explanation may be depicted on map; note also that, for this "Status and Trends of Land Change" study, transitional land-cover class was subdivided into mechanically disturbed and nonmechanically disturbed classes. Squares indicate locations of $10 \times 10 \mathrm{~km}$ sample blocks analyzed in study. Index map shows locations of geographic features mentioned in text. Abbreviations for Eastern United States ecoregions are listed in appendix 2. Also shown is part of one Midwest-South Central United States ecoregion, Mississippi Alluvial Plain (MAP). See appendix 3 for definitions of land-use/land-cover classifications. 
of specialized crops. The citrus industry focused its intensive orange production on the southern interior and southeastern coastal parts of the ecoregion (fig. 2), although there has been a recent southward translocation of orange-production operations to avoid tree-killing frosts aggravated by wetland loss (Marshall and others, 2003). Pastureland also has been an important agricultural resource in the ecoregion. Extensive pine (Pinus spp.) plantations for timber production are common (fig. 3). Stands of commercially harvested pine, which regenerate relatively quickly after harvest, constitute about one-third of Florida's forested land, primarily in the northern part of the state (Carter and Jokela, 2002).

Substantial population growth has occurred in the Southern Coastal Plain Ecoregion, causing an expansion of urban and developed land (fig. 4). Between 1970 and 2000, the population increased by more than 140 percent, from 4.2 million to 10.3 million people (U.S. Census Bureau, 1970-2000 [various

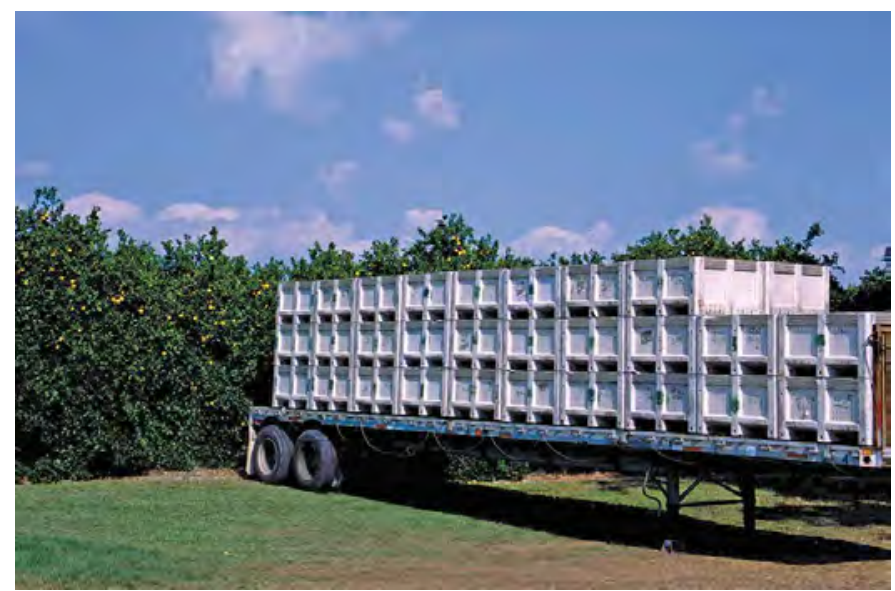

Figure 2. Orange grove ready for harvesting in southern interior of Southern Coastal Plain Ecoregion.

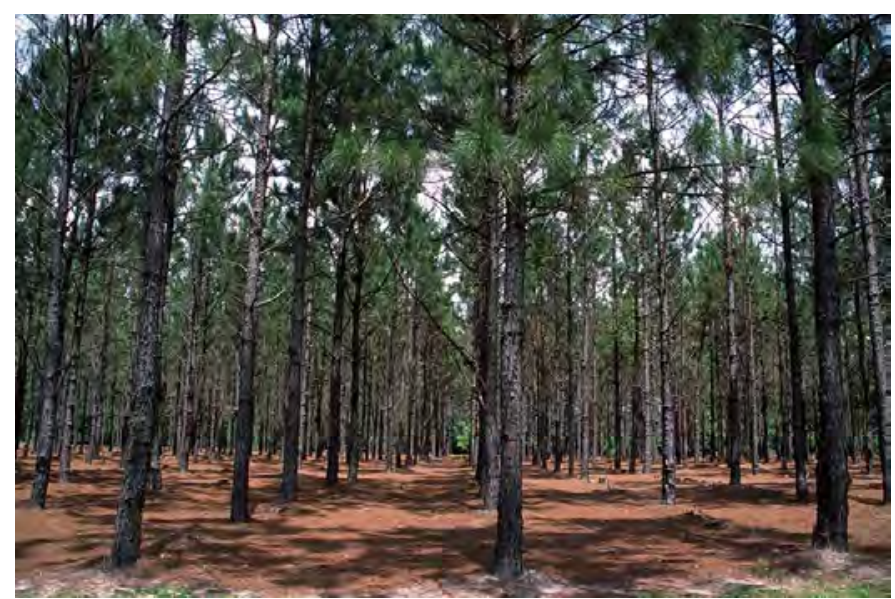

Figure 3. Managed pine stand in northern-central part of Southern Coastal Plain Ecoregion. years]). Large urban areas are prevalent on the Florida peninsula, including Orlando, Jacksonville, Saint Petersburg, and Tampa. Tampa Bay is one of the ten largest ports in the United States. In addition to agriculture and the extensive pine plantations, tourism and associated service industries are important to Florida's economy. Mining of rich phosphate reserves for use in agricultural fertilizers also is significant (fig. 5).

Pine and mixed-hardwood forests originally covered much of the ecoregion. The native longleaf pine (Pinus palustris) was the dominant tree species; however, by about 2000 , its extent had been reduced by as much as 98 percent (Wear and Greis, 2002). Forested areas were cleared for lumber and then converted to plantations that favor the faster growing species such as slash pine (Pinus elliottii) and loblolly pine (Pinus taeda). Forests of longleaf pine and other native trees also have been converted to cropland, pastureland, mining, and urban uses.

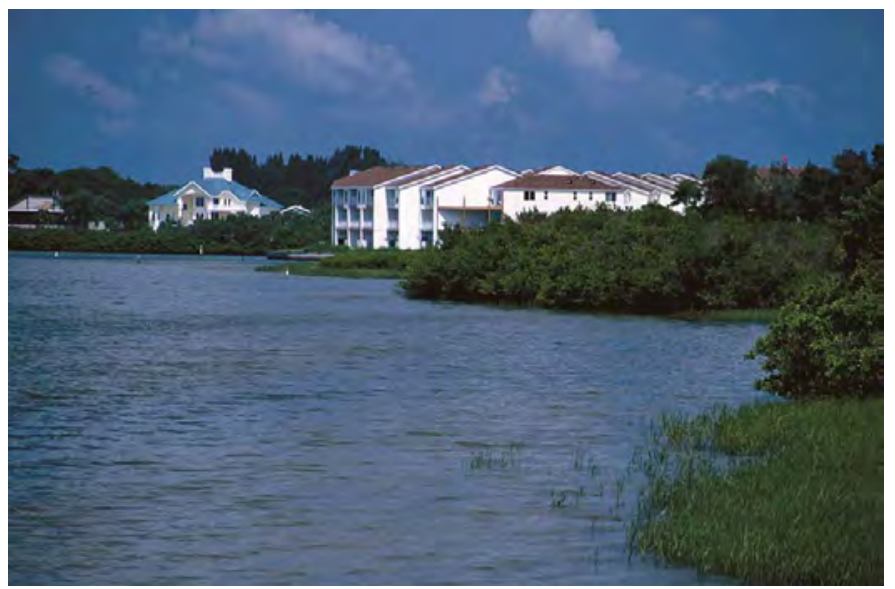

Figure 4. Large waterfront homes and apartment complex, examples of intensive development along Tampa Bay, Florida.

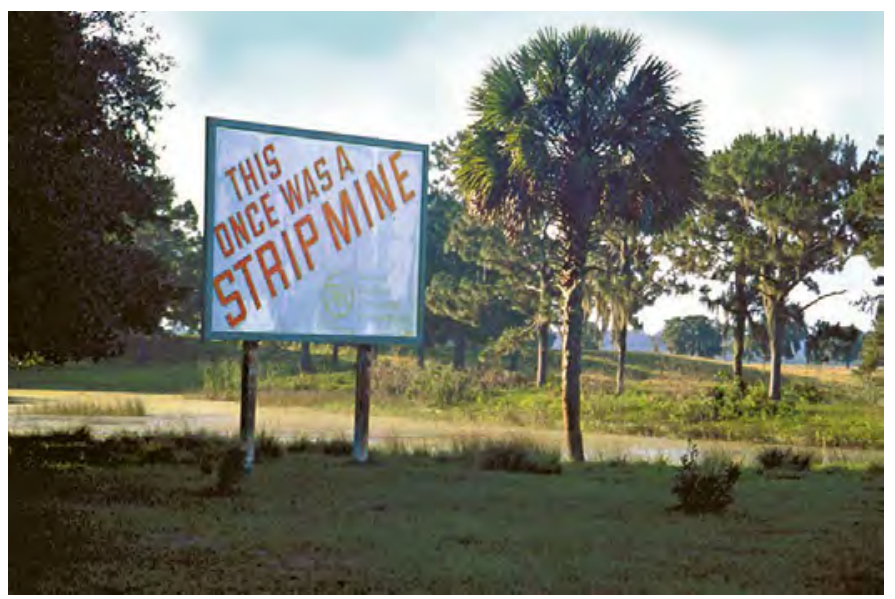

Figure 5. Reclaimed strip mine in central Florida. 


\section{Contemporary Land-Cover Change (1973 to 2000)}

The overall spatial change (the percentage of land area that changed at least one time) in the Southern Coastal Plain Ecoregion between 1973 and 2000 is estimated at 24.6 percent (table 1). Compared to other Eastern United States ecoregions, change in the Southern Coastal Plain Ecoregion was highest overall (fig. 6): an estimated 13.2 percent of the ecoregion changed only one time, and 11.3 percent changed two or more times. Multiple changes are indicative of cycles of timber harvesting and reforestation that occurred throughout the study period. When normalized to an average annual rate to account for unequal time periods, the highest rates of change occurred in the last two time periods (1986-1992, 1992-2000), when the average annual rate was 1.5 percent (table 2 ; fig. 7 ). The lowest rate of change occurred between 1973 and 1980, when the average annual rate was 1.2 percent.

Land-cover statistics show that forest is the predominant land-cover class, despite a decrease from a high of 28.2 percent of the ecoregion in 1973 to a low of 24.0 percent in 2000 (table 3). Wetland also decreased, from 22.8 percent of the ecoregion in 1973 to 20.4 percent in 2000 . Agriculture

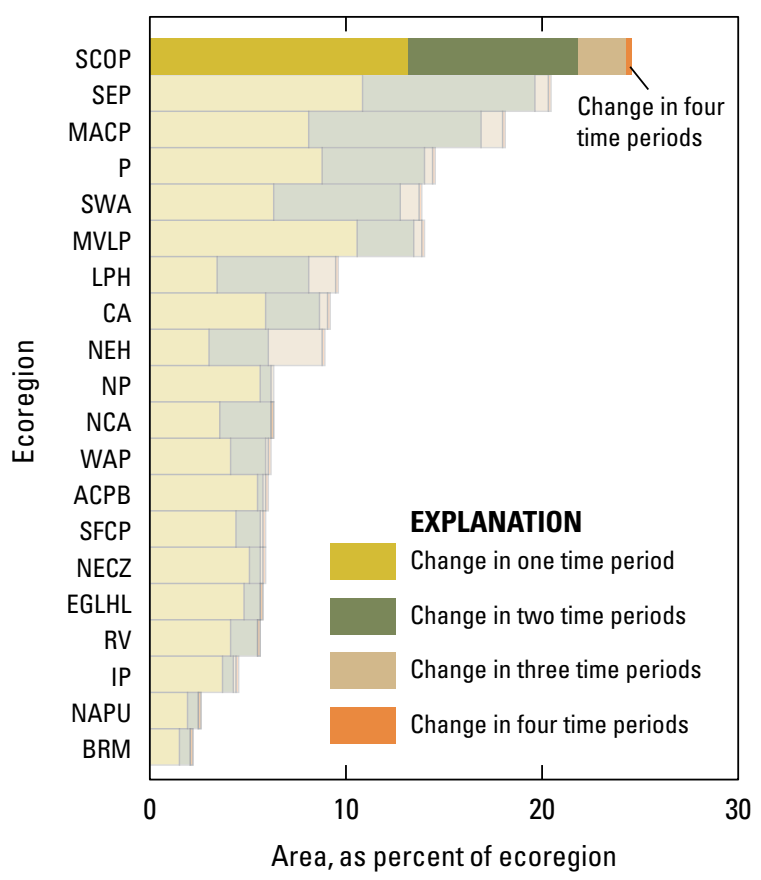

Figure 6. Overall spatial change in Southern Coastal Plain Ecoregion (SCOP; darker bars) compared with that of all 20 Eastern United States ecoregions (lighter bars). Each horizontal set of bars shows proportions of ecoregion that changed during one, two, three, or four time periods; highest level of spatial change in Southern Coastal Plain Ecoregion (four time periods) labeled for clarity. See table 2 for years covered by each time period. See appendix 2 for key to ecoregion abbreviations. decreased similarly, from 10.7 percent of the ecoregion to 7.9 percent between 1973 and 2000. The study also showed a substantial decrease in mining, from 2.0 percent of the ecoregion to 0.8 percent, as the total area of phosphate mines declined.

Developed had a large overall gain during the 27-year study period, from 14.7 percent of the ecoregion to 20.8 percent, becoming the second most common land-cover class in the ecoregion by 2000 . Grassland/shrubland increased from 5.1 percent of the ecoregion to 6.8 percent between 1973 and 2000 . The mechanically disturbed and nonmechanically disturbed land-cover classes both had moderate increases in land area. Overall (1973-2000), mechanically disturbed increased from 2.3 to 3.8 percent of the ecoregion. Forest, wetland, and developed each covered more than 20 percent of the ecoregion in 2000 , suggesting a highly variable pattern of land use and land cover.

Net-change statistics show that developed increased by 6.2 percent of the ecoregion between 1973 and 2000 (table 3). Grassland/shrubland had the next highest gain at 1.7 percent of the ecoregion. Mechanically disturbed increased by 1.5 percent of the ecoregion, primarily owing to the cutting of forest. The largest net decrease in ecoregion area was a 4.2 percent loss of forest between 1973 and 2000. Other net changes in ecoregion area during the study period included decreases in agriculture $(-2.8$ percent), wetland $(-2.4$ percent), and mining (-1.2 percent) (table 3 ; fig. 8 ).

The leading land-cover change in all four time periods was from forest to mechanically disturbed (through timber harvest), which accounted for 25.0 percent $\left(14,163 \mathrm{~km}^{2}\right)$ of all

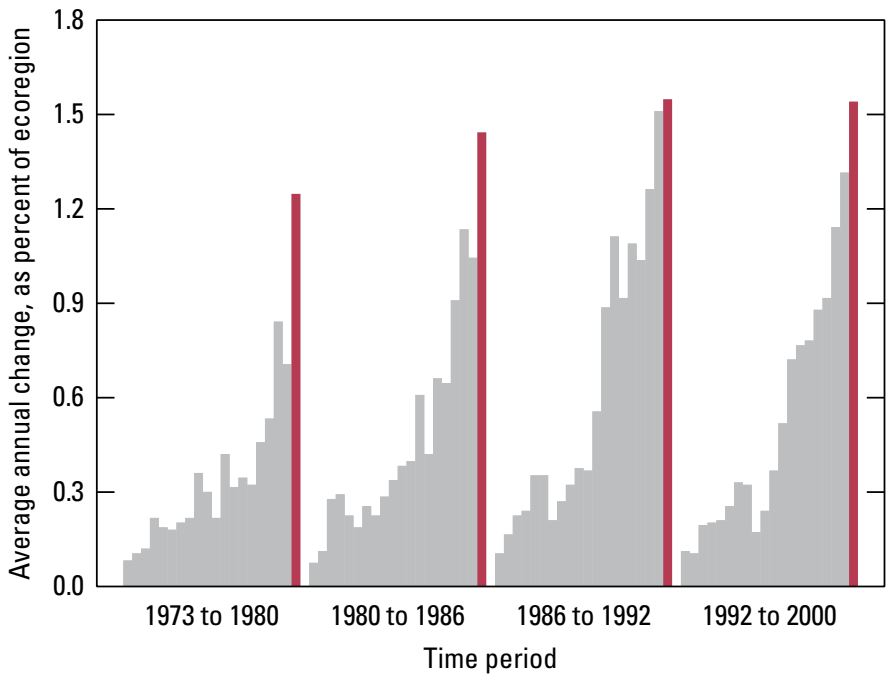

Figure 7. Estimates of land-cover change per time period, normalized to annual rates of change for all 20 Eastern United States ecoregions (gray bars). Estimates of change for Southern Coastal Plain Ecoregion are represented by red bars in each time period. 
change in the ecoregion during the study period (1973-2000) (table 4). The reforestation of mechanically disturbed land was the second most common conversion. These changes typically are cyclic, owing to forest harvesting and regrowth. Net-change statistics in the Southern Coastal Plain Ecoregion tend to mask much larger gross changes (total losses and gains) that may have occurred in a land-cover class. For example, the ecoregion experienced significant losses of forested land owing to mechanical disturbance (timber harvesting), but it also experienced significant gains in forested land owing to reforestation. Additional decreases in forested land most likely occurred from the loss of forested wetlands.

The 6.2 percent increase in developed land relative to the entire ecoregion area was the highest net increase in all 20 Eastern United States ecoregions during the study period. Overall, development occurred primarily on agricultural land $\left(2,707 \mathrm{~km}^{2}\right)$, forested land $\left(2,637 \mathrm{~km}^{2}\right)$, and wetlands $(2,024$ $\mathrm{km}^{2}$ ). Between 1973 and 1980, wetlands were the largest source of land that converted to developed land $\left(937 \mathrm{~km}^{2}\right)$, although the extent of the conversions had decreased by 2000 (table 4). Agricultural land was the dominant source for developed land in the period between 1992 and 2000, when an estimated $987 \mathrm{~km}^{2}$ were converted (table 4).

Although much of the overall change in the Southern Coastal Plain Ecoregion resulted from conversions caused by the timber-harvest-and-regrowth cycle, the rapid expansion of developed land throughout the ecoregion represented a significant and permanent change. Developed land expanded into areas formerly occupied by a number of other land covers. Although former agricultural land accounted for much of the newly developed land, agriculture remained an important component of human use of the ecoregion, even as it experienced a shift in geographic range as the needs of the citrus industry changed. Although wetland still occupied one-fifth of the ecoregion in 2000 (table 3), large areas of wetland were lost to developed, a conversion that may continue into the future.

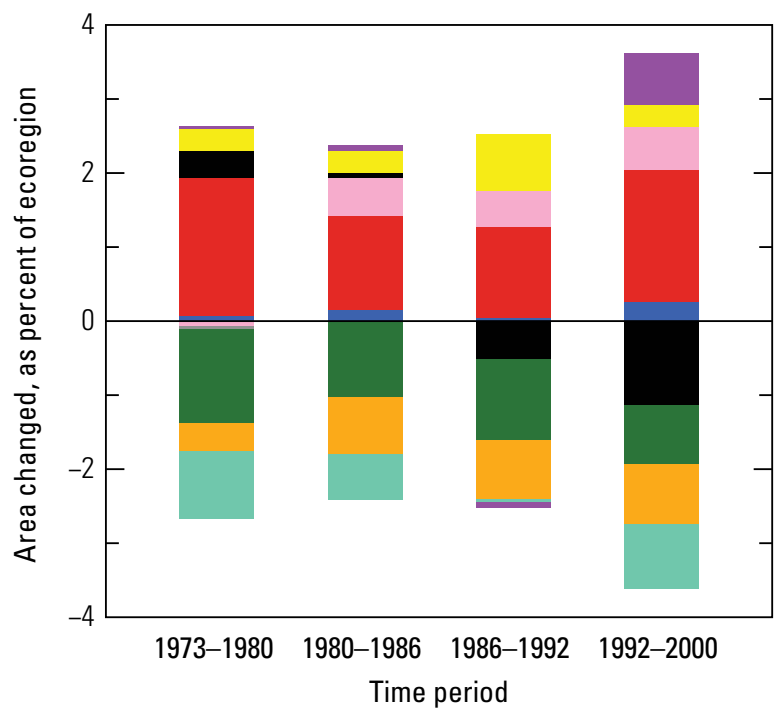

\section{EXPLANATION}

Land-use/land-cover class

\begin{tabular}{ll}
$\square$ Water & $\square$ Forest \\
Developed & $\square$ Grassland/Shrubland \\
\hline Mechanically disturbed & Agriculture \\
Mining & Wetland \\
\hline Barren & Nonmechanically disturbed \\
& $\quad$ Ice/Snow
\end{tabular}

Figure 8. Normalized average net change in Southern Coastal Plain Ecoregion by time period for each land-cover class. Bars above zero axis represent net gain, whereas bars below zero represent net loss. Note that not all land-cover classes shown in explanation may be represented in figure. See appendix 3 for definitions of land-use and land-cover classifications. 
Table 1. Percentage of Southern Coastal Plain Ecoregion land cover that changed at least one time during study period (19732000) and associated statistical error.

[Most sample pixels remained unchanged (75.4 percent), whereas 24.6 percent changed at least once throughout study period]

\begin{tabular}{ccccccc}
\hline $\begin{array}{c}\text { Number } \\
\text { of } \\
\text { changes }\end{array}$ & $\begin{array}{c}\text { Percent } \\
\text { of } \\
\text { ecoregion }\end{array}$ & $\begin{array}{c}\text { Margin } \\
\text { of error } \\
(+/-\%)\end{array}$ & $\begin{array}{c}\text { Lower } \\
\text { bound } \\
(\%)\end{array}$ & $\begin{array}{c}\text { Upper } \\
\text { bound } \\
(\%)\end{array}$ & $\begin{array}{c}\text { Standard } \\
\text { error } \\
(\%)\end{array}$ & $\begin{array}{c}\text { Relative } \\
\text { error } \\
(\%)\end{array}$ \\
\hline 1 & 13.2 & 2.0 & 11.2 & 15.2 & 1.4 & 10.3 \\
2 & 8.6 & 2.2 & 6.5 & 10.8 & 1.5 & 17.1 \\
3 & 2.5 & 0.9 & 1.6 & 3.4 & 0.6 & 24.8 \\
4 & 0.2 & 0.1 & 0.1 & 0.3 & 0.1 & 30.9 \\
\hline $\begin{array}{l}\text { Overall } \\
\text { spatial } \\
\text { change }\end{array}$ & 24.6 & 3.7 & 20.9 & 28.3 & 2.5 & 10.2 \\
\hline
\end{tabular}

Table 2. Raw estimates of change in Southern Coastal Plain Ecoregion land cover, computed for each of four time periods between 1973 and 2000, and associated error at 85-percent confidence level.

[Estimates of change per period normalized to annual rate of change for each period]

\begin{tabular}{|c|c|c|c|c|c|c|c|}
\hline Period & $\begin{array}{c}\text { Total change } \\
\text { (\% of ecoregion) }\end{array}$ & $\begin{array}{c}\text { Margin of } \\
\text { error } \\
(+/-\%)\end{array}$ & $\begin{array}{c}\text { Lower } \\
\text { bound } \\
(\%)\end{array}$ & $\begin{array}{c}\text { Upper bound } \\
(\%)\end{array}$ & $\begin{array}{c}\text { Standard } \\
\text { error } \\
(\%)\end{array}$ & $\begin{array}{c}\text { Relative } \\
\text { error } \\
(\%)\end{array}$ & $\begin{array}{c}\text { Average rate } \\
\text { (\% per year) }\end{array}$ \\
\hline \multicolumn{8}{|c|}{ Estimate of change, in percent stratum } \\
\hline $1973-1980$ & 8.7 & 1.9 & 6.8 & 10.7 & 1.3 & 15.0 & 1.2 \\
\hline 1980-1986 & 8.6 & 1.8 & 6.9 & 10.4 & 1.2 & 13.9 & 1.4 \\
\hline 1986-1992 & 9.3 & 2.1 & 7.2 & 11.4 & 1.4 & 15.5 & 1.5 \\
\hline 1992-2000 & 12.3 & 2.3 & 10.0 & 14.6 & 1.6 & 12.6 & 1.5 \\
\hline \multicolumn{8}{|c|}{ Estimate of change, in square kilometers } \\
\hline $1973-1980$ & 12,667 & 2,799 & 9,868 & 15,466 & 1,900 & 15 & 1,810 \\
\hline 1980-1986 & 12,541 & 2,567 & 9,974 & 15,108 & 1,743 & 14 & 2,090 \\
\hline 1986-1992 & 13,475 & 3,072 & 10,403 & 16,547 & 2,086 & 15 & 2,246 \\
\hline 1992-2000 & 17,887 & 3,330 & 14,557 & 21,217 & 2,261 & 13 & 2,236 \\
\hline
\end{tabular}


Table 3. Estimated area (and margin of error) of each land-cover class in Southern Coastal Plain Ecoregion, calculated five times between 1973 and 2000. See appendix 3 for definitions of land-cover classifications.

\begin{tabular}{|c|c|c|c|c|c|c|c|c|c|c|c|c|c|c|c|c|c|c|c|c|}
\hline & \multicolumn{2}{|c|}{ Water } & \multicolumn{2}{|c|}{ Developed } & \multicolumn{2}{|c|}{$\begin{array}{c}\text { Mechanically } \\
\text { disturbed }\end{array}$} & \multicolumn{2}{|c|}{ Mining } & \multicolumn{2}{|c|}{ Barren } & \multicolumn{2}{|c|}{ Forest } & \multicolumn{2}{|c|}{$\begin{array}{l}\text { Grassland/ } \\
\text { Shrubland }\end{array}$} & \multicolumn{2}{|c|}{ Agriculture } & \multicolumn{2}{|c|}{ Wetland } & \multicolumn{2}{|c|}{$\begin{array}{c}\text { Non- } \\
\text { mecha- } \\
\text { nically } \\
\text { disturbed }\end{array}$} \\
\hline & $\%$ & $+/-$ & $\%$ & $+/-$ & $\%$ & $+/-$ & $\%$ & $+/-$ & $\%$ & $+/-$ & $\%$ & $+/-$ & $\%$ & $+/-$ & $\%$ & $+/-$ & $\%$ & $+/-$ & $\%$ & $+1-$ \\
\hline \multicolumn{21}{|c|}{ Area, in percent stratum } \\
\hline 1973 & 14.0 & 6.8 & 14.7 & 5.3 & 2.3 & 0.9 & 2.0 & 1.5 & 0.1 & 0.1 & 28.2 & 5.0 & 5.1 & 2.5 & 10.7 & 2.7 & 22.8 & 3.8 & 0.0 & 0.0 \\
\hline 1980 & 14.1 & 6.8 & 16.5 & 5.9 & 2.2 & 0.8 & 2.4 & 1.8 & 0.1 & 0.1 & 26.9 & 5.0 & 5.4 & 2.4 & 10.3 & 2.7 & 21.9 & 3.7 & 0.1 & 0.1 \\
\hline 1986 & 14.3 & 6.8 & 17.8 & 6.2 & 2.7 & 1.0 & 2.5 & 1.9 & 0.1 & 0.1 & 25.9 & 4.9 & 5.7 & 2.3 & 9.6 & 2.5 & 21.3 & 3.7 & 0.2 & 0.2 \\
\hline 1992 & 14.3 & 6.8 & 19.0 & 6.4 & 3.2 & 1.2 & 1.9 & 1.4 & 0.1 & 0.1 & 24.8 & 4.7 & 6.5 & 2.7 & 8.7 & 2.4 & 21.3 & 3.7 & 0.1 & 0.1 \\
\hline 2000 & 14.6 & 6.8 & 20.8 & 6.7 & 3.8 & 1.3 & 0.8 & 0.7 & 0.1 & 0.1 & 24.0 & 4.5 & 6.8 & 3.2 & 7.9 & 2.1 & 20.4 & 3.4 & 0.8 & 0.8 \\
\hline $\begin{array}{l}\text { Net } \\
\text { change }\end{array}$ & 0.6 & 0.3 & 6.2 & 2.1 & 1.5 & 0.8 & -1.2 & 1.2 & 0.0 & 0.0 & -4.2 & 1.4 & 1.7 & 1.3 & -2.8 & 1.1 & -2.4 & 1.3 & 0.7 & 0.8 \\
\hline $\begin{array}{l}\begin{array}{l}\text { Gross } \\
\text { change }\end{array} \\
\end{array}$ & 0.8 & 0.3 & 6.2 & 2.1 & 7.8 & 2.3 & 2.7 & 2.0 & 0.0 & 0.0 & 9.6 & 2.3 & 5.3 & 1.6 & 3.6 & 1.1 & 3.5 & 1.3 & 1.2 & 0.8 \\
\hline \multicolumn{21}{|c|}{ Area, in square kilometers } \\
\hline 1973 & 20,322 & 9,911 & 21,265 & 7,731 & 3,340 & 1,259 & 2,910 & 2,207 & 213 & 153 & 40,950 & 7,285 & 7,409 & 3,603 & 15,532 & 3,932 & 33,151 & 5,586 & 31 & 45 \\
\hline 1980 & 20,463 & 9,907 & 23,963 & 8,608 & 3,230 & 1,160 & 3,436 & 2,639 & 201 & 152 & 39,044 & 7,261 & 7,818 & 3,486 & 15,006 & 3,852 & 31,847 & 5,328 & 116 & 168 \\
\hline 1986 & 20,689 & 9,892 & 25,813 & 9,007 & 3,958 & 1,412 & 3,558 & 2,809 & 204 & 151 & 37,577 & 7,067 & 8,257 & 3,328 & 13,865 & 3,637 & 30,981 & 5,327 & 223 & 227 \\
\hline 1992 & 20,756 & 9,863 & 27,619 & 9,350 & 4,626 & 1,787 & 2,809 & 2,052 & 205 & 152 & 35,973 & 6,805 & 9,370 & 3,939 & 12,696 & 3,460 & 30,930 & 5,356 & 140 & 203 \\
\hline 2000 & 21,130 & 9,860 & 30,228 & 9,752 & 5,470 & 1,927 & 1,176 & 1,080 & 207 & 152 & 34,824 & 6,483 & 9,824 & 4,626 & 11,504 & 3,089 & 29,655 & 4,970 & 1,104 & 1,129 \\
\hline $\begin{array}{l}\text { Net } \\
\text { change }\end{array}$ & 808 & 485 & 8,963 & 3,053 & 2,130 & 1,150 & $-1,733$ & 1,771 & -6 & 16 & $-6,126$ & 2,021 & 2,415 & 1,859 & $-4,028$ & 1,629 & $-3,496$ & 1,924 & 1,073 & 1,131 \\
\hline $\begin{array}{l}\text { Gross } \\
\text { change }\end{array}$ & 1,110 & 486 & 8,990 & 3,049 & 11,270 & 3,287 & 3,966 & 2,906 & 30 & 18 & 13,890 & 3,278 & 7,733 & 2,347 & 5,276 & 1,619 & 5,034 & 1,859 & 1,784 & 1,230 \\
\hline
\end{tabular}


Table 4. Principal land-cover conversions in Southern Coastal Plain Ecoregion, showing amount of area changed (and margin of error, calculated at 85-percent confidence level) for each conversion during each of four time periods and also during overall study period. See appendix 3 for definitions of land-cover classifications.

[Values given for "other" classes are combined totals of values for other land-cover classes not listed in that time period. Abbreviations: n/a, not applicable]

\begin{tabular}{|c|c|c|c|c|c|c|c|}
\hline Period & From class & To class & $\begin{array}{c}\begin{array}{c}\text { Area } \\
\text { changed }\end{array} \\
\left(\mathrm{km}^{2}\right)\end{array}$ & $\begin{array}{c}\text { Margin of } \\
\text { error } \\
\left(+/-\mathbf{k m}^{2}\right)\end{array}$ & $\begin{array}{c}\text { Standard } \\
\text { error } \\
\left(\mathrm{km}^{2}\right)\end{array}$ & $\begin{array}{l}\text { Percent of } \\
\text { ecoregion }\end{array}$ & $\begin{array}{c}\text { Percent of all } \\
\text { changes }\end{array}$ \\
\hline \multirow[t]{7}{*}{ 1973-1980 } & Forest & Mechanically disturbed & 2,598 & 1,064 & 723 & 1.8 & 20.5 \\
\hline & Mechanically disturbed & Forest & 2,049 & 935 & 635 & 1.4 & 16.2 \\
\hline & Grassland/Shrubland & Mining & 1,067 & 996 & 676 & 0.7 & 8.4 \\
\hline & Wetland & Developed & 937 & 841 & 571 & 0.6 & 7.4 \\
\hline & Mining & Grassland/Shrubland & 845 & 752 & 510 & 0.6 & 6.7 \\
\hline & Other & Other & 5,170 & $\mathrm{n} / \mathrm{a}$ & $\mathrm{n} / \mathrm{a}$ & 3.6 & 40.8 \\
\hline & & Totals & 12,667 & & & 8.7 & 100.0 \\
\hline \multirow[t]{7}{*}{ 1980-1986 } & Forest & Mechanically disturbed & 3,084 & 1,240 & 842 & 2.1 & 24.6 \\
\hline & Mechanically disturbed & Forest & 1,726 & 862 & 585 & 1.2 & 13.8 \\
\hline & Mechanically disturbed & Grassland/Shrubland & 817 & 384 & 261 & 0.6 & 6.5 \\
\hline & Mining & Grassland/Shrubland & 768 & 682 & 463 & 0.5 & 6.1 \\
\hline & Grassland/Shrubland & Forest & 738 & 315 & 214 & 0.5 & 5.9 \\
\hline & Other & Other & 5,407 & $\mathrm{n} / \mathrm{a}$ & $\mathrm{n} / \mathrm{a}$ & 3.7 & 43.1 \\
\hline & & Totals & 12,541 & & & 8.6 & 100.0 \\
\hline \multirow[t]{7}{*}{ 1986-1992 } & Forest & Mechanically disturbed & 4,079 & 1,754 & 1,191 & 2.8 & 30.3 \\
\hline & Mechanically disturbed & Forest & 2,237 & 1,069 & 725 & 1.5 & 16.6 \\
\hline & Mining & Grassland/Shrubland & 1,106 & 1,120 & 760 & 0.8 & 8.2 \\
\hline & Grassland/Shrubland & Forest & 858 & 363 & 246 & 0.6 & 6.4 \\
\hline & Mechanically disturbed & Grassland/Shrubland & 784 & 439 & 298 & 0.5 & 5.8 \\
\hline & Other & Other & 4,411 & $\mathrm{n} / \mathrm{a}$ & $\mathrm{n} / \mathrm{a}$ & 3.0 & 32.7 \\
\hline & & Totals & 13,475 & & & 9.3 & 100.0 \\
\hline \multirow[t]{7}{*}{$1992-2000$} & Forest & Mechanically disturbed & 4,401 & 1,693 & 1,149 & 3.0 & 24.6 \\
\hline & Mechanically disturbed & Forest & 3,471 & 1,659 & 1,126 & 2.4 & 19.4 \\
\hline & Mining & Grassland/Shrubland & 1,400 & 1,210 & 821 & 1.0 & 7.8 \\
\hline & Grassland/Shrubland & Forest & 1,262 & 665 & 452 & 0.9 & 7.1 \\
\hline & Agriculture & Developed & 987 & 462 & 313 & 0.7 & 5.5 \\
\hline & Other & Other & 6,365 & $\mathrm{n} / \mathrm{a}$ & $\mathrm{n} / \mathrm{a}$ & 4.4 & 35.6 \\
\hline & & Totals & 17,887 & & & 12.3 & 100.0 \\
\hline \multirow{7}{*}{$\begin{array}{c}1973-2000 \\
\text { (overall) }\end{array}$} & Forest & Mechanically disturbed & 14,163 & 4,896 & 3,324 & 9.8 & 25.0 \\
\hline & Mechanically disturbed & Forest & 9,483 & 3,794 & 2,575 & 6.5 & 16.8 \\
\hline & Mining & Grassland/Shrubland & 4,120 & 3,572 & 2,425 & 2.8 & 7.3 \\
\hline & Grassland/Shrubland & Forest & 3,110 & 1,114 & 756 & 2.1 & 5.5 \\
\hline & Mechanically disturbed & Grassland/Shrubland & 2,768 & 1,102 & 748 & 1.9 & 4.9 \\
\hline & Other & Other & 22,926 & $\mathrm{n} / \mathrm{a}$ & $\mathrm{n} / \mathrm{a}$ & 15.8 & 40.5 \\
\hline & & Totals & 56,570 & & & 39.0 & 100.0 \\
\hline
\end{tabular}




\section{References Cited}

Carter, D.R., and Jokela, E.J., 2002, Florida's renewable forest resources: Gainesville, University of Florida, Institute of Food and Agricultural Sciences, Florida Cooperative Extension Service, CIR 1433, 9 p.

Marshall, C.H., Pielke, R.A., Sr., and Steyaert, L.T., 2003, Crop freezes and land-use change in Florida: Nature, v. 426, p. 29-30.

U.S. Census Bureau, 1970-2000 [various years], Census of population and housing: U.S. Census Bureau database, accessed May 9, 2013, at http://www.census.gov/prod/ www/decennial.html.
Vogelmann, J.E., Howard, S.M., Yang, L., Larson, C.R., Wylie, B.K., and van Driel, N., 2001, Completion of the 1990s National Land Cover Data Set for the conterminous United States from Landsat Thematic Mapper data and ancillary data sources: Photogrammetric Engineering \& Remote Sensing, v. 67, p. 650-662.

Wear, D.N., and Greis, J.G., eds., 2002, Southern forest resource assessment: U.S. Forest Service, Southern Research Station, General Technical Report SRS 53, 635 p, accessed November 15, 2013, at http://www.srs.fs.usda.gov/pubs/4833.

Wiken, E., Jiménez Nava, F., and Griffith, G., 2011, North American terrestrial ecoregions-Level III: Montreal, Canada, Commission for Environmental Cooperation, 149 p., accessed May 1, 2013, at http://www.cec.org/ Storage/133/15860_QA07.30-32_NP_NA_Terrestrial_ Ecoregions_Level_3_Final-2june11.pdf. 


\title{
Chapter 20
}

\section{Southern Florida Coastal Plain Ecoregion}

\author{
By Steven Kambly
}

\section{Ecoregion Description}

The Southern Florida Coastal Plain Ecoregion covers $22,407 \mathrm{~km}^{2}\left(8,651 \mathrm{mi}^{2}\right)$ across the southern part of the Florida peninsula, from Lake Okeechobee southward through the Florida Keys. It is bounded on the north by the Southern Coastal Plain Ecoregion (fig. 1).

The ecoregion is composed of "flat plains with wet soils, marshland and swamp land cover with everglades and palmetto prairie vegetation types" (Wiken and others, 2011). The ecoregion's climate generally is subtropical and frost free, with a dry season and a wet season. About 1,400 mm (55 in.) of rain falls annually in the ecoregion, about 1,060 $\mathrm{mm}$ (42 in.) of which falls during the wet season between June and September. The long, warm, dry season, from October to May, allows for year-round crop production, and it has been essential to the cultivation of commercially grown winter vegetable crops. Sugarcane also is widely grown, forming the basis of the domestic sugar industry since the early 1960s (fig. 2). The nutrient-poor Everglades, with its flat and expansive terrain, is subject to urban and agricultural runoff. Surface-water levels and areas of sheet flow are affected by even slight variations in topography, which can have significant effects on plant and animal communities. The ecoregion experienced extensive land-cover change between 1950 and 1970, owing largely to the implementation of mosquito- and water-control measures, the widespread use of air conditioning, the improvements in transportation infrastructure, and the efforts by developers and government officials to promote Florida's growth potential (Solecki, 2001; see also, figs. 3,4$)$.
Figure 1. Map of Southern Florida Coastal Plain Ecoregion and surrounding ecoregions, showing land-use/land-cover classes from 1992 National Land Cover Dataset (Vogelmann and others, 2001); note that not all land-use/land-cover classes shown in explanation may be depicted on map; note also that, for this "Status and Trends of Land Change" study, transitional land-cover class was subdivided into mechanically disturbed and nonmechanically disturbed classes. Squares indicate locations of $10 \mathrm{x}$ $10 \mathrm{~km}$ sample blocks analyzed in study. Index map shows locations of geographic features mentioned in text. Abbreviations for Eastern United States ecoregions are listed in appendix 2. See appendix 3 for definitions of land-use/land-cover classifications.

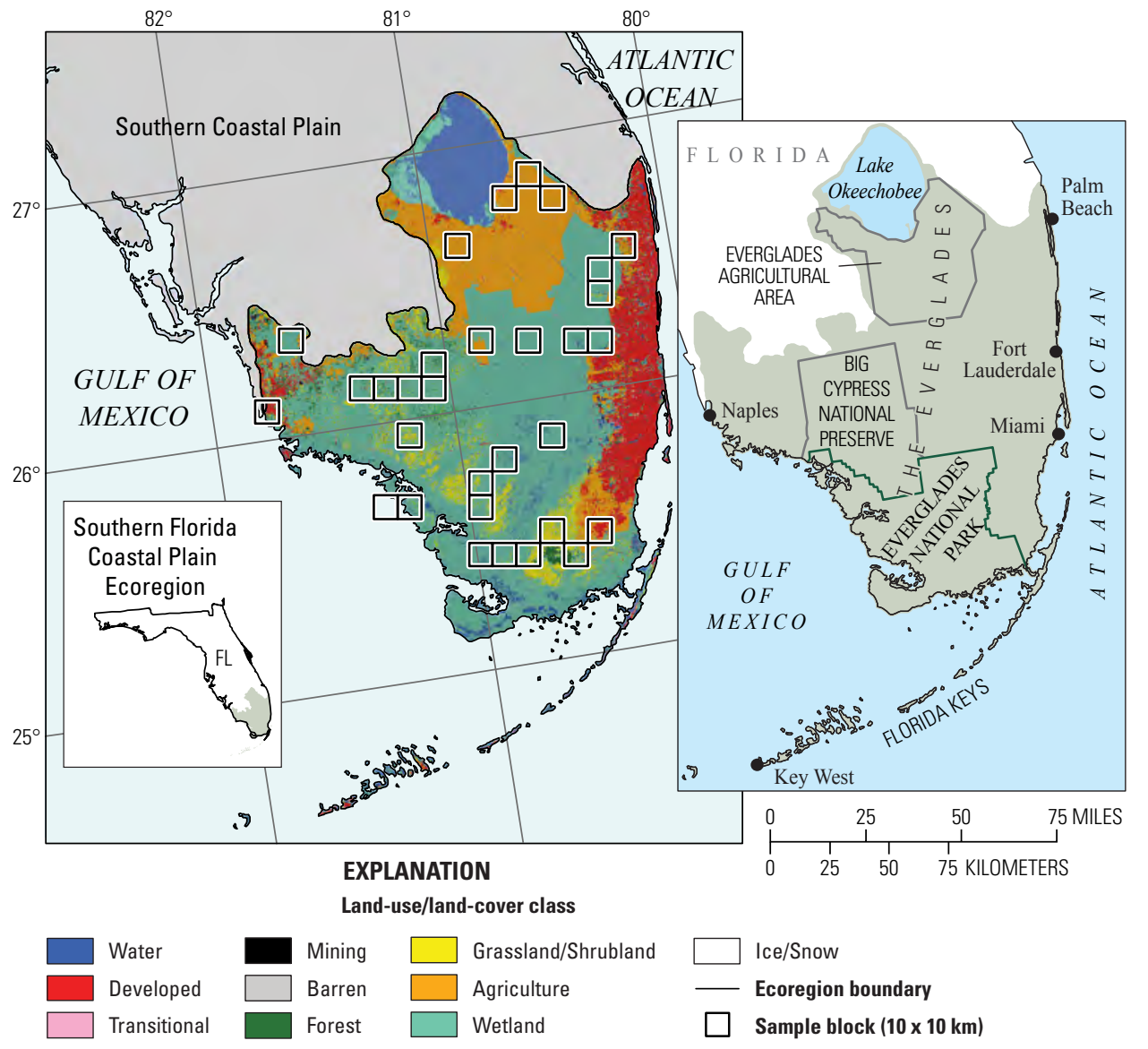




\section{Contemporary Land-Cover Change (1973 to 2000)}

The overall spatial change (the percentage of land that changed at least one time) in the Southern Florida Coastal Plain Ecoregion between 1973 and 2000 is estimated at 5.8 percent (table 1). Compared to other Eastern United States ecoregions, change in the Southern Florida Coastal Plain Ecoregion was moderate, particularly when compared to the neighboring Southern Coastal Plain Ecoregion, which experienced a 24.8 percent change (fig. 5): an estimated 4.4 percent of the Southern Florida Coastal Plain ecoregion $\left(986 \mathrm{~km}^{2}\right)$ changed only one time; 1.4 percent $\left(314 \mathrm{~km}^{2}\right)$ changed two or more times; and an estimated 94.2 percent of the ecoregion remained

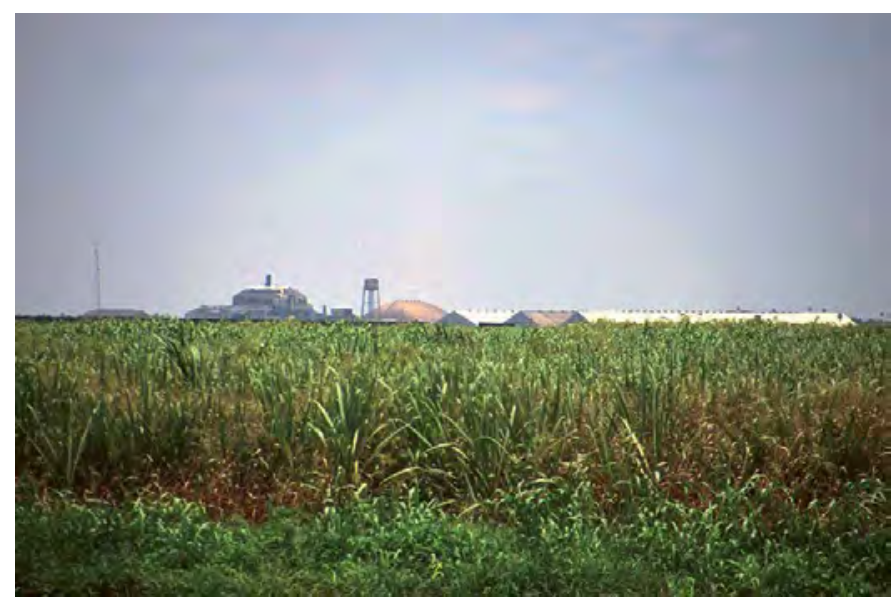

Figure 2. Sugarcane-cultivation and -processing operations, in Everglades Agricultural Area (Conservancy of Southwest Florida, 2013), south of Lake Okeechobee, Florida.

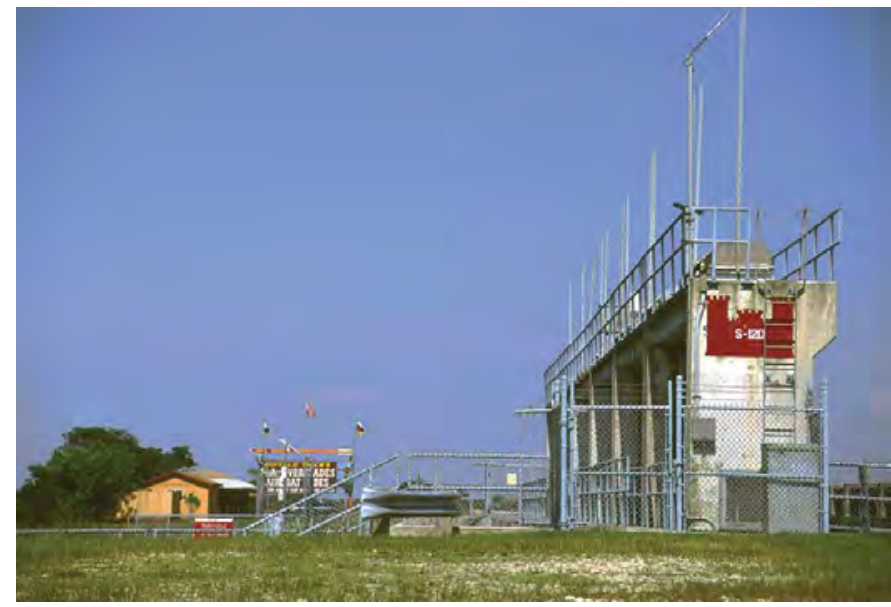

Figure 3. Flow regulator in Southern Florida Coastal Plain Ecoregion, part of water-control and -allocation infrastructure of Central and Southern Florida Flood Control Project, which was authorized by Congress in 1948 and constructed by U.S. Army Corps of Engineers, thereby ensuring continuation of urban and agricultural growth after World War II. unchanged (table 1). The spatial distribution of change was uneven; most change occurred in urbanizing coastal areas, and relatively little change occurred inland. When normalized to an average annual rate to account for unequal time periods, the estimated change per time period varied from a high of 2.5 percent between 1973 and 1980 to a low of 1.4 percent

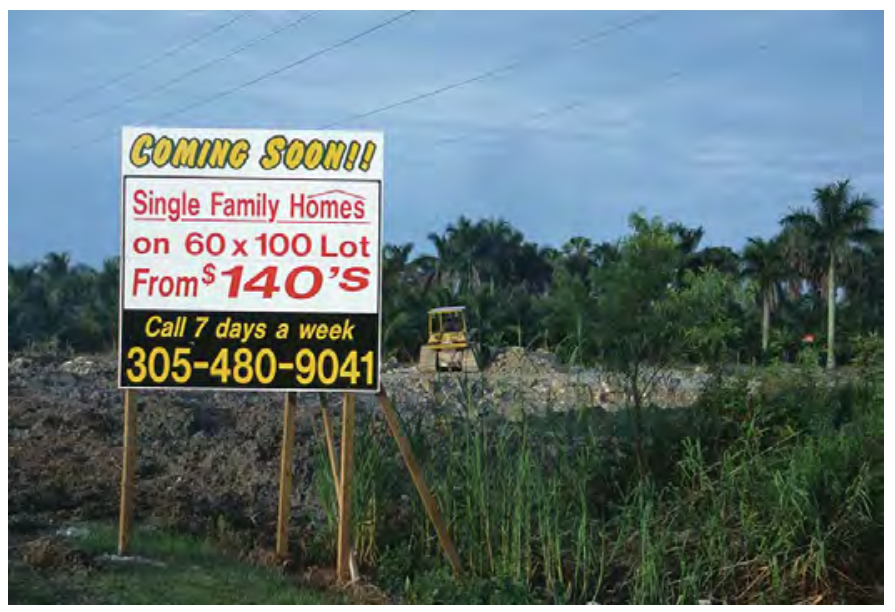

Figure 4. Field being cleared for development in Southern Florida Coastal Plain Ecoregion, as demand for housing and associated amenities continues to rise in coastal areas.

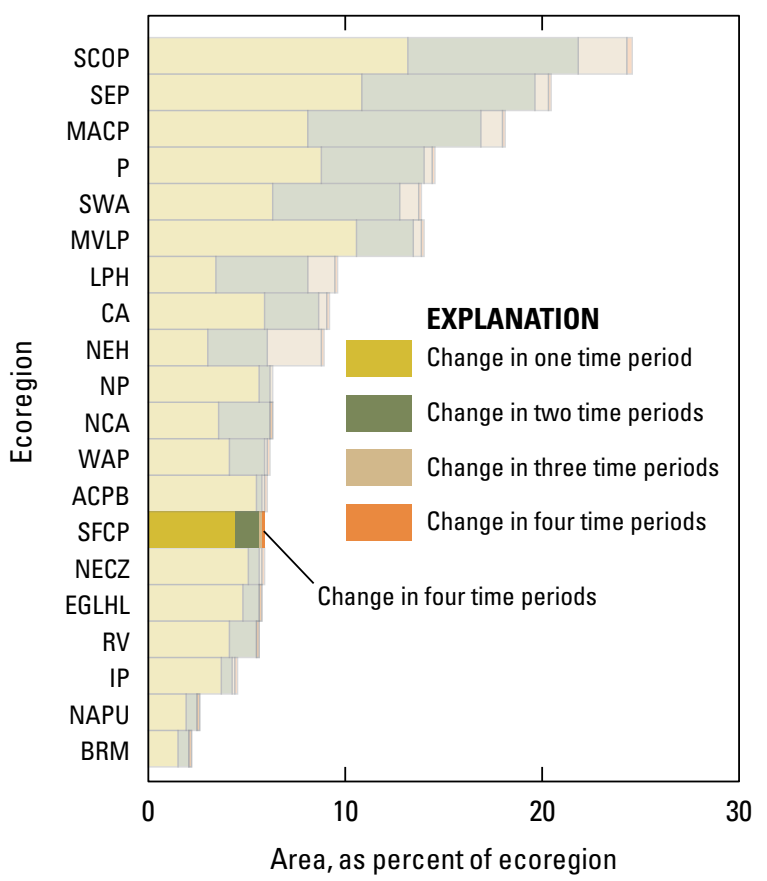

Figure 5. Overall spatial change in Southern Florida Coastal Plain Ecoregion (SFCP; darker bars) compared with that of all 20 Eastern United States ecoregions (lighter bars). Each horizontal set of bars shows proportions of ecoregion that changed during one, two, three, or four time periods; highest level of spatial change in Southern Florida Coastal Plain Ecoregion (four time periods) labeled for clarity. See table 2 for years covered by each time period. See appendix 2 for key to ecoregion abbreviations. 
between 1992 and 2000 (table 2). The two intervening time periods (1980-1986, 1986-1992) had rates of change of 1.7 and 1.9 percent, respectively. The estimated average annual rate of change was 0.3 percent across all time periods. The period between 1973 and 1980 had the highest annual rate of change, at 0.4 percent of the ecoregion $\left(80 \mathrm{~km}^{2}\right)$ (table 2; fig. 6 ); during this time period, the leading conversions were from wetland to agriculture and from nonmechanically disturbed to wetland, as wetlands recovered from the effects of fire. The time period between 1992 and 2000 had the lowest annual rate of change, at 0.2 percent of the ecoregion; the leading conversions during this time period were from agriculture to developed and from wetland to nonmechanically disturbed (the latter, owing to the occurrence of fire in wetland areas).

Changes in ecoregion land area by land-cover class are indicated in table 3. Developed increased in each time period, from 2.3 percent of the ecoregion in 1973 to 4.1 percent in 2000. Agriculture increased from 17.2 percent of the ecoregion in 1973 to 18.4 percent in 1980, and then it decreased in each subsequent period, occupying 17.3 percent of the ecoregion in 2000. In the time periods between 1973 and 1992, nonmechanically disturbed land fluctuated between 0.0 and 0.6 percent of the ecoregion, reflecting the natural cycle of fire and regrowth in the Everglades; by 2000, nonmechanically disturbed represented an estimated 0.3 percent of the ecoregion. Wetland decreased from 73.7 percent of the ecoregion in 1973 to 72.1 percent in 2000 , primarily the result of increases in agriculture and developed (fig. 7).

Wetland to agriculture was the most common landcover conversion overall (between 1973 and 2000), with an estimated $348 \mathrm{~km}^{2}$ converted (table 4), the highest amount of

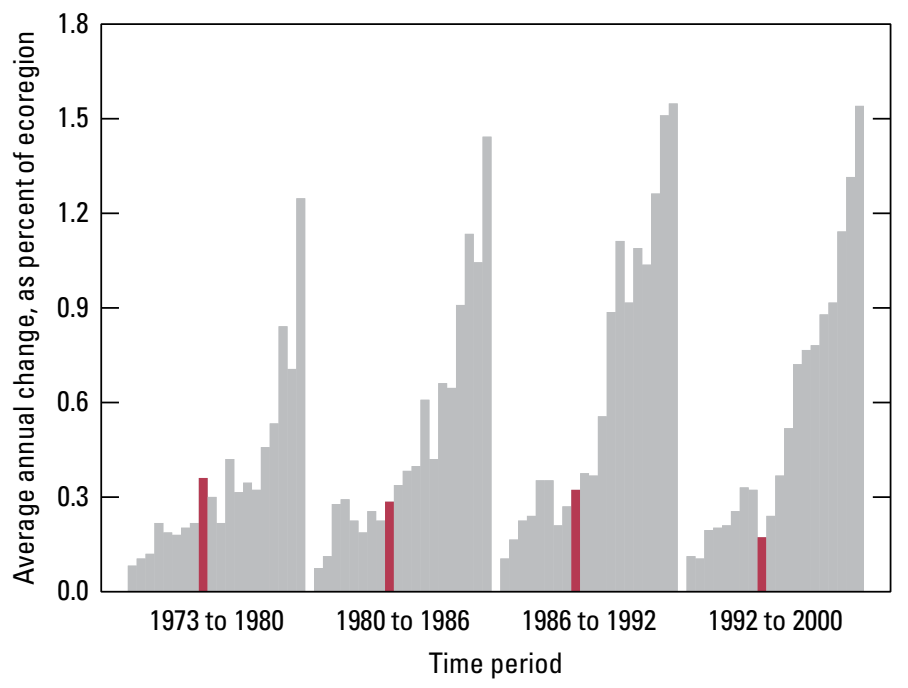

Figure 6. Estimates of land-cover change per time period, normalized to annual rates of change for all 20 Eastern United States ecoregions (gray bars). Estimates of change for Southern Florida Coastal Plain Ecoregion are represented by red bars in each time period. change $\left(284 \mathrm{~km}^{2}\right)$ occurring in the first time period (19731980). Conversions between nonmechanically disturbed and wetland, which represent the natural role of fire and habitat renewal in wetland areas, accounted for the second and fourth most common conversions overall. Agriculture to developed was the third most common conversion overall. Between 1973 and 2000, an estimated $414 \mathrm{~km}^{2}$ were converted to developed land. As a result, the developed land-cover class was involved in more than one-quarter of all changes, the most of any landcover class during the study period. Conversions to developed increased after 1980, as a significant amount of agriculture that had been converted earlier from wetland became urbanized. Despite a continual decrease between 1973 and 2000, wetland remained the dominant land-cover class.

Several factors contributed to land-cover change in the Southern Florida Coastal Plain Ecoregion during the study period (1973-2000). Extensive drainage- and flood-control measures, which were begun in the early 1950 s by the U.S. Army Corps of Engineers, ensured continual increases in

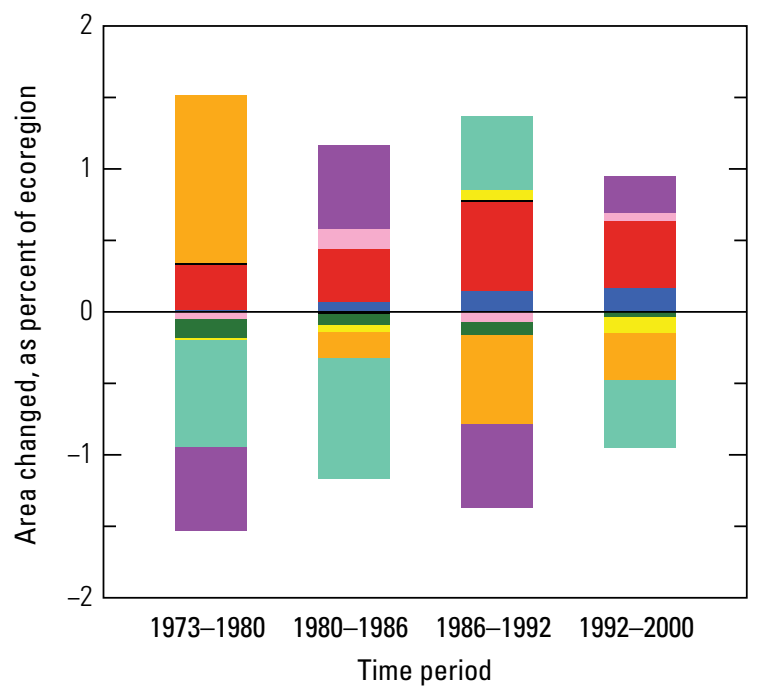

\section{EXPLANATION}

Land-use/land-cover class

\begin{tabular}{|c|c|}
\hline Water & Forest \\
\hline Developed & Grassland/Shrubland \\
\hline Mechanically disturbed & Agriculture \\
\hline Mining & Wetland \\
\hline Barren & Nonmechanically disturbed \\
\hline
\end{tabular}

Figure 7. Normalized average net change in Southern Florida Coastal Plain Ecoregion by time period for each land-cover class. Bars above zero axis represent net gain, whereas bars below zero represent net loss. Note that not all land-cover classes shown in explanation may be represented in figure. See appendix 3 for definitions of land-use and land-cover classifications. 
agricultural and development activities. Improvements to the transportation infrastructure to support these land uses made the ecoregion more accessible to tourists and new residents, and it also eased the movement of goods. The advent of private and public pensions and health-care programs enabled large numbers of retirees to settle in the ecoregion (Solecki, 2001).

National and state parks and wildlife refuges played a role in limiting new development, especially in wetland areas. Such protected lands constituted about 30 percent of the ecoregion (fig. 8). A growing awareness of environmental impacts has led to measures protecting ecologically sensitive areas, such as the creation of the Big Cypress National Preserve in 1974 and the ongoing efforts at restoring The Everglades (Carter, 1974; McCally, 1999).

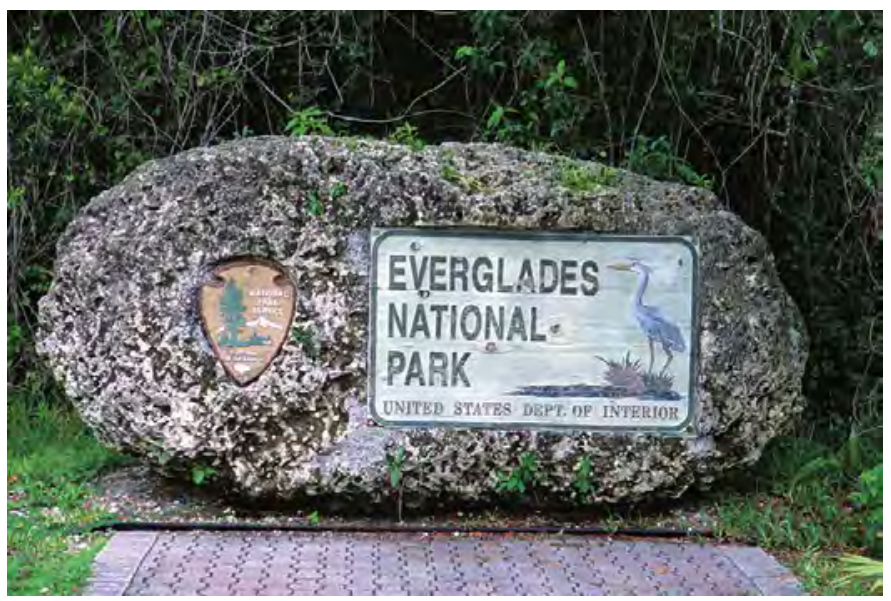

Figure 8. Roadside marker for Everglades National Park, established in 1947 in Southern Florida Coastal Plain Ecoregion. Although presence of Everglades National Park limits development, both plant and animal species within park are greatly affected by agricultural and urban areas beyond its borders.

Table 1. Percentage of Southern Florida Coastal Plain Ecoregion land cover that changed at least one time during study period (1973-2000) and associated statistical error.

[Most sample pixels remained unchanged ( 94.2 percent), whereas 5.8 percent changed at least once throughout study period]

\begin{tabular}{ccccccc}
\hline $\begin{array}{c}\text { Number } \\
\text { of } \\
\text { changes }\end{array}$ & $\begin{array}{c}\text { Percent } \\
\text { of } \\
\text { ecoregion }\end{array}$ & $\begin{array}{c}\text { Margin } \\
\text { of error } \\
(+/-\%)\end{array}$ & $\begin{array}{c}\text { Lower } \\
\text { bound } \\
(\%)\end{array}$ & $\begin{array}{c}\text { Upper } \\
\text { bound } \\
(\%)\end{array}$ & $\begin{array}{c}\text { Standard } \\
\text { error } \\
(\%)\end{array}$ & $\begin{array}{c}\text { Relative } \\
\text { error } \\
(\%)\end{array}$ \\
\hline 1 & 4.4 & 1.7 & 2.7 & 6.1 & 1.1 & 26.1 \\
2 & 1.2 & 0.7 & 0.5 & 1.9 & 0.5 & 40.1 \\
3 & 0.2 & 0.2 & 0.0 & 0.4 & 0.1 & 63.9 \\
4 & 0.0 & 0.0 & 0.0 & 0.0 & 0.0 & 90.5 \\
\hline $\begin{array}{l}\text { Overall } \\
\text { spatial } \\
\text { change }\end{array}$ & 5.8 & 2.3 & 3.5 & 8.1 & 1.5 & 26.3 \\
\hline
\end{tabular}


Table 2. Raw estimates of change in Southern Florida Coastal Plain Ecoregion land cover, computed for each of four time periods between 1973 and 2000, and associated error at 85-percent confidence level.

[Estimates of change per period normalized to annual rate of change for each time period]

\begin{tabular}{|c|c|c|c|c|c|c|c|}
\hline Period & $\begin{array}{c}\text { Total change } \\
\text { ( } \% \text { of ecoregion) }\end{array}$ & $\begin{array}{c}\text { Margin of } \\
\text { error } \\
(+/-\%)\end{array}$ & $\begin{array}{c}\text { Lower } \\
\text { bound } \\
(\%)\end{array}$ & $\begin{array}{c}\text { Upper bound } \\
(\%)\end{array}$ & $\begin{array}{c}\text { Standard } \\
\text { error } \\
(\%)\end{array}$ & $\begin{array}{c}\text { Relative } \\
\text { error } \\
(\%)\end{array}$ & $\begin{array}{l}\text { Average rate } \\
\text { (\% per year) }\end{array}$ \\
\hline \multicolumn{8}{|c|}{ Estimate of change, in percent stratum } \\
\hline 1973-1980 & 2.5 & 1.3 & 1.2 & 3.8 & 0.9 & 34.6 & 0.4 \\
\hline $1980-1986$ & 1.7 & 0.9 & 0.8 & 2.6 & 0.6 & 36.7 & 0.3 \\
\hline 1986-1992 & 1.9 & 1.1 & 0.8 & 3.0 & 0.7 & 38.8 & 0.3 \\
\hline $1992-2000$ & 1.4 & 0.7 & 0.7 & 2.0 & 0.5 & 33.1 & 0.2 \\
\hline \multicolumn{8}{|c|}{ Estimate of change, in square kilometers } \\
\hline $1973-1980$ & 559 & 286 & 273 & 845 & 194 & 34.6 & 80 \\
\hline $1980-1986$ & 380 & 206 & 174 & 587 & 140 & 36.7 & 63 \\
\hline 1986-1992 & 426 & 244 & 182 & 671 & 165 & 38.8 & 71 \\
\hline $1992-2000$ & 305 & 150 & 156 & 455 & 101 & 33.1 & 38 \\
\hline
\end{tabular}

Table 3. Estimated area (and margin of error) of each land-cover class in Southern Florida Coastal Plain Ecoregion, calculated five times between 1973 and 2000. See appendix 3 for definitions of land-cover classifications.

\begin{tabular}{|c|c|c|c|c|c|c|c|c|c|c|c|c|c|c|c|c|c|c|c|c|}
\hline & \multicolumn{2}{|c|}{ Water } & \multicolumn{2}{|c|}{ Developed } & \multicolumn{2}{|c|}{$\begin{array}{l}\text { Mechanically } \\
\text { disturbed }\end{array}$} & \multicolumn{2}{|c|}{ Mining } & \multicolumn{2}{|c|}{ Barren } & \multicolumn{2}{|c|}{ Forest } & \multicolumn{2}{|c|}{$\begin{array}{c}\text { Grass- } \\
\text { land/ } \\
\text { Shrubland }\end{array}$} & \multicolumn{2}{|c|}{ Agriculture } & \multicolumn{2}{|c|}{ Wetland } & \multicolumn{2}{|c|}{$\begin{array}{c}\text { Non- } \\
\text { mechanically } \\
\text { disturbed }\end{array}$} \\
\hline & $\%$ & $+/-$ & $\%$ & $+/-$ & $\%$ & $+/-$ & $\%$ & $+/-$ & $\%$ & $+/-$ & $\%$ & $+/-$ & $\%$ & $+/-$ & $\%$ & $+1-$ & $\%$ & $+/-$ & $\%$ & $+/-$ \\
\hline \multicolumn{21}{|c|}{ Area, in percent stratum } \\
\hline 1973 & 2.7 & 2.2 & 2.3 & 1.7 & 0.1 & 0.1 & 0.0 & 0.0 & 0.0 & 0.0 & 2.9 & 1.5 & 0.4 & 0.3 & 17.2 & 8.2 & 73.7 & 9.0 & 0.6 & 0.8 \\
\hline 1980 & 2.8 & 2.2 & 2.6 & 1.9 & 0.1 & 0.1 & 0.0 & 0.0 & 0.0 & 0.0 & 2.8 & 1.4 & 0.3 & 0.2 & 18.4 & 8.3 & 73.0 & 9.2 & 0.0 & 0.0 \\
\hline 1992 & 3.0 & 2.2 & 3.6 & 2.3 & 0.2 & 0.1 & 0.0 & 0.0 & 0.0 & 0.0 & 2.6 & 1.3 & 0.4 & 0.2 & 17.6 & 8.1 & 72.6 & 9.2 & 0.0 & 0.0 \\
\hline 2000 & 3.1 & 2.2 & 4.1 & 2.5 & 0.2 & 0.2 & 0.0 & 0.0 & 0.0 & 0.0 & 2.6 & 1.2 & 0.3 & 0.2 & 17.3 & 8.1 & 72.1 & 9.2 & 0.3 & 0.4 \\
\hline $\begin{array}{l}\text { Net } \\
\text { change }\end{array}$ & 0.4 & 0.3 & 1.8 & 1.1 & 0.1 & 0.2 & 0.0 & 0.0 & 0.0 & 0.0 & -0.3 & 0.5 & -0.1 & 0.1 & 0.1 & 1.8 & -1.6 & 1.6 & -0.3 & 0.9 \\
\hline $\begin{array}{l}\text { Gross } \\
\text { change }\end{array}$ & 0.5 & 0.3 & 1.8 & 1.1 & 0.6 & 0.4 & 0.0 & 0.0 & 0.0 & 0.0 & 0.5 & 0.5 & 0.4 & 0.3 & 3.1 & 1.6 & 4.1 & 2.6 & 2.0 & 2.4 \\
\hline 1980 & 620 & 498 & 586 & 429 & 19 & 15 & 3 & 4 & 6 & 7 & 619 & 317 & 77 & 50 & 4,124 & 1,865 & 16,350 & 2,057 & 0 & 0 \\
\hline 1986 & 636 & 497 & 671 & 463 & 52 & 56 & 0 & 0 & 6 & 7 & 602 & 300 & 64 & 40 & 4,085 & 1,836 & 16,160 & 2,041 & 131 & 180 \\
\hline 1992 & 667 & 497 & 814 & 514 & 36 & 31 & 3 & 3 & 6 & 7 & 583 & 283 & 79 & 48 & 3,943 & 1,815 & 16,275 & 2,060 & 0 & 0 \\
\hline 2000 & 705 & 497 & 922 & 553 & 46 & 44 & 2 & 2 & 6 & 7 & 575 & 280 & 56 & 39 & 3,871 & 1,805 & 16,166 & 2,061 & 58 & 79 \\
\hline $\begin{array}{l}\text { Net } \\
\text { change }\end{array}$ & 89 & 63 & 406 & 242 & 15 & 54 & 0 & 3 & 0 & 0 & -73 & 105 & -26 & 33 & 11 & 394 & -351 & 348 & -73 & 199 \\
\hline $\begin{array}{l}\text { Gross } \\
\text { change }\end{array}$ & 113 & 71 & 406 & 242 & 141 & 98 & 9 & 8 & 0 & 0 & 116 & 105 & 100 & 69 & 694 & 365 & 910 & 586 & 449 & 542 \\
\hline
\end{tabular}


Table 4. Principal land-cover conversions in Southern Florida Coastal Plain Ecoregion, showing amount of area changed (and margin of error, calculated at 85-percent confidence level) for each conversion during each of four time periods and also during overall study period. See appendix 3 for definitions of land-cover classifications.

[Values given for "other" class are combined totals of values for other land-cover classes not listed in that time period. Abbreviations: n/a, not applicable]

\begin{tabular}{|c|c|c|c|c|c|c|c|}
\hline Period & From class & To class & $\begin{array}{c}\text { Area } \\
\text { changed } \\
\left(\mathbf{k m}^{2}\right)\end{array}$ & $\begin{array}{c}\text { Margin of } \\
\text { error } \\
\left(+/-\mathbf{k m}^{2}\right)\end{array}$ & $\begin{array}{c}\text { Standard } \\
\text { error } \\
\left(\mathbf{k m}^{2}\right)\end{array}$ & $\begin{array}{l}\text { Percent of } \\
\text { ecoregion }\end{array}$ & $\begin{array}{c}\text { Percent of all } \\
\text { changes }\end{array}$ \\
\hline \multirow[t]{7}{*}{$1973-1980$} & Wetland & Agriculture & 284 & 224 & 151 & 1.3 & 50.9 \\
\hline & Nonmechanically disturbed & Wetland & 130 & 179 & 121 & 0.6 & 23.3 \\
\hline & Forest & Developed & 25 & 34 & 23 & 0.1 & 4.5 \\
\hline & Mechanically disturbed & Developed & 19 & 27 & 18 & 0.1 & 3.5 \\
\hline & Agriculture & Developed & 17 & 14 & 9 & 0.1 & 3.0 \\
\hline & Other & Other & 83 & $\mathrm{n} / \mathrm{a}$ & $\mathrm{n} / \mathrm{a}$ & 0.4 & 14.8 \\
\hline & & Totals & 559 & & & 2.5 & 100.0 \\
\hline \multirow[t]{7}{*}{ 1980-1986 } & Wetland & Nonmechanically disturbed & 131 & 180 & 122 & 0.6 & 34.3 \\
\hline & Agriculture & Mechanically disturbed & 37 & 46 & 31 & 0.2 & 9.7 \\
\hline & Wetland & Agriculture & 37 & 35 & 23 & 0.2 & 9.6 \\
\hline & Agriculture & Developed & 34 & 24 & 16 & 0.2 & 8.9 \\
\hline & Forest & Developed & 18 & 23 & 16 & 0.1 & 4.7 \\
\hline & Other & Other & 124 & $\mathrm{n} / \mathrm{a}$ & $\mathrm{n} / \mathrm{a}$ & 0.6 & 32.7 \\
\hline & & Totals & 380 & & & 1.7 & 100.0 \\
\hline \multirow[t]{7}{*}{ 1986-1992 } & Nonmechanically disturbed & Wetland & 131 & 180 & 122 & 0.6 & 30.6 \\
\hline & Agriculture & Developed & 86 & 64 & 43 & 0.4 & 20.3 \\
\hline & Agriculture & Grassland/Shrubland & 31 & 28 & 19 & 0.1 & 7.3 \\
\hline & Mechanically disturbed & Developed & 27 & 30 & 20 & 0.1 & 6.3 \\
\hline & Forest & Developed & 22 & 29 & 20 & 0.1 & 5.2 \\
\hline & Other & Other & 129 & $\mathrm{n} / \mathrm{a}$ & $\mathrm{n} / \mathrm{a}$ & 0.6 & 30.3 \\
\hline & & Totals & 426 & & & 1.9 & 100.0 \\
\hline \multirow[t]{7}{*}{$1992-2000$} & Agriculture & Developed & 60 & 51 & 35 & 0.3 & 19.6 \\
\hline & Wetland & Nonmechanically disturbed & 57 & 78 & 53 & 0.3 & 18.5 \\
\hline & Wetland & Agriculture & 22 & 27 & 18 & 0.1 & 7.1 \\
\hline & Wetland & Water & 19 & 18 & 12 & 0.1 & 6.2 \\
\hline & Agriculture & Mechanically disturbed & 18 & 22 & 15 & 0.1 & 6.0 \\
\hline & Other & Other & 130 & $\mathrm{n} / \mathrm{a}$ & $\mathrm{n} / \mathrm{a}$ & 0.6 & 42.6 \\
\hline & & Totals & 305 & & & 1.4 & 100.0 \\
\hline \multirow{7}{*}{$\begin{array}{l}1973-2000 \\
\text { (overall) }\end{array}$} & Wetland & Agriculture & 348 & 277 & 187 & 1.6 & 20.8 \\
\hline & Nonmechanically disturbed & Wetland & 261 & 359 & 243 & 1.2 & 15.6 \\
\hline & Agriculture & Developed & 197 & 138 & 93 & 0.9 & 11.8 \\
\hline & Wetland & Nonmechanically disturbed & 187 & 193 & 131 & 0.8 & 11.2 \\
\hline & Agriculture & Mechanically disturbed & 80 & 88 & 60 & 0.4 & 4.8 \\
\hline & Other & Other & 598 & $\mathrm{n} / \mathrm{a}$ & $\mathrm{n} / \mathrm{a}$ & 2.7 & 35.8 \\
\hline & & Totals & 1,671 & & & 7.5 & 100.0 \\
\hline
\end{tabular}




\section{References Cited}

Carter, Luther J., 1974, The Florida experience-Land and water policy in a growth state: Baltimore, Md., The Johns Hopkins University Press, 354 p.

Conservancy of Southwest Florida, 2013, Everglades Agricultural Area: Conservancy of Southwest Florida Web site, accessed May 1, 2013, at http://www.conservancy.org/ourwork/everglades-agricultural-area.

McCally, David, 1999, The Everglades-An environmental history: Gainesville, University Press of Florida, 215 p.

Solecki, W.D., 2001, South Florida-The role of globalto-local linkages in land use/land cover change in South Florida: Ecological Economics, v. 37, p. 339-356.
Vogelmann, J.E., Howard, S.M., Yang, L., Larson, C.R., Wylie, B.K., and van Driel, N., 2001, Completion of the 1990s National Land Cover Data Set for the conterminous United States from Landsat Thematic Mapper data and ancillary data sources: Photogrammetric Engineering \& Remote Sensing, v. 67, p. 650-662.

Wiken, E., Jiménez Nava, F., and Griffith, G., 2011, North American terrestrial ecoregions-Level III: Montreal, Canada, Commission for Environmental Cooperation, 149 p., accessed May 1, 2013, at http://www.cec.org/ Storage/133/15860_QA07.30-32_NP_NA_Terrestrial_ Ecoregions_Level_3_Final-2june11.pdf. 



\section{Appendixes 1-4}





\section{Appendix 1. Map of Ecoregions in Conterminous United States}

This volume-U.S. Geological Survey Professional Paper 1794-D, which covers 20 ecoregions in the Eastern United States - provides an assessment of the rates and causes of land-use and land-cover change in the Eastern United States region between 1973 and 2000. The other three volumes of this Professional Paper (1794-A, 1794-B, and 1794-C) provide similar analyses for the Western United States, the Great Plains of the United States, and the Midwest-South Central United States regions, respectively.

The map contained in this appendix (fig. 1.1) shows all 84 ecoregions in the conterminous United States, as originally defined by Omernik (1987) and later modified by the U.S. Environmental Protection Agency (1997), in addition to the ecoregions that are contained in the Western United States, Great Plains of the United States, Midwest-South Central United States, and Eastern United States regions. Also shown are the land-use/land-cover classes from the 2001 National Land-Cover Database (Homer and others, 2004).

\section{References Cited}

Homer, C., Huang, C., Yang, L., Wylie, B., and Coan, M., 2004, Development of a 2001 National Land-Cover Database for the United States: Photogrammetric Engineering and Remote Sensing, v. 70, no. 7, p. 829-840.

Omernik, J.M., 1987, Ecoregions of the conterminous United States: Annals of the Association of American Geographers, v. 77, no. 1 , p. 118-125.

U.S. Environmental Protection Agency, 1997, Descriptions of level III ecological regions for the CEC report on ecological regions of North America: U.S. Environmental Protection Agency database, accessed April 12, 2006, at http://www.epa.gov/ wed/pages/ecoregions/na_eco.htm\#Downloads.

\section{Ecoregion Abbreviations Used on Map}

[Map is on following pages]

$\begin{array}{ll}\text { ACPB } & \text { Atlantic Coastal Pine Barrens Ecoregion } \\ \text { ANMM } & \text { Arizona/New Mexico Mountains Ecoregion } \\ \text { CR } & \text { Coast Range Ecoregion } \\ \text { CRK } & \text { Canadian Rockies Ecoregion } \\ \text { EGLHL } & \text { Eastern Great Lakes and Hudson Lowlands Ecoregion } \\ \text { HELP } & \text { Huron/Erie Lake Plains Ecoregion } \\ \text { LPH } & \text { Laurentian Plains and Hills Ecoregion } \\ \text { MACP } & \text { Middle Atlantic Coastal Plain Ecoregion } \\ \text { MRK } & \text { Middle Rockies Ecoregion } \\ \text { MVFP } & \text { Montana Valley and Foothill Prairies Ecoregion } \\ \text { MVLP } & \text { Mississippi Valley Loess Plains Ecoregion } \\ \text { NAPU } & \text { Northern Appalachian Plateau and Uplands Ecoregion } \\ \text { NCA } & \text { North Central Appalachians Ecoregion } \\ \text { NCHF } & \text { North Central Hardwood Forests Ecoregion } \\ \text { NECZ } & \text { Northeastern Coastal Zone Ecoregion } \\ \text { NEH } & \text { Northeastern Highlands Ecoregion } \\ \text { NLF } & \text { Northern Lakes and Forests Ecoregion } \\ \text { NMW } & \text { Northern Minnesota Wetlands Ecoregion } \\ \text { PL } & \text { Puget Lowland Ecoregion } \\ \text { SCCCOW } & \text { Southern and Central California Chaparral and Oak Woodlands Ecoregion } \\ \text { SCM } & \text { Southern California Mountains Ecoregion } \\ \text { SEWTP } & \text { Southeastern Wisconsin Till Plains Ecoregion } \\ \text { SFCP } & \text { Southern Florida Coastal Plain Ecoregion } \\ \text { TBP } & \text { Texas Blackland Prairies Ecoregion } \\ \text { WUM } & \text { Wasatch and Uinta Mountains Ecoregion } \\ \text { WV } & \text { Willamette Valley Ecoregion }\end{array}$




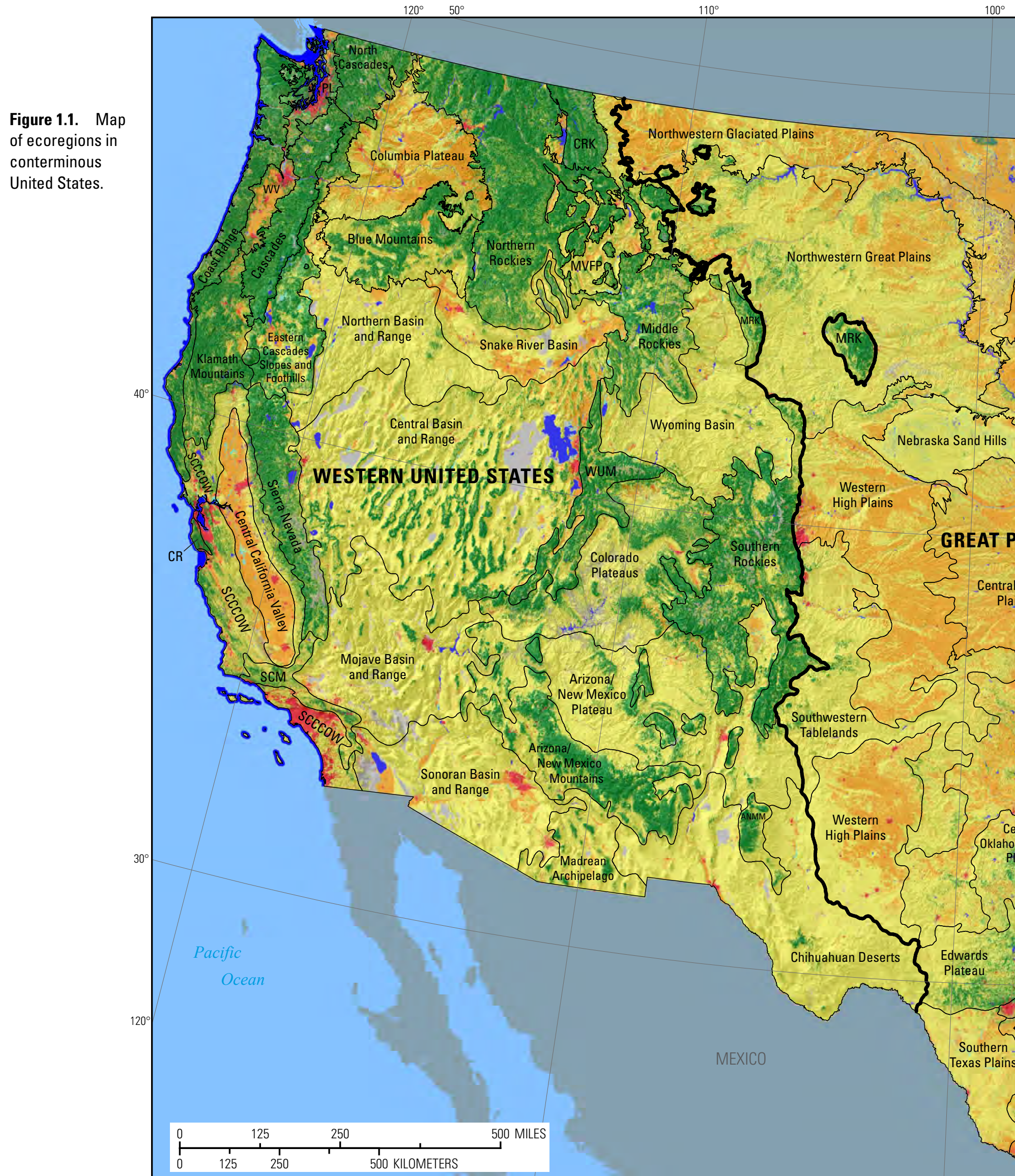




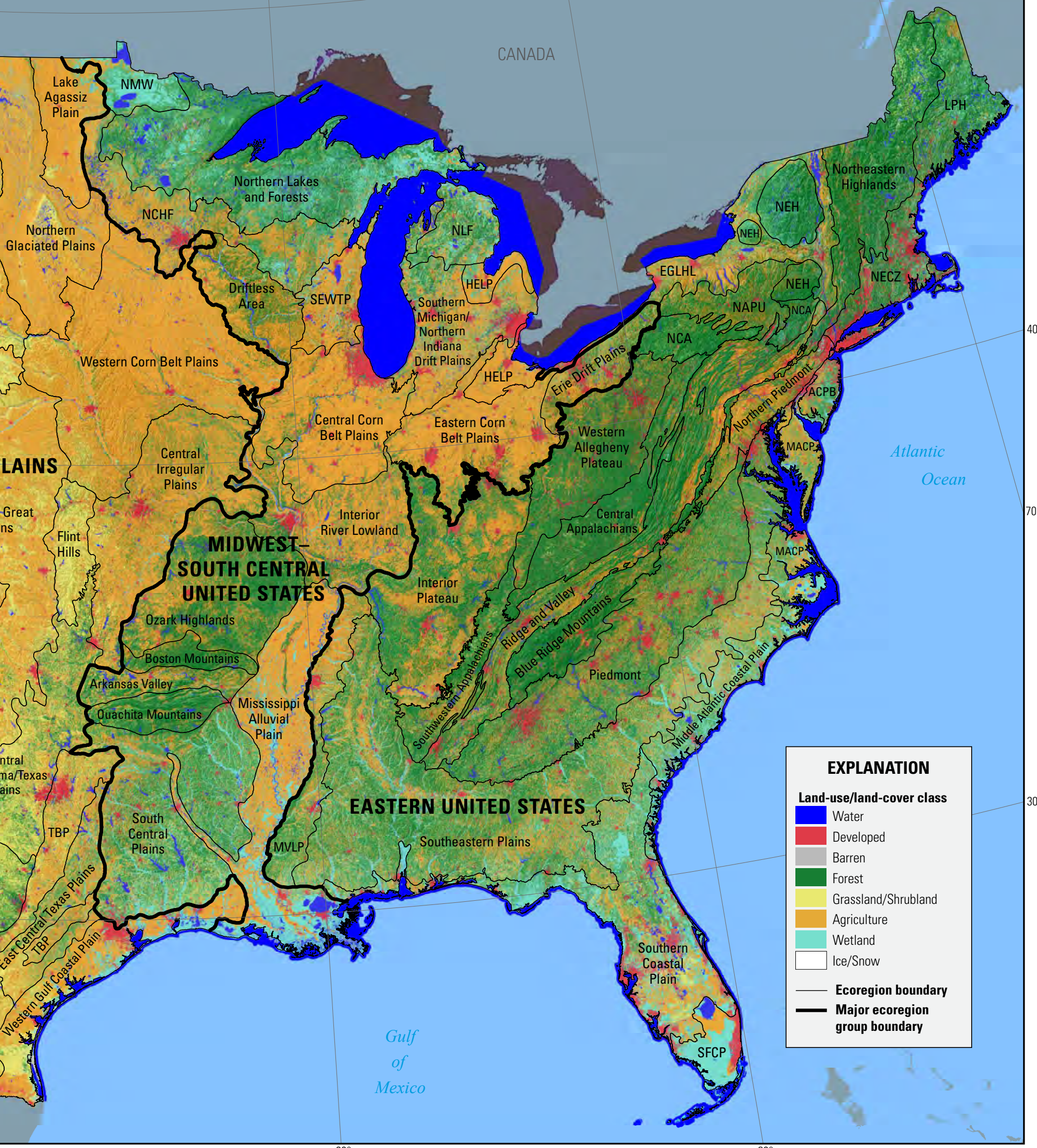




\section{Appendix 2. Abbreviations for Ecoregions in the Eastern United States}

$\begin{array}{ll}\text { ACPB } & \text { Atlantic Coastal Pine Barrens Ecoregion } \\ \text { BRM } & \text { Blue Ridge Mountains Ecoregion } \\ \text { CA } & \text { Central Appalachians Ecoregion } \\ \text { EGLHL } & \text { Eastern Great Lakes and Hudson Lowlands Ecoregion } \\ \text { IP } & \text { Interior Plateau Ecoregion } \\ \text { LPH } & \text { Laurentian Plains and Hills Ecoregion } \\ \text { MACP } & \text { Middle Atlantic Coastal Plain Ecoregion } \\ \text { MVLP } & \text { Mississippi Valley Loess Plains Ecoregion } \\ \text { NAPU } & \text { Northern Appalachian Plateau and Uplands Ecoregion } \\ \text { NCA } & \text { North Central Appalachians Ecoregion } \\ \text { NECZ } & \text { Northeastern Coastal Zone Ecoregion } \\ \text { NEH } & \text { Northeastern Highlands Ecoregion } \\ \text { NP } & \text { Northern Piedmont Ecoregion } \\ \text { P } & \text { Piedmont Ecoregion } \\ \text { RV } & \text { Ridge and Valley Ecoregion } \\ \text { SCOP } & \text { Southern Coastal Plain Ecoregion } \\ \text { SEP } & \text { Southeastern Plains Ecoregion } \\ \text { SFCP } & \text { Southern Florida Coastal Plain Ecoregion } \\ \text { SWA } & \text { Southwestern Appalachians Ecoregion } \\ \text { WAP } & \text { Western Allegheny Plateau Ecoregion } \\ \end{array}$




\section{Appendix 3. Land-Cover Classification System Used in "Status and Trends of Land Change" Study}

This analysis of land-use/land-cover change during the 1973-2000 study period is based on land-cover classifications mapped for five study dates - 1973, 1980, 1986, 1992, and 2000. The use of moderate-resolution imagery-Landsat Multispectral Scanner, Thematic Mapper, and Enhanced Thematic Mapper Plus-necessitated a land-cover classification system that was fairly general in order to achieve high levels of accuracy and consistency in the interpretations. The classification system also needed to contain classes that could be used as an appropriate surrogate for land use. This classification, which is based on the Anderson Level I classes (Anderson and others, 1976), was used because the classes have been designed as use surrogates, but this system has been further modified by adding two transitional disturbance categories, mechanically disturbed (human induced) and nonmechanically disturbed (natural).

The classification system used consists of the following 11 general land-cover classes: water, developed, mechanically disturbed, mining, barren, forest, grassland/shrubland, agriculture, wetland, nonmechanically disturbed, and ice/ snow. Classes are defined as follows:

Water-Areas that are persistently covered with water, such as perennial streams, canals, rivers, lakes, reservoirs, bays, and oceans.

Developed-Areas of intensive use, in which much of the land is covered with structures or other anthropogenically induced, impermeable surfaces (for example, high-density residential, commercial, and industrial areas, as well as roads, highways, and other transportation corridors), or less intensive use, in which the land-cover matrix includes both vegetation and structures (for example, low-density residential areas, recreational facilities, cemeteries, parking lots, and utility corridors). Land that is functionally related to urban or built-up environments (for example, parks and golf courses) is also included.

Mechanically disturbed - Land in an altered and often unvegetated state owing to disturbance by mechanical (that is, human) means. Mechanically disturbed land is in transition from one land-cover class to another. Processes leading to mechanical disturbance include forest clearcutting, earthmoving, scraping, chaining, reservoir drawdown, and other types of anthropogenically induced changes.
Mining - Areas of extractive mining activities that have significant surface expression, including mining buildings and apparatus, quarry pits, evaporation and leach ponds, tailings and overburden piles, and other components related to mining, to the extent that these features can be detected.

Barren-Areas of bare soil, sand, or rock, in which less than 10 percent of the area is vegetated. Barren lands generally are naturally occurring.

Forest-Tree-covered land where the tree-cover density is greater than 10 percent. Cleared forest land is mapped (according to land cover at the time of the imagery) as either mechanically disturbed or grassland/shrubland.

Grassland/Shrubland - Land that is predominately covered with grasses, forbs, or shrubs. Vegetated cover must make up at least 10 percent of the area.

Agriculture - Land, in either a vegetated or an unvegetated state, used for the production of food or fiber. This includes cultivated and uncultivated croplands, hay lands, pasture, orchards, vineyards, and confined-livestock operations. However, forest plantations always are classified as forest, regardless of how the wood products are used.

Wetland-Land where water saturation is the determining factor in soil characteristics, vegetation types, and animal communities. Wetlands usually contain both water and vegetated cover.

Nonmechanically disturbed - Land in an altered and often unvegetated state owing to disturbance by nonmechanical (that is, natural) means. Nonmechanically disturbed land is in transition from one land-cover class to another. Causes of nonmechanical disturbance include fire, wind, floods, animals, and other similar phenomena.

Ice/Snow - Land where the accumulation of snow and ice does not completely melt during the summer period (for example, alpine glaciers and perennial snowfields).

\section{Reference Cited}

Anderson, J.R., Hardy, E.E., Roach, J.T., and Witmer, R.E., 1976, A Land Use and Land Cover Classification System for Use with Remote Sensor Data: U.S. Geological Survey Professional Paper 964, 28 p., available at http://pubs.usgs. gov/pp/0964/report.pdf. 


\section{Appendix 4. Methodology Used in "Status and Trends of Land Change" Study}

This appendix describes the methodology used to document the temporal and spatial rates, trends, and types of change documented in this "Status and Trends of Land Change" study. The methodology is based on a statistical sampling approach, manual classification of land use and land cover, and postclassification comparisons of land cover over five different study dates (Loveland and others, 2002). U.S. Environmental Protection Agency's (1999) Level III ecoregions provided the geographic framework for regional land-cover change estimates, and land-use/land-cover change was estimated on an ecoregion-by-ecoregion basis using a probability sample of randomly selected blocks within each of 84 ecoregions across the conterminous United States. For each sample block, five dates of Landsat imagery were interpreted in order to map land use and land cover, using a classification system that consists of 11 general land-cover classes (see appendix 3, entitled "Land-Cover Classification System Used in 'Status and Trends of Land Change' Study"). The resulting land-cover data for each sample block were used to determine change for four time periods, and sample-block data were used to calculate change estimates for each ecoregion.

\section{Sampling Strategy}

In this study, a sampling strategy was used as a costefficient method for characterizing land-cover change in an area as large as the conterminous United States. The study used a stratified random sample of 2,688 square blocks (fig. 1); a random sample of these blocks was independently selected for each ecoregion analyzed. Because the study used a probability sample, the estimates of land-use/land-cover change that are derived can be considered as categorically representative of the population (Kish, 1987).

The size of each sample block in this study, as well as the sampling density (that is, the number of sample blocks analyzed per ecoregion), was based on a compromise between two conflicting objectives: (1) estimating change in landcover area, and (2) estimating change in landscape pattern. Larger numbers of smaller sample blocks would result in more precise estimates of change in land-cover area, whereas smaller numbers of larger sample blocks would be more desirable for characterizing landscape pattern.

\section{Size of Samples}

In the initial study design, a $20 \times 20 \mathrm{~km}\left(400 \mathrm{~km}^{2}\right)$ sampleblock size was used, and nine ecoregions were analyzed, each analysis consisting of 9 to 11 sample blocks. On the basis of results from these initial ecoregion analyses, a decision was made to use a higher density of smaller $\left(10 \times 10 \mathrm{~km} ; 100 \mathrm{~km}^{2}\right)$ sample blocks for the remainder of the ecoregion analyses in order to maximize the precision of the land-cover change estimates.

\section{Sampling Density}

The sampling density was determined by both the project requirements for precision in the change estimates and the expected characteristics of change within the ecoregion being studied. As precision requirements increase, so must the sampling density. Similarly, a greater sampling density is required when areas of change are expected to be less evenly distributed throughout an ecoregion.

In this study, the target precision level was to map gross overall change to within a $\pm 1 \%$ margin of error at an $85 \%$ confidence level for each ecoregion. On the basis of this target precision level and the expected characteristics of change within all 84 ecoregions in the conterminous United States, it was determined that between 25 and 48 of the $10 \times 10$ $\mathrm{km}$ sample blocks per ecoregion would likely be needed to adequately characterize overall change in each ecoregion.

\section{Implementation of the Sampling Strategy}

The sampling strategy outlined above was fairly straightforward to implement. A regular grid of $10 \times 10 \mathrm{~km}$ (or, in a few cases, $20 \times 20 \mathrm{~km}$ ) sample blocks was overlain on an ecoregion map of the conterminous United States. Blocks whose centers fell within the boundaries of an ecoregion were highlighted as potentially valid sample blocks for that ecoregion and then were assigned a unique numerical value from 1 to $\mathrm{N}$. A random number generator was then used to select sample blocks, one at a time, until the desired number was reached. Thus, each sample block within an ecoregion had an equal probability of being included in the final sample analysis.

Although the number of sample blocks selected and analyzed was based on both the target precision level and the expected characteristics of change within the ecoregion, unexpected heterogeneity in the distribution of change could still result in the estimates of change having levels of precision that are lower than desired. Should this occur, the sampling strategy allowed for the selection and interpretation of additional sample blocks. The inclusion of these reserve blocks allowed the analysis to achieve change estimates that have acceptable levels of precision. In actuality, for various reasons, no reserve blocks were implemented.

\section{Geographic Framework}

A central premise of the study design was the use of a geographic framework to provide regional land-cover change estimates. Geographers have long used regional frameworks because they capture the essence and potential of the landscape without masking the roles of environmental, social, and economic forces (Turner and Meyer, 1991). This "Status and Trends of Land Change" study chose to use ecoregions, 
as originally defined by Omernik (1987) and later modified by the U.S. Environmental Protection Agency (1999), as the framework from which to tell the regional story of change.

Ecoregions were chosen as the unit of analysis because (1) they provide a means to localize estimates of the rates and driving forces of change, (2) they were developed by synthesizing information on a wide variety of factors (for example, climate, geology, physiography, soils, vegetation, hydrology, and human influences) and, therefore, should reflect both current land-use and land-cover types and future change trajectories, and (3) they provide a framework that can be extended globally.

\section{Landsat Data}

Landsat satellite imagery was the primary source of data used for detecting land-cover change in this study. Data from the Landsat Multispectral Scanner (MSS), Thematic Mapper (TM), and Enhanced Thematic Mapper Plus (ETM+) instruments were acquired from the Landsat data archive: Landsat MSS datasets are available from late-1972 through late-1992; Landsat TM data are available from 1982 to the present; and Landsat ETM + data are available from 1999 to the present. Each of these products provided a consistent, synoptic, multispectral view of the land surface from which land cover could be interpreted for the period between 1972 and 2000. To analyze trends in land-use/land-cover change throughout this period, five target study dates spaced at semiregular intervals $(1973,1980,1986,1992$, and 2000) were selected. Landsat imagery corresponding to each $10 \times 10 \mathrm{~km}$ (or $20 \times 20 \mathrm{~km}$ ) sample block was extracted from full Landsat scenes, resulting in five dates of satellite imagery for each sample block. To reduce expenses, the initial data-acquisition strategy was to use existing geoprocessed Landsat datasets as the primary input data source. Four of the five dates of Landsat MSS, $\mathrm{TM}$, and ETM+ data were available in a geocoded format as a result of processing done for two previous projects: (1) the North American Landscape Characterization (NALC) project produced 1973, 1986, and 1992 geocoded Landsat MSS datasets for the conterminous United States and Mexico (Lunetta and others, 1998), and (2) the $1992 \mathrm{TM}$ and $2000 \mathrm{ETM}+$ data came from the Multiresolution Landscape Characterization initiative (Loveland and Shaw, 1996). New 1980 Landsat MSS acquisitions were obtained in order to maintain the six- to eightyear interval between the five target dates.

The Landsat MSS, TM, and ETM+ scenes obtained were previously georeferenced to root-mean-square error of 1 pixel or less but to differing map projections. For this study, all scenes were translated to a common Albers equal-area projection. Most of the NALC MSS data had also been terraincorrected, but approximately one-third of the NALC data (path and rows) had been processed before the implementation of terrain-correction techniques. However, this was not considered a problem because the early NALC scenes were located primarily in areas with negligible terrain variability.

\section{Ancillary Data}

Additional ancillary data were acquired to aid interpreters in delineating land use and land cover from the Landsat data. For example, aerial photography was acquired for each sample block to provide a high-resolution data source to help with difficult interpretations. The National Aerial Photography Program (NAPP) generally provided one or two dates of color-infrared (CIR) and (or) black-and-white aerial photographs from 1987 to the present. The National High Altitude Photograph (NHAP) Program generally provided one date of CIR and (or) black-and-white aerial photographs between 1980 and 1986. Although the Landsat imagery was always used as the source material for delineating land use and land cover, these higher resolution aerial photographs were invaluable for assisting in the interpretation of the imagery. Topographic maps, census data, other electronic sources of aerial photographs (for example, Google Earth), and digital raster graphics were among the other sources of information that interpreters found useful when processing the data.

\section{Land-Cover Classification Scheme}

The analysis of land use and land cover change during the 1973 to 2000 study period was based on classifications of land cover for the five target dates mentioned previously. The classification system used consists of the following 11 general land-cover classes: water, developed, mechanically disturbed, mining, barren, forest, grassland/shrubland, agriculture, wetland, nonmechanically disturbed, and ice/ snow. See appendix 3, entitled "Land-Cover Classification System Used in 'Status and Trends of Land Change' Study," for definitions of these 11 classifications.

Two primary factors affected the design of the classification system. The first factor was recognizing that the use of moderate-resolution Landsat imagery would necessitate a land-cover classification system that was fairly general in order to achieve high interpretation accuracy and consistency. The ability to identify and map land cover would be limited both by the technical specifications of the Landsat MSS, TM, and ETM sensors and by the local and regional landscape characteristics that affect the form and contrast visible in satellite imagery. This would be especially true when interpreting Landsat MSS data.

The second factor involved choosing land-cover classes that captured the land-cover changes of interest. Because the project's interest was in land-use change, with land cover serving as a surrogate for land use, the decision was to use the Anderson Level I classes (Anderson and others, 1976) because they were designed as use surrogates. However, the Anderson system was selectively modified by adding two disturbance categories, mechanically disturbed (human induced) and nonmechanically disturbed (natural). 


\section{Manual Land-Cover Delineation}

Land-cover delineation for each sample block began with the creation of a baseline reference land-cover dataset. The 1992 date usually was the starting point owing to the availability of the 30-m-resolution 1992 National Land Cover Data (NLCD) dataset (Vogelmann and others, 2001). The NLCD dataset provided a starting template after the more detailed NLCD classes were aggregated to match the general land-cover classification described above.

The NLCD data first were manually edited on the computer screen, using on-screen interpretation methods, while using the 1992 Landsat TM data and the NAPP aerial photographs as interpretation aids. This cleanup procedure to improve the NLCD classification accuracy was carried out because the NLCD data were created using automated imageprocessing procedures, and they were not meant for use in local- or ecoregional-scale assessments. A minimum mapping unit of $60 \times 60$ meters was used for this study. Thus, features having ground footprints less than $60 \mathrm{~m}$ wide generally were not mapped, resulting in the exclusion of high-contrast features such as roads, which have a distinct spectral signature but have ground dimensions of less than $60 \mathrm{~m}$.

To carry out the NLCD editing for a particular sample block, the analyst displayed the NLCD data alongside the 1992 Landsat TM data on the computer screen. These data sources, along with hard-copy prints of NAPP aerial photography roughly corresponding to the 1992 date, were visually inspected by the analyst to determine if any corrections were needed in the sample block. The analyst manually delineated polygons that consisted of contiguous blocks of specific land-cover classes. Each of these polygons was then given a code value that corresponded to the landcover classes outlined in the classification scheme in appendix 3 . The process continued until the entire sample block was manually inspected, mapped, and coded by the analyst.

To analyze change, land-cover classes for the 1973, 1980,1986 , and 2000 study dates were backward- or forwardclassified using the 1992 land-cover dataset as the template.
For example, creation of the 2000 land-cover product began by making an exact copy of the 1992 land-cover product. This copy served as a baseline for the 2000 land-cover product, in which identified changes between 1992 and 2000 were manually edited into the copied image. This baseline 2000 land-cover product was displayed on screen, along with the 1992 Landsat imagery and the 2000 Landsat imagery, allowing the analyst to pan through the entire area of the sample block while examining the 1992 and 2000 Landsat imagery and any relevant aerial photography for valid land-cover changes between the two study dates. Any identified land-cover changes were manually digitized on screen, and the land cover was recoded on the 2000 land-cover product.

Upon completion of the 2000 land-cover product, the same procedures were used to create the 1986, 1980, and 1973 land-cover products. This manual process eliminated errors that may occur between independently created land-cover products that are compared in a subsequent change analysis. Because only manually identified, delineated, and coded landcover changes were analyzed during this phase, classification errors were greatly reduced.

\section{Statistical Analysis}

The resulting land-cover data for each sample block was used in postclassification comparisons to determine change between study years (fig. 2). Sample blocks within each ecoregion were used to generate change statistics for all 84 ecoregions. These statistics were used to determine the predominant types of land-cover conversions occurring within each ecoregion, the estimated rates of change for these conversions, and whether these types and rates of change are constant or variable across time. The analysis of change also involved looking for spatial correlations between conversion types and selected socioeconomic and environmental factors, such as timber production, agricultural yields, precipitation amounts, population levels, proximity to urban development, and overall economic conditions, in order to improve the understanding of potential drivers of change. 


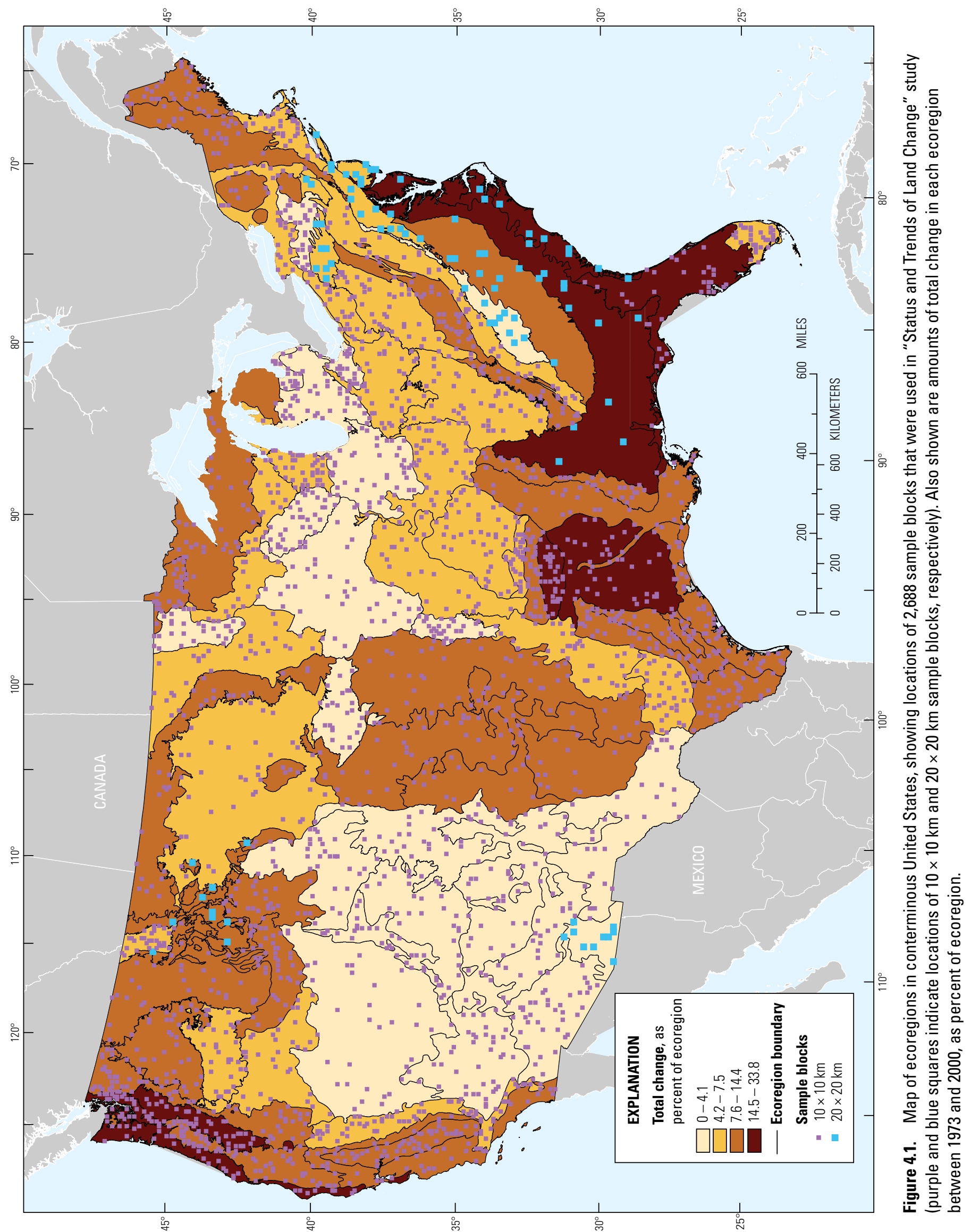



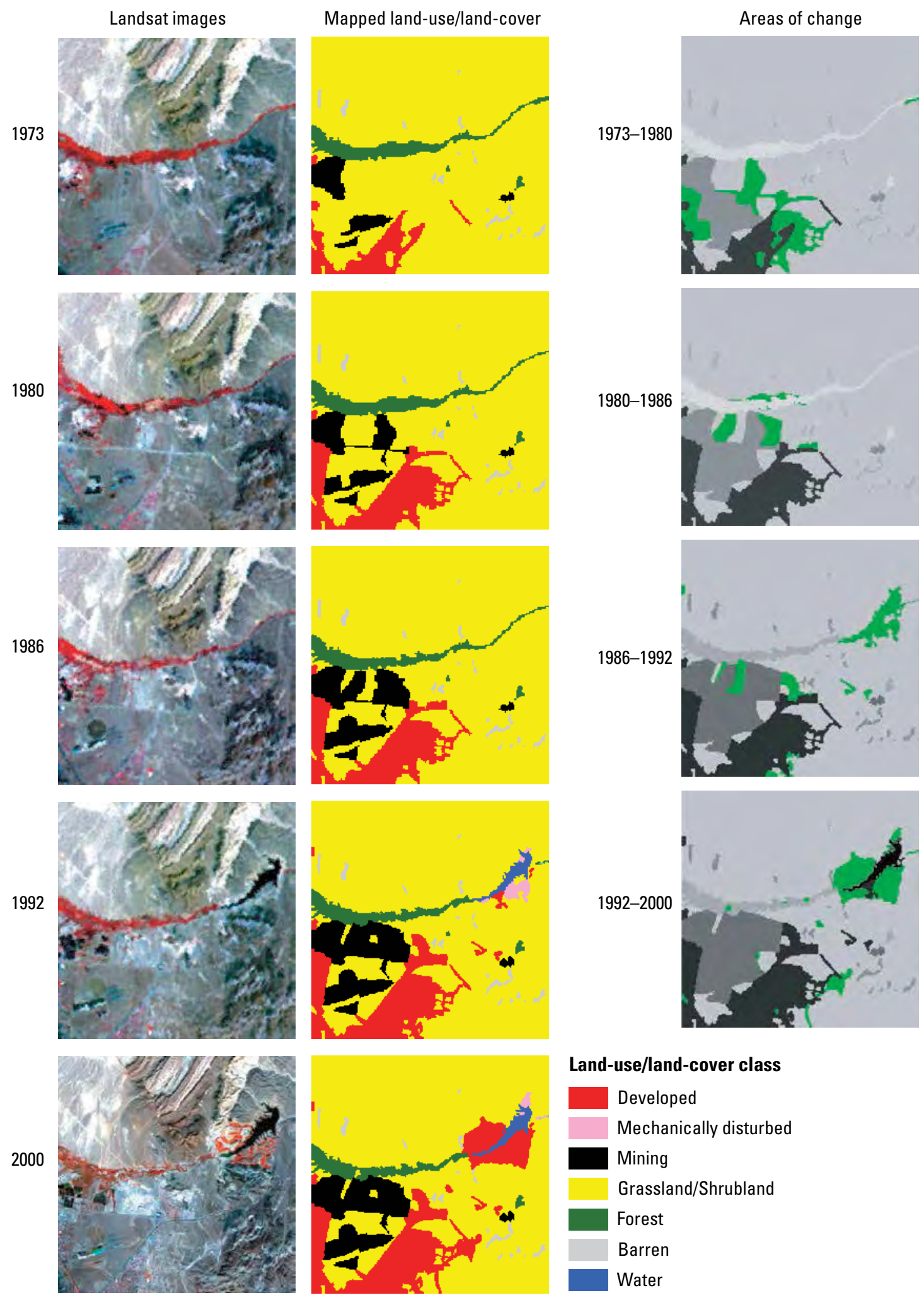

\section{Land-use/land-cover class}

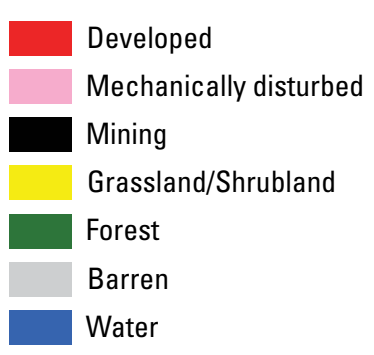

Figure 4.2. Example of data compiled for each sample block, showing sample block 14-0555 (located near Henderson, Nevada, in Mojave Basin and Range Ecoregion, one of Western United States ecoregions). Left column is satellite imagery collected for each of five years analyzed in study (imagery sources for study years: 1973, 1980, and 1986 are Landsat Multispectral Scanner (MSS) images; 1992 is Landsat Thematic Mapper (TM) image; 2000 is Landsat Enhanced Thematic Mapper (ETM) image). Center column is mapped land-use/land-cover data for each study year. Right column shows areas that changed (green areas) in each of four time periods between study years; lightand dark-gray-shaded areas show areas of previous change and represent overall land-change footprint throughout study period. 


\section{References Cited}

Anderson, J.R., Hardy, E.E., Roach, J.T., and Witmer, R.E., 1976, A Land Use and Land Cover Classification System for Use with Remote Sensor Data: U.S. Geological Survey Professional Paper 964, 28 p., available at http://pubs.usgs. gov/pp/0964/report.pdf.

Kish, L., 1987, Statistical Design for Research: New York, John Wiley \& Sons, Inc., 296 p.

Loveland, T.R., and Shaw, D.M., 1996, Multiresolution land characterization-Building collaborative partnerships, in Scott, J.M., Tear, T.H., and Davis, F.W., eds., Gap Analysis - A landscape approach to biodiversity planning: Bethesda, Maryland, American Society for Photogrammetry and Remote Sensing, p. 17-25.

Loveland, T.R., Sohl, T.L., Stehman, S.V., Gallant, A.L., Sayler, K.L., and Napton, D.E., 2002, A strategy for estimating the rates of recent United States land cover changes: Photogrammetric Engineering and Remote Sensing, v. 68, no. 10, p. 1,091-1,099.

Lunetta, R.S., Lyon, J.G., Guindon, B., and Elvidge, C.D., 1998, North American landscape characterization dataset development and data fusion issues: Photogrammetric Engineering and Remote Sensing, v. 64, no. 8, p. 821-829.
Omernik, J.M., 1987, Ecoregions of the conterminous United States: Annals of the Association of American Geographers, v. 77, no. 1, p. 118-125.

Turner, B.L., II, and Meyer, W.B., 1991, Land use and land cover in global environmental change-Considerations for study: International Social Science Journal, v. 130, p. 669-677.

U.S. Environmental Protection Agency, 1999, Level III Ecoregions of the continental United States: U.S. Environmental Protection Agency National Health and Environmental Effects Research Laboratory, scale 1:7,500,000, available at ftp://ftp.epa.gov/wed/ecoregions/ usgs/useco_March1999_v5.pdf.

Vogelmann, J.E., Howard, S.M., Yang, L., Larson, C.R., Wylie, B.K., and van Driel, N., 2001, Completion of the 1990s National Land Cover Data Set for the conterminous United States from Landsat Thematic Mapper data and ancillary data sources: Photogrammetric Engineering \& Remote Sensing, v. 67, p. 650-662. 
Produced in the Menlo Park Publishing Service Center, Menlo Park, California Manuscript approved for publication May 17, 2016

Edited by Taryn A. Lindquist and John S. Osias

Design and layout by Jeanne S. Dileo and David R. Jones 


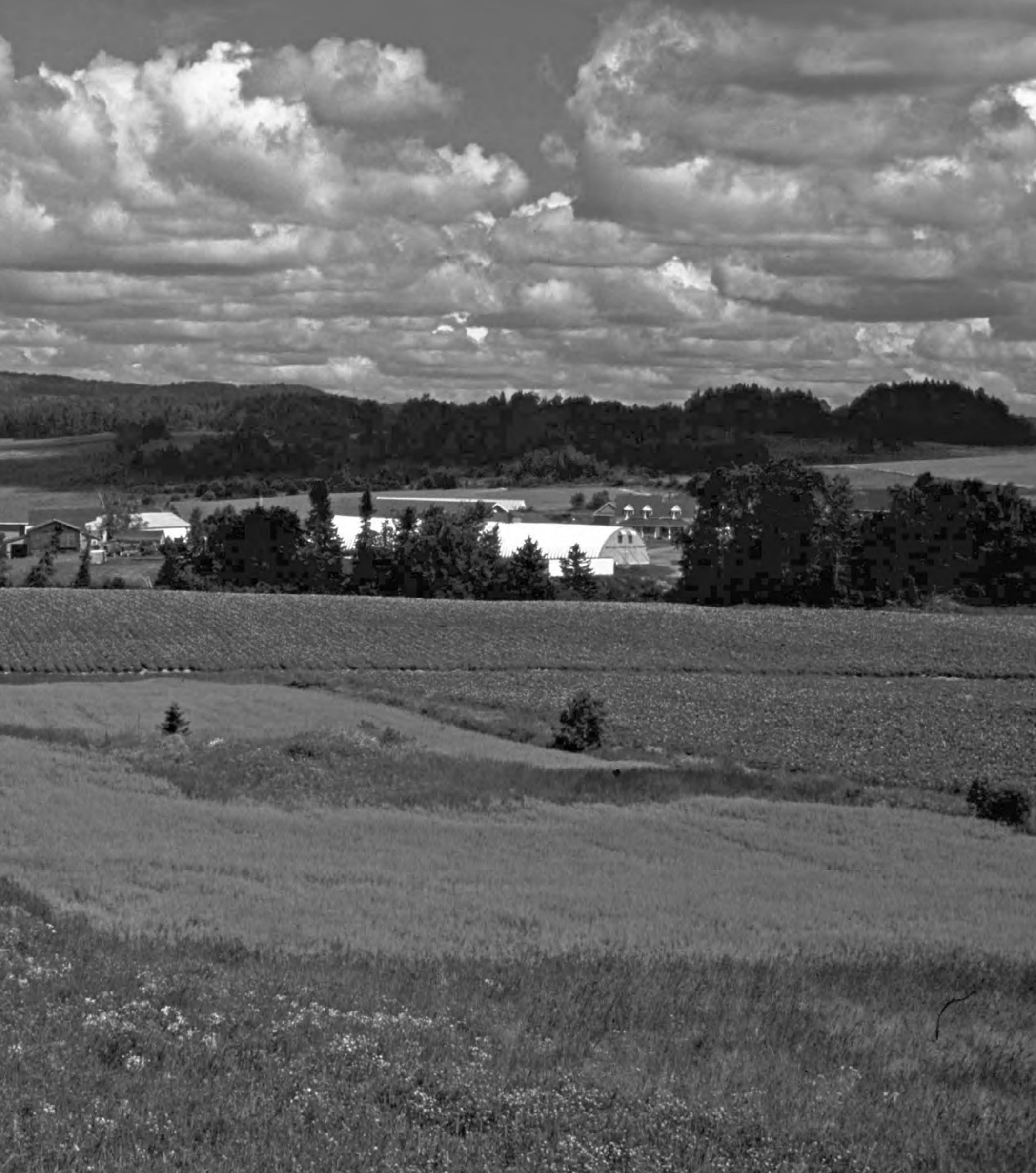




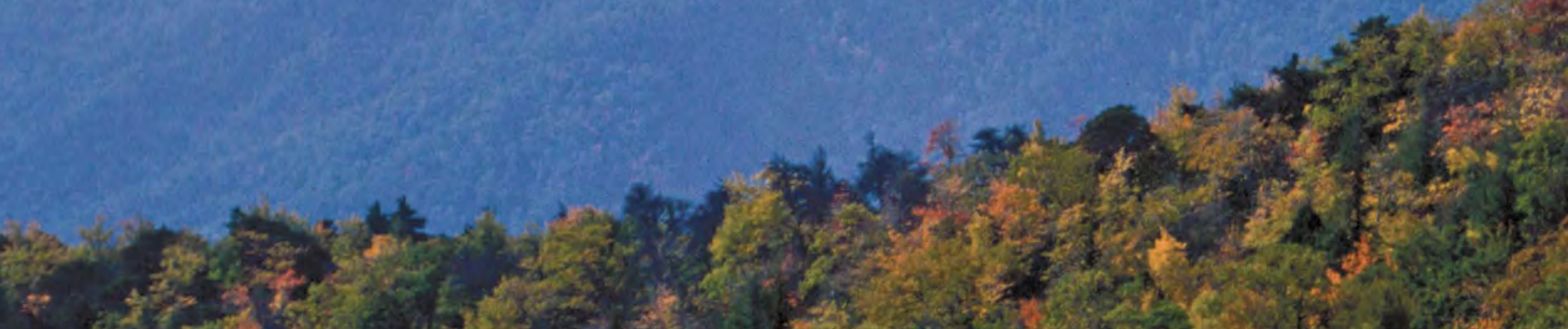

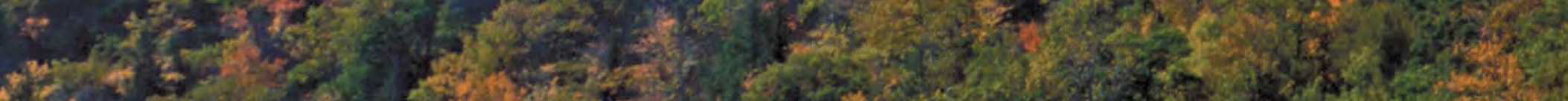

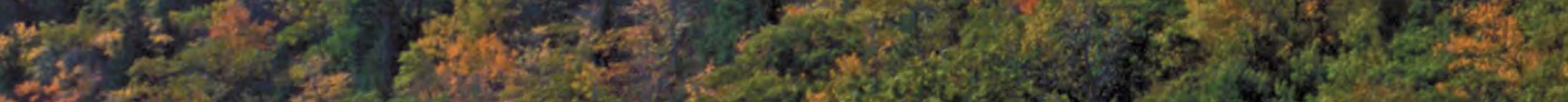

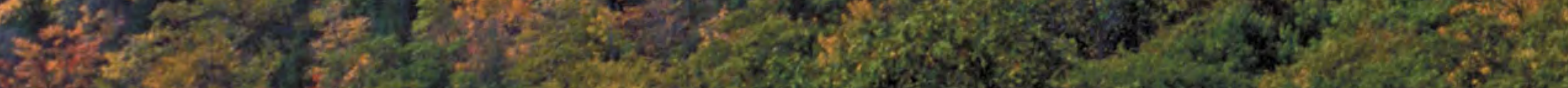

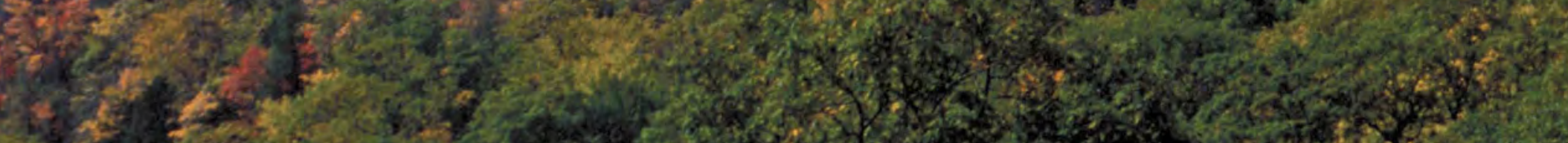

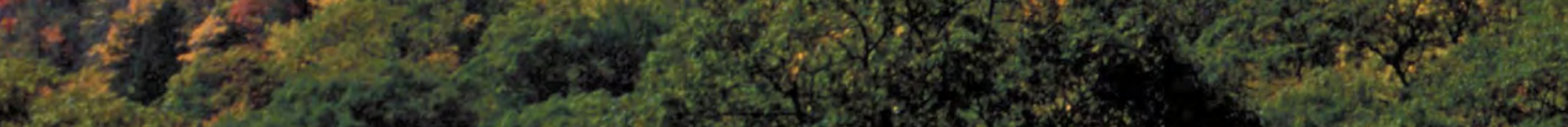
W.

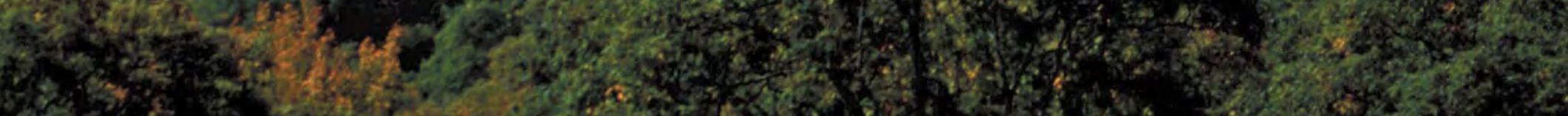

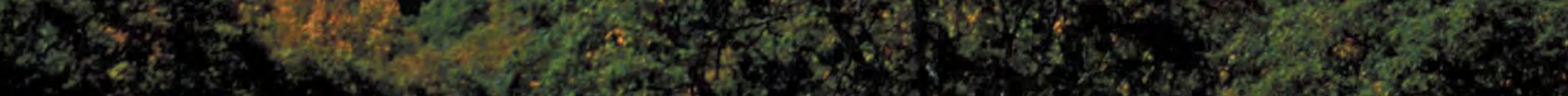
to

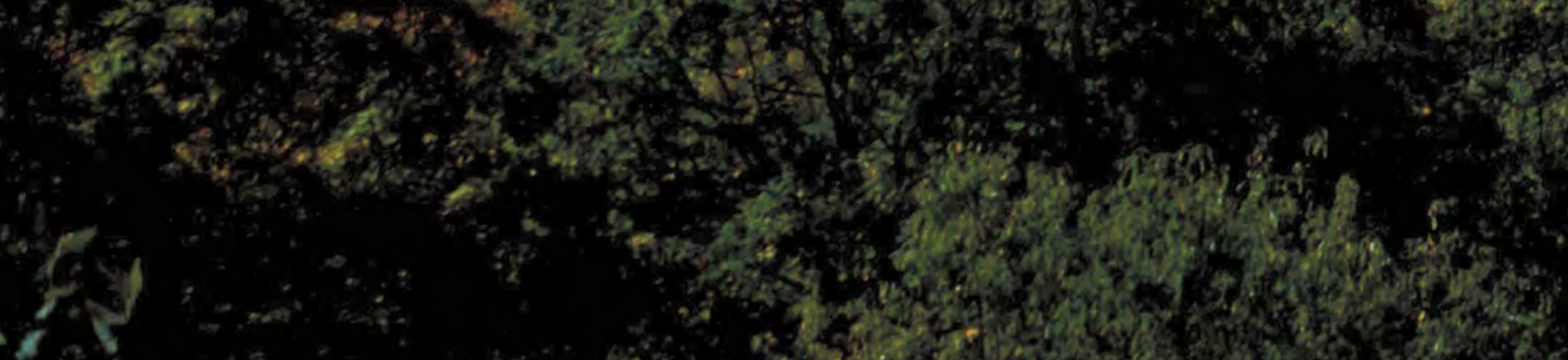
(a) (a)

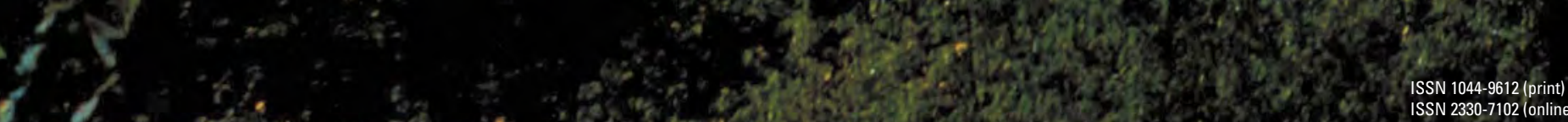

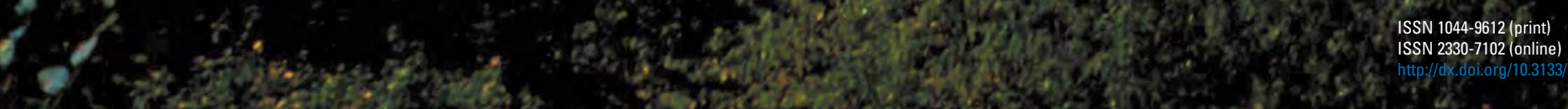

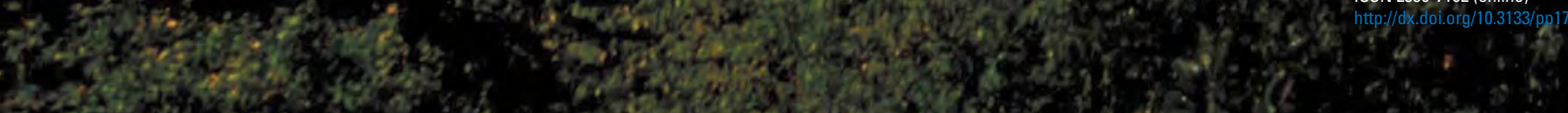

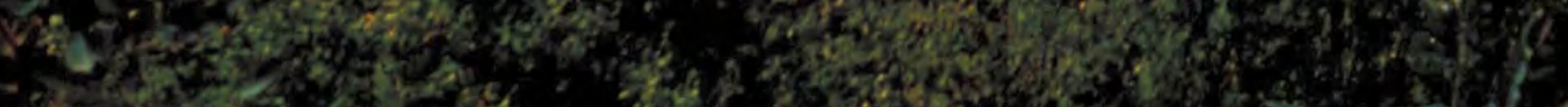
intority Kas, 